UNIVERSIDADE DE SÃO PAULO

FACULDADE DE FILOSOFIA, LETRAS E CIÊNCIAS HUMANAS

DEPARTAMENTO DE ANTROPOLOGIA

PROGRAMA DE PÓS-GRADUAÇÃO EM ANTROPOLOGIA SOCIAL

\title{
INGREDIENTES DE UMA IDENTIDADE COLONIAL: OS ALIMENTOS NA POESIA DE GREGÓRIO DE MATOS
}

Claude G. Papavero

Tese apresentada ao Programa de Pós-Graduação em Antropologia Social da Faculdade de Filosofia, Letras e Ciências Humanas da Universidade de São Paulo, para obtenção do título de Doutora em Antropologia Social.

Orientadora: Profa. Dra. Lília K. Moritz Schwarcz

São Paulo

2007 
Dedico essa tese com amor e carinho:

a meu Nelson por sua grande paciência, seu apoio discreto e suas pequenas impaciências, a meus filhos queridos, Júlio e Tatiana, à Dona Diva, que me ajudou a ter o tempo de escrever essa tese

e à Mona, minha irmã, companheira solidária de toda uma vida por seu apoio bem-vindo na realização dessa tese. 


\section{AGRADECIMENTOS}

Uma das primeiras noções que os professores apresentam a futuros antropólogos, a questão da importância de dar, de receber e de retribuir presentes impregnados de um poder espiritual que precisa ser respeitada. O princípio da reciprocidade no qual Marcel Mauss fundamentou as raízes da vida social, princípio de uma tripla obrigação da qual não se pode escapar foi um fator de descobertas essenciais durante os quase dez anos de mestrado e doutorado. Mais do que acumular conhecimento científico, nesse tempo aprendi, sobretudo, o valor da lição maussiana. Trocar idéias, amizade e solidariedade fizeram parte integrante do aprendizado em Antropologia Social que o PPGAS-USP me proporcionou. O prazer da pesquisa adquiriu nova dimensão ao ser dividido com outras pessoas. Descobri que ser demasiadamente auto-suficiente constitui uma limitação. Termino meu doutorado rica de uma experiência de vida que nada substitui, lembranças de discussões teóricas fantásticas, de conversas, do prazer de compartilhar piadas e iguarias.

Nesse tempo aprendi como é importante receber. Trata-se de uma aprendizagem que não se mostra sempre fácil, pois, valorizar a generosidade do próximo exige boa dose de humildade, mas é um gesto que se transforma numa outra maneira de se doar. Tentei retribuir o mana recebido de tantas fontes, porém a impressão final foi que sobrou uma enorme dívida de gratidão. Devo muito e reconheço a dívida. Meus melhores agradecimentos aos professores do Departamento que, apesar de sobrecarregados de obrigações, dedicam seu tempo e seus conhecimentos aos alunos com enorme generosidade. Devo muito também ao Departamento de Antropologia que me proporcionou uma bolsa da CAPES durante o mestrado e uma do CNPq durante o doutorado. Quanto aos amigos de longa data e de datas mais recentes, que em tantas ocasiões me deram dicas necessárias ou uma força extra, contrai em sua amizade uma dívida de longo prazo que mais adiante, espero quitar. Estou especialmente grata àqueles jovens maravilhosos com os quais tive o privilégio de estudar e torço para que levem adiante a nossa Antropologia. 
Aos amigos da família Jorge Llorente Busquets, Dante Martins Teixeira, Paulo Marques e William Overal a quem devo bibliografias indispensáveis e conselhos preciosos, uma vez mais, agradeço. À Dona Carmen e ao Professor Sixto Coscaron preciso dizer o quanto sua amizade de tantos anos foi um apoio. Estou muito obrigada também ao Professor Coscaron pela leitura criteriosa que ele fez de algumas partes da tese. À Adélia Engrácia Rodrigues de Oliveira, Lux Vidal e Muriel Waldman preciso lembrar como em muitos momentos dessa tese elas que me deram a força de prosseguir numa caminhada que não foi fácil. À Maria Fátima de Melo Toledo, a amiga historiadora que me assinalou diversas obras e questões pertinentes ao estudo, obrigadíssima. À Chantal Christine Limay, amiga desde a adolescência, minha gratidão por sua generosidade indefectível e pela bibliografia emprestada. Agradeço também à Ana Maria Rocha a quem ainda não tive a oportunidade de dizer como foi apreciada a ajuda espontânea que me ofereceu por ocasião do exame de seleção para o mestrado, quando me ensinou como se elaboram referências bibliográficas. Quanto à Julieta de Andrade, sou-lhe grata pela aprendizagem de Brasil que ela me proporcionou e pela descoberta de que minha auto definição brasileira prevalecia sobre todos os elementos anteriores, apesar do sotaque que não conseguia desbotar. Com minha amiga Julieta descobri também o valor de um respeito intransigente à voz do informante que enriquece uma pesquisa etnográfica.

A Sueli Monteiro amiga de tantos anos, revisora de minha dissertação e dessa tese agradeço o apoio eficaz e delicado. Agradeço também a minha Tati que preparou a capa dessa tese de madrugada, juntamente com a mala que a levaria estudar na Austrália. Ao Engenheiro Agrônomo Rui Soares de Castro sou grata pelo mapa das andanças de Gregório de Matos no Recôncavo baiano. Luiz Fernando e Rosa Dutra também merecem um enorme agradecimento pelas fotografias das litogravuras seiscentistas e os dados técnicos que acompanham essa tese nunca esquecerei seu gesto de amizade. Ao Museu de Arte Brasileira da FAAP e à sua Diretora, Dra Maria Izabel Branco Ribeiro, estou muito grata pela autorização de reproduzir na capa da tese a fotografia do magnífico altar baiano seiscentista que pertence ao Museu. A Paul Helfst que me ajudou na editoração dessa tese, à Mariana Facciolo Lima e à sua mãe Denise que me 
socorreram em situações vergonhosas de encrenca material, como, por exemplo, quando perdi a barra de ferramentas do computador, também estou muito agradecida. Preciso dizer ainda a Edgar e Maria Luiza, da Papelaria Fracaluma, como valeu o apoio que me proporcionaram com enorme gentileza, desde o mestrado.

Minha dívida também é enorme em relação à Dra. Ana Clara Ferreira Santos, Secretária da Educação de São Francisco do Conde e a seu esposo, Edivaldo. Ao Engenheiro Hamilton César Barufi Gomes do Instituto Baiano de Geografia e Estatística, ao Professor José Jorge do Espírito Santo, ao pessoal da Secretaria do Turismo e a todos que foram tão acolhedores em São Francisco do Conde, minhas melhores lembranças.

Aos professores dos Departamentos de Antropologia Social e de História ou do Museu de Arqueologia que, durante esses anos de pós-graduação me acolheram em seus cursos como aluna regular ou como ouvinte: o Prof. Robert Rowland, a Profa. Laura de Mello e Souza, o Prof. Adone Agnolin, o Prof. Pedro Puntoni e a Profa. Vera Lucia do Amaral Ferlini, a Profa. Fabíola Andréa Silva, a Profa. Beatriz Perrone Moisés, a Profa. Margarida Maria Moura, a Profa. Marta Rosa Amoroso, a Profa. Dominique Tilkin Gallois, a Profa. Maria Lúcia Montes, a Profa. Sílvia Caiuby Novaes, o Prof. Vagner Gonçalves da Silva, o Prof. Heitor Frugoli Jr., o Prof. Júlio Assis Simões, o Prof. John Cowart Dawsey, o Prof. Marcio Ferreira da Silva. À Profa. Ana Lúcia Pastore Schritzmeyer, de quem fui monitora num curso fantástico de Introdução à Antropologia, toda a minha gratidão e admiração.

Às Profas. Ellen Woortmann, Maria Eunice Maciel, Renata Menasce e Rosa Wanda Diez Garcia agradeço as perspectivas esplendidas de interlocução que me abriram. Sou muito grata também aos estudiosos da alimentação: a Profa. Mônica Chaves Abdala, o Prof. Luiz Mott e meus colegas: Janine Helfst Collaço, Wagner Lins (Arieh) e Herbert Rodrigues, que foram interlocutores privilegiados (não somente quando se tratou de discutir comidas mas também de saboreá-las).

Assumi, sobretudo uma dívida enorme de gratidão em relação a meu colega de doutorado Ugo Maia Andrade, sua esposa Marina e seus pais Ida e Ugo, que nos receberam regiamente, 
minha irmã e eu (como Gregório de Matos diria: "ao canto da mesa"), por ocasião da pesquisa de campo em Salvador. A Mona Cicurel, Maria José Campos (Dedé), Carolina de Camargo Abreu (Carol), André Kees de Moraes Schouten e Iara Maia Covas, Francirosy Campos Barbosa Ferreira, Fraya Frehse, Fernanda Lucchesi e José Henrique Artigas Godoy (Bozo), José Carlos Garcia Bispo, Rubens Alves Silva, Vanilza Jacundino Rodrigues, amigos próximos e leitores críticos de bom conselho, bem como a toda a patota da Casa laranja e a Eduardo Miyamoto (Mia) e Janaína Tavares da Silva, sem a qual essa tese não apresentaria um mapa das andanças de Matos pelo Recôncavo digo muito obrigada. Eles moram no meu coração. Aos colegas do grupo de etno-história também agradeço as boas idéias compartilhadas em nosso convívio agradável.

E por fim, o mais importante, agradeço do fundo do coração aos meus orientadores na vida acadêmica, uma longa trajetória percorrida ao longo da Iniciação Científica, do Mestrado e do Doutorado. Agradeço a Ulpiano T. Bezerra de Meneses que me ensinou a pesquisar e despertou em mim o gosto pela alimentação como tema de pesquisa. Serei grata para sempre à Renate Brigitte Viertler que aceitou orientar meu mestrado quando voltei à academia, após 25 anos de ausência, e que me ajudou ainda com sua imensa generosidade a retomar o fio da meada. Minha gratidão também a Lilia K. Moritz Schwarcz por me acolher no grupo dos antropólogos etno-historiadores. Com seu olhar experiente, ela me deu um presente régio ao me propor o desafio de mudar o tema de meu doutorado para estudar as metáforas alimentares na poesia de Gregório de Matos, um aspecto da alimentação colonial sobre o qual eu não planejava centrar a investigação.

Agradeço a todos imensamente e lhes digo que espero ter muitos anos de vida ainda pela frente, para que o mana recebido possa, de uma forma ou de outra, voltar, frutificar e multiplicar. 


\section{RESUMO}

No final do século XVII, quando Salvador era a capital do Brasil colonial, os hábitos alimentares da cidade e de seus arrabaldes rurais inspiraram muitas metáforas e metonímias ao advogado e poeta seiscentista Gregório de Matos, também conhecido pela alcunha de Boca de inferno. Transformados em fontes de tropos satíricos ou burlescos, os alimentos consumidos na colônia serviram ao poeta para ridicularizar muitos integrantes da sociedade soteropolitana. A obra de Matos documentou um processo histórico e revelou uma maneira local mazomba de conceber o mundo. Seus sarcasmos e suas ironias atacaram inimigos pessoais, cujos hábitos alimentares indignos ou aparências físicas criticaram. Eles se voltaram também contra categorias sociais de colonos que, por sua ascensão econômica, não respeitavam os códigos sociais e culturais vigentes na colônia. A obra de Matos permitiu a essa tese de doutorado em Antropologia Social investigar os conceitos de hierarquia que norteavam a sociabilidade das elites soteropolitanas. Ela foi preservada pelo público do poeta que copiou as poesias após seu exílio para Angola, comprovando a condição assumida por ele de porta-voz dos mazombos frente à crise que, nas últimas décadas do século XVII, afetou o estilo de vida perdulário da população colonial abastada. O recurso intencional a metáforas alimentares também delineou, involuntariamente, os hábitos cotidianos dos colonos. Apesar dos clichês e provérbios e das alusões obscenas do poeta aos manejos dos alimentos, os versos evidenciaram muitos hábitos de nutrição facilmente identificados pelo público. Verificou-se durante a investigação como três fontes principais de representações culturais modelavam a dieta alimentar soteropolitana: o pertencimento religioso dos colonos ao catolicismo, aspirações de ascensão social e a obediência aos preceitos da medicina humoral hipocrática.

Palavras chave: Dieta alimentar colonial - Gregório de Matos - Metáforas poéticas Antropologia da alimentação - História da alimentação. 


\begin{abstract}
At the end of the 17th. Century, when Salvador was the capital of the brazilian colony, the food habits of the city and of its rural surroundings inspired a series of metaphors and metonymies to the lawyer and poet Gregório de Matos, also known as "the mouth of hell'. Transformed into sources of satiric or burlesque poems, the food taken in the colony served him to ridicule many members of Salvador's society. Matos's work documented a local manner (mazomba) of conceiving the world, specific to the elites. His sarcasms and ironies attacked personal enemies whose alimentary habits or physical appearances were criticised. They where also directed against social categories of the colony which, due to their economic ascension, did not respect the social and cultural codes established until then in the Portuguese colony. Matos's poetic work allowed the present Ph.D. thesis on Social Anthropology to investigate the concept of hierarchy that guided the sociability in Salvador. The poet's work was preserved by his public, who copied the poems after his exile in Angola. This proves that he assumed the position of spokesman of the rich colonial population facing the crisis that, in the last decades of the 17th. Century, affected their spend thrift style of life. The intentional resource to alimentary metaphors also described, involuntary, the daily habits of the colony. Although the clichés and proverbs inserted in the poems, and in spite of the obscenity of the allusions to food manipulations, they referred to several nutrition processes easily identified by the public. During the investigation it was verified that three main sources of cultural representation modelled the alimentary diet in Salvador: the religious belonging of people to Catholicism, aspiration to social ascension and the obedience to the precepts of the Hippocratic humoural medicine.
\end{abstract}

Key-words: Colonial alimentary diet - Gregório de Matos - Poetical metaphors - Alimentary Anthropology - History of alimentation. 


\section{RÉSUMÉ}

A la fin du XVII ème. siècle, alors que Salvador était encore la capitale du Brésil colonial, les habitudes alimentaires des colons portugais, usuelles en milieu urbain ou dans les propriétés rurales des alentours, inspirèrent de nombreuses métaphores et métonymies à l'avocat et poète Gregório de Matos, surnommé "Bouche de l'enfer". Transformés en sources de tropes satiriques ou burlesques, les aliments du terroir local furent utilisés par le poète pour ridiculariser de nombreux soteropolitains. L'oeuvre de Matos permettait de documenter um moment de l'Histoire coloniale et révélait une manière locale mazomba de concevoir le monde. Sarcasmes et ironies attaquèrent les ennemis personnels de l'auteur. Il critica leurs habitudes alimentaires indignes ou compara leur apparence physique à l'aspect de certains ingrédients comestibles. Quelques catégories sociales de colons, qui ne respectaient pas les limites imposées par les normes sociales et culturelles mazombas, furentaussi comblés d'imprécations. L'oeuvre de Matos permità cette thèse de doctorat en Anthropologie Sociale d'investiguer la manière de concevoir la hiérarchie sociale, qui était celle des élites coloniales soteropolitaines. Le public, après l'exil de Matos envoyé en Angola, copia les poèmes connus, préservant l'oeuvre et de prouvant le rôle de porte-parole des mazombos, qui échut au poète, lors de la crise sociale des dernières décennies du XVII ème siècle, qui affecta le style de vie seigneurial des hommes riches. L'usage intentionnel de métaphores alimentaires permit aussi, fait qui n'avait pas été prévu par l'auteur, de décrire les coutumes alimentaires des colons. Malgré l'insertion dans les poèmes de clichés, de proverbes et d'allusions obscènes, de très nombreuses habitudes alimentaires quotidiennes, facilement identifiées par des mazombos, furent mises en évidence. Trois sources principales de représentations culturelles furent perçues lors de l'étude des poèmes. C'étaient elles surtout qui régissaient la diète alimentaire sotéropolitaine: l'appartenance religieuse des colons au catholicisme, l'ascension sociale à laquelle ils aspiraient et l'obeïssance qui était due aux presciptions de la médecine humorale d'Hyppocrate.

Mots-clefs: Diète alimentaire coloniale - Gregório de Matos - Métaphores poétiques Anthropologie de l'Alimentation - Histoire de l'alimentation. 


\section{SUMÁRIO}

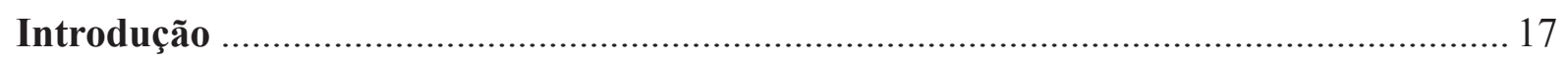

Hábitos alimentares e registro social soteropolitano na poesia de Matos........................ 17

- Convite à pesquisa: o objeto da tese e os propósitos da análise ........................ 17

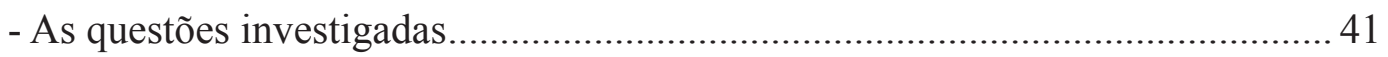

- As fontes primárias referentes ao último quartel do século XVII.......................52

- Outras fontes de referência pertinentes à análise.............................................. 57

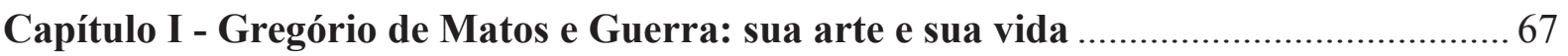

1.1 - A “vida espantosa” de Gregório de Matos ...................................................6 68

1.2 - As circunstâncias do resgate poético da obra................................................ 74

1.3 - A realidade como fonte de inspiração dos poemas ....................................... 78

1.4 - Objeções ao estudo da realidade colonial nos poemas de Matos ................. 82

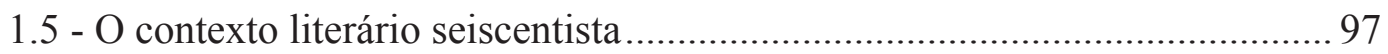

Capítulo II - O uso simbólico dos alimentos nos versos do poeta .................................. 107

2.1 - As referências a alimentos nos versos de Gregório de Matos....................... 108

2.2 - Descrição metafórica dos vícios que grassavam no Recôncavo................... 133

2.3 - As metáforas alimentares, recursos para uma critica da vida colonial ........ 138

2.3.1 - As sátiras endereçadas aos indivíduos ................................................... 141

- Clero regular e clero secular .................................................................... 143

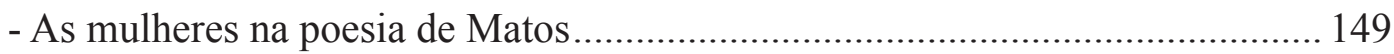

- Os governadores: a administração das farinhas, carnes e peixes........................ 159

2.3.2 - As críticas endereçadas a diversas categorias sociais de colonos ............. 171

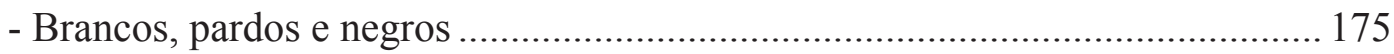

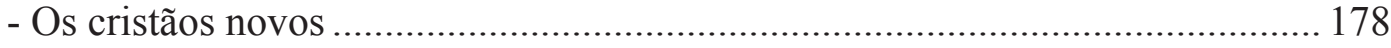




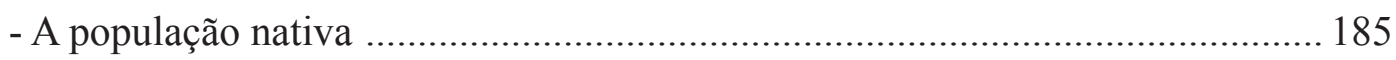

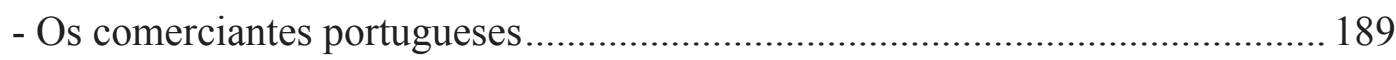

2.4 - A construção de um lugar de poder nas fofocas burlescas ou satíricas........ 199

Capítulo III - Uma Etnografia dos procedimentos alimentares coloniais....................... 207

3.1 - Os ingredientes de um cardápio mazombo ............................................... 210

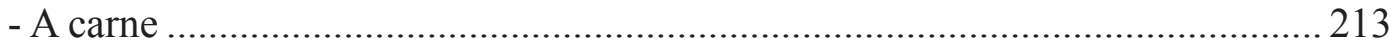

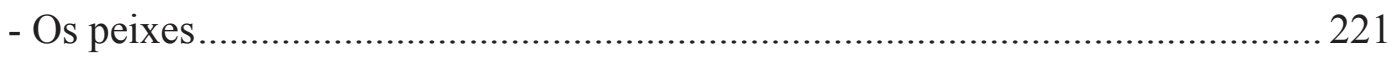

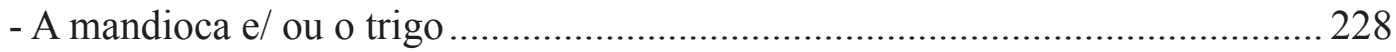

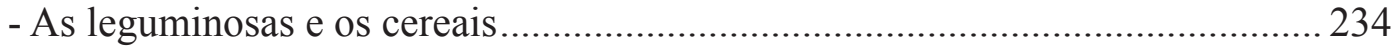

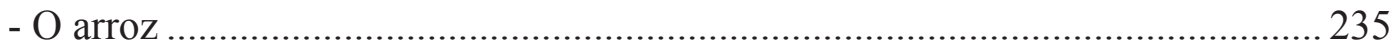

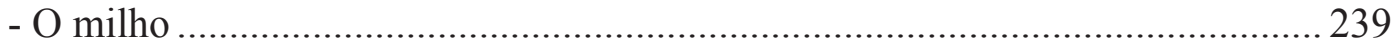

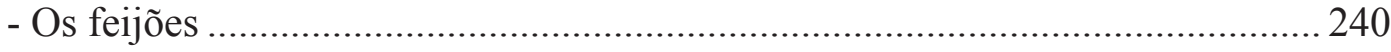

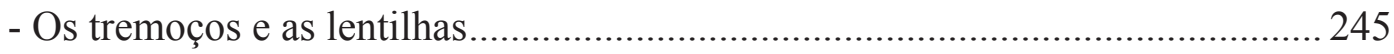

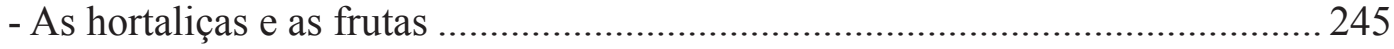

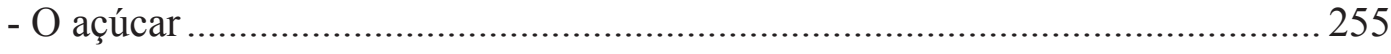

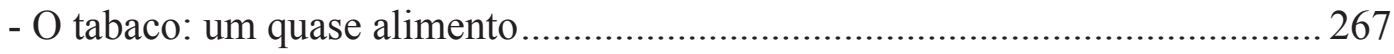

3.2 - O abastecimento colonial da capital e do Recôncavo...................................268

- Os alimentos como alvo de administração ........................................................2274

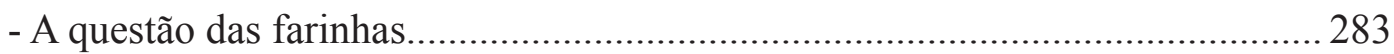

- A questão da carne de corte e dos açougues .......................................................228

3.3 - Iguarias e manejos de preparo soteropolitanos ......................................... 294

- Refeições lusas: almoço, jantar, merenda e ceia....................................................306

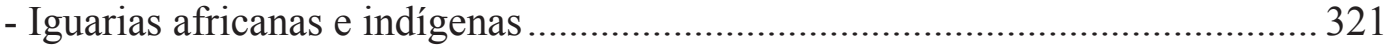

- A alimentação dos escravos .......................................................................... 324

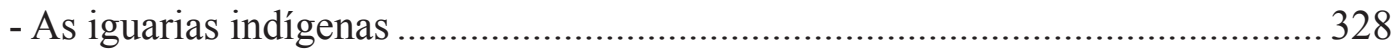

3.4 - A alimentação como fonte de vida social.................................................... 334 
- Os ritmos da vida social soteropolitana ........................................................ 336

- Os ritmos da vida rural nas freguesias do Recôncavo ........................................ 346

- A hospitalidade mazomba e seus problemas sociais...................................... 352

- Os ritmos da vida social: os alimentos como fonte de auto-identificação .......... 359

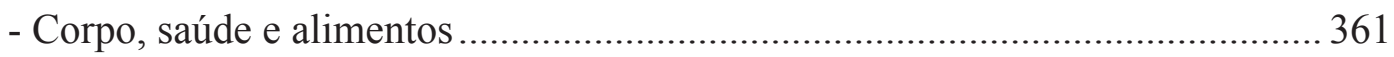

- O uso medicinal dos alimentos: os remédios................................................... 367

\section{Capítulo IV - As lógicas organizando a produção colonial e o consumo de alimentos em}

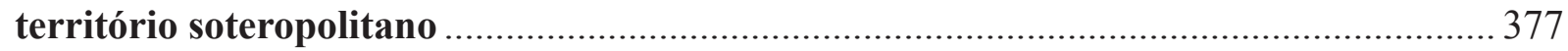

4.1 - Alguns processos sociais relevantes percebidos na etnografia alimentar .... 380

- O processo de uma desmediterraneização ou deslusitanização da dieta ........... 380

- A questão da dieta mínima .............................................................................. 393

- A assim chamada questão da integração social das três raças ............................ 399

4.2 - Os valores culturais que modelaram as práticas alimentares de um estilo

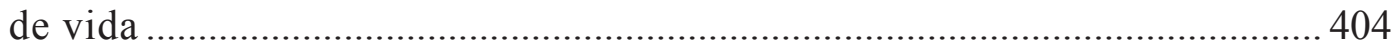

- Religião e corpo social dos mazombos.......................................................... 406

- Vida social e consciência mazomba da honra.................................................... 413

- Crenças sobre o funcionamento dos corpos e a manutenção da saúde.............. 423

4.3 - A arte de Gregório de Matos observada pelo prisma dos alimentos ............ 432

- Obscenidade, decoro e moralidade social....................................................... 433

- Uso simbólico e uso emblemático dos alimentos ............................................440

4.4 - Alimentação soteropolitana e significados culturais e sociais nos poemas de

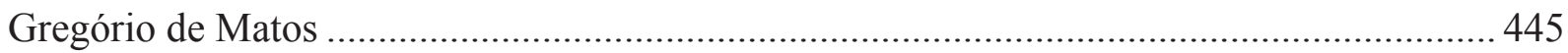

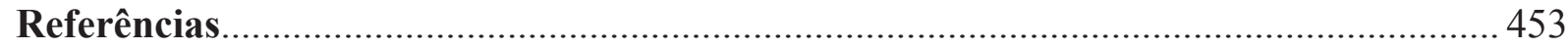




\section{ÍNDICE DAS ILUSTRAÇÕES}

Capa da tese preparada por Tatiana Papavero - Fotografia de um altar baiano do século XVII. Peça que pertence ao Museu de Arte Brasileira da FAAP (utilizada com autorização).

(Ficha técnica das litogravuras, informações de Luiz Fernando Moreira Dutra).

Entre as páginas preliminares e a introdução

Gravura: Salvador, Bahia, Brasil - 1695 - The city of St. Salvador Bahia - e seu porto e cidade - by J. Harris - 1695 - aquarelado 26 x $34 \mathrm{~cm}$.

Entre a introdução e o capítulo I

Gravura Salvador Bahia - Meteren, Emanuel (Meteranus) - description of the capture of Salvador Bahia - Gravura original de 1640. Amsterdam, Janssonius 1640. 25 x $33 \mathrm{~cm}$.

Final do capítulo I e antes do capítulo II

Mapa - Plan de la ville de Saint Salvador - Bahia - 1689 - Capitale du Brésil - Com margem: 44 x $32 \mathrm{~cm}$ - mapa 17 x 24 cm. (André sculp.).

Final do capitulo II e antes do capítulo III (à esquerda : texto, à direita: mapa em A3, dobrado):

Mapa do Recôncavo Baiano: as andanças de um mazombo. Rui Soares Castro.

Final do Capítulo III e antes do capítulo IV.

Brazil: San Salvador, Bahia - 1769 : aquarelado à mão: From Isaak Tirion's "Nieuwe en Beknopte Hand - Atlas bestaande in eene Verzameling van eeinge der algemeenste en nodigste landkaarten". Amsterdam: 1769. 41 x $49 \mathrm{~cm}$.

Fim do capítulo IV e antes das referências

Gravura: Ville de Salvador Brésil, 1695 - Froger, François. (1676 - 1715) Buril, $13 \times 26,5 \mathrm{~cm}$. 



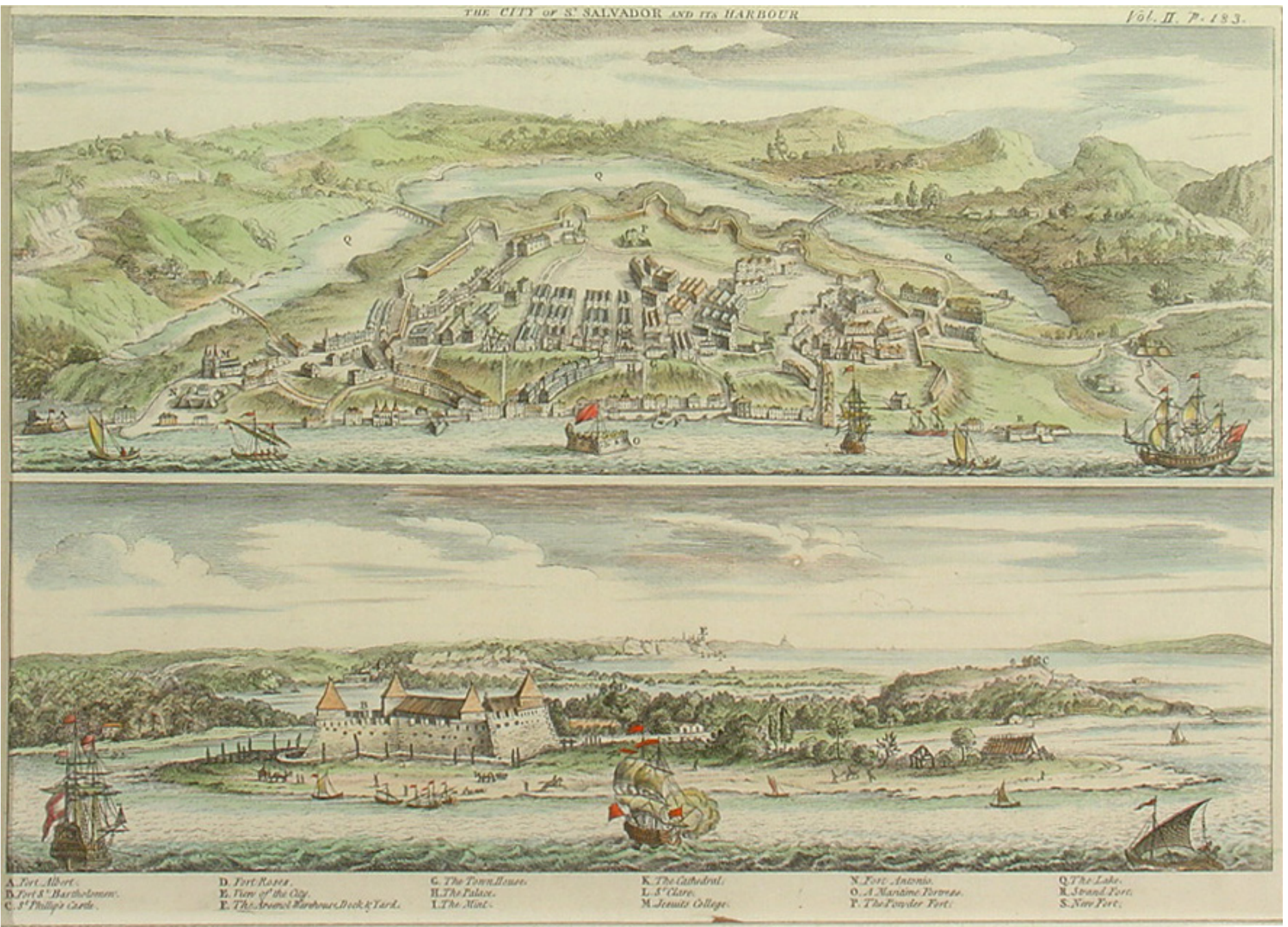

Gravura: Salvador, Bahia, Brasil - 1695 - The city of St. Salvador Bahia - e seu porto e cidade - by J. Harris - 1695 - aquarelado 26 x 34 cm. 



\title{
Hábitos alimentares e registro social soteropolitano na poesia de Matos
}

\author{
"O que é a alimentação? Não se trata somente de uma coleção de produtos, \\ fazendo jus a estudos estatísticos ou dietéticos. Também é, ao mesmo tempo, um \\ sistema de comunicação, um corpo de imagens, um protocolo de usos, de situações \\ e de condutas. Como estudar esta realidade alimentar, alastrada até a imagem e o \\ signo? Os fatos alimentares devem ser procurados em todos os lugares onde são \\ encontrados: pela observação direta na economia, as técnicas, os costumes, as \\ representações publicitárias; pela observação indireta na vida mental de uma dada \\ população"1 (Roland Barthes).
}

\section{Convite à pesquisa: o objeto da tese e os propósitos da análise}

O corpus volumoso de poemas líricos, satíricos ou burlescos: sonetos, romances, décimas e glosas, cuja autoria foi atribuída a Gregório de Matos e Guerra, filho letrado de um rico lavrador de canas do Recôncavo Baiano, foi concebido num âmbito de composição poética erudita barroca, mas reuniu um conjunto de textos destinados à apresentação oral. O poeta, nascido na capital da colônia e educado em Coimbra, incorporou em seus poemas muitas alusões às práticas alimentares e às idéias que regiam então essas práticas. Os versos, apesar de não constituírem uma gazeta fidedigna de acontecimentos ocorridos na colônia, registraram também debates em torno de questões sociais e de eventos que foram notícia em Salvador.

1 BARTHES, Roland. "Pour une psycho-sociologie de l'alimentation", in Annales ESC, septembre/octobre, (5), pp. 977- 986, 1961. p. 979. (Texto em português: Minha tradução).

“Qu'est-ce que la nourriture? Ce n'est pas seulement une collection de produits, justiciables d'études statistiques ou diététiques. C'est aussi et en même temps un système de communication, un corps d'images, un protocole d'usages, de situations et de conduites. Comment étudier cette réalité alimentaire, élargie jusqu'à l'image et au signe? Les faits alimentaires doivent être recherchés partout où ils se trouvent: par observation directe dans l'économie, les techniques, les usages, les représentations publicitaires; par observation indirecte dans la vie mentale d'une population donnée". 
Escrita num estilo que combinava linguagem acessível, imagens com forte poder de impacto visual e aplicação criteriosa de regras poéticas cultas, a arte de Gregório de Matos enfureceu aqueles que as sátiras ridicularizavam mas, de um modo geral, agradou tanto aos clérigos instruídos quanto ao resto da população soteropolitana, que não desfrutara de educação formal. Ocasionalmente, o poeta produziu até paródias de poemas de autores célebres, transformando jocosamente versos cultos em versões chulas nas quais o baixo-corporal intervinha. Como bem observou João Carlos Teixeira Gomes², o autor desempenhou na colônia um papel um pouco semelhante àquele de um goliardo local.

Os poemas de Matos, tão engenhosos quanto marcados por uma maneira local de conceber a colônia, se apresentaram como objeto de estudo frutífero para desenvolver uma tese sobre as idéias que norteavam a alimentação colonial. Compostos entre 1683 e 1694, os doze anos do retorno do autor à terra natal, eles continham inúmeras metáforas sobre gêneros alimentícios ou hábitos alimentares, que se referiam a questões extrapolando o plano material da vida colonial. As brincadeiras inseridas nos versos de Matos destinavam-se, com efeito, a um público de ouvintes ou de leitores que residiam na colônia e eram capazes de decifrar de imediato os significados sugeridos pelo autor, que recorria persistentemente a práticas concretas para exemplificar os pontos de vista que defendia. Muitos ingredientes da dieta alimentar colonial e muitos hábitos de consumo serviram de esteio à expressão poética, permitindo alusões encobertas aos valores culturais associados à ingestão de determinados alimentos ou preparos culinários. Pretextos para reafirmar a relevância das formas instituídas de vida social que a crise econômica e política, ao afetar os produtores de açúcar colocava em risco, os alimentos cotidianos revelavam o teor dos procedimentos, idéias e emoções que norteavam a vida social dos portugueses estabelecidos na capital colonial e seus arredores rurais.

Menos didáticos e formais que os textos dos cronistas, os versos de Matos não detalhavam as circunstâncias locais em benefício de forasteiros ignorantes das condições de vida no território, eles apenas aludiam de forma velada a fatos inteligíveis para os ouvintes. A despeito de pertencer ao domínio da ficção literária, por incluir episódios extravagantes e

2 GOMES, João Carlos Teixeira. Op. Cit., pp. 336 a 338. 
escabrosos fabricados para caluniar inimigos, a poesia do autor permite flagrar o contexto diário soteropolitano ${ }^{3}$. Matos deleitou uma elite colonial composta de proprietários rurais, de funcionários e de letrados formulando brincadeiras de linguagem no âmbito de um diálogo literário divulgado entre os conterrâneos. Que o poeta não julgasse necessário esmiuçar todos os significados subentendidos nas analogias marotas entre as regras de alimentação e os fatos da vida social, atestava como a sociedade a quem ele dirigia os versos, reconhecia como seus os conceitos e crenças insinuados nas entrelinhas dos poemas sob a forma de jogos de palavras ou de imprecações.

Apostou-se no fato da poesia do autor proporcionar um fio de meada interessante para entender o impacto das condições físicas e sociais da vida soteropolitana sobre as maneiras de pensar e de agir dos colonos lusos instalados na principal capitania da colônia. Ao comentar por intermédio de trocadilhos, de reflexões irônicas e de duplos sentidos, eventos e circunstâncias relevantes da vida cultural e social na capital do Brasil, durante o último quartel do século XVII, Matos assinalava práticas entranhadas na existência diária, idéias compartilhadas por muitos mazombos, e um rol suculento de fofocas locais revelador das representações que os colonos formulavam sobre o papel social que lhes cabia desempenhar no Brasil.

O próprio tema dos colonos mazombos interessava. Ao longo de toda a obra, Matos repetia a alcunha e dava corpo à especificidade da sociedade lusa soteropolitana, noção que o assentimento dos amigos consubstanciava. Mazombos, segundo Calmon ${ }^{4}$, eram todos os portugueses nascidos no Brasil. No entanto, os poemas de Matos apontavam para um uso mais restrito do termo. O poeta parecia considerar mazombos apenas os membros mais reluzentes da sociedade 3 Adjetivo designando os habitantes de Salvador. Termo em certa medida extensível aos demais moradores do Recôncavo baiano no período estudado .

4 CALMON, Pedro. A vida espantosa de Gregório de Matos. Rio de Janeiro, José Olympio/Instit. Nacional do Livro, 1983. Segundo a definição do autor (cf. nota 14, p. 8):

“Apelido quimbundo de branco, nascido no Brasil. Traduzimos sua proposição, zombo, de zumbi, senhor, arcaïsmo hoje na língua de Angola, mas tão vivo naquele tempo que assim se chamou o rei do quilombo dos Palmares. Marcgraf é o primeiro a usar a palavra, vulgar no século XVII." 
local, brancos, donos de terras, abastados e vivendo honradamente do trabalho de escravos. A exclusão dos outros colonos, daqueles que exerciam profissões manuais ou cujos ascendentes incluíam mestiços, mamelucos, mulatos, mouros ou cristãos novos, configurava uma questão relevante, sobretudo ao se considerar a boa aceitação de portugueses recém-chegados pelas elites açucareiras, desde que tivessem meios de viver "à lei da nobreza". O termo de crioulos reservado aos descendentes de cativos nascidos no Brasil ampliava o problema. Adotar um termo proveniente do quimbundo para designar elites coloniais portuguesas, que julgavam possuir sangue puro, quando nas colônias americanas pertencentes à Espanha os colonos se denominavam correntemente criollos, era fato que merecia ser perscrutado. $\mathrm{O}$ elemento recorrente que os poemas de Matos pareciam associar à condição mazomba era o estilo de vida, a maneira de agir das elites ${ }^{5}$, ideada entre 1580 e 1640 ou 1654, durante a construção e a expansão de uma rede de engenhos de açúcar. Os versos do autor indicavam a emergência, não de uma identidade local ${ }^{6}$ já constituída e nativista, mas de um processo social ativo de auto-identificação das elites soteropolitanas politicamente empenhadas em se distinguir das categorias menos nobres de indivíduos e preservar privilégios econômicos convenientes. Entre as práticas metafóricas citadas por Matos sobressaíam as referências freqüentes aos hábitos alimentares, itens fundamentais no que dizia respeito ao estilo de vida dito mazombo. Foi nesse sentido específico e restrito do processo de auto-definição que foram considerados na tese, os Ingredientes de uma identidade colonial: os alimentos na poesia de Gregório de Matos, fatores comestíveis diacríticos de uma identificação social que nunca chegou a se firmar efetivamente.

Investigar a maneira de perceber o mundo da sociedade lusa transplantada no Brasil foi a idéia central que motivou essa tese. Os versos ofereciam uma credencial promissora de pesquisa

5 WARNIER, Jean Pierre. Construire la culture matérielle: 1'homme qui pensait avec ses doigts. Paris, PUF. 1999. p. 89. Como observou o autor: "Si l'on admet, avec Foucault, que les styles de vie sont des techniques de soi, alors il faut analyser la consommation de masse comme um élément de la production de soi par soi...".

6 CUNHA, Manuela Carneiro da. Antropologia do Brasil: mito, história, etnicidade. São Paulo, Brasiliense /EDUSP, 1986. 
para examinar as condições da existência colonial e as escolhas de procedimentos materiais de alimentação que os membros daquela sociedade achavam condizentes com suas pessoas. Analisar dados porventura encontrados nos textos levava a examinar a própria ambigüidade existente nos ingredientes de uma consciência regional em formação durante um período da História do Brasil no qual pertencer à sociedade colonial não significava necessariamente romper vínculos com a matriz metropolitana?

O interesse pela arte poética de Gregório de Matos contendo indícios reveladores de um modo de vida local, capaz de apontar certa reapropriação da identidade portuguesa de origem, foi o ponto de partida da investigação. Supor que procedimentos implementados para obter alimentos ou escolher iguarias prediletas possibilitariam entender os significados atribuídos aos hábitos alimentares indiretamente associados a formulações ideais de cunho identitário, foi a hipótese de trabalho que transformou os ingredientes da dieta colonial num objeto empírico de pesquisa modelado por um conjunto intrincado de motivações. Produtos de uma arte de redigir idéias compondo rimas, as metáforas referindo alimentação que o poeta utilizou foram efetivamente consideradas como traduções potenciais de uma arte de viver. Considerouse como os colonos decifraram efetivamente o Brasil em termos de percepções sensoriais interpretadas pelo intelecto. O sabor dos alimentos, os preparos culinários usuais, o aporte energético proporcionado por sua ingestão, a adequação das substâncias comidas à construção de pessoas, a avaliação da sensação de saciedade que os ingredientes da dieta proporcionavam e a conveniência das fontes de sua produção ou obtenção foram algumas das questões atreladas ao tema.

A tentativa de implementar o campo de pesquisa de uma tese focalizando a vida social e cultural do Brasil colonial através da análise dos hábitos alimentares associados a padrões estéticos, religiosos ou políticos, deve muito a Roland Barthes. Ela derivou essencialmente de

7 SILVA, Rogério Forastieri da. Colônia e nativismo: a História como "biografia da nação", São Paulo, Hucitec, 1997. O autor afirmou "Segundo essa abordagem vê-se que o nativismo refere-se ao periodo colonial e é precursor do nacionalismo, bem como não implica oposição à metrópole, caracterizando-se mais como exaltação das coisas da terra..". Cf. pp. 75 e 76. 
uma reflexão fundamentada nos termos da citação destacada em epígrafe na apresentação da tese. Enquanto protocolos de usos sociais ou como elementos de um sistema de comunicação social dando origem a imagens carregadas de significados simbólicos, os alimentos consumidos pelos colonos lusos foram considerados objetos de um estudo capaz de proporcionar uma via indireta de acesso aos valores culturais que organizavam o cotidiano local e de permitir a compreensão do estilo de vida instituído.

Gregório de Matos, por ter demonstrado em seus poemas uma indignação sentida perante desrespeitos inaceitáveis, porém praticados, aos privilégios estabelecidos da elite açucareira, ofereceu um excelente ponto de partida para encontrar pistas sobre os procedimentos usuais e os problemas decorrentes de mudanças na situação colonial. Mesmo sem detalhar os procedimentos técnicos do abastecimento alimentar local, o autor encontrou no contexto das condutas alimentares uma fonte expressiva de metáforas para declarar os motivos de sua insatisfação com os rumos morais da vida colonial:

“Todos são ruins, todos perversos,/Só nos distingue o vício ou a virtude/De que uns são comensais, outros adversos"".

O procedimento literário corrente de formular metáforas para ressaltar analogias existentes entre o plano da vida material e o plano das idéias adquiriu, no caso, um relevo especial. Entre os estudiosos que se debruçaram sobre o assunto, o historiador Jean-Louis Flandrin, por exemplo, leitor do Dicionário filosófico de Voltaire, enfatizou como falar em gosto fora do campo alimentar podia resultar em instituição de metáforas capazes de oferecerem critérios sensíveis para formular rapidamente juízos de valores. Com efeito, à maneira de avaliações do paladar, discernindo sabores agradáveis ou convenientes de outros considerados menos

8 MATOS, G. Op. Cit., Vol. II, p. 471.

WISNIK, José Miguel também cita esses versos. Gregório de Matos: poemas escolhidos, São Paulo, Cultrix, 1976. p. 21 . 
apropriados, a noção intelectual de gosto, resultava especialmente propícia à formulação de metáforas sociais ${ }^{9}$.

Para analisar a articulação lógica entre alimentos absorvidos e idéias externadas, recorreu-se à circunstância assinalada pelo antropólogo da alimentação, Claude Fischler ${ }^{10}$, da ingestão dos alimentos imprescindíveis à manutenção da vida oferecer perigos físicos e perigos simbólicos e resultar em escolhas deliberadas de certos gêneros alimentícios. Considerou-se o fato dos ingredientes privilegiados transporem o limiar da boca sob forma de idéias formuladas antes mesmo de se transformarem em substância corporal dos indivíduos.

Anatureza material dos ingredientes comestíveis considerados adequados à construção de corpos idôneos permaneceu no centro da reflexão ao longo de toda a pesquisa sobre a alimentação soteropolitana e de toda a exposição dos dados coletados nos poemas de Gregório de Matos. Desse modo, a investigação de vínculos entre o reconhecimento de qualidades de boa nutrição, digestão, provimento fácil e honorabilidade social implicados nas escolhas de alimentos favorecidos na dieta colonial abriu caminho para abordar a questão da maneira como a população colonial ideava seu próprio lugar no mundo. Os procedimentos de provimento e de preparo alimentar soteropolitanos foram analisados como gestos tradutores de maneiras de ser, de pensar e de sentir. Citando metaforicamente manejos produtores de alimentos e ingredientes consumidos para enfatizar o teor de propriedades atribuídas aos gêneros alimentícios, Matos trazia à tona uma rica bagagem de crenças e conhecimentos, que conferia lastro às alusões engenhosas.

Em situações semelhantes, o estudioso Jan Vansina, também observou o potencial analítico de fontes orais de linguagem expressas com outros propósitos para alcançar um conhecimento circunstanciado do passado histórico:

9 FLANDRIN, Jean-Louis. “A distinção pelo gosto”, in História da vida Privada: da Renascença ao século das luzes, Vol 3, ARIÈS, Philippe e DUBY, Georges (Org.). São Paulo,Cia das Letras, 2002. pp. 300 e 301. 
"Pode se aprender muito sobre o passado a partir de fontes orais que não se preocupam com ele e portanto testemunham involuntariamente. Uma característica que certamente torna seu depoimento mais confiável, justamente por se tratar de uma contribuição inconsciente"11.

A noção formulada por Jean-Pierre Warnier, de uma visão escotomizada, isto é, de uma percepção de fatos exteriores ao foco de uma discussão principal, enxergados pelo canto dos olhos, também auxiliou na tentativa de alçar os usos e costumes soteropolitanos à condição de objeto de estudo. Em diversos momentos da investigação foram as circunstâncias materiais da geografia soteropolitana articulando homens, meio-ambiente, objetos manejados e representações, que permitiram encontrar rastros plausíveis e convincentes para explicar as escolhas de procedimentos alimentares e as representações culturais envolvidas.

“Aquele gesto, como tantos outros semelhantes, não se integrou num conjunto a meus olhos com alguma lógica, senão por volta de quinze anos depois. Durante todo esse período, não os mencionei, ou apenas os referi ligeiramente em meus escritos etnográficos, porque eles não se coadunavam uns com os outros. Para que aquilo acontecesse foi necessário que o gestual, as técnicas do corpo, as condutas motoras perdessem o estatuto de quase-palavras, de signos em sua relação com as substâncias e as coisas, e se articulassem enquanto práticas, técnicas de si, ações do sujeito sobre ele mesmo e sobre as ações dos outros.

A fecundidade heurística de uma teoria se mede por sua capacidade de colocar

11 VANSINA, Jan. Oral tradition as History. Madison, The University of Wisconsin Press, 1985. p. 28. (minha tradução).

"Much can be learned from the past from oral sources that are not concerned with the past and hence testify despite themselves. Indeed, that characteristic make them more reliable precisely because they are unconscious contributions". 
as boas questões, de enxergar e de levar em conta aquilo que anteriormente se encontrava escotomizado, em suma de renovar a investigação" ${ }^{12}$.

O conceito da "mise en objet"13, proposto por Warnier, também foi incorporado à reflexão sobre a alimentação colonial lusa transformada em objeto de análise para investigar parâmetros de ajustamento dos colonos lusos às condições da vida social e da topografia soteropolitana. Tratava-se do processo da simbiose ocorrida entre corpos humanos e objetos manuseados. Segundo Warnier o fato de consumir criava um espaço de produção de significados. Como sublinhava o autor, objetos de cultura material criados para ampliar a eficácia técnica dos gestos e facilitar a execução de tarefas cotidianas, serviam de "próteses" para multiplicar o escopo das ações possíveis, mas exigiam, em contrapartida, aprendizagens específicas de manuseio corporal ${ }^{14}$. No caso do estabelecimento de um estilo de vida mazombo, ressaltava, entre outros elementos, a dependência extrema dos colonos em relação aos cativos promovidos a implementos indispensáveis no trato da vida social.

12 WARNIER, Jean Pierre. Op. Cit., p. 59.

“Ce geste, comme tant d'autres de même sorte, ne s'assembla àmes yeux avec quelque logique que près de quinze ans plus tard. Pendant toute cette période, je ne les mentionnai pas, ou à peine, dans mes écrits ethnographiques car ils n'entraient pas en cohérence les uns avec les autres. Pour que cela se fasse, il a fallu que la gestuelle, les techniques du corps, les conduites motrices dans leur rapport aux substances et aux choses perdent leur statut de quasi-mots, de signes, et s'articulent en tant que pratiques, techniques de soi, action de soi sur soi et sur les actions des autres. La fécondité heuristique d'une théorie se mesure à sa capacité à poser les bonnes questions, à voir et à prendre en compte ce qu'on scotomisait auparavant, bref à renouveller l'enquête".

13 WARNIER, Jean Pierre. Op. Cit., cf. capítulo 3.

"L'ethnographie de la mise en objet". A Mise em objet resultaria de uma síntese corporal, percepção sintética e dinâmica do sujeito em relação à sua própria pessoa, aos gestos efetuados e ao lugar que lhe cabe ocupar num determinado tempo e espaço e envolveria aprendizagens de manuseio dos objetos que prosseguiriam ao longo de toda a vida.

14 O caso de árabes calçados de babuches conseguindo descer escadas sem deixar cair os chinelos graças ao traquejo adquirido no uso de tais implementos, se afigurava paradigmático. 
As queixas do autor, inseridas nos poemas sob forma de metáforas correlacionadas à alimentação (entre outras analogias) permitiram perceber quão tensa se apresentava a situação colonial nas últimas décadas do século XVII. Os procedimentos soteropolitanos relacionados, lato senso, à alimentação propiciaram ao poeta um instrumento de estilo popular, utilizado como adorno erudito, para formular considerações morais. Esmiuçar literariamente detalhes corriqueiros da vida colonial permitiu a Matos descrever com grande força de impacto as tensões sociais que opunham então colonizadores provenientes de levas recentes e antigas de imigração européia, populações autóctones remanescentes e cativos africanos. Transgressões cometidas contra os códigos morais vigentes foram sublinhadas pelo poeta, ora em termos de conselhos alimentares irônicos e abstratos, tais como: “Furte, coma, beba e tenha amiga..."15, ora em termos de práticas materiais lusas ou locais, carregadas de valor semântico. Destinaram-se a censurar atitudes que enfureciam o "Doutor", tais como a maneira como certas autoridades conduziam a colônia ou a sem cerimônia das condutas sociais de arrivistas enriquecidos. Contudo, a própria necessidade de se queixar revelava também que os valores sociais mazombos, nos quais o poeta acreditava, estavam se tornando utópicos.

Houve efetivamente um momento bastante crítico na vida da capital da colônia em torno do exercício do poder político na década de $1680^{16}$. O aparecimento de dois cometas, presságio nefasto, apavorou os colonos. Secas, epidemias de

15 MATOS, G. Op. Cit., Vol. VI, p. 1387.

16 SCHWARTZ, Stuart B. Burocracia e sociedade no Brasil colonial. São Paulo, Perspectiva, 1979, p. 195.

"Depois de1650, a crescente competição das ilhas açucareiras no mar das Caraibas e as vicissitudes da agricultura no Brasil impediram seriamente o desenvolvimento da indústria brasileira do açúcar. A crise chegou em 1680 e, embora a indústria tenha se recuperado em parte, sofreu um segundo golpe nos fins da década de 90". 
febre amarela, mortes de escravos, a retração da produção agrícola e da safra de açúcar se sucederam então num ritmo apavorante ${ }^{17}$.

Também repercutiu a questão espinhosa do desempenho da Companhia de Comercio encarregada de proteger o transporte das caixas de açúcar contra eventuais ataques de $\operatorname{corsários}^{18}$. Essa Companhia, mantida por grandes negociantes reinóis que proviam lucros polpudos à corte de Lisboa graças aos rendimentos do comércio do açúcar, armava frotas anuais para a navegação das naus em comboio e desfrutava de um monopólio sobre o fornecimento de mercadorias portuguesas aos colonos. Criaram-se, por vezes, situações de escassez. A diminuição deliberada das remessas de produtos importados necessários à colônia, como o sal, gerou profundos descontentamentos. Os interesses dessa companhia, incentivados em detrimento daqueles dos senhores de engenho e dos lavradores de canas, afetaram os proprietários rurais. Impedidos de negociarem diretamente com a metrópole, os senhores de engenho amargaram sérias perdas de rentabilidade na venda de suas safras de açúcar, que, além do mais, coincidiam com o surgimento de fortes concorrentes nas ilhas inglesas, 17 FERLINI, Vera Lúcia. Terra trabalho e poder: o mundo dos engenhos no nordeste colonial. Bauru, EDUSC, 2003. p. 110.

“Em 1683, o Senado de Salvador comunicava a Sua Majestade que 'os tempos cada vez vão sendo mais miseráveis, além da grande perda que houve com as bexigas nas escravarias que he a fabrica de todos os frutos deste Estado, pela inclemência do tempo na safra passada houve pouco açúcar e nesta menos porque não tem chegado a 10.000 caixas. E a fome de novembro até o presente tem sido grande... com que está a capitania muito extenuada e os credores sempre tratando de cobrar por execuções'. A década de 1680 representou, para Portugal e suas colônias, o ponto mais baixo da depressão econômica".

18 FERLINI, Vera Lúcia. Op. Cit., pp. 96 e 97.

“O padre Antônio Vieira articulou a Companhia Geral do Comércio do Estado do Brasil, em cuja organização poderiam participar cidadãos portugueses ou estrangeiros residentes em Portugal. Dotada de uma série de privilégios, a Companhia comboiaria todos os navios mercantes que viessem ao Brasil ou daqui voltassem, a uma taxa não superior a 10\% e seguro não inferior a 25\%. O vinho, o azeite, a farinha de trigo e o bacalhau eram gêneros estancados da Companhia". 
holandesas e francesas do Caribe e com a derrubada dos preços do açúcar no mercado internacional ${ }^{19}$.

Não foi no plano do contexto macro-econômico, todavia, que surgiu na tese o embate entre colonizadores, populações indígenas desalojadas, escravizadas ou dizimadas, cativos africanos transplantados e mestiços resultando dos convívios sexuais cotidianos. Por mais que, numa economia exportadora mercantilista, as relações de produção fossem essenciais à vida colonial, os fatos alimentares pesquisados, sínteses de procedimentos utilizados para lidar com a natureza sul-americana, precisavam ser estudados em sua vinculação com a organização social e cultural soteropolitana. As formas de produção da subsistência provinham de protocolos efetivos de manejos de fauna e de flora brasileiras, de métodos agropecuários europeus, africanos ou asiáticos, de adoções de técnicas de pesca e de agricultura indígenas, além de um universo de relações sociais interétnicas concebido nos termos de uma desigualdade social fundamental.

Crenças sobre as propriedades dos alimentos e gestos instituídos ofereciam, dessa forma, um enorme potencial de representação simbólica decorrente da imbricação entre a materialidade dos nutrientes e sua idealização cultural: produção, beneficiamento, transporte, armazenamento, aquisição e consumo de gêneros comestíveis. Os poemas de Matos, porém, raramente aludiam às técnicas da subsistência alimentar em uso na colônia com a intenção precípua de descrevêlas. Efetivamente, percorriam um caminho inverso. Eram os procedimentos conhecidos de produção de alimentos que, por meio de metáforas, remetiam aos valores sociais atribuídos a cada tipo de ingrediente comestível e permitiam observar uma articulação ampla de fatores culturais vigentes.

Valores sociais aceitos pelos soteropolitanos, sentimentos, conhecimentos sobre a fisiologia dos corpos humanos ou sobre os manejos apropriados para lidar com o meio ambiente se

19 FERLINI, Vera Lúcia. Op. Cit., p. 106.

“A baixa dos preços do açúcar gerava problemas monetários mais graves na Colônia. Ficando o saldo comercial desfavorável para os produtores, os comerciantes exigiam pagamentos em moeda, o que tornava o numerário mais escasso. E, se os produtos coloniais não baixavam na mesma proporção que no mercado europeu, para manter os lucros, os mercadores aumentavam os preços dos produtos que do Reino traziam". 
expressavam atrelados às metáforas do autor. Apresentavam um fenômeno familiar aos antropólogos, um fato social total ${ }^{20}$ semelhante àqueles analisados por Marcel Mauss, nos quais a confluência de inúmeros elementos de natureza diversa atuava para configurar situações sociais. O fio da meada a ser seguido para desvendar a imbricação peculiar de idéias subentendidas nos gestos alimentares dos colonos passava por uma análise das técnicas corporais associadas aos hábitos da nutrição (referenciando outro ensaio do mesmo autor ${ }^{21}$ ).

O corpus dos poemas de Matos revelou à leitura uma infinidade de exemplos, daquilo que Carlo Ginzburg chamou "premissas tácitas" ${ }^{22}$. Em sua obra, Relações deforça: história, retórica, prova, o estudioso sublinhava a existência, em cada sociedade, de regras locais "escritas com tinta invisível no tecido da vida cotidiana", resultando em formas de ação previsíveis e recorrentes, que nada tinham de universal, constituindo apenas as maneiras de proceder pertinentes a um determinado povo. Configuravam-se através de escolhas locais de gestos, como no caso do hábito convencional grego de se oferecer uma coroa de louro ao vencedor dos jogos olímpicos, um costume que foi estranhado por forasteiros como os soldados persas de Xerxes, a ponto de solicitarem informações sobre o significado desse uso.

No caso precitado dos poemas de Gregório de Matos, as numerosas metáforas alimentares introduzidas nos versos, mesmo que se apresentassem sobretudo sob forma de descrições rápidas de ações isoladas, suportavam polissemias complexas de valores. Ao serem aglutinadas, examinadas em conjunto e confrontadas com dados fornecidos por outras fontes documentárias do período, proporcionavam à pesquisa não somente fragmentos de premissas, mas ainda

20 MAUSS, Marcel. "Ensaio sobre a dádiva", in Sociologia e Antropologia, São Paulo, Cosac e Naify, 2003.

"Nesses fenômenos sociais "totais", como nos propomos chamá-los, exprimem-se, de uma só vez, as mais diversas instituições: religiosas, jurídicas e morais - estas sendo políticas e familiares ao mesmo tempo - econômicas - estas supondo formas particulares da produção e do consumo, ou melhor do fornecimento e da distribuição -; sem contar os fenômenos estéticos em que resultam esses fatos e os fenômenos morfológicos que estas instituições manifestam". p. 187.

21 MAUSS, Marcel. "As técnicas do corpo", in Sociologia e Antropologia, São Paulo, Cosac e Naify, 2003. GINZBURG, Carlo. Relações de força. São Paulo, Cia das Letras, 2000. p. 52 a 55. 
redes complexas de procedimentos interligados. Examinar esses conjuntos de práticas locais carregadas de significados que davam forma à subsistência da população colonial fundamentava o estudo etnográfico do estilo de vida soteropolitano. Salpicados ao acaso de argumentações ilustradas por exemplos práticos, cujo intento era criticar condutas inadequadas de indivíduos ou de grupos sociais, os gestos usuais da população colonial relatados nos versos retiveram a atenção. Apareciam de relance nos poemas do autor quitandeiras em tropel pela cidade, escravos enfrascados de jeribita (aguardente de cana fabricada nos alambiques da terra), pardos emborcados de soberba, sargentos que escondiam farinhas de mandioca nos aposentos, colonos munidos de varas para colher cajus maduros pelos campos, gente expondo mesuras, cortesias, vaidades e ódios figadais.

Nem todas as metáforas, que transbordaram a indignação de Matos contra infrações observadas aos códigos sociais tradicionais, pertenciam ao domínio alimentar e tampouco expressaram apenas criações originais (um grande número de frases feitas e de clichês também se infiltrou nos versos, como uma referência irônica e simbólica à cozinha da casa de grandes conselheiros, transformada num lócus de atividades pouco honoráveis ${ }^{23}$ ), porém, um grande número de analogias escapando ao universo dos lugares comuns, atestou a capacidade de observação do autor e seu agudo senso crítico. Muitas metáforas alusivas a temas cotidianos, tais como os termos náuticos ou os hábitos alimentares inspiraram imagens vistosas ao poeta. Mas ao traduzir seu ideal de vida colonial em ações concretas, que envolviam objetos de cultura material investidos com o poder de distinguir socialmente quem os utilizava ${ }^{24}$, o poeta recorreu sobretudo aos hábitos alimentares para desmerecer modos de agir que infringiam os parâmetros nobres dos senhores de engenho e dos lavradores de canas, apesar da memória lhe oferecer um espectro abrangente de outros acontecimentos miúdos.

23 Cf. citação do poema de Matos colocado em epígrafe ao capítulo II: "Não sabem governar sua cozinha, /E podem governar o mundo inteiro".

24 Poder consumir alimentos de maior preço ou raridade constituía para os homens importantes da colônia uma forma de se distinguirem dos demais. $\mathrm{O}$ fato de desfrutarem de melhores condições de vida ou de propiciarem tratamentos honrosos aos hóspedes recebidos atestavam sua preeminência social. 
Em suas poesias, Matos articulou práticas coloniais seiscentistas e idéias subentendidas. Encenou, assim, uma infinidade de ações ridículas para resguardar os princípios da hierarquia social das atuações de arrivistas, que critérios mazombos de precedência não impediam de tentar ascender na escala social. Atrelando valores culturais prestigiados pelas elites como o ócio, a generosidade ou a honra a ações vulgares do dia-a- dia para convencer os recalcitrantes, a verve satírica do autor, que não se apresentava desprovida de senso de humor ou de lirismo, acabou trazendo à tona, por ricochete, gestos significativos do cotidiano colonial. Hábitos alimentares carregados de uma polissemia de valores sociais ou culturais the ofereceram um rico manancial de termos de comparação para explicar seus pontos de vista. Por exemplo, ao voltar à ilha da Cajaíba, após um período de ausência, ele encontrou o engenho impossibilitado de moer e apenas o "bagaço do pecado" 25.

Escritos cerca de cento e trinta ou cento e quarenta anos após a instalação dos primeiros contingentes de emigrantes portugueses às margens do Recôncavo baiano ${ }^{26}$, os poemas de Gregório de Matos, ilustraram regras de conduta implícitas numa sociedade colonial que já se autodenominava mazomba, apesar de incorporar constantemente novas levas de imigrantes. Os versos compostos esboçavam uma imagem verossímil do universo colonial ao qual o poeta pertencia e confirmavam a sedimentação de formas de vida local, restritas, no entanto, ao uso das elites. As idéias que Gregório de Matos, artesão de palavras escritas, alinhavou sob forma de tropos obedeciam, como será visto no primeiro capítulo da tese, aos preceitos de uma arte poética barroca à moda ibérica. Porém, apesar de normas convencionais moldarem os relatos poéticos e a forma da versificação, tornando necessária uma análise dos recursos de estilo, a argumentação, que o autor desenvolveu, não se restringiu apenas a retomar temas poéticos correntes na metrópole.

Porta-voz auto-designado de mazombos espoliados pela crise do açúcar e pelas mudanças sociais introduzidas no modo de vida colonial, o autor, por sua condição de letrado, neto de 25 MATOS, G. Op. Cit., Vol. VI, p. 1458.

26 O povoamento da terra efetivou-se, por volta de 1549 , à partir da transformação da região em capitania real. 
um familiar da Inquisição, ex-magistrado quase clérigo e versejador de méritos reconhecidos na corte lisboeta, escolheu Tália como musa de versos, cujo registro cômico oscilou entre o burlesco ameno e a sátira feroz expressando, tanto alegrias da vida rural ou urbana na capitania real, quanto queixas soteropolitanas. A própria preservação dos poemas, nos quais o estilo chulo e as demonstrações de bufonaria visaram à moralização dos costumes, atestam o apreço efetivo do público pela arte de Matos e pelos valores apregoados. Com efeito, diversos códices setecentistas apógrafos, contendo coletâneas de poemas de Matos foram transmitidos de geração em geração de colonos após o exílio do poeta, enviado para Angola em razão da virulência dos versos compostos para desmerecer o governador Câmara Coutinho.

Descrever gestos em tais poemas, equivalia a falar de emoções despertadas e a referir movimentações intencionais dos corpos físicos das pessoas reunidas em território colonial. Esses corpos agindo socialmente, não obstante retratados em traços rápidos freqüentemente caricaturais, articulavam ações e valores, explicitavam os pontos de vista do poeta e revelavam o teor das considerações implicadas, de forma subjacente, no manejo dos principais ingredientes comestíveis incorporados à dieta. O fazer poético de Matos condensava efetivamente um leque amplo de elementos materiais dotados do poder de traduzir valores sociais e culturais. As alusões aos hábitos praticados localmente delineavam, além dos contornos do sistema alimentar vigente, toda uma concepção de vida e de categorias hierárquicas de pessoas. Como numa escavação arqueológica pré-histórica, cada objeto de cultura material resgatado no solo ou nos versos importava por seu valor próprio, pelos procedimentos de fabricação ou de uso que podia indicar e, ainda, pelos feixes de relações sociais que permitia inferir ${ }^{27}$.

Documentar indícios de costumes alimentares praticados pelos soteropolitanos e descobrir quais eram os significados atrelados a esses gestos proporcionava um caminho interessante à investigação. A micro-história de Carlo Ginzburg e sua investigação de pistas ínfimas de significados trouxe elementos para pensar os fatores que modelavam os procedimentos coloniais.

27 Concebida segundo o conceito de escavação desenvolvido pela escola francesa de Leroi-Gourhan a partir de escavações realizadas no sítio arqueológico de Pincevent. Cf., por exemplo, o verbete fouille pp. 105 a 107 : Dictionnaire de la préhistoire. Org. Michel BRÉZILLON, Paris, Larousse, 1969. 
Um ensaio do autor, em particular, "Sinais: raízes de um parâmetro indiciário" ${ }^{28}$, oferecia subsídios à análise. Segundo Guinzburg:

"Por milênios o homem foi caçador. Durante inúmeras perseguições, ele aprendeu a reconstruir as formas e movimentos das presas invisiveis pelas pegadas na lama, ramos quebrados, bolotas de esterco, tufos de pêlos, plumas emaranhadas, odores estagnados. Aprendeu a farejar, registrar, interpretar e classificar pistas infinitesimais como fios de barba. Aprendeu a fazer operações mentais complexas com rapidez fulminante, no interior de um denso bosque ou numa clareira cheia de ciladas.

Gerações e gerações de caçadores enriqueceram e transmitiram esse patrimônio cognoscitivo. "Na falta de uma documentação verbal para se pôr ao lado das pinturas rupestres e dos artefatos, podemos recorrer às narrativas de fábulas, que do saber daqueles remotos caçadores transmitem-nos às vezes como um eco, mesmo que tardio e deformado" ${ }^{29}$.

Havia pistas inegáveis de premissas tácitas provendo substância às metáforas alimentares de Gregório de Matos, tanto no plano das representações que definiam lugares apropriados para cada tipo de indivíduo na sociedade soteropolitana, quanto no plano das práticas alimentares mazombas mencionadas para remeter, nas entrelinhas, aos valores que os colonos atribuíam aos diversos ingredientes comestíveis. O fulcro da análise, no exame das metáforas alimentares de Matos, precisava, portanto, incidir sobre a investigação de uma constelação complexa de significados culturais subjacentes ao estilo de vida peculiar dos colonos e que incluía forçosamente um estilo específico de alimentação local.

A manutenção dos corpos, motivo de escolhas de hábitos culinários e de procedimentos de abastecimento alimentar, ofereceu suporte poético para analisar as associações de ações 28 GINZBURG, Carlo. "Sinais: raízes de um parâmetro indiciário", in Mitos, emblemas, sinais . São Paulo, Cia das Letras, 2002. 
práticas costumeiras dos colonos voltadas para a manutenção da saúde, da fé e do prestígio social e a maneira como eles consideravam sua identidade pessoal. Como observou David Le Breton, sociólogo e antropólogo que trabalhou sob influência dos conceitos de Mauss de fato social total e de técnicas corporais:

"Os usos fisicos do homem dependem de um conjunto de sistemas simbólicos. Do corpo nascem e se propagam as significações que fundamentam a existência individual e colectiva, ele é o eixo da relação com o mundo, o lugar e o tempo nos quais a existência toma forma através da fisionomia singular de um actor. Através do corpo, o homem apropria-se da substância de sua vida traduzindo-a para os outros, servindo-se dos sistemas simbólicos que compartilha com os membros de sua comunidade"30.

O estudioso exemplificava:

"A configuração dos sentidos, a tonalidade e contorno de seu desenvolvimento, são de natureza não somente fisiológica, mas também social. A cada instante decodificamos sensorialmente o mundo transformando-o em informações visuais, auditivas, olfactivas, táteis ou gustativas. Assim, certos sinais corporais escapam totalmente ao controle da vontade ou da consciência do ator, mas nem por isso perdem sua dimensão cultural e social" ${ }^{31}$.

30 LE BRETON, David. A sociologia do corpo. Petrópolis, Vozes, 2006. p.7. La sociologie du corps. Paris, Que sais-je?, PUF, 5 ème edition, 2004. p. 4.

"Les mises en jeu physiques de l'homme relèvent d'un ensemble de systèmes symboliques. Du corps naissent et se propagent les significations qui fondent l'existence individuelle et collective. Il est l'axe de la relation au monde, le lieu et le temps où l'existence prend chair à travers le visage singulier d'un acteur. A travers lui, l'homme s'approprie la substance de sa vie et la traduit à l'adresse des autres par l'intermédiaire des systèmes symboliques qu'il partage avec les membres de sa communauté".

31 LE BRETON, David. A sociologia do corpo. Op. Cit., p.55 ou La sociologie du corps. Op.Cit., p. 68.

“La configuration des sens, la tonalité et le contour de leur déploiement, sont de nature sociale et non seulement physiologique. A chaque instant nous décodons sensoriellement le monde en le transformant en informations visuelles, auditives, olfactives, tactiles ou gustatives. Certains traits corporels échappent donc totalement au contrôle de la volonté ou de la conscience de l'acteur, mais ils n'en perdent pas pour autant leur dimension culturelle et sociale". 
Como já afirmado anteriormente, considerar as metáforas alimentares contidas nos poemas de Gregório de Matos como pretexto, isto é, como ponto de partida para investigar as maneiras de pensar e as maneiras de agir dos colonos estabelecidos em Salvador, transformou os procedimentos de alimentação citados nos versos em objeto central para o desenvolvimento da tese. O tema da alimentação soteropolitana seiscentista permitiu, de fato, resgatar num documento literário, rico em conteúdo humano, elementos de conhecimento sobre o estilo de vida mantido pelos colonos mazombos, em fins do século XVII. Porém, ao ser promovido a instrumento de análise numa monografia histórica de intenção etnográfica, o tema da alimentação também se revelou propício para indicar os problemas sociais e materiais que a sociedade enfrentava, o teor das argumentações implícitas nas soluções implementadas e o alcance dos processos sociais travados no campo dos valores sociais e culturais instituídos.

Nos poemas do autor, encenações dramáticas de valores culturais carregados de emoção, entrelaçavam objetos de cultura material e concepções ideais, que envolviam os ingredientes comestíveis. Episódios soteropolitanos, autênticos ou inventados para os propósitos da argumentação poética, referiam um amplo elenco de manejos alimentares atrelados a conceitos, enveredando às vezes por anedotas bucólicas ou escabrosas e evidenciando uma sedimentação dos conhecimentos locais. Ofereciam, por conseguinte, uma via privilegiada de abordagem para pesquisar os processos sociais e os códigos culturais, que tinham modelado o estilo de vida mazombo instaurado na colônia e as crises que o afetavam. O cenário da vida cotidiana transparecia nos versos através de uma profusão de detalhes referentes a hábitos alimentares ou ao abastecimento dos colonos em mantimentos secos e víveres frescos. Na medida em que aprovisionamento e consumo alimentar correntes na capital do Brasil e no Recôncavo adjacente serviram ao poeta para formular críticas à sociedade que extrapolavam o plano da nutrição, ofereciam, pela mesma ocasião, um acesso indireto aos propósitos políticos, econômicos e sociais dos colonizadores portugueses, pois, afinal, a própria eficácia econômica e política do domínio colonial repousava neles. 
A articulação entre as formas de perceber o domínio colonial ou de conceber certa identidade da população lusa e o modo como os colonos lidavam com o meio ambiente e o meio social passavam inegavelmente pelas ações sociais de corpos imersos no contexto colonial e pelos manejos escolhidos em função de saberes adquiridos e de códigos sociais inculcados, cujas alterações estavam sendo discutidas. Frente à descoberta de peculiaridades do meio ambiente local a serem contornadas, conhecimentos técnicos, crenças e preocupações de âmbito cultural configuravam leques de procedimentos ideados para solucionar dificuldades locais de provimento e para oferecer aos homens maneiras de viver condizentes com suas pessoas.

Existiam continuidades óbvias entre o modo português de se levar a vida em Lisboa e na colônia e muitos procedimentos mazombos prolongavam hábitos lusos, mas o universo soteropolitano tinha imposto ajustamentos e compromissos em função da situação local. A enorme dependência corporal dos colonos em relação ao trabalho da mão-de-obra escrava para produzir açúcar, tabaco, mantimentos e subsistência ou criar gado, por exemplo, decorria de soluções locais imaginadas pelos colonos frente aos problemas sociais ou ambientais que precisaram contornar. De modo que, por mais que os colonos tivessem chegado ao Novo Mundo com bagagens de usos e de costumes portugueses e procurassem preservá-los, os acontecimentos do dia-a-dia soteropolitano incentivavam à modificação dos modos de agir e de pensar.

Em torno de alimentos, argumentos de natureza bastante diferenciada e discursos heterogêneos se confundiam. A convergência de considerações práticas, de considerações sociais e religiosas ou, ainda, de conhecimentos técnicos voltados para questões de gosto ou de crenças sobre a manutenção da saúde se mostrou elemento fundamental. Conjuntamente, tais argumentos definiam um universo intrincado de motivações necessárias à análise dos procedimentos alimentares vigentes. Joseph Delteil ${ }^{32}$, por exemplo, apresentando, num opúsculo intitulado: "La cuisine paléolithique", singela apologia do uso dos melhores ingredientes de sua região residencial (seu terroir), sublinhou a relevância das múltiplas funções de alimentos, simultaneamente respostas a desejos da alma, sustentos de apetites fisiológicos, metabolismos 
saborosos, transmutações de satisfação gástrica em deleites de convívio social e ainda fatores de uma gratidão devida à generosidade divina. Ao insistir sobre a importância do estímulo desencadeado pela degustação de matérias-primas vegetais ou animais aprestadas por meio de recursos técnicos, em momentos ideais de perfeição, o autor se referia à condensação complexa e prazerosa de elementos sensíveis e intelectuais em torno de iguarias consumidas.

A obra: "Sweetness and power: the place of sugar in Modern History" de Sidney Mintz serviu de referência teórica para essa tese. Mintz, com efeito, ao cabo de longos anos de experiência de campo no Caribe, que o levaram a manter um contato prolongado com as especificidades da produção de açúcar na região, resolveu se debruçar sobre documentos primários e textos, cuja leitura lhe permitiu abordar a questão do significado dos valores, que orientaram as práticas coloniais caribenhas, entre os séculos XVII e XIX. Ao analisar o fenômeno histórico, social e cultural da súbita expansão da produção colonial de um ingrediente alimentar anteriormente raro e caro, cujo consumo se tornara repentinamente indispensável numa sociedade inglesa em vias de industrialização, o antropólogo enfatizou a importância de se deixar guiar pelo conteúdo etnográfico ao escrever um livro, que apresentava uma tendência inesperada a "se escrever sozinho". Expressando, em tom de brincadeira, a esperança de que coisas que não soubesse lhe seriam reveladas, Mintz procurou ${ }^{33}$ trazer à tona significados implícitos nas maneiras de agir. Tratava-se, no caso, menos de renunciar a organizar a análise, que de rastrear nas fontes consultadas indícios fidedignos sobre o teor dos valores culturais e sociais que norteavam as ações relacionadas à produção do açúcar.

A charada antropológica que o estudioso investigou, a transformação dos significados atribuídos ao consumo do açúcar, acompanhando alterações nas condições britânicas de existência ocorridas ao longo do processo da industrialização, e o modo como o autor decifrou o mistério das mudanças no consumo de alimentos doces têm muito a ver com o resgate de valores culturais coloniais implícitos na versificação de Gregório de Matos. O empréstimo

33 MINTZ, Sidney. Sweetness and power: the place of sugar in Modern History. New York, Penguin Books, 1985. Introdução, p XXVIII. 
principal, que a investigação e a sistematização dos dados encontrados nos poemas efetuaram ao modelo, residiu na importância da dupla leitura de fatos proposta por Mintz para decifrar o significado dos eventos. Como o autor afirmou:

“A cultura precisa ser entendida 'não apenas como um produto, mas também como uma produção, não somente como constituída socialmente mas também como constituindo a sociedade’. Decodifica-se o processo da codificação, e não apenas o próprio código" 34 .

Efetivamente:

“A utilização implica a existência de significados; para aprender a antropologia do açúcar, precisamos investigar os significados de seus usos, descobrir as mais antigas e mais restritas utilizações do açúcar, e aprender onde e com que propósito original o açúcar foi produzido. O que implica examinar as fontes de provimento, a cronologia dos usos e a associação do açúcar com outros alimentos..." 35.

A construção social dos indivíduos, associada às escolhas de ingredientes comestíveis, também mereceu reparo de Mintz:

“Obviamente, as escolhas alimentares dependem de certa forma da disponibilidade, mas os seres humanos nunca comem todos os alimentos comestíveis disponíveis 34 MINTZ, Sidney. Op. Cit., p. 14 (texto português: minha tradução).

"Culture must be understood "not simply as a product, but also as production, not simply as socially constituted but also as socially constituting". One decode the process of codification, and not merely the code itself".

35 MINTZ, Sidney. Op. Cit., idem, (texto português: minha tradução).

"Uses imply meanings; to learn the anthropology of sugar, we need to explore the meanings of its uses, to discover the early and more limited uses of sugar, and to learn where and for what original purpose sugar was produced. This means examining the sources of supply, the chronology of uses, and the combination of sugar with other foods...". 
em seu meio ambiente. Além do mais, suas preferências alimentares se encontram estreitamente associadas à representação, que formulam a seu próprio respeito: pessoas que comem alimentos espantosamente diferentes ou alimentos semelhantes de forma bem diferenciada são considerados notavelmente diferentes, por vezes até menos humanos. [....] As escolhas alimentares e os hábitos de alimentação revelam distinções de idade, de sexo, de status, de cultura e até de ocupação profissional. Essas distinções constituem os requintes imensamente importantes de uma necessidade inapelável" ${ }^{36}$.

Conseqüentemente, os alimentos disponíveis em território soteropolitano, avaliados e manejados em função de suas propriedades nutritivas e gustativas ou das representações simbólicas que os colonos associavam a seu consumo, integravam o conjunto dos hábitos praticados na colônia na condição de marcadores sociais. Escolher alimentos aptos a prover substâncias corporais idôneas às diversas categorias de colonos reunidos no espaço colonial, parece ter constituído uma preocupação recorrente entre os colonos de maior projeção social. Eram, por exemplo, os homens de prol que decidiam de que maneira preferiam alimentar seus escravos, proporcionandolhes rações ou outorgando-lhes pedaços de terra cultiváveis e um dia da semana para produzir o próprio sustento. Eram eles também que procuravam adquirir para sua própria mesa gêneros alimentícios capazes de atestarem sua sabedoria e seu prestígio pessoal.

36 MINTZ, Sidney. Op. Cit., p. 3, cap. 1: “Food, sociality and sugar" (texto português: minha tradução).

"Of course, food choices are related in some ways to availability, but human beings never eat every edible and available food in their environment. Moreover, their food preferences are close to the center of their self-definition: people who eat strikingly different foods or similar foods in different ways are thought to be strikingly different, sometimes even less human. [....] Food choices and eating habits reveal distinctions of age, sex, status, culture and even occupation. These distinction are immensely important adornments on an inescapable necessity". 
Pícaros e homens bons ${ }^{37}$ não se alimentavam de maneiras similares. A latitude de escolher sem limitações a própria alimentação afigurou-se critério relevante de distinção social. Colonos livres, mas pobres, não conseguiam adquirir alimentos de custo elevado, sendo que mulheres de todas as condições sociais, pouco autorizadas a sair de casa, não iam escolher nas feiras soteropolitanas os víveres que desejavam fornecer a suas famílias.

Não havia correlações obrigatórias entre os alimentos consumidos por um indivíduo e a representação de sua pessoa. Porém, que existissem procedimentos alimentares formalmente constituídos, possibilidades de escolha de alimentos e indícios de argumentos lógicos envolvidos nas práticas do estilo de vida soteropolitano dava margem à criação de metáforas que sublinhavam analogias observadas.

A transformação literária que Matos operou, utilizando os hábitos alimentares de uma sociedade colonial ciosa de suas prerrogativas e de sua hierarquia social, para representar a condição social dos homens retratados nas sátiras ou nos poemas burlescos ofereceu um ponto de partida para investigar os alimentos que a população soteropolitana julgou convenientes à dignidade de suas pessoas.

Tomou-se por base a coletânea cuidadosamente organizada, que James Amado publicou em 1968 na Cidade da Bahia: a Crônica do viver baiano seiscentista feita em verso pelo Doutor Gregório de Matos e Guerra: fielmente copiada de manuscritos anônimos daquele tempo e disposta como melhor pareceu a um curioso de nome James Amado. Essa primeira edição não expurgada da obra expondo o texto de códices apógrafos, eivados de expressões chulas que impediram sua divulgação pública por cerca de trezentos anos continha efetivamente a grande maioria dos poemas conhecidos do autor: "Reúne toda a obra poética de G.M., ou a ele

37 Os pícaros, nos poemas de Matos, eram colonos astutos que praticavam o comércio e todos os demais aventureiros que aviltavam os efetivos coloniais. O termo mantinha vínculos com um dos gêneros literários em voga na época: as novelas picarescas. Os homens bons eram colonos abastados, que possuíam terras ou cargos relevantes e não viviam do trabalho das próprias mãos. Podiam designar os eleitores que escolhiam vereadores (cf. Laima MESGRAVIS. “Os aspectos estamentais da estrutura social do Brasil colônia”, in Estudos econômicos, $\mathrm{n}^{\circ}$ 13, pp. 799 a 811,1983, p. 801. 
atribuída, com centenas de inéditos, inclusive toda a erótica do poeta baiano. Pesquisada em 25 volumes de 17 códices manuscritos dos séculos XVII e XVIII...".

\section{As questões investigadas}

Apesar de não apresentar intencionalmente uma descrição naturalista da sociedade colonial, Matos, ao formular metáforas que citavam práticas de provimento e de consumo alimentar, registrou indiretamente muitos elementos do contexto social e geográfico soteropolitano. Ora comentando acontecimentos, ora distorcendo didaticamente os fatos para defender pontos de vista, ora criando peripécias extravagantes, a arte do poeta possibilitou flagrar o impacto de eventos e de temas de conversas de grande repercussão social. O corpo de indivíduos satirizados, enquanto suporte de ações alimentares, the serviu para delinear os contornos de uma concepção de vida subjacente. Em sua qualidade de fontes documentais, os versos do autor ofereceram uma via de acesso privilegiada aos parâmetros éticos e estéticos da sociabilidade colonial.

O interesse em pesquisar as informações alimentares contidas na obra de Gregório de Matos residiu na vinculação proporcionada pela arte poética entre modos de agir, de pensar e de sentir específicos à colônia associados às imagens que os membros da elite colonial formulavam a respeito de suas próprias pessoas $^{38}$. Os tropos referindo atos alimentares serviram a Gregório de Matos de instrumento de expressão para criticar a vida soteropolitana. O entrelaçamento de argumentos de natureza fisiológica, psicológica, cultural e social marcando as representações dos comensais lusos da capital do Brasil remetia a códigos sociais providos de coerência intrínseca. A concepção que colonos lusos nascidos no Brasil, desde que não demasiadamente pobres, tinham do papel social que pretendiam desempenhar e das formas de organização da colônia, que faziam questão de preservar, penetrou na composição dos versos sob forma de metáforas sobre alimentos, preparos culinários e consumos de alimentos.

\footnotetext{
38 Já, por volta de 1640, durante o período das invasões holandesas, os moradores de Pernambuco afirmavam aos representantes da Companhia das Índias holandesa, a WIC. que sem respeitarem as normas que regulavam as relações sociais entre portugueses, índios e escravos africanos, e os procedimentos locais de manejo da natureza, jamais conseguiriam tirar proveito do território conquistado.
} 
As comparações constituíram para o poeta um meio de formular representações e não um fim em si. Vituperaram os procedimentos locais de gestão administrativa, jurídica ou fiscal e os problemas que afetavam o modelo a sociedade. Em torno da discussão dos conceitos da dieta colonial, os versos do poeta indicaram efetivamente a existência de um estilo de vida em crise. Considerando que a colônia (da qual Matos foi banido em 1694) estava às vésperas de descobrir ouro nas Minas Gerais, circunstância que deslocaria, cerca de meio século depois, o centro de gravidade econômica para o Rio de Janeiro, a existência de uma obra literária que revelava os motivos de descontentamento dos soteropolitanos com a situação vivida era bastante atraente ao empreendimento da pesquisa imaginada ${ }^{39}$.

Apesar de trabalhar com fragmentos de informação espalhados com outros intentos, ao sabor da argumentação, o fato do poeta referir práticas de alimentação para conferir veracidade a mimeses de realidade, impregnadas de significados ocultos e formuladas para deleitar o público ${ }^{40}$, atestava sua condição de hábitos nativos. As menções feitas a ingredientes comestíveis e a usos soteropolitanos de alimentação encontraram na arte do autor um registro espontâneo e rico, assinalado por meio de floreios engenhosos de linguagem destinados a ouvintes, que reconheciam provavelmente sua cidade nas descrições poéticas. Para ouvintes mazombos as charadas propostas não apresentavam dificuldades de compreensão, pois remetiam às premissas

39 É preciso lembrar o alvoroço ocorrido, no decorrer dos anos 90, com a descoberta de minas de ouro no planalto central. Poucos anos após o "despacho" do poeta, o ouro mineiro atrairia um grande número de soteropolitanos e de imigrantes portugueses que não possuíam grandes capitais mas recursos modestos e escolheram tentar a sorte no interior do continente. Alteravam-se, dessa forma, a configuração demográfica da população e a primazia absoluta das atividades econômicas voltadas para a exportação do açúcar, afetando o estilo de vida local (a civilização do açúcar no dizer de Gilberto Freyre).

Cf. NOVAIS, Fernando. Estrutura e dinâmica do Antigo Sistema Colonial (séculos XVI - XVIII), 6ª ed., São Paulo, 1996. Capítulo “A crise do colonialismo mercantilista”.

FURTADO, Celso. Formação Econômica do Brasil. Rio de Janeiro, Fundo de Cultura, $5^{\mathrm{a}}$ ed., 1963. Capítulo XIII "Povoamento e articulação das regiões meridionais".

FREYRE, Gilberto. A presença do açúcar na formação brasileira. Rio de Janeiro, Instituto do açúcar e do Álcool, 1975. Capítulo "Uma possível sociologia: a do açúcar, tendo por principal modelo a experiência brasileira".

40 Às vezes até através de demonstrações pelo absurdo. 
do contexto cotidiano, isto é, aos procedimentos concretos de abastecimento, de distribuição, de preparo e de consumo de alimentos estabelecidos no quadro de um sistema alimentar elaborado para sustentar a contento o estilo de vida local dos colonos. Para leitores atuais, todavia, os significados permaneciam muitos mais opacos.

Mesmo sem intenção deliberada de descrever a realidade, a poesia barroca do autor registrou inúmeros elementos do cotidiano e retratou premissas tácitas e interações sociais que definiam as formas da sociabilidade soteropolitana. Aludir a procedimentos alimentares da população colonial carregados com uma polissemia complexa de valores culturais, permitiu a Matos discutir problemas que os colonos enfrentavam, entre os quais figuravam malversações escandalosas praticadas na gestão da colônia.

Reunidas em torno de temas centrais, as metáforas convergiam. Os fragmentos de usos e de costumes respigados na obra ofereciam, por conseguinte, um potencial interessante para decifrar as idéias inscritas nas práticas. A condição de obra literária dos poemas de Matos possivelmente interveio para impedir que certos hábitos alimentares nobres fossem arrastados na lama das sátiras obscenas, sendo que os poemas encomiásticos do autor também parecem ter levado em conta preceitos de decoro. A descrição do sistema de alimentação colonial, a partir dessa fonte poética, resultou talvez em algumas lacunas, porém, relatou elementos marcantes de nutrição local. Numerosos estereótipos vigentes no imaginário das elites rurais, traduzidos sob a forma de condutas ou de aparências físicas ridicularizadas, revelaram nos poemas do autor os critérios de um código de classificação social que demarcava rigidamente o lugar de cada soteropolitano em função da origem étnica, religiosa ou social de seus ascendentes, da profissão exercida ou da riqueza possuída.

Mesmo que Matos selecionasse apenas alguns procedimentos alimentares atrelados a maneiras de pensar para criticar condutas julgadas abusivas, os fragmentos de dados escolhidos remetiam a códigos de ação social abrangentes. O problema colocado era saber até onde as metáforas transformadas em instrumentos de análise permitiriam penetrar nos meandros dos valores e dos códigos sociais soteropolitanos e desvendar as categorias classificatórias ideadas pelo poeta e seus pares. 
As alusões literárias de Matos remetiam sobretudo ao valor simbólico das práticas alimentares e a etnografia empreendida em domínios históricos colocava-se na dependência de um documento norteado por normas próprias de composição. A questão da tripla fronteira disciplinar entrelaçando História, Literatura e Antropologia, apesar de não constituir uma meta específica de investigação, precisava ser levada em conta.

Outra questão precisava ser esclarecida. Matos, que se referia freqüentemente aos mazombos como a uma categoria social constituída de colonos, deixou, no entanto, pairar dúvidas e ambigüidades a respeito de quem seriam esses homens. Se, após 1650, uma nova denominação se firmou para designar os colonos portugueses, brancos, nascidos no Brasil, substituindo a perífrase em uso nos relatos de muitos cronistas da primeira metade do século: "moradores portugueses do Brasil" ${ }^{41}$, em que medida a identidade que os mazombos advogavam para si se distanciava daquela dos portugueses radicados em Portugal ou daquela de imigrantes recentes desembarcados em Salvador e arredores? Seriam plenamente nativistas os elementos de seu pendor local? Sérgio Buarque de Holanda enfatizou a diferença marcada que separava sentimentos de nacionalidade autênticos do mero reconhecimento de pertencer a algum universo $\operatorname{loca}^{42}$. As perguntas se desdobravam. Qual o efeito do distanciamento espacial (a travessia de um oceano e o impacto das condições materiais soteropolitanas) sobre os vínculos que os colonos mantinham com os portugueses da metrópole? Que elementos de separação interviriam no caso? Que mudanças um longo tempo de residência brasileira das famílias imigrantes induziria na própria imagem? À falta de uma ruptura consumada entre metrópole e colônia, até onde iam as gretas ocorridas na unidade do Império colonial português?

Nessa perspectiva, importava pesquisar a emergência de elementos que indicariam o surgimento de sentimentos de autoctonia, pois, em algum momento da História colonial,

41 Durante o período das invasões holandesas, cronistas como Frei Manuel Calado ou Duarte Coelho de Albuquerque utilizavam correntemente essa perífrase para designar os colonos lusos instalados em Pernambuco ou na Bahia.

42 HOLANDA, Sérgio Buarque de. Capítulos de Literatura colonial. Org. e introdução de Antônio Cândido, São Paulo, Brasiliense, 2000. pp. 410 e 411 (cf. citação no capítulo IV, item 4.1). 
entre o período da versificação barroca e zombeteira de Matos e o advento de uma literatura romântica no Brasil Imperial, foi efetivamente colocado ao lume um caldo de cultura nativista, que, talvez, não chegou a ebulição senão depois da morte do poeta, em 1696, mas cujos primórdios poderiam ser observados nos versos do poeta que associavam virtudes ou malefícios à ingestão de gêneros comestíveis.

Caberia lembrar, a esse propósito, a apologia poética dos ingredientes comestíveis brasileiros, promovidos a símbolos de prazeres de uma vida colonial, que figurou em outras obras escritas na colônia. O poema de Manuel Botelho de Oliveira: Ilha de Maré, publicado em 1711, e a obra ufanista de Sebastião da Rocha Pita, de publicação mais tardia (1736), são interessantes a esse respeito. Também mereceria menção a tentativa abortada do Desembargador José Mascarenhas Pacheco Pereira Coelho de Melo que, em 1758, propôs constituir, na capital do Brasil, uma academia literária de intento local: a "Academia dos Renascidos" destinada a escrever uma História do Brasil que exaltaria os feitos do rei D. João V e a especificidade da colônia. Na medida em que a decisão do grupo desses letrados inquietou as autoridades lisboetas, o fundador da Academia $^{43}$ foi degredado em 1760, no degredo.

No plano da literatura, semelhante questão levantou polêmicas. Debatendo, por exemplo, em Formação da Literatura Brasileira, a questão dos primórdios de uma autonomia literária do Brasil, Antônio Cândido de Mello e Sousa assinalou que a obra de Gregório de Matos poderia ser vista como um primeiro marco de independência da colônia em relação a Portugal. Por sua parte, o estudioso preferiu atribuir a autores românticos tais como Gonçalves Dias ou José de Alencar a primazia de terem iniciado um sistema literário brasileiro. Alegou como Matos não teria aparecido, em "perspectiva histórica", senão depois do Romantismo, em meados do século XIX, quando sua obra, pouco conhecida, começou a ser resgatada:

43 Esse episódio, contudo, escapa ao escopo do período estudado. 
“A nossa literatura é ramo da portuguesa: pode-se considerá-la independente desde Gregório de Matos ou só após Gonçalves Dias e José de Alencar, segundo a perspectiva adotada" ${ }^{44}$.

"embora tenha permanecido na tradição local da Bahia, ele [Matos] não existiu literariamente (em perspectiva histórica) até o Romantismo, quando foi redescoberto, sobretudo graças a Varnhagen; e só depois de 1882 e da edição Vale Cabral pôde ser devidamente avaliado. Antes disso não influiu, não contribuiu para formar nosso sistema literário, e tão obscuro permaneceu sob os seus manuscritos, que Barbosa Machado, o minucioso erudito da Biblioteca Lusitana (1714-1758), ignora-o completamente, embora registre quanto João de Brito e Lima pôde alcançar" ${ }^{45}$.

Apesar das críticas que essas afirmações suscitaram, quando Haroldo de Campos acusou o estudioso de seqüestrar o barroco brasileiro num ensaio intitulado " $O$ seqüestro do barroco na formação da literatura brasileira: o caso Gregório de Matos" ${ }^{46}$, parece pouco crível que Antônio Candido tenha realmente "seqüestrado o barroco brasileiro" ao excluir Matos como expoente da literatura brasileira. O contra-argumento, exposto nessa tese, derivou, não do âmbito literário propriamente dito, mas do caráter fortemente luso dos hábitos alimentares da população mazomba revelados nos poemas de Matos. Em sua qualidade de fazeres sócio-culturais envolvendo técnicas e artes, a escrita literária e a produção culinária mazombas, oriundas do mesmo espaço territorial, nutriram-se dos mesmos valores soteropolitanos.

\footnotetext{
44 SOUZA, Antônio Candido de Mello e, Formação da Literatura Brasileira. 2 vol., BH./RJ., Itatiaia, 9 ed., 2000, p. 28.

45 SOUZA, Antônio Candido de Mello e, Op. Cit., p. 24.

46 CAMPOS, Haroldo de. O seqüestro do barroco na formação da literatura brasileira: o caso Gregório de Matos. Salvador, Fundação Casa de Jorge Amado, 1989.
} 
Se, versejando episódios ocorridos em Salvador ou nos arredores da cidade, Matos expôs as idéias da sociedade à qual pertencia, fazendo uso das normas literárias de uma arte poética, que prolongava regras ibéricas de composição ${ }^{47}$, o recurso persistente aos procedimentos alimentares do cotidiano colonial também serviu de suporte a uma ampla polissemia de significados locais. Caso tivesse realmente ocorrido uma tomada de consciência de diferenças irredutíveis entre portugueses radicados na colônia e residentes na metrópole, as formas da vida material no Brasil ostentariam provavelmente indícios de ruptura emblemática e voluntária, tanto na expressão literária de Gregório de Matos, quanto nas alusões versejadas aos hábitos da nutrição.

A hipótese que fundamentou a investigação, era que os versos de Matos, escritos entre 1683 (quando, já viúvo e quase quinqüagenário, voltou à terra natal) e 1694 (quando sátiras contra um governador da colônia lhe valeram um exílio em Angola), conteriam elementos indicativos dos problemas existenciais dos colonos e os valores que eles atribuíam à ingestão de determinados ingredientes da dieta e às práticas de produção, aquisição, beneficiamento, armazenamento, transporte, venda e consumo dos alimentos. Para analisar os hábitos alimentares como gestos materiais incidindo sobre objetos de cultura material regidos por um rol heteróclito de considerações lógicas, tornava-se necessário considerá-los em sua qualidade de fatores de interação simbólica entre os homens e a terra colonial. A ser correta a suposição, os versos de Matos proporcionariam à pesquisa um manancial de pistas para investigar as escolhas de ingredientes comestíveis associados à construção da sociabilidade mazomba e permitiriam delinear os parâmetros locais de uma arte de viver exercida num momento efervescente de História colonial, caracterizado pelo impacto da crise da manufatura açucareira.

As diversas questões propostas ao estudo: os hábitos de alimentação metafóricos que consubstanciavam as atividades sociais das elites coloniais, a investigação de um estilo de vida local, a natureza do documento colonial analisado, o caráter fragmentário das informações proporcionadas, a ambigüidade de se falar numa sociedade mazomba com identidade sedimentada, as potencialidades e as limitações da pesquisa decorrentes dessa ambigüidade e o 
debate em torno da questão do nativismo soteropolitano conduziram a tese rumo a uma questão central na Antropologia da alimentação.

No rastro de indícios de usos alimentares e de explicações sobre as razões motivando os procedimentos escolhidos, a profusão dos argumentos suscetíveis de configurar tais modos de agir se condensou principalmente em torno dos elementos mais significativos na construção de imagens sociais regidas por valores culturais. Matos, efetivamente, brincou em seus versos com noções de honorabilidade social e religiosa e com noções de manutenção da saúde dos corpos, insistindo com muita ênfase num conjunto de condutas alimentares paradigmáticas de formas sedimentadas de interação social. A idéia da alimentação como um instrumento de análise para investigar idéias atreladas às práticas e padrões de convívio vividos com intensidade permitiu explorar num caso monográfico a noção das práticas alimentares como um lócus privilegiado de articulação entre os problemas enfrentados por uma sociedade e as soluções implementadas, revelador da maneira como os integrantes dessa sociedade concebiam suas pessoas.

A mudança de objeto de estudo ocorrida durante o doutorado ${ }^{48}$ tornou talvez a Antropologia da alimentação que seria protagonista da tese em mera coadjuvante, sua intervenção resumindose a comentários sobre dados encontrados nos poemas. Em compensação a questão do estilo de vida dos colonos mazombos adquiriu um relevo particular, muito interessante, em função do tema trabalhado.

48 O projeto inicial da tese contemplava uma análise etnográfica do sistema alimentar colonial no decorrer dos séculos XVI e XVII, isto é, a elaboração de procedimentos de alimentação condizentes com a maneira de ser dos colonizadores lusos. Por ocasião do exame de qualificação, a banca sugeriu a conveniência de restringir a análise no tempo e no espaço, aprofundando algum tema específico. Resolveu-se então centrar a análise nas atividades de provimento e de consumo alimentar em uso na capital da colônia relatadas por cronistas do século XVI ou da primeira metade do século XVII. Gregório de Matos figurava apenas como um contraponto para examinar a crise do sistema alimentar elaborado pelas primeiras gerações de soteropolitanos. Entretanto, em razão dos rumos da pesquisa e dos dados encontrados, a conselho da orientadora da tese, encarou-se o desafio estimulante de analisar a crise do modelo soteropolitano de alimentação no último quartel do século XVII, evidenciada na obra poética de Gregório de Matos. 
$\mathrm{Na}$ introdução à tese, foram apresentados: o objeto da pesquisa, a obra poética de Gregório de Matos e o propósito da análise, uma interpretação dos dados encontrados nos poemas sobre a alimentação colonial soteropolitana. Delinearam-se as principais questões abordadas na monografia. A escolha da obra desse poeta seiscentista como fio de meada para estudar os significados atribuídos aos ingredientes alimentares considerados idôneos ou que desmereciam aqueles que os ingeriam, se devia à vivacidade do texto ao descrever práticas e valores em uso entre os colonos portugueses que viviam em Salvador, no final do século XVII. Foi ressaltado o fato de Matos explicitar manejos alimentares e significados atrelados às práticas, dirigindo seus versos a um público que compartilhava com ele a mesma visão de mundo. Certas considerações teóricas ou metodológicas implicadas nos procedimentos da pesquisa foram expostas. Os textos de cronistas do período, que também discutiram os problemas abordados nos versos do poeta e que podiam oferecer subsídios à análise foram citados. Mencionou-se, afinal, as obras de estudiosos que auxiliaram à compreensão dos fenômenos soteropolitanos analisados.

No primeiro capítulo: "Gregório de Matos Guerra: sua arte e sua vida", as circunstâncias curiosas da vida do poeta seiscentista foram focalizadas. A obra poética satírica, lírica ou burlesca atribuída ao autor, seu contexto literário e a situação soteropolitana no último quartel do século XVII foram situados. O talento de Matos para manejar a linguagem poética, sua formação de Doutor em leis, desprezada pelas autoridades civis e eclesiásticas da colônia, e sua situação financeira periclitante o induziram provavelmente a tentar construir para si um lugar de poder através do favor público, que acolhia sua produção literária. Que tenha alcançado resultados além das expectativas, ao ser considerado perigoso e até exilado, outorga relevância suplementar à realidade comentada. Complementarmente, o capítulo enveredou também pela refutação de objeções passíveis de serem antepostas aos propósitos da análise.

$\mathrm{O}$ objeto da tese e as questões tratadas, assim como a obra literária e seu autor, o elo simbólico existente entre carnes comestíveis, condição carnal dos corpos humanos e formas de pensar o corpo ou de atuar sobre ele resultaram na necessidade de desdobrar a pesquisa sobre a alimentação colonial em dois rumos complementares, porém distintos, de investigação. Por um 
lado, afigurou-se necessário esclarecer porque Matos se valeu de procedimentos alimentares para compor tropos, isto é, quais foram suas intenções ao propor comparações envolvendo alimentos para ornamentar os versos. Por outro lado, sobressaia o caráter fidedigno dos comentários sobre as práticas alimentares do cotidiano soteropolitano, mesmo que as alusões não se destinassem especificamente a descrever a realidade colonial.

No segundo capítulo, os significados que Matos atribuiu às metáforas foram discutidos. As normas literárias da arte poética barroca e os princípios que regiam a elaboração das figuras de estilo estiveram no centro das preocupações, traduzindo uma concepção ideal da vida colonial, inventando peripécias fantasiosas para divertir o público, ridicularizando vícios para impedir a população de cultivá-los e vituperando a aparência física de pecadores contumazes. Recorrendo à obra do poeta, observou-se encenações de procedimentos materiais de subsistência que, por constituírem premissas tácitas, serviram de suporte expressivo, revelando uma concepção local das hierarquias sociais e das cortesias devidas, o papel do clero, os procedimentos políticos e administrativos praticados pelas autoridades e as anedotas bucólicas ou escabrosas de um viver local. Contudo, se os poemas do autor proviam rastros interessantes, também apresentavam uma mistura peculiar de opiniões pessoais e de elementos inspirados na concepção mazomba de como se deveria agir na cidade colonial. O fato de Matos exemplificar concretamente grande parte dos conceitos que defendia, mencionando pequenos gestos carregados de significados explícitos ou subentendidos, constituiu um trunfo importante de trabalho.

O terceiro capítulo ${ }^{49}$ focalizou uma miscelânea de fragmentos de informação relativos a manuseios de alimentação. Sob a forma de metáforas ou de metonímias, imagens dotadas de forte impacto e de significados relevantes mediaram o trânsito entre procedimentos cotidianos ou festivos de nutrição e o plano das propriedades simbólicas e dos valores culturais atrelados a gestos técnicos. Tais metáforas ilustravam a concepção peculiar que o poeta tinha da vida local. A despeito da pulverização dos dados entre milhares de versos e dos relatos fragmentários de gestos vinculados à alimentação, havia uma abundância interessante de citações aglutinadas

49 Remanescente do projeto inicial da tese. 
em torno de temas caros ao autor: refeições diárias e banquetes festivos, regras de deferência marcando a importância social de alguns colonos, padrões de reciprocidade no oferecimento de alimentos, alimentação diferenciada de classes sociais distintas, condições locais de provimento alimentar etc. De modo que os ingredientes da dieta foram vistos não somente como substâncias vegetais ou animais colocadas nos pratos mas, sobretudo, como indícios representativos das próprias noções polissêmicas dando forma aos consumos e aos atos de produção de alimentos.

Enquanto indícios de práticas decorrentes de um sistema alimentar referencial, os fragmentos de informação coligidos proporcionavam uma via de acesso aos valores prestigiados na condução da vida social soteropolitana. Efetivamente escolhidas por Matos em sua condição de objetos de cultura material abertos aos manejos, as práticas alimentares permitiam formular analogias facilmente decifradas pelo público, mas era preciso ainda sublinhar as linhas de força internas que as organizavam. Decidiu-se, portanto recorrer ao conceito de cadeias operatórias de Pierre Lemonnier ${ }^{50}$ para expor e interpretar informações logicamente interligadas. Lemonnier, com efeito, recorreu às seqüências encadeadas de operações técnicas, exercidas sobre objetos de cultura material durante o processo de sua transformação de matéria-prima em produto acabado, para analisar tanto o processo produtivo quanto o produto final. Alvos de operações físicas de transformação nas mãos de agentes treinados, os alimentos produzidos (cultivados ou importados), beneficiados (por desidratações eventuais, salgas ou outros procedimentos), transportados, armazenados, distribuídos e vendidos, preparados e consumidos afiguravam-se marcados pelos traços tecnológicos aplicados na sua transformação. Tratava-se de resgatar conhecimento a partir de gestos costumeiros de abastecimento e de consumo permeados de representações. Observar os manejos práticos de

50 LEMONNIER, Pierre. Les salines de l'ouest: logique technique, logique sociale. Lille, Maison des Sciences de l'Homme/Presses Universitaires de Lille. 1980.

“Définie comme action socialisée sur la matière, la technique peut s'appréhender à travers trois ordres de faits: des suites de gestes et d'opérations (processus techniques), des objets (moyens d'action sur la matière), et des connaissances spécifiques". p. 1.

Ao focalizar processos técnicos, o autor afirmou estudar cadeias operatórias, considerando como tais todos os conjuntos de operações levando uma matéria prima do estado natural ao estado de coisa manuseada. p. 8. 
alimentos incorporados à dieta soteropolitana equivalia a perceber os critérios simbólicos vigentes de classificação social.

No quarto e último capítulo, os elementos apurados sobre o estilo poético e os dados etnográficos foram retomados numa perspectiva liberada da preocupação de separar as vozes dos informantes: poetas, cronistas, edis, médicos e outros profissionais seiscentistas, da voz da pesquisadora empenhada em perceber questões interessantes nas informações recolhidas. A conclusão da tese remetia forçosamente à interpretação ampliada das argumentações desenvolvidas no trabalho. As principais questões levantadas na investigação foram retomadas e debatidas de maneira a alargar o panorama dos conhecimentos adquiridos sobre a vida soteropolitana.

\section{As fontes primárias referentes ao último quartel do século XVII}

Se a encenação de gestos e de argumentos associados à nutrição, traduziu modos de pensar e de sentir da população lusa dos seiscentos, implementando modos de agir, ou se uma leitura dos procedimentos alimentares mencionados na obra permitiu distinguir parâmetros de identidade mazomba representada simbolicamente, foi pelo trunfo apreciável das descrições de ações e pensamentos permeados de afetos, que o poeta teceu em seus poemas. Referindo a existência de muitos códices apógrafos, Pedro Calmon considerou:

"São dezenas de coleções exaustivas de escárnio, em que desponta a índole belicosa (e política) do povo, a rir, a opinar, a castigar com a destemida liberdade do cantor. Pelos sermões do padre Vieira sabemos o que pensava, pelas crônicas de Simão de Vasconcelos o que recordava, pelas décimas de Gregório o que dizia, nesta bruta América de 1682 a 1696. Os outros deram as razões, deu ele os sentimentos do país, encolhido na concha de isolamento e na adivinhação do destino" ${ }^{51}$.

51 CALMON Pedro, Vida espantosa de Gregório de Matos. Rio de Janeiro/ Brasília, José Olympio/ INL.,1983. p. 209. 
Versos comentando usos e costumes de alimentação soteropolitana avaliados por um viés moral, conferiram à própria subjetividade do autor matizes e vigor interessantes para formular idéias. Porém, a subjetividade limitou um pouco o alcance da discussão. Menções (feitas de passagem) em discussões jocosas ou iradas ao bom ou mau gosto dos alimentos ou à sabedoria ou à ignorância daqueles que os ingeriam, acabaram por obliterar um pouco a expressão dos sistemas simbólicos subjacentes às escolhas dos ingredientes da dieta. Felizmente, existem na historiografia do período outros textos versando sobre as mesmas questões que povoam as poesias de Matos. Fontes primárias impressas referentes ao período não são encontradas em grande abundância, mas propiciam elementos apreciáveis à discussão dos problemas em foco.

A principal fonte de informações complementares residiu no registro das Atas e das Cartas da Municipalidade do Salvador, correspondentes ao tempo da segunda permanência de Matos na Bahia, entre 1683 e 1694. As Atas da Câmara Municipal, com efeito, resumiram o teor de discussões ocorridas durante as reuniões dos representantes do povo: homens bons (isto é, ricos proprietários eleitos por sorteio entre três bolas de cera contendo uma lista de nomes apropriados que a mão inocente de uma criança escolhia). Os mandatos outorgados aos vereadores tinham um ano de duração. Os textos escritos pelo escrivão vitalício João de Couros Carneiro, ao final das reuniões de vereança, apontavam os diferentes tipos de problemas que a população colonial enfrentava no dia-a-dia, apresentavam discussões de medidas e enfatizavam resoluções tomadas: no "estilo do costume" para o "bem comum" da "res-pública". As cartas do Senado, redigidas pelo mesmo escrivão, procuravam apontar ao rei e aos administradores metropolitanos da colônia, no caso ao Conselho Ultramarino lisboeta, os problemas que afligiam a população. Semelhante documentação abre caminho para prosseguir na pesquisa das pistas encontradas em sonetos, romances ou glosas poéticas de Matos, sobre a concepção local de um ideal colonial permeado de fatos alimentares.

Diversos cronistas, que conheceram Salvador durante os anos seiscentos ou nas primeiras décadas dos anos setecentos, comentaram os mesmos eventos ou os mesmos hábitos costumeiros dos colonos, que o bacharel citou. Explicaram as mesmas dificuldades técnicas de 
abastecimento alimentar, discutiram os mesmos códigos de etiqueta social e seus conselhos, em alguns casos, permitem comparações, que multiplicam os olhares possíveis sobre os fenômenos representados.

As obras de três jesuítas contemporâneos do poeta se afiguraram imprescindíveis à análise. Com efeito, os sermões e as cartas do padre Antônio Vieira, obras-primas literárias amplamente enraizadas na arte da retórica, contêm elementos também relacionados por Matos. Vieira, nascido em Portugal em 1608, 28 anos antes de Matos, que nunca foi seu aluno no Colégio da Companhia em Salvador, foi criado na capital da colônia desde o ano de 1614. As convergências entre as obras dos dois autores foram mais numerosas do que se poderia supor à primeira vista. Ambos voltaram ao Brasil na mesma época: Vieira em 1681, Matos no princípio de 1683. Ambos receberam sólida formação acadêmica com ênfase na retórica e na escolástica, ambos ocuparam cargos de gestão administrativa, ambos tinham sido notados em Portugal por seus talentos e ambos vinham acompanhados pelo peso de dissabores sofridos na metrópole. Vieira pela perda de prestígio que sofreu na corte portuguesa após a morte do rei D. João IV e pelas perseguições que suas opiniões lhe valeram junto à Inquisição.

Com toda probabilidade deviam se conhecer pessoalmente. Matos admirava o irmão de Vieira: o secretário de estado Bernardo Vieira Ravasco e seu filho Gonçalo. E um dos irmãos de Matos, Eusébio, orador jesuíta apreciado que se tornou carmelita descalço, depois de problemas com a ordem, parece ter sido amigo pessoal do Padre Vieira.

Vieira em certa ocasião teria comentado que achava as sátiras de Gregório de Matos mais eficazes que seus próprios sermões, reconhecendo implicitamente que finalidades semelhantes orientavam as artes que praticavam. Matos, a despeito de criticar a fé sebastianista do padre por ocasião da aparição de um cometa e de se gabar de Vieira não saber como ele a arte de compor sátiras, teria até transformado em versos um sermão do padre Vieira. Ambas as famílias se insurgiram contra os abusos de poder do governador Antônio de Souza de Meneses, conhecido pela alcunha de Braço de Prata. 
As crônicas de dois outros jesuítas também contêm discussões pertinentes sobre problemas referidos na escrita de Gregório de Matos e ofereceram apoio à interpretação dos manejos alimentares.

A obra de Jorge Benci: A economia cristã dos senhores no governo dos escravos ${ }^{52}$, publicada na Bahia, em 1700, ofereceu à pesquisa uma fonte de reflexão sobre as idéias de outro jesuíta, que também se preocupou com os destinos da economia açucareira e com a condição social dos escravos numa colônia católica, que não acreditava possível prescindir dessa mão-de-obra. Os parâmetros morais da caridade cristã nortearam as considerações do autor, impelindo-o a defender deveres e limites a serem respeitados pelos senhores de engenho em relação aos cativos possuídos. As obrigações que a posse de escravos impunha aos homens livres, enunciadas em seu livro, deixam adivinhar, nas entrelinhas, os termos de um conflito existente entre o ponto de vista da Igreja colonial e as aspirações à riqueza e à nobreza dos homens bons, cujos lucros advinham do trabalho excessivo de escravos mal alimentados e mal vestidos. As circunstâncias da crise econômica e social, que grassava no período, emprestam interesse às recomendações do sacerdote.

Cultura e opulência do Brasil, do jesuíta italiano André João Antonil (anagrama de João Antônio Andreoni), natural de Luca na Toscana, onde nasceu em 1649, apesar de publicada em 1711 (e logo confiscada pela censura real portuguesa, temerosa de novos assaltos de nações européias às riquezas de sua colônia $\left.{ }^{53}\right)$, foi escrita por um homem que, acompanhou Vieira em seu retorno a Salvador, na frota anual de janeiro de 1681, desempenhou tarefas importantes na Companhia de Jesus e permaneceu no Brasil pelo resto de seus dias - falecendo em 1716. Foi, portanto, como contemporâneo de Matos, que vivenciou a grave crise econômica do período, formando opiniões sobre as circunstâncias que nem sempre coincidiram com as idéias do padre Vieira (principalmente naquilo que dizia respeito à escravidão indígena).

A obra de Manuel Botelho de Oliveira, Música do Parnaso (1705) e aquela de Antonil, foram ambas publicadas no decorrer dos primeiros anos do século XVIII, mas envolveram em sua

52 BENCI, Jorge. Economia cristã dos senhores no governo dos escravos. São Paulo, Grijalbo, 1977.

53 As invasões holandesas pareciam ter deixado traumas na monarquia lusa. 
concepção uma experiência de vida também amealhada nas últimas décadas do século XVII. O poema "Ilha de Maré" ${ }^{54}$ de Manuel Botelho de Oliveira teceu elogios particularmente ufanistas aos encantos da Ilha, celebrando, por meio de imagens maneiristas, os recursos alimentares locais, animais ou vegetais saboreados pelos colonos. Constituiu um contraponto interessante à obra satírica de Gregório de Matos.

Referenciei ainda, vez ou outra, informações provenientes da obra de expressão bastante otimista e empolada escrita por um senhor de engenho do Recôncavo baiano: Sebastião da Rocha Pita que, além de ser produtor de açúcar, também foi letrado e vereador municipal. A obra do autor, a História da América Portuguesa, mesmo que publicada em 1738, bem depois da morte de Matos, foi obra de alguém que na juventude conviveu com Matos e até se desentendeu com ele por uma questão de rimas solicitadas ${ }^{55}$ (e possivelmente por causa da corte que ambos fizeram à mesma jovem).

Existiam ainda alguns elementos de apreço nos relatos de viajantes, que tiveram a oportunidade de visitar Salvador durante o período do retorno de Matos na colônia, ou em décadas imediatamente posteriores. O conteúdo de seus escritos merece reparo. Testemunharam acontecimentos, observaram e estranharam costumes, emitiram juízos de valores, por vezes apaixonadamente negativos: Coreal $^{56}$, Dampier $^{57}$ e Frezier ${ }^{58}$, por exemplo ofereceram depoimentos que possibilitaram perceber como os padrões coloniais de alimentação e de conduta podiam ser considerados estranhos pelos forasteiros. Afonso d'Escragnole Taunay ${ }^{59}$, aliás, pôs em dúvida a vinda efetiva de Coreal, argumentando uma mistificação produzida por 54 In SILVA, Rogério Forastieri. Colônia e nativismo: a História como "biografia da nação". São Paulo, Hucitec, 1997.

55 Matos teria respondido "capim" a uma solicitação de termo rimando com "para mim".

56 COREAL, François. Voyages de François Coreal aux Indes Occidentales contenant ce qu'il y a vu de plus remarquable pendant son séjour depuis 1666 jusqu'en 1697. Paris, André Cailleau, 1722.

57 DAMPIER, Guillaume. Voyage aux terres australes, à la Nouvelle Hollande, \&c., fait en 1699.

58 FREZIER, Amadeo. Relacion del viaje por el mar del sur. Caracas, Biblioteca Ayacucho, s. data.

59 AUNAY, Adolfo Afonso d'’Escragnole. Impressões de viajantes estrangeiros na Bahia colonial (1610 -1774). Rio de Janeiro, Imprensa Nacional, 1925. 
algum calvinista e alegando o fato do suposto viajante se dizer espanhol e descrever condutas de colonos observadas em Salvador, com anti-clericalismo pouco católico.

No que diz respeito à interpretação das intenções literárias de Matos, que se valeu de dados sobre alimentação para construir boa parte de suas figuras de estilo, recorri diretamente às fontes textuais da Antiguidade Clássica que, durante os séculos XVI e XVII, serviram de inspiração a reformulações progressivas da arte poética, dando lugar aos diversos estilos rotulados, $a$ posteriori, como obras barrocas características. Incentivada pela leitura das obras de Hansen e de Teixeira Gomes - textos fundamentais para a compreensão das normas de versificação obedecidas por Matos - solicitei à Poética de Aristóteles e à Epístola aos Pisões de Horácio ${ }^{60}$ esclarecimentos sobre os elementos pertinentes às poesias analisadas.

No que tange à interpretação das noções específicas de corporalidade (subjacentes à expressão das idéias mazombas), a obra de referência, que se mostrou muito elucidativa, foi o primeiro tratado português de medicina publicado em 1721: Ancora medicinal: para conservar a vida e a saúde $^{61}$, obra de Francisco da Fonseca Henríquez, conhecido como o Doutor Mirandela, médico do rei D. João V na corte lisboeta. Suas prescrições em prol de uma manutenção saudável dos corpos humanos, inspiradas por uma versão lusa dos tratados de medicina humoral atribuídos a Hipócrates e a Galeno, revelaram a presença de preceitos medicinais da antiguidade orientando as práticas alimentares soteropolitanas.

\section{Outras fontes de referência pertinentes à análise}

O recorte temporal do objeto da pesquisa tornou necessário conciliar informações procedentes do âmbito de diversas disciplinas das ciências humanas e de diferentes linhas de análise antropológica em torno das questões estudadas. Os procedimentos de alimentação dos

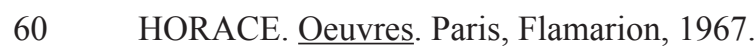

ARISTOTE. Poétique. Paris, Les Belles Lettres. s/ data.

61 HENRIQUEZ, Francisco da Fonseca. Âncora medicinal: para conservar a vida e a saúde. Cotia, Ateliê Editorial, 2004. 
portugueses e dos descendentes de emigrantes lusos que residiam em Salvador entre 1683 e 1694, foram considerados como fenômenos espelhando a maneira como os soteropolitanos concebiam sua sociedade.

Pensar alimentos ingeridos pelos corpos numa perspectiva antropológica remetia às técnicas corporais estudadas por Marcel Mauss ${ }^{62}$, no ensaio sobre As técnicas do corpo, mas envolvia ainda o célebre Ensaio sobre a dádiva do autor. Pensar o corpo como lócus relevante de encontro entre fatores fisiológicos e psicológicos através de manejos práticos, integrados no âmbito da vida social, serviu efetivamente de esteio à pesquisa. Por extensão, objetos manuseados de cultura material, também se apresentaram atrelados ao tema. Por mais que questões referentes à cultura material tenham ficado em segundo plano durante a segunda metade do século XX, à margem das principais preocupações antropológicas, alguns estudiosos franceses não deixaram de investigá-las. As obras de André Leroi-Gourhan ${ }^{63}$ etnoarqueólogo, autor, por exemplo, de Le geste et la parole e de Milieu et technique, ofereceram enfoques particulares. O estudioso foi aluno de Mauss e seus próprios discípulos, tais como Jean-Pierre Lemonnier ${ }^{64}$, ao darem seqüência a investigações preocupadas com o tema da cultura material também forneceram subsídios à concepção do universo pesquisado. David Le Breton ${ }^{65}$, cujas pesquisas enfatizaram o dimensionamento sócio-cultural do corpo, Claude Fischler ${ }^{66}$ e Jean-Pierre Poulain ${ }^{67}$, antropólogos da alimentação, pela compreensão abrangente que ambos demonstraram sobre

62 MAUSS, Marcel. "Ensaio sobre a dádiva" e "as técnicas do corpo", in Sociologia e Antropologia, São Paulo, Cosac e Naify, 2003.

63 LEROI-GOURHAN, André. Milieu et technique. Paris, Albin Michel, 1945. Le geste et la parole. 2 T., Paris, Albin Michel, 1964, 1965.

64 LEMONNIER, Jean-Pierre. Les salines de l'ouest: logique technique, logique sociale. Lille, Maison dês Sciences de l’Homme/Presses Universitaires de Lille. 1980.

65 LE BRETON, David. La sociologie du corps. Paris, Que sais-je?, PUF., 5 ème edition, 2004. A sociologia do corpo, Petrópolis, Vozes, 2006.

66 FISCHLER, Claude. L'homnivore. Paris, Odile Jacob, 2001.

67 POULAIN, Jean-Pierre. Sociologias da alimentação. Florianópolis, UFSC. 2004. 
o campo da alimentação, Jean-Pierre Warnier ${ }^{68}$, antropólogo que analisou a repercussão dos manejos técnicos de objetos utilizados sobre as condutas corporais e Maurice Godelier ${ }^{69}$, por sua ênfase na inferência de condições materiais em etnografias focalizando os conceitos de vida econômica ideados por outros povos, compuseram um panorama bastante coerente e complementar de análise, apesar das diferenças existentes entre suas perspectivas. Em conjunto, esses estudiosos, voltados para uma questão que a Antropologia francesa das últimas décadas não deixou de trabalhar, compartilhavam efetivamente denominadores comuns situados na obra de Mauss em torno do fato social total e das técnicas corporais.

Jack Goody ${ }^{70}$ com sua obra clássica, Cooking cuisine and class auxiliou a perceber a importância dos fatores sociais na construção de sistemas alimentares, incentivando a observação dos elementos sócio-culturais imbricados na elaboração do estilo de vida colonial. Não que os trabalhos de autores como Audrey Richards ${ }^{71}$, Mary Douglas ${ }^{72}$, Norbert Elias ${ }^{73}$ ou Stephen Mennell ${ }^{74}$ tivessem deixado de influenciar o direcionamento do trabalho, porém, a intervenção de seus ensinamentos não se fez diretamente. No que tange às obras brasileiras sobre o tema, a leitura de obras versando sobre o tema como aquelas de Luis da Câmara Cascudo ${ }^{75}$, Roberto

68 WARNIER, Jean Pierre. Construire la culture matérielle: l'homme qui pensait avec ses doigts. Paris, PUF. 1999.

69 GODELIER, Maurice. L'idéel et le matériel, pensée, économie, société. Paris, Fayard, 1984.

70 GOODY, Jack. Cooking, cuisine and Class a study in comparative sociology. London/New York, Cambridge University Press, 1982.

71 RICHARDS, Audrey. Hunger and work in a savage tribe, a functional study of nutrition among the southern Bantu . London, Routledge \& Sons Ltd., 1932. Land, Labour and diet in Northern

Rodesia. Oxford, Oxford University Press, 1939.

72 DOUGLAS, MARY. Pureza e perigo: ensaio sobre as noções de poluição e tabu. Lisboa, ed. 70, sem data. E "Les structures du culinaire” in Communications (31), 145-170. 1979.

73 ELIAS, Norbert. O processo civilizador: uma História dos costumes. 2 vol., Rio de Janeiro, Zahar, 1990.

74 MENNELL, Stephen. All manners of food: eating and taste in England and France from the Middle Ages to the present. Urbana and Chicago, University of Illinois Press, 1996.

75 CASCUDO, Luis da Câmara. História da alimentação no Brasil. 2 Vol., BH./ SP., Itatiaia/EDUSP, 1983. 
da Matta $^{76}$, Maria Eunice Maciel ${ }^{77}$, Eduardo Frieiro ${ }^{78}$, Mônica Chaves Abdala ${ }^{79}$, Rosa Wanda Garcia $^{80}$, Rosimeire Lorimer ${ }^{81}$, Paulinha Pinto e Silva ${ }^{82}$, etc., mesmo que não tenham sido referidas especificamente na tese, foi elemento fundamental para efetuar o recorte das questões trabalhadas.

Obras de historiadores da alimentação auxiliaram, em particular, a entender o contexto histórico, os processos sociais e os códigos da alimentação colonial considerada no período analisado. Fernand Braudel ${ }^{83}$, Frédéric Mauro ${ }^{84}$, Jean-Louis Flandrin ${ }^{85}$, Massimo Montanari ${ }^{86}$,

76 DAMATTA, Roberto. O que faz o Brasil, Brasil? Rio de Janeiro, Rocco, 1987.

77 MACIEL, Maria Eunice. "Identidade cultural e alimentação", in CANESQUI, Ana Maria e GARCIA, Rosa Wanda Diez. Antropologia e nutrição um diálogo possível. Rio de Janeiro, Ed. Fiocruz, 2005.

78 FRIEIRO, Eduardo. Feijão, angu e couve. Ensaio sobre a comida dos mineiros. $2^{\mathrm{a}}$ ed. BH./SP., Itatiaia/ EDUSP, 1982.

79 ABDALA, Mônica Chaves. Receita de Mineiridade: a cozinha e a construção da imagem do mineiro. EDUFU. 1997.

80 GARCIA, Rosa Wanda Diez. Antropologia e nutrição um diálogo possível. Rio de Janeiro, Ed. Fiocruz, 2005.

81 LORIMER, Rosemeire Bertolini. O impacto dos primeiros séculos de História da América Portuguesa na formação da brasilidade alimentar. Tese de Doutorado apresentada ao Departamento de Nutrição da Faculdade de Saúde Pública da USP, São Paulo. 2001.

82 SILVA, Paula Pinto e. Farinha, feijão e carne seca: um tripé culinário no Brasil colonial, São Paulo, Senac, 2005.

83 BRAUDEL, Fernand. Civilisation matérielle, économie et capitalisme, XV ème - XVIII ème Siècle, Tome I, II e III, Paris, Armand Colin, Livre de poche, 1979.

84 MAURO, Frédéric. Portugal, o Brasil e o Atlântico. 1570 - 1670. 2 vol., Lisboa, Imprensa Universitária/ Editorial Estampa, 1989. E Nova História e Mundo Novo. São Paulo, Perspectiva, 1969.

85 FLANDRIN, Jean Louis e MONTANARI, Massimo (Org). História da alimentação. São Paulo, Estação Liberdade, 1996. "A distinção pelo gosto", in História da vida Privada: da Renascença ao século das luzes, Vol 3, ARIÈS, Philippe e Duby, Georges (Org.). São Paulo,Cia das Letras, 2002.

86 MONTANARI, Massimo. A fome e a abundância: História da alimentação na Europa. Bauru,EDUSC, 2003. "Un historien gourmand" in REDON, Odile. SALLMANN, Line. \& STEINBERG, Sylvie (org.). Le désir et le goût: une autre histoire (XIII - XVIII e siècles), Saint Denis, PUV. 2005.

El mundo en la cocina: História, identidad, intercambios. (Org.). Buenos Aires, Paidós Diagonales, 2003. 
Piero Camporesi ${ }^{87}$ e Ulpiano Bezerra de Meneses $^{88}$ mereceram a esse respeito menções específicas.

Recorrer a um grande número de fontes secundárias com enfoques especializados constituiu efetivamente um procedimento profícuo para abordar a questão das metáforas alimentares de Gregório de Matos. Estudos sobre o contexto histórico ou o conteúdo literário da vida colonial proporcionaram reflexões indispensáveis à análise. Uma coletânea de mapas e de desenhos do período colonial, reproduzidos e comentados por Nestor Goulart Reis: Imagens de Vilas e cidades do Brasil colonial ${ }^{89}$, obra que complementava um estudo anterior do mesmo autor sobre a Evolução urbana do Brasil (1500 -1720), auxiliaram a formar uma imagem do espaço territorial ocupado pelos colonos soteropolitanos. Roberta Delson ${ }^{90}$ e Paulo César Garcez Marins ${ }^{91}$ também proporcionaram leituras a essa reflexão.

Subsídios relevantes sobre o tema também foram solicitados a uma miscelânea de autores versados em diferentes aspectos da vida colonial. A leitura das obras de historiadores como Fernando da Rocha Peres, que se debruçou sobre a vida de Gregório de Matos, documentando a veracidade de aventuras atribuídas ao poeta, não faltaram ao estudo ${ }^{92}$. Diferentes trabalhos

87 CAMPORESI, Piero. O pão selvagem. Lisboa, Editorial Estampa, 1989.

88 MENESES, Ulpiano Bezerra de, CARNEIRO, Henrique. "A história da alimentação: balizas historiográficas". In Anais do Museu Paulista, São Paulo, 1998.

89 REIS, Nestor Goulart dos. Imagens de cidades e vilas do Brasil colonial.. São Paulo, EDUSP. 2000. Evolução urbana do Brasil (1500 -1720). São Paulo, Pioneira/EDUSP, 1968.

90 DELSON, Roberta. Marx. Novas vilas para o Brasil-colônia. Brasilia, Alva-Ciord, 1979.

91 MARINS, Paulo César Garcez. Através da rótula: sociedade e arquitetura urbana no Brasil, séculos XVII a XX. São Paulo, Humanitas, FFLCH-USP, 2001.

92 PERES, Fernando da Rocha e LA REGINA, Silvia. Um códice setecentista: inédito de Gregório de Matos, Salvador, EDUFBA, 2000.

PERES, Fernando da Rocha. Gregório de Mattos Guerra - uma re-visão biográfica. Salvador, Macunaíma, 1983. Gregório de Mattos e a Inquisição. Salvador, Centro de Estudos Baianos, 1987.

Gregório de Mattos: o poeta devorador. Rio de Janeiro, Manati, 2004.

A família Mattos na Bahia do século XVII. Salvador, Centro de Estudos Baianos, 1988. 
de Stuart Schwarz ${ }^{93}$, permitiram entender melhor o contexto historiográfico dos fatos da alimentação colonial com os quais estava lidando. Obras de Sérgio Buarque de Holanda ${ }^{94}$, Capistrano de Abreu ${ }^{95}$, Pedro Calmon ${ }^{96}$, Wanderley Pinho, ${ }^{97}$ Russell-Wood ${ }^{98}$, Katia Matoso ${ }^{99}$, Theodoro Sampaio ${ }^{100}$, Gilberto Freyre ${ }^{101}$, etc. foram devidamente consultadas, assim como publicações de autores como Fernando Novais ${ }^{102}$, Vera Lúcia do Amaral Ferlini ${ }^{103}$, Laima

93 SCHWARTZ, Stuart B. Burocracia e sociedade no Brasil colonial. São Paulo, Perspectiva, 1979.

Segredos internos: engenhos e escravos na sociedade colonial 1550 -1835. São Paulo, Cia das Letras, 1999.

Escravos roceiros e rebeldes. Bauru, EDUSC. 2001.

94 HOLANDA, Sérgio Buarque de. Raízes do Brasil. Rio de Janeiro, 12ª ed., José Olympio, 1978.

História geral da civilização brasileira - "A época colonial". 2 vol., R J./S., Difel, 1977.

Caminhos e fronteiras. São Paulo, Cia. das Letras, 1995.

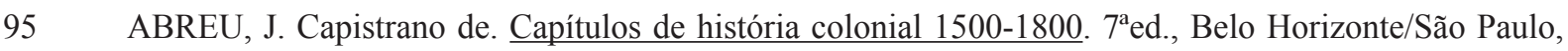
Itatiaia/EDUSP, 1988.

Caminhos antigos e povoamento do Brasil. Belo Horizonte/ São Paulo, Itatiaia/EDUSP, s/data.

96 CALMON, Pedro. Vida espantosa de Gregório de Matos. Rio de Janeiro/ Brasília, José Olympio/ INL.,1983. História da Fundação da Bahia. Rio de Janeiro, Publicações Museu do Estado, 1949.

97 PINHO, Wanderley. História de um engenho do Recôncavo 1552 - 1944. Rio de Janeiro, Zelio Valverde SA., 1946. História social da cidade do Salvador. Salvador, Prefeitura Municipal do Salvador. 1968.

98 RUSSELL-WOOD, A. J. R. Fidalgos and philanthropists: the Santa Casa da Misericórdia of Bahia, 1550 -1755. Berkeley, University of California Press, 1968.

99 MATTOSO, Kátia de Queirós. Ser escravo no Brasil. São Paulo, Brasiliense, 1982.

100 SAMPAIO, Theodoro. História da fundação da Cidade do Salvador. Bahia, Tipografia Beneditina, 1949.

101 FREYRE, Gilberto. Casa grande e senzala. Rio de Janeiro, José Olympio, 1966.

Sobrados e mucambos. 3 vol., $2^{\mathrm{a}}$ ed., Rio de Janeiro, José Olympio, 1951.

102 NOVAIS, Fernando. "O Brasil nos quadros do antigo sistema colonial", In Brasil em Perspectiva. C.G. Mota (ed.), São Paulo, Difel, 1968. Estrutura e dinâmica do antigo sistema colonial. São Paulo, Brasiliense, 1996.

103 FERLINI, Vera Lúcia.Terra trabalho e poder: o mundo dos engenhos no nordeste colonial. Bauru, EDUSC, 2003. O engenho Sergipe do Conde: contar, constatar e questionar Bahia $(1622-1653)$. Dissertação de mestrado em História Econômica apresentada ao Departamento de História da FFLCH-USP. São Paulo, 1980. 
Mesgravis ${ }^{104}$, Luiz Mott ${ }^{105}$, Pedro Puntoni ${ }^{106}$, Luiz Felipe Alencastro ${ }^{107}$ Mafalda Soares Cunha e Nuno Gonçalo F. ${ }^{108}$, Maria Yedda Leite Linhares ${ }^{109}$, Rogério Forastieri Silva ${ }^{110}$.

Os professores do Departamento de História, que permitiram a participação nos cursos ministrados também contribuíram com uma bagagem necessária à percepção dos problemas enfrentados na vida cotidiana pelos colonos. Os ensinamentos de Robert Rowland, Laura de Mello e Souza, Adone Agnolim, Pedro Puntoni e Vera Lúcia Ferlini permitiram selecionar melhor os elementos que deram rumo à pesquisa. A leitura de diversas teses de historiadores também ofereceram referenciais para o trabalho. Cabe a esse respeito mencionar particularmente Avanete Pereira Sousa ${ }^{111}$ e Maria José Rapassi ${ }^{112}$

104 MESGRAVIS, Laima. "Os aspectos estamentais da estrutura social do Brasil colônia", in Estudos econômicos, n 13, pp. 799 a 811, 1983.

105 MOTT, Luíz R.. "In vino veritas: vinho e aguardente no cotidiano dos sodomitas luso brasileiros à época da Inquisição", in Álcool e drogas na História do Brasil. VENÂNCIO, Renato Pinto e CARNEIRO, Henrique, São Paulo/Belo Horizonte, PUC. Minas/Alameda, 2005.

106 PUNTONI, Pedro. A guerra dos bárbaros: povos indígenas e a colonização do sertão nordeste do Brasil, 1650 - 1720. São Paulo, FAPESP/Hucitec/EDUSP, 2000.

107 ALENCASTRO, Luiz Felipe. O trato dos viventes: formação do Brasil no Atlântico Sul. São Paulo, Cia das Letras, 2000.

108 CUNHA, Mafalda Soares. \& MONTEIRO, Nuno Gonçalo F. “Governadores e capitães-mores do império atlântico português nos séculos XVII e XVIII', in Optima Pars, Elites Ibero-americanas do Antigo Regime, Lisboa, Estudos e investigações 36, 2005.

109 LINHARES, Maria Yedda Leite. História do abastecimento: uma problemática em questão (1530 -1918). Brasilia, Binagri, 1979.

110 SILVA, Rogério Forastieri. Colônia e nativismo: a História como "biografia da nação". São Paulo, Hucitec, 1997.

111 SOUSA, Avanete Pereira. Poder local, cidade e atividades econômicas (Bahia, século XVIII). Tese em História econômica apresentada ao Departamento de História da FFLCH-USP. São Paulo, 2003.

112 MASCARENHAS, Maria José Rapassi. Fortunas coloniais: Elite e riqueza em Salvador 1706 - 1808 . Tese em História econômica apresentada ao Departamento de História da FFLCH-USP. São Paulo,1998. 
Quanto aos estudiosos da literatura do período barroco, Antônio Cândido de Mello e Souza ${ }^{113}$, Sergio Buarque de Holanda ${ }^{114}$, Mikhail Bakhtin ${ }^{115}$, João Adolfo Hansen ${ }^{116}$ e João Carlos Teixeira Gomes $^{117}$, seus estudos forneceram subsídios imprescindíveis à escrita da tese.

113 SOUZA, Antônio Cândido de Mello e. Formação da Literatura Brasileira. BH./RJ., Itatiaia, 9ª ed., 2000. 114 HOLANDA, Sérgio Buarque de. Capítulos de Literatura colonial. org. e introdução de Antônio Cândido, São Paulo, Brasiliense, 2000.

115 BAKHTIN, Mikhail. A cultura popular na Idade Média e no Renascimento: o contexto de François Rabelais, São Paulo/Brasília, Hucitec, 1999.

116 HANSEN, João Adolfo. A sátira e o engenho: Gregório de Matos e a Bahia do século XVII. $2^{\mathrm{a}}$ ed., São Paulo, Atelier Editorial/UNICAMP, 2004.

117 GOMES, João Carlos Teixeira. Gregório de Matos, o Boca de Brasa: um estudo de plágio e criação intertextual. Petrópolis, Vozes, 1985. 


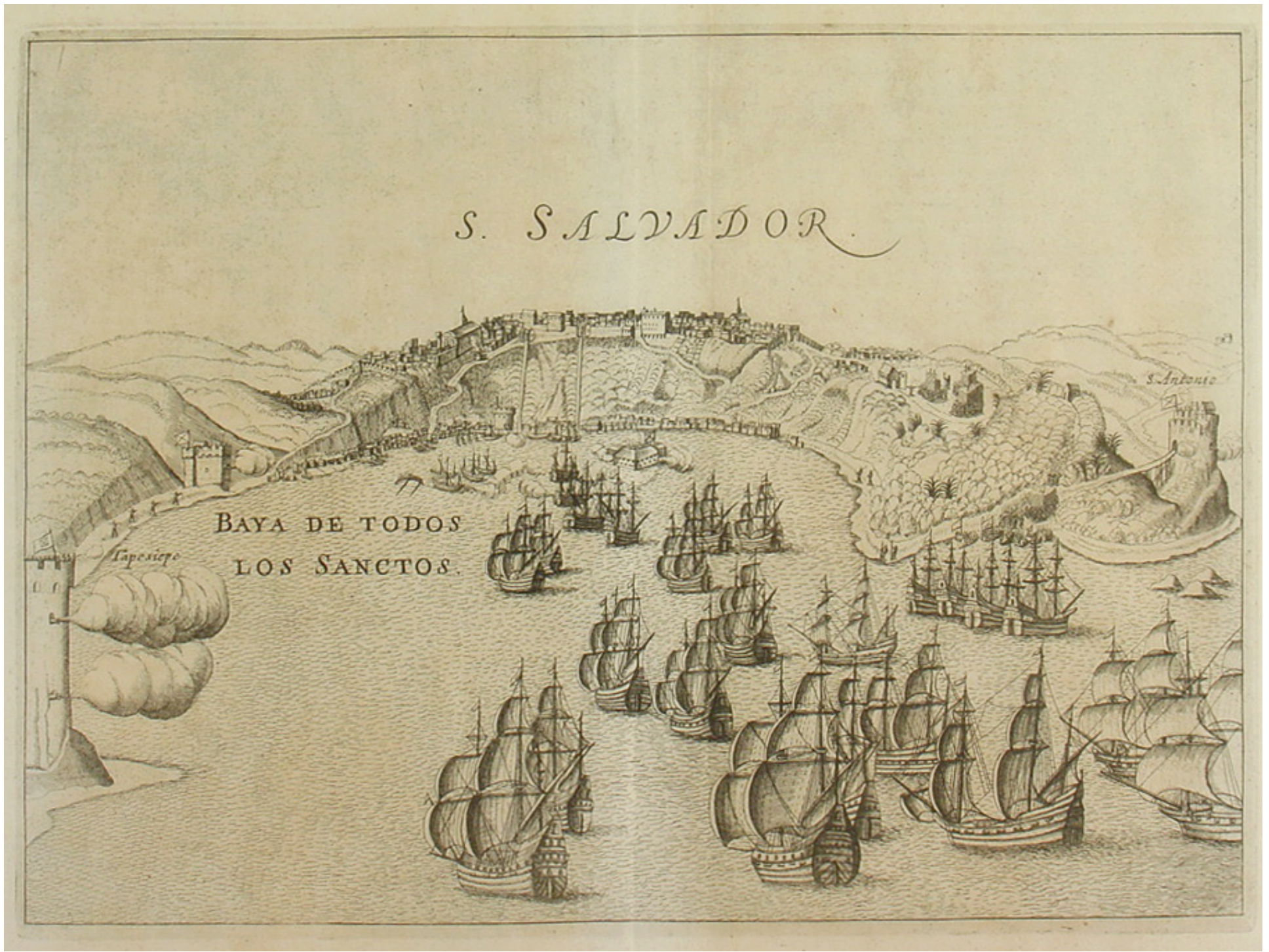

Gravura Salvador Bahia - Meteren, Emanuel (Meteranus) - description of the capture of Salvador Bahia - Gravura original de 1640.

Amsterdam, Janssonius 1640. 25 x $33 \mathrm{~cm}$. 


\section{Capítulo I - Gregório de Matos e Guerra: sua arte e sua vida}

"Depois de consoarmos um tramoço,

A noite se passou jogando a polha, Amanheceu, e pôs-se-nos a olha

De que não sobejou caldo, nem osso.

Reinou, por não ficar-lhe nada, o Môço, De um berro, que lhe dei, fiz-lhe uma bolha,

Rasguei-lhe uma camisa ainda em fôlha,

E a ceia se acabou, jantar e almoço.

O Môço tal se despediu por isso,

E eu fiquei a beber vinho sem gesso

Sobre ovos moles, que me pus um uço.

Neste tempo topei de amor o enguiço,

Tive com Antonica o meu tropeço,

E parti de carreira no meu ruço".

(Gregório de Matos, Vol. IV, p.835).

Como documento a ser analisado, objeto de um estudo focalizando metáforas referentes à alimentação, a obra de Gregório de Matos e Guerra, poeta seiscentista, requer apresentação prévia. Escrita em língua portuguesa, apesar de conter também poemas concebidos em espanhol, ela foi composta por um homem bastante fora do comum, mesmo que afinado com a arte literária de seu próprio tempo.

Efetivamente, a poesia de Matos não escancarou um retrato fidedigno da vida colonial suscetível de ser imediatamente interpretado. Em se tratando de produção literária concebida 
para ser ouvida ou lida pelos colonos, ela obedeceu aos parâmetros preconizados pelos autores barrocos da primeira metade do século XVII, que o autor estudara durante sua formação acadêmica. As metáforas referindo ingredientes comestíveis e hábitos alimentares foram utilizados nos versos como recursos convencionais de versificação e destinaram-se a falar da sociedade soteropolitana aos próprios membros dessa sociedade.

Enveredar pela análise antropológica de práticas alimentares mencionadas nos poemas do autor pressupunha um conhecimento prévio das regras de produção poética envolvidas em sua composição, mas era preciso também esclarecer as intenções do poeta que as formulava.

Gregório de Matos, personagem de uma "vida espantosa" repleta de peripécias, reforçadas pelas circunstâncias curiosas da preservação de sua obra (resgatada à obscuridade em meados dos séculos XIX e XX), era um poeta peculiar, cuja arte cheia de subentendidos requeria um exame bastante minucioso para ser entendida.

\section{1 - A "vida espantosa" de Gregório de Matos}

O pouco que se soube sobre as circunstâncias atribuladas da vida de Gregório de Matos pertenceu, sobretudo, ao domínio das reminiscências de soteropolitanos que o conheceram pessoalmente ou conheceram pessoas de seu convívio. Um licenciado, Manuel Pereira Rabelo ${ }^{118}$, com efeito, empreendeu em meados do século XVIII escrever uma biografia do autor e para tanto recolheu rumores em Salvador. Chegou a entrevistar, por exemplo, dois amigos de infância de Gonçalo de Matos, filho do poeta. O relato produzido por Rabelo foi um texto cheio de elogios à singularidade do autor. O biógrafo procurou desculpas para muitas atitudes censuráveis do poeta e insistiu principalmente, em seu relato intitulado "Vida do excelente poeta lírico, o doutor Gregório de Matos Guerra", sobre os detalhes que enfatizavam a excentricidade do personagem.

118 RABELO, Manuel Pereira. "Vida do excelente poeta lírico, o doutor Gregório de Matos Guerra", in MATOS, Gregório de. A Crônica do viver baiano seiscentista feita em verso pelo Doutor Gregório de Matos e Guerra: fielmente copiada de manuscritos anônimos daquele tempo e disposta como melhor pareceu a um curioso de nome James Amado. Vol. VII, pp. 1689 - 1721. 
Seria tudo - e ainda muito pouco - caso um historiador baiano, Fernando da Rocha Peres ${ }^{119}$, dotado de enorme paciência não tivesse descoberto documentos que confirmaram vários dados mencionados pelo Licenciado Rabelo. Esses permitiram retificar erros de datas e rechaçar a proposta de estudiosos, que, duvidando da existência efetiva do poeta, preferiram atribuir a uma coletividade de letrados residentes em Salvador o acervo dos poemas encontrados nos códices apógrafos existentes no Brasil ou em Portugal.

Segundo a narrativa de Rabelo, Gregório de Matos, terceiro filho de ricos lavradores de cana, era integrante nato de uma elite rural lusa estabelecida no Brasil. Por esse motivo o autor professava os valores da "nobreza da terra":

"Nasceu na Bahia de Todos os Santos ao Cruzeiro de São Francisco da parte do Nascente, em casa cuja figurada cornija de romanas medalhas ainda hoje os distingue caprichosamente nobres. Os pais que o deram á luz em 20 de dezembro de mil e seiscentos e trinta e três, foram Gregório de matos fidalgo da série dos Escudeiros em Ponte de Lima, natural dos Arcos de Valdevez: e Maria da Guerra matrona geralmente conhecida de respeito em toda a cidade [...]. Eram estes de tal maneira ricos que possuíam com outras fazendas um soberbo canavial na Patatiba, fabricado com perto de centro e trinta escravos de serviço, que repartia a safra por dous engenhos: cujo rendimento supria largamente os gastos de um liberal tratamento de caridade com os pobres" ${ }^{120}$.

Peres, entretanto, encontrou um documento de 1661 no qual o autor, então com vinte e cinco anos, dizia ter desembarcado em Lisboa em 1650, "sendo menor de treze para quatorze anos". Ao cabo de dois anos preparatórios, Matos, aos dezesseis anos, ingressou afinal na Universidade de Coimbra, em 1652. Cursou inicialmente uma cadeira de Direito Romano e nos 119 PERES, Fernando da Rocha. Gregório de Mattos Guerra - uma re-visão biográfica. Salvador, Macunaíma, 1983. 
anos seguintes (1653 -1660) o conjunto de disciplinas que proviam aos alunos formação em Cânones. Diplomado em 1661, casou-se no mesmo ano com Michaela de Andrade, filha de uma família de letrados influentes na magistratura. Na ocasião ele solicitou a imediata averiguação da limpeza de sangue de sua família, o que lhe permitiria exercer um cargo público.

O primeiro cargo exercido foi o de Juiz de Fora em Alcácer do Sal, seguido por diversos outros. Em 1671 Gregório de Matos era Juiz do Cível em Lisboa. Por duas vezes até, em 1668 e em 1674, ocupou assento nas Cortes reunidas, com desempenho notado. Teria oferecido a D. Pedro II conselhos apreciados por ocasião dos procedimentos para a deposição de D. Afonso VI, para a anulação eclesiástica do casamento do rei deposto com Maria Francisca Izabel de Sabóia e para o subseqüente enlace do novo rei com a ex-cunhada ainda virgem. Em 1674, entretanto, Matos não conseguiu defender os interesses dos plantadores de fumo soteropolitanos e foi exonerado ${ }^{121}$.

Segundo afirmou o licenciado Rabelo: Gregório de Matos recebeu educação esmerada em Portugal, se doutorou em Coimbra e "assombrou na poesia", particularmente na sátira. Teve boa atuação de advogado na Corte e até o favor "Do Senhor rei D. Pedro II, então Príncipe Regente", sendo inclusive promovido a "Juiz do Cível de um dos bairros, de que não pude alcançar individual notícia". Casou-se, enviuvou ${ }^{122}$ e sua verve satírica parece ter lhe causado problemas, pois o licenciado citava versos de um amigo de Matos, Tomás Pinto Brandão, aludindo às circunstâncias de sua volta à Bahia, na década de 1680:

"Procurei ir-me chegando/a um Bacharel Mazombo,/que estava para a Bahial despachado, e desgostoso:/de lhe não darem aquilo,/com que rogavam a outros,/ pelo crime de Poeta/sobre Jurista famoso" ${ }^{123}$.

\footnotetext{
121 PERES, F. R. Op. Cit., pp. 55 a 69.

O historiador encontrou o atestado de óbito dessa primeira esposa do poeta, falecida em 1678, quanto Matos tinha quarenta e dois anos. 
Peres reuniu informações mais detalhadas. Matos teria cometido pelo menos um erro imperdoável provindo de um magistrado desejoso de promoção: uma sátira mordaz contra um expoente conhecido da boa sociedade cortesã: Marinícolas, texto amplamente divulgado e apreciado, que o teria apontado como poeta perigoso. Despeitado por ser preterido em cargo de maior prestígio na Magistratura como desembargador do cível, o autor conseguiu obter do primeiro arcebispo nomeado do Brasil, D. Gaspar Barata de Mendonça, um dos três cargos de desembargador, que estavam sendo criados para o estabelecimento de uma Relação Eclesiástica em Salvador. Os estudos canônicos, a experiência na magistratura e a condição de viúvo habilitavam Gregório de Matos para ocupar tal cargo. O rei não se opôs à nomeação e, após receber a tonsura com ordens menores, Gregório de Matos voltou ao Brasil provido de um cargo leigo a serviço da Igreja. Tornou-se vigário-geral e tesoureiro-mor da Sé, deixando Lisboa em fins de 1682 para assumir imediatamente o cargo, quando o arcebispo adoentado pediu demissão sem jamais ter ido ao Brasil.

O novo arcebispo, Frei João da Madre de Deus, chegou à Bahia em maio de 1683 e se escandalizou ao constatar que Matos apenas usava a batina no desempenho de suas funções e mantinha uma conduta excessivamente livre o resto do tempo. Instado a receber as ordens sacras e a usar batina em tempo integral, Matos preferiu não obedecer. Já em agosto do mesmo ano, foi demitido de seus cargos, em meio a intrigas promovidas por diversos padres e frades que, depois, foram alvos das sátiras do autor ${ }^{124}$.

Matos, provavelmente por seu pendor mulherengo, preferiu não desistir de "conversar" com moças de seu agrado. O poeta continuou a participar ativamente da vida social da colônia, na qual, por ser letrado e arguto, foi expoente notado. Em certo poema dedicado ao grumete do navio, que o trouxe de volta ao Brasil (reencontrado na condição de barqueiro em Marapé), Matos afirmou que ninguém tinha namorado tanto quanto ele, vangloriando-se de ter "namorado o mapa" ${ }^{125}$ do Recôncavo. Contudo, além de namorar, também se apaixonou por diversas

124 PERES, Fernando da Rocha. Op. Cit., capítulo III, pp. 77 a 97. 
vezes. Dona Ângela de Paredes filha dos donos do engenho de Caípe não correspondeu a seus sentimentos. Afinal o autor, apresentado a uma viúva de poucos recursos, sobrinha do senhor de engenho de Marapé, resolveu casar-se pela segunda vez, em alguma data que Peres situa antes de 1691. Não desistiu, entretanto, das desenvolturas costumeiras. O licenciado Rabelo sublinhou:

"Era a Espôsa um pouco impaciente talvez pelo pouco pão que via em casa, e tal pelo distraimento de seu Marido, cujas desenvolturas claro se patenteiam destas obras; posto que nem a todas se deva inteiro crédito, como veremos pelas rubricas de cada uma; e enfadada de uma e outra desesperação saiu de casa, e entrou pela de seu Tio, que depois de a repreender asperamente, veio rogar ao poeta com razões de amigo, que a fosse buscar, ou consentisse ao menos que ele lha trouxesse; e foi lhe respondido que de nenhum modo admitiria sua mulher em casa sem vir atada em cordas por um capitão-de-mato, como escrava fugitiva" ${ }^{126}$.

Nesses termos, segundo afirmou Rabelo, Gregório de Matos:

"Por este paraíso de deleites estragava a Cítara de Apolo com suas harmoniosas consonâncias em assuntos menos dignos de tão relevante estrondo. Lascivas Mulatas e torpes Negras se ufanizaram dos tropos e figuras de tão delicada poesia" ${ }^{127}$.

O licenciado reportou diversos passeios pelos arredores do Recôncavo:

"Tinha fantesia natural no passeio, e quando algumas vezes por recreação surcava os quietos mares da Bahia a remo compassado com tão bizarra confiança, interpunha os óculos, examinando as janelas de sua cidade que muitos curiosos

126 MATOS, G. Op. Cit., Vol. VII, p. 1706.

127 MATOS, G. Op. Cit., Vol. VII, p. 1707. 
iam de propósito a vê-lo. Trajava cabeleira suposto que naquele tempo era pouco versado" 128 .

No rol das notícias que permaneciam vivas na capital do Brasil, em meados do século XVIII, figuravam o gosto e o talento do advogado e poeta pelo canto e pela música. Rabelo o descreveu como "consumado solfista, e modulando as melhores letras daquele tempo, em que a solfa portuguesa aventajava a tôdas as de Europa tangia graciosamente" ${ }^{129}$. Entretanto, a "musa praguejadora" que lhe proporcionou uma vida intensa também lhe suscitou inimigos influentes. As críticas acerbas a conterrâneos satirizados como pretensiosos e ignorantes e suas aventuras amorosas lhe proporcionaram inúmeros inimigos. Na década de 1690 ele chegou a atacar a honra do próprio Governador Antônio da Câmara Coutinho que lhe recusara uma mercê à qual acreditava fazer jus. As sátiras subseqüentes que o poeta endereçou a essa autoridade lhe valeram, afinal, em 1693, uma sentença de degredo:

"Com estas prendas fazia aprêço particular de uma viola, que por suas curiosas mãos fizera de cabaço, freqüentado divertimento de seus trabalhos: e nunca sem ela foi visto nas funções, a que seus amigos o convidavam; recreando-se muito com a brandura suave de suas vozes. Por esta viola, que havia deixado na Madre de Deus, fazia extremos tais, receando que sem ela o embarcassem: mas o Vigário Manuel Rodrigues a quem feriam nalma suas desgraças, prontamente lha mandou com um liberal donativo para as cordas dela" ${ }^{130}$.

Em Angola, para onde tinha sido exilado o governador local da colônia, agradecido pela ajuda prestada durante um motim, "deu-lhe liberdade de embarcar-se para Pernambuco" ${ }^{131}$. Matos aproveitou a oportunidade e se instalou na capitania onde morreu em novembro de 1696.

128 MATOS, G. Op. Cit., Vol. VII, p. 1721.

129 MATOS, G. Op. Cit., Vol. VII, pp. 1709 e 1710.

130 MATOS, G. Op. Cit., Vol. VII, p. 1710.

131 MATOS, G. Op. Cit., Vol. VII, p. 1713. 


\section{2 - As circunstâncias do resgate poético da obra}

Abordar o corpus dos poemas atribuídos a Gregório de Matos para analisar temas de pesquisa interessantes, requer forçosamente algum conhecimento prévio das discussões suscitadas pela interpretação dos versos e das peripécias do resgate dessa obra que a obscenidade dos versos relegou ao esquecimento. Com efeito, estudar uma obra preservada do desaparecimento por admiradores, que permaneceu semi-clandestina por mais de um século e meio após a morte daquele que compôs os versos, requer um entendimento mais acurado de seus propósitos. Enquanto Matos ainda residia em Salvador, folhas volantes parecem ter circulado no âmbito do público letrado. Após o exílio e a morte do poeta em 1696, ainda no século XVIII, essas folhas volantes foram transcritas em códices transmitidos de geração em geração. Tendo existido efetivamente ou não, o caderno que Rabelo afirmava ter sido colocado às portas do palácio pelo governador João de Lencastre para que colonos transcrevessem nele os poemas de Matos que conheciam, diversos códices apógrafos encontraram o caminho das bibliotecas brasileiras e portuguesas, um deles chegando até a ser conservado na Biblioteca do Congresso americano ${ }^{132}$, em Washington.

Segundo Antônio Cândido de Mello e Souza, os poemas de Matos permaneceram inéditos até Varnhagen publicar, em 1850, versos de teor lírico no Florilégio da literatura brasileira, ou então até Vale Cabral apresentar uma edição mais abrangente das poesias, em 1882. Calmon ressalvou, contudo, o fato de vinte anos antes de Varnhagen se debruçar sobre a obra, Januário da Cunha Barbosa, Secretário do Instituto Histórico e Geográfico Brasileiro, já ter publicado algumas estrofes de poemas de Matos.

À primeira redescoberta da existência do autor seguiu-se, como bem ressaltou João Adolfo Hansen ${ }^{133}$, um expurgo sistemático dos poemas considerados licenciosos. A edição, em 19231933, de: "As obras completas de Gregório de Matos", organizada por Afrânio Peixoto para a

132 TOPA, Francisco. O mapa do Labirinto: inventário testemunhal da poesia atribuída a Gregório de Mattos, Salvador, Bahia Prosa e Poesia, Secretaria de Cultura e Turismo/Imago, 2001.

133 HANSEN, João Adolfo. A sátira e o engenho: Gregório de Matos e a Bahia do século XVII. $2^{\mathrm{a}}$ ed., São Paulo, Atelier Editorial/UNICAMP, 2004. p. 39. 
Academia Brasileira de Letras, edulcorou a riqueza expressiva da linguagem de Gregório de Matos, transformando-o artificialmente em autor lírico. Para que a obra fosse conhecida do grande público o primeiro obstáculo a vencer consistiu no puritanismo de uma época em que a linguagem obscena dos poemas chocava. Essa atitude começou a mudar somente em 1968, data de uma primeira edição completa dos poemas, preparada por James Amado ${ }^{134}$.

Hansen detalhou as características de composição e de estilo da arte poética de Gregório de Matos em sua tese: “A sátira e o engenho: Gregório de Matos e a Bahia do século XVII”. O autor assinalou a longa seqüência cronológica de interpretações equivocadas, "ao gosto do dia", que a leitura dos poemas sugeriu a estudiosos durante a segunda metade do século XIX, deixando que questões alheias às normas seiscentistas da versificação permeassem a interpretação da obra.

Ter sido o primeiro poeta a escrever no Brasil poemas contendo traços enxertados de cor local, fez provavelmente com que estudiosos dos séculos XIX e XX, ao retirarem a obra de Matos da obscuridade, projetassem nela suas próprias esperanças de distanciamento rápido em relação às origens lusas.

Os adeptos de diversas escolas literárias, criadas no cenário das letras brasileiras, avaliaram a obra de Matos em função de seus próprios critérios de composição poética. Deixaram de examinar as normas seiscentistas, que melhor explicariam a escrita dos poemas do "Bacharel mazombo". Autores do século XIX, por exemplo, que avaliavam obras poéticas em função da originalidade dos temas tratados, dos sentimentos expressos e da estética pessoal da forma poética, viram a obra de Matos como um sinal precoce da independência do Brasil em relação à tutela lusa. Cobrando critérios extemporâneos de afirmação pessoal da arte de Matos, consideraram-no ora como um imitador desprovido de caráter próprio (acusando o poeta de praticar plágio) ${ }^{135}$, ora como um marco inicial e genuíno de brasilidade (fechando os olhos perante as impropriedades da linguagem e as evidências de cópia de modelos poéticos conhecidos).

134 MATOS, Gregório de. Crônicas do viver baiano seiscentista. Obra completa de Gregório de Matos, 7 Vol., Amado, James (Org.). Bahia, Ed. Universitária, sem data. 
A contribuição relevante do enfoque analítico de Hansen residiu em seu estudo do caráter engenhoso da arte do poeta mazombo. Ressaltou a importância de situar o estilo de Gregório de Matos num contexto de "agudeza barroca" e de "prudência" e enveredou pela análise das alegorias estereotipadas e dos trocadilhos insultuosos que ornamentavam os versos de Gregório de Matos. O autor especificou:

\footnotetext{
"Ao poeta barroco nada repugna mais do que a inovação, sendo sua invenção antes uma arte combinatória de elementos coletivizados que, propriamente, expressão individual original..." ${ }^{136}$.

"Contrastivamente, a sátira dirige-se sempre a um público que ela fantasia iletrado, tematizando os discursos locais em sua forma aberta" 137.
}

Segundo o estudioso, no período modernista, diversos autores interpretaram também a seu próprio modo a poesia do "Bacharel mazombo". Atribuíram-lhe intenções nativistas. Que Gregório de Matos se queixasse da conduta de muitos conterrâneos, induziu esses autores a considerá-lo de forma extemporânea como um precursor do "antropofagismo cultural".

Em contraposição Hansen ${ }^{138}$, que defendia o papel puramente convencional dos insultos endereçados àqueles que desrespeitavam normas de conduta social estipuladas pelos homens bons da colônia, negou qualquer intento realista às narrativas poéticas de Matos. Destacando a ausência notória na arte poética seiscentista de preocupações em relação à veracidade dos fatos alegados, as citações freqüentes de obras famosas (que incluíam paródias cômicas de poemas de estilo elevado, transpostas em estilo popular) e o uso corrente de fórmulas poéticas codificadas. O estudioso assinalou enfaticamente o respeito estrito de Matos às regras de versificação observadas em seu tempo.

\footnotetext{
136 HANSEN, João Adolfo. Op. Cit., p. 61.

137 HANSEN, João Adolfo. Op. Cit., p. 39.

138 HANSEN, João Adolfo. Op. Cit., p. 55.
} 
Que modelos poéticos convencionais gregos, latinos ou ibéricos tenham, de fato, marcado sua arte, como Hansen alegou, não impediu o poeta de buscar também inspiração nas experiências da vida cotidiana para propor trocadilhos, ironias e duplos sentidos críticos ou jocosos, alusivos aos usos e costumes dos colonos. Subentendiam um conhecimento apurado dos argumentos envolvidos na escolha de procedimentos alimentares destinados à manutenção do território colonial. As mais variadas práticas soteropolitanas de manejo alimentar delinearam, por conseguinte, as metáforas satíricas ou burlescas do autor. Mesmo que não pretendessem a veracidade naturalista das descrições, os versos de Gregório de Matos registraram muitos elementos significativos do contexto social e geográfico local. Ofereceram, por esse motivo, um documento histórico e literário fortemente impregnado pelos valores e pelas práticas da vida cotidiana colonial e bastante apropriado à análise antropológica.

Nem as alusões a obras-primas literárias, nem a imitação do estilo de autores lusos celebrados, nem a recorrência de idéias convencionais retomadas de poema em poema, nem a elaboração de paródias cômicas, que endereçavam discursos elevados a objetos pífios, impediram os versos do autor de retratar particularidades de uma cidade que atravessava então um momento delicado de sua história e de comentar os escândalos locais. Na década de 80 do século XVII, marcada por uma crise da lucratividade do açúcar e ainda pela diminuição do poder político dos senhores de engenho em prol do predomínio dos grandes negociantes e dos administradores da colônia, os episódios escabrosos, e até por vezes fantasiosos, que o poeta mencionava, revelavam indiretamente o teor dos conflitos sociais que dividiam a sociedade.

O principal talento de Matos podia até residir em seu uso excepcionalmente hábil de formas poéticas clássicas. A obra do autor não sobreviveria na memória da cidade sem a vivacidade de sua expressão literária, o colorido das imagens propostas à imaginação e os subentendidos a eventos de inegável sabor local. Talvez fosse até esse viés local dos versos, chamariz para que ouvintes das recitações conservassem cópias escritas dos poemas, uma prática que o próprio autor não fez ou não pôde fazer, em razão das circunstâncias atribuladas de sua vida. 
Apesar de criticar seus pares (e quiçá justamente por sua qualidade de integrante das elites soteropolitanas), o autor pode ser analisado como um porta-voz acreditado das elites mazombas. Filho de lavradores de canas e letrado, acolhido em muitas propriedades do Recôncavo por senhores de engenho e lavradores de tabaco ou de mantimentos, ele explicitou em seus versos seus motivos de queixa perante mudanças ocorridas nos códigos de conduta social vigentes na colônia. Ao expressar seu repúdio às ações imorais de indivíduos ou de categorias de colonos, os versos de Matos revelavam seu temor perante as alterações de parâmetros ocorridas no viver colonial. Que a intenção de corrigir anomalias portadoras de perigo para a ordem social tivesse inspirado a obra, que modelos poéticos ibéricos, gregos ou latinos fossem imitados na empreitada e que parte dos casos relatados não pertencesse ao domínio dos fatos plausíveis não impedia os poemas de Matos de expressarem a experiência colonial de um homem apelidado de "Boca de inferno".

\section{3 - A realidade como fonte de inspiração dos poemas}

O soneto de Gregório de Matos, citado em epígrafe ${ }^{139}$, sugeriu a idéia da pesquisa ora apresentada. Descrevia em traços rápidos e concisos uma noitada de jogo de cartas reunindo amigos. Antes do jogo começar, tremoços foram beliscados, merenda que fez as vezes de ceia frugal. Durante a noite ninguém pensou em comer. Ao amanhecer trouxeram um almoço (um desjejum matinal) tão substancial que parecia um jantar (a refeição principal, comida por volta do meio-dia). Levaram à mesa uma ôlha, ou seja, uma olla podrida: sopeira contendo um cozido de carnes e de legumes fervidos em miscelânea saborosa (uma das principais iguarias ibéricas). Os companheiros esfomeados apreciaram tanto a refeição que "caldo e ossos" desapareceram. Não foi guardado um prato para um dos convivas, que se ausentara por um momento. O rapaz preterido se zangou e protestou. Gregório de Matos lhe deu uma bronca, chegando a lhe rasgar a camisa nova durante a altercação. O jovem despeitado se retirou e o poeta continuou a comer, 
se deliciando com uma sobremesa de ovos moles, talvez salpicados de canela, acompanhada de um vinho de qualidade (sem mosto), que não tinha sido necessário filtrar através de gesso.

No último terceto, o soneto terminava de forma um pouco melancólica com Matos relembrando sua paixão passageira pela jovem Antonica: provavelmente Catona, uma escrava bonita que servia na cozinha do engenho de Pernamerim (Paramirim: localidade próxima da Vila de São Francisco do Conde). A jovem tinha sido cruel, não se deixara conquistar, impelindo o poeta à retirada, montado num cavalo ruço.

O tom levemente jocoso do relato afigurava-se bastante sedutor. A partir de poucas ações esboçando cenas curtas, o autor possibilitava inferir modos locais de agir, de pensar e de sentir, cujos parâmetros compartilhava com um público de letrados de sólida erudição e ouvintes de educação pouco formal. Efetivamente Matos, ao recortar pequenos gestos escolhidos entre tantos outros que poderia lembrar, fragmentos justapostos de condutas sociais observadas, compôs um mosaico interessante de atos carregados de significado, permitindo imaginar o desenrolar da vida seiscentista na Capital da colônia, agilmente representada por meio de uma descrição à l'emporte-pièce.

Um século e meio após a fundação da “Cidade da Bahia”, diversas gerações sucessivas tinham elaborado um estilo de vida local sui generis, cujos traços se revelavam no soneto. Fazendo uso de hábitos alimentares para produzir um amplo leque de metáforas simbólicas Matos, por esse prisma de análise, parecia oferecer uma fonte autorizada de conhecimento sobre a sociedade que consumia os alimentos, obedecia aos valores preconizados pelos códigos sociais locais e reagia à ocorrência de eventos. Ao criticar um governador que julgava relapso, como será discutido mais adiante, o poeta acusou essa autoridade máxima da colônia de negligenciar sua responsabilidade de "governar as farinhas". Muitos poemas do autor atestaram a repercussão cultural e social de acontecimentos calamitosos.

O autor que residiu na Bahia por doze anos, durante as duas últimas décadas dos anos seiscentos, afigurava-se um autêntico mazombo, versado nos significados autóctones de gestos e emoções que governavam a vida dos portugueses na capital e suas adjacências, não obstante 
seus estudos universitários cursados em Coimbra e cerca de vinte anos de exercício profissional das leis em Portugal.

Apermanência do poeta em Salvador, mesmo que relativamente curta, coincidiu com um período agudo de tensões políticas, econômicas, climáticas ${ }^{140}$ e sociais, que ele versejou sob forma de alusões críticas, registrando diversas atividades econômicas e sociais da população soteropolitana e um grande número de procedimentos práticos dos colonos. Ele comentou efetivamente as idéias e os desmandos de seus conterrâneos, como letrado ciente dos usos locais.

O conjunto dos poemas compunha afinal um retrato enviesado da maneira como o autor concebia a sociedade baiana. Pseudo-fidalgos cheios de empáfia vestindo roupas cor de pimentão, comerciantes empenhados em poupar dinheiro, militares corruptos que vendiam paios podres, membros do clero que não respeitavam seus votos de castidade, etc. desfilavam pela narrativa poética.

Constituiu um tema freqüente, gerador de muitas metáforas raivosas, a rivalidade entre emigrantes antigos e recentes, isto é, entre negociantes de passagem ou comerciantes locais que embolsavam a maior parte dos lucros da produção do açúcar e os colonos estabelecidos na área rural que produziam os gêneros exportados. As dificuldades pessoais que o poeta enfrentou no Brasil coincidiram com o desenvolvimento de tensões sociais em torno da queda dos preços do açúcar e da falta de dinheiro líquido em Salvador e adjacências. A escassez do numerário impeliu até os vereadores a tomar medidas drásticas. Os ourives locais foram mesmo proibidos de transformar em jóias ou baixelas as moedas de ouro e de prata que circulavam na praça ${ }^{141}$. A prosperidade das elites produtoras de açúcar colocada em risco, bem como o estilo de vida pomposo dos $\operatorname{colonos}^{142}$,

140 Secas extremas devastaram as plantações nessa época. Cf. as Atas da Câmara Municipal do período.

141 Cf. as Atas da Câmara e as Cartas do Senado do período estudado.

142 Estilo instaurado no rastro da grande expansão da rede dos engenhos de açúcar, entre 1580 e 1640. Como bem assinalou Fernando Novaes:

"De fato, é essa concentração da renda que faz com que, apesar de os mecanismos do regime de comércio transferirem o maior quinhão para a burguesia européia, os colonos-senhores possam manter a continuidade do sistema produtivo, e mesmo levar uma vida faustosa; da mesma forma e ainda dentro da mecânica do sistema, têm os mesmos colonos recursos para importar os produtos da economia européia". NOVAES, Fernando. Estrutura e dinâmica do Antigo Sistema colonial. São Paulo, Brasiliense, 6 ${ }^{\text {a }}$ ed. 1993. p. 93. 
os eventos discutidos pelos soteropolitanos encontraram uma expressão veemente de repúdio nos versos do autor. Ao vituperar a cidade num de seus poemas mais virulentos, Matos expressou sentimentos que não configuravam apenas sua voz pessoal: "Senhora Dona Bahia/nobre e opulenta cidade,/Madrasta dos Naturais,/e dos Estrangeiros Madre" ${ }^{143}$.

De fato, quando a dinastia de Bragança subiu ao trono português em 1640, num império encolhido pelas guerras contra os holandeses e amputado de várias possessões asiáticas, a monarquia passou a depender mais dos lucros gerados pela venda do açúcar brasileiro. $\mathrm{O}$ controle que a metrópole exercia foi ampliado paulatinamente ao longo da segunda metade do século XVII. No conjunto do Império, filhos segundos de grandes famílias nobres foram chamados a exercer cargos de maior representatividade na administração colonial ${ }^{144}$.

Por sua vez, o Conselho Ultramarino, instituído em 1642, preferiu escolher indivíduos pouco relacionados com as elites locais ${ }^{145}$ para cargos vinculados ao desempenho da justiça, já que os homens bons ${ }^{146}$ da colônia, aqueles que possuíam propriedades rurais prósperas, se mostravam lenientes na aplicação de castigos a membros influentes da sociedade. Os homens considerados bons, que "andavam na governança" e podiam ser eleitos para ocupar cargos de poder local nas Câmaras Municipais, eram obrigados a se apresentar nobremente segundo os códigos oficiais de praxe; eles gastavam muito em roupas, cavalos, criados e escravos, viviam no ócio e na ostentação: "à lei da nobreza". Queriam ainda os códigos sociais que tivessem "limpeza de sangue", isto é, não descendessem de negros, de mulatos, de cristãos novos ou de mouros considerados portadores de sangue contaminado, não praticassem atividades de comércio a varejo, ou vivessem de produzir artesanato. Tampouco podiam descender de 143 MATOS, G. Op. Cit., Vol. II, p. 429.

144 CUNHA, Mafalda Soares. \& MONTEIRO, Nuno Gonçalo F. “Governadores e capitães-mores do império atlântico português nos séculos XVII e XVIII", in Optima Pars, Elites Ibero-americanas do Antigo Regime, Lisboa, Estudos e investigações 36, 2005.

145 SCHWARTZ, Stuart B. Burocracia e sociedade no Brasil colonial. São Paulo, Perspectiva, 1979. p. 193. CUNHA, Mafalda Soares. \& MONTEIRO, Nuno Gonçalo F. Op. Cit.

146 MESGRAVIS, Laima. Os aspectos estamentais da estrutura social do Brasil colônia, in Estudos econômicos, n $^{\circ}$ 13, 1983. pp. 799 a 801. 
pequenos comerciantes ou de oficiais mecânicos que tivessem auferido rendas ou subsistência do trabalho manual.

Em 1652, uma Casa da Relação foi reinstituída no Brasil, semelhante àquela que o rei espanhol instaurara em 1609 (Casa dissolvida em 1626, durante o período das invasões holandesas). Encarregada de administrar a justiça, a Relação vinha provida de Chanceler, de Ouvidor-Geral e de Desembargadores, cujos proventos sobrecarregaram as despesas da colônia. Após 1650, o número dos funcionários coloniais, civis e militares a serviço da metrópole cresceu. O custo da gestão colonial se fez mais pesado ${ }^{147}$. E além do mais, foi necessário financiar a paz com a Holanda e prover um dote para a infanta Catarina, que desposou o monarca inglês. E tudo recaiu sobre os colonos, obrigados a contribuírem ao bem comum, num momento delicado de crise local.

\section{4 - Objeções ao estudo da realidade colonial nos poemas de Matos}

Objeções de peso militavam contra a investigação pretendida. A serem corretas as afirmações de autores como Hansen ou como João Carlos Teixeira Gomes, o caráter de criações puramente convencionais dos versos de Gregório de Matos e as acusações de plágio de modelos poéticos ibéricos endereçadas ao conjunto da obra impossibilitariam o propósito de uma pesquisa de elementos de realidade soteropolitana nos versos atribuídos ao poeta. Acusações persistentes e iradas de plágio e de falta de originalidade na composição poética foram dirigidas à Gregório de Matos, contrastando com apologias apaixonadas, tanto quanto desprovidas de senso crítico. Teixeira Gomes ${ }^{148}$, por exemplo, analisando as acusações de plágio, sublinhava o caráter convencional da escrita poética de Matos ao recolocar a arte do letrado no contexto literário de sua época e no contexto das peripécias de sua vida pessoal. João Adolfo Hansen ${ }^{149} \operatorname{também~}^{-}$

147 SCHWARTZ, Stuart B. Op. Cit., pp. 207 e 208.

148 GOMES, João Carlos Teixeira. Gregório de Matos, o Boca de Brasa (um estudo de plágio e criação intertextual). Petrópolis, Vozes, 1985. 
alegava a obediência do autor a parâmetros europeus de composição poética para argumentar a ausência de qualquer intenção de Matos de retratar a vida na colônia, exceto em poemas satíricos criticando a gestão política da colônia.

Um outro obstáculo se destacava ainda contra a escolha da obra de Matos como objeto de uma tese voltada para a realidade da vida colonial. Vários estudiosos atuais duvidavam da autoria da obra, sugerindo que o conjunto dos poemas conhecidos poderia incluir versos de diferentes autores do mesmo período ${ }^{150}$. Alguns chegavam até a duvidar da existência efetiva de um poeta chamado Gregório de Matos. Por conseguinte, se não fosse comprovada a existência de um homem chamado Matos ou se esse homem não fosse o autor dos versos que lhe atribuíram ou ainda se, apenas preocupado em plagiar modelos poéticos europeus, o autor nunca tivesse procurado descrever a realidade soteropolitana, a escolha da fonte primária e o trabalho planejado estariam invalidados.

Efetivamente, nada garante a autoria de todos os versos. Não se pode assegurar que poemas de outras lavras não tenham sido incorporados à obra. Tampouco se poderia certificar que os poemas registrados nos códices apógrafos não contenham erros de transcrição ou lacunas. Além do mais, a primeira edição completa dos poemas conhecidos, uma edição publicada por James Amado em 1968, incluiu versos compostos em torneios de composição literária por colonos como Tomás Pinto Brandão, ou Bernardo Vieira Ravasco, irmão do Padre Vieira e secretário de Estado da colônia, que pertenciam ao mesmo círculo de convívio. A edição de Amado, por outro lado, conservou também um duelo de poemas satíricos, integralmente transcrito. Tratava-se de um duelo literário que resultara de uma sátira que acusava Matos de plagiar poemas de Góngora e de "arranhar como gato/no Parnaso de Quevedo" ${ }^{151}$. A autoria do ataque foi atribuída (falsamente, segundo consta), ao vigário de Passé, Lourenço Ribeiro, que era mulato. Replicando violentamente, Matos insultou o vigário que, indignado e provavelmente inocente do feito, replicou tratando o 150 AMADO, James (Org.). Gregório de_MATOS, Crônicas do viver baiano seiscentista. Obra completa de Gregório de Matos. 7 Vol., Bahia, Ed. Universitária, sem data. 
poeta de "pirata do verso alheio" e perguntando-lhe à guisa de refrão: "não te envergonhas magano?" 152 .

Em decorrência de tais circunstâncias muitos estudiosos, preferindo adotar uma atitude cautelosa, consideraram a obra registrada nos códices em meados do século XVIII apenas como uma coletânea de composições coletivas seiscentistas. João Carlos Teixeira Gomes bem ressaltou:

“Existe, hoje, uma tendência para se considerar a poesia dita gregoriana, reunida em numerosos códices manuscritos que nos legaram, desde o século XVII, uma poderosa tradição autoral, ao lado de rico patrimônio petiço, muito mais como expressão de toda uma época da evolução da poesia brasileira do que, propriamente, como a produção regular de um único poeta, suposta fonte de uma obra ampla e diversificada" ${ }^{153}$.

A medida cautelosa, todavia, se afigurou excessiva. Em muitos poemas apógrafos, alusões à vida pessoal do autor inseridas ao acaso das rimas em versos satíricos, burlescos ou laudatórios ofereciam, segundo Teixeira Gomes, coincidências estreitas entre as circunstâncias da vida de Matos eos comentários apresentados: "o poeta costumava fazer, em numerosos poemas referências a situações pessoais por ele vividas, todas em regra, confirmadas pelas informações biográficas que dele dispomos" ${ }^{154}$.

Gomes sublinhando o emprego de vocábulos pouco comuns ou: "certos recursos reiterativos de linguagem, indicativos de procedência uniforme" ${ }^{155}$ concluía o raciocínio considerando que “Raras vezes em língua portuguesa uma poesia terá sido tão autobiográfica como a que nos foi deixada pelo satírico baiano" ${ }^{156}$.

152 MATOS, G. Op. Cit., Vol. IV, p. 794 a 803.

153 GOMES, João Carlos Teixeira. Op. Cit., p. 14.

154 GOMES, João Carlos Teixeira. Op. Cit., p. 33.

155 GOMES, João Carlos Teixeira. Op. Cit., p. 23.

156 GOMES, João Carlos Teixeira. Op. Cit., p. 41. 
Acresciam à credibilidade da obra diversas provas que resultavam de investigações aprofundadas levadas adiante pelo historiador Fernando da Rocha Peres ${ }^{157}$. Gregório de Matos, sua vida, sua família e seus amigos, comprovadamente tinham existido, confirmando o caráter fidedigno de circunstâncias da vida colonial ou da vida familiar do autor mencionados nos versos, graças ao testemunho de documentos mantidos em arquivos ou bibliotecas portuguesas ou brasileiras. Correlações comprobatórias entre dados biográficos e comentários inseridos nos versos inclinavam a optar pela autenticidade da autoria na maioria dos poemas. De forma que, a despeito do risco de conter trechos alterados e poemas de outros versejadores, a obra atribuída a Gregório de Matos se apresentou como uma coletânea de trechos de discursos referindo práticas e eventos que realmente teriam alvoroçado Salvador no último quartel do século XVII.

Se o propósito do estudo fosse analisar detalhadamente o estilo literário de Matos, em lugar de confirmar ou desmentir a veracidade das menções aos procedimentos habituais de um sistema alimentar que os colonos lusos do ultimo quartel do século XVII julgavam adequado às suas pessoas e às suas atividades, as circunstâncias, talvez, pediriam cautela. Mas, no caso de uma tese interessada nos hábitos da dieta alimentar soteropolitana, as referências do poeta a alimentos e usos alimentares, transformados em fontes de metáforas ou de metonímias, de trocadilhos irônicos e de brincadeiras obscenas, foram apenas pontos de partida para a investigação e importava menos que as figuras de estilo não se devessem todas genuinamente ao poeta, como será argüido nos próximos capítulos da tese. Por outro lado, pouco se acrescentou ao conhecimento sobre a obra de Matos durante a pesquisa. A escolha do texto deveu-se antes aos comentários sobre procedimentos sócio-culturais em uso, que às características literárias próprias que porventura apresentariam.

157 PERES, Fernando da Rocha. Gregório de Mattos Guerra - uma re-visão biográfica. Salvador, Macunaíma, 1983.

PERES, F da R. Gregório de Mattos e a Inquisição. Salvador, Centro de Estudos Baianos, 1987.

PERES, F da R. A família Mattos na Bahia do século XVII. Salvador, Centro de Estudos Baianos, 1988.

PERES, F da R. Gregório de Mattos: o poeta devorador. Rio de Janeiro, Manati, 2004. 
A apropriação do corpus poético efetuada por colonos seiscentistas ou setecentistas, poderia, de fato, obliterar os limites a serem traçados entre traduções de poemas de outros autores, poemas de outros autores dados como obras de Matos ou atribuições de composições de Matos a outrem, já que o autor, além de compor os próprios versos, verteu para o português composições eruditas originalmente escritas em língua espanhola, compôs letras de músicas (durante as reuniões sociais ele costumava cantar, acompanhado da viola, que ele mesmo tinha fabricado) e incluiu em seus poemas, prática usual naquele tempo, citações de trechos de poesias conhecidas. Contudo, a despeito da opinião pública soteropolitana ter se apossado coletivamente da obra, parece correta a suposição formulada por Gomes, da autoria única da obra, devida a um indivíduo chamado Gregório de Matos. Em prol dessa identificação, como salientou Gomes, repetições freqüentes de frases feitas, de provérbios, de idéias ou de imagens pontuavam a obra e assinalavam a marca de um estilo pessoal ${ }^{158}$. Por outro lado, as informações recolhidas durante a pesquisa da tese sobre hábitos alimentares específicos dos colonos, relatados por Matos, apresentavam uma enorme coerência de conteúdo quando os dados contidos nos versos do poeta eram cotejados com textos de cronistas da mesma época.

A própria preservação dos poemas, evidenciada pela circulação clandestina de escritos transmitidos de uma geração para outra, atestava o agrado com o qual a obra de Gregório de Matos foi recebida na capital do Brasil, a despeito do desfavor oficial, que afastou o poeta e exmagistrado do torrão natal. Se não traduzisse em palavras adequadas o modo de vida da época, a grande divulgação que seu conteúdo eivado de calúnias mereceu, quase trezentos anos após ter sido composta, não se justificaria. Os esforços para preservar poemas com os quais muitos colonos pareciam obviamente se identificar, conferiu credibilidade suplementar aos códices apógrafos.

Transitando num terreno ambíguo, que articulava os domínios da oralidade e da erudição, as Crônicas do viver seiscentista, editadas por Amado, lembravam um pouco o destino da obra medieval popularmente conhecida como "Roman de Renard", no qual o astuto Renard, 
uma raposa, enganava seguidamente um lobo chamado Ysengrin. O tema da raposa astuta enganando os tolos, por ser atraente, recebeu contribuições sucessivas de recitadores, que apresentavam os episódios, viajando de uma corte senhorial para outra, criando novas peripécias, acrescentando detalhes ao sabor dos espetáculos, omitindo elementos, e, de uma forma geral, transformando a inspiração original numa obra coletiva. A população letrada de Salvador e dos engenhos de açúcar também parece ter assimilado dessa forma a obra poética de Matos e suas articulações engenhosas entre domínios cultos e populares ${ }^{159}$. Comentando uma "espécie de dupla personalidade" presente na literatura brasileira, Sérgio Buarque de Holanda reconheceu Gregório de Matos Guerra como o mais genuíno representante da fusão de elementos populares e eruditos:

"No Seiscentos, nota-se a coexistência pacifica, quase a interdependência, das duas maneiras. O culto requer o popular, o sublime necessita do burlesco, como se a poesia, elevando-se a altitudes inumanas e proibidas, precisasse, com Anteu, voltar constantemente à terra para retemperar forças e sobreviver" 160 .

As informações sobre alimentos, que constavam nos poemas de Matos, permitiram introduzir na tese uma discussão das práticas efetivas e dos valores em uso na colônia. Elas operavam no plano de uma poesia culta permeada de elementos populares, próximo das preocupações com o folclore de Mikhail Bakhtin ${ }^{161}$. Mesmo transmitidos através de procedimentos escritos, os versos de Gregório de Matos foram concebidos no âmbito de uma arte culta fortemente impregnada de oralidade. Sua forma assumia os contornos das regras poéticas eruditas vigentes nos anos seiscentos, mas não poderia ser analisada somente pelo prisma da erudição, sem considerar a

\footnotetext{
159 HANSEN, João Adolfo. Op. cit., pp. 102 e 103.

160 HOLANDA, Sérgio Buarque. "Panorama da literatura colonial", in Capítulos de literatura colonial.
} São Paulo, Brasiliense, 2000. p.415.

161 BAKHTIN, Mikhail. A cultura popular na Idade Média e no Renascimento: o contexto de François Rabelais, São Paulo/Brasília, Hucitec, 1999. 
presença de arcabouços mnemônicos provenientes da poesia popular, aptos a liberar a memória de esforços desnecessários. Tributária de uma época que dispunha de raros manuscritos, a arte poética do século XVII conservava em sua feitura elementos dos estilos poéticos antigos e releituras Renascentistas dos conselhos poéticos de Aristóteles e de Horácio. Tais elementos auxiliavam o poeta a compor, em miscelânea generosa, sonetos eruditos, burilados à maneira dos modelos quinhentistas italianos desenvolvidos por Petrarca ou Marino e poesias populares de fatura menos cuidadosa, como os romances ${ }^{162}$. Walter Ong, aliás, assinalando as dificuldades encontradas pela escrita ao tentar prescindir da oralidade, enfatizou como "'ler' um texto significa convertê-lo em som, em voz alta ou na imaginação" ${ }^{163}$. Não estava em jogo, ali, a "oralidade primária" de uma sociedade que não conheceu a escrita ou a impressão, mas aquela de um gênero literário escrito que conservava vínculos formais, antes populares que cultos, com antigos parâmetros da arte poética recitada de Homero:

"Na cultura oral, o conhecimento, uma vez adquirido, devia ser constantemente repetido ou se perderia: padrões de pensamento fixos formulares, eram essenciais à sabedoria è̀ administração eficiente [...] A nova maneira de estocar conhecimento não estava em fórmulas mnemônicas, mas no texto escrito. Este libertava a mente para um pensamento mais original, mais abstrato $" 164$.

Outra questão investigada exaustivamente por Teixeira Gomes foi o problema das acusações de plágio associadas à obra de Gregório de Matos. A troca de farpas satíricas supostamente ocorrida entre Lourenço Ribeiro, o vigário de Passé, e Gregório de Matos parece ter dado cria a uma longa seqüência de acusações que continua a repercutir até a atualidade.

162 Longas narrativas entremeadas de refrões, por vezes, acompanhadas de cantos

163 ONG, Walter. Oralidade e cultura escrita. Papyrus. 1998. p.16.

164 ONG, Walter. Op. Cit., p. 33. 
Teixeira Gomes, ao "documentar e analisar os processos de criação literária em textos que uma tradição formada desde o século XVII atribui a Gregório de Matos", partiu efetivamente das acusações de plágio endereçadas a Matos para assinalar a existência de "um problema Gregório de Matos" ${ }^{165}$. O autor desdobrava o problema em três aspectos que suscitavam a controvérsia: o da autoria, o da biografia e o dos supostos plágios propriamente ditos. Dúvidas sobre a paternidade da obra (efetivamente carente de fontes precisas), segundo Gomes, induziam à inibição do estudo e da fruição dos textos. A idéia proposta na edição James Amado, do corpus constituir uma criação coletiva $^{166}$ que incorporava versos de "uma constelação de poetas", não satisfazia Gomes por anular indevidamente os numerosos indícios de autoria de grande parte dos poemas: "falando com dicção própria mesmo quando sua voz parece dissolvida no coro das convenções barrocas" 167 .

O foco do problema, segundo o estudioso, residia no anacronismo de leituras feitas em épocas recentes. Gomes, como Hansen, argumentava em favor dos cânones de composição poética praticados, que precisariam ser considerados em seus próprios contextos de produção. Lembrando que os conceitos poéticos de individualidade e de originalidade literária somente passaram a vigorar a partir do Romantismo, Gomes ressaltava "os flexíveis limites" existentes entre imitação e plágio ${ }^{168}$. Assinalava como paródias poéticas citações de trechos célebres, imitações de inspiração temática ou de formas poéticas cristalizadas pelo costume eram procedimentos literários valorizados, assaz diferenciados de apropriações indevidas de versos alheios $^{169}$, enfatizando ainda o fato dos principais autores plagiados por Matos Góngora e Quevedo terem, eles próprios, imitado elementos poéticos encontrados na obra de predecessores tais como Camões ou Lope de Vega ${ }^{170}$.

\footnotetext{
165 GOMES, João Carlos Teixeira. Op. Cit., p. 46 e p. 42.

166 Como no caso de Homero ou de Camões.

167 GOMES, João Carlos Teixeira. Op. Cit., p. 17.

168 GOMES, João Carlos Teixeira. Op. Cit., p. 330.

169 GOMES, João Carlos Teixeira. Op. Cit., p. 90.

170 GOMES, João Carlos Teixeira. Op. Cit., p. 61. Ver também, HOLANDA, Sergio Buarque. Op. Cit., pp. 416 a 418.
} 
Resumindo argumentos favoráveis ou contrários à arte de Gregório de Matos, Gomes apontava o substrato apaixonado das acusações de plágio e de falta de originalidade dirigidas ao poeta. Críticos literários como Varnhagen, Silvio Júlio ou Paulo Ronai, com efeito, tinham desprezado os poemas por sua obscenidade e sua falta de personalidade estética própria. Varnhagen, segundo reportava Gomes, teria afirmado em seu Florilégio da poesia brasileira ${ }^{171}$ que "Matos, pelas tendências do seu caráter, fez-se, não discípulo mas escravo imitador de Quevedo" ${ }^{172}$. Quanto a Sílvio Júlio, considerado por Gomes o mais cáustico dos detratores do poeta, dedicou-se, entre 1930 e 1940, a recensear exemplos comprobatórios de imitações descaradas ${ }^{173}$. Nas críticas de Paulo Ronai, Gomes ressaltava sua frustração, “compreensível num crítico estrangeiro", perante a ausência de formas poéticas inovadoras, lamentando o fato de Matos se limitar a copiar fontes ibéricas ${ }^{174}$. Em contraposição o estudioso destacava a perspicácia de autores, como Araripe Jr., que perceberam o enriquecimento da poesia de Matos proveniente de um certo contato com os meios populares do Brasil ${ }^{175}$.

O estilo poético de Matos imitou ou prolongou certamente um jeito português de escrever versos, que multiplicava os empréstimos da literatura espanhola especialmente florescente no período seiscentista. Os versos continham frases feitas, idéias copiadas, lugares comuns, refrões ou estribilhos emprestados diretamente de poemas conhecidos de autores ibéricos dos séculos XVI e XVII. Os temas que inspiravam o autor eram de uso corrente desde tempos medievais, os temas da vida breve, do mundo às avessas, os elogios ditirâmbicos a grandes figuras da sociedade lusa, ou ainda os poemas de amor cortês, as sátiras menos corteses, os lirismos de inspiração religiosa, amorosa ou pessoal.

171 VARNHAGEN, Francisco Adolfo. Florilégio da poesia brasileira. Rio de Janeiro, Academia Brasileira, 1946. Vol. I, p. 74.

172 GOMES, João Carlos Teixeira. Op. Cit., p. 55.

173 GOMES, João Carlos Teixeira. Op. Cit., pp. 62 a 74.

JÚLIO, Silvio. Fundamentos da poesia brasileira, Rio de Janeiro, Coelho Branco Fo ${ }^{\text {., }} 1930$.

174 GOMES, João Carlos Teixeira. Op. Cit., p. 74.

175 GOMES, João Carlos Teixeira. Op. Cit., p. 85. 
Matos praticou, em suma, uma arte empenhada em dar mostras de conhecimentos apurados de erudição clássica, de engenhosidade no uso da linguagem e de normas prescritas de versificação. Orgulhava-se de manejar perfeitamente semelhante tipo de expressão de linguagem. Hansen e Teixeira Gomes tiveram razões de sobra para assinalar o anacronismo de interpretações dos poemas do autor instruídas por parâmetros de composição poética alheios a seu tempo de produção. Quando a obra de Gregório de Matos foi resgatada do anonimato, em meados do século XIX, a concepção vigente de arte poética obedecia a exigências de afirmação pessoal distintas daquelas observadas em períodos anteriores. Na segunda metade do século XVII, com efeito, nem a expressão da linguagem, nem os temas de poemas mantinham qualquer obrigação de se revelarem inovadores.

Tampouco averiguaram-se fundamentadas as esperanças daqueles que quiseram a todo custo enxergar nas críticas de Matos à sociedade colonial, os primórdios de uma "antropofagia cultural" ${ }^{176}$. Apesar de conter críticas, as sátiras do autor apresentavam apenas os versos de um homem que, voltando à terra natal, não pôde exercer atividades condizentes com sua formação de magistrado e de quase sacerdote. A verve mordaz do autor tinha a ver com o desespero de um homem vaidoso, filho de colonos pertencentes às elites coloniais, que se encontrava em situação financeira precária e julgava fazer jus a uma "mercê ordinária", pensão honorífica outorgada a homens de menos méritos que ele, mas que lhe recusavam, esquecidos de serviços relevantes prestados à coroa. Os ressentimentos experimentados podiam não ser o móvel central da escrita dos poemas mas, já que criticar o universo colonial se fazia necessário, as convenções existentes se revelavam assaz convenientes. De forma que, mesmo compondo versos segundo regras impessoais e predeterminadas de vituperação, seus inimigos pessoais não deixaram de ser visados com grande virulência, como será observado nos próximos capítulos. Mesmo

176 Têm poucas chances de corresponder às intenções de Matos, opiniões como aquela de Lúcia Helena:

"É Gregório de Matos que inicia em nossa literatura a festa da carnavalização antropofágica, na qual se sacrifica simbolicamente o colonizador e se pratica uma espécie de "parricídio inaugural".

HELENA, Lúcia. Uma literatura antropofágica. Rio de Janeiro, Cátedra/Instit. Nac. do Livro/MEC, 1982. pp. 19 a 45. 
vivendo em situação financeira precária, após a demissão dos cargos eclesiásticos, Gregório de Matos residia numa terra onde homens ricos tinham como ponto de honra acolher parentes em dificuldade. O poeta, aliás, era parente próximo de um dos homens mais ricos da colônia, João de Mattos Aguiar. O Doutor em Leis era apreciado por muitos colonos. Além de inimigos óbvios, ele tinha um círculo extenso de amigos fiéis. Os relatos de excursões pelo Recôncavo, os comentários sobre aparições de cometas, as chegadas de arcebispos ou de governadores, as festas, jogos e reuniões freqüentadas, atestam que ele desfrutou, a despeito de tudo, de uma vida social invejável.

No que tange à questão das acusações de plágio, associadas implicitamente a uma negação de qualquer qualidade de originalidade aos versos do autor, Gomes sublinhou o procedimento freqüente daqueles que apreciavam a obra pioneira de Matos. Obliterando qualquer senso crítico, eles fechavam os olhos às denúncias para incensar com louvores extremos, de cunho ufanista, os poemas atribuídos ao poeta.

Segundo Hansen, Gregório de Matos escrevia versos que prolongavam uma maneira ibérica de conceber a poesia, tributária ainda da escrita poética de Aristóteles ou de Horácio, porém repensada na Época Moderna. O poeta teria entrelaçado estórias, narrativas, cantos, oratória etc. com a métrica e as rimas de uma expressão artística previamente delineada em suas formas, temas de expressão e até nos insultos estereotipados contra seus desafetos. Fiel às normas cultas, às citações impregnadas de erudição acadêmica, às alusões que requeriam argúcia para ser decifradas, Matos teria recorrido a metáforas, a trocadilhos insultuosos, a alegorias estereotipadas, a lugares comuns e a provérbios para ridicularizar as condutas extravagantes de seus contemporâneos. O intuito principal de metáforas e metonímias teria sido evidenciar os vícios que acometiam a sociedade soteropolitana e convencer colonos recém-desembarcados, crioulos e mazombos a evitarem a pratica de ações condenáveis. A aparência corporal monstruosa dos indivíduos ridicularizados, esboçada nos versos, subentendia condutas imorais. Elementos recortados na anatomia dos indivíduos, uma vez tornados independentes do resto do corpo eram comparados a alimentos e recebiam nos versos mudanças de função grotescas 
e desabonadoras. Hansen demonstrou efetivamente quão distante de uma descrição naturalista de hábitos soteropolitanos se situava o propósito poético de Gregório de Matos. O recurso freqüente de Matos aos alimentos para construir imagens marcantes, constituiu efetivamente um procedimento estilístico mais abstrato que prático.

No entanto, Sérgio Buarque de Holanda observava:

“O poeta satírico é por definição um realista, embora realista do traço grosso e da caricatura. E Gregório de Matos seria o mais brasileiro dos nossos poetas se a simples escolha dos temas indígenas e locais constituísse padrão de brasileirismo.[...] Quase se pode dizer de Gregório de Matos que, onde carrega mais fortemente as tintas nas pinturas dos conterrâneos, é freqüentemente onde mostra maior dependência dos modelos ultramarinos. Dependência que se confunde muitas vezes com o plágio mais deslavado" ${ }^{177}$.

Hansen, todavia, não convenceu ao defender a idéia da ausência de qualquer intenção descritiva na obra atribuída a Matos. O primeiro poeta de uma longa linhagem de letrados nascidos no Brasil podia, inspirado nos gêneros literários produzidos em Coimbra ou Lisboa, manter estreita interlocução com a formação acadêmica de origem, praticar uma arte convencional e proclamar até seu orgulho de saber manejar com maestria as normas poéticas ibéricas. Negar aos versos do poeta qualquer intenção de retratar a realidade, exceto no que dizia respeito à gestão inepta ou corrupta de alguns administradores coloniais, seria levar demasiadamente a sério o argumento do aspecto convencional da obra. Indiretamente a realidade impôs sua presença nos versos e um exame atento do conjunto de metáforas e metonímias elaboradas em torno de gêneros comestíveis permite matizar a argumentação em favor do caráter puramente convencional de sua arte. Nos textos, a presença de um certo número de metáforas sem raízes na vida colonial não impediu as relações sociais locais de irromperem nas entrelinhas. Quanto aos retratos 
fantasiosos que o poeta elaborou para desancar seus desafetos, as descrições propostas não se desejavam verídicas, nem podiam ser recebidas como tais, mas escancaravam indiretamente o teor dos conflitos e das fofocas, que afetavam a capitania real. Tais imagens espelhavam a maneira como os soteropolitanos concebiam os aspectos cotidianos significativos de sua vida colonial. Não seria, pois, totalmente verídico afirmar:

\begin{abstract}
"No ramilhete de víboras da sátira atribuida a Gregório de Matos e Guerra algo falta irremediavelmente, contudo, flor ausente de todos os buquês, hoje em terra, em cinza, em pó, em sombra e em nada convertida: falta o passado mesmo, singularidade de um tempo, perfume e cor de um lugar e de suas práticas" ${ }^{178}$.
\end{abstract}

Mesmo pautando sua arte em convenções poéticas, incorporando aos versos alusões à Bíblia ou às mitologias antigas ou, ainda, citações de poemas alheios, provérbios, frases feitas ou clichês, Gregório de Matos não deixou de enxertar também referências aos fatos do cotidiano. Se o autor compôs sonetos (à moda de Petrarca e Marino), romances (com longas narrativas) e silvas (cantadas), se alinhavou décimas, oitavas e tercetos, poemas com epílogos ou poemas de cabo-roto, se glosou motes picantes, e se, ao sabor da inspiração, entrelaçou temas clássicos, atento às normas cultas, que regiam métrica e rimas, não foi apenas para exibir perícia técnica e obedecer a convenções. O poeta pode não ter sido o nativista revolucionário que os autores de um Brasil já independente de Portugal imaginaram que fosse, tampouco foi apenas um mero aplicador cego de regras poéticas convencionais. Seus poemas ostentavam um inconfundível sabor local a ponto de consubstanciar uma visão etnográfica interessante de sua época.

Não há como negar a sólida experiência de vida seiscentista aflorando nos textos: ora o poeta mencionou a aparição de um cometa considerado presságio nefasto de pestes e de fome, anunciando castigos divinos pelos vícios praticados, ora relatou festejos em tom burlesco, ora informou rumores escandalosos que circulavam na cidade e nos engenhos do Recôncavo 
Baiano. Se as confraternizações soteropolitanas, as festas e os passeios da sociedade mazomba, os hábitos de luxúria, as práticas ilícitas e as agiotagens de comerciantes locais ou de negociantes de passagem, os apetites desmedidos do clero e dos leigos, os abusos de poder das autoridades coloniais não retratassem o estilo de vida praticado na capital do Brasil colonial, muitas setas ferinas do poeta perderiam sentido e graça para os conterrâneos. Mesmo que Matos enveredasse antes pela expressão de idéias, que pelos relatos fidedignos de episódios ocorridos no palco social da colônia, ao recorrer a usos e costumes efetivos para ilustrar didaticamente um grande número de comparações abstratas, era a própria realidade da existência em Salvador ou em sua área rural que irrompia nos versos, coexistindo com um bom número de metáforas de caráter meramente convencional, como o pão para designar um sustento de farinha de mandioca.

Como bem notou Victor Hugo em Hernani: “Chassez le naturel, il revient au galop" ${ }^{179}$ ). Ao escolher alimentos da dieta mazomba ou manejos produtores de alimentos para enfatizar propriedades dos gêneros alimentícios, era a própria bagagem de crenças e de conhecimentos do autor e dos ouvintes que conferia lastro às alusões engenhosas.

A discussão das objeções ao projeto de analisar as metáforas alimentares imaginadas por Gregório de Matos enquanto fontes de conhecimento sobre os procedimentos da alimentação soteropolitana no último quartel do século XVII, deveria ser retomada à luz dos argumentos expostos. Plagiando ou apenas imitando outros autores seiscentistas e se propondo, ou não, como meta uma descrição realista e consciente da vida social, o poeta exemplificou seus pontos de vista recorrendo a termos de comparação emprestados da realidade cotidiana e suscetíveis de observação direta por parte dos colonos. Que o público destinatário não fosse explicitado, não impedia a obra de expor o diálogo do poeta com os conterrâneos. A presença desse público explicava a seleção de hábitos e de valores culturais relevantes apresentados sob a forma de brincadeiras carregadas de subentendidos. Os poemas compostos num momento importante da história colonial, espelharam eventos excepcionais e fatos corriqueiros de alimentação colonial.

179 HUGO, Victor. Hernani. "Enxotem o natural, ele volta a galope" (minha tradução). Retomando, ao que parece, uma frase originalmente criada por Philippe Destouches, em sua peça de teatro: Le glorieux. 
Nenhum outro autor seiscentista permitia flagrar, tão de perto quanto Matos, a intimidade dos soteropolitanos.

Os versos, além de incluírem metáforas que figuravam no rol dos clichês genéricos de uso comum na língua portuguesa, referiam também inúmeros procedimentos concretos de alimentação, um aspecto da arte do poeta que Hansen deixou na penumbra. Alusivas aos ritmos da vida cotidiana, essas comparações ofereciam à pesquisa pistas involuntárias, dados que precisavam ser examinados independentemente das intenções que Matos podia nutrir ao compor seus versos. Entrava em liça, a observação de Vansina, já citada acima, sobre a maior confiabilidade de objetos retratados incidentalmente que permitiam formular uma percepção acurada de objetos situados em posição excêntrica no campo da visão. Sobressaia, nessa mesma linha de análise, uma observação interessante de Jean François Revel sobre a importância da literatura para a compreensão de sistemas específicos de alimentação. A diferenciação dos enfoques adotados nos capítulos II e III da tese fundamentou-se em tais considerações:

“De Aristófanes a Zola, de Juvenal a Gogol, passando por Fielding ou Goldoni, a poesia, o romance e o teatro nos fornecem para cada sociedade um reflexo da sensibilidade gastronômica corrente, muito mais plausível por ser, na maioria das vezes, involuntário e marginal. Claro que se deve, também aí, levar em conta o exagero "pantagruélico" que é um efeito precisamente "literário”, assim como se deve levar em conta o exagero "famélico" em sentido contrário, freqüente em particular no romance picaresco " 180 .

Era preciso prestar atenção às eventuais distorções provenientes da elaboração literária. Talvez Matos tenha evitado mencionar, por questões de decoro, hábitos alimentares

180 REVEL, Jean François. Um banquete de palavras: uma história da sensibilidade gastronômica. São Paulo, Cia das Letras, 1996. p. 19. 
cerimoniosos em sátiras compostas em estilo baixo, enquanto que nos poemas burlescos de tom ligeiramente encomiástico estavam ausentes referências aos vegetais que pertenciam às dietas de pessoas pobres. Os gêneros literários praticados e as regras de composição poética nortearam provavelmente a seleção dos alimentos ou de hábitos alimentares que o poeta efetuou para ilustrar sua argumentação, mas apenas algumas lacunas flagrantes foram constatadas no material estudado.

\section{5 - O contexto literário seiscentista}

Quando Gregório de Matos resolveu se valer de metáforas envolvendo ingredientes comestíveis e hábitos alimentares para expor idéias que extrapolavam o âmbito da alimentação, o procedimento de linguagem utilizado não constituía nenhuma novidade. Já existiam precedentes famosos. Os autores da Antiguidade Clássica, cujas obras serviram de modelos de expressão literária, no despertar da Época Moderna, também tinham recorrido a semelhante subterfúgio de estilo. Eram conhecidos, desde a Antiguidade Clássica, textos que descreviam banquetes ( simposiuns), durante os quais a ingestão de comida e sobretudo de bebida pontuavam a discussão de questões filosóficas, aproximando do leitor sérios problemas de moral ou de etiqueta pertinentes à vida social, como o Banquete de Platão ou aquele de Xenofonte. Salientavam-se ainda obras, como a oitava sátira no livro II das sátiras ${ }^{181}$ de Horácio, que satirizava novos ricos faltos de traquejo social em suas pretensões ridículas à elegância, retratadas indiretamente por meio de relatos de festins ridículos. Outro texto conhecido, que oferecia modelo a ser imitado, era a famosa descrição de um festim promovido por Trimalcião, incluída na obra o Satiricon de Petrônio.

181 HORÁCIO, Sátiras, Oitava sátira do livro II (acompanhada até de um diagrama explicando o lugar de cada um dos convivas na sala da refeição). 
Poderiam ter sido citados ainda diversos textos de viajantes quinhentistas, seiscentistas, ou setecentistas, como aqueles de Jean de Léry ${ }^{182}$, André Thevet ${ }^{183}$ ou Yves d'Evreux ${ }^{184}$, para não falar nos cronistas portugueses tais como Pero de Magalhães Gandavo ${ }^{185}$, o padre Fernão Cardim ${ }^{186}$, Gabriel Soares de Sousa ${ }^{187}$, Ambrósio Fernandes Brandão ${ }^{188}$ etc., todos empenhados em descrever e interpretar a realidade observada em território brasileiro.

Com efeito, a circunstância das ações humanas regidas por valores culturais se desenvolverem sob forma de movimentos físicos e expressarem nos gestos efetuados uma incorporação de idéias implicadas, transformou os relatos de procedimentos de alimentação mencionados nos versos de Matos em objetos privilegiados para revelar os significados atribuídos aos gestos. Hábitos alimentares e manejos de ingredientes comestíveis destinados a fornecer energia a corpos necessitados de subsistência apresentavam um enorme potencial para traduzir princípios abstratos de vivência social, em termos facilmente decifrados. As metáforas de cunho alimentar utilizadas por Gregório de Matos constituíram elementos, tanto ornamentais quanto funcionais, pois lhe forneceram ingredientes ontológicos para avaliar o valor de indivíduos diferenciados em termos da maior ou menor adequação das substâncias ingeridas.

Como um todo, a poesia barroca dos séculos XVI e XVII acusou um impacto especial com a redescoberta de um texto de Aristóteles que discutia a arte da escrita de poesias.

182 LÉRY, Jean. Histoire d'un Voyage faict en la terre du Brésil, texte établi, présenté et annoté par Frank LESTRINGANT, Paris, Livre de poche, 1994.

183 THEVET, André. As singularidades da França Antártica. Belo Horizonte/São Paulo, Itatiaia/EDUSP, 1978.

184 EVREUX, Yves D’. Viagem ao Norte do Brasil. Rio de Janeiro, Livraria Leite Ribeiro, 1929.

185 GANDAVO, Pêro de Magalhães. Tratado da Província do Brasil e História da Província de Santa Cruz. Belo Horizonte/São Paulo, Itatiaia/EDUSP, 1980.

186 CARDIM, Fernão. Tratados da terra e gente do Brasil. $3^{\text {a }}$ ed., São Paulo, INL/MEC./ Cia. Ed. Nac., 1978.

187 SOUSA, Gabriel Soares de. Tratado descritivo do Brasil em 1587. $4^{\mathrm{a}}$ ed., São Paulo, Cia. Ed. Nacional/ EDUSP, 1971. 
Efetivamente, em razão da queda de Bizâncio, diversas cópias do manuscrito foram obtidas, lidas e traduzidas em Veneza, onde textos de autores da Antigüidade clássica grega e latina alimentavam a reflexão humanista. Durante a segunda metade do Cinquecento, vários preceitos de composição, emprestados tanto à Poética, de Aristóteles, quanto à Epístola aos Pisões, de Horácio, enriqueceram, por conseguinte, a reflexão dos letrados.

As academias italianas, que discutiam parâmetros necessários do fazer poético, debateram, adotaram e difundiram essas noções da arte poética de Aristóteles e de Horácio - o tratado de um estudioso do tema, Scaliger, serviu até de manual em colégios jesuíticos ${ }^{189}$. As regras técnicas de composição e de decoro preconizadas por Aristóteles e Horacio fundamentaram também as normas éticas e estéticas da arte poética italiana, que surgia justamente no momento em que a descoberta da impressão espalhava obras em quantidade inaudita pelos diferentes países do continente europeu, incluindo no processo um grande apreço pelas novas formas de arte poética criadas, como os sonetos de Petrarca e de Marino.

Segundo defendia Aristóteles, diferenças de intento entre epopéias, tragédias ou comédias requeriam tratamentos estilísticos apropriados à expressão de cada gênero de poesia. A arte poética, que ele preconizava, se propunha comover o público para convencê-lo da justeza de seus pontos de vista. Preceito fundamental de criação poética preconizado por Aristóteles, a verossimilhança das ações afigurava-se elemento crucial da expressão literária. Enquanto ficções elaboradas, as imitações da realidade expressas nos poemas desejavam transmitir mensagens e emoções a um público espectador. A exatidão factual dos relatos poéticos, por conseguinte, importava menos que o poder de oferecer imagens plausíveis. Semelhante gênero literário procurava convencer por meio de representações fabricadas convincentes, diferindo dos relatos históricos obrigatoriamente verídicos e dos textos científicos também obrigados a respeitar a veracidade.

189 ARISTOTE. Poétique. Paris, Les Belles Lettres, 1990. Tradução e comentários de M. Magnien. p. 58. 
Aristóteles ${ }^{190}$ preconizava a primazia do efeito estético, recomendando que poetas inventassem peripécias, caso a ficção pudesse surpreender melhor os ouvintes, despertando neles sentimentos de temor e de piedade pela contemplação de espetáculos dolorosos transformados no deleite de uma catarse didática e no prazer de uma representação simbólica envolvente.

Horácio, por sua vez, fazia questão não somente de ser didático, mas também de colocar sua arte a serviço de ensinamentos morais. Valia em seu estilo, como argumentava Hansen, o princípio do "Ut pictura poesis".

“Um poema é como um quadro pintado: tal pintura agradará vista de perto, outra olhada de longe; essa requer a meia-luz, outra uma iluminação plena, sem precisar temer a avaliação do crítico; aquela agrada por um momento, a outra cem vezes exposta continuará sempre a agradar" ${ }^{191}$.

É possível reconhecer em tais considerações um elemento comum de reflexão que lembra um pouco os comentários de Merleau-Ponty ${ }^{192}$ sobre a deformação necessária à qual uma representação simbólica precisa se submeter para recriar ilusões de realidade, ao transpor, por exemplo uma paisagem figurada observada em três dimensões no plano bidimensional de um quadro.

\section{ARISTOTE. Op. Cit., Capítulo IX.}

“le rôle du poète est de dire non pas ce qui a réellement eu lieu mais ce à quoi on peut s'attendre, ce qui peut se produire conformément à la vraissemblance ou à la nécessité. En effet, la différence entre l'historien et le poète ne vient pas du fait que l'un s'exprime en vers ou l'autre en prose (on pourrait mettre l'oeuvre d'Hérodote en vers, et elle ne serait pas moins de l'histoire en vers qu'en prose); mais elle vient de ce fait que l'un dit ce qui a eu lieu, l'autre ce à quoi on peut s'attendre. Voilà pourquoi la poésie est une chose plus philosophique et plus noble que l'histoire: la poésie dit plutôt le géneral, l'histoire le particulier".

191 HORACE “Art poétique” in Oeuvres. Paris, Flammarion. 1967. p. 268. (minha tradução).

"Un poème est comme un tableau : tel plaira à être vu de près, tel autre à être regardé de loin; l'un demande le demi-jour,l'autre la pleine lumière, sans avoir à redouter la pénétration du critique; l'un plaît une fois ; l'autre cent fois exposé, plaira toujours".

192 MERLEAU-PONTY, Maurice. O olho do viajante, in Textos selecionados. São Paulo, Abril Cultural, 1980. 
Gregório de Matos pode ou não ter lido no texto os conselhos poéticos de Aristóteles e de Horácio, porém, ocorrendo ou não o contato direto com as obras de ambos os autores, importa que ele tenha recebido, até a formatura em 1661, uma educação que incluía princípios de composição poética ensinados por estudiosos apreciadores de formulações conceptistas e de afirmações engenhosas. A crer em Máxime Chevalier ${ }^{193}$, entretanto, se Matos escreveu a maioria de seus poemas durante a segunda metade do século XVII (em particular após o retorno a Salvador), a arte poética aguda que ele praticou, começava então a ser rejeitada na Europa por excessivamente superficial e as expressões jocosas, cuja facilidade encantava ouvidos europeus no século XVI, passaram a ser consideradas vulgares no decorrer da segunda metade do século XVII.

O estilo das poesias que Gregório de Matos compôs configurou-se no contexto de uma época definida retrospectivamente por historiadores das artes sob o rótulo abrangente de época barroca, termo que recobria diversos fenômenos e englobava diversas regiões européias ${ }^{194}$. Não interessaria esmiuçar detalhadamente as diferenças de expressão assumidas por essa arte em diversos lugares da Europa, emergida inicialmente na Itália renascentista, para se espalhar rapidamente pelos países vizinhos, adquirindo contornos particulares ao contato com as especificidades de cada país, mantendo vivos traços pertencentes a escolas anteriores e acrescentando paulatinamente novos elementos à sua linguagem. Pouco significaria frisar como à arte renascentista seguiu-se um período neo-clássico prolongado por um maneirismo arcádico, de vocação menos engenhosa e arguta, que a arte praticada por Gregório de Matos. Importa, no caso, sublinhar como, entre os séculos XVI e XVIII, diferentes manifestações européias de arte arquitetura, oratória, pintura, literatura etc., apresentaram denominadores comuns e como o vínculo estreito que associava a literatura da Espanha (vivendo então seu século de ouro) e a literatura portuguesa deu origem em particular a uma releitura irônica dos romances de cavalaria transformados em romances picarescos de grande sucesso como o Don Quixote de la Mancha de Miguel de Cervantes ou o Ledesma de Quevedo.

193 CHEVALIER, Máxime. Quevedo y su tiempo: la agudeza verbal. Barcelona, Editorial Crítica, 1992. 
Nessa linha de argumentação, ressaltava o fato da arte poética de Matos tentar despertar emoções, fundamentada numa imitação de modelos poéticos admirados. O poeta procurou cativar seu público pela beleza de alusões cultas à mitologia grega e latina ou à Bíblia e pela ornamentação rebuscada e arguta de suas metáforas preciosas. Pertenceu a um momento de criação artística dominado, nos países católicos da península ibérica, pela influência do Concílio de Trento, da contra-reforma e da educação jesuítica ministrada nos colégios da Companhia. Os Jesuítas empenhavam-se realmente em despertar a fé através das emoções.

Os poetas mais considerados na primeira metade dos anos seiscentos, Góngora e Quevedo, procediam dessa forma. Góngora, o poeta das Soledades praticava uma arte hiperbolicamente ornamentada e engenhosa. Matos, sem deixar de ser influenciado por sua maneira de escrever, estava mais afinado com o estilo de Quevedo. Em conseqüência, eliminando parte da sobrecarga conceptista tão ao gosto dos letrados de seu tempo, ele evitou abusar do hermetismo. Os mais diversos estilos poéticos de seu tempo inspiraram Gregório de Matos. Ele experimentou a mão na elaboração de poemas que obedeciam às principais formas poéticas vigentes na península ibérica. Porém, foi sobretudo na arte satírica engenhosa que o autor deu a medida de sua perícia. Seus poemas, ora burilados, ora apresentando indícios prováveis de improvisação oral, se mantiveram estritamente fiéis aos preceitos de versificação que em sua época eram considerados apropriados ao desenvolvimento de cada tipo de gênero poético, enfatizando, em diversas ocasiões, seu orgulho de conhecer e de saber manejar temas e normas de versificação, que remetiam aos ensinamentos de uma boa formação acadêmica: "que algum diga carrancudo,/quando escrevo para todos,/que não falo em cultos modos,/mas em frase corriqueira!/Boa asneira" ${ }^{195}$.

Quevedo, poeta espanhol da primeira metade do século XVII, cujos poemas e canções serviram de modelo predileto para Matos, também se referia a alimentos de forma jocosa com o mesmo propósito de expressão. Fez uso de semelhantes brincadeiras de estilo, por exemplo num baile, gênero poético cantado, menos engajado em crítica social. O refrão do "Baile de los nadadores" assinalava efetivamente: 
“Los amores , madre,/son como güevos,/los pasados por agua/son los más tiernos./ Leandro en tortilla,/estrellada Hero;/los pobres perdidos,/los ricos revueltos./Los celosos fritos,/asados los necios,/los pagados dulces,/los sin blanco güeros"196.

Gregório de Matos, segundo afirmava Rabelo, também costumava cantar na sociedade freqüentada, levando sua viola para onde dirigia os passos e ele também citava refrões de outros poetas nos poemas e canções de sua lavra, apenas se recusando a cantar quando tinha: "pança farta e pé dormente" ${ }^{197}$.

As imagens que o autor criou remetiam à existência de formas culturais cristalizadas de conceber o mundo e de agir para modificá-lo. Os códices apógrafos contendo textos poéticos nos quais Matos se permitiu criticar a gestão colonial de certos governadores, a ignorância, a cobiça e a má-fé de diversos membros do clero ou do poder judiciário, decisões aberrantes de vereadores, pretensões exorbitantes de mercadores, desmandos de militares e a promiscuidade das mulheres forneciam muitos indícios da crise vigente. Os problemas de natureza cultural desencadeados pela situação econômica e política da colônia também marcaram presença nos versos, como atestava a explicação setecentista (didascália) que encabeçava o poema colocado em epígrafe: "Descreve o que era realmente naquele tempo a cidade da Bahia de mais enredada por menos confusa".

De fato, a originalidade, que, por vezes, despontava na arte de Matos, residiu essencialmente no vigor das metáforas ideadas e na contundência de retratos produzidos que misturavam elementos verídicos, elementos verossímeis e elementos ironicamente inverossímeis para defender os códigos de conduta soteropolitanos.

196 QUEVEDO, Francisco de, Antologia poética. Buenos Aires, Espasa - Calpe Argentina, 1948. cf. p. 136.

197 MATOS, G. Op. Cit., Vol. III, p. 589.

"Já levantado da mesa/se quis cantar, senão quando/a pança me estava impando/a goela entupida, e presa:/ eu tenho essa natureza,/que depois de manducar/não me é possivel piar:/será porque certamente/pança farta e pé dormente/como diz o adágio popular". 


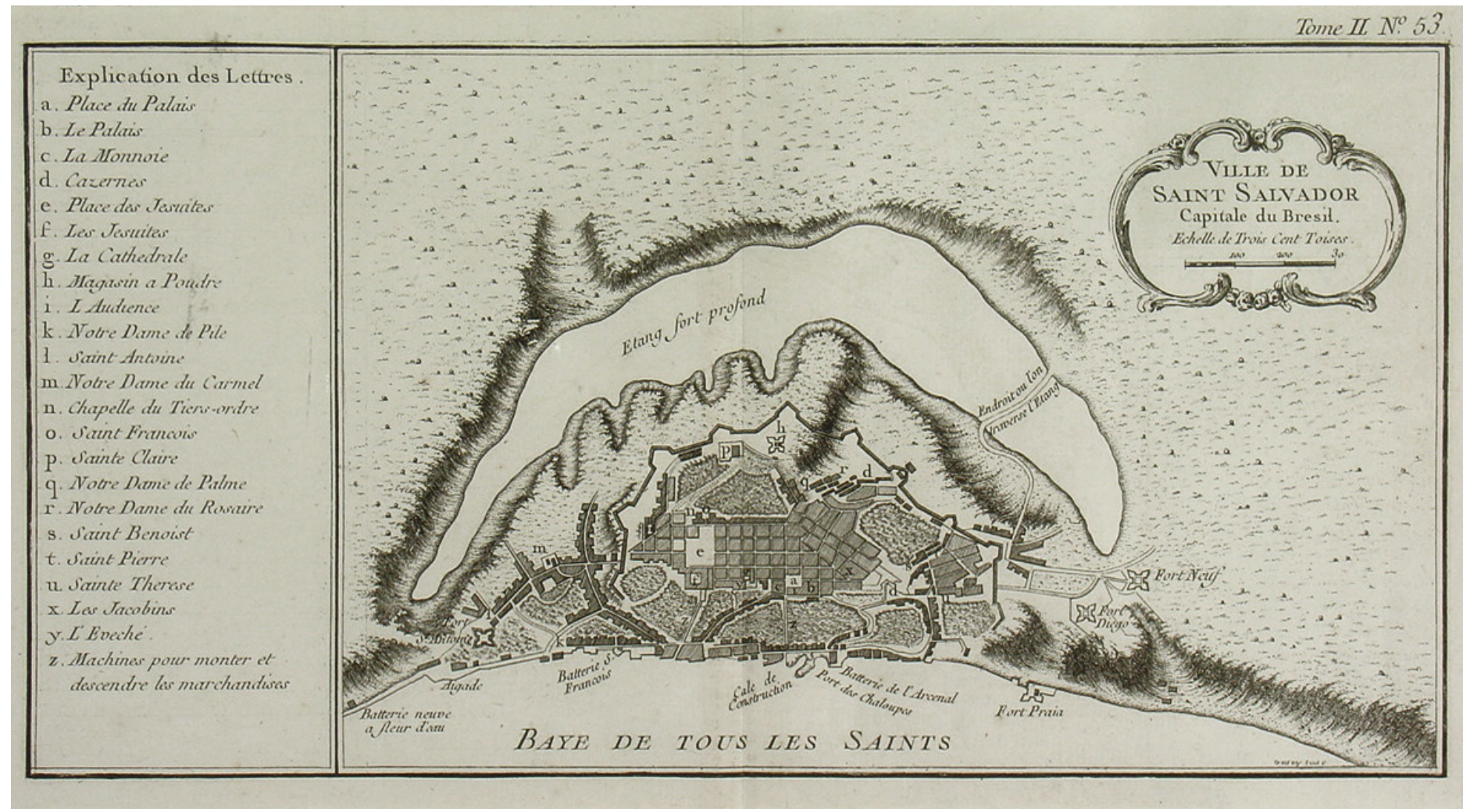

Mapa - Plan de la ville de Saint Salvador - Bahia - 1689 - Capitale du Brésil - Com margem: 44 x 32 cm - mapa 17 x 24 cm. (André sculp.). 


\title{
Capítulo II - O uso simbólico dos alimentos nos versos do poeta
}

\author{
"A cada canto um grande conselheiro, \\ Que nos quer governar cabana e vinha, \\ Não sabem governar sua cozinha, \\ E podem governar o mundo inteiro.
}

Em cada canto um olheiro,

Que a vida do vizinho e da vizinha

Pesquisa, escuta espreita, e esquadrinha

Para a levar à Praça e ao Terreiro.

Muitos Mulatos desavergonhados,

Trazidos pelos pés os homens nobres,

Posta nas palmas tôda a picardia.

Estupendas usuras nos mercados,

Todos os que não furtam, muito pobres,

E eis aí a cidade da Bahia" $"$.

Nos versos de Gregório de Matos figurava um grande número de referências a alimentos, como já apurado no capítulo anterior. O autor se valeu freqüentemente de hábitos de alimentação para criar imagens sugestivas que extrapolavam os domínios da nutrição. O procedimento poético merecia ser investigado. Era necessário entender os mecanismos de elaboração literária envolvidos na composição dos poemas e as intenções do poeta que se valia desse recurso estilístico. Os procedimentos práticos que inspiravam as analogias e os valores que a população

198 MATOS, G. Op. Cit., Vol. I, p. 3. 
soteropolitana atribuía aos principais ingredientes de sua dieta alimentar também precisavam ser analisados.

\section{1 - As referências a alimentos nos versos de Gregório de Matos}

Expressar idéias por meio de alusões a manejos da vida cotidiana foi uma estratégia de composição poética que envolveu não somente metáforas de teor culinário, mas ainda metáforas referentes à navegação. A sociedade soteropolitana compartilhava efetivamente um amplo rol de conhecimentos relacionados à navegação e à nutrição. Assimilar mulheres a naus, veículos indispensáveis e categorias de objetos materiais relevantes no pensamento de uma sociedade articulada com a metrópole, política e economicamente através da navegação atlântica, permitiu ao poeta ilustrar conceitos que explicavam seus pontos de vista e brincar com uma ampla gama de premissas tácitas.

Hansen, ao analisar as sátiras de Matos, caracterizou o gênero poético ao qual os poemas pertenciam como um tipo de dramatização que carregava na escrita uma forte presença da oralidade. Segundo o estudioso, a arte de compor do poeta: "articula o oral em quadros de tragicomédia, em que ocorrem diálogos" ${ }^{199}$, sendo que "Os romances contêm a redundância própria da oralidade, geralmente não encontrável nos sonetos dada a estrutura de demonstração deles" ${ }^{200}$. A notável freqüência das metáforas náuticas nos poemas de Gregório de Matos não escapou ao estudioso ${ }^{201}$, todavia, ele não chegou a investigar a materialidade dos hábitos locais que motivavam as comparações. Preocupado em comprovar a obediência estrita do poeta às convenções da arte poética praticada em território ibérico, notou apenas algumas referências abstratas à alimentação. Escapou-lhe, portanto, o sólido lastro de realidade colonial entranhado nas metáforas que ornamentavam a poesia do autor. Concedendo vínculos com a realidade

\footnotetext{
199 HANSEN, João Adolfo. Op. Cit., p. 65.

200 HANSEN, João Adolfo. Op Cit., p. 67.

201 HANSEN, João Adolfo. Op. Cit., pp. 373, 376 e 377.
} 
apenas às críticas de Matos à política colonial, Hansen defendeu a idéia da ausência de intenção de retratar a vida soteropolitana, na versificação do autor ${ }^{202}$.

Parte das alusões de Matos a hábitos alimentares e a procedimentos de provimento alimentar permaneceu no plano das abstrações ou das generalidades e constituiu sobretudo uma fonte de afirmações engenhosas. Era grande o contraste com informações de caráter prático também incluídas nos versos, tais como a referência a um consumo de tremoços beliscados durante um jogo de cartas (cf. epígrafe do capítulo I). Na primeira estrofe da poesia citada em epígrafe do presente capítulo, o poeta mencionava homens que, apesar de não saberem governar a própria cozinha, pretendiam "governar cabana e vinha", isto é, decidir a gestão da vida colonial. O poeta delineou por intermédio desse recurso estilístico a discussão de um fazer político e moral distante de qualquer debate sobre o cultivo local de videiras ou a organização prática de cardápios familiares. Descrevendo atos que envolviam alimentos, Matos enfatizou a ignorância de muitos administradores coloniais. Nas estrofes seguintes do soneto, ele reforçou suas queixas sobre a sociedade colonial ao associar práticas de alimentação aos códigos de conduta desrespeitados. Vizinhos maledicentes prontos para divulgarem boatos na Praça ou no Terreiro, mulatos livres ou alforriados à procura de prestígio social e comerciantes desonestos, mencionados nos poemas, expuseram a decadência do estilo de vida nobre instaurado pelos colonos entre 1580 e 1640, durante o processo de expansão da rede de engenhos nas terras de massapés férteis da Bahia.

Ambos os domínios, náutico e culinário, diziam respeito a objetos de cultura material, cujo manuseio ampliava a atuação dos corpos humanos, mas exigia, em retorno, um ajustamento dos corpos aos requisitos técnicos dos manejos. Efetivamente, as idéias que norteavam as ações costumeiras encenavam, de forma mais ou menos explícita, maneiras de pensar subjacentes às práticas cotidianas. Como no caso dos tremoços comidos, inúmeros poemas nos quais Matos associou alimentos a uma diversidade polissêmica de valores culturais evidenciaram uma articulação fundamental entre elementos ideais e materiais descrevendo procedimentos alimentares.

202 HANSEN, João Adolfo. Op. Cit., p. 102. “A sátira não é realista, como se vê, porque tem direção referencial mimetizando casos retóricos não o referente. Opera, na constituição dos casos, o verossímil como caricatura, monstruosidade". 
Os principais estilos poéticos inspiraram Gregório de Matos, que se orgulhava de saber aplicar com propriedade os preceitos de versificação vigentes na península ibérica em meados do século XVII. Seus sonetos, suas glosas, ou seus romances, seus versos de cabo-roto e seus versos com epílogos ${ }^{203}$, eruditos ou improvisados, parecem ter deleitado um público colonial principalmente masculino. No entanto, mulheres também lhe pediam cópias de poemas celebrados $^{204}$. Diversas didascálias ${ }^{205}$ explicando as circunstâncias de cada poema, comentavam motes picantes, propostos por mulheres. E até moças alforriadas de todos os matizes de cor de pele ou escravas das cozinhas dos engenhos para quem uniões livres ou amores passageiros eram fonte de renda, parecem tê-lo ouvido e temido, a ponto de alegarem menstruações para escapar a seus assédios. Os códices apógrafos que preservaram muitos versos escritos durante a permanência do poeta em Salvador, atestam a variedade dos gêneros poéticos e das inspirações nas quais o poeta experimentou a lira. Porém, foi a composição satírica engenhosa que lhe permitiu dar mostras de sua perícia.

As celeumas levantadas em torno do valor estético atribuído à produção literária de Matos, resgatada a partir do século XIX, deveram muito ao fato do autor ter sido o primeiro poeta nascido na colônia que enxertou traços de cor local nos versos. Que ele permanecesse fiel às convenções poéticas ibéricas e parecesse pouco original foi uma circunstância que desmereceu o conjunto da obra aos olhos de pesquisadores ávidos de eventos primevos. Merecem lembrança as críticas que Sylvio Júlio ${ }^{206}$ endereçou a Gregório de Matos, acusado de plagiar autores ibéricos e de

203 Versos de cabo-roto eliminavam a última sílaba de cada verso: “Oh se quisesse o Padre Santo Antô-/Que se falsificara este pressa-/Para ficar corrido este Frisá-/E moído em salada este Chico-". MATOS, G. Op. Cit., Vol. VII, p. 1592.

Versos com epílogos: “Que lhe dão tão fracas linhas? ...... Sardinhas/Nenhuma coisa mais quis? ....... Siris/Por tão pouco tantas bulhas? ...... Agulhas". MATOS, G. Op. Cit., Vol. VI, p.1431.

204 Uma soteropolitana lhe mandou pedir uma cópia da sátira relativa à morte do cavalo de Pedro Álvares da Neyva, Matos lhe respondeu, versejando, que o cavalo, por ser morto, já não corria mais.

205 Explicações de fatos associados à composição de cada poema. Títulos elucidativos acrescentados por aqueles que em meados do século XVIII transcreveram diversos poemas do autor nos códices apógrafos.

206 JÚLIO, Sylvio. Fundamentos da poesia brasileira, Rio de Janeiro, Coelho Branco Fo ., 1930. p. 42. 
escrever versos sem ímpeto criador, isto é, sem originalidade de forma ou de conteúdo (dotados de "esparsos elementos de autonomia mental", como a própria literatura portuguesa).

Para fundamentar seu ponto de vista, Júlio recorreu a um pressuposto teórico improvável de nações com propensão natural à inovação, contrapostas a outras apenas capazes de reciclar idéias. O autor, no caso, esquecia simplesmente a possibilidade da sociedade mazomba, na qual Matos se inseria, continuar a se considerar lusa e agir como tal. A suposição de que os colonos já se auto-definiriam como brasileiros, distintos dos portugueses, era o elemento que destoava das idéias vigentes. Comentando os primórdios da literatura brasileira, Sérgio Buarque de Holanda observou acertadamente que convém não confundir os sentimentos de uma naturalidade (decorrendo de ter raízes locais) com aqueles da nacionalidade ${ }^{207}$. O equívoco cometido por Sylvio Júlio em sua interpretação da obra seiscentista, consistiu, pois, numa procura frustrada - anacrônica - de elementos comprovassem a brasilidade do poeta e da população colonial seiscentista. Todavia, a argumentação elaborada para demonstrar a ausência de originalidade na arte poética de Matos estimula a reflexão:

"Pensamos que o núcleo dos elementos, o fio condutor das partículas de caracterização da literatura brasileira, apezar de oriundo de phenomenos physiopsychicos e socio-raciaes, pode procurar-se na parte instintiva das artes, que é o folk-lore" ${ }^{208}$.

As metáforas de Gregório de Matos remetiam efetivamente a formas culturais cristalizadas de conceber o mundo e de agir. Patenteava-se na versificação a interpenetração entre os

\section{HOLANDA, Sérgio Buarque de. Capítulos de Literatura colonial. p. 409 e 410.}

"Dessa fidelidade ao pequeno rincão de origem pode-se dizer, quando muito, que representa um patriotismo da espécie paroquial, patriotismo que, como se sabe, costuma ser tanto mais exacerbado quanto ais deliberado e consciente. É um erro de perspectiva querer equipará-lo ao que, em nossos dias, chamamos consciência nacional". 
domínios do erudito e do popular. As imagens propostas salientavam, ora nexos fortes com as práticas populares, ora idéias provenientes de um universo mais culto. Existia em meados do século XVII, segundo apontava Buarque de Holanda, um vínculo recrudescido entre formulas populares e eruditas de expressão poética e uma franca circularidade entre gostos populares e gostos eruditos:

\begin{abstract}
"Durante o período intermediário, o pendor idealista de um lado, a inclinação para valores mais imediatos e rasteiros de outro, revelam-se acentuadamente nas duas correntes opostas, que já na Idade Média tinham cindido a expressão literária: vulgar e cortesã; mester de juglaria e mester de clerezia. No seiscentos, notase a coexistência pacífica, quase a interdependência das duas maneiras. O culto requer o popular, o sublime necessita do burlesco, como se a poesia, elevando-se a altitudes inumanas e proibidas, precisasse, como Anteu, voltar constantemente à terra para retemperar forças e sobreviver" ${ }^{209}$.
\end{abstract}

Chamar de folclore o núcleo sedimentado de idéias e de práticas culturais dos colonos seiscentistas, isto é, o estilo de vida soteropolitano também seria uma designação anacrônica. Porém, um fenômeno aparentado às práticas que posteriormente deram vida ao conceito de folclore já se encontrava em cena, na forma como Matos se referia aos hábitos da população colonial e aos valores que subentendiam ${ }^{210}$. Ao acusar o poeta de falta de originalidade por se ater às formas literárias da metrópole - onde ele estudou desde o final da adolescência, se formou, casou e praticou a magistratura - Júlio deixou de perceber a especificidade da arte poética que Matos apresentava ao público. A ruptura com as origens, que o estudioso cobrava do poeta, não se coadunava nem com os preceitos da arte poética composta, nem com os sentimentos do autor.

209 HOLANDA, Sérgio Buarque de. Op. Cit., cf. pp. 415.

210 O termo surgiu no contexto do século XIX. 
Os poetas quinhentistas e seiscentistas empenhavam-se, como bem demonstraram Hansen e Gomes, num artesanato engenhoso da palavra, fundamentado em procedimentos convencionais que pressupunham demonstrações de erudição e um conhecimento sólido de obras-primas ${ }^{211}$. Citar nos versos obras admiradas era procedimento de praxe. Engenhosidade e argúcia, contudo, não constituíam nenhum empecilho à inclusão de referências à vida cotidiana nas composições poéticas. O potencial de descrição da realidade soteropolitana oferecido pelas alusões que Matos propunha, como no caso de suas narrativas de excursões pelo Recôncavo baiano, não deveria ter sido menosprezado por Hansen. Numa cidade que recebia por navegação de cabotagem o açúcar e os mantimentos produzidos na zona rural, deslocamentos de pessoas e de mercadorias pelas águas do mar interno não ofereciam somente temas metafóricos e distanciamento para vituperar a infâmia de certas categorias sociais de $\operatorname{colonos}^{212}$. Muitas menções de Matos, às práticas em uso na capital do Brasil evidenciaram a existência de um estilo de vida específico à colônia, de modo que não surpreende observar como até mesmo Manuel Botelho de Oliveira, poeta de estilo gongórico e requintado, atestava a freqüência do trânsito de embarcações nos ancoradouros do Recôncavo, em seu poema Ilha de Maré, redigido por volta da mesma época:

"Por um e outro lado vários lenhos se vem no mar salgado;/Uns vão buscando da Cidade a via,/Outros dela se vão com alegria;/E na desigual ordem/Consiste a fermosura da desordem" ${ }^{213}$.

\footnotetext{
211 HANSEN, João Adolfo. Op. Cit., p. 76.
}

GOMES, João Carlos Teixeira. Op. Cit., p. 20.

“A poesia de conteúdo amoroso ou religioso pode ser encarada como manifestação do convencionalismo barroco, dissolvendo-se na produção da época pela sua impregnação gongórica, de caráter padronizador, o mesmo não se pode dizer dos poemas satíricos, burlescos, eróticos ou de circunstância que trazem o carimbo de uma fatura homogênea, até porque exprimem situações, fatos e experiências que se articulam solidamente, com o que hoje sabemos da vida do poeta".

212 HANSEN, João Adolfo. Op. Cit., pp. 191 a 193.

213 OLIVEIRA, Manuel Botelho de. Poema "Ilha de Maré", in SILVA, Rogério Forastieri. Colônia e nativismo: a História como "biografia da nação. São Paulo, Hucitec, 1997. p. 112. 
Matos, alheio aos propósitos de afirmação individual da arte poética romântica, respeitou as normas poéticas preconizadas em seu tempo para cada gênero poético. Incluiu em sua escrita referências cultas à mitologia, paródias cômicas de poemas famosos, provérbios conhecidos, clichês, lugares-comuns, provérbios e frases feitas reiteradas (servindo de refrão), procedimentos usuais de uma "arte verbal" preocupada em facilitar a memorização ${ }^{214}$, mas também se divertiu com brincadeiras de linguagem ao referir circunstâncias locais que o público saberia decifrar. A leitura da obra do autor permitiu detectar a presença de temas poéticos clássicos, como o mundo às avessas, a vida breve ou o carpe diem, e observar um elenco de diferentes intenções poéticas: satíricas, burlescas, líricas, sacras ou encomiásticas (celebrando os feitos de pessoas influentes), que serviram a Matos para reivindicar a depuração moral dos usos e dos $\operatorname{costumes}^{215}$, compor relatos didáticos de episódios inspirados em acontecimentos ou inventar peripécias prováveis ou improváveis, ora sarcásticas, ora burlescas.

As metáforas alimentares inseridas nos poemas repartiram-se de maneira bastante desigual no conjunto da obra. Foram quase ausentes em poemas de inspiração lírica sacra, nos quais figuravam apenas menções deferentes ao pão e ao vinho da eucaristia ${ }^{216}$, à maçã edênica ou à flor do maracujá que encerrava em si os instrumentos da paixão de Cristo. As alusões a atos de nutrição tampouco marcaram presença em poemas de expressão lírica amorosa que incorporavam floreios gongóricos e formulavam comparações etéreas entre mulheres cortejadas e flores, pedras preciosas, sol, lua ou estrelas. O lirismo amoroso de Matos, aparentado aos

214 FINNEGAN, Ruth. Oral tradition and the verbal arts: a guide to research practices. London, Routledge, 1992.

215 Ao criticar condutas absurdas de conterrâneos, como o encarceramento, a pedido do capitão Mangará, de duas mulatas, mãe e filha, por causa de um papagaio furtado (a mais nova era amásia grávida do queixoso), permitem supor, com uma margem razoável de confiabilidade, que semelhantes encenações, recriadas por Matos, perderiam provavelmente em comicidade se não possuíssem um fundo de realidade, permitindo à população mazomba reconhecer acontecimentos ocorridos no seio da sociedade.

216 Muitos sonetos expressaram um lirismo sacro que parecia sincero, apesar de Peres observar neles um ligeiro viés heterodoxo em razão da liberdade tomada de fazer rimar as palavras Jesu e cu, ou nas brincadeiras apresentadas em torno do tema de Adão e Eva, quando cajus faziam às vezes de maçãs. 
poemas de Góngora e à inspiração medieval dos poemas de amor cortês ${ }^{217}$, destinou-se a cortejar moças casadoiras de boa família, como Ângela ou Maria de Povos. Por esse motivo o poeta seguiu regras obrigatórias de decoro, produzindo versos nos quais as referências à digestão e ao baixo corporal não seriam aceitáveis.

Nos poemas de inspiração laudatória, compostos por Matos em estilo elegante para homenagear autoridades metropolitanas ou coloniais, versejaram-se feitos de pessoas importantes e eventos que afetavam suas vidas, com fórmulas ditirâmbicas muito ao gosto seiscentista. Nesses poemas as menções a alimentos também escasseavam. Os sonhos que a filha de um amigo fez questão de oferecer ao poeta na Ilha Grande, todavia, foram mencionados. O poeta comeu os doces, comovido pelo impecável trato de hospitalidade proporcionado pela jovem e compôs um poema para celebrá-lo. Mesmo saboreados em sua condição material de preparos culinários, os sonhos de Macota ocasionaram apenas metáforas nobres, o poeta cauteloso evitando qualquer possibilidade de equívoco:

"Deu-me a rapariga uns sonhos/tão ricos como ela própria,/sonhava em me regalar ${ }^{218}:$ /não foi mentira, o que sonha./Visitou-me sua Avó,/que é mui honrada pessoa,/só quem tem honra, dá honra./Assim o façam meus Filhos,/como então o fez Macota" ${ }^{219}$.

A grande maioria das metáforas de cunho alimentar pareceu, por conseguinte, se concentrar nos poemas de inspiração satírica ou burlesca. Destacaram-se particularmente em poemas marcados por uma veia erótica. O soneto referente à Ilha de Itaparica, por exemplo, evidenciava uma sexualidade que, a despeito dos preceitos e da vigilância da Igreja, parece ter se efetivado sem demonstrações excessivas de culpa:

217 Poemas de amor cortês, pertencentes à literatura cortês. Segundo o Petit Larousse Illustré: “Literatura refinada, que se manifestou nos séculos XI - XII nas pequenas cortes senhoriais, sobretudo no sul da França e que celebrava o amor e as façanhas dos cavaleiros" (minha tradução).

218 Regalar, dar regalo, o prazer de comer alimentos saborosos.

219 MATOS, G. Op. Cit., Vol. VI, p. 1521. 
"Ilha de Itaparica, alvas areias,/ Alegres praias, frescas deleitosas,/Ricos polvos, lagostas deliciosas,/Farta de putas, rica de baleias. // As putas tais, ou quais não são más preias,/Pícaras, ledas, brandas, carinhosas ${ }^{220}$.

Contudo, nem todos os poemas mordazes de Matos pertenceram somente ao gênero satírico. Grande parte dos versos inspirados por acontecimentos ocorridos em Salvador ou no Recôncavo foram relatados num tom antes burlesco que mordaz. Além de desqualificar inimigos, ele também brincou com os amigos, ressaltando com ironia um tanto benevolente acontecimentos ocorridos na cidade ou nos engenhos, no decorrer de festejos acompanhados de consumo de alimentos. Mesmo não se apresentando isentos de críticas a indivíduos ou a diversas categorias de colonos, tais como os membros do clero lúbricos ou as mulheres promíscuas, os poemas burlescos compostos num registro jocoso destinaram-se a divertir. Farpas inseridas em seus versos não deixavam de satirizar conhecidos, mas não costumavam atingir sua honra. Existiam efetivamente gradações tão sutis nas críticas que sátiras e poemas burlescos não chegaram a constituir categorias estanques. $\mathrm{O}$ autor, por conseguinte, encenou fatos ligeiramente distorcidos ou episódios ridículos, inventados para divertir os amigos reunidos, sem feri-los. Nesses termos, encenando os prazeres de convívios sociais adequados, Matos tanto se riu dos outros, quanto de si mesmo. Relatando, certa vez, uma excursão memorável ao rio Vermelho, para onde se dirigiu com vários amigos, ele narrava ter sido transportado numa rede alugada, suspensa em longa vara, que dois escravos, os "pais de ganho", carregavam nos ombros. Matos então se comparou ironicamente a um peixe recém-pescado: "eu na rede um cação"221.

Apesar das críticas acerbas endereçadas a muitos tipos de indivíduos, emanava, paradoxalmente, um intenso amor à vida dos poemas burlescos, que Gregório de Matos produziu para assinalar festas ou passeios, ou ainda para tentar seduzir as jovens que despertavam seus

220 MATOS, G. Op. Cit., Vol. VI, p. 1522.

221 MATOS, G. Op. Cit., Vol. III, p. 585.

FREZIER, Amédée. A visão de colonos assim transportados impressionou tanto Amédée Frézier, que ele até incluiu uma prancha retratando uma dessas redes em seu relato de viagem. 
desejos. O ensejo brincalhão das metáforas alimentares lhe permitiu cortejar jovens bonitas e disponíveis, fossem elas brancas, mulatas, negras ou mamelucas, apresentando-lhes alusões picantes, que assimilavam o sexo à comida.

Parece redutor, portanto, explicar, como fez Hansen, a riqueza do poema irônico dedicado à hospitaleira Itaparica apenas por referência a "um sol inquisidor", inferindo da expressão um intento satírico extensível ao conjunto do soneto ${ }^{222}$. Se crítica houve, foi amena, salientando os banquetes e prazeres do sexo que fundamentavam o estilo de vida folgado e alegre praticado por Matos e seus amigos. Nesses termos os poemas burlescos, mesmo incorporando um leve tom irônico, faziam antes a apologia que a crítica dos hábitos sociais dos soteropolitanos ricos.

As principais figuras de estilo, metáforas, metonímias e sinédoques, e o recurso seguido a trocadilhos, duplos sentidos e ironias, procedimentos ornamentais de linguagem freqüentes nos textos poéticos dos séculos XVI e XVII, ofereceram a Gregório de Matos veículos atraentes de expressão para apresentar sua concepção ideal do universo colonial. O autor soube manejá-los com maestria. Com efeito, a pesquisa efetuada permitiu constatar como analogias criadas por meio de tropos entre os ingredientes comestíveis e a aparência física dos colonos colocavam em foco corpos reveladores dos critérios sociais envolvidos na elaboração de imagens de caráter identitário.

O corpo humano, fonte de ações sociais e mediador que articula modos de pensar e modos de agir atrelados a sentimentos, afigurou-se operador simbólico de extrema relevância na elaboração de uma arte poética barroca na qual o significado dos gestos ultrapassava o âmbito dos atos descritos. Nesses termos, os preceitos de alimentação que fundamentavam manejos corporais concretos, proveram suporte ao trânsito entre o plano configurado dos hábitos de nutrição e o âmbito configurante dos valores culturais. Os usos alimentares soteropolitanos serviram a Matos de pretexto para aludir aos motivos culturais subentendidos na implementação dos hábitos, por saber que o público identificaria de imediato os significados ocultos. Matos referiu inúmeros hábitos alimentares em seus versos, porém, mesmo mencionando fatos do 
cotidiano, descrevê-los raramente constituiu o propósito da encenação poética. Obedecendo às convenções prescritas para cada tipo de composição poética ou de inspiração, satírica, encomiástica, burlesca ou lírica, Matos recortou algumas premissas alimentares tácitas e um certo número de clichês conhecidos para ilustrar sob forma de gestos concretos as idéias que desejava formular. Hansen, a esse propósito, assinalou na obra a presença de paródias cômicas endereçando discursos em estilo pomposo a objetos pífios ${ }^{223}$.

As imagens satíricas ou burlescas elaboradas pelo autor proporcionavam substância engenhosa às representações, ao escancararem conflitos e fofocas locais. Fizeram apelo à inteligência de ouvintes ou leitores convidados a decifrar os elementos subentendidos na linguagem poética. Porém, se o procedimento de escolha das metáforas levou Matos a apontar hábitos de grande relevância, nem todo os hábitos alimentares figuraram nos poemas. Efetivamente, a arte poética do autor não implicava nenhum compromisso de descrição abrangente dos usos alimentares soteropolitanos.

Em decorrência, certas lacunas puderam ser observadas durante a pesquisa, seja porque os ingredientes vegetais ou animais correntes na dieta e ausentes nos versos não tivessem despertado o interesse do poeta, seja porque prescrições regulamentadas de decoro poético interferissem para obrigá-lo a selecionar fatos alimentares condizentes com o estilo de cada poema. Talvez o autor tenha evitado incluir hábitos que pertenciam a um registro de interações sociais elegantes em sátiras que criticavam aspectos populares da vida social. Uma raridade notável das referências aos assados destinados a grandes ocasiões foi percebida nos poemas. Entretanto, os doces e os pastéis dos festejos cerimoniosos figuraram sem pejo nos poemas burlescos, sendo que o rol plebeu dos vegetais e das hortaliças apareceu de maneira bastante comedida no conjunto da obra e que os clichês abstratos, os provérbios e as frases feitas se multiplicaram nos poemas. Não obstante o interesse do tema, não foi possível desenvolvê-lo a contento.

Os alimentos associados aos corpos físicos dos colonos, manejados tanto para afirmar a posição social e o pertencimento religioso de quem os ingeria, quanto para evitar seqüelas 
nefastas à saúde, proporcionaram a Gregório de Matos um instrumento notável de expressão literária para falar da sociedade soteropolitana. Alusões aos manuseios dos alimentos, objetos de cultura material, norteados por saberes locais e idéias lusas sobre as propriedades dos diferentes ingredientes comestíveis, no entanto, incitaram o poeta a relatar, para ilustrar seus pontos de vista, um leque amplo dos principais conhecimentos que ele compartilhava com os conterrâneos. Não ter que explicar os significados subentendidos nos procedimentos alimentares mencionados pressupunha efetivamente a aceitação tácita do público em relação às práticas, mesmo que permanecesse para o leitor atual certa opacidade nas alusões proferidas.

A própria polissemia inerente aos atos de alimentação transformou as metáforas referentes ao tema em subsídios para criticar indivíduos atribuindo-lhes hábitos inadequados de venda ou de consumo de alimentos. Matos, dessa forma, expôs detalhadamente gestos que ofendiam seus brios conservadores de ex-magistrado, quase-sacerdote e ardente defensor da moral mazomba. Ao versejar as mazelas da sociedade colonial com a qual conviveu em sua volta ao Brasil, o autor exemplificou de modo pitoresco e jocoso os procedimentos que mereciam suas queixas, recorrendo, como Quevedo tinha feito antes dele, a metáforas extraídas da experiência cotidiana.

Comentários irônicos, trocadilhos brincalhões ou insultuosos e duplos sentidos, construídos por meio de metonímias, de sinédoques ou de metáforas, transformaram as alusões do poeta aos usos e costumes locais em fatores de um discurso voltado para a discussão utópica dos princípios que deveriam reger a gestão da colônia. As representações poéticas de Gregório de Matos se revelaram instrumentais para localizar os lugares peculiares que a sociedade soteropolitana, extremamente hierárquica ${ }^{224}$, atribuía às diferentes categorias de pessoas e para situar as modalidades costumeiras de interação entre homens e mulheres.

Em suma, o exame de metáforas e metonímias que citavam procedimentos alimentares e gêneros comestíveis para desmerecer inimigos ou vituperar indivíduos e grupos de indivíduos

224 HANSEN, João Adolfo. Op. Cit., p. 116.

“A hierarquia não é ambígua, no século XVII, sendo entendida como reflexo da lei natural ou como ditado de Deus revelado em uma Igreja visivel e corporeificado nas leis positivas de um Estado absolutista". 
que infringiam os códigos da ética mazomba, permitiu matizar a argumentação em favor do caráter puramente convencional da arte do poeta e instrumentou a análise da obra de Gregório de Matos e do sistema social da colônia retratado pelo autor.

Contra inimigos particulares, o autor propôs registros corporais monstruosos, provavelmente hilariantes para quem conhecia a fisionomia das pessoas caricaturadas. Metonímias ou sinédoques satíricas intervieram para selecionar traços físicos marcantes e encarregaram detalhes avulsos de representar o todo, ou ainda condensaram a descrição de todo o corpo num determinado aspecto ridículo do personagem. Matos encenava, como ressaltou Hansen, narrativas fantasiosas, condutas caricatas e mudanças extravagantes de funções, como olhos ditos "cagões" 225 ou "olhos de alpistre"226. O caráter desfrutável dos alimentos desqualificou a corporeidade de muitos adversários. Os exemplos abundavam. Dirigindo-se a certo soteropolitano Matos lhe declarou:

“Vosso pai vos amassou,/porém com miséria tanta,/que temeu a natureza,/que algum membro vos faltara./Deu-vos tão curto o nariz, que parece uma migalha"227.

A crioula Chica, ciumenta e infiel, também mereceu uma descrição ressentida de sua anatomia:
“Cada pé junto/forma a peanha,/onde se amanha/a estátua do pernil,/e do presunto" 228 .

E ainda, ao se despedir da população soteropolitana quando ia para Angola, Matos celebrou os encantos soteropolitanos de modo dúbio:

\footnotetext{
225 HANSEN João Adolfo. Op. Cit., p. 395.

226 MATOS, G. Op. Cit., Vol. II, p. 339.

227 MATOS, G. Op. Cit., Vol. VI, p. 1309.

228 MATOS, G. Op. Cit., Vol. V, p. 1121.
} 
“Os pés são duas lagostas/de andar montes, passar vaus,/as mãos são dois bacalhaus/já bem ardidos"229.

No âmbito de uma sociedade, na qual todos espreitavam as condutas dos vizinhos e na qual falhas de caráter eram associadas às aparências físicas estapafúrdias, tais caricaturas que atingiam a honra da pessoa satirizada extrapolavam o domínio das brincadeiras.

De poema em poema, avolumou-se no decorrer da investigação um rico acervo de comparações. A multiplicidade e a diversidade das analogias engenhosas, porém facilmente explicadas, que o autor percebeu entre situações nobres e hábitos prosaicos, ressaltaram devidamente seu talento para assinalar semelhanças tão inesperadas quanto inteligíveis, entre elementos distintos aproximados na intenção de ridicularizar os inimigos por meio de imagens de impacto, que estimulavam a imaginação. A comicidade de muitas metáforas advinha efetivamente do contraste entre as situações apresentadas e os hábitos alimentares, ou os ingredientes comestíveis amiúde evocados para criticá-las. Num soneto versando sobre a festa de batizado da filha de Baltasar Vanique, flamengo radicado em Marapé, o poeta alegou, considerando o domingo chuvoso, que a própria Virgem tinha resolvido aguar o vinho, deixando entender com tal semelhança (um pouco forçada) o caráter semi-pagão do pai da criança:

"Choveu tanto ao Domingo em tal maneira,/Que cada qual Monsiur indo uma brasa/Ficou aguado o gôsto e o vinho aguado./Porque não quer a Virgem da Oliveira,/Que lhe entrasse pagão na sua Casa/Vinho que nunca fôra batizado"230.

As metáforas criadas não assinalaram apenas semelhanças amenas. Caricaturas grotescas sublinharam freqüentemente a malevolência do autor contra todos aqueles que não se 
enquadravam nas condutas que ele preconizava. A bela Joana Gafeyra se recusando a conversar com Matos recebeu tratamento ignominioso:

"Andai, Puta de torresmos,/porque sois, e haveis de ser/puta de membros torrados/ por sempre jamais amém"231.

O mesmo autor que recorria à obscenidade para denunciar desvios exorbitantes à moral, brincava também em torno de temas como as relações de gênero. Alusões à maçã de Eva, transformada em caju tentador, trouxeram à tona a idéia de mulheres fazendo parte constitutiva de um vergel paradisíaco. A certo amigo, Matos indagava:

"se está o Antônio/recolhido a seu vergel,/onde era geral Adão/das Evas que Deus lhe deu" ${ }^{232}$.

Diversos relatos de expedições a ilhas do Recôncavo ou a localidades da faixa costeira também pertenceram a uma inspiração cheia de malícia ${ }^{233}$. Mereceria citação especial uma ida aos cajus, durante a qual os excursionistas foram metaforicamente comparados a meirinhos (oficiais de justiça): "prendendo e executando cajus" e deixando enforcados os cajus verdes velhacos ${ }^{234}$.

Poemas que pareciam citar práticas inocentes continham, de fato, alusões sub-reptícias (geralmente picantes) a outros temas, cuja explanação se desenvolvia simultaneamente em

231 MATOS, G. Op. Cit., Vol. VI, p. 1474.

232 MATOS, G. Op. Cit., Vol. VI, p. 1414.

233 Merecem destaque, a esse respeito, os relatos de um passeio ao rio Vermelho, de um passeio ao Dique do Tororó, da caçada de um javali, de uma fuga perante o ataque da vaca Camisa, da degustação de uma pipa de vinho oferecida ao convento e ainda da vida no convento do Carmo onde Matos se refugiou em 1683, quando fugia à ira do governador Braço de Prata.

234 MATOS, G. Op. Cit., Vol. III, pp. 604 a 606. 
diferentes dimensões. O poeta, por exemplo, ironizou uma moça que, longamente solicitada, acedeu afinal a seu pedido, desde que ele consentisse em aguardá-la um pouco, o tempo de tomar um banho antes de se entregar a seus braços:

"Lavar a carne é desgraçalem toda a parte do Norte/porque diz, que dessa sortel perde a carne o sal, e graça/[...]/ Se me quereis dar a sopa,/dai-ma com todo sainete $" 235$.

No caso, o apreço dos colonos portugueses pela carne seca salgada, mantimento mais saboroso que as carnes magras de reses abatidas na seqüência da longa viagem do sertão para a costa (produto às vezes comprado já fétido, nos açougues da cidade), foi um pretexto de Gregório de Matos para expressar sua impaciência diante da demora que aquele banho impunha a seus desejos e aludia, de fato, ao gosto da pele da jovem.

A transferência de críticas acerbas para o plano das brincadeiras permitiu muitas vezes ao poeta ridicularizar inimigos com maior eficácia. Menções a alimentos sólidos ou líquidos, associados ao sexo eram correntes. Matos narrou, por exemplo uma bebedeira fantástica ocorrida durante a festa promovida por uma irmandade de mulatas para festejar a Virgem da Guadalupe:

"o Hermanito/viu que o parto era vinhaça:/chorou tão grande desgraça/a triste Macotinha,/vendo, que a sua Madrinha/ao botar o tal monstrinho/parira como com vinho,/porém não como convinha"236.

A diversidade dos efeitos visuais que as analogias despertavam na imaginação dos ouvintes e a riqueza dos trocadilhos marcavam presença. Contigüidades de sentido e similaridades de sonoridade aproximavam elementos distintos que o poeta afetava considerar equivalentes. No

\footnotetext{
235 MATOS, G. Op. Cit., Vol. IV, p. 765.

236 MATOS, G. Op. Cit., Vol. III, p. 628.
} 
caso da negrinha angola, com quem um caboclo "falava", destacaram-se os duplos sentidos: "que o Tapuia desumano/sabe mais do que cará"237.

Os mesmos trocadilhos retomados em diversas circunstâncias, como no caso da confusão proposital entre diversos significados do verbo saber, proporcionaram certa coesão ao estilo. Também era sabida: “A Beleta gritadeira,/que se gruda de maneira/com xaropes que cozinha,/ que fica uma donzelinha/e não sabe a parideira"238.

Esses trocadilhos incluíram convites freqüentes ao coito, mascarados simbolicamente por um uso maroto de alusões a alimentos:

"Enxugai, Beleta, o pranto,/em riso se torne a queixa,/comei cajus, e voltai,/que a minha fruita está certa"239.

Mas, quando as moças solicitadas ousavam pedir remuneração excessiva pelos serviços solicitados, elas podiam contar que suas genitais tornariam-se "ôlhas podridas", "vasos" ou "bacalhau" ardido, ou fariam jus a outros termos ofensivos relacionados com alimentos, como no caso de uma alusão a uma crica de azeitona ${ }^{240}$.

"Em que vaso heis de cozer/o que haveis de manducar?/pois tendes vaso tão mau,/ que sobre ser bacalhau/tem muchissima pimenta"241.

Cozido e assado, termos contrapostos, deram lugar a um certo número de trocadilhos fonéticos aproximando cozido de cosido (a costura também era tarefa prescrita às mulheres de
237 MATOS, G. Op. Cit., Vol. V, p. 1190.
238 MATOS, G. Op. Cit., Vol. VI, p. 1458.
239 MATOS, G. Op. Cit., Vol. VI, p. 1442.
240 MATOS, G. Op. Cit., Vol. III, p. 574.

Termo ausente dos dicionários portugueses consultados, mas que poderia provir do francês crique, significando pequena angra.

241 MATOS, G. Op. Cit., Vol. IV, p. 980. 
boa família). Estar "assado por uma moça cosida" equivalia a desejar casar com uma moça, que tinha deixado de ser virgem e pretendia enganar o cônjuge prospectivo. Os versos valiam, portanto, ao mancebo casadoiro uma acusação desabonadora de ser corno. Entretanto, o termo cozido também desembocou eventualmente sobre idéias de secreções e de humores corporais:

"e se o peixe vos doíalem que agora me escaldo,/se o fazieis pelo caldo,/o caldo eu vo-lo daria" ${ }^{242}$.

No que tange aos procedimentos culinários propriamente ditos, andar assado, como revelam expressões recolhidas na obra, equivalia a dizer que a pessoa assada estava com fortes vontades de algo. Tensões e conflitos, por sua vez, encontravam registro numa chave de fritos: "Que Vicência vinha assada/por ver a Marana frita"243. "São os vossos olhos fritos"244. "Frigir como posta de cação"245. "Assado e frito"246.

Antes de Matos, Quevedo já utilizava num sentido simbólico os métodos de cocção de alimentos. Se de fato os ovos cozidos eram mais tenros quando quentes, se os ovos fritos crepitando no óleo das frigideiras lembravam vozes brigando e se os tolos podiam ser ditos assados, Matos não perderia tão boa oportunidade para demonstrar seus conhecimentos de arte poética.

Outro procedimento de estilo muito presente na linguagem poética do autor, a adoção episódica da ironia, merece citação. Professar opiniões diametralmente opostas àquelas que sustentava de fato, ou proferir asneiras para divertir o público, ciente de que os ouvintes não se deixariam enganar pela falsa candura das alegações, foi um recurso de expressão rotineiro nos versos de Matos. Em sua escrita poética, as ironias sublinharam geralmente críticas leves

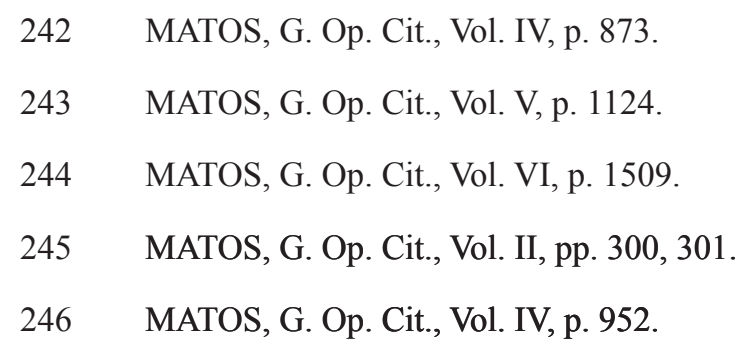


mas ocasionalmente as metáforas alimentares propuseram também insultos mais pesados: “ $O$ ladrão mata a porcada e o Fisco come os presuntos"247.

Como visto anteriormente, nem todas as metáforas apresentadas por Gregório de Matos mantinham relação estreita com as práticas diárias da vida soteropolitana. Numerosos clichês, provérbios e frases feitas estavam longe de encenar práticas da vida cotidiana, como comprova o soneto colocado em epígrafe do presente capítulo ${ }^{248}$. Eles ofereciam figuras de estilo com pouco teor local, mas com significados já cristalizados na linguagem lusa. Tratava-se de expressões tais como: "Amor manjar que não enfastia"249, "a casca é prisão das fruitas", "a pipa é prisão do vinho e da água fugitiva", ou ainda, "A galinha põe os ovos e põe os cornos a puta" ${ }^{250}$.

Nada obrigava o poeta ao papel de cronista fidedigno de eventos soteropolitanos. Por vezes suas sátiras enveredaram pela invenção fantasiosa, apresentando apenas brincadeiras fundamentadas em duplos sentidos. Colocando em cena a própria voz da Cidade da Bahia numa seqüência de metáforas gongóricas, Gregório de Matos se queixou:

"Eu me lembro que algum tempo/(isto foi no meu princípio)/a semente que me davam/era boa e de bom trigo./Por cuja causa meus campos/produziam pomos lindos./de que ainda se conservam/alguns remotos indícios./Mas depois que vós viestes/carregados como ouriços,/de sementes invejosas/e legumes de maus vícios..." ${ }^{251}$.

"Levou um livreiro a dente/de alfaces todo um canteiro,/e comeu, sendo livreiro,/ desenquadernamente:/porém eu digo que mente,/o que nisso o quer culpar;/antes

\footnotetext{
247 MATOS, G. Op. Cit., Vol. II, p. 366.

248 O governo da cabana, das vinhas e da cozinha tomados como metáforas de um fazer político colonial.

249 MATOS, G. Op. Cit., Vol. V, p. 1227.

250 MATOS, G. Op. Cit., Vol. II, p. 337.

251 MATOS, G. Op. Cit., Vol. I, pp. 13 e 14.
} 
é para notar,que trabalhou como um Mouro,/que o meter folhas no couro/também

é enquadernar" 252 .

Metáforas sem raízes na vida colonial, no entanto, não impediram que a realidade das relações sociais locais irrompesse nas entrelinhas de inúmeros poemas.

Sem deixar de buscar ocasionalmente fontes de inspiração na crônica escandalosa da cidade, Matos fez amplo uso da liberdade recomendada pela Poética de Aristóteles, para forjar situações verossímeis, que exemplificavam seus pontos de vista melhor que a própria realidade. Não seria possível afirmar que os episódios versejados correspondessem todos a acontecimentos realmente ocorridos. Porém, tanto as Atas e as Cartas da Câmara Municipal de Salvador, quanto outros textos de autores do mesmo período, aludiram seguidamente a fatos bastante semelhantes àqueles que Matos relatou.

Não surpreende encontrar luxúria e gula tão estreitamente associadas nos textos satíricos ou burlescos de Gregório de Matos, onde perpassou a idéia recorrente da equivalência carnal simbólica entre sexo e alimentos. Mulheres carinhosas como aquelas encontradas nas areias da ilha de Itaparica ${ }^{253}$ ou nos engenhos do Recôncavo, "caindo no visgo" quando "fretadas"254, foram apropriadas da mesma maneira predatória com a qual os colonos se apoderavam da natureza brasileira, desmatando o litoral para prover lenha aos engenhos. Em contextos sociais e culturais distantes do universo colonial soteropolitano seiscentista, tanto Jack Goody ${ }^{255}$, quanto Leach ${ }^{256}$ ou Roberto DaMatta ${ }^{257}$ observaram a existência de vínculos de linguagem entre

252 MATOS, G. Op. Cit., Vol. V, p. 1220.

253 MATOS, G. Op. Cit., Vol. VI, p. 1522.

254 MATOS, G. Op. Cit., Vol. VI, p. 1400.

“Há cousa como estar em São Francisco,/onde vamos ao pasto a tomar fresco,/Passam as negras, fala-se ao burlesco,/Fretam-se tôdas, tôdas caem no visco".

255 GOODY, Jack. Cooking, cuisine and Class: a study in comparative sociology. London/New York, Cambridge University Press, 1982, p. 14.

256 LEACH, Edmund. "Aspectos antropológicos da linguagem: categorias animais e insulto verbal”, in Antropologia. R. DaMatta (org.), São Paulo, Ática, 1983. 
relatos de coitos, procedimentos de nutrição e relações de afinidade. Semelhante aproximação transitava no terreno ambíguo da obscenidade e da anomalia. O corpo humano, promotor de atos fisiológicos de sexo e de hábitos de nutrição, serviu de pretexto para criar uma multiplicidade de brincadeiras que equiparavam os órgãos sexuais masculinos a gêneros comestíveis e invertiam a função desses órgãos, transformando-os em ingredientes comestíveis inertes.

O poeta não se mostrou particularmente sutil ao formular representações simbólicas para se referir ao baixo corporal. As metáforas alimentares que ele propôs ressaltaram as formas

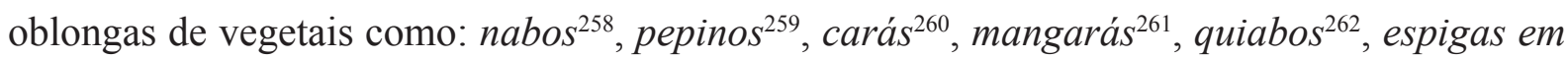
grão ${ }^{263}$, frutas em geral ${ }^{264}$ e bananas $^{265}$, ou ainda de preparos culinários elaborados com carnes de animais comestíveis tais como: peixes ${ }^{266}$, a moqueca de petitinga preparada por Susana, amásia do feitor-mor da Cajaiba ${ }^{267}$, os camarões $^{268}$, mas sobretudo as iguarias de formas fálicas sugestivas, feitas de carnes moídas e temperadas embutidas em tripas como paios (por vezes salpimentados), chouriços e lingüiças ${ }^{269}$.

No caso dos vegetais, a ironia residiu na transformação da expressão máxima da virilidade masculina em apêndice vegetal: legume ou fruta, de textura branda. Diferentemente dos insultos verbais animais analisados por Leach, o trocadilho instituído não derivou de um qüiproquó fonético entre palavras de sonoridades semelhantes, reunindo áreas distintas e descontínuas do

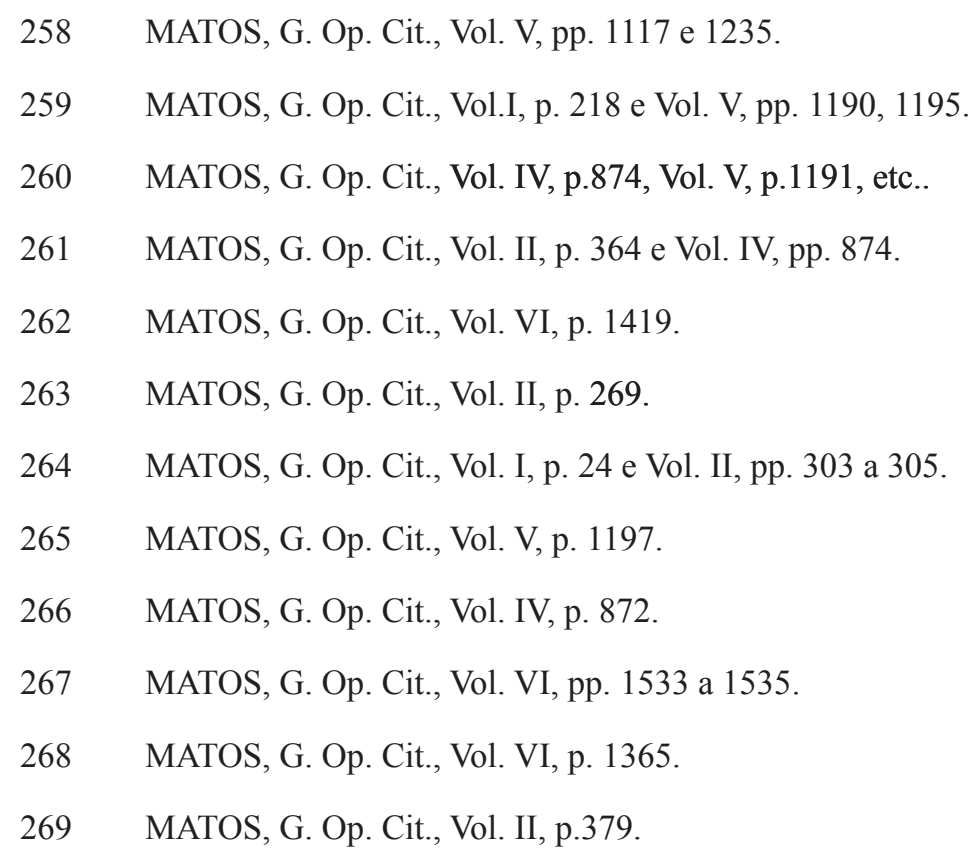


espaço social, que deveriam ser mantidas separadas. Proveio de uma sugestão de continuidade natural, ontológica, entre categorias naturais distintas. A condição humana e a condição de ingrediente comestível superpunham-se nos versos para criar um estranhamento suscitado pelas imagens metafóricas inusitadas. A continuidade elaborada pelo poeta entre categorias independentes dissolvia, desse modo, os limites da pessoa para propor uma identidade vegetal ou animal ridícula:

“Que por um cará cozido/leveis o meu, que anda assado./[...] de carás hei de cozer uma boa caldeirada,le de tôda esta tachada/tal conserva heis de tomar,que vos venhais a pagar/do cará com a caralhada"270.

"Comi o chouriço cozido/com sossêgo, e sem empenho,/porque outro chouriço tenho/para pagar o comido:/vós tendes melhor partido,/mais liberal e mais franco,/ pois como em real estanco/tal seguro vos prometo,/que por um chouriço prêto/heis de levar o meu que é branco"271.

Rapazes atraentes foram ironicamente descritos por Gregório de Matos na condição de condimentos, "das moças o perrexil" ${ }^{272}$. Mulheres foram comparadas a fruitas ${ }^{273}$ ou a um xinxim $^{274}$ (preparo nativo) e Matos as instou a darem-lhe o doce ${ }^{275}$. Os seios das moças, por sua vez, foram comparados a frutas ou à peitos tenros de aves (titelas) ${ }^{276}$. Marmelos ${ }^{277}$ e sobretudo

270 MATOS, G. Op. Cit., Vol. II, pp. 364, Vol. IV, p. 875 e 972.

271 MATOS, G. Op. Cit., Vol. IV, p. 878.

272 MATOS, G. Op. Cit., Vol. IV, p. 894.

273 MATOS, G. Op. Cit., Vol. I, pp. 24, Vol. IV, p. 833 e Vol. V, p. 1253.

274 MATOS, G. Op. Cit., Vol. VI, p. 1469.

275 MATOS, G. Op. Cit., Vol. IV, p. 857.

276 MATOS, G. Op. Cit., Vol. VI, p. 1399.

MATOS, G. Op. Cit., Vol. VI, p. 1468. 
figos foram associados por Matos à anatomia feminina: "apolegada como um figo"278, foi uma expressão que o autor reiterou diversas vezes (a comparação se repetiu também nos conselhos, que o poeta deu a uma noiva $\left.{ }^{279}\right)$.

Matos também apresentou uma lista extensa de expressões metafóricas para se referir aos coitos. Parece digno de nota a expressão: "cozinhar o dado", utilizada num poema, retomando a idéia expressa de que a relação sexual transformaria o cru em cozido:

"Eu là a irei cozinhando [ao pé de um mangue]/de sorte que o vosso dado/com ser de sangue queimado,/não me ande o sangue queimando..."280.

Na definição do priapo (falus), solicitada por umas freiras à Gregório de Matos, o coito foi descrito em termos de panificação:

“amassa tendo gamela/doze vezes sem cansar,/e traz já para amassar as costas tão bem dispostas, /que traz envolto nas costas fermento de levedar ${ }^{2281}$.

Em compensação, as vaginas permaneceram, para Gregório de Matos, como coadjuvantes do ato sexual. Foram raramente consideradas itens comestíveis. Exceções houve, contudo, em alusões à "nata do cono"282:

"comendo uma, e outra vez/da nata que amor cobiça"283.

\footnotetext{
278 MATOS, G. Op. Cit., Vol. IV, p. 856.

279 MATOS, G. Op. Cit., Vol. V, p. 1093.

280 MATOS, G. Op. Cit., Vol. VI, p. 1399.

281 MATOS, G. Op. Cit., Vol. V, p. 1196.

282 MATOS, G. Op. Cit., Vol. III, p. 569 e Vol. V, p. 1084.

283 MATOS, G. Op. Cit., Vol. V, p. 1084.
} 
"Senhora Cota Vieira,/[...] Tive debaixo da língua/o pedir-vos uma lasca/da nata do vosso cono,/se é, que tem côdea essa nata"284.

O registro da parceria no ato sexual limitou-se à enfatizar o papel de recipientes fabricados para conter alimentos: vasos ${ }^{285}$, ôlha podrida ou simplesmente olha $^{286}$, odre o $^{287}$ e gamela ${ }^{288}$, quando não se transformavam em emplastros de tripas $^{289}$.

Noutros versos Matos aludiu a hímens reconstituídos. As "virgos ensopadas"290, costuravam o berbigão, (ou o sururu) ${ }^{291}$, antes de casarem a fim de melhor enganar os noivos. A idéia do molusco cozido transformou-se, no caso, na noção de um molusco "cosido"292, referência à tarefa de cuidar das roupas, também confiada às mulheres:

"e é que o Noivo em sua vida/não quis, que o povo malvado/dissesse, que andava assado/por uma mulher cozida. // Se coseu o berbigão,/como diz a gente tôda,/ muito a moça me acomoda/para arrais de um galeão" 293 .

“o Môço por ela assado,/ e ela por ele cozida/[...]/a verdade aqui só conto,/sem lhe acrescentar um ponto/dos que ela no vaso deu. ${ }^{2294}$.

\footnotetext{
284 MATOS, G. Op. Cit., Vol. III, pp 568 a 570.

285 MATOS, G. Op. Cit., Vol. IV, p. 980.

286 MATOS, G. Op. Cit., Vol. V, pp. 1201, Vol. VI, pp. 1436, 1500 e 1501.

287 MATOS, G. Op. Cit., Vol. II, p. 269 ou Vol. VI, p. 1439, etc.

288 MATOS, G. Op. Cit., Vol. v, p. 1196.

289 MATOS, G. Op. Cit., Vol. VI, p. 1488.

290 MATOS, G. Op. Cit., Vol. IV, p. 953.

291 Moluscos providos de conchas.

292 MATOS, G. Op. Cit., Vol. IV, p.951.

293 MATOS, G. Op. Cit., Vol. V, p.1329.

294 MATOS, G. Op. Cit., Vol. III, p. 729.
} 
No caso do esperma, o tabu infringido, era a ausência de separação nítida entre o âmbito dos elementos corporais externos e internos. Matos, brincando com as palavras, transgrediu jocosamente o caráter sério das exsudações do corpo humano ao assimilar o sêmen a caldos ou a sopas: $\operatorname{caldos}^{295}$, caldos mornos ${ }^{296}$, caldo de lentilhas ${ }^{297}$, caldo de grão ou caldo de grão de homem. ${ }^{298}$, sustância ${ }^{299}$ (isto é, caldo de sustância), leite ${ }^{300}$, mingau ${ }^{301}$, molho de escamas $^{302}$, caramelo ou xarope ou cordial $^{303}$, substâncias externas ingeridas e assimiladas pelos corpos.

No que tange ao coito, uma miscelânea de expressões tais como: "meter os bois na vinha"304, "trocar odre por odre"305, "comer cuscuz"306, "comer alhos galegos"307, "ser amiga do alho"308, "moer o trigo"309 ou "moer como a bom trigo"310, "moer o sal" 311 foi recolhida nos poemas. Porém, em pelo menos um caso, moer o sal indicou a surra dada a uma amásia infiel. Valeria ainda mencionar o castigo que um amante traído infligiu à sua

\footnotetext{
295 MATOS, G. Op. Cit., Vol. IV, p. 873.

296 MATOS, G. Op. Cit., Vol. II, pp. 437, 453, Vol. V, p. 1153, Vol. VII, p. 1566.

297 MATOS, G. Op. Cit., Vol. IV, pp. 1107 a 1109.

298 MATOS, G. Op. Cit., Vol. IV, pp. 1107 a 1109 e Vol. VII, p. 1575.

299 MATOS, G. Op. Cit., Vol. VI, p. 1534.

300 MATOS, G. Op. Cit., Vol. V, p. 1197.

301 MATOS, G. Op. Cit., Vol. VI, p. 1292.

302 MATOS, G. Op. Cit., Vol. VI, p. 1533.

303 MATOS, G. Op. Cit., Vol. IV, pp. 832 e 969 e Vol. VI, pp. 1355 e 1476.

304 MATOS, G. Op. Cit., Vol. VI, p. 1490.

305 MATOS, G. Op. Cit., Vol. VI, p. 1440, Vol. VII, p. 1572.

306 MATOS, G. Op. Cit., Vol. I, p. 209.

307 MATOS, G. Op. Cit., Vol. II, p. 296.

308 MATOS, G. Op. Cit., Vol. V, pp. 1118 e Vol. VI, p. 1292.

309 MATOS, G. Op. Cit., Vol. V, p. 1273.

310 MATOS, G. Op. Cit., Vol. IV, p. 830.

MATOS, G. Op. Cit., Vol. IV p. 969.
} 
amásia: uma dolorosa lavagem da vagina com pimentas juquitaias, que deixaram a moça de vinha-d'alho ${ }^{312}$.

\section{2 - Descrição metafórica dos vícios que grassavam no Recôncavo}

Adjetivando práticas alimentares da vida soteropolitana ou elaborando cenas curtas a partir de gestos observados, as expressões metafóricas do autor fustigaram vícios de conduta teoricamente reprovados (mas praticados) em Salvador e adjacências. Os alimentos, por conseguinte, lhe serviram para referir idealmente tudo que dá gosto à vida e pode reverter em pecadilhos ou em infrações aos mandamentos divinos. A idéia dos pecados e dos vícios operou reiteradamente na composição poética como um crivo para expor uma classificação mazomba estereotipada de categorias sociais. As pessoas colocadas em foco mereceram até figurar com letras maiúsculas no texto dos poemas: o Canastreiro, o Marinheiro, o Letrado, o Pai etc.. Matos apresentou, portanto, uma maneira de conceber o Brasil que, sem se confundir com a realidade colonial observada, encontrou ressonância entre muitos colonos, a ponto de resolverem preservar a obra produzida.

Gregório de Matos satirizou indivíduos que não obedeciam aos preceitos e grupos sociais, que desrespeitavam os limites impostos e colocavam em perigo uma certa concepção das estruturas sociais e culturais soteropolitanas. Ressaltou na escrita do autor seu intento de moralizar a vida colonial por meio de metáforas alimentares, que lhe serviram de veículo para defender as idéias que acalentava.

O desejo que os alimentos despertavam traduziu metaforicamente diversos tipos de apetites. Não era somente a gula que satisfazia a fome dos colonos. Por intermédio de tais figuras de estilo, Matos registrou a presença, em território soteropolitano, de paixões tão avassaladoras quanto impróprias. Numa sociedade cuja moralidade costumava ser enquadrada firmemente 312 MATOS, G. Op. Cit., Vol. IV, p. 979 a 981.

A juquitaia ou inquitaia era a mistura indígena de sal e de pimentas nativas que os colonos portugueses adotaram com grande prazer. 
pela Igreja e onde era preciso constantemente comprovar adesão à fé católica pela prática de jejuns e de sacrifícios corporais, todas as condutas carnais que davam prazer ao corpo e gosto à vida foram vistas como suscetíveis de extrapolarem os limites da prudência e de resultarem em vícios ou pecados. Condutas alimentares indecorosas foram encarregadas pelo autor de encenarem demonstrações de cunho moral.

Os portugueses instalados no Brasil, mesmo quando provinham de cadinhos familiares plebeus, almejavam desfrutar de melhores condições de vida. Ao longo da segunda metade do século XVI e da primeira metade do século XVII, as noções locais de fidalguia e honra nortearam as condutas e as vantagens de ser considerado um homem bom passaram a ser uma meta almejada por muitos colonos que, segundo os parâmetros mazombos, não faziam jus a tal dignidade. Em torno da condição social de cristãos velhos, da posse de terras férteis cultivadas por grandes contingentes de escravos compelidos ao trabalho e da promoção de gastos suntuosos excessivos elaboravam-se os códigos da honra mazomba. Os mazombos, nesse sentido restrito, não eram apenas colonos lusos de sangue considerado puro, mas sobretudo membros das elites sociais empenhadas em comprovar que eram ricas, munificentes e generosas.

As considerações de Antonil sobre as restrições que os senhores de engenho deveriam observar em relação às obrigações da hospitalidade, ofereceram pistas para avaliar a inconveniência do desperdício exacerbado (um pouco aparentado ao potlach dos indígenas da costa noroeste canadense e americana), com o qual os mazombos tentavam comprovar sua idoneidade social. Em seu retrato da sociedade colonial, Laima Mesgravis ${ }^{313}$ enfatizou a importância social de nunca se vender o trabalho das próprias mãos ou de não possuir ascendentes, pais ou avós, que teriam exercido alguma profissão manual para assegurar a subsistência. Colonos considerados como " $a$ nobreza da terra" se mostraram especialmente ávidos em serem reconhecidos como "homens bons" para desfrutarem das vantagens sociais desse status social privilegiado. Eles podiam efetivamente ser caracterizados como esfaimados de prestígio, de riquezas ou de honras.

313 MESGRAVIS, Laima. "Os aspectos estamentais da estrutura social do Brasil colonia", in Estudos econômicos, $n^{\text {o }} 13$, pp. 799 a 811, 1983. 
Despojado de suas funções de juiz e de padre, o doutor em leis Gregório de Matos se dispôs a expressar julgamentos morais sobre a sociedade soteropolitana fundamentado nos termos de sua formação acadêmica: "Que os tais com gula que espanta,/se o mundo fôra guisado/o comeram de um bocado "314.

Sobretudo o pecado da avareza lhe mereceu censura. Resultava em condutas absurdas. O desejo de poupar para acumular riquezas e ascender na hierarquia social, por exemplo, ia precisamente na contramão da maneira de viver que mazombos, dependentes do trabalho dos escravos, consideravam nobre:

"Mas que outros mil à porfia/por toda a vida o dinheiro/ajuntem, que o seu herdeiro/ há de gastar num só dia:/que andem com melancolia/sem comer e sem cear/para poder ajuntar/todos cheios de lazeira!/Boa asneira"315.

A trajetória usual de enriquecimento dos negociantes lusos foi um tema que Matos se empenhou ardentemente em denunciar. Mercadores lusos costumavam praticar a usura, poupavam os lucros extorsivos amealhados com seu trabalho e comiam diariamente carne de baleia como se fossem pobres ou escravos ${ }^{316}$. Afiguravam-se tão avarentos que Matos chegou a representá-los como homens dados a ingerirem pepinos: "de tôda a iguaria isenta, com seu limão, e pimenta"317, ou como homens que ceavam parcamente, à noite, comendo apenas saladas de chicória com azeitonas $^{318}$. Alguns desses homens, por cúmulo de desprestígio, mereciam até ser caricaturados como: "cristão que apenas janta e não ceia"319. Invejar o dinheiro alheio também foi um vício que Matos traduziu em termos de hábitos alimentares: "Que haja alguns,

\footnotetext{
314 MATOS, G. Op. Cit., Vol. II, p.507.

315 MATOS, G. Op. Cit., Vol. II, p. 492.

316 MATOS, G. Op. Cit., Vol. II, p.430.

317 MATOS, G. Op. Cit., Vol. II, p. 444.

318 MATOS, G. Op. Cit., Vol. II, p. 491.

319 MATOS, G. Op. Cit., Vol. IV, p. 1108.
} 
que se consomem/inda com vício mais feio,/que por não comer o alheio logo de inveja se consomem" $" 320$.

Os exemplos de vaidade e de arrogância percebidos nas ações de muitos membros da população colonial se multiplicavam de verso em verso:

"que ande pois a fidalguia/vendida assim por dinheiro,/como trigo no terreiro,/só porque há nisso vangloria! Boa história // [...] Que alguns tanto por seu mal/ vistam (por não ser comuns)/de altos, e ricos tissuns,/destruindo o cabedal;/que com porfia fatal/se mostram nisso empenhados,/sendo à noite os seus guisados/ azeitonas, e chicória!/Boa história" ${ }^{321}$.

"Que os valentões arrojados/andem feitos tranca-ruas/com suas espadas nuas/ comendo a gente a bocado.../ Boa história!"322.

Também eram boas asneiras, "que haja nos fracos ira,/e nos que são pobres gula" 323 .

Outro tema amplamente criticado nos versos foi a luxúria de muitos frades e padres. O autor censurou sacerdotes e frades, "orates da venerável igreja" que mantinham "casa de cerveja"324 e visitavam os paroquianos apenas para arrecadar dinheiro.

A preguiça, pela força das circunstâncias, uma tara menos associada à gula, não deixou de ser traduzida em termos de condutas alimentares, paradoxalmente pertinentes numa sociedade dominada pela necessidade de mão-de-obra escrava:

\footnotetext{
320 MATOS, G. Op. Cit., Vol. II, p. 508.

321 MATOS, G. Op. Cit., Vol. II, p. 491.

322 MATOS, G. Op. Cit., Vol. II, p. 506.

323 MATOS, G. Op. Cit., Vol. II, p. 510.

324 MATOS, G. Op. Cit., Vol. II, p. 500
} 
"Mas que outros, que se desfazem,/façam muito por serem pobres, /isto porque nada fazem:/que com fome êstes se abrasem,/que tanto mal ocasiona sendo a preguiça potrona..." 325 .

Apesar dos colonos costumarem "Gastar para comer muito dinheiro" ${ }^{326}$ na festa do entrudo, Matos reconheceu que muitos colonos, cujas finanças se encontravam em estado precário, devoravam estupidamente o dinheiro possuído e, uma vez o pecúlio comido, se encontravam em situação difícil ${ }^{327}$ :

"sem ter um par de vinténs:/que padecendo vaivens/gastem tudo como tolos,/e em bolos e bolinholos/despejem sua algibeira!/Boa asneira" ${ }^{328}$.

Situação pior, no entanto, era aquela de colonos que emprestavam quantias imediatamente desperdiçadas em prazeres tolos: "que o credor cuide contentelque bem empregado está,/ estando o dinheiro já na casa da confeiteira! Boa asneira" 329.

As condutas, que Gregório de Matos satirizou por infringirem a ética colonial, delineavam um universo costumeiro de discursos mazombos permeados de intenções morais. Matos, insistindo na afirmação dos valores que ele compartilhava com os conterrâneos, comprovava simultaneamente a relevância local dessas noções e o fato de que existia em Salvador uma parte substancial da população que já não pautava estritamente suas condutas pelos códigos sociais das elites açucareiras mazombas:

\footnotetext{
325 MATOS, G. Op. Cit., Vol. II, p. 508.

326 MATOS, G. Op. Cit., Vol. III, p. 580.

327 MATOS, G. Op. Cit., Vol. I, p. 7.

328 MATOS, G. Op. Cit., Vol. II, p. 496.

329 MATOS, G. Op. Cit., Vol. II, p. 507.
} 
“A Donzela embiocada $330 /$ mal trajada e mal comida/antes quer na sua vida/ter saia que ser honrada:/à pública amancebada..." ${ }^{331}$.

Efetivamente, a indignação do poeta recaía com maior vigor sobre pessoas de origem modesta que aspiravam a melhorar de vida:

"Mas que o pobre que não tem,/que comer, ou que gastar,/nem tem sangue, nem solar,/seja soberbo também:/que não tenha um só vintém,/e se inche como pirum,/ conhecendo cada um,/que fora a Mãe taverneira! Boa asneira"332.

O poeta dramatizou correntemente a falta de senso crítico dos colonos, em relação aos códigos de honra mazombos. Maneiras impróprias de agir traduzidas em gestos cotidianos foram tratadas por ele a par de pecados capitais. Matos mostrou-se, aliás, particularmente intolerante com ações que revelavam simultaneamente a ignorância e a pretensão à sabedoria de soteropolitanos que, menos letrados ou íntegros que ele próprio, desfrutavam de proventos certos e de posição social invejável. Afirmava, por exemplo: "É grande coninbricense,/sem jamais pôr pé em Coimbra,/e sendo ignorante sabe/mais que galinha"333.

\section{3 - As metáforas alimentares, recursos para uma critica da vida colonial}

Matos se valeu de alimentos e de hábitos alimentares para satirizar os conterrâneos. Ele apontou os procedimentos inadequados de muitos indivíduos, vituperou medidas absurdas de gestão colonial e preconizou o respeito aos códigos morais soteropolitanos. Sublinhando

330 MORAES, Antônio. Diccionário da língua portugueza. 2 tomos. Lisboa, Tipografia Lacerdina, 1813.

"Embiocar-se: tapar o rosto com o manto".

331 MATOS, G. Op. Cit., Vol. I, p. 6.

332 MATOS, G. Op. Cit., Vol. II, p. 494.

333 MATOS, G. Op. Cit., Vol. II, p.283. 
a inconveniência de gestos observados, ele ilustrou, por contraste, os valores culturais que considerava apropriados. Numa cidade vigiada pelas confissões ao clero, onde se acreditava que os malfeitos de indivíduos privados podiam atrair a ira divina sobre toda a comunidade, não espantava a importância que revestiam as críticas às condutas do próximo, nem o modo consistente como o domínio público se apoderava dos recatos da vida privada. Hansen ressaltou o caráter de "prática moralizante articulada a outras práticas discursivas" 334 dos poemas do autor, compostos numa sociedade que se via como um corpo único dominado pela Igreja. O engajamento na atividade poética permitiu a Matos, impedido de exercer a magistratura em sua cidade natal, continuar a desfrutar do prestígio que coroava suas habilidades de letrado e seus conhecimentos das leis e das etiquetas sociais.

As convenções de composição poética satíricas ou burlescas proporcionaram-lhe um instrumento de linguagem regido por normas claras de escrita e de decoro. As alegações obscenas desqualificaram, ora indivíduos nomeados especificamente, ora uma pletora anônima de transgressores dos códigos sociais. As metáforas alimentares incorporando valores morais ofereceram, portanto, um veículo interessante para expressar idéias. Nos versos, pequenas encenações dramáticas de fatos cotidianos e gestos carregados de significado ilustraram os pontos de vista defendidos. Matos delineou, dessa forma, imagens destinadas a repercutir na imaginação do público que ele esperava influenciar. Às premissas tácitas referindo gestos de alimentação coube, por conseguinte, a tarefa ingrata de tentar impedir a derrocada de uma visão de mundo.

No decorrer da pesquisa foi possível observar a importância operacional das metáforas. Por meio de um artesanato bastante sutil da palavra, apesar do recurso a termos chulos e situações desprezíveis, Matos, fundamentado nas concepções de mundo das elites mazombas, representou a sociedade colonial soteropolitana da qual foi expoente. Ele retratou corpos lidando ridiculamente com ingredientes comestíveis ou sublinhou analogias entre gêneros alimentares e corpos dotados de particularidades físicas risíveis. Manejos intempestivos de alimentos e 
problemas digestivos também assinalaram as infrações cometidas contra as normas da boa sociedade soteropolitana. Episódios inventados ou fatos verídicos distorcidos implementaram suas maledicências. Ora uma moça ultrajada pelos galanteios de um sacerdote mandava uma panela de doces ao admirador desavisado (mas a vasilha, ao ser destampada, continha apenas fezes frescas) ${ }^{335}$, ora uma mazomba da boa sociedade, obrigando seu escravo a lhe coçar o braço, se enfurecia ao perceber a ereção do "camarão" do moleque ${ }^{336}$, ora um amante traído se vingava da amásia infiel lhe infligindo uma lavagem do sexo com molho de pimentas ardidas ${ }^{337}$, ora era uma amásia que castigava o amante relapso, oferecendo-lhe um doce de araçá com poderoso efeito laxante ${ }^{338}$.

Os problemas da colônia marcaram presença nos versos, no entanto, descrever a realidade soteropolitana não foi o objetivo precípuo da arte de Matos, a despeito de muitas reivindicações das elites mazombas relativas à gestão administrativa da colônia figurarem nos poemas. Ele bem podia versejar acontecimentos de importância social, como a chegada de um governador ou de um arcebispo, episódios escandalosos da crônica local ou resvalar para o domínio dos fatos inventados capazes de lembrar didaticamente aos incautos as conseqüências possíveis de suas ações. As narrativas de fatos constituíram um meio e não a finalidade de sua arte poética. Mas a própria necessidade de se queixar revelava também que o universo mazombo já escapava aos parâmetros da imagem ideal da colônia acalentada pelo poeta durante sua juventude ou a permanência em Portugal.

Duas grandes categorias de críticas sobressaíam no conjunto da obra. Por um lado, existiam indivíduos satirizados a título pessoal, por suas condutas. De outro lado, distinguiam-se categorias sociais de homens, cujos procedimentos afrontavam o decoro da hierarquia social e que, ao tentarem ascender socialmente, colocavam em risco a própria organização social da colônia. Desqualificados através de formulas estereotipadas que expressavam classificações MATOS, G. Op. Cit., Vol. II, pp. 316 a 318.

336 MATOS, G. Op. Cit., Vol. VI, p. 1365.

337 MATOS, G. Op. Cit., Vol. IV, p. 979.

338 MATOS, G. Op. Cit., Vol. 
sociais relevantes aos olhos do poeta e de seus pares, os versos que referiam sua presença soteropolitano registravam insultos vigorosos.

\subsection{1 - As sátiras endereçadas aos indivíduos}

Gregório de Matos retratou hábitos alimentares que deslustravam quem os praticava, sem perceber, talvez, que ocorriam mudanças de rumo nas atividades da colônia. Poucos anos faltavam então para a descoberta de ouro nas Minas Gerais e o deslocamento de grandes contingentes de população para o interior, precedendo também em algumas décadas a decisão da coroa lusa de transferir para o sul a capital da colônia ${ }^{339}$. Como apontou Vera Lúcia Ferlini:

"A corrida para as Gerais, além de desestimular a produção açucareira - pois muitos lavradores abandonavam suas terras, para aventurar-se na lavra do ourogerava o aumento do preço dos escravos. A carestia geral, além do mais, sangrava o numerário, já escasso nas regiões do açúcar "340.

O caráter ridículo de cenas vistas em Salvador ou no Recôncavo e a indignação que feitos destoantes ou aparências físicas dos conterrâneos suscitavam entre gente bem- nascida justificavam o procedimento do poeta. Nas sátiras que ele endereçou a indivíduos relapsos, desfilavam colonos que não respeitavam os papéis exercidos: clérigos lúbricos, autoridades coloniais corruptas, letrados ineptos, mulheres promíscuas, etc.. Essas infrações afrontavam a moral, mas não colocavam em risco os próprios preceitos coloniais de interação social.

Atos reveladores de falta de decoro envolviam pessoas praticando gestos inadequados. $\mathrm{Na}$ trama dos versos, amplos elencos de metáforas obscenas se encarregaram de rebaixar a dignidade

339 O ouro das Minas Gerais começou a aparecer em 1695 e o Rio de Janeiro se tornou a capital da colônia em 1763.

340 FERLINI, Vera Lúcia do Amaral.Terra trabalho e poder: o mundo dos engenhos no nordeste colonial. Bauru, EDUSC., 2003. p. 120. 
desses indivíduos. Traduziam a inconveniência de suas atitudes e aparências em termos de manejos alimentares errôneos, que resultavam em disfunções previsíveis nas atividades da digestão e da vida sexual. Matos se permitiu até, ocasionalmente, lembrar a circunstância dos alimentos serem parte integrante de um processo de ingestão e digestão de nutrientes, que comportava também o descarte fisiológico dos resíduos.

A inspiração erótica adquiriu grande destaque na obra de Gregório de Matos. Amores freiráticos ou cantadas às mulatas, às negras e às mamelucas soteropolitanas, moças alforriadas ou escravas, que não recusavam as propostas compensadoras de união livre, motivaram leques amplos de metáforas alimentares. Se ao iniciar romances, o tom dos poemas escritos às mulheres cortejadas, interpeladas pelo nome ou pelo apelido, se mostrava relativamente cortês, bastava que a moça exorbitasse nos pedidos de retribuição financeira ou se mostrasse infiel, para que o poeta a castigasse em termos vivos. Os poemas seguintes resvalavam da segunda para a terceira pessoa do singular contendo imprecações e acusações. De modo que, com o passar do tempo, o poeta que já tinha "namorado o mapa" ${ }^{341}$, alcançando a terceira idade, sua reputação de mordacidade e mesquinhez parece ter-lhe dificultado encontrar jovens dispostas a "lhe vazar a tripa"342.

Pela freqüência dessas composições nos códices apógrafos, conquistar mulheres por meio de galanteios rudes, sob capa de metáforas poéticas, parecia constituir um procedimento que não afrontava excessivamente os preceitos de decoro vigentes (ou pelo menos, tais galanteios não pareciam contradizer em demasia o papel de censor dos usos e costumes coloniais assumido pelo autor). Matos jocosamente se recusava a pedir desculpas por seus gostos: "Quem tem gôsto na culpa./o perde por se desculpar:/( muito mais sabe o furtado)" ${ }^{\prime 343}$.

\footnotetext{
341 MATOS, G. Op. Cit., Vol. V, p. 1188.

342 MATOS, G. Op. Cit., Vol. V, p. 1218.

343 MATOS, G. Op. Cit., Vol. V, p. 1085.
} 


\section{Clero regular e clero secular}

No entorno do Terreiro de Jesus localizavam-se os principais edifícios da vida religiosa da colônia: a Catedral, o convento dos Jesuítas, onde jovens estudavam, e a Santa Casa da Misericórdia. Nas demais freguesias na capital e no Recôncavo também estavam localizadas paróquias que congregavam os moradores da redondeza e permitiam ao clero um controle estrito do cumprimento das obrigações religiosas da população. Por vezes, as paróquias auxiliavam ainda a administração colonial no desempenho de tarefas de interesse público local, tais como a cobrança de contribuições para a execução de obras necessárias. Ali registravam-se nascimentos, casamentos e óbitos. As paróquias, que constituíam unidades territoriais para a expressão da sociabilidade e da fé, também abrigavam irmandades destinadas à arrecadação de fundos para socorrer os pobres ou para celebrar festas de santos. Conforme a importância social de seus membros, desfrutavam de maior ou de menor prestígio social.

As igrejas reuniam um público de ambos os sexos e eram um dos poucos destinos de passeio permitidos às mulheres de boa família. Schwartz, comentando o florescimento das irmandades religiosas na cidade, explicitava:

“Os principais passatempos da população urbana parecem ter sido sexo e religião.

[...] De fato entre 1650 e 1750 essa religiosidade encontrou uma forma de expressão na intensa atividade arquitetural"344.

O uso que Gregório de Matos fez de tropos utilizando a alimentação para falar de outros temas confirmava a propriedade da observação do historiador. O alimento que assegurava a continuidade da vida física dos indivíduos foi chamado a representar, por extensão, problemas relacionados à moralidade da vida colonial ou às as atividades sociais daqueles que sua ingestão mantinha vivos. Desse modo, as queixas do poeta contra procedimentos inaceitáveis dos 
membros do clero assumiram freqüentemente a forma de acusações genéricas:

"Para o Cônego observante/todo dia, e tôda a hora,/cuja carne é pecadora/das completas por diante:/cara de disciplinante,/queixadas de penitente,/e qualquer jimbo ${ }^{345}$ corrente/serve para seus subornos: sete cornos" 346 .

"Mas que muitos professôres,/da lei católica, e santa/se metam pela garganta/dos infernos tragadores:/que por uns tristes amôres,/ou por uns negros tostões/vão para os eternos tições/lá na hora derradeira!/Boa asneira"347.

"Se virdes um Dom Abade/sobre o púlpito cioso,/não lhe chameis Religioso,/ chamai-lhe embora de Frade:/e se o tal Paternidade/rouba as rendas do Convento/ para acudir ao sustento da puta ..." ${ }^{348}$.

Muitos frades foram alvos do escárnio do autor, acusados de manterem grosseiros amores freiráticos:

"e o Frade a mui limpo ser,/sempre há de vir a feder/ao cepo de um pasteleiro. // Em chegando à grade um Frade/sem mais carinho nem graça,/o braço logo arregaça,/ e o trespassa pela grade:/ e é tal a qualidade/de qualquer Frade faminto,que em um átomo sucinto/se vê a freira coitada/como um figo apolegada, e molhada como um pinto $" 349$.

\footnotetext{
$345 \quad$ No sentido de dinheiro.

346 MATOS, G. Op. Cit., Vol. II, p. 453.

347 MATOS, G. Op. Cit., Vol. II, p. 478.

348 MATOS, G. Op. Cit., Vol. I, p. 8.

349 MATOS, G. Op. Cit., Vol. IV, p.856.
} 
A um frade apelidado Frei Garrafa Matos aconselhava:

"Livre-se na relação,/dos cargos, em que é culpado,/ser glutão como um capado,/ como um bode fodinchão" ${ }^{350}$.

A abordagem do tema dos desmandos de eclesiásticos não constituía novidade no panorama colonial, pois, em 1549 o padre Manuel da Nóbrega já lastimava as condutas imorais de sacerdotes, que cuidavam do rebanho soteropolitano. No entanto, não deixava de existir no caso uma pontinha pessoal de inveja, compreensível num poeta que de motu próprio renunciara à inclusão num grupo prestigiado de colonos que o beneplácito real sustentava. Matos, viúvo e demitido dos cargos de Tesoureiro e de Vigário geral da Sé por se recusar à ordenação plena, para continuar a "conversar" com mulheres, se mostrava muito sensível à imoralidade dos eclesiásticos.

Havia entre as poesias reunidas no códice de James Amado um poema revelador de certa saudade das oportunidades perdidas. Uma didascália interessante acompanhava os versos: "Pondera estando homiziado no Carmo quam gloriosa he a paz da religião". Em 1683, o poeta se encontrava refugiado no Carmo para escapar à perseguição do Governador Antônio de Souza de Menezes, em conflito aberto com o padre Vieira e seu irmão, Bernardo Vieira Ravasco (demitido de um cargo de secretário de Estado) e com parte expressiva da população colonial. Ao lastimar não ter uma paciência de frade para desfrutar em paz o maná de Jesus, o tom do poema, sem resvalar realmente para o satírico, sugeria uma critica leve, um pouco dúbia:

"Esta vida religiosa/tão sossegada e segurala tôda boa alma apura,lafugenta a alma viciosa:/há cousa mais deliciosa,/que achar o jantar e almoço/sem cuidado e sem sobrosso/tendo no bom, e no mau ano/sempre o pão cotidiano/e escusar o Padre nosso! // Há cousa como escutar/o silêncio que a garrida/toca depois da comida/ 
para cozer o jantar!/há cousa como calar, e estar só na minha cela/considerando a panela,/que cheirava, e recendia/no gosto de malvasia na grandeza da tigela! // Há cousa como estar vendo/uma só Mãe religião/sustentar a tanto Irmão/mais ou menos Reverendo!"351.

Matos se queixou recorrentemente de clérigos soteropolitanos que abusavam do poder conferido por seu estado sacerdotal e extorquiam dinheiro dos "fregueses" para sustentar amantes. Segundo afirmava o autor, esses clérigos costumavam "mamar o pão da esmola" $352 \mathrm{e}$ passavam uma vida regalada, comendo do bom e do melhor, visitando as casas dos paroquianos para "papar a cabidela" ou para navegar metaforicamente escravas imponentes como urcas ${ }^{353}$. Certo vigário de uma freguesia soteropolitana (não especificada) foi acusado de cobiça voraz ao "tosquear o vosso gado":

"Reverendo vigário,/Que é título de zotes ordinário,/Como sendo tão bôbo,/E tendo tão larguíssimas orelhas,/Fogem vossas ovelhas/De vós, como se fôsseis voraz Lobo. // [...] Intentastes sangrar tôda a comarca,/Mas ela vos sangrou a veia d'arca,/Pois ficando faminto, e sem sustento,/Heis de buscar a dente qual jumento/Erva para o jantar e para a ceia,..." ${ }^{\prime 35}$.

O tema do jumento pastando ervas a dente, parece recorrente na obra, talvez por fundir numa única imagem metafórica palavras, dentes mordendo e nutrição. Porém, as queixas de Gregório de Matos contra o clero soteropolitano não criticavam o sacerdócio, apenas se voltavam contra indivíduos, cujos procedimentos causavam escândalo. Tratava-se provavelmente de clérigos que o tinham prejudicado pessoalmente. $\mathrm{O}$ autor não procurou desmerecer a religião. Caso se 351 MATOS, G. Op. Cit., Vol. II, pp. 235 a 237.

352 MATOS, G. Op. Cit., Vol. II, p. 340.

353 Navios bojudos destinados principalmente ao transporte de mercadorias.

354 MATOS, G. Op. Cit., Vol. IV, pp. 271 e 272. 
atrevesse a tanto, teria sido preso pela Inquisição $0^{355}$. Sua fé, aparentava genuína e sem grandes laivos de heterodoxia, apesar de Fernando da Rocha Peres assinalar rimas ousadas na obra: Jesu rimando com cu, ou trocadilhos perigosos em torno do tema de Adão e Eva ${ }^{356}$ :

"Passou o surucucu,/e como ele estava no cio,/com um e outro assobio, pediu a Luisa o cu:/Jesu, nome de Jesu,/disse a mulata assustada/[...] porque o bom Adão achou/no Paraíso, ao entrar, sem poder a Eva falar,jurando o seu santo nome em vão,/pecou no segundo então,/por no sexto não pecar" ${ }^{357}$.

Merecia reparo, ainda, outra brincadeira ocasional do poeta: a tarefa de glosar a expressão "Bêbado está Santo Antônio"358, transformada engenhosamente num aviso a um bêbado que estava na igreja, prestes a derrubar a estátua do santo.

Longe de se mostrar anticlerical, Gregório de Matos centrou as críticas contra o desrespeito aos votos de castidade e de pobreza e a utilização do dinheiro da igreja para financiar amantes e amásias (práticas correntes num mundo “às avessas”, cujas infrações aos códigos o enraiveciam). O tema do padre pobre, guloso, hipócrita e dado à luxúria, recorrente na obra, adquiriu relevo notável tanto num longo romance que satirizava as atitudes do padre Damaso, quanto noutro poema que ridicularizava o aspecto físico diminuto do padre Antônio Marques de Perada ${ }^{359}$.

Ressaltava na obra a narrativa dos gestos atribuídos ao padre Damaso da Sylva. A descrição do sacerdote era ferina e maldosa. Esse padre, segundo a didascália, era: "Damaso da Sylva parente do poeta, e seu opposto, homem desbocado, e presunçoso com grandes impulsos de ser

355 PERES, Fernando da Rocha. Gregório de Mattos e a Inquisição. Salvador, Centro de Estudos Baianos, 1987. Segundo o autor, um colono tentou denunciar o poeta perante o Santo Ofício. Mas as acusações não foram adiante.

356 PERES, Fernando da Rocha. Gregório de Mattos Guerra - uma re-visão biográfica. Op. Cit., p. 110.

357 MATOS, G. Op. Cit., Vol. II, p. 387.

358 MATOS, G. Op. Cit., Vol. I, p. 78.

359 MATOS, G. Op. Cit., Vol. II, pp. 274 a 276. 
vigário, sendo por algum tempo em Nossa Senhora do Loreto" ${ }^{360}$. Damaso, também alcunhado Frisão noutros versos do poeta, serviu de modelo para o retrato impertinente de um papajantares. Matos vituperou o modo como ele comia à mesa, acusando-o de ser interesseiro, adulador, mentiroso, hipócrita, avarento e ignorante, delineando em poucas imagens ásperas a conduta desse protótipo ideal de $z o t e^{361}$ :

“O Padre papa jantares,/hóspede tão importuno,/que para todo o banquete/traz sempre de trote o bucho:/Professo da providência,/que sem lograr bazaruco,/para passar todo um ano/nem dois vinténs faz de custo:/Que os amigos o sustentam,/e lhe dão como de juro/o jantar, quando lhes cabela cada qual por seu turno/Essa vez, que tem dinheiro,/que é de sete em sete lustros:/três vinténs com um tostão,/ou dois tostões quando muito:/Com um vintém de bananas,/e de farinha dous punhos,/ para passar dia, e meio/tem certo o pão e conduto:/Lisonjeiro sem recato/adulador sem rebuço,/que por papar-lhe um jantar/de um sacristão faz um Núncio:/De um Tambor um General/um Branco de um Mamaluco/de uma senzala um palácio,/e um galeão de um pantufo./Em passando a ocasião,/tendo já repleto o bucho,/desanda co'a taramela,le a todos despe de tudo:/Outro sátiro de Esopo,/que com o mesmo bafo astuto/esfriava o caldo quente,/e aquentava o frio punho: /..."362.

Noutras peripécias caricaturais, talvez verídicas mas levadas ao exagero, um frade, quase apedrejado por pregar despropósitos na Ilha da Madre de Deus, fugiu levando por matalotagem o jantar do vigário, amigo de Gregório de Matos:

\footnotetext{
360 MATOS, G. Op. Cit., Vol. II, p. 277.

361 Sacerdote ignorante, inconveniente e burro.

362 MATOS, G. Op. Cit., Vol. II, pp. 278 e 279. Merece registro a referência do poeta à dieta mínima composta de "banana com farinha", que constou também em várias outros poemas do autor, figurando nesse poema apenas como o mantimento vergonhoso de um homem pobre.
} 
"sendo que sois tão má preia,/que lhe poupaste a ceia por lhe roubar o jantar"363.

\section{As mulheres na poesia de Matos}

Outro fio condutor relevante para a compreensão do lugar a partir do qual a literatura de Gregório de Matos falava ao público foi seu olhar de macho mulherengo. Na cidade que os poemas retratavam, as atividades masculinas predominavam, apesar das limitações à movimentação física que os critérios mazombos da honra introduziam na vida cotidiana. Os preconceitos vigentes contra o trabalho braçal - atribuição exclusiva de escravos e de homens demasiadamente pobres para possuírem pelo menos um escravo - restringiam o elenco das ações permitidas a homens bem-nascidos. As mulheres casadas de boa reputação e as filhas dos colonos lusos apareciam pouco em público, porém, Matos, freqüentador assíduo dos engenhos do Recôncavo, circulava bastante entre os logradouros da cidade, das ilhas e da área rural. Ele celebrou, assim, moças de boa família em termos recatados e circunspetos, visitou freiras menos castas e importunou com suas atenções mulatas, mamelucas e negras, escravas ou alforriadas; isto é, as serviçais asseadas das casas que o acolhiam. Algumas moças brancas e pobres, que sobreviviam mantidas por amantes, também desfrutaram ocasionalmente de sua companhia.

Gregório de Matos, como seus conterrâneos, se exercitou nos vários matizes da arte de cortejar, mas brilhou sobretudo na arte de compor poemas eróticos engenhosos que referiam amor e sexo, conquistas e traições, temas correntes nas conversas dos homens quando se reuniam nas varandas das casas. A esposa Maria de Povos e outras mulheres de todas as condições sociais, afiguraram-se para ele objetos de desejos e de inspiração poética. O poeta, pois, galanteou respeitosamente moças de boa família, formulando para celebrá-las elogios marcados pelo hermetismo ornamental de Góngora, poeta das Soledades. Ele abusou nesse empreendimento de clichês elegantes e de alusões eruditas à Bíblia ou à Antiguidade grega ou latina. Metáforas mencionando pedras preciosas, metais valiosos, pérolas, aves de plumagem 
colorida ou flores fluíam então de sua pena. O nome dessas jovens costumava ser substituído por algum pseudônimo emprestado ao universo bucólico de uma inspiração poética antiga, deixando pouco lugar para alusões aos hábitos alimentares praticados na colônia.

Em compensação, nos poemas líricos eróticos ele aderia plenamente a malemolência dos costumes incentivando, além do gosto pelas iguarias, o gosto por outros tipos de prazeres da carne. A luxúria na colônia fazia parte do cardápio cotidiano, resultando numa ampliação do volume dos mestiços; fato que não abolia as diferenças de status social entre mazombos e escravas negras, mamelucas ou mulatas, escravas alforriadas e suas descendentes livres. Não surpreende, portanto, encontrar nos poemas de Matos muitas alusões a hóspedes de passagem e agregados das casas grandes competindo pela atenção das jovens, nas noites que não eram consagradas à fabricação do açúcar.

Segundo indicavam os poemas de Matos, nas vilas do Recôncavo ou nos engenhos, tais amores se abrigavam em lugares apropriados a encontros furtivos. Geralmente ocorriam à noite, nas capoeiras ${ }^{364}$, nos pastos, nas praias, nas ladeiras ${ }^{365}$, nos bananais ${ }^{366}$ ou até se recostando contra alguma torre ${ }^{367}$. Se escondiam, por vezes, nas casas de purgar o açúcar ou nas casas das caldeiras $^{368}$

Os poemas amorosos destinados a cortejar moças que não se recusavam aos amores passageiros e às uniões livres, contrastavam com aqueles dedicados às moças de família.

\footnotetext{
364 MATOS, G. Op. Cit., Vol. VI, p. 1507.

365 MATOS, G. Op. Cit., Vol. VI, p. 1318.

366 MATOS, G. Op. Cit., Vol. VI, p. 1475.

367 MATOS, G. Op. Cit., Vol. II, p. 379.

368 MATOS, G. Op. Cit., Vol. VI, p. 1464.
}

MOTT, Luiz. "In vino veritas: vinho e aguardente no cotidiano dos sodomitas luso brasileiros à época da Inquisição", in ي́lcool e drogas na História do Brasil. VENÂNCIO, Renato Pinto e CARNEIRO, Henrique, São Paulo/Belo Horizonte, PUC. Minas/Alameda, 2005. p. 59.

O autor relatou que, em 1693, Francisco Rodrigues, mestiço cativo de Antônio de Moura Rolim, morador da Cajaíba, assediou diversos escravos e forros, chegando a levar um deles para a casa das caldeiras do engenho, onde "o solicitou para o nefando". 
Nos amores ancilares, a veia erótica do autor se revelava com malícia em alusões explícitas a ingredientes comestíveis apresentadas às musas pouco ariscas. Matos não relutava em revelar o nome ou a alcunha das jovens. Ao cortejar Cipriana, por exemplo, conhecida como a Supupema, Matos, com leve ponta de ironia, declarou à moça tratada de "Crioula da minha vida":

"Claro está, que não sou negro,/que a sê-lo tu me buscaras;/nunca meu pai me fizera/branco de cagucho, e cara./Mas não deixas de querer-me,/porque sou branco de casta,/que se me tens cativado,/sou teu negro e teu canalha"369.

À Teresa, guapa mulata e à mestiça Mariquita, Matos versejou elogiando:

"porque Brancas, e Mulatas,/Mestiças, Cabras, e Angolas/são azeviche em parolas,/ e as duas são duas pratas" 370 .

Antes de conquistar alguma jovem, os versos que o Doutor Matos lhe dedicava associavam citações eruditas a referências que envolviam alimentos ou bebidas:

"Bebi e não matei a sêde,/porque no inferno de amar/fui Tântalo, cuja pena,/o beber acende mais" ${ }^{371}$.

"Se comestes por regalo,/Brites, o caju vermelho,/tomastes mui mau conselho,/e temo, que heis de amargá-lo:/no pomo há de ter abalo/tôda a vossa geração,/pois vós sem comparação/gulosa à Eva excedestes, /quando só por só comestes,/sem dar parte a vosso Adão"372.

369 MATOS, G. Op. Cit., Vol. VI, p. 1327.

370 MATOS, G. Op. Cit., Vol. VI, pp. 1290 e 1291.

371 MATOS, G. Op. Cit., Vol. IV, p. 926.

MATOS, G. Op. Cit., Vol. IV, p. 935. 
Convites a moças disponíveis pressupunham remuneração indispensável e presentes. Matos aconselhava aos colonos:

"introduza-se ao burlesco/nas casas onde se achar./Que há Donzela de belisco,/que aos punhos se gastará,/trate-lhes um galanteio,/e um frete, que é principal"373.

Noutro poema ele explicava, estendendo ao sexo a noção dos gostos do paladar ${ }^{374}$ :

"são tais as misérias nossas, /que havemos mister as moças/para regalo da pica"375.

Fundamental, a seu ver, era dispor da complacência de alguma cachopa:

"Como tenho já segura/a carne no garavato,/me rio, que o sítio ingrato/tenha, ou não fartura:/porque em sendo conjuntura,/que é lá pela noite alta,/nunca a mulatinha falta,/e dêem-me outra parda forralem que tudo isto concorra,/geme gosta, atura e salta" 376 .

Mas, a medida que a idade foi chegando começaram a ocorrer recusas. Matos obteve menos sucesso junto às mulheres. Sua reputação de língua ferina, o fato de estar casado e ainda seus parcos recursos pecuniários não lhe facilitavam a situação. Por vezes, ele se queixava: "Outras putinhas malsins/[....] não me dão descarga aos rins" ${ }^{\prime 377}$.

373 MATOS, G. Op. Cit., Vol. VII, p. 1594.

374 Merece reparo o termo regalo, designando um gosto saboreado, pertencer ao vocabulário da alimentação.

375 MATOS, G. Op. Cit., Vol. VI, p. 1299.

376 MATOS, G. Op. Cit., Vol. VI, p. 1457.

377 MATOS, G. Op. Cit., Vol. VI, p. 1457. 
Se a exclusividade não fosse possível, ele afirmava se contentar com menos. Ora dizia se contentar do sobejo do gozo de dois mancebos ${ }^{378}$, ora cortejava:

"Parti o bolo, Luzia,/que assim mesmo me acomoda,/não deis a fatia tôda,/daí-me parte da fatia:/quem pede, como eu pedia/pede tudo, o que lhe importa,/e aceita o que se lhe corta,/e quem dá com manha ou arte,/seus dados sempre reparte,/se tem mais pobres à porta. // [....] com pouco se alegra o pobre:/não deis cousa, que me sobre,/dai- me sequer um bocado" ${ }^{379}$.

A luxúria foi pecado tão corriqueiro no Brasil colonial, que nem Matos nem os outros colonos pareciam levá-la muito a sério. Sérias, na sociedade mazomba, eram mais facilmente as questões que giravam em torno de problemas de honra e de vaidade:

"tudo causa a lei da guerra,/o sossêgo se desterra,/perde-se o jantar e a ceia:/e quando a guerra se ateia,/segue-se a fome e a peste"380.

Ao "agradar-se dos donaires de huma cabrinha do padre Simão Ferreyra"381, o convite endereçado à Córdula se fez explícito:

"Valha-te Deus por cabrinha,/valha-te Deus por Mulata,/e valha-me Deus a mim,/ que me meto em guardar cabras./Quando te apolego as tetas/como uns marmelos inchadas/me dão tentações, porque/cuido que são marmeladas" ${ }^{\prime 382}$.

378 MATOS, G. Op. Cit., Vol. VI, p. 1488.

379 MATOS, G. Op. Cit., Vol. VI, p. 1496.

380 MATOS, G. Op. Cit., Vol. VI, p. 1402.

381 Segundo a definição do Diccionário da língua portugueza de Moraes: "Donaires: graça, garbo". 
Mas o doce cobiçado lhe foi recusado e Matos comentou:

"Se lhe fala um Branco em fretes/co'a donzelice o derrenga:/e depois que a muita arenga/a tem convencida já,/lhe responde, que ela irá,/e indo, ela manda dizer, que para o padre beber/pisando está carimá”383.

No caso, a esquivança da moça foi aparentemente motivada pela recusa de um presente de roupas que pedia em troca dos préstimos, despertando fortes rancores. Bastava, pois, que alguma moça exagerasse nos pedidos de retribuição financeira, que se mostrasse infiel ou que negasse ao poeta o que ele desejava, para que ele se enfurecesse. Quando Matos se sentia extorquido por alguma jovem, o endereçamento cortês dos poemas compostos para celebrá-la mudava da segunda pessoa do singular para a terceira, e o autor passava a enfileirar acusações e calúnias para ridicularizá-la publicamente:

"Beleta é ôlha podrida,/de que Deus livre meu odre,/se é ardida como é podre,/não vi puta mais ardida" 384 .

"E não sou tão insensato,/que inda que faminto ando,/vos vá o pato pagando,/se sei que outro coma o pato"385.

A ingratidão de uma jovem infiel foi assinalada, por exemplo, nos termos de uma comparação simbólica entre ingredientes comestíveis sublinhando diferenças de apreço entre a carne do xaréu, peixe gordo e apreciado, e aquela do bagre, peixe de menor preço que se destinava em geral à mesa dos menos abastados:

\footnotetext{
383 MATOS, G. Op. Cit., Vol. VI, p. 1471.

384 MATOS, G. Op. Cit., Vol. VI, p. 1439.

385 MATOS, G. Op. Cit., Vol. VI, p. 1493.
} 
“Vós por um Dom Tabaréu/deixais um Doutor em Leis,/eu deixo, como sabeis um bagre por um xaréu:" 386.

Contudo, a idade madura não o ajudava em tais circunstâncias e Matos se via forçado a constatar:

"Geralmente é mui custoso/o conchego das Mulatas,/que se foram mais baratas, não há mais Flandes" ${ }^{387}$.

Matos, todavia, não se deixava resvalar para os temas poéticos do desencanto ou da crueldade feminina, tão ao gosto de Quevedo. Mais pragmático que seu modelo poético espanhol, quando traído, ele partia para novas aventuras. Confirmava, dessa forma, quão procedente podia ser o comentário de Stuart Schwartz ${ }^{388}$ referente à importância do sexo e da religião no estilo de vida soteropolitano. Tanto na capital, quanto nas propriedades rurais do Recôncavo, as aventuras amorosas constituíam os passatempos favoritos. Algo que não surpreende ao se considerar que a população abastada possuía casas na cidade, mas preferia viver em ambiente rural, o que resultava numa continuidade essencial entre o que se pensava e praticava na cidade ou no campo. Sexo e amores foram assuntos publicamente apregoados na colônia, dando lugar a convites tão explícitos, que ao receber uma iguaria preparada por Susana, a amásia do feitor Azevedo, Matos se sentiu obrigado a retribuir-lhe a gentileza cortejando-a engenhosamente por meio de um poema. O autor brincava:

"Susana: o que me quereis,/que me trazeis tão mimoso,/não sou homem tão baboso,/ que com pouco me enganeis:/que o vosso peixe me deis,/convém que dar-mo vos

\footnotetext{
386 MATOS, G. Op. Cit., Vol. VI, p. 1440.

387 MATOS, G. Op. Cit., Vol. VII, p. 1589.

388 SCHWARTZ, Stuart. Burocracia e sociedade no Brasil colonial, Op. cit., p. 194.
} 
deixe,/mas é razão que me queixe,/de dar-mo, por que eu vos dê,/que não sou eu homem, que/a carne vos dê por peixe"389.

O princípio da reciprocidade encontrava, no caso, expressão bem formulada. Configuravamse no texto poético a impossibilidade simultânea de se recusar o presente oferecido e a obrigação de retribuir a dádiva. Porém, era o próprio poema com suas alusões picantes que constituía a retribuição necessária do autor à gentileza da oferta.

As metáforas referindo alimentos apontavam para a presença de uma forte proporção de mulheres e de homens promíscuos na sociedade colonial, sem que fosse possível inferir, em função desses dados, qual a proporção existente de escravas casadas ou as especificidades de sua vida familiar.

Dois jesuítas contemporâneos de Matos, Antonil e Benci, analisaram ambos a questão do casamento dos escravos nas propriedades do Recôncavo ${ }^{390}$. Discutindo a questão da administração da mão-de-obra cativa, ambos assinalavam a relutância de muitos proprietários em permitir as uniões legais de seus escravos já que o sacramento do matrimônio representava um empecilho quando se tratava de apartar os cônjuges. Pelo que se depreende dos textos, não havia unanimidade de opinião. Da mesma forma, parecia não existir consenso formado dos senhores de engenho em relação ao sistema de alimentação que convinha prover aos escravos: se valia mais a pena lhes proporcionar um pedaço de terra e a liberdade de trabalharem para si mesmos um dia por semana no cultivo de suas próprias hortas, ou o fornecimento de rações.

No que tange à expansão do número dos cativos, Katia M. de Queirós Mattoso ${ }^{391}$ assinalou a ocorrência de fenômenos interessantes. Desde os primórdios do tráfico negreiro, os navios trouxeram da África um número muito maior de homens que de mulheres, já que o interesse dos senhores de engenho concentrava-se principalmente na obtenção de grandes contingentes

389 MATOS, G. Op. Cit., Vol. VI, p. 1533.

$390 \quad$ ANTONIL. Op. Cit., pp. 159 a 161.

BENCI, Jorge. Op. Cit., pp. 102 a 105. 
de trabalhadores musculosos. A autora sublinhou, por conseguinte, a escassez proporcional das mulheres e a dependência subseqüente da colônia em relação ao tráfico.

De modo geral, os procedimentos adotados na época pareciam variar bastante de um engenho para outro, mas a crer Benci e Antonil, é possível afirmar que a condição de escravo resultava em circunstâncias de vida bastante sofridas.

Antônio Vieira, pregando sobre o tema Maria de qua natus est Jesus, qui vocatur Christus, em seu primeiro sermão proferido ${ }^{392}$, exortou os cativos a não se rebelarem contra o destino, enfatizando a oportunidade que o cativeiro lhes propiciava de acederem pela via dos sofrimentos padecidos ao paraíso que seus pais desconheciam. O padre afirmava, pois, que os escravos deviam ser considerados tão filhos de Maria quanto o Cristo. Tornava-se explícita nesse sermão uma visão local da escravidão, considerada como um mal necessário conduzindo ao bem:

\begin{abstract}
"Em um Engenho sois imitadores de Cristo crucificado: Imitatoribus Christi crucifixi, porque padeceis em um modo muito semelhante o que o mesmo Senhor padeceu na sua Cruz, e em toda a sua Paixão. A sua Cruz foi composta de dois madeiros, e a vossa em um Engenho é de três. Também ali não faltaram as canas, porque duas vezes entraram na Paixão: uma vez servindo para o cetro de escárnio, e outra vez para a esponja em que lhe deram o fel. A Paixão de Cristo parte foi de noite sem dormir, parte foi de dia sem descansar, e tais são as vossas noites e os vossos dias. Cristo despido, e vós despidos: Cristo sem comer, e vós famintos: Cristo em tudo maltratado, e vós maltratados em tudo" ${ }^{993}$.
\end{abstract}

Mas as escravas e as ex-escravas não constituíam o único alvo das atenções do poeta. Matos costumava também visitar o convento do Desterro, onde se encontravam moças enclausuradas, obrigadas ao sacrifício da juventude por suas famílias para não empobrecerem o herdeiro da 392 Pregação ocorrida num engenho, em 1633, por ocasião do dia de São João Evangelista.

393 PÉCORA Alcir (org.). Antônio Vieira Sermões. Tomo I, "Sermam XIV. Na Bahia, A Irmandade dos Pretos de hum Engenho em dia de São João Evangelista, Anno de 1633”, São Paulo, Hedra, 2001. p. 651. 
família com pagamentos de dotes. As jovens clarissas não primavam, por conseguinte, pela vocação monástica. O autor se condoía de sua situação:

"Que o pai pela descendência/do filho ou de seu aumento/meta a filha num convento/ freira da conveniência ... Boa história" ${ }^{394}$.

Às freiras, ele endereçou convites poéticos, ora ternos e elegantes, ora picantes e chulos. Tais poemas, pertenciam ao gênero estabelecido dos amores freiráticos (mas insinuavam dúvidas a respeito do teor efetivo das relações mantidas entre "ralo, roda e grade" ${ }^{395}$ e o mundo exterior):

"Um doce, que alimpa a tosse,/cousa muito grande era,/e se eu não trocara, e pudera/a doçura pelo doce:/se quisera Amor, que eu fosse/tão digno, e tal me fizera,/que juntos vos merecera/ora o doce, a doçura ora,/maldita a minha alma fôra,/se tudo vós não comera" ${ }^{396}$.

As visitas do poeta e de outros homens a esse logradouro afiguravam-se menos religiosas que sociais e o autor satirizou a permanência de frades no recinto. As freiras efetivamente se ocupavam preparando doces providos à população. Por sua parte, o poeta atendia aos desejos das freiras endereçando-lhes versos ternos ou picantes. A uma delas ele agradeceu o sabor de ambrósias recebidas ${ }^{397}$, de uma outra - impedida afinal de enviar o quitute - quase saboreou um preparo de peixe vermelho ${ }^{398}$. Uma terceira, segundo afirmava o poeta, teria mandado a seu galante um cará simbólico em lugar de "pão por Deus": "A certa freyra que em dia de Todos os Santos mandou a seu amante graciosamente por pam por Deos hum cará" ${ }^{399}$.

\footnotetext{
394 MATOS, G. Op. Cit., Vol. II, p. 489.

395 MATOS, G. Op. Cit., Vol. IV, p. 842.

396 MATOS, G. Op. Cit., Vol. IV, p. 868.

397 MATOS, G. Op. Cit., Vol. IV, p. 869.

398 MATOS, G. Op. Cit., Vol. IV, p. 872 a 874.

399 MATOS, G. Op. Cit., Vol. IV, p. 875.
} 
A proximidade entre sexo e religião verificava-se na estreita imbricação entre referências a sexo e à comida, ambos necessidades vitais e simbólicas, fundamentando trocas de guloseimas e de cortesias.

Encontravam-se ainda poemas inesperados entre os códices apógrafos. Certa didascália referenciava: "Regra de bem viver, que a persuasões de alguns amigos deo a huns noyvos, que se casavam" ${ }^{400}$. Causam espécie, no caso, o estreito espaço social permitido às mulheres e a recomendação específica do poeta para que a jovem evitasse tratar seu marido de maneira infantil.

Os improváveis bons conselhos que Matos tratou de dar à noiva incluíram recomendações sobre o teor das tarefas que convinham a uma moça prendada:

“Irá mui poucas vêzes à janela,/Mas as mais que puder irá a panela:/Ponha-se na almofada até o jantar,/E tanto há de coser como de assar/Faça-lhe um bocadinho mui caseiro/Porém podendo ser coma primeiro,/E ainda que o veja pequenino,/Não lhe dê de comer como a menino".

\section{Os governadores: a administração das farinhas, carnes e peixes}

Se, no início da conquista territorial, os filhos mamelucos de colonizadores lusos aliados dos grandes chefes indígenas encontravam motivos certeiros de orgulho em ascendências nativas ilustres, ao término do período seiscentista as populações Tupi tinham deixado há algumas décadas de ameaçar a posse da faixa costeira do Brasil. A maioria dos colonos desembarcados em levas posteriores de imigração já não mantinha mais contatos senão com remanescentes escravizados das antigas nações tupi. Cem anos antes do retorno de Matos à terra natal, colonos que contavam entre seus ascendentes os principais nativos aliados dos portugueses, não imputavam demérito à circunstância. Como bem enfatizou Laima Mesgravis ${ }^{401}$, formalmente, 400 MATOS, G. Op. Cit., Vol. V, pp. 1089 e 1090.

401 MESGRAVIS, Laima. Os aspectos estamentais da estrutura social do Brasil colônia, in Estudos econômicos, n 13, pp. 799 a 811, 1983. 
segundo a lei da colônia portuguesa, origens nativas não implicavam em pecha de sangue impuro. Posteriormente foram os índios ditos tapuias do sertão que obstaram o avanço do processo de colonização do sertão. Segundo Pedro Puntoni:

"Os ataques constantes dos tapuias do sertão às fazendas, plantações e povoados do Recôncavo Baiano resultariam em uma série de expedições punitivas que moldariam a dinâmica futura da guerra no sertão. Nesse sentido, entre os anos de 1651 e 1679, as guerras contra os tapuias que 'assolavam'o Recôncavo Baiano serviram de campo de provas para novas estratégias que determinariam a forma do extermínio que seria praticado nos séculos vindouros. A partir de 1687, os levantes dos tapuias ganharam radicalidade, em particular no sertão norte do então Estado do Brasil, isto é Pernambuco e capitanias anexas, principalmente no Rio grande e Ceará" ${ }^{402}$.

Descendentes do português Diogo Álvares Corrêa ${ }^{403}$, o Caramuru, e de sua mulher Paraguaçu batizada (como Catarina ou como Luiza), pessoas que desempenharam um papel fundamental na instalação dos lusos às margens do Recôncavo e mereceram ser enobrecidas por relevantes serviços prestados ao rei, não tiveram seu status social reconhecido pelo poeta. Andavam longe os tempos em que os serviços relevantes de mamelucos, prestados à coroa na conquista da terra resultavam em reconhecimento de nobreza, doações de sesmarias e respeito. No último quartel do século XVII, o escárnio de Matos perseguia até descendentes do Caramuru, alcunhados pelo poeta como "Adãos de massapé" e apresentados nos versos como antropófagos sanguinários de gosto duvidoso em suas escolhas alimentares:

402 PUNTONI, Pedro. A guerra dos bárbaros: povos indígenas e a colonização do sertão nordeste do Brasil, 1650 - 1720. São Paulo, FAPESP/Hucitec/EDUSP, 2000. p. 44.

403 PINHO, Wanderley. História social da Cidade do Salvador. Prefeitura Municipal do Salvador, 1968.

O autor contestou o acréscimo do sobrenome Corrêa ao nome de Diogo Álvares pioneiro da colonização, segundo o estudioso, desprovido de fundamento documental. Cf. p.51. 
"Sem mais Leis que as do gôsto quando erra,/de Paiaiá virou-se em Abaeté. // Não sei, onde acabou, ou em que guerra,/Só sei, que deste Adão de Massapé,/Procedem os fidalgos desta terra"404.

Paiaiá, denominação de um dos grupos tupi da região, e Cobé, ao que parece um nome próprio, tornaram-se epítetos genéricos injuriosos. Em prol da sátira, Gregório de Matos tomou amplas liberdades. Tornaram-se conhecidos os versos dedicados "Aos principais da Bahia chamados Caramurus":

“Há cousa como ver um Paiaiá/Mui prezado de ser Caramuru,/Descendente de sangue de Tatu,/Cujo torpe idioma é cobé pá. // A linha feminina é carimá/Moqueca, pititinga, caruru/Mingau de puba, e vinho de caju/Pisado num pilão de Piraguá. // A masculina é um Aricobé/Cuja filha Cobé um branco Pai/Dormiu no promontório de Passé // O Branco era um marau, que veio aqui,/ela era uma índia de Marél Cobé pá, Aricobé, Cobé Pai ${ }^{{ }^{4} 05}$.

Entre os governadores nomeados para o cargo depois da volta de Gregório de Matos ao Brasil, vale observar que o poeta somente satirizou Antônio de Sousa de Meneses (1682 1684) e Antônio Luis Gonçalves da Câmara Coutinho ${ }^{406}$ (1690 - 1694). Equivocaram-se os estudiosos que viram nas queixas de Matos contra algumas autoridades coloniais um repúdio consciente e generalizado ao domínio da metrópole sobre a colônia ${ }^{407}$. O poeta celebrou em termos laudatórios as ações de outro governador, o marquês das Minas e de seu filho, o conde do Prado. O governador Antônio Luiz de Souza Telles de Menezes (1684 - 1687) só mereceu

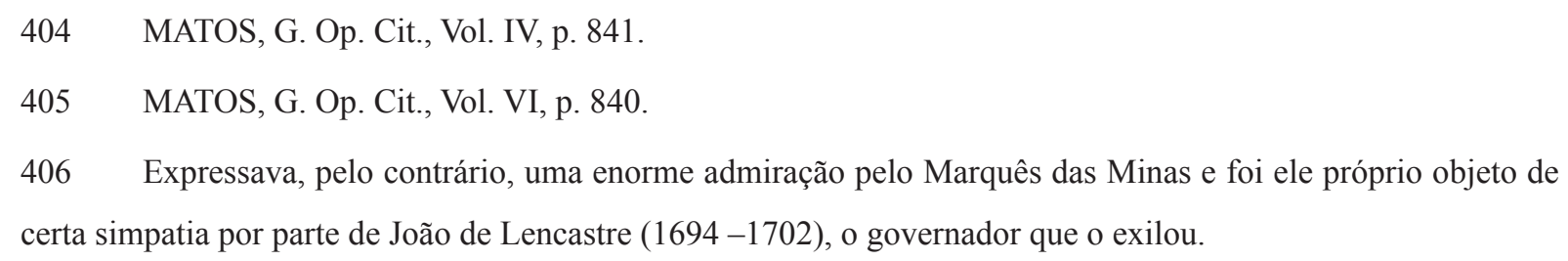
certa simpatia por parte de João de Lencastre (1694 -1702), o governador que o exilou.

407 Cf. capítulo anterior. 
elogios elegantes de Matos e dos soteropolitanos em geral. Constavam nas cartas dos vereadores soteropolitanos enviadas ao rei, relatos da penúria em alimentos que grassou na capitania durante o mandato do marquês e as marcas extremadas de sua dedicação ao cargo. Três anos de seca e uma epidemia de bicha (febre amarela mortífera) tinham resultado na morte de muitos escravos e colonos. Vendo lavradores empobrecidos obrigados a venderem os últimos escravos que possuíam para pagar taxas devidas ao fisco, o governador deu mostras de generosidade e desprendimento pessoal. Numa carta datada de quinze de julho de 1686, o escrivão da Câmara, João de Couros Carneiro, relatava a situação trágica e enfatizava:

“e ninguém nisto pode informar | a Vossa Magestade com mais | verdade que o dito Márquez | que desde o princípio de seu Go-| verno comessou asoccorrer a | muitas emuitas pobres epagou | por elles não somente as fin | tas mas outros Empenhos, $e$ | neste grande conflito descobrio | os quilates desua generozi- | da-de, e grandeza assestindo $\mid$ publicamente atodos os ne-| cessitados, edoentes com mão $\mid$ mui liberal edispeza desua $\mid$ Fazenda"408.

A mesma carta assinalava também que, em razão da escassez dos alimentos na cidade, o marquês provera mantimentos à frota a suas próprias custas, impedindo que ela invernasse em Salvador e sobrecarregasse a capital com tripulações de bocas famintas.

O primeiro dos dois governadores criticados, Antônio de Souza de Meneses, um velho militar pouco diplomático, apelidado o Braço de Prata por ter perdido o braço durante a guerra contra os Holandeses, se deixou enredar em disputas entre facções de colonos, e parece ter sido bastante inábil em seu afã de enriquecimento no cargo. Atraiu a hostilidade de muitos colonos influentes, dividindo em duas facções rivais a sociedade soteropolitana, sendo afinal chamado de volta 
a Portugal, antes do término de seu mandato ${ }^{409}$. Como parece que o Caramuru figurava entre seus ascendentes, foi alvo de zombaria certeira por parte do poeta. Matos, desdenhosamente, imputou-lhe o parentesco como tara de sangue. Acusado de ser um Adão de Massapé e de praticar hábitos alimentares indígenas pouco ilustrados, ele mereceu descrições metonímicas extravagantes de partes de seu corpo. Matos o acusou também de manter uma casa de jogos no palácio a fim de depenar homens ricos de pouca expressão social:

"Não reputeis por favor,/nem tomeis por maravilha/vê-lo jogar a espadilha"10/co Marquês, co grão Senhor:/porque como é perdedor,/e mofino adredemente,/e faz um sangue excelente/a qualquer dos ganhadores,/qualquer daqueles Senhores/por fidalgo igual o adora./Entendeis-me agora?"411.

Outro dirigente da colônia, o governador Antônio Luis da Câmara Coutinho, que exerceu mandato entre 1690 e 1694, também provocou a ira do poeta, por se recusar a apoiá-lo numa questão urgente. Ele não costumava convidar Matos a freqüentar o palácio e tampouco se prestou a solicitar ao rei uma mercê ordinária, à qual o poeta acreditava fazer jus em razão dos serviços relevantes prestados à coroa portuguesa. O descaso com o que o governador desconsiderou o pedido repercutiu profundamente na mente do poeta que tinha mulher, filhos e poucas rendas, sofrendo não somente o revés da indiferença perante suas reivindicações, mas ainda a humilhação de viver com recursos escassos. Por esse motivo, retomando um tema experimentado contra o Braço de Prata, Matos acusou Câmara Coutinho de descender em quarto grau de uma tapuia que "manducava de cuia" ${ }^{\prime 12}$.

409 VAINFAS, Ronaldo. Dicionário do Brasil colonial (1500 - 1808). Rio de Janeiro, Objetiva. 2000. pp. 49 e 50 .

410 Jogo de cartas.

411 MATOS, G. Op. Cit., Vol. II, pp. 473 e 474.

412 MATOS, G. Op. Cit., Vol. II, p. 198. 
Ambos os governadores da colônia insultados nos versos, por meio de referências à dieta alimentar desprestigiada de seus supostos ascendentes, foram acusados de terem sangue mameluco nas veias, justamente numa época em que o Brasil, parte do Império luso, começou a receber, governadores de nobreza cada vez mais evidente, segundo assinalaram Mafalda Soares da Cunha e Nuno Gonçalo F. Monteiro $^{413}$. A qualidade inata de limpeza atribuída ao sangue de um indivíduo luso constituía então um fator cultural relevante de prestígio social, tão importante quanto a manutenção da higidez das substâncias corporais assegurada através de consumos alimentares adequados. A acusação de falta de limpeza do sangue, que o poeta endereçou aos dois governadores, apresentava uma gravidade extrema, por manchar a honorabilidade desses homens.

De fato, após a Restauração Portuguesa em 1640 e o advento da monarquia de Bragança ao trono, num império encolhido pela perda de territórios asiáticos e africanos ${ }^{414}$, o acesso aos postos mais relevantes do império colonial foi reservado, cada vez mais, à elite da nobreza lusitana. Os governadores nomeados para dirigir as diferentes colônias do Império português passaram a pertencer à maior nobreza de sangue. Evitou-se a partir de então designar para exercer esses cargos administradores ligados por vínculos familiares aos membros influentes das comunidades administradas. Afastados dos principais postos de mando da gestão colonial em benefício dos fidalgos, os moradores lusos da colônia perderam, por conseguinte, parte de seu poder para influir sobre os destinos locais. Segundo os mesmos autores ${ }^{415}$, parte importante da remuneração dos governadores nomeados para reger os destinos da colônia não consistia em proventos recebidos no desempenho do cargo, mas nas mercês às quais esses homens faziam jus depois do término do mandato - recompensas que firmavam a posição social e as finanças de filhos segundos de grandes famílias nobres.

413 CUNHA, Mafalda Soares. \& MONTEIRO, Nuno Gonçalo F. “Governadores e capitães-mores do império atlântico português nos séculos XVII e XVIII", in Optima Pars, Elites Ibero-americanas do Antigo Regime, Lisboa, Estudos e investigações 36, 2005.

414 Durante o período da reunião das duas coroas, as hostilidades dos holandeses contra os reis espanhóis resultaram na perda de diversas colônias portuguesas.

415 CUNHA, Mafalda Soares \& MONTEIRO, Nuno Gonçalo F. Op. Cit.. 
Os governadores que pertenciam à alta nobreza metropolitana, e tinham sido nomeados para controlar os privilégios mazombos, foram paradoxalmente bem acolhidos. Sua designação parece ter sido vista pelos colonos como um sinal do apreço da metrópole em relação à "nobreza da terra", reforçando o sentimento de pertencimento dos colonos em relação à metrópole e exacerbando as exigências de pureza de sangue. Porém, como as autoridades coloniais nomeadas, nem sempre possuíam capitais para viver condignamente durante os mandatos quadrienais que os habilitariam a requerer e receber vantagens financeiras, o novo sistema instituído de nomeações representou, de certa forma, um convite aos abusos ${ }^{416}$.

As diferentes esferas do poder colonial possuíam em princípio atribuições distintas. Ao governador cabia a vigilância para que os diferentes órgãos da burocracia desempenhassem suas tarefas a contento, aos desembargadores da Relação, exercer a Justiça, à alfândega cobrar taxas sobre os produtos exportados, aos soldados defender a cidade contra ataques de inimigos, aos vereadores e aos almotacés da Câmara, resolver problemas ordinários de gestão da vida colonial entre os quais figuravam o provimento alimentar da população. Quanto à Igreja, dirigida por um arcebispo, o papel que exercia ao enquadrar espiritualmente e praticamente a fé dos colonos, não deixava de estruturar o ritmo da vida social e cultural soteropolitano.

Segundo Schwartz muitas autoridades coloniais, cuja nomeação passou a ser ratificada em Lisboa pelo Conselho Ultramarino a partir de 1642, não deixavam de agir movidos por interesses pessoais, fator apenas mitigado pelo fato da administração civil tripartida subdividir a delegação dos poderes políticos, militares, fiscais ou judiciais:

“Cada ramo do governo mantinha sua própria organização, membros, regulamentos e padrões. Embora estes emanassem em todos os casos da Coroa, muitas vezes eram contraditórios [...] Deveres, funções e jurisdições que se sobrepunham dentro dos

\footnotetext{
416 CUNHA, Mafalda Soares. \& MONTEIRO, Nuno Gonçalo F. Op. Cit..
} 
vários ramos do governo e que eram vistos pela Coroa como controle e contrapeso tornaram-se fonte de constante atrito e desentendimento da colônia" ${ }^{417}$.

Stuart Schwartz constatou ainda:

"No império português do século XVII, ter um alto cargo colonial era o mesmo que entrar para uma aventura comercial e raro era o governador ou vice-rei que não se aproveitava de seu posto para obter lucros. Entretanto, até certo ponto as oportunidades eram limitadas pelo controle administrativo, pelas leis e pelos recursos pessoais" ${ }^{418}$.

Os desembargadores da Relação, encarregados da Justiça, também se deixavam levar por interesses escusos, abusando dos cargos em prol de vantagens pessoais. Segundo Matos não sofriam de fome: "Sobejar-lhe á na mesa vinho e pão"419.

Schwartz ${ }^{420}$, ao assinalar a venalidade e os desvios da lei e das normas burocráticas praticados pelos magistrados, sublinhou a preferência do Conselho Ultramarino por funcionários que não possuíam vínculos prévios com a população colonial. Observou, no entanto, como, uma vez estabelecidos na capital, não faltavam aos magistrados oportunidades para estabelecer vínculos locais de parentesco ou de compadrio.

Schwartz citou justamente os poemas de Matos para esmiuçar alguns tipos de condutas observadas, enfatizando as metáforas associadas aos jogos de cartas, mas as metáforas alimentares não faltaram nos poemas do autor. Permitiram-lhe vituperar a imoralidade das autoridades locais, enquanto ele aconselhava ironicamente à sociedade mazomba: "Furte, coma, beba, e tenha amiga,/Porque o nome d'El-Rei dá para tudo, /A todos que trazem El-Rei na barriga"421.

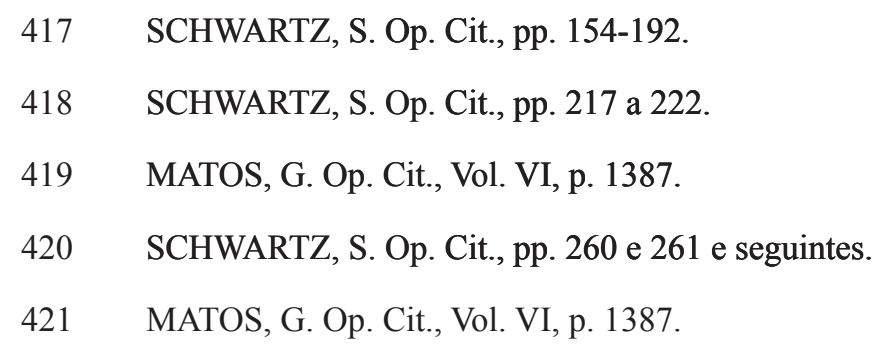


As injustiças recorrentes no âmbito da sociedade colonial marcavam presença nos versos. A metáfora da água unindo colonos desonestos se destacava:

"De Diques de água cercaram/esta nossa cidadela,/todos se molharam nela,/e todos tontos ficaram:/eu, a quem os céus livraram/desta água fonte de asnia,/fiquei são da fantesia/por meu mal, pois nestes tratos/entre tantos insensatos/por sisudo eu só perdia" ${ }^{\prime 22}$.

A prevaricação dos representantes do poder colonial enfurecia o poeta. Ele desqualificou em versos ásperos, associando ingredientes comestíveis e vinhos à cobiça desenfreada ou à vaidade para criticar soteropolitanos influentes que usavam seus cargos para obter vantagens pecuniárias. Matos concluía a diatribe por uma observação de impacto destinada a enfatizar o caráter geral da desonestidade: “Bebemos todos num copo". Nem mesmo a autoridade máxima da colônia escapou à sanha do autor.

Contra Câmara Coutinho foram utilizadas imprecações que não tinham sido aventadas no caso do Braço de Prata. O governador, afirmava o autor, apreciava ver enforcar gente. Foi também acusado insistentemente de praticar a sodomia, alegação acachapante para a autoridade máxima da colônia numa época de vigência inquisitorial. Preparos alimentares aproximando metaforicamente quartos de carne bovina, quartos de enforcados e perna do governador criaram imagens complexas de teor alimentar ${ }^{423}$. Outros preparos culinários também desmereceram ironicamente o governador: "A vós vaca sempiterna/cozida, assada e de molho,/Boi sempre, galinha nunca"'424.

No entanto, o principal argumento utilizado por Matos contra o governador residiu na negligência desse homem em relação à obrigação de bem "governar as farinhas". O abastecimento

\footnotetext{
422 MATOS, G. Op. Cit., Vol. II, p. 447.

423 MATOS, G. Op. Cit., Vol. I, p. 215.

424 MATOS, G. Op. Cit., Vol. I, p. 214.
} 
alimentar da população local, prejudicado por motivos escusos, figurou na arte poética de Gregório de Matos como fonte de opróbrio desmerecendo o governador. Efetivamente, o elenco das tarefas que o poeta julgava apropriadas à atuação de um governador colonial, transpareciam nos comentários irônicos formulados nos poemas:

"Ora vamos a farinha/foi pouca, cara e ruim:/mas vos não sois sol, nem chuval para a haver de produzir./Eu confesso, que houve fome,/governando vos aqui,/sois mofino, e por contágio/ficou mofino o Brasil /[....] Não vos mandou governar ? ElRei farinhas aqui,/as carnes, nem os pescados,/porém a fôrca isso sim"425.

Matos acrescentava:

"O certo é seres um caco,/um ladrão da mocidade,/por isso nesta cidade/corre um tempo tão velhaco:/farinha, açúcar, tabaco/no teu tempo não se alcança/e por tua intemperança/te culpa o Brasil inteiro,/porque sempre és o primeiro/movel de qualquer mudança"426.

Um governador, consciente de suas responsabilidades, podia impedir medidas administrativas ineptas ou corruptas, tais como a decisão da Câmara ${ }^{427}$ de prover à frota mantimentos já em falta na capital. A intervenção evitaria o desencadear

\footnotetext{
425 MATOS, G. Op. Cit., Vol. I, p. 198.

426 MATOS, G. Op. Cit., Vol. I, p. 160.

427 As elites locais do "Antigo Regime Colonial", "os homens bons", faziam jus à honra de ser eleitos para a Câmara Municipal. Não bastava ter riqueza para ocupar semelhante posto, era preciso ainda demonstrar limpeza de sangue e fidalguia, isto é, não se podia descender de mulatos ou de cristãos-novos, nem se ter exercido profissão manual. Até os colonos que desejavam estudar em alguma universidade de Portugal para se tornarem letrados também precisavam provar limpeza de sangue.
}

Cf. MESGRAVIS, L. Os aspectos estamentais da estrutura social do Brasil colônia, in Estudos econômicos, no 13, pp. 799 a 811, 1983. 
de uma crise de escassez dos alimentos destinados aos residentes locais. O poeta se indignava:

"a frota tudo abarrota/dentro nos escotilhões/a carne, o peixe, os feijões, /e se a Câmara olha, e ri,/porque anda farta até aqui,/é cousa que não me toca;/Ponto em boca // [...] mas tenho por mais inteiro /o conselho, que reparte/com igual mão, igual arte/por todos, jantar e ceia,/mas frota com a tripa cheia,/e povo com a pança oca!/Ponto em bôca. // A fome me tem já mudo,/que é muda a boca esfaimada;/mas se a frota não traz nada,/porque razão leva tudo?/[...] o lastro que traz de areia,/ por lastro de açúcar troca!/[...] Quem o açúcar lhe dá,/perde a caixa e paga o frete,/porque o ano não promete/mais negócio que perder/o frete, por se dever,/a caixa porque se choca..."${ }^{428}$

Matos reiterou o mesmo tema. Noutro poema, mencionava a "frota levando tudo a peso de engano", se queixando também da desvalorização do valor da moeda que resultava num aumento substancial do preço das mercadorias lusas ${ }^{429}$.

As dificuldades locais de abastecimento alimentar foram, portanto, consideradas por Gregório de Matos apenas como obras de indivíduos incapazes ou mal intencionados. As críticas desfechadas à condução da vida econômica colonial, por acerbas que fossem, não chegaram ou não se atreveram a afrontar a monarquia lusa. Os versos que ele compôs dificilmente poderiam ser atribuídos ao despertar precoce de um sentimento de brasilidade, fundamentando reivindicações de independência em relação a Portugal. Mesmo desfilando em seus versos as mazelas que afligiam a nata da sociedade rural, o autor, longe de se revoltar contra o princípio da autoridade metropolitana, fez questão de se reafirmar simultaneamente luso e mazombo. As imprecações do poeta contra as autoridades coloniais não configuravam, por conseguinte, uma ruptura de lealdade.

428 MATOS, G. Op. Cit., Vol. II, pp. 435 a 437.

429 MATOS, G. Op. Cit., Vol. II, p. 440. 
Haveria, portanto, uma impropriedade intrínseca no desejo de considerar a poesia de Gregório de Matos como expressão plena de nativismo brasileiro. Não estava em jogo a nacionalidade lusa da população, apenas discutia-se a maneira como as elites locais concebiam a sociedade escravocrata, produtora de mercadorias tropicais, implantada na capitania real a partir de 1549.

Referindo-se a Câmara Coutinho, chamado metaforicamente de tucano em razão do formato de seu nariz, o poeta comentava:

"Se fosse El-Rei informado,/de quem o Tucano era,/nunca à Bahia viera/governar um povo honrado:/mas foi El-Rei enganado,/e eu com o povo o paguei,/que é já costume, e já lei/dos reinos sem intervalos, /que pague o triste vassalo/os desacertos de um Rei." ${ }^{430}$.

Detalhe interessante, o sucessor do governador Câmara Coutinho, João de Lencastre, governador da colônia entre 1694 e 1702 (o próprio cunhado do antecessor), parecia experimentar grande apreço pelos talentos do poeta, a despeito de tê-lo exilado. Durante todo o tempo de seu mandato ele manifestou uma preocupação louvável, atestada nas Atas da Câmara Municipal, com a boa administração dos mantimentos básicos em uso na colônia: as farinhas, as carnes e os peixes.

Tais fundamentos imprescindíveis da dieta alimentar colonial, aliás, não incluíam ainda em larga escala os feijões, que posteriormente, em meados do século XVIII, seriam incorporados à alimentação e transformariam os dois binômios alimentares alternativos: a farinha com carne ou seu substituto dos dias magros, a farinha com peixe, num "tripé" fundamental da alimentação brasileira, ao incorporar corriqueiramente feijões e seu caldo de cocção à alimentação local, como constatou Paula Pinto e Silva ${ }^{431}$.

\footnotetext{
430 MATOS, G. Op. Cit., Vol. I, p. 202.

431 SILVA, Paula Pinto e. Farinha, feijão e carne-seca: um tripé culinário no Brasil colonial. São Paulo, SENAC, 2005. Capítulo: "Farinha, feijão e carne-seca, um tripé alimentar".
} 


\subsection{2 - As críticas endereçadas a diversas categorias sociais de colonos}

Privado do exercício de atividades à altura de sua formação religiosa e jurídica, sobrou a Matos o talento poético para reafirmar a superioridade honrosa de sua condição social. Na linha de uma defesa da moral colonial, como bem assinalou Hansen, o autor se valeu dos conselhos de composição poética de Horácio que desfrutavam de grande aceitação em meados dos séculos XVI e XVII.

O ut pictura poesis ${ }^{432}$, conselho de Horácio aos poetas ou aos leitores de poesias, sublinhava a semelhança existente entre poemas e representações pictóricas. Algumas obras necessitavam ser observadas prestando-se atenção aos detalhes, outras ganhavam em ser vistas de longe, ora era o efeito de surpresa que valorizava um conjunto de versos, ora, pelo contrário, o poema ganhava em ser relido, continuando sempre a agradar. A adequação que Horácio queria encontrar entre tipos de inspiração poética e estilos de linguagem foi um preceito que Matos também levou a sério. As metáforas alimentares enfatizando funções correntes do baixo corpo, digestão e vida sexual não se coadunavam com a expressão em estilo culto. As tragédias pediam versos dignos, enquanto, cabia às sátiras evitar quaisquer excessos de preciosismo.

A obscenidade, por sinal, cumpriu uma função didática precípua na arte de Matos. $\mathrm{O}$ poeta referiu procedimentos alimentares excessivos para se queixar de condutas que julgava indignas e de gestos pecaminosos da população colonial que deveriam ser reprimidos. Ao acoplar gestos alimentares e significados de cunho moral, o poeta deu voz a um leque amplo de conceitos e de preconceitos amplamente acolhidos pela sociedade colonial, como atestava a transcrição dos códices apógrafos. Falhas morais como a prática hipócrita e ostensiva do catolicismo por parte de cristãos novos, a promiscuidade das mulheres e a prática da sodomia foram amplamente criticados em seus versos (sendo que a sodomia pouco reverteu em metáforas culinárias). Suscitaram-lhe diatribes contra indivíduos que não respeitavam as

\footnotetext{
432 HANSEN, João Adolfo. Op. Cit., pp. 321 a 325.

HORACE. Oeuvres . Paris, Flammarion, 1967. p. 268. Cf. capítulo I da tese.
} 
normas instituídas ou contra categorias de indivíduos cujas condutas colocavam em perigo a organização social vigente.

Iravam-no com especial vigor os esforços de ascensão na hierarquia social, tanto de comerciantes portugueses recém-chegados, quanto da crescente população mestiça ou cristã nova, razoavelmente bem sucedida, cujas aspirações ameaçavam o status dos colonos, de sangue limpo, estabelecidos de longa data na capitania. Matos, que não aceitou passivamente desmandos de governadores, tampouco perdoou ascendências cristãs novas, mouras, negras, mulatas ou indígenas a membros conhecidos da sociedade soteropolitana. Taras de origem dos pais, como a prática bem sucedida de atividades manuais ou de vendas a varejo, que despertavam ambições de ascensão social nos filhos enriquecidos, foram ainda denunciadas raivosamente em seus poemas. $\mathrm{O}$ poeta ${ }^{433}$ expressou sua indignação frente às ambições de uma camada ascendente de população, desejosa de ocupar lugar de destaque na sociedade soteropolitana. Como afirmou Hansen:

\section{“A Hierarquia não é ambígua, no século XVII, sendo entendida como reflexo da lei natural ou como ditado de Deus revelado em uma Igreja visivel e corporificado nas leis positivas de um Estado absolutista, segundo seus teóricos"434.}

Com efeito, na sociedade constituída na capital do Brasil, como noutros lugares do Império colonial luso, a posição social de cada colono permanecia atrelada aos antecedentes familiares. Os versos de Matos comentaram seguidamente a condição social inferior dos imigrantes recémchegados, enriquecidos em tratos de comércio ou no exercício de atividades manuais. Gregório de Matos achava particularmente inconcebível o arrivismo de um "Lobato patifão, marido da confeiteira", artesã bem sucedida ${ }^{435}$. Percebia-se sua adesão profunda aos códigos de conduta

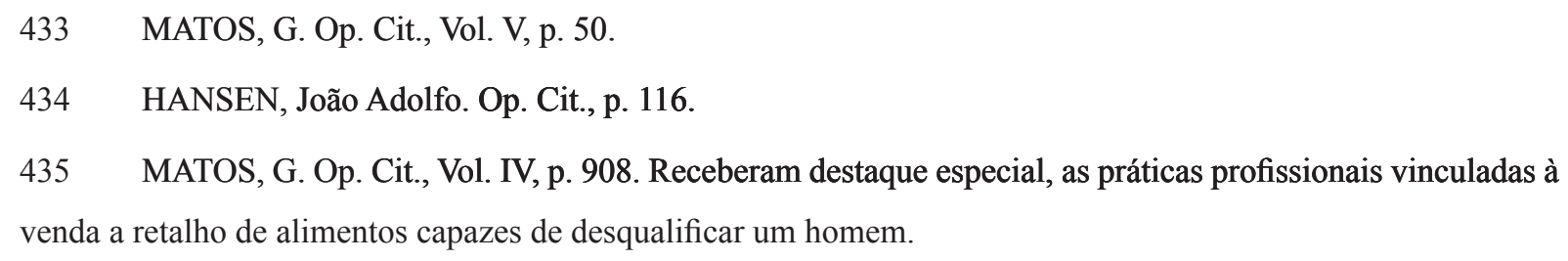


pautados pelo estilo perdulário dos grandes proprietários rurais entre os quais encontrava acolhida. Foi nos termos do código da nobreza da terra, que ele criticou imigrantes como o: "Fidalgo tendeiro que o pai sapateiro lhe fez o solar" $" 436$ e criou em seus versos narrativas pitorescas e cenários estapafúrdios para enfatizar a impropriedade daqueles que queriam desfrutar de uma importância social, que não condizia com seus antecedentes pessoais.

Destacaram-se, ainda, em suas composições, afirmações raivosas relacionadas à população negra ou mestiça, fossem os indivíduos vituperados nascidos livres, alforriados ou escravos. $\mathrm{O}$ contingente crescente dos mestiços alforriados começava a contar na vida produtiva da cidade, mas o poeta não se conformava com sua ascensão social:

“Gerou o maldito Cão/não só negros negregados,/mas como amaldiçoados,/sujeitos à escravidão:/ficou todo o canzarrão/sujeito a ser nosso servo/por maldito e por protervo;/ e o fôrro, que inchar se quer,/não pode deixar de ser/dos nossos cativos nervos"437.

Segundo Reis analisou, observando o crescimento urbano:

"Pode se dizer que, até meados do século XVII as atividades econômicas urbanas não foram suficientemente produtivas para adquirirem uma dinâmica própria. Até então apenas o comércio importador e exportador apresentava alguma vitalidade, mesmo assim concentrada em alguns pontos, mais especialmente Salvador. Foi somente depois dessa época, e por influência de condições exteriores, que ocorreram alterações estruturais, permitindo a consolidação da economia urbana e provocando o aparecimento de camadas sociais urbanas, com características urbanas: o comércio de maior vulto, os ofícios mecânicos e o pequeno comércio" ${ }^{\prime 438}$.

436 MATOS, G. Op. Cit., Vol. II, p. 466.

437 MATOS, G. Op. Cit., Vol. VI, p. 1321.

438 REIS Filho, Nestor Goulart. Evolução urbana do Brasil (1500-1720). São Paulo, Pioneira- EDUSP, 1968. 
Viu-se acima como o poeta chegou até a incluir no rol das famílias que não primavam pelo sangue limpo, os descendentes mamelucos do famoso Caramuru, Diogo Correia, que possuíam preeminência social e grandes propriedades no Recôncavo.

Boa parte das críticas, que a situação observada mereceu em sua escrita, não castigaram apenas infrações inconseqüentes às normas da colônia, devidas a indivíduos relapsos. De poema em poema, os mesmos argumentos reiterados delineavam os parâmetros de uma hierarquia fundamentada sobre uma noção peculiar de prestígio social, tal como a concebiam as elites, ciosas de sua condição de nobreza da terra. O autor apresentou, afinal, um retrato bastante coerente sobre o modo como os homens bons da sociedade soteropolitana concebiam o espaço social da colônia. Escritos de outros autores do período, consultados no decorrer da investigação, confirmaram o caráter de premissa tácita dessa crença coletiva na superioridade dos cristãos velhos sem pecha de ofícios manuais, vendas a varejo, ou contaminação por sangue infecto.

Mas, a própria necessidade imperiosa de se queixar, que Gregório de Matos experimentou entre 1683 e 1694, demonstrava também que o estilo de vida soteropolitano não se apresentava imune às reformulações. As lamúrias de Matos evidenciavam alterações nos parâmetros éticos e estéticos da organização social da colônia. De fato, após 1650, o rei e o Conselho Ultramarino ao favorecerem grandes comerciantes, que proporcionavam taxas de lucro interessantes às finanças reais, tornaram os produtores locais de açúcar, tabaco, couros e outros produtos exportados reféns dos novos monopólios desfrutados pela companhia comercial, tanto para a aquisição de insumos importados quanto para a venda de sua produção na Europa.

A ruptura nas práticas instituídas evidenciava simultaneamente a centralidade dos códigos modelando condutas e a presença desagregadora de tensões sociais. No rastro da crise econômica e política, os principais esteios da hierarquia colonial pareciam prestes a ruir. A defesa calorosa que o autor propôs dos códigos culturais tradicionais dos mazombos se inseria efetivamente na perspectiva analítica de Sidney Mintz. Permitia à pesquisa contrapor códigos e processos sociais. Contrastavam-se os valores culturais cujos parâmetros estruturavam a vida social e a maleabilidade das soluções adotadas frente a 
novos problemas, nos quais se espelhava o ajustamento dos colonos aos acontecimentos eventuais.

As encenações poéticas dramatizadas nos poemas resultaram, portanto, em elaborações de elencos exemplares, estereotipados, de categorias humanas transitando pelos versos com mazelas didaticamente expostas, expressas em termo de hábitos alimentares inadequados. As afirmações de Matos marcadas pelo parti-pris se distanciavam de qualquer descrição densa à maneira de Geertz ${ }^{439}$. Isto é, não permitiam confrontar o ponto de vista do poeta com as opiniões divergentes que outros atores da cena social teriam das mesmas situações. Pelo contrário, nos "encontros culturais" intolerantes, que os poemas retrataram, o ponto de vista dos adversários, primou sempre pela ausência de registro, a sátira do poeta, arrogante, desqualificando identidades alheias $^{440}$.

\section{Brancos, pardos e negros}

Matos expressou em termos virulentos seu ressentimento contra o contingente dos mulatos alforriados, categoria da população colonial que começava então a contar no panorama da vida profissional da capital e incluía eventualmente um certo número de homens bem sucedidos. Para referi-los o poeta forjou expressões desdenhosas assemelhando sua aparência física a ingredientes comestíveis ou sublinhando erros imperdoáveis de manejo alimentar cometidos. Por meio de analogias grotescas, o poeta assinalou o desplante de ambições que afrontavam os códigos sociais mazombos. A ouvir o poeta, defensor ardoroso dos valores das elites locais, a pretensão insensata dos falsos fidalgos à honorabilidade destoava dos parâmetros soteropolitanos de respeitabilidade. Nesse caso, como em outros tantos, o poeta recorreu a alimentos para desmerecer aqueles contra os quais ele não tinha nenhum poder de ação.

\footnotetext{
439 GEERTZ, Clifford. A interpretação das culturas. Rio de Janeiro, LTC, 1989.

440 Vale relembrar como ele foi sistematicamente preterido em sua solicitação de mercê ordinária.
} 
Sob o calor da escrita, a perna dos mestiços transformou-se em pernil tostado, imagem que Matos passou a utilizar insistentemente para caracterizar muitos tipos de fidalguias duvidosas. A idéia recorrente do pernil tostado tornou-se quase automática na escrita do autor, adquirindo valor emblemático:

“Tinha o Fidalgo tostado/(como ladrão tão astuto)/os bens em lugar enxuto, mas mal acondicionados" ${ }^{\prime 41}$.

Com toques de ironia, o poeta não deixou de sugerir ainda procedimentos alimentares, que somente ocorreriam a ignorantes, tais como o uso da aguardente da terra como remédio para flatos (era um álcool menos nobre, que as aguardentes e os vinhos do reino e muito pouco apropriado para corrigir flatos):

"Para o bêbado mestiço,/e fidalgo atravessado,/que tendo o pernil tostado,/cuida que é branco castiço:le de flatos enfermiço/se ataca de jeribita,/crendo, que os flatos lhe quita,/quando os vomita em retornos:/ seis cornos" ${ }^{442}$.

"a mulatinha se esfrega/c'um mestiço requeimado/destes de pernil tostado,/que a cunha do mesmo pau/em obras de bacalhau/fecha como cadeado"443.

Pernil tostado, sangue requeimado e vasos cozidos fizeram efetivamente parte de um conjunto de idéias mestres emblemáticas, ancoradas em sua arte poética:

\footnotetext{
441 MATOS, G. Op. Cit., Vol. II, p. 366.

442 MATOS, G. Op. Cit., Vol. II, p. 453.

443 MATOS, G. Op. Cit., Vol. II, p. 289.
} 
"Tomem de leite um cabaço,/lancem-lhe um golpe de tinta,/a brancura fica extinta,/todo o leite sujo, e baço:/assim sucede ao madraço,/que com as negras se tranca..." ${ }^{444}$.

Mas o fenômeno que incomodava sobremaneira o poeta era a falta de cerimônia com a qual os pícaros se permitiam agir:

“No Brasil a fidalguia/no bom sangue nunca está,/nem no bom procedimento,/pois logo em que pode estar?/Consiste em muito dinheiro,/ e consiste em o guardar,/cada um o guarde bem,/para ter que gastar mal" 445 .

“Compre tudo, e pague nada,/deva aqui, deva acolá/perca o pejo, e a vergonha,/e se casar, case mal./Com branca não, que é pobreza,/ trate de se mascavar;/vendo-se já mascavado, /arrime-se a um bom solar" ${ }^{446}$.

Até os esforços dos mestiços livres ou alforriados para sobreviver no espaço colonial afrontavam Matos:

"Alerta Pardos do trato/a quem a soberba emborca/Que pode ser hoje fôrca/O que foi ontem mulato..." ${ }^{447}$.

\footnotetext{
444 MATOS, G. Op. Cit., Vol. IV, p.1322.

445 MATOS, G. Op. Cit., Vol. VII, p. 1595.

446 MATOS, G. Op. Cit., Vol. VII, p. 1594.

447 MATOS, G. Op. Cit., Vol. II, p. 423.
} 
Pardos que aceitavam a condição de inferioridade atribuída e permaneciam no lugar que os mazombos lhes reservavam, não afrontavam $\operatorname{Matos}^{448}$. Ele até se permitiu defender duas mulatas injustiçadas, que certo Capitão, apelidado o Mangará, mandou encarcerar por causa de um papagaio furtado (uma delas sendo a amásia grávida do próprio reclamante). Mestiços subalternos ou mulatas bonitas, quando agregados em casas freqüentadas, faziam parte aceita da paisagem colonial, porém, suas aspirações à melhoria de condições de vida não eram programadas.

\section{Os cristãos novos}

A presença de cristãos novos na colônia desagradava profundamente ao poeta, mas não reverteu freqüentemente em metáforas de cunho alimentar. Para vituperar colonos que contavam ascendentes judeus, Gregório de Matos se valeu mais facilmente de insultos diretos que de jogos de linguagem elaborados. Uma exceção, entretanto, se destacou no conjunto da obra. $\mathrm{O}$ poeta desenvolveu um longo romance narrativo, composto de doze décimas (doze estrofes de dez versos), para contar o caso malcheiroso de uma mulher "que se borrou estando na igreja em quinta feira de Endoenças" ${ }^{\text {449 }}$. O episódio escatológico consistia obviamente numa ficção criada para desqualificar inimigos, cuja propriedade parecia estar localizada nos arredores de 448 SCHWARTZ, Stuart. “Gente da terra braziliense da nasção”. Pensando o Brasil: a construção de um povo". In MOTA, Carlos Guilherme (org.). Viagem incompleta (1500- 2000): formação: histórias, São Paulo, SENAC, 1999. pp. 113 e 114.

"Nos lugares onde uma economia vibrante, baseada no açúcar, na mineração e no cultivo de algodão se desenvolveu, e onde o fluxo constante de imigrantes europeus, a grande corrente de imigrantes forçados africanos, e o eventual desenvolvimento de instituições européias civis e religiosas, assim como a reprodução de hierarquias sociais baseadas em padrões europeus se consolidou, o papel desempenhado pelos mestiços tendia a permanecer cada vez mais reduzido. Na medida em que continuavam a ser reconhecidos como diferentes dos escravos africanos ou dos negros, havia, não obstante, uma tendência a outorgar um status comum a todas as pessoas de origem mista. Além disso, os mestiços passaram a ser, cada vez mais, separados e diferenciados da sociedade branca. Essa mudança constituiu um segundo estágio no processo da integração dos mestiços à sociedade colonial”. 
Santo Amaro da Purificação. O fato alimentar em torno do qual Matos centrou o poema girou em torno das seqüelas da refeição imprudente de uma mulher, cujo nome Matos manteve no anonimato. Ela teria comido um caldo de feijão isento de condimentação na ceia, antecedendo o dia de Endoenças, sendo acometida de forte diarréia no próprio recinto da igreja, durante a celebração da missa que rememorava a morte de Cristo.

Desqualificando por contigüidade o companheiro da mulher, acusada de ser cristã nova, Matos foi tecendo insinuações fundamentadas basicamente na ingestão de feijões, alimento substancioso e saboroso, que os colonos abastados pareciam evitar consumir. Acumulando aos poucos de estrofe em estrofe um acréscimo de detalhes obscenos, o poeta foi construindo um jogo de duplos sentidos desenvolvido simultaneamente no plano dos hábitos alimentares soteropolitanos e no plano das práticas judaizantes conhecidas. Apesar de manter no anonimato o nome daquela que teria cometido tão grande impropriedade, os indícios fornecidos nos versos ${ }^{450}$ deviam permitir aos moradores da região descobrir sem muita dificuldade a identidade do casal satirizado.

Nas quatro primeiras estrofes da poesia - de caráter introdutório - Matos comentou a situação pela voz de um narrador. Nas oito estrofes seguintes, o relato mudava de pessoa, dando lugar à uma narrativa, que simulava expor o caso nos próprios termos da vítima.

\section{"Diz que a mulher da buzeira/na Cachoeira nasceu,/e assim quando a dor lhe deu,/ vazou como cachoeira:".}

A buzeira referia um estrondo metafórico de armas de fogo, e a Cachoeira uma localidade do Recôncavo às margens do rio Paraguaçu, que não era situada nos férteis solos de massapé, onde a elite da colônia se dedicava a cultivar canas e fabricar pães de açúcar. Na Cachoeira, às margens do rio Paraguaçu, em terreno mais seco que nos massapés, os colonos viviam sobretudo

\footnotetext{
450 Foi possível elucidar parcialmente o significado das alusões contidas no poema, por estarem vinculadas
} aos parâmetros, que regiam o consumo dos feijões. 
de produzir e comercializar tabaco ou mantimentos, atividades que proporcionavam menor renda e prestígio social que a produção açucareira. A primeira estrofe continuava:

\section{"Mas a gente a quem mal cheira/a cebolinha cecém,/disse que era de Siquém,/e outra ali se confrangia/ou judia ou não judia/não me cheira a mulher bem".}

A alusão à localidade médio-oriental de Siquém, na Palestina, trazia à mente uma acusação de judaísmo, reforçada pela referência a vagens e feijões. As vagens e os feijões, com efeito, eram chamadas judias na Espanha, sendo que existia um consumo tradicional sefaradita aos sábados, dias consagrados ao repouso, de grãos-de-bico, de favas ou de feijões brancos cozidos de véspera com carnes, (hábito que os inquisidores vigiavam especificamente ${ }^{451}$ ). Judeus sefaraditas também costumavam comer feijões às quartas feiras, dia reservado à lavagem hebdomadária das roupas ${ }^{452}$. O termo espanhol judias designando um ingrediente presente na 451 Cf. PAPAVERO, Claude, dissertação de mestrado. p. 187.

"Sua presença clandestina no Brasil [dos feijões preparados com carne], sob domínio português (e sobretudo espanhol) a ser confirmada, tornaria improvável a mera derivação da feijoada a partir do cozido português, como desejava Câmara Cascudo. Nelson Omegna, por exemplo, documentou as conseqüencias do preparo: "O Tribunal do Santo Ofício caçava judeu até nas panelas. Sem conta os denunciados de heresia por 'comer em mesa baixa', por 'não comer galinha enforcada', por 'comer carne de galinha fria molhada no azeite', por 'não comer certos peixes' por 'lançar grãos em pés de bois', e outras baboseiras...”. (OMEGNA, Nelson. Diabolização dos judeus e presença dos sefardins no Brasil colonial. Rio de Janeiro, Record, 1969).

452 PAPAVERO, Claude. Dissertação de mestrado p. p. 188.

"Esther Benbassa, por exemplo, atraiu a atenção sobre o consumo judeu de feijões e favas no dia prescrito pela tradição para a lavagem da roupa, enfatizando o gosto pela iguaria kalduda:

"Alhad: dublo i guadro "Domingo: dobro e guardo

Lunes: lavo i espondjo Segunda: lavo e enxugo

Martes: no vo lo digo* Terça: não lhes digo *

Mierkoles: lavo i enchugo Quarta: lavo e enxáguo

Djugueves: despojo i alimpio Quinta: estendo e limpo

Viernes: guizo i frego Sexta: cozinho e lavo a louça

Chabat: jo me reposo, Sábado: descanso, marido asi bivach vos". marido tenha longa vida".

* abluções rituais femininas. 
alimentação dos camponeses europeus ${ }^{453}$ e na dieta de índios tupi, serviu para Gregório de Matos, anti-semita como seus conterrâneos, insinuar uma falta de limpeza do sangue da mulher criticada.

O estigma estereotipado dos cheiros desabonadores ocupou parte da segunda e da terceira estrofe, ampliando a argumentação. Matos, em seguida, estendeu a sátira à parentela da vítima:

"Estavam ao redor dela/umas mocinhas garridas/de todos nos conhecidas/por vista e por parentela:/".

Na seqüência, a função da purga se fez metafórica, associando o tema do sangue impuro à idéia da doença e sugerindo que não bastaria uma purga para limpar a moça:

“...disse uma camarada,/era bem mais evidente ser limpa e viver doente,/que suja e ficar purgada // [...]/um [sic] mulher que se alimpa,/e entre gente tão honrada/não lhe basta estar purgada,/para se crer, que está limpa".

$\mathrm{Na}$ quinta estrofe, o autor sublinhou ironicamente as desculpas esfarrapadas e as práticas alimentares absurdas que a mulher teria alegado ao considerar como iguaria leve o caldo de feijão comido e confessar sua ausência de condimentação ${ }^{454}$. Indiretamente, Matos insultava a mulher por sua ignorância crassa em relação aos saberes fundamentais da medicina humoral hipocrática ou galênica e às prescrições alimentares saudáveis.

Médicos e povo acreditavam então que a saúde ou a doença de um indivíduo dependia do estado de seus fluídos corporais: sangue, fleuma, bílis negra e bílis amarela. Sem humores não havia vida possível.

453 Cf. quadro do pintor italiano, Annibal Carracci, datado do século XVI, que representava um homem rústico comendo uma refeição de feijões.

454 Feijões eram considerados, espessos, quentes e indigestos, iguarias mais apropriadas a um jantar diurno que a uma ceia, enquanto que a condimentação teria prestado auxílio ao processo da digestão. 
O problema consistia em mantê-los em estado de equilíbrio nos corpos. Calor e frio, umidade ou secura podiam diluí-los ou espessá-los. Quando circulavam livremente, os corpos ficavam imunes e rechaçavam as doenças.

Sexo, idade, classe social e o temperamento inato de cada indivíduo: quente e úmido (sanguíneo), frio e úmido (fleumático), quente e seco (colérico), ou frio e seco (melancólico) eram fatores levados em conta. As condições climáticas do meio ambiente também mereciam reparo. Em condições normais uma alimentação correta bastava à manutenção da saúde. Desconfortos costumavam ser sanados com farto uso de purgantes, de clisteres, de vomitórios, de suadouros, de sangrias, de banhos, de exercícios físicos, de jejuns e de prescrições alimentares julgadas apropriadas.

Nas estrofes seguintes Matos esmiuçou o tema dos malefícios provocados por ceias de feijões, sobretudo quando procediam de propriedade sita às margens do rio Pericoara $^{455}$ :

"Que fôra, se hoje jantara!/ontem ceei parcamente;/não vi coisa mais corrente,/que feijões da Pericoara".

"Pó diabo há de dizer,/sem ser diabo, nem pó:/bebi o caldinho só,/e o feijão não quis comer/que lhe havia eu de fazer,/se o caldo era solutivo,/e no corpo semivivo /sem ter puxo nem repuxo,/antes de eu tomar o puxo/se saiu de seu motivo".

"Era água simples de cubos/a caca de meus calções,/com que entendam, que os feijões/não tinham dez réis de adubos:/não fedem pubas, nem pubos/o que fedia meu rabo".

455 Essa Pericoara não deve ser confundida com outra Periquara também existente na região. 
Diversas alegações mereciam reter a atenção: além das propriedades purgativas ${ }^{456}$ e da procedência dos feijões ${ }^{457}$, transformados em consumos impróprios ${ }^{458}$. Ressaltava-se o fato de serem comidos à noite, por ocasião da ceia, e não durante o jantar (no começo da tarde) e o preparo inconveniente sob forma de caldo pouco condimentado.

Aos hábitos alimentares absurdos, correspondia a inadequação dos gestos de uma pessoa néscia. Feijões indigestos comidos na ceia de uma quarta-feira, dia magro, o desarranjo intestinal subseqüente serviu cabalmente como demonstração de falta de juízo, transferindo para o âmbito do baixo-corporal outras insinuações de inferioridade e atestando a virulência do anti-semitismo que a sociedade soteropolitana acalentava.

Quanto a menção à mandioca puba - recurso metafórico reiterado em diversos poemas de Matos para desqualificar descendentes do Caramuru e de sua mulher nativa - apresentava nos versos analisados uma escala metafórica curiosa de falta de nobreza a partir dos cheiros: a disenteria provocada pelos feijões resultando, segundo Matos, num fedor mais desagradável, que aquele da fermentação de raízes de mandioca mergulhadas por alguns dias em água corrente.

456 Entre alguns Poemas comentados por Luiz Mott (poemas que teriam sido compostos por Gregório de Matos durante uma viagem à capitania de Sergipe), figurou também uma referência explícita às flatulências provocadas pela ingestão de feijões. MOTT, Luiz. "Sergipe del Rei: Três sonetos seiscentistas", in Estudos Humanísticos. Aracajú, ano 1, no. 1, 1990. pp. 123 - 130.

457 Durante duas semanas de pesquisa de campo no Recôncavo, em Junho de 2006, as localidades mencionadas por Gregório de Matos foram investigadas. A Pericoara, ou melhor dizendo o rio da Pericoara, seria um rio correndo nas redondezas de Santo Amaro da Purificação. Constaria uma cachoeira conhecida em seu curso. A família de Gregório de Matos, que possuiu terras na Patativa, nessa mesma região, devia conhecer bem a população residente e a topografia local. Não foi possível identificar quem foram os proprietários de terras situadas ali no final do século XVII. Talvez tenha algo a ver com uma referência de Wanderley Pinho a descendentes do Caramuru - em meados do século XVII pareciam possuir terras nas redondezas.

458 As propriedades purgativas atribuídas a esses feijões da Pericoara colocavam em pauta a questão de seu preparo com pouco tempero, e de seu consumo à noite, sob forma de caldo. Os valores atribuídos, em Salvador e no Recôncavo, aos ingredientes da dieta alimentar prolongavam a herança cultural recebida da metrópole portuguesa. Os médicos sabiam melhor o que convinha comer, mas o vulgo não permanecia alheio à questão. 
Na época do retorno de Gregório de Matos à cidade natal, os proprietários de terras costumavam já manter feijoais em seus domínios ${ }^{459}$. Num poema versando sobre o aprisionamento do poeta Tomás Pinto Brandão, amigo de Matos, alguns versos comprovavam a existência dessa prática:

“Dais-me a presumir, Senhor,que ElRey com força distinta/tirar vos da vossa Quinta/ foi sò para me dispor:/se me plantaes por favor/neste de ferro quintal,/por ser planta natural, mais bem disposto estarei/fora do Pomar delRey/lá no vosso feijoal" ${ }^{360}$.

O lugar reservado por Matos aos hábitos alimentares ou suas alusões ao estado e às propriedades dos humores corporais, freqüentes nos poemas, na ausência de documentos específicos, atestavam a familiaridade do público com metáforas que referiam processos cotidianos de alimentação e de digestão.

O primeiro tratado de medicina escrito em Portugal, publicado em 1721 sob o título de $a$ Ancora medicinal: para conservar a vida com saúde ${ }^{461}$, pelo médico do rei D. João V, Francisco da Fonseca Henríquez, poucos anos após a morte de Gregório de Matos, continha explicações sobre os princípios vigentes de manejo corporal. Estes eram subentendidos nas alusões que os poemas de Gregório de Matos destinaram a uma população lusa colonial, cujos hábitos alimentares se pautavam por tais mandamentos.

Segundo o autor do tratado, conhecido pelo apelido de doutor Mirandela, feijões eram quentes e secos, $\operatorname{crassos}^{462}$, melancólicos e terrestres e seu consumo perturbava o sono com fantasias tristes e oprimia a cabeça. O autor afirmava também que, no estômago, esses legumes bastante 459 Proprietários de terras possuíam seu feijoal mas eram sobretudo os escravos, os marinheiros e talvez os judeus que desfrutavam correntemente das virtudes nutritivas dos feijões.

460 PERES Fernando da Rocha e LA REGINA Silvia. que analisaram um códice inédito, acrescentaram alguns poemas novos ao corpus das peças conhecidas. Um códice setecentista inédito de Gregório de Mattos. Salvador, EDUFBA, 2000. pp. 139 e 140.

461 HENRIQUEZ, Francisco da Fonseca. Âncora medicinal: para conservar a vida e a saúde. Cotia, Ateliê Editorial, 2004. 
nutritivos se "coziam" e digeriam com dificuldade ${ }^{463}$, provocando desagradáveis flatulências, isto é, durante o processo de fermentação, os ingredientes eram cozidos não somente pelo calor do corpo, mas sobretudo pelo ácido fermentativo, que dissolvia os alimentos sólidos, transformados, num quilo líquido e tênue ${ }^{464}$.

\section{A população nativa}

Convém relembrar como, durante a primeira metade do século XVII, descender de mamelucos ilustrados ainda constituía uma ascendência honrosa. Porém, por volta de 1666, os comentários do padre Simão de Vasconcelos sobre a ferocidade dos povos ditos de língua travada e as estórias sobre a Guerra dos Bárbaros ${ }^{465}$, que circulavam entre os colonos, sugeriam que diferenças entre os usos e costumes dos grupos Jê e Tupi começariam talvez a se diluír na memória dos colonos. Na medida em que, escravizados, mortos, assimilados ou fugidos para lugares longínquos, os nativos não ameaçavam mais o domínio luso na faixa costeira, a reputação de ferocidade dos tapuias ${ }^{466}$ confundiu-se um pouco com lembranças de revoltas tupis ocorridas no litoral. Utilizando alternadamente os termos: Tapuia, Cobé ou Paiaiá (ou Palalá) e outros assemelhados como sinônimos para designar os índios, a memória de resistências indígenas à conquista portuguesa do território soteropolitano se transformou em agravo e descender de autóctones. um insulto. Matos, versejando, externou simbolicamente seu ressentimento por meio de metáforas que ridicularizavam os ingredientes alimentares da dieta nativa.

Nos versos do poeta, certos lugares da geografia regional, como Jacaracanga e Pirajá, se transformaram em fontes de alusões pérfidas. O uso de pilões, apetrechos indispensáveis da

\footnotetext{
463 HENRIQUEZ, Francisco da Fonseca. Op. Cit., pp. 161 e 162.

464 HENRIQUEZ, Francisco da Fonseca. Op. Cit., pp. 45 e 46.

465 PUNTONI, Pedro. A guerra dos bárbaros: povos indígenas e a colonização do sertão nordeste do Brasil, 1650 - 1720. São Paulo, FAPESP/Hucitec/EDUSP, 2000.

466 VASCONCELOS, Simão de. Notas curiosas \& necessárias das cousas do Brasil. Lisboa, João da Costa, 1668.
} 
culinária nativa, e de cestos indígenas tornaram-se motivo de desprezo, sobretudo quando manufaturados em Pirajá. A aldeia de Pirajá fora o primeiro aldeamento indígena organizado pelos jesuítas e o cenário de um episódio que Matos nunca perdoou. Os índios do lugar se revoltaram. Destruíram o primeiro engenho erigido no Recôncavo, o engenho de Jacaracanga, e mataram os colonos a quem deviam prestar serviços. Cairu, por sua vez, figurou nos versos de Matos, como um sinônimo geográfico de lugar distante associado aos nativos. O promontório de Passé e a ilha de Maré também foram sobrecarregadas de subentendidos tenebrosos.

Matos atribuiu reiteradamente conotações pejorativas aos ascendentes mestiços de colonos influentes. Acusou, por exemplo, um colono afidalgado, Cosme Moura Rolim que, segundo a didascália era: "mordaz contra os filhos de Portugal", do canibalismo que seus ancestrais teriam praticado:

\section{“Tenha embora um Avô nascido lá,/Cá tem três para as partes do Cairu,/Chama-se o principal Parauaçu/Descendente este tal de um Guinamá. // Que é fidalgo nos ossos, cremos nós,/Que nisto consistia o mor brasão/Daqueles, que comiam seus avós"467.}

Muitos mazombos foram acusados de terem sangue manchado por semelhante parentesco e nem mesmo os governadores, como foi visto acima, escaparam à sanha de um poeta avesso a considerar honrado aqueles que possuíam parentescos nativos, sendo que o preconceito não figurava oficialmente nas normas da colônia e inexistia nos primórdios da vida social da colônia.

Umavezmais, foram os alimentosidealmente fundamentais na construção dos corpos coloniais, que proveram substância poética para transpor os hábitos alimentares concretos para o plano simbólico da reputação do grupo ${ }^{468}$. Julgava-se que os alimentos ingeridos se transformavam em humores no decorrer do processo da digestão, isto é sobretudo em sangue, um fator de vida que

\footnotetext{
467 MATOS, G. Op. Cit., Vol. IV, p. 842.

468 Uma imprecação do poeta atribuindo sangue impuro de Tatu aos índios, animal local estranho, coberto de carapaça dura e vivendo em tocas escavadas na terra, era longe de constituir um elogio rasgado.
} 
precisava ser manejado adequadamente. Escolher ingredientes comestíveis honrados equivalia a demonstrar sabedoria e senso crítico. Numa sociedade onde todos observavam todos e na qual a honra constituía um fator culturalmente supervalorizado ${ }^{469}$, a respeitabilidade individual e familial (hereditária) dos colonos dependeu forçosamente de escolhas paradigmáticas de ação social. Mesmo que não bastasse apenas praticar uma alimentação impoluta para ocupar um lugar de prestígio na colônia, as condutas alimentares figuraram com destaque especial na definição pessoal de cada colono. Em lugar de espelhar apenas condições ambientais ou sociais de provimento alimentar, a escolha cultural de ingredientes comestíveis privilegiados ou descartados, tornando-se simbólica e por vezes emblemática (quando o consumo simbólico passava a representar a própria pessoa que o incorporava fisicamente), integrava o rol dos fatos dotados de poder para impor estruturas culturais à sociedade.

No caso, além de propor metáforas que representavam o estilo de vida indígena, Matos estabeleceu na linguagem poética uma equivalência sistemática de substância entre preparos nativos e identidade desabonadora. Alimentos usuais na dieta dos índios, mingau de puba, carimá, caruru, moqueca de pititinga e vinho de caju configuravam, no entender do poeta, erros intrínsecos de gosto e desmereciam quem os consumia. Na medida em que as iguarias indígenas citadas estigmatizaram recorrentemente a inferioridade daqueles que as ingeriam, eles passaram à condição de categorias emblemáticas de exclusão social ${ }^{470}$.

Em certo poema, Matos, enraivecido pela esquivança da escrava do padre Simão Ferreira da Cajaíba, que o fez esperar em vão um frete prometido (cf. caso já citado acima), pretextando que não estava disponível porque preparava um mingau para o padre, desfilou uma seqüência violenta de imprecações:

\footnotetext{
469 Segundo Barleu, Nassau, antes de voltar para a Holanda, teria enfatizado a importância que os colonos lusos outorgavam à honra, recomendando que as autoridades coloniais evitassem afrontá-los nesse quesito de suma importância. BARLÉU, Gaspar. História dos fatos recentementes praticados durante oito anos no Brasil. BH/SP, Itatiaia/EDUSP, 1974.

470 Contudo, noutro poema, Matos agradeceu à Susana, amásia do feitor da Cajaiba, o oferecimento de uma moqueca de pititinga.
} 
"Maldito seja tal caldo,/e tal mingau de Aratus,/que boto a Deus, e a Jesu,/que de ouvi-lo só me escaldo;/tanta pimenta rescaldo,/tanta manipuba impressa/no vão da tal boa peça,/na tal puta Jacutinga/faz, com que sôbre a catinga/a manipuba me fessa" ${ }^{471}$.

O problema era que a moça desejava receber roupas em troca dos serviços prestados, um presente que Matos não tinha nenhuma intenção de lhe dar. O tema escolhido pelo autor para insultar a jovem foi o preparo da (carimá) carimã. O cheiro característico de fermentação das raízes de mandioca deixadas em água corrente foi motivo de zombaria. A farinha de carimã obtida serviria na confecção de uma iguaria nativa: um mingau, tigela fumegante de farinha de carimã escaldada com um caldo apimentado de caranguejos aratus ${ }^{472}$. Confundindo o corpo da moça com preparos alimentares toscos, o poeta permitiu perceber a mudança ocorrida nos códigos nutricionais dos colonos. De fato, em fins do século XVI, cronistas bem informados, como Gabriel Soares de Souza, não se envergonhavam de relatar que apreciavam mingaus. E Piso e Marcgrave, autores do Brasil holandês que experimentaram versões dessa iguaria corrente entre os portugueses entre 1637 e 1644, também confessavam que as achavam deliciosas.

Ao satirizar uma freira do Desterro que impediu outra de mandar um peixe vermelho ao poeta, para não desencadear comentários intempestivos, Matos, queixando-se do jejum forçado, praguejou: "praza ao demo, que um Cobé/vos plante tal mangará,/que parais um Paiaiá,/mais negro que um Guiné"473.

A intenção de Matos, ao usar de forma burlesca o vocabulário indígena, era mesmo retratar elementos da vida local, porém, numa perspectiva distanciada de qualquer ufanismo. Segismundo Spina, entretanto, não deixou de afirmar candidamente:

471 MATOS, G. Op. Cit., Vol. VI, p. 1471.

472 Ainda hoje, a riqueza excepcional do Recôncavo baiano em moluscos, peixes, crustáceos continua a ser trunfo do "terroir" local e uma fonte de inesgotável de preparos saborosos. 
"Concordamos que a proporção de brasileirismos encontráveis em Gregório de Matos é grande, relativamente ao tempo em que o poeta viveu no Brasil: a sua mocidade e os últimos quinze anos de vida. Seria, então, uma interessante tese de metafisica saber se Gregório, na hipótese de que tivesse vivido sòmente no Brasil, acabaria escrevendo suas poesias em tupi ou africano..." $"$.

\section{Os comerciantes portugueses}

Outra questão de forte presença nos poemas de Matos foi o status social dos comerciantes. A rivalidade entre os colonos que eram donos de terras e produziam riquezas agrícolas ou pastoris (muitos deles estabelecidos na terra por mais de uma geração) e os imigrantes recentes, desembarcados com pouco ou nenhum capital, mas que conseguiam enriquecer pela via dos negócios, transpareceu na arte poética de Matos. O tema requeria atenção. O poeta pertencia pelo nascimento à categoria dos lavradores de canas que, segundo Stuart Schwartz ${ }^{475}$, mais sofreu perda de status na crise dos anos 1680. A coroa lusitana, com efeito, em lugar de apoiar as elites açucareiras da colônia, à vista da crise internacional, favoreceu os negociantes, que lhe proviam maior retorno financeiro.

Diversos poemas de Gregório de Matos registraram as queixas dos homens bons, proprietários rurais abastados, contra as calamidades enfrentadas na colônia ${ }^{476}$ em decorrência da crise do açúcar que provocava uma queda da demanda e dos preços do açúcar no mercado internacional. Reduzidos substancialmente os lucros auferidos na venda das safras de açúcar ou de tabaco ou na exportação de couros dos bovinos do sertão tornou-se difícil para os colonos manter intactos

474 SPINA, Segismundo. Gregório de Matos: introdução seleção e notas. São Paulo, Assunção Ltda. Sem data.

475 SCHWARTZ, V. L. Op. cit., p. 195.

476 Merece lembrança também o alvoroço ocorrido, nos anos 90, com a descoberta de minas auríferas no planalto central, que acabaram atraindo um grande número de imigrantes, algo que, obviamente, não aparece nos poemas de Matos 
seus padrões de vida generosos e perdulários, marca honrosa de uma importância social que as elites coloniais não concebiam abandonar. Segundo Vera Lúcia Ferlini:

\begin{abstract}
"Os senhores não tinham lucros de vulto, mas usufruíam dos favores e da proteção da Coroa, reproduzindo internamente os mecanismos de exploração colonial. Sua perpetuação garantia as rendas fiscais do Estado e a usura dos comerciantes, a lhes adiantar dinheiro fazendas e escravos, em troca de açúcar barato. E se não eram homens de dinheiro, a eles nunca faltaram os frutos da colonização: terras, trabalho e poder" ${ }^{\prime 47}$.
\end{abstract}

Outros fatores, como a falta de moedas e a escassez da prata, afetaram ainda a prosperidade dos colonos. A falta de dinheiro líquido incentivou a população a comprar à crédito antes da safra, atitude que resultava em juros extorsivos na hora de acertar as $\operatorname{contas}^{478}$. Porém, foi sobretudo o monopólio comercial outorgado por D. João IV a uma Companhia de Comércio lusa, após a guerra com os holandeses, que desencadeou a espoliação dos produtores de açúcar. A idéia tinha sido oferecer vantagens atraentes à Companhia para incentivá-la a armar frotas anuais que, navegando em comboio, protegeriam as naus contra os ataques de piratas ou de corsários. Mas os senhores de engenho, impedidos pelo privilégio concedido de negociarem sua produção em melhores condições, perderam parte substancial das rendas. Igualmente reféns dos negociantes para a aquisição de produtos lusos a preços exagerados e para a venda do açúcar a preços aviltados, manifestavam um descontentamento que Gregório de Matos espelhava em seus versos, ao se despedir da terra natal:

"Que os brasileiros são bestas/e estarão a trabalhar/toda a vida por manter/ maganos $^{479}$ de Portugal' 480 .

477 FERLINI, Vera Lúcia do Amaral. Terra trabalho e poder: o mundo dos engenhos no nordeste colonial. Bauru, EDUSC., 2003. p. 348.

478 Cf. as cartas do Senado e as Atas da Câmara Municipal.

479 Maganos: Termo não encontrado no Diccionário da língua portugueza de Moraes.

480 MATOS, G. Op. Cit., Vol. VII, p. 1594. Trata-se da única aparição do termo brasileiro, no conjunto da obra, utilizado, no caso, para designar os colonos soteropolitanos. 
As queixas de Matos contra a usura, os engodos e os abusos praticados por grandes negociantes lusos e por pequenos comerciantes que vendiam a retalho (ditos comerciantes de loja aberta ${ }^{481}$ ) testemunhavam a ocorrência freqüente de atritos. Em versos de teor pesado o poeta ralhou os novos ricos que, nem sempre primavam pela limpeza do sangue e que, enriquecidos pelo trabalho das próprias mãos ou das mãos de seus ascendentes, não se qualificavam, segundo os preceitos mazombos, para ocupar posições sociais de destaque. Com o decurso dos anos o tom dos poemas de Gregório de Matos se tornou mais acerbo. Sua virulência, entretanto, não deve ser considerada apenas conseqüência da amargura de um homem vingativo se desforrando da miséria ao ridicularizar os sonhos de grandeza dos comerciantes. A venda dos alimentos que proviam nutrição à colônia foi encarregada de relembrar, nos versos do autor, quão pouco reluzentes eram consideradas as atividades de provimento de gêneros alimentícios à varejo:

"Se hoje vos fala de perna/quem ontem não pôde ter/ramo, de quem descender/ mais que o de sua taverna:/tendes paciência interna,/que foi sempre D. Dinheiro/ poderoso Cavalheiro,/que com poderes iguais/faz iguais aos desiguais,/e Conde ao vilão cad'hora./Entendeis-me agora?" 482 .

Não deixa de ser curioso observar como, vivendo num entreposto comercial urbano que oferecia oportunidades de trabalho principalmente aos comerciantes, aos artesãos (oficiais mecânicos) e aos administradores coloniais (que exerciam cargos executivos, judiciários ou fiscais), Gregório de Matos criticava tanto o mercantilismo, razão mesma de ser da existência colonial.

481 SOUSA, Avanete Pereira. Poder local, cidade e atividades econômicas (Bahia, século XVIII). Tese de História econômica apresentada ao Departamento de História da FFLCH-USP. São Paulo, 2003. 
A cidade que o autor avaliava tão severamente constituía o centro vital do Antigo Sistema Colonial $^{483}$. A preocupação do advogado e poeta com as formas tradicionais de vida mazomba ameaçadas revelava, por contraste, a complexidade da vida colonial. Matos, por conseguinte, criticou os abusos, condenando a usura, a avareza e toda espécie de procedimentos fraudulentos, bem como o espírito de poupança dos comerciantes. Um ponto de vista cristão sustentava sua postura, mas a violência dos termos, mesmo compreensível em função de sua história de vida, estava longe de situá-lo como depoente isento.

O testemunho contido na Crônica do viver baiano seiscentista permite imaginar a repercussão das medidas administrativas do poder colonial, dificultando a vida cotidiana num momento de crise especialmente delicado e ameaçando os parâmetros culturais do estilo de vida elaborado pelas elites coloniais entre 1550 e 1640. O poeta, arvorado em porta-voz de mazombos bem sucedidos, permitiu olhar para os fenômenos cotidianos soteropolitanos: "por cima do seu ombro"484 e por cima daquele dos amigos que freqüentava na Cidade da Bahia ou no Recôncavo.

A trajetória do enriquecimento de negociantes recém desembarcados constituiu um tema persistente na obra do autor. Matos se empenhou em denunciar a mesquinhez daqueles que não praticavam a liberalidade fidalga. Mazombos que se prezassem, segundo afirmava o poeta, gastavam os bens sem contar, ciosos da própria honra:

"Que este mal há nos mazombos,/têm tão pouca habilidade, /que o seu dinheiro despendem/para haver de sustentar-se" ${ }^{\$ 485}$.

483 NOVAIS, Fernando. Estrutura e dinâmica do Antigo Sistema Colonial (séculos XVI -XVIII). $6^{\text {a }}$ ed., São Paulo, 1996.

484 GINZBURG, Carlo. A micro-história e outros ensaios. Capítulo "O inquisidor como Antropólogo". Rio de Janeiro, Bertrand Brasil. 1991.

O fato de ser neto de um familiar da Inquisição pode ter propiciado a Matos essa escolha de postura. Cf. PERES, Fernando da Rocha. Gregório de Mattos e a Inquisição. Salvador, Centro de Estudos Baianos, 1987. 
Gregório de Matos retratou, portanto, em termos mordazes a epopéia brasileira dos imigrantes recentes, incorporando um leve tom de novela picaresca às narrativas. Muitos comerciantes reinóis que nada possuíam desembarcavam no cais de Salvador. Desejavam se estabelecer e guardavam o dinheiro amealhado. Residiam em moradias sem conforto, praticavam usuras e tramóias. Em lugar de desfrutarem os lucros dos negócios, poupavam-nos e alcançavam afinal a prosperidade desejada. Ao cabo de alguns anos de sacrifícios, estabelecidos na praça, aspiravam a uma importância social, que não condizia com suas origens familiares modestas e as atividades praticadas para alcançar a riqueza:

"Salta em terra, toma casas,/arma a botica dos trastes,/em casa come Baleia,/na rua entoja manjares./Vendendo gato por lebre,/antes que quatro anos passem,/já tem tantos mil cruzados,/segundo afirmam Pasguates ${ }^{486} . /$ Começam a olhar para êle/os Pais, que já querem dar-lhe/Filha e dote porque querem homem, /que coma e não gaste" ${ }^{\text {487. }}$.

Acusados de venderem gato por lebre, de não se envergonharem de comer carne de baleia como os colonos pobres e os escravos, os comerciantes, no entender de Matos, personificavam a falta de nobreza. Não obstante, depois de estabelecidos, arrotavam falsas fidalguias. Matos os satirizou retomando uma inspiração metafórica semelhante àquela privilegiada por Cervantes:

"y Sancho alivió el jumento, y, tendidos sobre la verde yerba, com la salsa de su hambre, almorzaron, comieron, merendaron y cenaron a un mesmo punto"488.

\footnotetext{
486 Termo não encontrado no Diccionário da língua portugueza de Moraes.

487 MATOS, G. Op. Cit., Vol. II, pp. 430 e 431.

488 CERVANTES, Miguel de. Dom Quixote de la Mancha. In : NÚÑEZ, Florêncio Rafael. Con la salsa de su hambre: los extranjeros ante la mesa hispana. Madrid, Alianza Editorial, 2004. p. 11.
} 
Por requintes de avareza esses comerciantes pícaros ingeriam tristes iguarias. Depois de enriquecidos conseguiam casamentos honrosos. Comiam também, além de carne de baleia, pepinos "de tôda a iguaria isenta, com seu limão, e pimenta" 489 . À noite, ceavam parcamente e comiam apenas saladas de "chicória com azeitonas"490. Indivíduos havia, que se privavam até de cear. Matos, por exemplo descreveu em certo poema um: "cristão que apenas janta e não ceia"491:

"pobrete de Cristo" saído "de Portugal ou do Algarve/cheio de drogas alheias para dai tirar gages ${ }^{492}: / O$ tal foi sota-tendeiro/de um cristão-novo em tal parte,/que por aquêles serviços/o despachou a embarcar-se"493.

Enriquecido o pícaro procurava ostentar fidalguia:

“Entra logo nos pilouros ${ }^{494}, /$ e sai do primeiro lance/Vereador da Bahia,/que énotável dignidade./Já temos o Canastreiro,/que inda fede a seus beirames,/metamorfórsis da terra/transformado em homem grande:/e eis aqui a personagem"495.

A ira de Matos era visível quando ele conspurcava mestiços desejosos de melhorar de situação e colonos que, não obstante terem vivido do exercício de atividades manuais, pretendiam ser eleitos para cargos honoríficos:

\footnotetext{
489 MATOS, G. Op. Cit., Vol. II, p. 444, por exemplo.

490 MATOS, G. Op. Cit., Vol. II, p. 491.

491 MATOS, G. Op. Cit., Vol. IV, p. 1108.

492 Gages: Segundo a definição do Diccionário da língua portugueza de Moraes: "a coisa que se dá em penhor... Soldo, salário, soldada".

493 MATOS, G. Op. Cit., Vol. II, p. 430.

494 Pilouro ou pellouro. Segundo o Diccionário da língua portugueza de Moraes: "bola de cera".

495 MATOS, G. Op. Cit., Vol. II, p. 431.
} 
"Se notais ao mentecapto/a compra do Conselheiro,/o que nos custa dinheiro/isso nos sai mas barato:/e se da mesa do trato,/de bôlsa, ou da companhia/virdes levar Senhoria/mecânicos deputados;/crede, que nos seus cruzados sangue esclarecido mora" $" 496$.

Além dos canastreiros, dos filhos de taberneiros, dos maridos de confeiteiras e dos pasteleiros (que exerciam ofícios manuais) e dos cristãos velhos de sangue limpo que escolhiam se "mascavar" ${ }^{497}$ desposando moças ricas de sangue duvidoso ${ }^{498}$, os mestiços livres, alvos certeiros de escárnio, despertavam ainda os ciúmes do poeta. Figuravam nas narrativas poéticas diversas personagens dotados de resquícios quixotescos: "do mesmo lote": "eis aqui a personagem". Não deixavam de ser interessantes os relatos rápidos debuxados pelo poeta, que mencionavam D. Quixote. "Quixotes" na obra de Matos eram, por exemplo, os estudantes, que furtavam "carne à ama" - subentendendo-se repastos de cama ou de mesa - os frades "com presunções de gentilhomem" ou os tabeliões recém-nomeados:

“Mancebo sem dinheiro, bom barrete,/[...] Tirar falsídia ao Môço de seu trato,/ Furtar a carne à ama que promete./[...] Cartinhas de trocado para a Freira,/Comer Boi, ser Quixote com as Damas,/Pouco estudo, isto é ser estudante"499.

As menções de Matos ao herói de Cervantes não faziam em nada justiça à grandeza idealista do "cavaleiro da triste figura" ${ }^{000}$, rebaixado à condição de "pícaro", termo que, nos poemas de Matos, designava colonos astutos e aventureiros malandros. Esses homens viviam de praticas duvidosas e afetavam uma nobreza que não condizia com seu status social, quando efetivamente

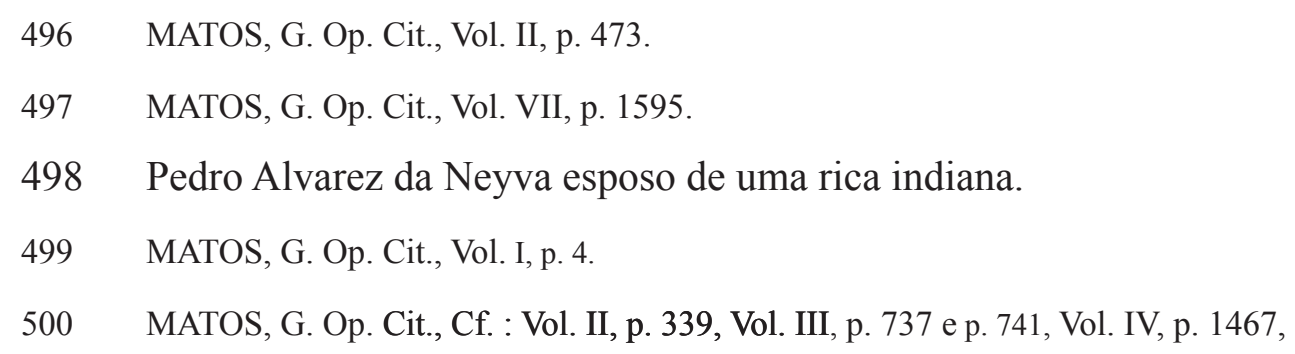


não sabiam como assegurariam as próximas refeições. Sancho Pança, por sua vez, lhe serviu de referência para descrever uma cavalhada ocorrida por ocasião da festa das onze mil virgens, descrita em registro burlesco:

"Uma aguilhada por lança/trabalhava a meio trote,/qual o moço de Dom Quixote,/ a que chamam Sancho Pança:" 501.

É curioso que a transformação dos romances épicos medievais de cavalaria em novelas picarescas, em meados do século $\mathrm{XVI}^{502}$, tenha resultado debaixo da pena de Matos num desprezo explícito pelos homens de baixa extração que, à falta de um lugar ao sol para sobreviver, enfrentavam seqüências rocambolescas de aventuras, enquanto carregavam o estômago no calcanhar, por causa da dificuldades em assegurar o pão cotidiano.

A falta de nobreza e de escrúpulos que semelhantes personagens ostentavam, o hábito de promoverem intrigas que Matos relatava ou lhes atribuía eram elementos que tinham tudo para desagradar às elites locais, assaz conservadoras. A imagem dos ratos, pragas de armazéns urbanos, voltava insistente nos poemas do autor:

"mas tenho o meu pesarzinho/de ser mercador ratinho/quem é filho de Lisboa"s03.

A imagem complementar dos gatos, que deveriam ter dado conta da peste dos ratos, mas tinham maior vocação para serem gatunos que policiais, expressou magistralmente o furor, que a prevaricação dos gestores da colônia, fossem eles de alto ou de baixo escalão, despertava no poeta:

501 MATOS, G. Op. Cit., Vol. III, p. 639

502 Cf. ainda, além do Gil Blas de Santillane de Lesage, o Candide de Voltaire e a novela picaresca escrita por Quevedo.

503 MATOS, G. Op. Cit., Vol. II, p. 394. 
"Em casa deste Escrivão/me criei com tal regalo,/que os demais gatos da casaleram comigo uns bichanos./Mas cresci, e aborreci,/porque se cumpra o adágio,/que o oficial do mesmo ofício/é inimigo declarado./Foi-me tomando tal ódio,/porque foi vendo e notando, /que era capaz eu de dar-lhelaté no ofício um gataço./Topou-me em uns entreforros,/e tirando-me porraços, eu lhe miava os narizes, /quando êle me enchia os quartos./Fugi como tenho dito,/e me acolhi ao sagrado/de uma vara de justiça,/que é valhacouto de gatos./Sai meu amo aos prendimentos, /e eu fico em casa encerrado/por caçador de balcões, onde jejuo o trespasso./Porque em casa de um meirinho/nas suas arcas e armários/é quaresma tôda a vida e têmporas ${ }^{504}$ todo o ano./Não posso comer ratinhos, /porque cuido e não me engano,/que de meu amo são todos/ou parentes ou paisanos./Porque os ratinhos do Douro/são grandissíssimos velhacos:/em Portugal são ratinhos/e cá no Brasil são gatos" 505 .

Pessoas que tentavam galgar patamares na hierarquia social podiam contar com a antipatia de Matos. Pedro Alvarez da Neyva, por exemplo, um comerciante estabelecido em Marapé, casado com uma mulher indiana rica, pretendeu adquirir em Portugal foros falsos de fidalgo. Mereceu, por esse motivo, diversos poemas irados de Matos:

"Ser fidalgo na Bahialé suma felicidade,/porque há de arder a cidade/numa e noutra cortesia:/heis de mamar Senhoria,/quer vos dê, quer não pesar:/porque se um triste alveitar/a mama, sendo ancião,/vós tão novo, e simplalhão/como a não heis de mamar" 506 .

504 Segundo a definição do Diccionário da língua portugueza de Moraes: Têmporas dias de jejum praticados em cada uma das quatro estações do ano..

505 MATOS, G. Op. Cit., Vol. II, pp. 456 e 457.

506 MATOS, G. Op. Cit., Vol. IV, p.899. 
"E como vós sois doente/de fidalgos frenesis,/por ficar enfidalgado/ tôda a mofa heis de rustir./O que trareis de vestidos!/Uns assim, outros assim:/sereis o molde das modas, /e o modelo dos Turins./A conta disto me lembra,/quando em Marapé vos vi/vestido de pimentão/com fundo de flor de $\mathrm{Li}^{\prime}{ }^{507}$.

"que êste povo é tão ruim,/tão jocoso, e tão burlesco,/que por vos pôr ao tudesco,/tendo vós cara de nata,/levantam, que a vossa pata/tem dedo de queijo fresco. // Triste da vossa parceira,/que se vos muda talvez/a cabeça para os pés, /e os pés para a cabeceira,/sempre o presunto lhe cheira $" 508$.

O problema efetivo de semelhantes colonos era:

"Que se despache um caixeiro/criado na mercancia/com fôro de fidalguial sem nobreza de Escudeiro!/e que a poder de dinheiro,/e papeis falsificados/se vejam entronizados/tanto mecânico vil,/que na ordem mercantil/são criados dos criados!" 509 .

Mas os comerciantes portugueses não eram os únicos a praticar negócios escusos.

“Que o Letrado lisonjeiro/venda fazendo negaças/em almoeda as trapaças,/e por muito bom dinheiro..." 510 .

507 MATOS, G. Op. Cit., Vol. IV, p. 896.

508 MATOS, G. Op. Cit., Vol. IV, p. 900.

509 MATOS, G. Op. Cit., Vol. IV, p. 907.

510 MATOS, G. Op. Cit., Vol. II, p. 483. 
“Que hajam muitos que às centenas/entre os amigos e socios/façam bem os seus negócios,/cometendo mil onzenas ${ }^{511}$ : que conhecendo-se as penas, /que pelo direito têm,/não os demande ninguém/cum carta citatória! Boa história" ${ }^{512}$.

No período analisado, as atas da Municipalidade comentavam seguidamente as dificuldades encontradas para fornecer rações aos soldados que privados de soldo e de alimento, em virtude das dificuldades financeiras do momento, atacavam e roubavam os colonos que deveriam defender contra inimigos externos. Matos concluía:

"Que falta nesta cidade .... Verdade/Que mais por sua deshora .... Honra/Falta mais que se lhe ponha .... Vergonha/... Quem faz os sirios mesquinhos?... Meirinhos/Quem faz as farinhas tardas? .... Guardas/Quem as têm nos aposentos? .... Sargentos ...." ${ }^{, 13}$.

Muitas transações efetivadas na Cidade da Bahia envolviam alimentos. As práticas escusas dos militares incomodaram o autor. Matos ressaltou com afinco especial a desonestidade dos comerciantes, que vendiam mercadorias podres a preços exorbitantes 514. Certo tenente apelidado o Surdo mereceu um poema inteiro ${ }^{515}$. Ele tinha, segundo o texto do poema, adquirido paios, queijos e vinhos e não hesitava em revender aos amigos por preços excessivamente salgados esses gêneros comestíveis que a frota trazia de Portugal.

\section{4 - A construção de um lugar de poder nas fofocas burlescas ou satíricas}

\footnotetext{
511 Segundo a definição do Diccionário da língua portugueza de Moraes: "onzenas: usuras".

512 MATOS, G. Op. Cit., Vol. II, p. 501.

513 MATOS, G. Op. Cit., Vol. I, pp. 31 e 32.

514 MATOS, G. Op. Cit., Vol. II, pp. 429 a 434.

515 MATOS, G. Op. Cit., Vol. II, pp. 392 a 395.
} 
Cioso de ocupar um lugar de destaque na colônia, mas se deparando com a relutância das autoridades administrativas e eclesiásticas locais em favorecer seus projetos, Gregório de Matos, sabedor do favor público que acolhia seus poemas, encarregou versos líricos, satíricos, burlescos ou eróticos de comprovar a engenhosidade de seu talento para formular tropos surpreendentes e mordazes. Censor auto-proclamado da integridade dos usos e costumes soteropolitanos ele, talvez, julgou poder contribuir dessa forma à manutenção dos valores culturais e sociais das elites mazombas, fundamentados na existência de uma hierarquia social, tão claramente definida quanto ameaçada de desrespeito, como se viu.

Não foi sem motivos que o Padre Vieira comentou, certa vez, que os poemas de Matos se revelavam mais eficazes que seus próprios sermões, junto à população colonial. De fato, e apesar do contraste óbvio entre os instrumentos de expressão utilizados, ambos os autores compuseram obras literárias que discursavam no mesmo registro moral. Ambos expuseram um mapa de classificações sociais dos indivíduos e um elenco extenso de conceitos sobre relações sociais aceitáveis ou escandalosas, formuladas segundo critérios que uma grande parte da boa sociedade soteropolitana compartilhava.

A prática da arte poética não trouxe estabilidade financeira a Matos, mas lhe permitiu ocupar um lugar razoavelmente bem sucedido na sociedade freqüentada. Tanto o exílio que coroou a obra, quanto o conselho recebido em Angola e depois em Pernambuco, onde o autor morreu em 1696, de não mais escrever poemas, atestam que ele conseguiu de fato construir uma imagem de poder simbólico em torno de seus poemas.

Manejando ironia e sarcasmos ou lirismos, Gregório de Matos entrelaçou estórias, narrativas e cantos, com a métrica e as rimas de uma expressão pessoal de cunho popular, ainda que inspirada nas normas cultas metropolitanas. O uso de metáforas, de trocadilhos insultuosos, de alegorias estereotipadas, de frases feitas e de provérbios pertinente à arte poética que era produzida entre os séculos XVI e XVIII, marcou presença nas sátiras do poeta, enquanto que as analogias entre hábitos alimentares e valores éticos foram instrumentais em seus protestos contra uma cidade, que instigava a rivalidade entre colonos 
antigos e recentes: "Senhora Dona Bahia/nobre e opulenta cidade,/Madrasta dos Naturais,/ e dos Estrangeiros Madre"

Autores como Varnhagen viram na arte poética de Matos apenas a obra de um marginal despeitado, rancoroso e reduzido ao ócio ${ }^{517}$. Condenado efetivamente ao ócio e temendo deixar de viver à lei da nobreza, numa sociedade, que não trabalhava senão pelas mãos e pelos pés de seus escravos, segundo a fórmula cunhada por Antonil, Matos foi certamente um homem amargurado e vindicativo. Porém, não deveria ser pelo prisma psicológico fácil que sua arte deveria ser interpretada.

Se Max Gluckman, autor de um ensaio: Gossip and scandal ${ }^{518}$, sobre o papel social e as implicações técnicas da fofoca, tivesse lido poesias de Gregório de Matos, teria provavelmente incluído a arte do bacharel no rol das obras empenhadas em defender a manutenção de um espaço social vigente. Mais relevantes que os indícios de inveja e de ódio presentes na escrita poética ou que as evidências inegáveis de obediência a padrões convencionais de composição de versos, o antropólogo britânico teria sublinhado os esforços do poeta para unir a comunidade mazomba em torno de maneiras de conceber o universo colonial que implementavam premissas tácitas soteropolitanas. Ele confirmaria também, como no caso dos romances escritos por Jane Austen, o papel moralizador da fofoca como arma mestra de controle social, manejada por pessoas consideradas superiores para recolocar os inferiores em seus devidos lugares ${ }^{519}$.

Mas Gluckman não veria nos poemas de Matos apenas artifícios judiciosos de linguagem utilizados para recriar diálogos possíveis. Teria provavelmente assinalado os elementos de oralidade que se fizeram muito presentes no estilo do corpus de seus poemas. Apesar de lidar com as emoções do público por meio da expressão de suas próprias emoções, em versos que

\footnotetext{
516 MATOS, G. Op. Cit., Vol. II, p. 429.

517 GOMES, João Carlos Teixeira. Op. Cit., pp. 54 a 56.

518 GLUCKMAN, Max. "Gossip and scandal”, in Current Anthropology, vol. 4, nº 3, Junho de 1963.

519 "Gossip and even scandal unite a group within a larger society, or against another group, in several ways". "A fofoca e mesmo o escândalo unem um grupo de diferentes maneiras, seja no seio de uma sociedade mais abrangente, seja contra um outro grupo" ( minha tradução).
} 
procuraram influenciar os conterrâneos, o intento dos poemas do autor afigurou-se um fenômeno de caráter mais social do que psicológico.

Impressiona, aliás, a maneira ágil como Matos conseguiu integrar preceitos literários e técnicas práticas de fofoca. Nem a recorrência repetitiva de fragmentos de discurso, nem a imitação de poemas conhecidos, nem as alusões a obras-primas literárias, nem o endereçamento de discursos elevados a objetos pífios para compor paródias cômicas impediram os versos do poeta de aludir aos escândalos locais e aos episódios ocorridos no cotidiano de uma cidade, que atravessava uma crise assustadora.

Consideradas por seu aspecto positivo, as fofocas de Matos, segundo os argumentos do antropólogo inglês, seriam virtuosas por sua propriedade de reafirmar a coesão social e de atenuar os motivos de brigas e de escândalo. A preocupação do advogado e poeta com as formas tradicionais da vida mazomba revelava, por contraste, a complexidade da ordem colonial. Rumores circularam em Salvador ou no Recôncavo adjacente, de forma semelhante àquela apresentada nos textos estudados pelo antropólogo inglês. Elas alimentaram interesses coletivos e reforçaram as censuras aos fatores que pervertiam a ordem cultural e social estabelecida. $\mathrm{O}$ ciúme dos mazombos, proprietários de terras, filhos ou netos de portugueses brancos contra as ambições de comerciantes lusos e mestiços livres em franco processo de ascensão social, correspondia a maneiras diversas de conceber a vida. Mas, ainda assim, a função dos sarcasmos divulgados por Matos, a pretexto de entretenimento, era uma tentativa de manutenção da ordem social instituída.

Não deixou de se mostrar irônico que, ao partir paraAngola, Matos se queixasse tão amargamente dos observadores coloniais à espreita. Após ter censurado livremente tudo e todos, se revelou magoado pelas censuras que lhe dirigiam. A segunda estrofe do poema colocado em epígrafe ao capítulo comprovava efetivamente seu desconforto ao ser, ele próprio, alvo de fofocas:

"Em cada canto um olheiro,/Que a vida do vizinho e da vizinha/Pesquisa, escuta espreita, e esquadrinha/Para a levar à Praça e ao Terreiro". 


\section{O Mapa}

Durante uma semana de pesquisa de campo em São Francisco do Conde, em Junho de 2006, foi possível perceber que a profusão de nomes de lugarejos dos tempos coloniais encontrada nos poemas de Gregório de Matos, se concentrava num raio de cerca de vinte quilômetros da cidade. Cachoeira e a Saubara eram localidades situadas do outro lado do Recôncavo, em solos menos úmidos que os massapés predominantes na região canavieira.

Os lugares mencionados de forma recorrente na obra poética foram aqueles que o poeta parece ter freqüentado mais seguidamente: as ilhas da Cajaíba ${ }^{520}$, de Gonçalo Dia (a Ilha Grande) ${ }^{521}$, ou ainda a Ilha da Madre de Deus. Mas ocasionalmente Matos celebrou também as ilhas de Itaparica ${ }^{522}$, de Jorge de Sá ${ }^{23}$, da Maré ${ }^{524}$, ou a Ilha das Fontes ${ }^{525}$. Alguns rios da região foram assinalados nos versos: o rio de Caipe $^{526}$ com sua Fonte do Paraíso ${ }^{527}$, aquele de Serigi-Mirim e, ainda, o riozinho da Pericoara ${ }^{528}$.

520 MATOS, G. Op. Cit.. No caso as referência foram extremamente numerosas e incluiram também poemas nos quais a ilha não figurava explicitamente.

521 MATOS, G. Op. Cit., Vol. III, pp. 607a 610 e Vol. VI, pp. 1519 a 1521e 1523.

522 MATOS, G. Op. Cit., Vol. VI, p. 1522.

523 MATOS, G. Op. Cit., Vol. III, pp. 604 a 606.

524 MATOS, G. Op. Cit., Vol. IV, p. 840 e Vol. V, pp. 1253 a 1256.

525 MATOS, G. Op. Cit., Vol. VI, p. 1523.

526 MATOS, G. Op. Cit., Vol. III, p. 556.

527 MATOS, G. Op. Cit., Vol. III, pp. 546 e 565.

528 MATOS, G. Op. Cit., Vol. VI, p. 1345. 
Outras localidades da região apareceram apenas de relance nos poemas: Areal ${ }^{529}$, Cachoeira $^{530}$, Guaíba ${ }^{531}$, Saubara ${ }^{532}$, Passé ${ }^{533}$, Cairu ${ }^{534}$, Jacaracanga ${ }^{535}$ e Pirajá ${ }^{536}$, às vezes em citações que continham comentários pérfidos, como no caso da aldeia de Pirajá e do engenho de Jacaracanga. O povoado de Cairú, por sua vez, serviu a Matos, como um exemplo metafórico de fronteira sita no limite do mundo civilizado. Outras localidades, tais como Sergipe d'El Rei e Parati, traduziram também uma idéia de distância espacial.

529 MATOS, G. Op. Cit., Vol. V, p. 1235.

530 MATOS, G. Op. Cit., Vol. VI, pp. 1344 e 1393.

531 MATOS, G. Op. Cit., Vol. VI, pp. 1502 e 1503.

532 MATOS, G. Op. Cit., Vol. VI, pp. 1514 a 1516.

533 MATOS, G. Op. Cit., Vol. IV, 782 a 806 e 840 e Vol. V, 1147.

534 MATOS, G. Op. Cit., Vol. IV, p. 842, Vol. VI, pp.1346 e 1380.

535 MATOS, G. Op. Cit., Vol. IV, p. 1147.

536 MATOS, G. Op. Cit., Vol. IV, p. 840, Vol. V, p. 1148. 


\title{
Capítulo III - Uma Etnografia dos procedimentos alimentares coloniais
}

\author{
"Deveis das minhas palavras \\ Tomar discreta e cortês \\ Não aquilo que elas dizem, \\ Mas o que querem dizer" 537. \\ (Gregório de Matos, Vol.IV, p. 824)
}

No capítulo anterior foram examinadas as metáforas sobre procedimentos de alimentação carregados de significados simbólicos que Gregório de Matos utilizou para argumentar seus pontos de vista e ilustrar uma imagem ideal da sociedade soteropolitana, tal como a ele a concebia. Grande parte das comparações parecia corresponder a práticas usuais, cujos significados seriam imediatamente entendidos pelos conterrâneos. Foi demonstrado que havia nexo entre a materialidade dos gestos mencionados e as representações. Todavia, os mesmos versos, que revelavam conceitos ideais soteropolitanos, podiam também instrumentar uma investigação sobre os manejos alimentares praticados na cidade de Salvador ou no Recôncavo rural adjacente. Retomadas numa perspectiva de análise um pouco diversa, as mesmas metáforas referentes a gêneros comestíveis permitiam identificar um leque amplo de noções estratégicas que davam forma a procedimentos de abastecimento e de consumo característicos na dieta alimentar local.

Mesmo fastidiosas, não era possível evitar as reiterações. A despeito do texto da tese apresentar uma sistematização de dados respigados, e não os próprios meandros da pesquisa, os versos de Matos ostentavam, aqui e ali, fragmentos isolados de conhecimento que se tornavam significativos apenas no quadro de uma teia de premissas tácitas interligadas. Por essa razão, focalizar os ingredientes da dieta e os hábitos alimentares mencionados por Matos não constituiu uma tarefa evidente. Para recompor numa perspectiva abrangente o quebra- 
cabeça das informações coligidas, os dados precisavam ser apresentados em função de algum item inicial, mas cada elemento do conjunto, visto por um novo ângulo, descortinava outros panoramas ou complementava temas já abordados. E além disso, o autor não deve ter imaginado que seria apreciado por públicos de outros tempos e lugares. Muitas práticas da alimentação soteropolitana seiscentista que permitiam formular imagens interessantes foram registradas na obra, enquanto outros procedimentos deixaram poucas pistas. Existia ainda nos poemas clichês, frases feitas e provérbios, menções abstratas aos alimentos que não revelavam ações efetivas.

Procurar referências que confirmassem, refutassem ou complementassem os dados proporcionados pelos poemas de Matos, tomados como ponto de partida, se constituiu numa etapa necessária da pesquisa. Apesar de lidar com dados fragmentários, as informações propiciadas pelo autor soavam convincentes, sobretudo nos casos onde foi possível verificar que correspondiam de fato a usos correntes, permitindo inferir de antemão que outros textos seiscentistas confirmariam seu testemunho.

Para reunir informações de segunda mão sobre a sociedade colonial durante o último quartel do século XVII e compor uma descrição etnográfica da alimentação soteropolitana no período, foi necessário juntar fragmentos esparsos de gestos técnicos encontrados nos versos e organizar em torno desses fragmentos de gestos relatados, um entrelaçamento de premissas tácitas, cujo tecido remetia para além dos discursos, a um substrato de vida cotidiana. Extraídas do contexto original da produção literária, pistas infinitesimais sobre maneiras de agir permeadas pela discussão de questões de caráter moral, referenciavam indiretamente a materialidade das formas de abastecimento da população. De modo que, desaparecidos os homens e as circunstâncias da existência soteropolitana, os poemas de Gregório de Matos ofereciam ainda pequenos discernimentos sobre a vida seiscentista. Os procedimentos de provimento e de consumo alimentar, que ilustravam a argumentação do poeta, confirmavam a idéia de Vansina ${ }^{538}$, do caráter fidedigno de testemunhos involuntários. Muito presentes na composição poética, figuravam também elementos geográficos locais e relatos de ações, cuja veracidade a historiografia 
comprova. Através de semelhante viés analítico começaram a se tornar inteligíveis os problemas enfrentados na colônia, as soluções instituídas e as maneiras de pensar implícitas em gestos impossíveis de serem diretamente observados. O propósito antropológico da reconstituição histórica continuava sendo, como no capítulo anterior, o exame dos processos locais e dos códigos envolvidos na formação de uma auto-identificação soteropolitana dos colonos.

Passar no crivo o corpus das obras atribuídas a Gregório de Matos para selecionar indícios de práticas correntes foi a tarefa micro-histórica desenvolvida. Buscar nos textos do poeta indícios de procedimentos instituídos para prover alimentos à Cidade da Bahia e ao Recôncavo, revelouse, no entanto, uma investigação tributária não apenas do paradigma indiciário formulado por Ginzburg $^{539}$ (numa derivação da semiótica médica inspirada no século XIX, a Freud, Conan Doyle ou Morelli), mas sobretudo do paradigma venatório dos povos caçadores, mencionados pelo historiador para demonstrar a viabilidade de se inferir os contornos de objetos ausentes em função dos rastros deixados por sua passagem.

Perguntas simples foram endereçadas à obra poética de Matos, tais como: que alimentos estariam disponíveis na cidade? O que a população das áreas rurais comia? Quando? Preparados de que maneira? Que diferenças existiam entre os alimentos que os mazombos comiam e aqueles que eles reservavam à alimentação dos escravos? Que ritmos de vida eram perceptíveis nos hábitos alimentares? O que os colonos sabiam produzir? O que achavam que deveriam comer? O que desejavam saborear?

Alguns conceitos prévios forneceram um apoio valioso para pensar a especificidade dos dados encontrados e ampliar a reflexão, não obstante as lacunas existentes na documentação. No âmbito do empreendimento etno-histórico proposto era importante não perder de vista as repercussões possíveis de gestos técnicos exercidos sobre os objetos materiais que integravam o sistema colonial de alimentação. A corporeidade forçosa dos produtores de ingredientes comestíveis e dos comensais se apresentava como um suporte prenhe de valor cultural. O

539 GINZBURG, Carlo. "Sinais: raízes de um parâmetro indiciário", in Mitos, emblemas, sinais . São Paulo, Cia das Letras, 2002. 
manuseio de objetos de cultura material, seja nas atividades agrícolas, seja nas atividades da pesca, do mariscar ou dos preparos culinários constituiu, portanto, um referencial implícito para pensar ${ }^{540}$, causas e conseqüências de procedimentos materiais implementados em função do trabalho de escravos.

Tampouco os manejos alimentares mencionados nos poemas podiam ser considerados isoladamente. Correspondiam a intenções e subentendiam motivos. Se os caçadores foram, na opinião de Ginzburg, os primeiros homens a "narrar uma história", por serem os primeiros capazes de ler séries coerentes de eventos em pistas imperceptíveis deixadas na lama pelos animais caçados, as estórias que as técnicas de provimento e consumo alimentar citadas nos versos contavam, eram parte integrante de seqüências de gestos produtivos. Com efeito, as cadeias operatórias: conceito apresentado pelo etnoarqueólogo Pierre Lemonnier ${ }^{541}$ para analisar encadeamentos de gestos técnicos norteados por intenções deliberadas, representaram um fio de meada utilizado para interpretar as idéias que presidiam aos procedimentos.

\section{1 - Os ingredientes de um cardápio mazombo}

Parece que, na época da volta de Gregório de Matos ao torrão soteropolitano, os colonos abastados continuavam a desfrutar de condições de vida confortáveis em suas propriedades rurais. A descrição encantada do Recôncavo baiano redigida, por volta de 1612, por Diogo de Campos Moreno, autor do Livro que dá razão do Estado do Brasil, ainda permanecia atual:

“O sítio em todas as partes é sadio, fértil e viçoso de todos os mantimentos da terra, legumes e hortaliças de Portugal; nas fazendas e engenhos, além das boas fábricas de caças, têm muitas hortas e árvores de espinho, que fazem as vivendas viçosas e alegres; é este Recôncavo o mais povoado sítio de tôda a costa, e nele, por suas

540 Nos termos sublinhados por Warnier: cf. introdução da tese.

541 Retomando também um conceito do autor exposto na introdução da tese. 
fazendas vive a gente nobre e passam de três mil os moradores brancos, os quais, além da lavrança do açúcar, valem-se do algodão, gengibre, arroz, milho, madeiras e outras cousas, suposto que disto e de criações não trato, quando a bondade da terra oferece, porque a lavrança das canas leva todo o trabalho" 542.

Instalada no Brasil, a população lusa comeu os alimentos que conseguiu produzir ou obter nos diferentes núcleos de povoamento onde se estabeleceu. De fato, os colonos aclimataram rapidamente e sem grandes dificuldades boa parte dos vegetais e dos animais domésticos europeus, descobriram o sabor dos gêneros alimentícios da flora e da fauna local, que os índios conheciam, e implantaram na colônia muitas espécies vegetais asiáticas ou africanas apreciadas noutras colônias do Império Ultramarino português.

Árvores cujos frutos agradavam, como os coqueiros ou as bananeiras e inúmeras espécies vegetais cujas folhas, frutos ou raízes eram comestíveis, tais como o gengibre ou o gergelim, disseminaram-se rapidamente em solo brasileiro, seja visando o lucro de sua venda, seja por serem saborosos e convenientes, seja pelos acasos da carreira das Índias, pois, muitos navios a caminho do Extremo Oriente, ou na volta do périplo longínquo, invernavam em Salvador para consertar avarias ocorridas durante a viagem ${ }^{543}$. De forma semelhante, raízes de mandioca, amendoins, pimentas locais , cajus, etc., foram levados do Brasil para outras plagas, no decorrer do amplo processo de disseminação de homens e de espécies naturais iniciado com as Grandes Descobertas do período Moderno ${ }^{544}$.

Algumas espécies vegetais, entretanto, não frutificaram no Brasil, como as oliveiras, ou, não granaram de modo uniforme, dificultando o trabalho da colheita, como o trigo ou as uvas (mas, no planalto da capitania de São Vicente, os paulistas conseguiram obrigar cativos indígenas a

542 MORENO, Diogo de Campos. Livro que dá Razão do Estado do Brasil. Recife, Arquivo Público Estadual, 1955. p. 140.

543 LAPA, José Roberto do Amaral. A Bahia e a Carreira da Índia. São Paulo, Ed. Nacional/EDUSP, 1968. pp. 22 e 23.

544 BOUDAN, Christian. Géopolitique du goût: la guerre culinaire. Paris, PUF, 2004. 
cultivar trigais). Lutar constantemente contra o apetite das formigas saúvas também inutilizou os esforços de diversos imigrantes para reproduzir nas hortas e nos pomares do novo meioambiente, todos os frutos e frutas familiares do Velho Mundo.

Faltou justamente aos moradores lusos do Brasil conseguirem produzir localmente o trio principal da alimentação pátria, base das dietas alimentares mediterrâneas: farinha de trigo, vinho e azeite ${ }^{54}$. Por conseguinte, os colonos aderiram a um consumo cotidiano de farinha de mandioca e de beijus, transformados em pão da terra e mantimento ordinário. Todavia, a substituição de produtos fundamentais na dieta de origem por gêneros obtidos localmente sem muitos esforços e dispêndio, não excluiu o gosto por gêneros cujo valor não era apenas gustativo, mas envolvia memórias, tradições e possuía ainda um forte apelo litúrgico. $\mathrm{Na}$ medida em que a prosperidade do açúcar brasileiro passou a atrair um maior número de naus lisboetas, o provimento da colônia em gêneros europeus que suportavam a travessia atlântica sem deterioração excessiva, deixou de ser o problema premente dos primórdios da colonização. As hóstias, o pão, o vinho de missa e de mesa, o azeite e o sal, continuaram a sustentar o catolicismo da população e passaram a singularizar o consumo dos homens abastados.

Talvez a dieta praticada pelos colonos não fosse, em Salvador e adjacências, a dieta referencial ${ }^{546}$ carregada de memórias e de tradições que eles apreciariam saborear, uma dieta composta de ingredientes conhecidos na Europa, aprestados segundo preparos culinários carregados de saudades e marcados por um viés simbólico de identificação pessoal. Contudo, essa dieta parecia se aproximar suficientemente do ideal almejado para ser aceita sem grandes tormentos de consciência, sobretudo no caso de imigrantes recentes, pobres, que nem sempre dispunham de fartura alimentar em Portugal.

As poesias de Gregório de Matos, ao apontarem problemas de provimento alimentar e mencionarem os ingredientes mais freqüentes na dieta colonial, atestavam a realidade de muitas práticas. Será argumentado no presente capítulo como não houve então nenhuma ruptura 545 MELLO, Evaldo Cabral de. Nas fronteiras do paladar, in Folha de São Paulo. Caderno Mais, $28 / 5 / 2000$.

546 Diferenciação percebida em função dos dados observados durante a pesquisa. 
drástica com uma maneira lusa metropolitana de conceber a alimentação. Apenas aconteceu uma carência local de espécies vegetais que não se deram bem com o clima brasileiro e foram substituídas por vegetais locais.

A incorporação à dieta de novos ingredientes comestíveis resultou sobretudo numa ampliação do elenco dos produtos guisados à moda portuguesa. O único fenômeno digno de nota verificado parece ter sido a transformação de alguns alimentos lusos, que suportavam razoavelmente a viagem ultramarina, em itens custosos que eram oferecidos aos hóspedes de marca e que conferiam prestígio, tanto aos comensais, quanto aos anfitriões.

\section{A carne}

Os versos de Gregório de Matos permitem perceber a carne como o principal ingrediente desejado pelos mazombos, tanto no espaço urbano, quanto nas propriedades agrícolas do Recôncavo. Panelas de cozidos, preparadas à moda portuguesa com hortaliças, legumes e carnes eram iguarias de forte presença nos versos do poeta. Poucas vezes, porém, a presença empírica de vegetais nos preparos das refeições coloniais foi especificada pelo autor. Matos não fazia exceção à regra e, como se verá mais adiante, quando dizia preferir bocadinhos caseiros de carnes em lugar de iguarias de peixes.

Todos na colônia sonhavam em comer carne: a população que residia nos canaviais ou nos engenhos, os lavradores das terras nas quais o algodão e o tabaco se transformavam em mercadorias valiosas, ou daquelas que produziam frutas em pomares extensos, os proprietários de engenhocas (alambiques) que transformavam o melaço em aguardente, os lavradores que cultivavam roças de mantimentos e supriam a capitania com mantimentos e víveres de farinha de mandioca, de arroz, de legumes ou de hortaliças. Segundo Antonil: 
“O certo é que não somente a cidade, mas a maior parte dos moradores do recôncavo mais abundantes, se sustentam nos dias não proibidos da carne do açougue, e da que se vende nas freguesias e vilas..." ${ }^{547}$.

Apesar das dificuldades do provimento, a população colonial ansiava pelo consumo de carnes. Refeições sem iguarias de carne eram consideradas tristes. As Atas da Câmara Municipal de Salvador confirmavam a preferência. O principal problema do abastecimento em reses para o corte e em animais de tiro, na capital e na área rural do Recôncavo, residiu no translado de boiadas do sertão, onde grandes rebanhos eram criados, até o litoral onde os animais se faziam imprescindíveis. Antonil, em Cultura e opulência do Brasil, detalhou a dificuldade do transporte e da comercialização desses animais. Deslocada para o sertão e situada em localidades de águas e pastos fartos, os criadores não tinham o fornecimento de carnes como seu único propósito. A colônia exportava muitos couros do tipo meia-sola, explicava Antonil ${ }^{548}$. Os rolos de tabaco também vendiam-se encourados, sendo que as caixas de açúcar exportadas costumavam ser forradas internamente com couros para proteger seu conteúdo da umidade.

Os bois, além do mais, eram essenciais às atividades econômicas. Lavradores de canas, de tabaco, de mandioca, lenhadores e serrarias dependiam de animais de tiro para puxar os carros e, fator não menos importante, nos lugarejos onde não era possível construir moendas acionadas por rodas d'água, eram bois que moviam as moendas. Em compensação o aproveitamento dos laticínios afigurou-se mínimo. Nem sempre era fácil conciliar os interesses da pecuária e das criações litorâneas com aqueles da produção açucareira como explicitou Antonil:

“As cabras, tanto que a cana começa a aparecer fora da terra, logo a vão investir; os bois e os cavalos, ao princípio, lhe comem os olhos e depois a derrubam e a pisam. [...] E, posto que os lavradores se acomodem de qualquer modo a sofrer os

\footnotetext{
547 ANTONIL. André João. Cultura e opulência do Brasil. São Paulo, Ed. Nacional, 1967. p. 310.

$548 \quad$ ANTONIL. Op. Cit., pp. 307 a 313.
} 
furtos pequenos dos frutos do seu suor, vêem-se às vezes obrigados, de uma justa dor, a matar porcos, cabras e bois, que outros não tratam de divertir e guardar nos pastos cercados, ou em parte mais remota ainda, depois de rogados e avisados que ponham cobro a êste dano; donde se seguem queixas, inimizades e ódios, que se rematam com mortes ou com sanguinolentas e afrontosas vinganças" ${ }^{549}$.

Durante a maior parte do ano (períodos de forte estiagem ou de chuvas abundantes excetuados), boiadas (comportando, às vezes, cem ou trezentas cabeças de gado) chegavam diariamente do sertão e eram tangidas até os currais de Capuame, a cerca de oito léguas de Salvador, para que as reses se refizessem ali do cansaço da viagem. Dependendo do local de procedência, situado a quinze, vinte ou mais léguas da cidade e dos pastos e rios encontrados ou não pelo caminho, a viagem comportava jornadas diárias de 4 ou 6 léguas diárias (entre 28 a 42 quilômetros) ou prosseguia marchando de dia e de noite. Na chegada, os bois esgotados, valiam já entre quatro e cinco mil réis e precisavam passar de 4 a 6 meses nos pastos para refazerem as forças. Se atrelavam-nos antes do prazo aos carros, exigindo-se deles tarefas demasiadamente penosas, morriam em grande número ${ }^{550}$. Por essa razão os marchantes, que compravam reses destinadas ao corte no Capuame, procuravam fornecê-las sem tardar aos currais de abate, provendo à população, para lucrarem mais, animais magros e, por vezes, doentes. Era grande, por conseguinte, o gosto dos colonos por animais de carne gorda considerada mais saudável e saborosa $^{551}$. O ápice da vida escolástica lusa, tanto no colégio dos jesuítas em Salvador, quanto na Universidade de Coimbra, incluía segundo o poeta mazombo incluía "comer boi" e "furtar

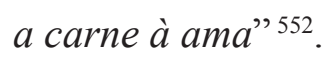

\footnotetext{
549 ANTONIL. Op. Cit., p. 178.

$550 \quad$ ANTONIL. Op. Cit., p. 182.

551 ATAS da Câmara, $1669-1684,5^{\circ}$ e $6^{\circ}$ volumes, Salvador, Prefeitura do Município do Salvador. 1950 e
} 1952. Documentos históricos do Arquivo Municipal. (Os dois volumes correspondem ao período da permanência soteropolitana de Matos).

552 MATOS, G. Op. Cit., Vol. I, p. 4. 
As carnes de uso comum na colônia eram aquelas que Matos assinalava por ocasião do entrudo: "galinhas, porco, vaca e mais carneiro" e também "perus em poder do Pasteleiro" ${ }^{553}$. A preferência parecia ir para a carne de vaca fresca (dita verde), porém, as carnes salgadas e as carnes-secas, facilitando provimento e armazenamento, não tardaram a se tornar também mantimentos de uso generalizado. Como bem observou Paula Pinto e Silva ${ }^{554}$, o clima seco do sertão onde o gado era criado, revelou-se altamente favorável à produção de carne-seca, que dispensava o uso do sal, ao transformar finas mantas de carnes expostas ao sol, num item comestível facilmente transportado e conservado por longo período de tempo.

Entre as carnes colocadas à disposição dos colonos, além da carne salgada ou da carneseca, os fiambres mereceram também, na obra de Matos, uma presença notável. Preparados em Portugal esses gêneros vinham embarcados nos porões dos navios de comércio. Os colonos apreciavam também sobremaneira as carnes de porcos e de cabritos. Matos, com efeito, ao se despedir do engenho de Pernamirim, versejou: “Adeus vizinhas do pasto/que na varanda de cima/nos mataram a marrã/e a comemos de rebimba" ${ }^{n 55}$.

O amigo, Tomás Pinto Brandão respondeu a esses versos do poeta com outros que aludiam às mesmas peripécias dessa permanência memorável num engenho acolhedor: "Não vou de Pernamerim,/sem ver por essas cozinhas/penduradas as marrãs,/e às cabritas as cabritas" ${ }^{556}$. Torresmos deviam igualmente fazer parte do cotidiano alimentar ${ }^{557}$.

553 MATOS, G. Op. Cit., Vol. III, p. 580.

554 SILVA, Paula Pinto e, Farinha, feijão e carne-seca: um tripé culinário no Brasil colonial, São Paulo, Senac, 2005. p. 107.

555 MATOS, G. Op. Cit., Vol. VI, p. 1406. O termo rebimba não consta no Diccionario da lingua portuguesa de Antônio Moraes.

556 ATOS, G. Op. Cit., Vol. VI, p. 1417.

557 MATOS, G. Op. Cit., Vol. VI, p. 1474 - Ao satirizar uma mulata, que o enfurecera, o autor mencionou sua pele cor de torresmo (cf. capítulo II da tese). 
Rocha Pita, por sua vez, assinalava a presença de grandes criações do gado dito miúdo, nas propriedades da área rural:

"Do menor é grande a criação, porque não há morador dos termos ou recôncavos, que o deixe de ter em tanto número, quanto lhe baste para o seu regalo e para o seu interesse, mandando-se buscar das povoações para comida, mimos e matalotagens ${ }^{558}$. São excelentes os capados, que se sustentam e criam com a mandioca, e alguns chegam a ter de peso doze e quatorze arrobas; tenríssimos os leitões, saborosos e grandes os carneiros, brandos os borregos, mimosos ou saudáveis os cabritos" $" 559$.

Às quartas-feiras, sextas-feiras e ainda aos sábados, a Igreja recomendava abstinência da carne de quadrúpedes de sangue quente. Nas vésperas de festas recomendavam-se jejuns mais severos. Nos meses que antecediam à Páscoa, os colonos, como bons portugueses católicos se resignavam a comer uma dieta considerada frugal de peixes e frutos do mar regados com azeite. Segundo Rosemeire B. Lorimer, durante cerca de 68 dias por ano ${ }^{560}$ não se podia abater reses ou adquirir carne na cidade. Outros autores mencionavam cerca de 150 dias de

558 Matalotagem: provisões embarcadas destinadas a alimentar os passageiros e a tripulação das embarcações.

559 PITA, Sebastião da Rocha. História da América portuguesa. p. 32, parágrafo 62.

560 LORIMER, Rosemeire Bertolini. O impacto dos primeiros séculos de História da América Portuguesa na formação da brasilidade alimentar. Tese de Doutorado apresentada ao Departamento de Nutrição da Faculdade de Saúde Pública da USP, São Paulo. 2001. p. 63. "Somados a isso estavam os muitos dias de jejuns compulsórios, 68 no total, determinados pela Igreja, (que, consciente ou inconscientemente, regulava o consumo de alimentos disponiveis)". 
jejum anuais ao incluir no rol dos dias de sacrifício as vésperas de dias santos e a quaresma ${ }^{561}$. Privações sentidas de carne traduziram-se em palavras na escrita poética do autor. Durante uma quaresma, por exemplo, Gregório de Matos, que estava na Cajaíba, chegou a sonhar com iguarias de carne de caça: "Vem chegando-se a Páscoa, e se eu me empasco,/os lombos de um Tatu é o pão, que busco" ${ }^{" 562}$.

Em tais momentos era melhor se resignar a comer peixes. Mas por vezes até mesmo o peixe se tornava inacessível: "pois querendo mandar-me um/vermelho uma Freira guapa/vós me destes sem ser paga/êsse dia de jejum" "563.

Os poemas de Matos atestavam além de caças aos tatus, a perseguição, considerada hilária, de uma porca selvagem ${ }^{564}$ (dita javali, que devia ser um caetetu ou uma queixada branca). Rocha Pita, por sua vez, citava um rol mais amplo de animais caçados:

"Das caças quadrúpedes silvestres há veados, capivaras, coelhos, cutias, quatis, perias, teús, tatus e pacas; estas, posto que nocivas para a saúde, têm a carne superior no gosto a todas as do Brasil" ${ }^{965}$.

561 MONTANARI, Massimo. A fome e a abundância: História da alimentação na Europa. Bauru, EDUSC, 2003. pp 102 e 103.

“A esta sociedade de 'carnivoros' (com todas as distinções e precisões pertinentes) a norma eclesiástica impunha a abstenção de carne por aproximadamente 140 - 160 dias ao ano. Era uma forma de renuncia - cuja importância como já tivemos oportunidade de observar, confirma, indiretamente, o papel central da carne no sistema alimentar da época - difundida havia muitos séculos no meio cultural cristão: no início a praticavam, sobretudo os monges, como escolha individual ou como observância de uma regra; depois o 'modelo' alargara-se para toda a sociedade, fortalecido e consolidado pelas prescrições das autoridades eclesiásticas, que reservaram alguns dias da semana (em particular a quarta e a sexta feira; depois somente esta última) e certos dias ou períodos do ano: vigília de festividades, grandes e pequenas Quaresmas (além da pascal havia três 'menores', de diferente duração de acordo com os costumes locais)".

562 MATOS, G. Op. Cit., Vol. VI, p. 1400.

563 MATOS, G. Op. Cit., Vol. IV, p. 872.

564 MATOS, G. Op. Cit., Vol. III, pp. 593 a 598.

565 PITA, Sebastião da Rocha. Op. Cit., p. 33, parágrafo 65. 
De fato, a ter escolha entre carnes e peixes, a preferência da população mazomba ia para o consumo de carnes, mas, por mais que gostassem de carnes, os colonos, entre ceias e dias magros, dependeram muito do provimento pescado. Enunciando com segurança uma verdade sabidamente compartilhada pelos colonos, o poeta reiterou em diversas poemas:

"e com ser dia de peixe,/sem que a consciência se queixe,/todos gostamos da vaca" ${ }^{566}$.

“ouvi dizer em um dia/(e é rifão dos Mazombos)/que a carne é, que cria os lombos/ e não peixe de água fria" ${ }^{567}$.

O doutor Mirandela apreciava também a carne dos quadrúpedes:

“De quantos alimentos se compõem as mesas, a carne é o que mais nutre; e entre as carnes as dos quadrúpedes, porque são mais sólidos, mais duros e de mais substância que os outros animais; e por isto as suas carnes são de mais difícil cozimento; que tudo o que nutre muito, coze-se mais devagar no estômago, assim como se coze depressa o que nutre pouco" ${ }^{568}$.

Energia, saúde e sensualidade costumavam ser associados ao consumo dessas carnes. Lorimer citando Rieira-Melis enfatizou:

"No imaginário coletivo da época [séculos XII e XIII] , a alimentação abundante e sobretudo a quantidade de carne continuam sendo símbolo do poder, de fonte de

566 MATOS, G. Op. Cit., Vol. III, p. 600.

567 MATOS, G. Op. Cit., Vol. VI, p. 1534.

568 HENRIQUEZ, Francisco da Fonseca. Op. Cit., p. 91. 
energia física, de potência sexual e representam uma das principais manifestações de alegria de viver e da felicidade" ${ }^{569}$.

Agradecendo à Susana a cortesia de uma iguaria de peixe, Matos gracejou certa vez:

"Se sois a Susana mesmo/de juizo acreditado,/como imitais o pecado, com manjares de quaresma".

No mesmo poema, o autor solicitava: "Mandai me de carne um pouco/as galinhas, as posturas/ [...]./Eu tenho grande jactância/de dar minha sustância a quem sustância me dá" ${ }^{570 .}$ Dedicando versos a outras mulheres, o poeta, por diversas vezes, expressou idéias semelhantes: "Porque estáveis vós então/com tanta declinação/de carnes e de saúde,/que nunca convosco pudelfazer minha obrigação" 571 .

Metáforas voltadas para o sexo, associadas ao consumo de carnes se repetiram no conjunto da obra, associando ôlhas (ou vasos) e órgãos sexuais masculinos apreciadores de carne crua 572 , ou de cozidos apimentados: "se não sempre sois mulher, /que na cabeça vos entre/ser justo, se reconcentre/minha carne em vossa olha" ${ }^{573}$.

569 RIEIRA-MELIS, A. "Sociedade feudal e alimentação (séculos XII e XIII)", in FLANDRIN Jean-Louis e MONTANARI, Massimo (org.) História da alimentação. São Paulo, Estação Liberdade. 1998.

LORIMER, Rosemeire B. Op. Cit., p. 110.

LE GOFF Jacques e TUONG, Nicolas. Uma história do corpo na Idade Média. Rio de Janeiro, Civilização Brasileira, 2006. pp. 133 e 134. "A tensão que atravessa o corpo no Ocidente medieval permanece viva apesar de tudo. É pelo corpo que passam a penitência e o ascetismo, a mortificação e os jejuns. Um dos piores pecados é a gula (a goela), quase sempre associada à luxuria".

570 MATOS, G. Op. Cit., Vol. VI, p. 1533.

571 MATOS, G. Op. Cit., Vol. VII, p. 1574.

572 MATOS, G. Op. Cit., Vol. V, p. 1195.

573 MATOS, G. Op. Cit., Vol. V, p. 1201. 
Muitas vezes os escravos também sentiam falta de comer carnes, tanto na área rural, quanto na capital. As quantidades e a qualidade da alimentação, que lhes foi fornecida, parecem ter dependido bastante da vontade dos proprietários. Mas, de uma forma geral, o aporte de proteínas e matérias graxas em sua dieta deve ter sido insuficiente. O Dialógo das grandezas do Brasil, escrito por volta de 1618, assinalava um tipo de ocorrência freqüente:

“Começarei pelo netunino, ligeiro e belicoso cavalo, dos quais, posto que há muitos, abundara inumerável quantidade nestes campos americanos, em tantos que nos de Buenos Aires se não criara tanta cópia deles, mas têm cruéis inimigos que os perseguem com lhes tirarem a vida; os quais são os escravos de Guiné, que os matam sem reparo, para os haverem de comer, em qualquer parte que os acham, e ainda aos regalados e de muito preço furtam nas estrebarias, onde estão, para o mesmo efeito" ${ }^{574}$.

Avaliava-se de modos diversos o valor nutritivo e o sabor dos diferentes tipos de carnes, como poderá ser visto mais adiante, mas a questão mais premente relacionada à obtenção de carnes nos açougues residiu na qualidade, às vezes duvidosa, da carne das reses abatidas para alimentar a população urbana.

\section{Os peixes}

Apesar de serem alimentos menos valorizados que as carnes, peixes, crustáceos e moluscos eram nutrientes disponíveis na colônia. Ao entardecer, escravos pescadores e negrinhas mariscadeiras voltavam à cidade ou aos engenhos carregados de peixes, polvos e lagostas, comidos nas ceias. Além de referências metafóricas clássicas, possivelmente desvinculadas das práticas às mesas coloniais soteropolitanas, como no caso dos arenques, os versos de Matos brincavam com um rol restrito, mas interessante, de espécies comestíveis consumidas na região: 
"O que te vir ser todo rabadilha/Dirá, que te perfilha/Uma quaresma (chato percevejo)/Por Arenque de fumo, ou por Badejo:/Sem carne, e osso, quem há ali, que creia,/Senão que és descendente de Lampreia" ${ }^{\circ 75}$.

Além do bacalhau, produto salgado enviado de Lisboa ${ }^{576}$, também amplamente citado nos poemas, tanto por seu consumo corrente quanto pelas alusões obscenas que propiciava, uma lista representativa de peixes comidos na capital do Brasil e seus arredores mereceu comentários do poeta, mais interessado em expor queixas de modo satírico ou burlesco que em descrever uma fauna marinha, bem conhecida pelos conterrâneos. Arraias chatas e curimãs ovadas $^{577}$,

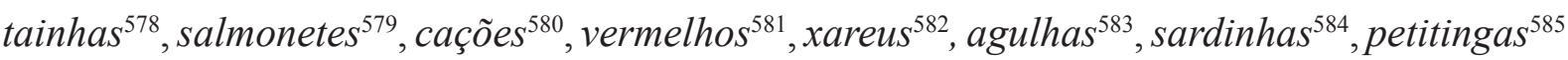
,(sob forma de moqueca provavelmente preparada à moda indígena), manjubas ${ }^{586}$, traíras $^{587}$,

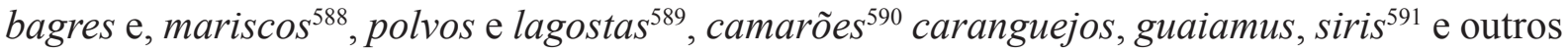

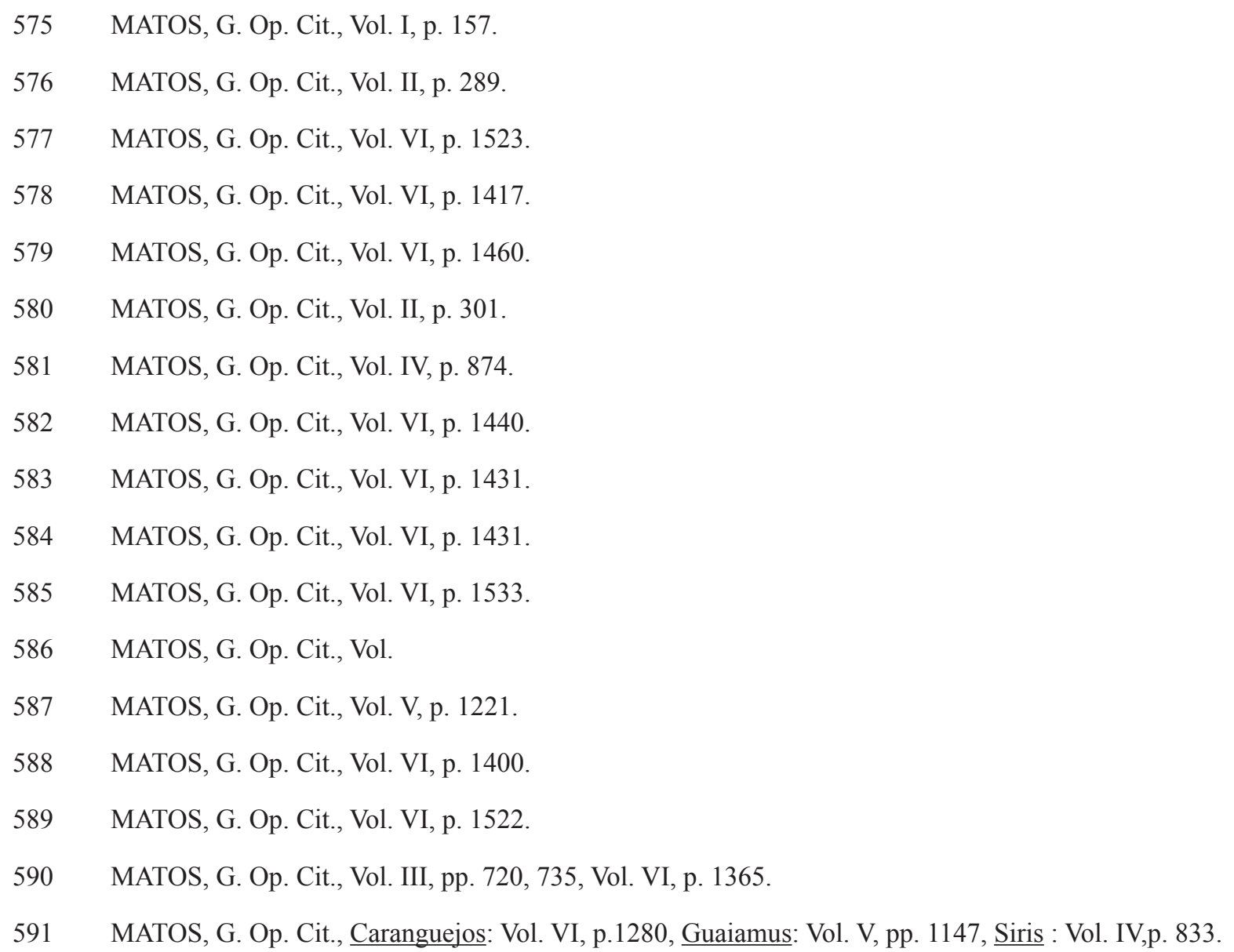


animais, hoje abrangidos na categoria dos frutos do mar, freqüentaram os versos de Matos. Num poema jocoso Matos até citou entre as iguarias, o baiacu, peixe cujo fel era veneno letal. Rocha Pita, no caso, mais prolixo que o autor (e menos extenso que Piso e Marcgrave), assinalou a pesca de espécies assemelhadas às européias, que podiam ser capturadas nas águas da colônia:

"linguados, sáveis, tainhas, pescadas, salmonetes, robalos, meros, arraias, cações, galos enxarrocos, voadores, carapaus, chernes, sardos, corvinas, agulhas e sardinhas".

Havia ainda espécies nativas, diversas dos peixes europeus, entre as quais os colonos classificavam então as baleias. Dos peixes locais o estudioso assinalava:

“beijupirás, cavalas, garoupas, vermelhos, corimás, pâmpanos, carapebas, parus, ubaranas, guaracemas, jaguaraçás, camoropins, olhos-de-boi, dourados, exaréus; este último, ainda que muito vulgar pela sua quantidade, merece especial notícia pela grandeza de sua pescaria, e por ser o sustento dos escravos e do povo miúdo da Bahia" ${ }^{992}$.

Manuel Botelho de Oliveira, por sua vez, ao citar pescados e mariscos comidos na Ilha de Maré, enumerou encantado:

“Aqui se cria o peixe regalado/Com tal sustância e gosto preparado/Que sem tempero algum para apetite/Faz gostoso convite/E se pode dizer em graça rara/Que a mesma natureza os temperara./Não falta aqui marisco saboroso/Para tirar fastio ao melindroso/Os polvos radiantes/Os lagostins flamantes,/Camarões excelentes,/ Que são dos lagostins pobres parentes./Retrógrados caranguejos,/Que formam

592 PITA, Sebastião da Rocha. Op. Cit., p. 34, parágrafo 70. 
pés das bocas com festejos./Ostras que alimentadas/Estão nas podras onde são geradas;/Enfim tanto marisco que não falo/Que é vário perrexil para o regalo"593.

Matos foi muito menos prolixo que outros autores a respeito do consumo de pescados. Em seus poemas a riqueza em fauna marinha do terroir ${ }^{594}$, isto é, o provimento em peixes, crustáceos e moluscos disponíveis nas águas do Recôncavo ou em mar aberto, compareceu antes sob forma de valores simbólicos associados ao consumo de algumas espécies animais que aos procedimentos da pesca ou da cozinha propriamente ditas. Todavia, ocasionalmente os comentários permitem entrever propriedades atribuídas a certos peixes ou preferências de gosto: "Na praça comerei um salmonete singular,/e aqui não quero trocar/a Cioba pelo Atum"595. De forma que os indícios de consumo encontrados nos versos foram complementados com dados provenientes de textos de outros autores do período.

O salmonete que Matos pretendia degustar na praça da Vila de São Francisco, defronte à ilha da Cajaíba, era peixe estimado, segundo Mirandela ${ }^{596}$, por sua carne friável e facilmente digerida, mesmo que um tanto dura. $\mathrm{O}$ poeta podia subentender ali, seja realmente um salmonete pescado, seja seu equivalente feminino a ser comido do outro lado do rio Serigi-mirim.

Quanto ao atum, a referencia metafórica comparando as qualidades físicas de duas moças se explicava. Piso, médico de Maurício de Nassau, que governou o Brasil holandês entre 1637 e 1644, considerava relativamente perigoso o consumo de atum (ou albacora) pelo fato da carne se apresentar dura e compacta. Ele aconselhava temperá-la para torná-la mais digestível: "Se

593 OLIVEIRA, Manuel Botelho de. Op. Cit. pp. 111 a 122. Repare-se de passagem o uso do perrexil, uma erva cheirosa quente e seca que costumava condimentar os preparos, tanto para aprimorar o sabor dos pratos preparados, quanto para aquecer um ingrediente demasiadamente frio, e portanto perigoso, da dieta. Matos também referiu-se ao mesmo ingrediente na mesma acepção.

594 O terroir, termo francês sem equivalente exato em português, designando os recursos regionais de um território, cujo meio-ambiente proporciona um conjunto de produtos de qualidade reconhecida, incentivando à criação culinária e à fixação dos preparos considerados mais saborosos.

595 MATOS, G. Op. Cit., Vol. VI, p. 1460.

596 HENRIQUEZ, Francisco da Fonseca. Op. Cit., p. 134. 
for condimentada e como a da carpa servida com condutos aromáticos, antes de adulto o peixe, não é desprezado pelos paladares um tanto esquisitos" $" 597$.

O papel atribuído aos condimentos era de facilitar a digestão dos alimentos. Comentando a maneira saudável dos indígenas consumirem seus peixes, o cientista relatava:

"Se percebem que beber água não basta para a digestão do alimento um tanto cru, mormente peixes, preparam um pó com sal e um pouco de pimenta brasileira denominada Iuquitaja e daí conseguem um condimento muito saudável ao estômago e com boa razão levado em todas as viagens" ${ }^{\prime 598}$.

O doutor Mirandela também acreditava no caráter indigesto de peixes de carne sólida e dura. Falando do atum afirmava:

“coze-se com muita dificuldade, geram-se dele humores crassos, terrestres e melancólicos. O seu ventre é muito pingue e, por isto, subverte o estômago, causa náuseas e fastios. As partes pingues e oleosas do atum convertem-se em cólera e causam muitas vezes dores de cólicas. Não se deve dar a pessoas delicadas e que vivem sedentariamente, senão a homens robustos, trabalhadores e exercitados. O atum seco e salgado é mais duro que o fresco, coze-se com mais dificuldade no estômago, mas de qualquer modo que seja, se se cozer bem, nutrirá muito" 599 .

Nos versos de Matos bacalhau e sexo foram reiteradamente associados, indicando indiretamente a popularidade do produto que continuou a ser importado pelos colonos, a despeito

597 PISO, Guilherme, História natural do Brasil. São Paulo, Companhia Ed. Nacional, 1948. p.179.

598 PISO, Guilherme, Op. Cit., p. 62.

599 HENRIQUEZ, Francisco da Fonseca. Op. Cit., p. 140. 
da abundância inconteste e da facilidade da pesca local. O Doutor Mirandela foi extremamente preciso em sua avaliação desse peixe:

"O bacalhau, que é uma espécie de pescada, mais duro e de pior alimento que ela, coze-se com dificuldade, gera humores melancólicos e mal depurados das suas partes excrementícias. É o alimento dos pobres e dos rústicos e próprio para pessoas que trabalham e se exercitam muito. Não se deve usar em pessoas delicadas, nem nas que passam vida sedentária" ${ }^{600}$.

Outra oposição flagrante entre peixes diversamente apreciados ressaltou numa comparação entre bagre e xaréu. Também referia uma troca de amantes: "eu deixo como sabeis,/um bagre por um xaréu" ${ }^{\prime 61}$. Visivelmente os bagres não eram tidos em alta conta, mas a acidez do vinagre não deixou de interferir na composição das alusões metafóricas. Ao satirizar um rapaz Matos afirmou: "Não me espanto não da perda/que então teve o tal vinagre,/porque como o moço é bagre/se havia de ir logo à merda:" ${ }^{602}$. Noutro poema com epílogos, onde expressava seu ciúme em relação a um rival, Matos rimou ainda: "Lá tem o amigo vinagre bagre" 603 .

Segundo o doutor Mirandela, o vinagre, condimento de natureza fria e seca, convinha muito aos alimentos por sua virtude de excitar o apetite, de dar vigor ao ácido do estômago e de auxiliar o processo da digestão. Existia uma associação mais estreita entre vinagre e bagre que a rima fácil. Condimentações com vinagre acompanharam efetivamente o preparo de diversos peixes considerados difíceis de serem digeridos, entrando por exemplo, a par das folhas de louro, no preparo de escabeches.

Peixes miudinhos ou de poucas carnes e crustáceos saborosos, mas pouco substanciosos, também ornamentaram com subentendidos picantes os poemas de Matos:

600 HENRIQUEZ, Francisco da Fonseca. Op. Cit., p. 138.

601 MATOS, G. Op. Cit., Vol. VI, p. 1440.

602 MATOS, G. Op. Cit., Vol. VI, p. 1438.

603 MATOS, G. Op. Cit., Vol. VI, p. 1431. 
"Que lhe dão tão fracas linhas? Sardinhas/Nenhuma coisa mais quis?

Siris/Por tão pouco tantas bulhas? Agulhas./Eucreio, que isto são pulhas, /que negra de entendimento/não toma por pagamento? Sardinhas, Siris e Agulhas" ${ }^{\circ 04}$.

As sardinhas, segundo o doutor Mirandela, eram peixes de excelente sabor, mas de mau cozimento, por terem carne demasiadamente oleosa:

"geram-se delas humores salsuginosos, de muita acrimônia e mordacidade. As sardinhas frescas ainda são piores que as salgadas, porque têm mais gordura e umidade, que o sal lhes desseca. É o peixe que melhor sofre o sal. E depois de salgada dura dois anos sem corrupção" ${ }^{605}$.

No caso dos peixes-agulha Piso especificava:

“Tem a carne sêca, sem espinhos, bom sabor mormente fritos na frigideira, com óleo ou manteiga. Pela pouca quantidade de carne, é excluido da mesa dos ricos" ${ }^{\circ 06}$.

Quanto às atividades do mariscar, agarrar crustáceos e mariscos, exigiam um contato desagradável com lama e lodos e bastante destreza, mas não necessariamente grande dispêndio de força. Resultaram numa fonte de provimento alimentar especialmente farto e saboroso nas vilas do Recôncavo. A acreditar-se o testemunho de Gregório de Matos, foi atividade especificamente reservada às escravas jovens, negrinhas mariscadeiras e constituía uma tarefa desabonadora para homens:

604 MATOS, G. Op. Cit., Vol. VI, p. 1431.

605 HENRIQUEZ, Francisco da Fonseca. Op. Cit., p. 150. Segundo o glossário anexo à obra (pp. 287 a 292) "Salsuginoso: Que tem salsugem, humor salgado".

606 PISO, Guilherme, Op. Cit., p. 156. 
"Siris nem moles, nem duros/tocam a tão alta saia,/que isto de ir servir à praia, são serviços de monturos:/lavar serviços impuros, como é o serviço do mar,/isto mesmo é mariscar,le as negrinhas desta Ilha/mariscam por maravilha/só por nos maravilhar. // Se quis êsses bons siris,/que não lhes nego a bondade, bem sabe a minha vontade,/que os há cá muito gentis:/e se por lisonja o fiz,le os pedi por agradar,/a quem tem gôsto de os dar,/agora me emendarei,/e jamais os pedirei/às Negras de mariscar" ${ }^{607}$.

Stuart Schwartz, que analisou uma revolta de escravos no engenho de Santana, ocorrida no Sul da Bahia, em Ilhéus, em 1789, analisou as reivindicações dos amotinados. Entre as condições solicitadas em prol da paz, além de pedirem as sextas-feiras e os sábados livres para cultivarem suas roças, os rebeldes afirmavam categoricamente:

"Não nos hade obrigar a fazer camboas, nem amariscar, e quando quizer fazer camboas e mariscar mande os seus pretos Minas. Para o seu sustento tenha Lanxa de pescaria o canoas do alto, e quando quiser comer mariscos mande os seus pretos Minas" ${ }^{608}$.

Semelhante depoimento confirmava a existência do preconceito que os versos do poeta insinuavam.

\section{A mandioca e/ou o trigo}

A farinha de mandioca, pela impossibilidade de se conseguir grandes quantidades de trigo na colônia, ocupou lugar de destaque na dieta como substituta do produto europeu escasso.

607 MATOS, G. Op. Cit., Vol. IV, pp. 833 e 834.

608 SCHWARTZ, Stuart. Escravos roceiros e rebeldes. Bauru, EDUSC. 2001. Cf. p.119. 
Preparos indígenas de raízes de mandiocas bravas, tóxicas ou preparos de aipins (macaxeiras), serviram de mantimento local complementando, no cotidiano, as reservas de farinha do reino armazenadas nos trapiches do cais, nas lojas da cidade ou nas despensas dos particulares abastados.

Cabe lembrar, a esse respeito, o apreço do primeiro governador-geral do Brasil, Tomé de Souza, pela mandioca. Em 1549, ao estabelecer uma capital da colônia às margens do Recôncavo, ele afirmava preferir produtos feitos de mandioca ao pão. Agradaram-lhe o gosto da raiz americana e suas propriedades digestíveis ${ }^{609}$. Naquele momento inaugural da colonização, o abastecimento em trigo ainda permanecia precário. A preferência alegada pelo primeiro governador soteropolitano e seus sucessores imediatos tinha muitas chances de ser de natureza política (o sacrifício de autoridades, dando o exemplo, teria o poder de calar resmungos dos descontentes). Havia menos engenhos produzindo açúcar, menos colonos prósperos, dispostos a gastar dinheiro para demonstrar a riqueza amealhada e um número menor de naus para efetuar a viagem anual até os principais portos da colônia. De forma que a possibilidade da panificação em larga escala somente começou com a prosperidade do açúcar. Rocha Pita, já nas primeiras décadas do século XVIII, afirmava:

"As capitanias do norte carecem de farinha de trigo, de que abundam algumas do sul, mas a comum e geral em todas é a da mandioca. Esta se planta com uns ramos, ou garfos, que em qualquer tempo (exceto nos meses de Abril, Maio e Junho, que são os do mais rigoroso inverno no Brasil) se metem na terra, chamados manaíbas, os quais lançam grossas raízes, que os doze até os dezesseis meses conforme os sítios em que se cultivam, de mais ou menos simpatia com esta planta as arrancam, e ralam em uma forma de engenho, que chamam bolandeira, e espremem em instrumentos de palha, que nomeiam tapitis, e logo as cozem em alguidares de barro

609 SOUSA, Gabriel Soares de. Tratado descritivo do Brasil em 1587. São Paulo, Cia. Ed. Nacional, 5 Ed., 1987. p. 180. 
ou de cobre, e fazem farinha dos gêneros e nomes que diremos, e umas delgadas e tênues fatias que suprem o pão, com o nome de beijus" $" 10$.

Ao adotarem a farinha de mandioca prensada e torrada e os beijus como ingredientes básicos da dieta local, os colonos quinhentistas selecionaram apenas alguns dos preparos que os índios conheciam. Esses produtos acabaram sendo promovidos à condição de mantimentos controlados e taxados pelas autoridades:

"Também costumam levar para o mar de matalotagem de beijus grossos muito torrados, que dura um ano, e mais sem sedanarem, como a farinha de guerra. Desta carimã e pó dela bem peneirado fazem os portugueses muito bom pão e bolos amassados com leite e gemas de ovos, e desta mesma massa fazem mil invenções de beilhós, mais saborosos que de farinha de trigo, com os mesmos materiais, e pelas festas fazem as frutas doces com a massa dessa carimã, em lugar da farinha de trigo, e se a que vai à Bahia do reino não é muito alva e fresca, querem as mulheres antes a farinha de carimã, que é alvissima e lavra-se melhor com a qual fazem tudo muito primo" 611 .

O processo da transformação da farinha seca ou farinha de guerra indígena, (alimento utilizado nas viagens ou nas expedições bélicas), em mercadorias manejadas de forma européia e concebidas de modos distintos, quando produzidas por lavradores de mantimentos ou pelos nativos, resultou numa diferença que parece ter escapado a muitos autores. A origem autóctone do preparo foi enfatizada pela maioria dos autores, de modo que permaneceu um tanto obliterada a mudança de perspectiva implicada na promoção de parte das iguarias indígenas à condição de mantimentos indispensáveis do sustento colonial.

\footnotetext{
610 PITA, Sebastião da Rocha. Op. Cit., p. 27, parágrafo 33.

611 SOUSA, Gabriel Soares de. Op. Cit., pp. 178 e 179.
} 
Os outros preparos indígenas que os colonizadores do Brasil experimentaram foram caracterizados por cronistas como Gabriel Soares de Sousa como luxos diários consumidos sobretudo por aqueles que dispunham de muitos escravos e podiam se dar o luxo de reservar alguns para thes proverem regalos supérfluos.

"O mantimento de mais estima e proveito que faz da mandioca é a farinha fresca, a qual se faz destas raizes, que se lançam primeiro a curtir, de que se aproveita o gentio; e os portugueses, que não fazem a farinha da mandioca crua, de que atrás temos dito, senão por necessidade. [...] a qual farinha fresca dura sem se danar cinco a seis dias, mas faz-se seca; e quem é bem servido em sua casa, come-a sempre fresca e quente" ${ }^{612}$.

Não foi constatado na leitura das fontes primárias nenhum repúdio luso ao consumo de tais iguarias, nem durante o século XVI, nem durante a primeira metade do século XVII.

Apesar de enfatizarem sobretudo o beneficiamento clássico das raízes raladas cruas, prensadas e peneiradas, produzindo uma massa cozida em fogo brando e acessoriamente farinha de tapioca, os cronistas do período relatavam também a confecção freqüente de uma farinha de carimã preparada com mandiopuba seca e pilada, isto é, de raízes de mandioca brava curtidas por alguns dias em água corrente até começarem a apodrecer. Tratava-se de outro procedimento que os índios tupi conheciam para eliminar o veneno contido nas raízes. Com a farinha de carimã os nativos engrossavam caldos chamados mingaus. Segundo Rocha Pita:

Da mandioca, que depois de posta em molho chama puba, feitos uns bolos cozidos e depois ralados, se faz em farinhas, que sovadas e amassadas em forma de pães e de fatias de biscoito, e cozidos em fornos, saem com admirável gosto, o mesmo feitio e perfeição que os do trigo" ${ }^{13}$.

612 SOUSA, Gabriel Soares de. Op. Cit., p. 176.

613 PITA, Sebastião da Rocha. Op. Cit., p. 27, parágrafo 34. 
Transformada em "pão da terra", a farinha de mandioca foi objeto de cuidados específicos por parte das autoridades coloniais. Encomendaram-se com antecedência aos produtores plantios de múltiplos de mil covas (era necessário cerca de um ano para que as raízes estivessem em ponto de ser colhidas, mesmo que, uma vez sazonadas, se conservassem intactas na terra por longos meses).

Depois de fabricadas, as farinhas eram transportadas pelos barcos da navegação de cabotagem, soltas ou colocadas em cestos: os sírios (ou círios), com capacidade estipulada ${ }^{614}$. No porto de Salvador taxavam-nas. Eram vendidas a peso de alqueire, ou por sírios. O cálculo das rações diárias necessárias à sobrevivência de um indivíduo era item de conhecimento geral. Media-se à punhos a quantidade de farinha necessária para cada refeição. Conforme Gregório de Matos repetia em diversos poemas, dois punhos bastavam para uma ração reputada satisfatória. Bons governadores cuidavam de "governar as farinhas". Tudo que dizia respeito a esse mantimento era concebido em termos de racionalização da produção, entretanto, poucos gêneros alimentícios se mostravam tão propensos às fraudes:

"Quem faz os círios mesquinhos? Meirinhos/Quem faz as farinhas tardas?

Guardas/Quem as tem no aposento? Sargentos. // Os círios lá vêm aos centos, /e a terra fica esfaimando,/porque os vão atravessando/Meirinhos, Guardas, Sargentos"615.

Nos versos de Gregório de Matos, se a farinha seca e os beijus, que podiam ser armazenados e conservados por um período de até um ano foram amplamente aceitos, outros tipos de preparos como mingaus e caldos de carimã, pareceram despertar rejeições antes inexistentes. A despeito 614 Segundo as Atas da Câmara Municipal, as farinhas que provinham das Vilas de Baixo, as localidades de Cairu, Camamu e Boipeba colocavam-se em cestos de 2 alqueires, enquanto as farinhas feitas nas localidades da margem sul do Recôncavo eram colocadas sem invólucro no fundo das lanchas ou das sumacas, sendo comercializadas soltas e vendidas por quartas, por meios alqueires ou por alqueires. In ATAS da Câmara, Op. Cit., $5^{\circ}$ e $6^{\circ}$ volumes (Diversas renovações de conchavos figuram nesses volumes retomando sempre os mesmos temas). 
de críticas ressentidas à gestão relapsa de governadores que negligenciaram o abastecimento colonial em farinha seca, o poeta, ao relatar consumos efetivos, mencionou antes um consumo de pão à moda européia do que a ingestão de farinha de mandioca como acompanhamento das refeições. Já no texto dos Diálogos das grandezas do Brasil, o colono Brandônio afirmava:

"não poucos [colonos] usam também de pão, que mandam amassar e cozer em suas casas, feito de farinha que compram do Reino ou mandam buscar às casas das padeiras, porque há muitas que vivem desse oficio. As mulheres se trajam muito bem e custosamente, e quando vão fora caminham em ombros de escravos, metidas dentro em uma rede. $" 616$.

Na obra do poeta, eram biscoitos feitos de pão cozido e depois ressecado que acompanhavam os cozidos. Serviam-se sopas de pão e leite no almoço matinal, sopas de pão e broa ou sordas de vinho e alho nos jantares. No dia de Todos os Santos, os colonos enviavam aos amigos presentes de "pão por Deus" ${ }^{617}$. Por ocasião do entrudo, comiam fatias (rabanadas fritas) de pão impregnadas com leite, ovos, açúcar e canela. Citavam-se ainda os brotes $^{618}$. A bordo de um navio pronto para levar para Angola um sacerdote degredado por ter se recusado a ser de bom grado capelão em Angola, Matos sugeria um cardápio irônico de: pão preto e vinho branco ${ }^{619}$.

Mas o próprio termo pão merece um segundo olhar. Piero Camporesi ${ }^{620}$, ao analisar a produção européia de pães durante a Idade Média, numa obra extremamente elucidativa,

616 BRANDÃO, Ambrósio Fernandes. Op. Cit., Diálogo sexto, p. 246.

MELLO, Evaldo Cabral de. Op. Cit., pp. 7 e 8.

617 DEL PRIORE. Mary Lucy. Festas e utopias no Brasil colonial.São Paulo, Brasiliense, 2002.

618 MATOS, G. Op. Cit., Vol. III, p. 711. “Outro vem, que casou em Moçambique,le vive co'a razão de vinho e brote, /que o Sogro deu e o Clérigo Cacique". Tratava-se de um pão de cor escura que, além de farinha de trigo, incorporava outras farinhas.

619 MATOS, G. Op. Cit., Vol. II, p. 299.

620 CAMPORESI, Piero. O pão selvagem. Lisboa, Editorial Estampa, 1989. 
assinalou a enorme variedade de qualidades de pães que era possível fabricar e a freqüência da adição de outras farinhas de menor custo durante a panificação e até de vegetais entorpecentes em períodos de carências extremas do provimento. O autor, assim como Braudel, assinalava também a existência de um controle do preço e do peso dos pães destinados às camadas menos favorecidas da população ${ }^{621}$. A farinha de mandioca seca, como mantimento principal dos colonos lusos, foi, por esse motivo, objeto de diversas medidas reguladoras promulgadas pelos administradores coloniais e de taxações específicas e rentáveis, que auxiliavam a arrecadar rendas para a gestão do bem comum da colônia.

Já por volta de 1586, Fernão Cardim atestava que os colonos tinham adquirido um domínio suficiente da farinha de carimã a ponto de elaborarem uma receita de pão de farinha de carimã, que "parece de trigo" ${ }^{22}$ e que, levando fermento, era misturada com certa proporção de farinha de milho ou de arroz.

\section{As leguminosas e os cereais}

Rocha Pita, às vezes mais prolixo que Matos, documentava:

"De outros grãos e legumes produz a nossa América em quantidade trigo, feijão, milho, favas, algumas ervilhas do reino, andus como elas na forma e melhores no gosto, mangalôs, mendobis, gengibre do qual se faz útil conserva, e serve de simples em vários mistos de doces e de guisados; batatas, inhames jerimus, carás brancos, roxos e de outras cores e castas, mangarás, mangaritos, tamataranas, remédio insigne para os enfermos de estilicídio ${ }^{623}$ e asma"624.

621 BRAUDEL. Fernand. Civilisation matérielle, économie et capitalisme, XV ème - XVIII ème Siècle. Tome I, Paris, Armand Colin, Livre de poche, 1979. pp. 112 a 156.

622 CARDIM, Fernão. Tratados da terra e da gente do Brasil. São Paulo, 1978. p. 46.

623 HENRIQUEZ, Francisco da Fonseca. Op. Cit.. Glossário, pp. 287 a 292. "Estilicidiosos: Sofrem de estilicídio, defluxo nasal, coriza".

624 PITA, Sebastião da Rocha. Op. Cit., p. 28, parágrafo 39. 
Segundo o doutor Mirandela:

"Legumes chamou Galeno às sementes cereais de que se não faz pão, ainda que se faça farinha. E costumam ser o mais comum alimento da gente rústica, posto que pela graça de seu sabor, também sobem muitas vezes a mesas nobres. Estes são as favas, as ervilhas, os grãos, as lentilhas, os feijões, os chicharos, os tremoços, o arroz e o gergelim. Todos eles são crassos, térreos, melancólicos, flatulentos, principalmente sendo verdes, por cuja causa se hão de temperar com condimentos e cebolas, como corretivo de seu pravo suco e da sua muita flatulência" ${ }^{25}$.

\section{O arroz}

Poucas referências ao cereal foram assinaladas nos versos do poeta. Mereceu reparo particular uma descrição metonímica do padre Damaso da Silva, desafeto particular do autor. Ele foi retratado num romance como tendo uma cara longa assemelhada a um fardo de arroz ${ }^{626}$, que seria a ração de um elefante. Crítica que poderia eventualmente levar a pensar na comercialização do produto sob forma de fardos.

Além desses detalhes, foram identificadas apenas três menções dignas de nota referentes ao arroz, no conjunto da obra do poeta. O amigo $\mathrm{Chico}^{627}$ tinha prometido que iria buscar Matos para alguma excursão náutica programada pela Baía de Todos os Santos mas, no dia marcado, faltou ao compromisso já que supervisionava o plantio de arroz em seus domínios, detalhe certamente verídico e que atestava o cultivo do cereal nas lavouras de mantimento sitas na costa sul do Recôncavo, entre as ilhas da Cajaíba e a ilha Grande.

\footnotetext{
625 HENRIQUEZ, Francisco da Fonseca. Op. Cit., p. 159.

626 MATOS, G. Op. Cit., Vol. II, p. 281.

627 MATOS, G. Op. Cit., Vol. VI, p. 1511 e 1512.
} 
No que diz respeito ao consumo, duas menções a preparos de arroz ressaltavam nos versos. Durante o entrudo ${ }^{628} \mathrm{o}$ arroz figurava entre as iguarias apetecidas, enquanto que, na visita feita a Domingos Borges em sua casa do Rio Vermelho, o anfitrião após uma olha imperial, mandou servir um repolho ensopado acompanhado de arroz de leite: "E houve repolho fatal/ensopado, e não de azeite/com pratos de arroz de leite e vontade garrafal"629.

Efetivamente, o mundo ibérico já tinha descoberto e adotado o arroz sob a dominação árabe e não deixou de consumi-lo após a reconquista do território. Entre as receitas lusas transcritas no final do século XVI pela Infanta portuguesa Dona Maria, neta do Rei D. Manuel I o Venturoso e esposa do duque de Parma, constou por exemplo uma receita de beilhós de arroz e outra de manjar branco, cujo preparo levava além de peito de frango cozido e desfiado, leite, açúcar e farinha de arroz. O manjar branco da princesa quinhentista, segundo informações de livros de receitas atuais, é preparo que continua a ser saboreado na Turquia.

Barthélemy Joly, conselheiro do rei da França que viajou pela Espanha em 1603 e foi recebido por anfitriões, que eram homens políticos ou eclesiásticos destacados, comeu ali diversas variedades de pratos de arroz de leite servidos na refeição diurna. Costumavam aparecer à mesa após as frutas refrescantes que iniciavam o repasto. Ofereciam-nos juntamente com as carnes, mas antes das azeitonas e do cozido. Rafael Núñez Florencio, estudioso que analisou o cardápio servido em tais ocasiões, comentou: "Dicen que el arroz, que nace em água, debe morir em vino" ${ }^{630}$

O poema de Gregório de Matos, arrematado pela afirmação de uma vontade garrafal atestava, pois, além do conhecimento implícito do dito popular, o mesmo tipo de hábitos alimentares. Comprovava também o fato de que, no Brasil, os colonos lusos não esperaram pela introdução do arroz da Carolina, no final do século XVIII, para comerem iguarias de arroz e ofereceremnas a convidados honrados em suas reuniões sociais.

628 MATOS, G. Op. Cit., Vol. III, p. 580.

629 MATOS, G. Op. Cit., Vol. III, pp. 587 e 588.

630 NÚÑEZ, Rafael Florêncio. Con la salsa de su hambre: los extranjeros ante la mesa hispana. Madrid, Alianza Editorial, 2004. pp. 68 a 71. 
Discorrendo sobre o arroz, o Doutor Mirandela qualificava o cereal:

"o melhor e o mais nobre de todos os legumes e o que mais que todos nutre e alimenta em todos o tempo a maior parte da gente de toda a esfera e condição que seja. Que a sua cópia o facilita para as mesas baixas e a graciosidade de seu sabor o levanta aos banquetes e mesas ilustres. É quente e seco, mas mais seco do que quente. Coze-se com dificuldade e distribui-se mal, porque dá alimento muito crasso, que obstrui os vasos e ductos da primeira via; porém, depois de cozido, é de grande nutrição e só o trigo nutre mais do que ele"

O médico enfatizava ainda as múltiplas virtudes terapêuticas do vegetal. Parece, portanto, acertada a opinião do autor dos Diálogos das grandezas do Brasil, que apontava o arroz como um mantimento de grande relevância na colônia.

\begin{abstract}
“O mantimento que ocupa o segundo lugar (posto que em muitas partes do mundo se tem pelo primeiro) é o arroz, que nesta província se produz em muita abundância a custo de pouco trabalho, mas os seus moradores por respeito da mandioca de que já tenho tratado, plantam muito pouco, porque reputam quase por fruta e não mantimento por acharem a farinha de mais sustância"632.
\end{abstract}

Segundo Corsino Medeiros dos Santos ${ }^{633}$, entretanto, o consumo do arroz em Portugal até meados do século XVIII permanecia insignificante, pois, os camponeses mantinham sérios preconceitos contra a cultura do cereal. Durante a permanência dos holandeses no Nordeste brasileiro, Elias Herckman, por um tempo governador da Paraíba, observou:

631 HENRIQUEZ, Francisco da Fonseca. Op. Cit., p. 163.

632 BRANDÃO, Ambrósio Fernandes. Op. Cit., p. 168.

633 SANTOS, Corsino Medeiro dos. "Cultura indústria e comércio do arroz no Brasil colonial", in $\underline{\mathrm{RIHGB}}$, 1978. pp. 36 a 61. 
“O arroz que esta capitania produz é comquanto bom, mui pouco, pois o trabalho é ahi tão caro ou precioso (costelyck), que a essas cousas miudas não se presta muita atenção, tendo cada um os olhos fitos no açúcar, que é o que dá o máximo proveito" ${ }^{634}$.

A opinião de Rocha Pita confirmava o ponto de vista de Brandão:

“É imensa no Brasil a produção do arroz, igual na bondade ao de Espanha, ao de Itália, e melhor que o da Ásia, e pudera servir de pão, como na Índia, se em nosso clima se não acomodaram os corpos mais à farinha de mandioca, que melhor os nutre; porém continuamente se usa dele por regalo, assim guisado em muitas viandas, como em outros vários compostos. Na Província da Bahia os alqueires que se colhem, não têm número; são tantos nas dos Ilhéus e do Porto Seguro, que sai para várias partes em sírios, como a farinha" ${ }^{635}$.

Talvez o pouco caso que se fez do cereal, durante o século XVI ou nos momentos críticos da primeira metade do século XVII se devesse sobretudo à primazia da rentabilidade econômica para colonos empenhados em se destacarem entre os homens bons. Seus descendentes bem sucedidos, contudo, teriam menos motivos para se privar à mesa de um consumo prestigiado, capaz de apontá-los como homens estabelecidos. O aumento populacional verificado no final dos anos seiscentos e a prosperidade alcançada por uma grande proporção dos colonos resultaria certamente em crescimento visível do volume produzido de gêneros comestíveis supérfluos e agradáveis.

Interessante, no caso, parece ser o fato das poucas referências ao consumo soteropolitano de arroz encontradas nos versos de Matos permitirem retificar a noção previamente aceita de que 634 HERCKMAN, Elias. "Descripção geral da Capitania da Parahyba por Elias Herckman". In RIAGP, tomo $4,31,1886$. p. 272.

635 PITA, Sebastião da Rocha. Op. Cit., p. 27, parágrafo 38. 
o consumo de arroz não teve nenhuma relevância na dieta da colônia antes do final do século XVIII.

\section{O milho}

A ausência de referências ao milho na obra de Matos fala por si. Apenas destacou-se uma única vez o termo milho nos versos do autor. O poeta se queixava então de "um grande atravessamilhos" ${ }^{\prime 36}$. Porém, a expressão atravessa-milhos utilizada naquele único poema poderia referir o mileto africano, cereal que amplamente consumido pelos camponeses europeus antes da grande difusão do Zhea mays, o milho americano.

Outro detalhe associado à farinha de milho, registrava-se no pseudo-testamento satírico de Pedro Cabra da Índia (provavelmente Pedro Alvarez da Neyva, de Marapé, que ostentava sinais de falsa fidalguia, após o casamento com uma noiva rica indiana). No caso, a presença pérfida de uma tigela dos angus ${ }^{637}$ no poema de Matos, acompanhada de um cabaço das ervas, de uma cumbuca de carimá e de um tacho de aferventar destinou-se a desqualificar o moço satirizado, sugerindo a existência de preconceito mazombo contra o consumo de iguarias de milho.

No Brasil colonial nordestino o milho nunca foi um rival à altura da farinha de mandioca, como em regiões mais sulinas. A dieta dos holandeses, que ocuparam Pernambuco entre 1630 e 1654, estudada durante o mestrado ${ }^{638}$, permitiu constatar que os representantes da Companhia das Índias Ocidentais imitaram os hábitos da população portuguesa e utilizaram o milho nativo apenas como alimento dos cavalos e das galinhas. Um relatório de Herckman sobre a situação na Paraíba, por exemplo, revelava as prevenções que pesavam contra o consumo do vegetal:

\footnotetext{
636 MATOS, G. Op. Cit., Vol. I, p. 172.

637 MATOS, G. Op. Cit., Vol. V, p. 1282.

638 PAPAVERO, Claude Op. Cit., pp. 184 e 185.
} 


\begin{abstract}
"O milho chamado na Hollanda fromento da Turquia (Urksche Tarwe), é produzido ahi em quantidade e serve para alimentar os escravos e os negros, também o dão geralmente aos cavallos en logar de aveia. Amadurece duas vezes por ano, a primeira vez em Maio e a segunda em Setembro e Outubro" ${ }^{639}$.
\end{abstract}

\title{
Os feijões
}

Uma questão fundamental para o estudo da dieta alimentar soteropolitana residiu no problema do papel que coube à produção e ao consumo de feijões, durante o último quartel do século XVII ${ }^{640}$. Durante o século XVI e a primeira metade do século XVII, a base da alimentação dos colonos lusos instalados no Brasil consistiu sobretudo num binômio alimentar composto de farinha de mandioca e de carne fresca ou seca eventualmente substituída por peixe (fresco ou seco). A dieta dos moradores lusos do Brasil oferecia então um equivalente local do "Fan-tsai" básico (arroz acompanhado de uma mistura de carnes e verduras) usual na alimentação chinesa ${ }^{641}$. O sustento básico dos colonos foi assegurado por ingredientes alimentícios selecionados em razão da durabilidade que permitia armazená-los e planejar a constituição de reservas. Carnessecas e farinha seca de mandioca, os principais mantimentos da vida no Brasil e os peixes secos garantiam que haveria sempre alimentos nas mesas coloniais mas não eliminaram o consumo de uma diversidade aprazível de víveres frescos e sumarentos.

Sempre que possível, as carnes e os peixes secos cediam a primazia às carnes ou aos peixes frescos. Os cronistas portugueses, quinhentistas ou seiscentistas e os homens que serviam a 639 HERCKMAN, Elias. Op. Cit., p.272.

640 No capítulo II, o uso simbólico dos feijões como um ingrediente comestível, presente na dieta de pessoas vistas como inferiores, foi delineado em suas linhas gerais. No presente item do capítulo III, os elementos etnográficos referentes à produção e ao consumo do vegetal foram focalizados. Os mesmos dados serão ainda retomados no capítulo IV, quando usos simbólicos e práticas da dieta alimentar colonial serão analisados num contexto mais abrangente.

641 CHANG, Kwang Chi. Food in Chinese culture: anthropological and historical perspectives. New Haven \& London, Yale University Press, 1977. 
Companhia das Índias Ocidentais holandesa citavam incidentemente a presença de favas e de feijões entre os legumes nativos brasileiros de gosto saboroso. Mas nem os europeus, nem os indígenas tupi, demonstravam predileção pelo vegetal, exceto os soldados da West Indische Companie ou WIC.. Eles recebiam estipêndios exíguos e apreciavam-no por ser substancioso e custar pouco ${ }^{642}$. Conforme observou Câmara Cascudo em sua História da alimentação no Brasil $^{643}$ os feijões, mesmo conhecidos e disponíveis, demoraram muito para serem integrados à dieta dos portugueses.

Feijões também eram alimentos convenientes ao se conservarem desidratados por longo tempo. Armazenados, eles podiam assegurar reservas administradas de alimentos. Mas as variedades sulamericanas desses vegetais, que tinham tudo para se tornarem mantimentos básicos da alimentação colonial, como acabou acontecendo posteriormente, quando passaram a integrar um tripé alimentar de feijões, farinhas e carnes secas, na expressão de Paula Pinto e Silva ${ }^{644}$, não mereciam ainda, no final do século XVII, o reconhecimento pleno de seu potencial nutritivo e gustativo.

O ponto específico a ser sublinhado nesse processo social da transformação dos feijões, de ingredientes desprovidos de nobreza a alimentos saboreados sem receios, era o fato dessa iguaria, vista com circunspeção pelos inquisidores como alimento de cristãos novos ou pelos colonos como ingrediente apropriado para nutrir cativos e gente pobre, surgir em algum momento histórico como ingrediente valorizado da dieta local.

Conhecidos de longa data na Europa, os feijões não constituíam novidade por ocasião das grandes viagens da Época Moderna ${ }^{645}$. Que um pintor italiano, Annibal Carracci, em meados do

642 PAPAVERO Claude. Dissertação de mestrado. Op. Cit., pp. 188 e 189.

643 CASCUDO, Luís da Câmara. História da alimentação no Brasil. 2 vol., BH./ SP., Itatiaia/EDUSP., 983. pp. 494 e 492.

$644 \quad$ SILVA, Paula PINTO e. Op. Cit., pp. 114 a 118.

645 MONTANARI, Massimo. Op.Cit., pp. 112 e 113.

“no Bertoldo de Giulio Cesare Croce, os médicos da corte tentavam curar a doença do 'plebeu' confortando-o com alimentos raros e delicados totalmente inadequados ao seu estômago de camponês; e ele em vão a implorar 'que lhe trouxessem uma panela de feijão com a cebola dentro, e nabos cozidos sob as cinzas'. Somente assim, comendo de acordo com sua natureza, teria se salvado". 
século XVI, tenha representado um camponês rústico comendo uma refeição plebéia de feijões não indicava a incorporação de algum hábito novo. Jean François Revel ${ }^{646}$ se deixou levar pela ampliação do universo dos feijões conhecidos após a descoberta do continente americano, ao situar no Renascimento o início de tal consumo. O estudioso esquecia que o Velho Mundo já conhecia e comia, além dos feijões brancos, o feijão fradinho de origem africana. O acervo dos feijões consumidos localmente e que foram levados à Europa, aliás, pode ser observado nas pranchas do Theatrum Rerum Naturalium Brasiliae ${ }^{647}$. É possível notar que não figuravam nessa representação nem o feijão branco, nem o feijão fradinho, que Jorge Marcgrave mencionava entre as espécies vegetais disponíveis em Pernambuco ${ }^{648}$.

Os versos de Gregório de Matos forneceram pistas valiosas para entender o papel então atribuído aos feijões. Acusados de provocar perturbações do sono e flatulências na obra do Doutor Mirandela, foi exatamente a essas propriedades que o poeta fez alusão em suas críticas aos feijões da Pericoara, utilizados para desmerecer uma moradora da região da Patatiba.

Segundo o médico do rei:

"Os feijões são quentes e secos, crassos, melancólicos e terrestres, e ainda que haja entre eles alguma diferença, porque uns são grandes, outros pequenos, uns são brancos, outros vermelhos, isto é em relação à cor e à figura, que em relação à forma e temperamento substancial em nada diferem, se bem que alguns querem que os vermelhos excedam no calor aos brancos. Todos se cozem e digerem com

646 REVEL, J. F. Um banquete em palavras: uma história da sensibilidade gastronômica. São Paulo, Cia., das Letras, 1996. cf. p. 41.

647 Cf. Ilustração pictórica do Brasil holandês representando variedades locais de feijões nativos, figuradas nos“Icones vegetabílium”do Theatrum Rerum Naturalium Brasiliae. Cf. TEIXEIRA, Dante M. (org.)

Brasil-Holandês: Miscellanea Cleyeri, Libri Principis \& Theatrum rerum naturalium Brasiliae. 5 V., Ed. Ilustrada, Rio de Janeiro \& Lisboa, Index, 1995.

648 MARCGRAVE, Jorge. Op. Cit., p. 52. “MANDATIA (termo indígena). É a Lablab de Alpino, a cujo respeito veja-se Car. Clus., Rar. Plant. História, pág. CCXXVII. Esta planta veio da África para o Brasil; comemse os seus feijões cozidos". 
dificuldade, são flatulentos e nutrem bastantemente. Geram-se deles humores crassos e melancólicos, de que nascem obstruções. Perturbam o sono com fantasias tristes, oprimem a cabeça e ofendem a audição" ${ }^{649}$.

A despeito de certa má vontade em relação ao vegetal, Matos apresentou duas referências claras ao consumo efetivo. No primeiro caso, o poeta criticava a carência dos feijões na praça, pois a Câmara permitira que a frota açambarcasse os mantimentos existentes nos escotilhões das naus, deixando a população colonial à míngua. Listando os ingredientes do cardápio consumido nas viagens de retorno à Lisboa, o autor citava os mantimentos rarefeitos: "a carne, o peixe, os feijões" ${ }^{650}$. No segundo caso, um poema inédito atribuído ao autor que constava de um códice inédito publicado por Peres e De la Regina ${ }^{651}$, referia não somente o costume corriqueiro de se cultivar feijões nas roças, mas especificava que se chamavam feijoais ao espaço dessas plantações em terras de lavoura.

Antonil confirmava o plantio de feijões nas hortas dos escravos que os senhores autorizavam a produzir os próprios alimentos, mencionando também que esses vegetais representavam itens valorizados nos escambos entre cativos que possuíam garapa azeda fermentada, recebida durante o processo de manufatura dos açúcares, e cativos que cultivavam feijões ${ }^{652}$. O acréscimo de relevância desse consumo alimentar parece ter se efetivado após o advento da dinastia portuguesa dos Braganças, principalmente no decurso da segunda metade do século XVIII, quando o marquês de Pombal aboliu as restrições que pesavam nas sociedades lusas (metropolitana ou colonial) sobre os pequenos comerciantes, os oficiais mecânicos, os cristãos novos e os mouros.

\footnotetext{
649 HENRIQUEZ, Francisco da Fonseca. Op. Cit., pp. 161 e 162. Crassas (cf. glossário): "grossas, espessas, gordas"

650 Não mencionou aqui a farinha de mandioca e os beijus, que também constavam entre as matalotagens: as provisões que se levava nas viagens.

651 Cf. Capítulo II da tese.

652 ANTONIL. Op. Cit., p. 164.
} 
No período histórico estudado, Gregório de Matos assinalava caldos de grãos (feijões, lentilhas, ervilhas, grão de bico, etc.) comidos em dias de peixe ${ }^{653}$, seja pelo fato dos jantares serem menos substanciais em tais ocasiões, seja para evitar a mistura de carnes e de grãos numa mesma refeição, pois a Inquisição perseguia quem preparava a iguaria, cujo consumo judaizante costumava coincidir com as quartas feiras e os sábados, dias de abstinência de carne.

Russell-Wood ${ }^{654}$, aliás, mencionou feijões e carnes no provimento alimentar fornecido, em 1749, às moças do Recolhimento. Fornecia-se mensalmente um barril de sal e três quartas de farinha de mandioca a cada jovem recolhida, nove quartas de feijões, 2 libras de gordura de porco, uma vasilha de azeite para os dias magros e 320 réis mensais destinados à compra de bananas. O Recolhimento das mulheres recebia ainda 2 libras diárias de carne por pessoa, 80 réis para a compra de peixe nos dias de abstinência e 30 reis de repolho diários, aves e frangos sob prescrição médica. A fartura relativa de tal alimentação contrastava com o caráter caritativo do provimento.

Com o aumento do volume da população colonial e dos mestiços livres, em meados dos anos seiscentos, uma outra maneira de sobreviver e de se alimentar na colônia parecia emergir, à sombra das elites mazombas associadas à produção açucareira, que se autodefiniam como lusas e agiam como tais ${ }^{655}$. Por conseguinte, seria cometer um contrasenso tomar Gregório de Matos como símbolo representativo de uma nova sociedade soteropolitana, justamente aquela parte da população que ele satirizou insistentemente através de metáforas de cunho alimentar.

653 MATOS, G. Op. Cit., Vol. V, p. 1093: "Para dia de peixe: caldo.... de grão".

654 RUSSELL-WOOD, A. J. R. Fidalgos and philanthropists: the Santa Casa da Misericórdia of Bahia, 1550 1755. Berkeley, University of California Press, 1968. p. 333.

655 Estavam, é preciso reiterá-lo, às vésperas de perderem parte de seu poder político em razão do papel proeminente que os mercadores estavam desempenhando, da descoberta de ouro nas Minas Gerais e da mudança da capital para o Rio de Janeiro, em meados do século XVIII (1763). 


\section{Os tremoços e as lentilhas}

Além de relatar que tinha consoado um tramoço ${ }^{656}$ durante uma noite de jogatina, Gregório de Matos mencionou pouco os legumes secos que integravam os cardápios europeus. Referidas com intenções assaz distanciadas do consumo alimentar diário, as alusões do poeta a caldos nutritivos (metáforas para falar do sêmen) apontavam para a freqüência do consumo de caldos de grãos, sem, entretanto, especificar quais eram as leguminosas cozidas que entravam na composição dos caldos: "quereis um caldo de grãos,/por um caldo de lentilhas"

Causa igualmente certa estranheza, a ausência na obra de Matos de referências a abóboras, a jerimuns ou a batatas, vegetais que, à par dos mangarás e dos carás, se faziam presentes nas hortas coloniais e eram vistos pelos cronistas quinhentistas como legumes usuais na dieta das populações nativas. Esse descaso, provavelmente, tinha uma relação com o fato de que os poemas de Matos não pretendiam descrever a dieta, mas se valiam de ingredientes carregados de valores simbólicos para estigmatizar os adversários por meio desse recurso de estilo.

\section{As hortaliças e as frutas}

Segundo um opúsculo interessante editado pela Fundação Pedro Calmon: Tachos, panelas e companhia: pequena historiografia da alimentação na Bahia:

“Com a criação do Bispado, em 1551, a Coroa concedeu ao primeiro bispo, o direito de receber o dízimo de miunças e de primícias (imposto sobre a venda de frutos e legumes) recolhido dos colonos. Posteriormente, a Fazenda Real, ávida de rendas, tributou à Igreja as oblatas (tudo quanto se oferece a Deus ou aos Santos) e benesses (beneficios) pelo pasto espiritual (zonas de catequese)"

656 MATOS, G. Op. Cit., Vol. IV, p. 835.

657 MATOS, G. Op. Cit., Vol. V, p. 1107.

658 Tachos, panelas e companhia: pequena historiografia da alimentação na Bahia. Fundação Pedro Calmon. 
Não foi possível conseguir informações sobre a permanência ou o desaparecimento de tais cobranças em fins do século XVII. Nas Atas da Câmara Municipal de Salvador constava, todavia, uma taxa paga, a Renda do Ver (ou do Verde) sobre a comercialização de semelhantes produtos. Exigia-se também dos vendedores ambulantes ou dos tendeiros que costumavam prover a população em víveres frescos, a aquisição de uma licença anual para vender alimentos que proveninham do cinturão de lavouras localizado nos arredores da capital ${ }^{659}$.

Supervisionar a qualidade dos alimentos fornecidos era obrigação atribuída a dois almotacés eleitos para exercer o cargo pelo prazo de dois meses. Contudo, dois homens apenas para fiscalizar o volume extenso dos produtos vendidos numa cidade que contava então com cerca de 40000 habitantes, é possível imaginar quão falha não seria sua verificação da qualidade e dos preços dos alimentos vendidos.

Rocha Pita, ao inventariar as hortaliças européias cultivadas no Brasil, enumerou:

"Das ervas naturais comestiveis são principais os quiabos, os jilós e os maxixes, as largas taiobas, a peitoral maniçoba, que se guisa das folhas da mandioca, as cheirosas pimentas de muitas espécies e cores, que servem ao gosto, ao olfato e à vista. Das hortaliças da Europa há no Brasil alfaces, couves de várias castas, repolhos, nabos, rabãos, cenouras, pepinos, espinafres, abóboras d'água, cebolas, alhos, cardos, bredos, mostarda, tomates e beldroegas; das ervas cheirosas, hortelãs, segurelha, poejo, coentro, funcho, salsa manjerona, endro, manjericão, alecrim, arruda e losna; das medicinais, canafístula, tamarindos, jalapa, salsaparrilha, filipódio, pau-da-China, malva, tanchagem, sene, a que os naturais chamam tacumburi" ${ }^{660}$.

659 SOUSA, Avanete Pereira. Poder local, cidade e atividades econômicas (Bahia, séculoXVIII). Tese em História econômica apresentada ao Departamento de História da FFLCH-USP. São Paulo, 2003. 
Merece reparo, nessa citação de um autor do começo do século XVIII, a primeira alusão de um cronista ao tomate, vegetal, que os espanhóis encontraram no México e levaram para a Europa, e que passou provavelmente pela mediação dos hábitos alimentares do Velho Mundo antes de ser transplantado na América Portuguesa. Na época os homens atribuíam pouco prestígio ao consumo de hortaliças ${ }^{661}$. Segundo afirmava o Dr. Mirandela:

"Toda hortaliça dá pouca nutrição ao corpo, mas serve de graça e desfastio das mesas além de outras utilidades de que falaremos tratando de cada uma delas. Comecemos pela alface, a que Galeno deu o primeiro lugar, talvez com queixa e escândalo da borragem e da chicória" ${ }^{662}$.

"A alface é fria e úmida, coze-se com facilidade e nutre pouco, ainda que digam que dela se gera mais sangue que das outras hortaliças. Há de comer-se sem se lavar mais que o que baste para a comer limpa, porque, lavando-a muito, larga na lavagem parte de sua virtude e substância, ficando mais úmida e flatulosa. Galeno diz que, enquanto teve dentes, comeu alfaces cruas e depois comia-as cozidas. As cruas retêm todo o seu vigor em si; as cozidas perdem parte dela com ofogo e largam muito no cozimento. Os antigos comiam-nas no fim da mesa, depois usavam delas no princípio, como se colhe do que escreveu Márcial: Hoje duram nas mesas desde o princípio até o fim, feitas em saladas, como desfastio para os mais alimentos" ${ }^{663}$.

O caso das chicórias era semelhante:

661 Como bem observou (em comunicação verbal), Maria Verônica CAMPOS, as hortaliças eram alimentos sobretudo consumidos pelos pobres.

662 HENRIQUEZ, Francisco da Fonseca. Op. Cit., p. 164. 
"A chicória é fria seca e algum tanto estítica; se é bem alporcada ${ }^{664}$, tem bom gosto, coze-se facilmente e nutre pouco como as mais hortaliças" 665 .

Gregório de Matos somente citou em seus poemas repolhos ensopados servidos com arroz de leite ${ }^{666}$, e saladas de vegetais crus: pepinos servidos sem tempero de limão e pimenta na refeição do avarento ${ }^{667}$ ou saladas de alfaces ${ }^{668}$ e de chicórias ${ }^{669}$ acompanhadas de azeitonas. Entre as três referências a pepinos encontradas no conjunto da obra, aliás, somente uma referia um consumo de cunho alimentar, em lugar de aludir ironicamente ao membro masculino, carne nobre e viril reduzida à condição de vegetal passivo.

No conjunto dos versos de Gregório de Matos, não deixa de ser interessante o fato de produtos das hortas serem mencionados antes pelo aspecto fálico e a consistência branda (desqualificando desafetos do poeta) que na qualidade de alimentos cotidianos, cultivados em hortas caseiras. Os mangarás ${ }^{670}$, vegetais encontrados na escrita do poeta (além de designarem sexos masculinos, também figuraram um nariz longo e roxo de frio) e os carás ${ }^{671}$, freqüentemente mencionados em virtude da rima obscena, eram vegetais nativos, carregando talvez por essa razão uma ponta adicional de sarcasmo.

664 HENRIQUEZ, Francisco da Fonseca. Op. Cit.. Segundo o glossário incluído na obra, pp. 287 a 292.

“Estitica: Que tem virtude adstringente”. “Alporcada: Feitas as folhas em maçarocas, junto as raízes, para ficarem menos adstringentes".

665 HENRIQUEZ, Francisco da Fonseca. Op. Cit., p.165.

666 MATOS, G. Op. Cit., Vol. III, pp. 587 e 588.

667 MATOS, G. Op. Cit., Vol. II, p. 444.

668 MATOS, G. Op. Cit., Vol. V, p.1220.

669 MATOS, G. Op. Cit., Vol. II, p.49.

670 MATOS, G. Op. Cit., Vol. II, pp. 363 a 365, Vol. IV, p. 874, Vol. V, p. 1191, Vol. VI, p. 1519, etc..

671 MATOS, G. Op. Cit., Vol. IV, p.874, Vol. V, p.1191, etc.. 
Nabos e quiabos ${ }^{672}$ sustentaram, dessa forma, diversas alusões de teor sexual. Matos, por exemplo gabou: "a imensa grandeza daquele nabo" escornado/por ter pouco e brando nabo" ${ }^{974}$.

O perrexil ${ }^{675}$ incluído entre as ervas cheirosas de Rocha Pita, serviu a Matos para ridicularizar um rapaz com pretensões à elegância, que desejava ser tão apreciado quanto um arremate de ervas cheirosas coroando alguma iguaria, mas que, vestido de ricos tecidos verdes, apenas parecia um pimentão ${ }^{676}$ (o verde, aliás, era então considerado a cor do pecado em razão das folhas com as quais Adão e Eva cobriram sua nudez quando comeram o fruto proibido).

Alhos entraram na composição dos versos de Matos pelo viés de expressões lusas que tampouco se referiram exatamente à alimentação.

Entre as frutas citadas por Gregório de Matos, nem todas tiveram consumo cotidiano e o poeta ignorou em seus versos muitas espécies européias, nativas, asiáticas ou africanas que os textos dos séculos XVI e XVII diziam cultivadas regularmente nos pomares soteropolitanos.

Escassos melões ${ }^{677}$, melancias ${ }^{678}$, cajus $^{679}$, bananas $^{680}{\text {, } \operatorname{laranjas~}^{681}, \operatorname{cocos}^{682}, \operatorname{limões}^{683} \text {, araçás }}^{684}$,

672 MATOS, G. Op. Cit., Vol. V, p. 1116 e Vol. VI, p. 1431.

673 MATOS, G. Op. Cit., Vol. V, p. 1234.

674 MATOS, G. Op. Cit., Vol. V, p. 1117.

675 MATOS, G. Op. Cit., Vol. IV, p. 895.

676 MATOS, G. Op. Cit., Vol. IV, p. 896.

677 MATOS, G. Op. Cit., Vol. V, p. 1256, Vol. VI, p. 1522.

678 MATOS, G. Op. Cit., Vol. II, p.301, Vol. V, p. 1256, Vol. VI, pp. 1466, 1515, 1522. etc..

679 MATOS, G. Op. Cit., Vol. II, pp. 303, Vol. III, pp. 604 a 606 e 607 a 610, Vol. IV, pp. 840, 935, 936.

680 MATOS, G. Op. Cit., Vol. I, p. 192, Vol. III, p. 608 , Vol. V, p. 1197 etc..

681 MATOS, G. Op. Cit., Vol. III, p. 609, Vol. VI, p. 1519 (laranjas ou frutas de espinho ditas chinas).

682 MATOS, G. Op. Cit., Vol. VI, p. 1519.

683 MATOS, G. Op. Cit.,Vol. V, pp. 1176 e 1177.

684 MATOS, G. Op. Cit., Vol. II, p. 364 e p. 386. 
muricis ${ }^{685}$, amoras ${ }^{686}$, figos $^{687}$, marmelos $^{688}$, pêras $^{689}$, pitombas $^{690}$ e maracujás ${ }^{691}$ figuraram nos versos do poeta. Comparada à grande variedade das frutas encontradas nas propriedades dos colonos ou na natureza soteropolitana, a lista das frutas citadas por Matos não foi muito extensa. O poeta também registrou de passagem o aspecto de produção econômica que esses vegetais representavam para certos lavradores, ou o lugar que as frutas ocupavam na sociabilidade dos colonos, enquanto itens oferecidos ou recebidos no reforço de vínculos de amizade. Mas o inventário das frutas mencionadas por Gregório de Matos surpreende também ao ignorar completamente os frutos do ananás celebrados pelos cronistas, ou as goiabas e as mangabas colhidas regularmente nos pomares das capitanias nordestinas.

Poucos anos depois da morte de Matos, outro poeta soteropolitano, Manuel Botelho de Oliveira apresentou, num poema sobre a Ilha de Maré ${ }^{692}$, a riqueza da fauna e da flora local como um motivo acertado de orgulho regional. Nesses versos, o autor citava um rol extenso de frutas saboreadas confessando que existiam ainda outras: uva moscatel, melão, melancia, figo, romã, coqueiro, caju e castanha, pitanga, pitomba, araçá, banana, pimenta, mamão, marcujá, ananaz, mangava e macujé, foram incluídos nesse texto ufanista, bem como uma grande variedade de frutas cítricas, provenientes das arvores ditas de espinho: laranja da terra, china, limão, cidra etc., que produziram novidades maravilhosas no Brasil.

Foi também possível perceber na obra algumas raras pistas de gostos alimentares pessoais de Matos. Em diversos poemas, o autor registrou sua predileção pelas bananas, pelos cajus e pelas

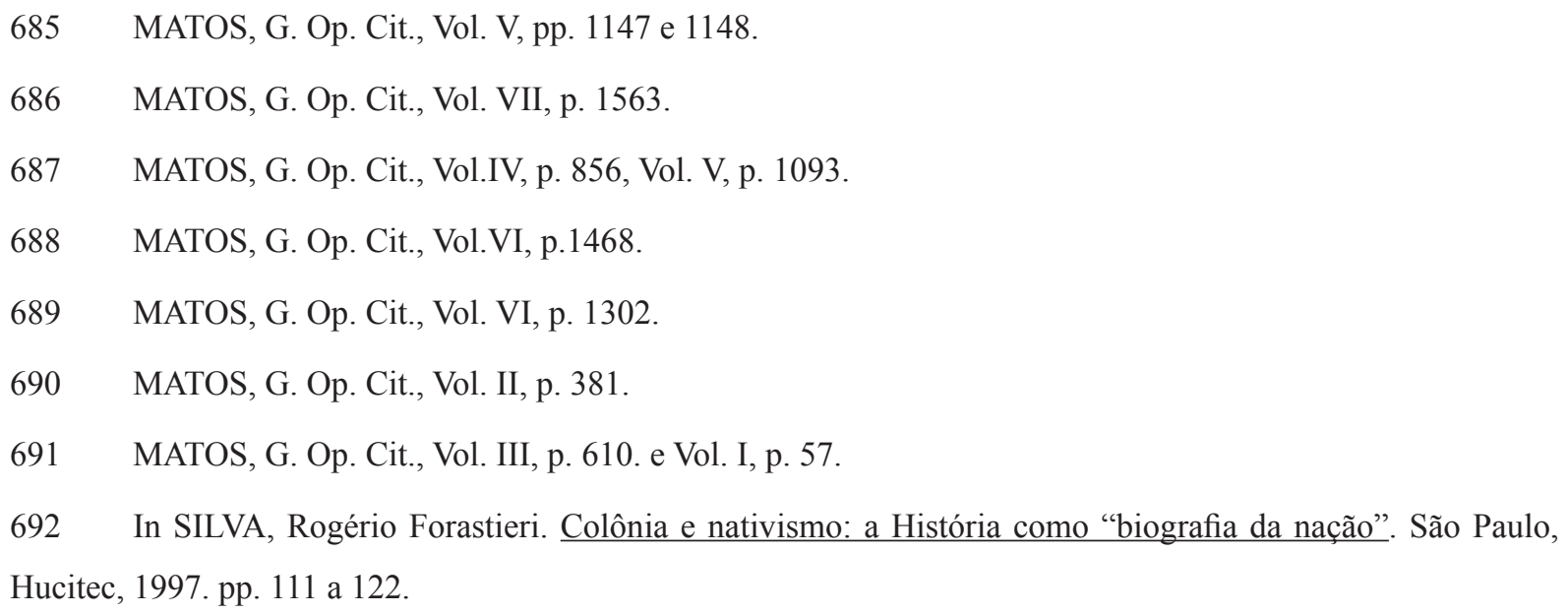


melancias, cantadas a par do "fresco melão" no soneto "Ilha de Itaparica" ${ }^{693}$. Em outra ocasião Matos afirmou: "Em vez de belota má,/que comeram nossos Pais,/teremos melões reais,/que é belota de cá:/cavando aqui, e acolá/nos verão todos os dias/comer ricas melancias" ${ }^{694}$.

Dignas de nota, havia ainda queixas sentidas do poeta contra um mulato, Lopo Teixeira, a quem o autor provera dinheiro para comprar melancias na Saubara ${ }^{695}$ (uma região de lavouras de mantimentos e de víveres situada na margem do Recôncavo oposta à Vila de São Francisco), mas que efetuou um péssimo negócio. Outras frutas refrescantes, foram mencionadas pelo autor em metáforas alusivas às pecaminosas maçãs do jardim do Éden ${ }^{696}$. Rocha Pita como Matos elogiava as frutas estrangeiras transplantadas no Brasil:

“melancias seletas, regalados melões; e em sumo grau formosas e deleitáveis todas as frutas, que se chamam de espinho, excedendo às que deste gênero há em Europa $" 697$.

Na opinião de Rocha Pita, todavia, não eram os cajus, mas as bananas que mereciam ser consideradas uma versão tropical da fruta paradisíaca.

Quanto aos maracujás, não deixaram de fazer curtas aparições na obra de Matos. Em vez de cajus maduros, certa vez, os companheiros de viagem decepcionados, apenas encontraram dois maracujás numa ilha visitada ${ }^{698}$. A flor do maracujá, por sua vez, fez jus a um poema lírico de Matos. A aparência dessa flor maravilhava os colonos lusos desde os primórdios do povoamento e todos a celebravam por sua bela cor arroxeada e sua forma que lembrava a coroa de espinhos e os pregos da paixão de Cristo.

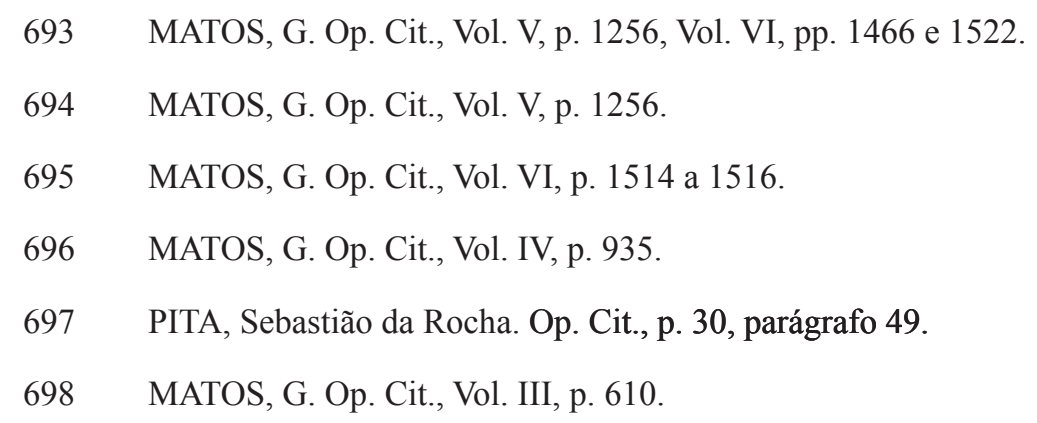


Outras alusões a frutas foram escolhidas por referirem ironicamente procedimentos, que nada tinham de gastronômico. Matos, por exemplo, pretendeu que para tratar uma impotência, doença dita fria, um colono desavisado aplicou-se absurdamente talhadas de limão no anus, à guisa de sacamano, remédio contra as disenterias provocadas pelo maculo, uma infecção intestinal letal, quando não curada em tempo. No plano do consumo prático, limões e pimentas ardidas, como foi visto anteriormente, acompanhavam as saladas de pepinos de colonos, que não se mostravam demasiadamente avarentos.

Noutro relato escabroso, Matos descreveu a vingança de uma mulher traída, que ofereceu ao amante infiel um doce de araçá preparado com a polpa de uma fruta cozida junto com um pinhão de purga para diminuir o vigor do efeito laxante.

Figos, marmelos e pêras foram termos utilizados para descrever seios de jovens. Menções esparsas às vinhas remeteram a imagens abstratas, tais como "meter os bois na vinha" metáforas utilizadas pelo poeta, sem referência prática às parreiras que alguns colonos teimavam em produzir na colônia, disputando as frutas, cacho a cacho, com formigas saúvas. Amoras, por outro lado, ironizaram a cor de uma mulata, Inácia Parede, que, por algum motivo, irritara o autor, Matos lhe declarou: "sois branca como amora"700, metáfora que contrastava amoras brancas ou roxas.

Outra cativa foi dita "lisa como uma pitomba"701, enquanto que, em tom de mofa, Matos pretendeu que um Cobé ou Paiaiá (termos com os quais ele designava índios tupi), ao cortejar a mulher amada, teceu loas gongóricas a seus olhos de murici ${ }^{702}$. Essa frutinha mole, de cor amarela, já assinalada por Gabriel Soares de Sousa ${ }^{703}$, integrava o rol das frutas comidas pelos nativos, segundo Paulo Cavalcante ${ }^{704}$, com acompanhamento usual de farinha de mandioca.

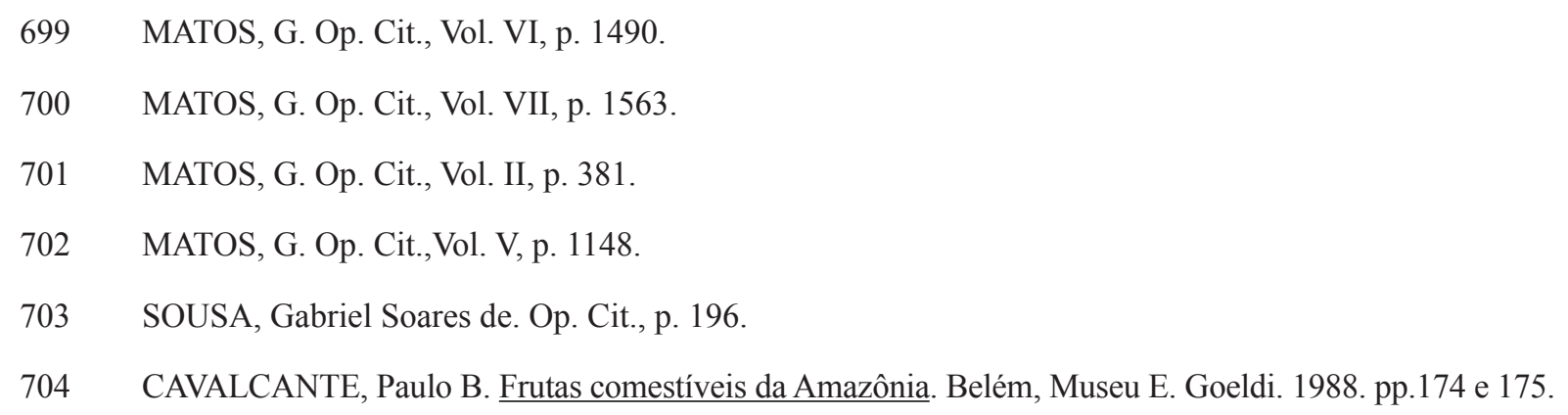


Na leitura dos poemas de Matos destacou-se a associação freqüente entre bananas e farinha de mandioca. A merenda, que o autor levou numa expedição aos cajus, compunha-se efetivamente de farinha seca e de bananas. De farinha e bananas constou também a refeição sumária (paga com recursos próprios) do padre papa-jantares, na ausência de algum anfitrião disposto a alimentá-lo. Rocha Pita, rival de Matos nas atenções dispensadas a Beleta, também apontava o mesmo padrão de uso. Na América Portuguesa havia:

"bananas de dois gêneros que servem de regalo, e por muitos modos de mantimento, na falta da farinha, e assadas são melhores que as maçãs camoesas: pelo seu regalo, cheiro e formosura, se pode presumir foi o pomo com que a serpente tentou no paraíso a nossos primeiros pais, podendo também o comprimento e largura das suas folhas persuadir foram as de que eles se cobriram, das quais podiam cortar grandes roupas" 705 .

Farinha com peixe ou carne, cozidos num caldo, sob forma de alimento fresco ou de mantimento seco, asseguraram um esteio mínimo à dieta soteropolitana, garantindo aos colonos, senão o luxo pelo menos um sustento básico que podiam complementar com a adição de outros víveres. Matos, tão empenhado em fazer pouco de descendentes dos índios parece, no entanto, ter saboreado sem trauma visível uma versão frugal mínima da dieta local herdada dos nativos, isto é, uma dieta reduzida à farinha com fruta. A população mazomba transformou efetivamente os ingredientes do sustento básico em massas de consistência pastosa entre úmidas e secas, que acreditavam prover equilíbrio à digestão, aplicando os procedimentos alimentares nativos ao consumo de variedades de bananas introduzidas pelos colonizadores.

Francisco Ferreyra, Chico, ocasionalmente lavrador de arroz, ofereceu certa vez china (laranja) e melado quente para "socorrer" os amigos da Cajaíba, que foram buscá-lo de canoa para uma expedição aos cajus na Ilha Grande. Havia chinas também nessa ilha (também chamada

705 PITA, Sebastião da Rocha. Op. Cit., p. 30, parágrafo 51. 
por Matos de ilha de Gonçalo Dias) e muitos cocos. O dono de uma propriedade situada nessa ilha, um amigo do poeta também chamado Francisco, os vendia em grandes quantidades às frotas que seguiam viagem em direção ao Extremo Oriente ou às naus armadas para a viagem de regresso a Portugal. Endereçando um poema a essa ilha Grande, Matos versejou num soneto elegante:

\section{“Tu a todo o Brasil podes dar vaia,/Pois tantos lucros dás a pouco risco:/Tu abundas aos filhos de Francisco/ Picote de cação burel de arraia // Tu só em cocos dás à frota o lastro,/Fruta em tonéis, a china às toneladas,/Tu tens a sua carga a seu cuidado. //Se sabe o preclaríssimo Lancastro,/Que tais serviços fazes às armadas,/ Creio, que há de fazer de ti um condado" $"$.}

No quadro da dieta soteropolitana, tanto as frutas quanto as hortaliças foram consideradas alimentos perigosos por serem de natureza fria. Entretanto as frutas, talvez por serem facilmente confeitadas em açúcar, por sua doçura e seus aromas saborosos foram melhor aceitas que os outros vegetais. No plano metafórico, sua condição de produção arborícola propiciou muitos jogos de palavras interessantes ao poeta.

As metáforas de Matos, não pretenderam proporcionar nenhum depoimento esclarecedor sobre o uso local das frutas cultivadas. Entre os produtos que Matos não assinalou até figuraram as castanhas dos cajus que ele apreciava. Segundo Rocha Pita, pinhões, sapucaias e castanhas de caju depois de assados costumavam ser confeitados, suprindo a falta das amêndoas. As castanhas ainda verdes eram chamadas muturis: "e deles se fazem excelentes guisados, e compostos regalados" ${ }^{707}$. Deve-se também ao mesmo autor menções interessantes à introdução recente de novas frutas. Com efeito, o senhor de engenho comentou o cultivo recente das

\footnotetext{
706 MATOS, G. Op. Cit., Vol. VI , p. 1519. 
mangas asiáticas "de que já se fazem preciosos doces"708, citando igualmente a presença dos cacaus e do tomate ${ }^{709}$, sem sublinhar o fato de que ambos os vegetais, apesar de americanos (isto é, mexicanos), chegaram ao Brasil por intermédio de uma adoção prévia, consumada na península ibérica:

"O cacau, cujo fruto não tem flor, é arvore de mediana altura, de ramos mui apartados do tronco; nasce o pomo todas as luas, sendo mais perfeitos os do verão; tem a forma de um pequeno melão, a cor amarela, suave o cheiro, e dentro umas pequenas pevides menores que as amêndoas, mas do mesmo feitio, que são o que propriamente chamam cacau, e dão o nome à árvore e ao pomo; a polpa deste, desfeita em licor suave, serve de regalado vinho aos naturais; as amêndoas ou pevides secas ao sol é a matéria principal do chocolate: produzem em terras úmidas e alagadiças; semeiam-se os grãos frescos, porque secos não nascem, e os troncos se vão dispondo em forma de bem ordenados pomares: o benefício é mais fácil aos que cultivam as árvores que o resguardo dos frutos, sempre combatidos e penetrados dos pássaros" ${ }^{\prime 710}$.

\section{O açúcar}

Instruído sobre o processo da manufatura açucareira, durante sua permanência num dos maiores engenhos do Recôncavo, o jesuíta Antonil, que, nos primórdios do século XVIII, visitou o Engenho de Sergipe do Conde ${ }^{711}$, propriedade do colégio de Lisboa, descreveu minuciosamente a fabricação dos pães de açúcar que teve oportunidade de observar in loco. Manteve longas conversas com um homem que dirigira a manufatura açucareira por cerca de 708 PITA, Sebastião da Rocha. Op. Cit., p. 30, parágrafo 49.

709 PITA, Sebastião da Rocha. Op. Cit., p. 28, parágrafo 40.

710 PITA, Sebastião da Rocha. Op. Cit., pp. 30 e 31, parágrafo 54.

711 Nas imediações da cidade atual de Santo Amaro da Purificação. 
trinta anos. O relato de Antonil publicado na obra: Cultura e opulência do Brasil. e seus comentários sobre o tema do açúcar inspiraram diversos estudiosos que analisaram o lugar do açúcar, produto exportado, na vida econômica e social da colônia. Wanderley Pinho que redigiu uma monografia específica sobre a História do engenho ${ }^{712}$, Alice Canabrava ${ }^{713}$, Fraginals $^{714}$, Frédéric Mauro ${ }^{715}$ e Vera Lúcia do Amaral Ferlini ${ }^{716}$, por exemplo, recorreram aos escritos do padre ou às contas do engenho de Sergipe para analisar os aspectos técnicos e sociais pertinentes à atividade econômica.

Quanto a Gilberto Freyre, tampouco não lhe passou desapercebida a importância vital do produto nas configurações assumidas pela vida social brasileira:

"Para uma Sociologia do açúcar que possa ser apresentada como específica ou sistemática, uns poucos estudiosos da emergência do açúcar como produto rei vêm concorrendo com trabalhos nos quais à consideração do puro fenômeno econômico se vêm acrescentando considerações dos aspectos sociais, psicossociais, culturais e psicoculturais, desenvolvidos em torno do estímulo econômico e do favor ecológico; e desenvolvidos de tal modo que alguns desses desenvolvimentos há muito excedem a importância do aspecto puramente econômico ou do apenas ecológico do processo. [...] O açúcar de cana vem sendo, na história humana, o que, em Sociologia certos mestres

712 PINHO, Wanderley. História de um engenho do Recôncavo, 1552 - 1944. Rio de Janeiro, Zélio Valverde SA, 1946.

713 CANABRAVA, Alice. “João Antônio Andreoni e sua obra”, in ANTONIL, André João. (João Antonio Andreoni). Cultura e opulência do Brasil. $2^{\text {a }}$ ed., (Texto ed. de 1711), São Paulo, Ed. Nacional, 1967.

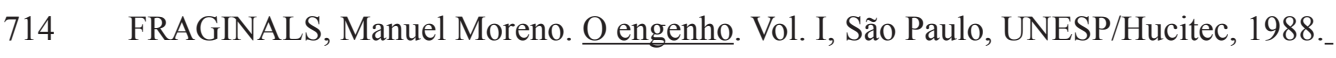

715 MAURO, Frédéric. Portugal, o Brasil e o Atlântico 1570 - 1670. 2 vol., Lisboa, Imprensa Universitária /Editorial Estampa, 1989. (Segunda parte, Capítulo IV, pp. 279 a 317).

716 FERLINI, Vera Lúcia do Amaral. O engenho Sergipe do Conde: contar, constatar e questionar - Bahia $(1622$ - 1653). Dissertação de mestrado em História Econômica apresentada ao Departamento de História da FFLCH-USP. São Paulo, 1980. 
franceses denominam um fenômeno social total. Ou antes, um fenômeno sóciocultural total. Fenômeno ou complexo" "717.

Para investigar os significados associados ao consumo de açúcar e de doces por intermédio das metáforas de Gregório de Matos, conviria relembrar algumas questões essenciais da cadeia operatória da produção açucareira, antes de enveredar pelo universo da sociabilidade soteropolitana e pelos usos cotidianos do produto. Existiam efetivamente diferenças de eficácia de um engenho para outro, afetando a capacidade de processar as canas e a amplitude das teias de relações sociais instauradas em torno de cada um. As diferenças em volume de produção repercutiam, por vezes, nas escolhas de formas de comercialização do produto.

Engenhos reais, movidos a água, conseguiam moer maiores quantidades de canas que os trapiches acionados por bois. Eram maiores também suas necessidades de lenha para aquecer as caldeiras, de animais de tiro, de madeiras nobres para fabricar moendas, carros e barcos de navegação costeira (utilizados no transporte de canas ou de caixas de açúcar). A dependência que os senhores de engenho tinham de um bom relacionamento com lavradores de canas livres para escolherem o engenho que processaria sua safra, ou com lavradores obrigados, pela força de contratos prévios ou dívidas, a moerem sua produção em algum lugar específico, tornava cruciais as interações sociais e as comemorações festivas no Recôncavo, necessárias para que houvesse quantidades suficientes de cana a moer por ocasião da safra.

Observando-se as metáforas formuladas por Gregório de Matos para se referir a uma mercadoria que era o principal esteio da colonização, poucos elementos poderiam ser acrescentados às análises macro-econômicas e técnicas existentes. Circunstância marcante nos poemas de Matos, todavia, as reuniões festivas das elites mazombas e os subprodutos derivados da manufatura do açúcar surgiam evidentes. Colocava-se em pauta a questão do consumo local de iguarias doces.

717 FREYRE, Gilberto. A presença do açúcar na formação brasileira. Rio de Janeiro, Instituto do Açúcar e do Álcool. 1975. pp. 32 e 33. 
Nos poemas encomiásticos, o sabor doce deu lugar, previsivelmente, a clichês sobre a doçura da mulher amada ou as doçuras do amor e do sexo. Já nos poemas burlescos, nos quais os prazeres da existência soteropolitana davam mote ao estilo, brincadeiras entre amigos e alusões a reuniões sociais ou a festas resvalaram freqüentemente para o domínio da doçaria e das regras da hospitalidade, atestando ainda a presença material das canas na paisagem colonial. Em compensação, nos poemas satíricos transpareceu um açúcar vivido em sua dimensão de ingrediente cotidiano, sob forma de lascas de açúcar furtadas, de negociatas em torno de caixas de branco, de jeribitas embriagadoras, de rapaduras e de caramelos metafóricos, de doces de botica com virtudes medicinais, de xaropes cordiais e de laxantes poderosos.

Convencionalmente todos os subprodutos da fabricação do açúcar, escumas e melado pertenciam aos senhores de engenho. Os lavradores somente recebiam uma proporção estipulada dos pães fabricados com suas canas, que variava segundo fossem ou não donos dos canaviais e obrigados ou não a moer canas em determinado engenho, em razão de dívidas contraídas junto a algum senhor de engenho.

Gregório de Matos, amigo de proprietários de terras situadas na melhor área de produção açucareira, era filho de um lavrador de canas que possuiu terras na Patatiba. Aliás, durante o período das guerras com os holandeses no Nordeste brasileiro, o avô do poeta se arriscou até a arrendar, por alguns anos, o engenho de Sergipe do Conde ${ }^{718}$. Matos, por conseguinte não deixou de mencionar as canas em seus poemas, com a familiaridade que o conhecimento íntimo dessa região do Recôncavo lhe proporcionava.

Um comentário sobre a importância das chuvas para a produtividade dos canaviais: "era num dia mofino/de chuva, que as canas rega"719, atestou, por exemplo, a centralidade das atividades canavieiras na região. Outros versos confirmaram um hábito criticado por Antonil: qualquer pessoa andando ao lado de um canavial se permitia cortar canas para chupar pelo caminho, um procedimento que acabava afetando o rendimento dos canaviais. Ao versejar sobre os encantos 718 PERES, Fernando da Rocha. Gregório de Mattos Guerra - uma re-visão biográfica. Salvador, Macunaíma, 1983. p. 36. 
do engenho de Pernamirim, Gregório de Matos comprovava o fundamento dessas queixas: "Adeus terras agradáveis/cheias de canas tão ricas,/que estão dizendo comei-me,/a quem passa, a quem caminha"720.

Outro poema de Matos, relatando um susto experimentado quando ele passeava pelos campos em companhia de um irmão do vigário da Madre de Deus, ao ser perseguido por uma vaca brava chamada Camisa ${ }^{721}$, também sugere a veracidade das circunstâncias da vida nos engenhos que Antonil descreveu:

“As cabras, tanto que a cana começa a aparecer fora da terra, logo a vão investir; os bois e os cavalos, ao princípio, lhe comem os olhos e depois a derrubam e a pisam; os ratos e os porcos a roem; os ladrões a furtam a feixes, nem passa rapaz ou caminhante que se não queira fartar e desenfadar à custa de quem a plantou. E, posto que os lavradores se acomodem de qualquer modo a sofrer os furtos pequenos dos frutos do seu suor, vêem-se às vezes obrigados, de uma justa dor, a matar porcos cabras e bois, que outros não tratam de divertir e guardar nos pastos cercados, ou em parte mais remota ainda, depois de rogados e avisados que ponham cobro a êste dano; donde se seguem queixas inimizades e ódios, que se rematam com mortes ou com sanguinolentas e afrontosas vinganças" $" 722$.

O processo da fabricação do açúcar em si encontrou pouca ressonância na escrita poética do autor. Porém, o próprio espaço físico das casas de purgar ganhou dimensão ao servir de palco a uma cena de amor, cujos traços parecem gravados em água-forte. Zombando de Henrique da Cunha, Matos misturou as costumeiras metáforas comestíveis com metáforas náuticas cheias de duplos sentidos, relatando:

\footnotetext{
720 MATOS, G. Op. Cit., Vol. VI, p. 1407.

721 MATOS, G. Op. Cit., Vol. III, p. 599 a 603.

722 ANTONIL, Op. Cit., p. 178.
} 
"Vós, que partindo de casalou seja a remo ou seja a vela/bem que venhas sem velame,/vindes fiado na verga./E apenas tendo chegado/a esta Cajaiba amena,/ logo São Francisco o sabe,/logo Apolônia se enfeita./Logo chovem os recados,/ logo a canoa se apresta,/logo vai, e logo encalha, logo toma, e logo chega./Logo vós a conduzis/para a casa das galhetas,/onde o melado se adoça onde a garapa se azeda"723.

Sobressaía na prosa de Gregório de Matos uma presença muito discreta dessa garapa ${ }^{724}$, a segunda escuma do caldo de cana retirada das caldeiras durante o processo da purificação do sumo, um item de alimentação que, segundo Antonil, costumava ser oferecido à mão-deobra em sistema de rodízio, contemplando todos aqueles que tinham parte na fabricação do produto.

Havia, no texto de Antonil sobre a fabricação do açúcar, informações interessantes sobre o uso dos subprodutos obtidos com a fabricação dos pães: as escumas, o mel e o remel. O sumo das canas moídas colocado no tacho da primeira caldeira passava durante a primeira fervura por uma operação de clarificação, semelhante à clarificação atual do caldo de cozidos fervido com claras de ovo. Juntava-se então ao sumo espremido uma decoada de cinzas de madeiras queimadas que auxiliava a depurá-la. Parte das primeiras escumas, cheias ainda de impurezas, era oferecida aos animais de tiro. Uma porção das escumas retiradas durante a cocção na segunda caldeira alimentava os escravos. O resto das escumas depuradas era reaproveitado na fabricação de novos pães. Distinguia-se uma garapa doce nutritiva, da garapa fermentada que, além de nutrir embriagava e constituía, por essa razão, um dos alimentos prediletos dos escravos. Fora dos meses de safra ou no espaço urbano, outra versão de garapa azeda podia

\footnotetext{
723 MATOS, G. Op. Cit., Vol. VI, p.1464.

724 Foi com essa bebida de custo reduzido, que os soldados dos exércitos da WIC., Companhia das Índias Ocidentais holandesa, se embriagaram correntemente.
} 
ser preparada com melaço fermentado ou com açúcar mascavo dissolvido em água ${ }^{725}$. Antonil indicou ainda a existência de claros, a terceira escuma totalmente clarificada, que formava um xarope límpido muito apreciado pelos colonos:

“A derradeira espuma da última meladura, que é a última purificação do caldo, chamam claros, e estes, misturados com água fria, são uma regalada bebida para refrescar e tirar a sede nas horas em que faz maior calma"726.

Tal escalonamento no uso dos subprodutos do açúcar deixava patente um papel de marcador social hierárquico. Quanto à garapa azeda, bastante nutritiva e de teor alcoólico mais brando que as águas ardentes destiladas com a mesma matéria-prima ou com melaço, era inegável o parentesco técnico com os vinhos indígenas de frutas e raízes fermentadas. A presença maciça desses preparos, até meados de 1645, na área produtora do açúcar acusava provavelmente a presença de muitos índios e mamelucos na composição demográfica da população que gravitava em torno dos engenhos. Inicialmente fabricada e consumida em larga escala, seu preparo parece ter arrefecido na segunda metade dos anos seiscentos. As metáforas do poeta sobre o consumo de subprodutos do açúcar na colônia, no último quartel do século XVII, sugerem efetivamente uma mudança interessante nos padrões do aproveitamento dos subprodutos da manufatura açucareira.

Os cronistas quinhentistas ou da primeira metade do século XVI, com efeito, não mencionavam as rapaduras e tampouco se observava em seus textos alguma primazia do consumo de aguardente da terra, designada como jeribita. Parece ter diminuído, após o advento ao trono da dinastia de

\footnotetext{
725 PISO, Guilherme. Op. Cit., p.13. Era uma bebida que o cientista observou em Recife: "Aliás, a turba dos soldados e dos africanos indistintamente enfrascam-se da bebida aromática e muito comum chamada vulgarmente garapa, que os taberneiros ávidos de lucros, preparam com açúcar prêto e água, e, apenas defecada, vendem a baixo preço, ajuntando-lhe as folhas da árvore Acajuéra, pelo calor das quais os vapores são excitados, produzindo-se mais depressa a embriaguez".

726 ANTONIL. Op. Cit., p. 203.
} 
Bragança, a proporção de escumas transformadas em garapa, apesar de Antonil reconhecer que a garapa doce, e até mesmo a garapa azeda, eram menos prejudiciais à saúde que as aguardentes destiladas fornecidas aos escravos ${ }^{727}$.

Foi possivelmente a escassez de escravos na colônia e o gosto dos vendedores africanos de escravos pelo tabaco e pelas aguardentes brasileiras que induziram tal mudança. Schwartz ${ }^{728}$ assinalou também uma mudança que teria ocorrido na procedência dos escravos em meados do século XVIII: os escravos levados de Angola para a Bahia sendo substituídos por escravos provenientes da costa da Mina. Quiçá merecesse, portanto, uma investigação detalhada o incremento no volume da produção colonial de aguardente, paralelo ao incremento do tráfico negreiro, fato bastante conveniente para os senhores de engenho e para os pequenos lavradores de canas, que dispuseram assim de um mercado expandido para vender barris de melado aos donos de engenhocas. Os poemas de Matos, contudo, apenas deixam adivinhar a presença de tais acontecimentos, sem que a obra permita ir muito longe na exploração do tema.

Outro subproduto valorizado do açúcar foi o melaço, que escorria do fundo das formas de barro, quando se retirava o calço que as vedava - uma vez cristalizadas as três têmperas de concentrações diferentes e progressivas, que eram misturadas nas vasilhas de barro para obter um produto final de boa consistência. Efetuada a homogeneização dos três tipos de caramelos ${ }^{729}$, Antonil relatava que o líquido, mel, melado ou melaço, era recuperado, seja para voltar a ser beneficiado nas caldeiras, dando origem a um açúcar de menor qualidade e menos doce (dito açúcar batido), seja para a fabricação de garapa ou de aguardente, seja para o consumo direto. O resíduo escorrido das formas do açúcar batido chamava-se remel. Rocha Pita comentava:

"quando os senhores dos engenhos não querem usar destes inferiores gêneros de açúcar, vendem os meles aos fabricadores das águas ardentes, que em pipas e

\footnotetext{
727 ANTONIL. Op. Cit., p. 164.

728 SCHWARTZ, B Stuart. Burocracia e sociedade no Brasil colonial. Op. Cit., p. 194.

729 ANTONIL. Op. Cit., pp. 206 e 207.
} 
tonéis os levam para suas oficinas, onde tendo-os algum tempo em certa infusão, os põem a cozer em lambiques, cuja destilação é água ardente, de que consta a maior parte da carga das embarcações que navegam para a costa da África a buscar escravos, e se gasta por eles e pela plebe do Brasil, em lugar das do reino" $" 730$.

Os poemas de Gregório de Matos, recorrendo a brincadeiras de gosto muitas vezes duvidoso, que envolviam as premissas tácitas da manufatura açucareira, atestavam a familiaridade dos colonos tanto com o açúcar, quanto com o uso regular dos subprodutos bebidos ou comidos dessa fabricação. No caso da moça que tentava parecer virgem se grudando com "xaropes que cozinha" ${ }^{731}$, ou naquele do colono satirizado (o próprio Sebastião da Rocha Pita): "Um Sansão de caramelo/quis a Dalila ofender" 732 , nas comparações entre lusos e africanos "o Preto é porra tisnada/mas sobre ser porra dura,/é porra dura que atura,/o Branco mais lindo, e belo/é porra de caramelo, desfaz-se na cozedura" ${ }^{933}$, ficava comprovado a que ponto o açúcar podia ser visto como item colonial de consumo corrente.

Em alguma ocasião não localizada no tempo, mas provavelmente associada à crise econômica que afetou a colônia e particularmente Salvador, Matos, encontrou o engenho da Cajaiba "pejado" (não moeria) e a maioria das escravas ausentes. O poeta saudoso de momentos memoráveis passados ali, culpou, então, o feitor-mor:

"Viva o insigne ladrão/que todo o melado estanca/segundo Jorge da Franca/em contas, e expedição:" 734 .

\footnotetext{
730 PITA, Sebastião da Rocha. Op. Cit., p. 26, parágrafo 29.

731 MATOS, G. Op. Cit., Vol. VI, p. 1458.

732 MATOS, G. Op. Cit., Vol. IV, p. 969.

733 MATOS, G. Op. Cit., Vol. IV, p. 832.

734 MATOS, G. Op. Cit., Vol. VI, p. 1528.
} 
Acusou também esse feitor, o Azevedo, de furtar lascas de açúcar:

"Se furtais tanto fragmento/de açúcar para as mulheres,/pode ser, se lho não deres,/ que tenhais entendimento:" 735 .

As caixas de açúcar eram mercadorias exportadas, mas os colonos reservavam sempre algumas para o uso do engenho. Durante as invasões holandesas, frei Manuel Calado, se escandalizou ao ver os credores batavos de senhores de engenho endividados levarem toda a produção, não deixarem no local nem uma só caixa de branco para "confortar os doentes" "736. A crer Gregório de Matos, na ausência de dinheiro líquido, colonos também propunham açúcar às mulheres em troca de favores sexuais:

“Tudo a Môça suportou,/tudo sofreu a tal Môça,/porque a caixa tudo adoça,/e a ela tudo amargou:/nèsciamente se enganou/sem desculpa, e sem razão,/pois na fôrça da sezão,/devia ver, que a encaixa/quem lhe promete uma caixa,/para correr-lhe o caixão" 737 .

O açúcar depois de seco, cortado e encaixotado, seja branco, seja mascavado, macho (de primeira qualidade) ou batido (feito de melado reaproveitado) constituía antes um produto comercializado que um item de consumo local. Porém, os colonos não se privaram de comer doces, confeitos ou conservas (frutas cozidas em açúcar). Forçosamente a metáfora do doce 735 MATOS, G. Op. Cit., Vol. VI, p.1462.

736 CALADO, Frei Manuel. O valeroso Lucideno e triunfo da liberdade. 2 v., BH./ SP., Itatiaia/EDUSP, 1987. p. 219:

"Se algum senhor de engenho devia alguma coisa aos da Companhia, lhe mandavam pôr olheiros em seus engenhos, os quais não the deixavam tirar nenhuma arroba de açúcar para fazer doces para os enfermos, senão que tudo lhe levavam, e sobretudo lhe sustentavam os olheiros enquanto a safra durava...". 
simbolizando prazeres corporais, isto é, alimentos saboreados ou amores, sobressaiu na escrita poética. Recebendo doces preparados pelas freiras no convento do Desterro, Matos agradecia o favor:

"Senhora minha: se de tais clausuras/tantos doces mandais a uma formiga,/Que esperai que vos diga,/se não for muchíssimas doçuras"738.

"quando sabe que a doçura/se se come, é por natura,le os mais doces por bemol"739.

Discorrendo sobre o consumo do melado, Antonil especificava:

"O melado que se dá em pratos para comer é o da primeira ou segunda têmpera"740.

Os versos de Matos confirmavam a predileção. Numa excursão da Cajaíba à Ilha Grande com alguns amigos, os companheiros margeando a costa do fundo do Recôncavo com seu barco, foram buscar Chico (lavrador de arroz) em sua propriedade:

"Tocou-se logo a trombeta,/que um búzio era potente,/em sinal de haver chegado/a capitânia de Ostende. // Deu-nos um pouco de apupos,/e vendo que o Chico desce,/ embarcou-se, e socorreu-nos com China, e melado quente" ${ }^{741}$.

Matos brincou também com a idéia das rapaduras, tijolos duros de açúcar mascavo, feitos de açúcar levado ao ponto da terceira têmpera (a mais compacta), guloseima que o jesuíta Antonil dizia especialmente apreciada pelos estudantes do colégio:

738 MATOS, G. Op. Cit., Vol. IV, p. 870.

739 MATOS, G. Op. Cit., Vol. IV, p. 868.

$740 \quad$ ANTONIL. Op. Cit., p. 207.

741 MATOS, G. Op. Cit., Vol. III, p. 609. 
"Do da terceira, bem batido na repartideira, se fazem as rapaduras, tão desejadas dos meninos, e vem a ser melado coalhado sobre um quarto de papel com todas as quatro partes levantadas como se fossem paredes dentro das quais endurece esfriando-se, de comprimento e largura da palma da mão. E bem aventurado o rapaz que chega a ter um par delas, fazendo-se mais de boa vontade lambedor destes doces papeis do que escrivão nos que lhe dão para trasladar o alfabeto" $"$.

As rapaduras surgiram na escrita poética de Matos para sustentar analogias de teor fecal em poemas que relatavam o caso de uma moça traída, que ofereceu ao amante um doce de araçá preparado com uma fruta na qual um pinhão de purga tinha sido cozido:

"Minha gente, você vêlas loucuras tão borrachas/dêste Capitão das Taxas,/ que agora direi, quem é:/veio pedir de mercê,/que lhe celebrasse a cura/de uma purgação madura,/que a amiga lhe tinha dado,/porque, sem comer melado/o fêz cagar rapadura. // [...] Estribilho: Saiba-se em qualquer lugar,que esta rapadura inteira,/foi da casa da caldeira/para a casa de purgar" $" 743$.

Noutro poema no qual satirizava um colono apelidado Mangará, Matos retomou o tema do araçá, que provavelmente correspondeu a algum escândalo soteropolitano comentado ou a uma invenção muito bem recebida pelo público:

"Pondo-se o pleito em julgado/dar testemunhas procura/com o Primo Rapadura,/e um compadre seu melado:/mas há de ficar borrado/como o tal Primo ficou,/quando a Mulata o purgou/naquele triste araçá/Mangará" ${ }^{744}$.

\footnotetext{
742 ANTONIL. Op. Cit., p. 207.

743 MATOS, G. Op. Cit., Vol. II, p. 385 e 386.

744 MATOS, G. Op. Cit., Vol. II, p. 364.
} 


\section{O tabaco: um quase alimento}

Discorrendo sobre o tabaco, Alfredo Margarido ${ }^{745}$ observou que essa planta sul-americana de uso sacralizado entre os índios, uma vez conhecida dos europeus no final do século XV, passou rapidamente a desempenhar um papel semelhante àquele do chá asiático, cabendo-lhe um lugar central na convivialidade das sociedades ocidentais:

“Letrados que cachimbais,/quando estudais nos Jasões/e assentai conclusões/com as letras garrafais..." ${ }^{ং 46}$.

Apresentando sua casa situada nos arredores do Dique do Tororó, Matos explicitava:

"Palha seca e frondosa/Um tanto refolhada/Da que sendo erva Santa, é vício imundo" $" 747$.

Ao descrever, Vanique o beberrão flamengo, confrade da bota, Matos versejou uma reunião social animada ${ }^{748}$ :

"Se a morte anda de ronda, a vida trota,/Aproveite-se o tempo, e ferva o Baco,/Haja galhofa, e tome-se tabaco,/venha rodando a pipa, e ande a bota" ${ }^{749}$.

Gregório de Matos também pediu, em versos, tabaco a um amigo:

745 MARGARIDO, Alfredo. As surpresas da flora no tempo dos descobrimentos. Lisboa, Ed. Elo, sem data. pp. 116 e 117.

746 MATOS, G. Op. Cit., Vol. III, p. 734.

747 MATOS, G. Op. Cit., Vol. V, p. 1222.

748 MATOS, G. Op. Cit., Vol. VI, p. 1538.

749 MATOS, G. Op. Cit., Vol. VI, p. 1537. 
"Senhor: o vosso tabaco/que muito me ensoberbeça/se uns fumos lança à cabeça/ mais divinos, que os de Baco:/e bem, que nunca em meu cacolentra tão rico alimento,/por isso mesmo eu intento/para o meu proveito, e pró,/porque me deis dêsse pó,/mandar-vos êste memento" "750.

Quanto a Antonil, o jesuíta prudente sublinhava a importância de uma vigilância especial dos feitores em relação ao tabaco fumado pelos escravos:

“E esteja muito atento que se não pegue o fogo nos canaviais por descuido dos negros boçais que às vezes deixam ao vento o tição de fogo que levam consigo para usarem do cachimbo; e em vendo qualquer lavareda, acuda-lhe logo com tôda a gente e corte com fouces o caminho à chama que vai crescendo, com grande perigo de se perderem em meia-hora muitas tarefas de cana"751.

\section{2 - O abastecimento colonial da capital e do Recôncavo}

Ciclos anuais marcavam o ritmo das atividades econômicas, das atividades que organizavam o provimento da subsistência alimentar e os ritmos da vida cultural e social da colônia. Tais padrões ritmados de organização social transpareceram na obra de Gregório de Matos, apesar do poeta não esmiuçar, senão como pretextos, os hábitos alimentares dos colonos lusos. As exemplificações materiais de idéias simbólicas, incluídas nos versos, trouxeram à tona diversos manejos sociais dos alimentos, permitindo examinar o modo como os colonos lusos lidavam com o meio ambiente local. Ofereciam palcos de premissas tácitas à pesquisa, por intermédio de gestos carregados de significados e revelavam saberes ou formas de agir atreladas a maneiras recorrentes de pensar o mundo.

\footnotetext{
750 MATOS, G. Op. Cit., Vol. V, p. 1185.

751 ANTONIL, Op. Cit., p. 153.
} 
As críticas versejadas de Matos a muitas autoridades coloniais, nas quais estudiosos (como Lúcia Helena ${ }^{752}$ ) viram um rompimento da identificação entre portugueses do reino e população colonial, assinalaram fatos que Matos apontava como erros de gestão colonial:

“Triste Bahia! Oh quão dessemelhante/Estás, e estou do nosso antigo estado!/Deste em dar tanto açúcar excelente/Pelas drogas inúteis, que abelhuda/simples aceitas do sangaz Brichote ${ }^{753}$. // Oh se quisera Deus, que de repente/Um dia amanheceras tão sisuda/Que fôra de algodão o teu capote!"754.

As vituperações de Matos contra a precedência concedida às necessidades da frota, em detrimento dos colonos, incidiram sobre os procedimentos de uma Câmara relapsa e de governadores desatentos ou sobre as novas modalidades de comercialização menos favoráveis aos produtores de açúcar:

"Tôda a cidade derrotalesta fome universal,/uns dão a culpa total/à Câmara, outros à frota:/a frota tudo abarrota/dentro nos escotilhões/a carne, o peixe, os feijões, /e se a Câmara olha, e ri,/porque anda farta até aqui,/é cousa, que me não toca;/Ponto em bôca. // [....] // "A fome me tem já mudo,/que é muda a boca esfaimada;/mas se a frota não traz nada,/por que razão leva tudo?/que o povo por ser sisudo/largue o ouro, e largue a prata/a uma frota patarata,/que entrando co'a vela cheia,/o lastro que traz de areia,/por lastro de açúcar troca! Ponto em boca // Se quando vem para cá,/nenhum frete vem ganhar,/quando para lá tornar,/o mesmo não ganhará:/quem o açúcar lhe dá,/perde a caixa e paga o frete,/porque o ano

752 HELENA, Lúcia. Op. Cit., Cf. capítulo I da tese.

753 Segundo a definição do Diccionário da língua portugueza de Moraes: "Brichote: nome que por desprezo se dá aos estrangeiros". Segundo Hansen,: corruptela de British.

754 MATOS, G. Op. Cit., Vol. II, p. 428. 
não promete/mais negócio que perder/o frete por se dever,/a caixa porque se choca:/Ponto em bôca"755.

As idas e vindas da frota mercantil portuguesa obedeciam a ritmos anuais de ventos de monção e a alterações correlatas na direção das correntes marinhas. A chegada da frota saída de Lisboa durante os primeiros meses do ano constituía, por conseguinte, um marco notável na vida cotidiana colonial enfatizado pela maioria dos cronistas. Naus metropolitanas navegando em comboio traziam cargas de mercadorias úteis e de luxos supérfluos, entre os quais figuravam certos gêneros comestíveis que os colonos saudosos das delícias portuguesas apreciavam devidamente. Mas a Companhia Geral de Comércio do Brasil, a quem o monopólio comercial foi outorgado após a Restauração Portuguesa, nem sempre tomava o bem público soteropolitano como sua principal meta de ação. Provia quantidades insuficientes de certos produtos necessários para elevar os preços e maximizar os lucros. Quando os navios partiam carregados de produtos locais, açambarcavam boa parte dos mantimentos da cidade provocando as queixas da população.

A permanência da frota, que vinha buscar o açúcar preparado, era o período do ano convencionado para acertar dívidas pendentes ou negócios. As taxas então arrecadadas na comercialização dos produtos ativavam as finanças. Era também o momento reservado para escrever cartas aos correspondentes reinóis.

Matos ressaltou ocasionalmente o impacto visual causado pela aproximação da costa brasileira, quando a orla luxuriante da praia aparecia de chofre aos viajantes. Num poema em que o autor relatava o retorno a Salvador de Pedro Alvarez da Neyva, comerciante enriquecido que tentou comprar um título de fidalgo e voltou de Lisboa alegando ter obtido a distinção, ele colocou na boca do fidalgo arrevesado uma exclamação que não lhe ocorreria se não tivesse experimentado semelhante emoção: "Ontem avistamos terra/e quando na barra vi/coqueiros e bananeiras,/disse comigo: Brasil"'756.

\footnotetext{
755 MATOS, G. Op. Cit., Vol. II, pp. 435 e 436.

756 MATOS, G. Op. Cit., Vol. IV, p. 897.
} 
O dinheiro dos colonos, arrecadado com a venda das caixas de açúcar, dos rolos de tabaco, dos couros, dos algodões etc., lhes permitia comprar produtos lusos (ou abrir novas contas de dívidas). Proviam-se então de sal indispensável, de bacalhau, de farinha de trigo, de azeite, de vinagre, de vinho, de aguardentes do reino ou de frascos de rosa soles ${ }^{757}$ e também de ingredientes regalados: azeitonas, queijos do reino e fiambres, tais como presuntos, paios e chouriços defumados, cujo consumo ornamentava as festividades dos homens remediados. Esses gêneros alimentícios, secos ou molhados, com efeito, quando bem preparados e acondicionados agüentavam os percalços da viagem e foram os principais gêneros reinóis carregados nos porões dos navios, que vinham buscar o açúcar, o tabaco os couros, os algodões e outros produtos da colônia apreciados em Portugal. Eles serviam, por serem caros e raros, como itens de prestígio para demonstrar a riqueza, a honradez e o pertencimento ao universo da metrópole portuguesa dos mazombos bem sucedidos, que os comiam ou os ofereciam a hóspedes ocasionais.

O sal sobretudo afigurava-se indispensável à criação do gado e ao preparo dos couros ou de mantimentos como as carnes bovinas, os peixes salgados ou os laticínios. Apesar de existir em abundância nas salinas do Ceará ou do Rio de Janeiro, constituía um monopólio real que a coroa lusa fez questão de manter, provocando, em alguns momentos infelizes, escassez do produto e alta nos preços.

Outros gêneros, entretanto, produtos indispensáveis à realização das missas, como a farinha de trigo para as hóstias e o vinho, eram também vendidos a colonos abastados, que buscavam um gostinho da terra lusa em tais consumos. Comprar vinhos fabricados em Portugal, nas ilhas da Madeira ou nas Canárias, aguardentes do reino, paios salpimentados, presuntos ou queijos, sublinhava também a riqueza de uma mesa colonial e comprovava que o chefe da casa se tratava à lei da nobreza. De modo que coube às iguarias consumidas ou oferecidas o papel simbólico de tornar explícitas as diferenças sociais existentes no bojo da sociedade colonial. 
O provimento colonial em vinhos, aguardentes e azeites do reino constituiu um monopólio da coroa cedido à Companhia Geral de Comércio. Em terra, a venda desses gêneros alimentícios aos colonos se efetuava por meio de terceirização. Vendiam-se pipas e barris de vinhos, de aguardentes, de azeite ou de vinagre, seja diretamente aos colonos, seja a taberneiros munidos de licenças que os revendiam por canadas ${ }^{758}$ à população. $\mathrm{O}$ elenco das bebidas citadas nos poemas de Matos, vinhos de malvasia ou moscastel ${ }^{759}$, vinhos sem especificação particular, aguardentes do reino, rosa solis ${ }^{760}$ e jeribita, ou aguardente da terra, permearam a composição dos poemas com matizes de crítica social:

“Seja solteiro, ou casado,/é questão, é já sabido/não estar sem ter borracha/seja do bom, ou mau vinho./Em chegando a embebedar-se/de sorte perde os sentidos, /que deixa a mulher em couros, /e traz os filhos famintos:/mas a sua concubina /há de andar como um palmito"761.

Num poema consagrado à saga de um tenente apelidado o "Surdo", que comerciava paios podres, tapando a boca do Alferes para melhor vender gato por lebre, Matos vituperou os atravessadores, que praticavam negócios sorrateiros, provavelmente em razão das dificuldades enfrentadas pela Câmara para prover o salário e a ração dos militares com suas rendas exíguas:

"porque sois tão mau cristão,/que o que vos custa um tostão,/vendeis por duzentos réis / [...]/sobre perder a queijeira,/em que ganhais quatro reis,/virão os Almotacéis,/ meter-vos na Leoneira. // [...]/Se os paios tão podres são,/quando vo-los pede alguém,/quando os vendeis muito bem,/como é cada qual tão são?/[....]/pois,

\footnotetext{
758 Segundo o Diccionário da Língua portugueza de Morais: “Canadas: Medida de líquidos: contém quatro quartilhos, a duodécima parte de um almude...".

759 MATOS, G. Op. Cit., Vol. III, p.631.

760 MATOS, G. Op. Cit., Vol. II, pp. 394 e 395.

761 MATOS, G. Op. Cit., Vol. I, p. 23.
} 
sois na verdade tal,/que gabando-os sem sal/no-los vendeis bem salgados./[...]/ pôde nunca a diligência/do Alferes vosso parceiro/tirar do vosso fumeiro/um fole de pestilência. // [...]/Sôbre a partida dos queijos,/que vós intenteis comprar,/me dizem, que eis de ganhar mais do que quatro percevejos:/creio, que dêstes sobejos/tirareis ganância boa,/com que honreis casa, e pessoa;/mas tenho o meu pesarzinho/de ser mercador ratinho, quem éfilho de Lisboa. // Quanto ao outro negocinho/da frasqueira rosa soles, /que intenteis vender aos goles/a frasquinho por frasquinho:/tirareis tal coscorinho/deles, como de um crisol/[...]/má cousa, Senhor Tenente”762.

Não foram apenas trâmites comerciais organizados em torno da frota que marcaram os ritmos da vida soteropolitana. A sazonalidade de atividades agrícolas tais como o plantio de canas ${ }^{763}$ ou de $\operatorname{arroz}^{764}$ e a periodicidade das queixas contra a escassez de gado de corte, nos invernos chuvosos, quando os rios do sertão transbordavam e quando a falta de pontes dificultava a travessia dos rebanhos, também alternou situações de fartura ou de escassez em mantimentos ${ }^{765}$ que transpareceu indiretamente nos versos.

Foram sazonais ainda as atividades das armações de baleias em Itaparica ${ }^{766}$ que derretiam as gorduras dos animais arpoados, provendo aos colonos um combustível menos dispendioso que o azeite português e bastante conveniente para alumiar casas e engenhos.

762 MATOS, G. Op. Cit., Vol. II, pp. 392 a 395. Segundo o Diccionário da Língua portugueza, Moraes:

"Almotacé ou almotacel: Juiz eleito pela Câmara,que tem inspeção sobre pesos, medidas, preços dos víveres, limpeza da Cidade e outos objectos de Polícia". "Coscorinho: Pecúlio, dinheiro junto, mealheiro". (O Limoeiro e a Leoneira eram prisões lusas).

763 MATOS, G. Op. Cit., Vol. VI, p. 1464.

"Logo Apolônia se enfeita/[...] Logo vós a conduzis/para a casa das galhetas,/onde o melado se adoça/onde a garapa se azeda".

764 MATOS, G. Op. Cit., Vol. VI, p. 1511.

765 CARTAS do Senado. $2^{\circ}$ vol., Bahia, Prefeitura Municipal do Salvador, p. 51.

766 ELLIS, Myriam. A baleia no Brasil colonial: feitorias, baleeiros, técnicas, monopólio, comércio, iluminação. São Paulo, Ed. Melhoramentos/EDUSP, 1969. 
A carne das baleias (consideradas peixes pelos colonos) era subproduto dessa pesca fundamental, operada sob contrato. Podia ser adquirida a pouco custo por colonos de recursos escassos, pelos armadores das naus (eles alimentavam as tripulações com semelhante matalotagem durante as viagens de retorno à metrópole) e pelos donos de escravaria numerosa, que mandavam cozinhá-la e conservá-la embarrilada ${ }^{767} \mathrm{em}$ sal para distribuí-la aos escravos nos meses subseqüentes.

A despeito do ciúme que a importância social de mamelucos afidalgados despertava na alma de Gregório de Matos, sua própria conduta atestava pelo menos uma continuidade autóctone, no agrado assinalado dos colonos com a safra dos cajus. Mesmo explicitando seu desprezo pelos vinhos nativos, fabricados com sumo fermentado dessas frutas, o poeta também deixou claro o quanto apreciava os cajus que amadureciam pela época do Natal. A espera da safra dos cajus figurou em sua obra como um momento muito especial no ano. De novembro a janeiro, as arvores apresentavam drupas maduras, sumarentas e castanhas a serem coletadas. Os cajueiros, que cresciam espontaneamente nos matos, forneciam então ocasiões ideais para excursões campestres.

\section{Os alimentos como alvo de administração}

Administrar a colônia implicava, entre outras tarefas, uma gestão planejada do abastecimento alimentar. Criar condições de vida adequadas à prosperidade econômica e à tranqüilidade da vida social dependeu muito das autoridades garantirem à população meios de adquirir gêneros comestíveis em quantidades razoáveis e a preços acessíveis. À Câmara Municipal de Salvador cabiam, entre outras responsabilidades, as providências que se impunham para resguardar a qualidade e o preço dos alimentos vendidos.

Por vezes, no entanto, aconteciam sobrecargas inesperadas de população e as provisões rareavam, insuficientes para assegurar a subsistência de todos. Circunstâncias imprevisíveis,

767 PITA, Sebastião da Rocha. Op. Cit., p. 35, parágrafo 75. 
como secas, enchentes, epidemias, guerras, chegadas de naus avariadas que resolviam invernar no ancoradouro da cidade ou então condições climáticas adversas (provocando atrasos na chegada da frota anual), afetavam o volume dos mantimentos armazenados ou dos víveres frescos comercializados. Ocorriam, então, momentos penosos de carestia, durante os quais o custo dos alimentos deixava à mingua colonos de poder aquisitivo modesto.

Apesar da fertilidade reconhecida da terra, onde vegetais plantados e animais domésticos vingavam sem grandes cuidados, aconteciam, de quando em quando, situações de escassez que afetavam sobretudo os mais pobres. Quem costumava comprar a varejo pequenas quantidades de cada produto e dependia dos mercadores de lojas abertas para o provimento, não podia competir com os colonos remediados e os atravessadores que açambarcavam os produtos disponíveis. As crises, uma vez instaladas, demoravam alguns meses para serem resolvidas. Era necessário planejar previamente o plantio de um número condizente de raízes de mandioca e esperar, por cerca de um ano, que amadurecessem, ou ainda aguardar que condições climáticas favoráveis possibilitassem o envio de boiadas do sertão para o litoral. Por outro lado, se muitos proprietários preferiam adquirir mantimentos em lugar de produzi-los em suas próprias terras pelo preço módico de sua aquisição, os lucros proporcionados aos lavradores de mantimentos da terra não eram tais que incentivassem à produção de muitos excedentes para fazer frente aos imprevistos.

Por semelhantes motivos, formara-se na colônia uma distinção conceitual entre os mantimentos, alimentos estratégicos, armazenados por longos meses nas despensas e garantindo sozinhos um sustento básico à população e os víveres alimentos frescos, de valor nutritivo reconhecido e de sabor agradável, cujo consumo complementava a ingestão dos ingredientes secos escolhidos como base da subsistência colonial. A diferença estratégica entre os mantimentos que proviam uma dieta mínima ${ }^{768}$ aos colonos, e os víveres fundamentavase menos em considerações gastronômicas, do que em cautelas e cálculos de ordem política ou econômica. As medidas tomadas para que quantidades apropriadas de alimentos fossem

768 PAPAVERO, C. Dissertação de mestrado. Op. Cit., pp. 172 e 198. 
produzidas e vendidas à população constituíam tarefa confiada aos vereadores. As decisões relevantes desses administradores coloniais registravam-se nas Atas e nas posturas da Câmara Municipal soteropolitana. Quando necessário, eram também comunicadas ao rei por meio de Cartas do Senado.

Os colonos costumavam adquirir e armazenar nas despensas de suas casas cestos ou alqueires soltos de farinha seca, mantas de carnes-secas ou de bacalhau e barris de carnes de reses ou de peixes salgadas. Lavradores de roças, proprietários de grandes pesqueiros e pecuaristas do sertão forneciam a maior parte dos mantimentos produzidos localmente. Donos de terras, que possuíam muitos de escravos de serviço ocupados em atividades lucrativas, preferiam comprar na praça reservas de mantimentos de longa conservação do que ocupar terras e mão-de-obra nessas atividades menos lucrativas para produzi-los em seus domínios.

Na dieta que era praticada na colônia em meados do século XVII, carne-seca ou fresca, peixe seco, peixe fresco e farinha de mandioca seca ou beijus de farinha de mandioca foram os principais mantimentos. Feijões, como visto acima, marcavam presença discreta nas refeições, pois era notório entre pessoas honradas que comê-los, assim como ingerir batatas doces, provocava flatulências desagradáveis ${ }^{769}$. Em circunstâncias normais, pessoas que se consideravam nobres preferiam saborear outras iguarias.

Nas viagens marítimas para Angola ou Portugal requerendo bagagens pouco volumosas, alimentos de baixo custo e de alto poder nutritivo, esses grãos costumavam ser embarcados à guisa de matalotagem ${ }^{770}$. Em terra, era a pobreza dos comensais, homens livres ou escravos, que incitava ao consumo. Pesava também contra eles a pecha de serem alimentos sabáticos de cristãos novos judaizantes, consumidos sobretudo às quartas-feiras e aos sábados (dias magros

769 MOTT, Luiz. “Sergipe del Rei: Três sonetos seiscentistas”, in Estudos Humanísticos. Aracajú, ano 1, no. 1, 1990. pp. $123-130$.

PAPAVERO, Claude. Dissertação de mestrado. Op. Cit., p. 210.

"A Batata ou Ietica: (Ipomoea batatas Lam.). Segundo Piso esses tubérculos: "São pingues, doces e flatulentos; muito cultivados nas hortas". Wagener os declarava raizes consumidas por gente pobre".

770 LAPA, José Roberto do Amaral. Op. Cit., cf. Capítulo 7: "Matalotagens e municionamento". 
católicos). Quem preparava grãos com carne nesses dias se expunha à perseguição do Santo Oficio $^{771}$.

Nenhum desses fatores prenunciava a grande voga que os feijões mereceriam posteriormente no Brasil. Consideravam-se a carne e os peixes preservados secos como os verdadeiros condutos das farinhas. Contudo, quando possível, a população preferia consumir carnes verdes e peixes frescos apesar desses, por serem perecíveis, merecerem uma atenção especial, nem sempre eficaz, das autoridades coloniais. Em decorrência, como será visto mais adiante, o abate de bovinos ou de suínos e a venda de suas carnes constituíam atividades tão importantes quanto complexas. No caso da pesca, que era também controlada, a ingerência oficial se fazia menos sentir. Havia em Salvador, além de contratos com grandes pesqueiros, muitos indivíduos que viviam da pesca. Na volta dos pescadores, os compradores iam até os barcos atracados no cais para adquirirem o necessário. Mencionava-se nos textos de cronistas da época a existência na cidade de escravos e até de soldados ${ }^{772}$ que se dedicavam à pesca e pagavam as taxas que incidiam sobre tal atividade.

Segundo Avanete Pereira Sousa ${ }^{773}$, muitos vendedores ambulantes, dos quais parte significativa era composta de negros livres e de escravos de ganho, adquiriam peixes frescos para revendê-los com benefício de porta em porta, já que em Salvador feiras e mercados públicos afiguravam-se extremamente embrionários. De fato, as mulheres de boas famílias permanecendo semi-enclausuradas, entende-se a razão pela qual os colonos preferiam que os produtos frescos fossem levados até as casas. O sistema adotado gastava as pernas de negros e de mulatos e dispersava ao extremo os pontos de venda, o que complicava a fiscalização do comércio dos gêneros alimentícios e permitia um recrudescimento da atuação de pequenos e grandes atravessadores. Efetivamente, muitas negras de ganho ou vendeiras de lojas abertas

771 OMEGNA, Nelson. Diabolização dos judeus e presença dos sefardins no Brasil colonial. Rio de Janeiro, Record, 1969.

PAPAVERO, Claude G. Cf. Capítulo I da tese e Dissertação de mestrado. Op.Cit., p. 187 e 188.

772 SOUSA Avanete. Op. Cit., p.171.

773 SOUSA Avanete. Op. Cit., pp. 261 e 268, 
e muitos soldados e marchantes que proviam reses de corte, viviam de atravessamento das mercadorias.

Salvador parece ter contado, desde essa época, com os serviços de diversos profissionais nas tarefas do provimento alimentar ${ }^{774}$. Segundo atestavam os poemas de Matos existiam em particular colonos que praticavam ofícios de pasteleiros (possuíam cepos e fornos, onde preparavam empadas e tortas de carne), de confeiteiras (elaboravam doces e confeitos) e de taverneiros licenciados para vender vinhos e aguardente. Nas Atas da Câmara mencionavam-se ainda padeiras entre os comerciantes respeitados.

Alimentos preparados podiam ser adquiridos nas ruas ou em vendas de lojas abertas. Circulando nas ruas ou instaladas com seus tabuleiros em alguma esquina, negras de ganho quitandeiras, que muitas vezes pertenciam a viúvas portuguesas, vendiam manjares: os mesmos bolos e bolinholos de receitas indeterminadas que os comerciantes mofinos comedores de carne de baleia rejeitavam nos versos de Matos.

Os demais víveres frescos provinham principalmente do entorno rural da cidade, onde localizavam-se roças, hortas e pomares bem como criações domésticas de aves e de pequenos quadrúpedes. Os quintais urbanos também deviam produzir alguns vegetais ou comportar alguns galinheiros ou animais de pequeno porte, como atestava um poema satírico ridicularizando um frade que roubara o cabrito de um vizinho para ter matalotagem em sua ida ao Recôncavo. Os versos de Matos aludiam ainda a uma Horta da cachaça em Salvador, além de uma metáfora referindo moças da família Parede, floridas como um jardim: “A nobreza dos Jardins, /que tem seu solar nas Hortas,/cortando galas de nôvo,/veio com elas em fôlha"775.

A gestão dos problemas da cidade era atribuição específica dos vereadores da Câmara Municipal. Designados para exercer o cargo pelo prazo de um ano, esses colonos privilegiados

\footnotetext{
774 A leitura das Atas da Câmara do período analisado se afigurou assaz instrutiva. Seria talvez interessante comparar os relatos de discussões ocorridas e as menções específicas a problemas, que inspiraram comentários ao poeta, para datar certos poemas de forma mais acurada.
}

775 MATOS, G. Op. Cit., Vol. VII, p. 1562. 
integravam a lista dos homens bons da colônia. Foram escolhidos, até $1696^{776}$, a partir de listas de homens elegíveis colocadas dentro de bolas de cera (chamadas pelouros). A mãozinha de uma criança de menos de sete anos escolhia um pelouro ao acaso. Depois dessa data a Relação teve maior poder de intervenção em sua nomeação.

Participar das reuniões no Senado da Câmara Municipal obrigava esses homens, em geral ricos proprietários de terras que não pertenciam à nobreza do reino, a residirem por longos períodos de tempo na cidade e a efetuarem gastos maiores do que fariam em suas terras. Pelo desempenho da função honorífica não recebiam proventos, apenas algum auxílio de custo por ocasião das procissões. Cabia-lhes sanar todos os males que afligiam a capital. Mandavam consertar fontes de água cujos canos quebrados ou entupidos eram motivos de brigas entre os escravos. Retomavam fontes de água públicas que algum particular desviava para fabricar aguardente da terra. Ora permitiam ora proibiam o preparo de aguardentes de cana, seja a fim de proteger o monopólio da venda de vinhos e aguardentes do reino, seja com o propósito de incentivar a troca de jeribita por escravos na costa africana. Estipulava-se o tamanho das redes que os pescadores podiam utilizar. Por vezes, a abertura de uma nova rua era decidida. Anunciava-se, tocando sinos para conclamar a população, a obrigação de se colocar lamparinas às janelas por três dias seguidos para festejar algum feito cívico ocorrido em Portugal. Em situações de crise do abastecimento promulgava-se medidas para tentar regularizar a retomada do fornecimento, exigindo que algumas categorias de colonos, cujas atividades requeriam grande consumo de farinha seca, providenciassem o plantio de números estipulados de covas de mandioca e mandassem fabricar as próprias farinhas. Atuações acintosas dos atravessadores costumavam também ser investigadas, sendo que multas e cadeia castigavam os abusos.

Efetivamente a tarefa principal da Câmara consistia em fixar preços justos para a venda dos gêneros alimentícios e em vigiar as condições da comercialização dos gêneros alimentícios, sobretudo quando se tratava do fornecimento de mantimentos da terra. Nas reuniões, os vereadores, a pedido de algum governador atento a suas responsabilidades, tomavam decisões

776 SCHWARTZ, Stuart. Burocracia e sociedade no Brasil colonial. Op. Cit., p. 214. 
pertinentes ou fixavam preços de venda máximos ou mínimos dos produtos. Segundo Avanete Pereira Sousa:

"Encarregados do funcionamento da vida econômica local, juizes vereadores, procuradores e almotacés eram, de fato, os principais agentes desse processo, porque lhes competiam a definição dos meios e das formas de gestão municipal em questões que, por costume ou delegação régia, dependiam diretamente das câmaras" $" 777$.

No plano prático, os vereadores recebiam auxílio de dois almotacés, eleitos para exercer seus mandatos pelo prazo de dois meses. Esses homens encarregavam-se diariamente de fiscalizar as condições de venda ao público dos gêneros alimentícios, tendo poder para coibir os abusos ${ }^{778}$. Eram solicitados a estar presentes no abate das reses, a verificar a aferição das balanças dos comerciantes e as licenças de todos os vendedores que comercializavam produtos. Por conseguinte, esses almotacés exerciam um cargo assaz honorífico, mas sem grande entusiasmo. Resignavam-se a aceitar a função estafante para a qual tinham sido designados, quando desejavam se firmar socialmente na hierarquia colonial. Efetivamente, a despeito de manifestações de boa ou de má vontade de vereadores e almotacés, pouco se podia fazer para colocar ordem no mercado dos produtos comestíveis; na maioria das vezes vereadores e almotacés corriam atrás de prejuízos que não podiam estancar e tentavam somente amenizar.

Mas nem sempre a Câmara reduzia o preço dos gêneros comercializados. Os mesmos alimentos básicos, que as autoridades coloniais tentavam episodicamente proteger contra a exploração desenfreada de atravessadores, carregavam também o ônus das taxas pagas à municipalidade. Para fazer frente aos gastos da administração colonial, a Câmara Municipal recebia parte importante das rendas do tesouro real, que incidiam sobre a venda de alimentos aos colonos.

\footnotetext{
777 SOUSA, Avanete Pereira. Op. Cit., p. 64

778 SOUSA, Avanete Pereira. Op. Cit, p. 72.
} 
Com essas quantias os vereadores mandavam executar obras, proviam ração e soldo aos militares e distribuíam benesses decididas pelo rei, como o sustento das religiosas. Financiavam também o funcionalismo local, as festas obrigatórias e socorriam os enjeitados. Recebiam rendas ao alugarem bens imóveis que pertenciam à instituição e colocavam em pregão as rendas do conselho. Isto é, concediam ao melhor candidato de um leilão o direito de arrecadar impostos em troca da antecipação de quantias contratadas, em datas estipuladas. Os rendeiros da cobrança terceirizada dos impostos ressarciam-se posteriormente do investimento e do trabalho efetuado por meio das quantias arrecadadas.

Algumas obras julgadas necessárias, no entanto, extrapolavam as finanças da municipalidade. Para poder realizá-las, criavam-se taxas excepcionais que incidiam em geral sobre a venda de algum item comestível indispensável. Surgiam ainda casos de fintas como o donativo para a paz com a Holanda e a contribuição para o dote da princesa Catarina, que vigorou durante trinta anos, requerendo uma tributação complementar. Nas Atas e nas Cartas do Senado transparecia, às vezes, um certo despreparo dos vereadores para se mostrarem realmente equânimes. Quando procuravam fazer justiça, era freqüentemente para ampliar o número dos colonos atingidos por tributações que cabiam exclusivamente aos grandes proprietários de terras, categoria de colonos à qual pertencia a maioria dos homens bons ${ }^{779}$.

Certa carta, que os vereadores endereçaram ao rei em 2 de julho de $1685^{780}$, expunha a circunstância de mais de dois mil lavradores de canas e senhores de engenho precisarem de lenha para ativar as moendas e as fornalhas dos mais de cem engenhos à beira-mar, e de existirem na região soteropolitana mais de dois mil carros de bois utilizados na região e trezentas embarcações de cabotagem com oitenta ou cem palmos de quilha necessitando todos de reparos anuais. Os vereadores tentavam atrair a atenção do rei sobre a competição pelo uso das madeiras e os inconvenientes que adviriam da construção de um galeão na Ribeira das naus, incidindo sobre os bosques soteropolitanos, já bastante despojados de madeiras nobres. Em 16/ 11/1672 A

779 ATAS da Câmara, Op. Cit., Vol. 5 , pp. 185 a 187 (30/5/1676).

$780 \quad$ CARTAS do Senado. $3^{\circ}$ vol (1684 - 1692). Bahia, Prefeitura Municipal do Salvador, p. 4. 
Câmara discutiu a possibilidade de comprar terras vizinhas da cidade para que o povo pudesse se prover mais facilmente de lenha, um item que estava começando a escassear ${ }^{781}$.

A venda de contratos de exclusividade para o fornecimento aos colonos de itens, como sal, carnes, peixes, trigo, vinhos e aguardentes do reino ou aguardentes da terra e óleo de baleia utilizado na iluminação foi uma maneira cômoda para a Câmara de antecipar a arrecadação das rendas destinadas à gestão da capital colonial. Arrendava-se o Dízimo real, imposto sobre tabaco, aguardente de cana e outros gêneros da terra. Existia ainda um contrato de aferição das Balanças e pesos utilizados no comércio local (aferidas duas vezes ao ano, segundo Sousa). Arrendavam-se a particulares a pesca das baleias, parte da venda da carne bovina e havia também uma Renda do Ver (ou do Verde) cobrança que incidia sobre os produtos comprados a vendeiros de legumes, de hortaliças ou de comidas preparadas, a taberneiros e a regateiros. Além disso, esses profissionais eram instados, a pagar licenças anuais para ter o direito de vender a varejo, desde que respeitassem os preços de venda estipulados pela municipalidade ${ }^{782}$. Segundo Rocha Pita, por exemplo, o contrato das baleias oferecia uma fonte substancial de rendas:

\section{"Importa à fazenda real o seu contrato, de seis em seis anos, termo da sua arrematação, cento e oitenta mil cruzados; e no ano de mil setecentos e vinte e três chegou a duzentos e cinco mil: vinte mil se gastam na sua pescaria cada ano. A fábrica das casas, armazéns, tanques, formas para recolher azeite tachos para o cozer, e outros instrumentos, assim de sua majestade como dos contratadores, vale mais de quarenta mil cruzados" ${ }^{9783}$.}

Na vigência dos contratos, os arrematantes procuravam auferir os maiores lucros possíveis. Contudo, adquirir um monopólio sobre a venda de mantimentos básicos da dieta colonial estava longe de resultar em latitude para fornecer qualquer produto aos colonos.

\footnotetext{
781 ATAS da Câmara, Op. Cit., Vol. 5 , p. 81.

782 SOUSA, Avanete Pereira. Op. Cit., pp. 172 e 230.

783 PITA, Sebastião da Rocha. Op. Cit., p. 35, parágrafo 73.
} 
Os demais víveres adquiridos na cidade provinham da área rural. Ressaltava a complementaridade fundamental entre cidade e campo para o provimento, já que regateiros carregavam gêneros europeus em seus barcos e iam vendê-los aos moradores do Recôncavo. Nas vilas da área rural, no entanto, as atividades da pesca, do mariscar, da caça e as atividades agropecuárias asseguravam certa autonomia do provimento. O lavradores da região adquiriam barris de peixes salgados ou secos, de carnes de boi secas ou salgadas, carnes de baleia, bacalhaus salgados e um grande volume de farinhas secas. Segundo observava Antonil, cada casa dispunha de animais domésticos destinados ao abate:

“Andam no pasto, além das éguas e bois, ovelhas e cabras; e ao redor do engenho a criação miúda, como são perus, galinhas e patos, que são o remédio mais pronto para agasalhar os hóspedes que vêm de improviso. Mas porque as ovelhas e os cavalos chegam muito com o dente à raiz da grama, são de prejuízo ao pasto dos bois, e por isso se o dêstes fôsse diverso, seria melhor" ${ }^{784}$.

\section{A questão das farinhas}

O último quartel do século XVII não foi um momento muito tranqüilo no que tangia ao abastecimento da população soteropolitana em farinha de mandioca. As queixas de Gregório de Matos relativas à escassez das farinhas corresponderam a problemas vivenciados no cotidiano colonial como bem demonstram as Atas da Câmara Municipal que serão examinadas a seguir. Quando o poeta escrevia versos ao governador Antônio Luis da Câmara Coutinho, fustigando-o pelo descaso em relação ao provimento de farinhas aos colonos, apontava uma questão crucial relacionada com os gêneros alimentícios de primeira necessidade, farinhas, carnes e peixes:

“Ora vamos a farinha,/foi pouca, cara, e ruim:/mas vós não sois sol, nem chuval

$784 \quad$ ANTONIL. Op. Cit., p. 174. 
para a haver de produzir./Eu confesso, que houve fome,/governando vós aqui,/sois mofino, e por contágio/ficou mofino o Brasil./Ser mofino não é culpa,/a fortuna o quer assim:/quem é mofino consigo,/cos mais há de ser feliz?/Não vos mandou governar/El-rei farinhas aqui,/as carnes nem os pescados,/porém a fôrca isso $\operatorname{sim}^{\prime \prime 785}$.

A expansão demográfica urbana tornou necessária uma produção abundante desse gênero fundamental, que lavradores de mantimentos, sediados em regiões de solos mais secos e menos propícios às canas, mandavam preparar com as raízes que seus escravos plantavam nas roças. Aos almotacés cabia fiscalizar a lisura das vendas e a qualidade dos produtos, aos vereadores exigir que os colonos produzissem maiores quantidades e ao governador se assegurar que providências adequadas fossem implementadas. Alguns governadores, contudo, mereceram censura por sua imprevidência irresponsável que ia contra o estilo local.

O volume da fabricação dependia, portanto, do número de proprietários de terras dispostos a investir nesse tipo de atividade. O preço de venda das farinhas não era muito elevado, apesar de pesar bastante no bolso dos mais pobres, uma situação que não encorajava muito à fartura da produção. Os vereadores da Câmara de Salvador tentaram, em determinadas ocasiões, forçar incrementos da produção doméstica daqueles que consumiam grandes quantidades do produto, tais como os traficantes de escravos quando armavam seus navios, ou lavradores de grande porte, donos de escravaria numerosa. Porém a maioria desses homens preferia comprar a farinha, em lugar de ocupar terras e mão-de-obra nesses cultivos.

Faz sentido, conseqüentemente, que nenhum monopólio tenha incidido sobre as farinhas. Os produtores das vilas do sul da capitania ou das regiões mais afastadas do Recôncavo, que viviam de produzi-las, traziam-nas à vender acomodadas em cestos de dois alqueires ou sob forma de farinhas soltas, pagando apenas as taxas do costume. 
Tudo que dizia respeito à farinha de mandioca envolvia cálculos precisos. Efetivamente a produção de farinhas requeria planejamento prévio, com antecedência de pelo menos um ano (o tempo das raízes começarem a ser colhidas). Era preciso assegurar o plantio de quantidades adequadas de raízes para poder acudir em tempo a consumos previstos ou imprevistos. Calculava-se o número de covas em que cada escravo colocaria pedaços de raízes chamados manivas, estimava-se o volume das raízes a coletar e processar e embalavam-se farinhas prontas em círios (ou sírios) com capacidade de dois alqueires pela medida de Salvador, nas Vilas de Baixo, Camamu, Boipeba e Cairu ou em algumas localidades do Recôncavo como Maragogipe e Jaguaripe. Todo mundo na colônia também sabia que cada alqueire de farinha era ração destinada a alimentar um homem pelo prazo de um mês.

Por mais herdadas dos índios que fossem as farinhas secas, seu aproveitamento alimentar foi alterado em mãos européias ${ }^{786}$. Piso, o médico do príncipe de Nassau, que teve oportunidade de conhecer o Brasil durante as invasões holandesas, retratou de modo expressivo a nova maneira de conceber esse produto:

"Sendo aqui desconhecido o arado e o seu uso, e para se evitarem as fadigas de um trabalho penoso e de muita sujeição, dão-se com afã até agora a essa agricultura fácil e menos infeliz, tanto para satisfazer às necessidades domésticas, como para poupar dinheiro. Pois, pela indústria e trabalho de um único escravo aprontam uns cem tubérculos, às vezes no decurso de um só dia. Ora um ou meio Alkeire (que contém vinte cântaros dos nossos), i. é. um ou meio módio, quási sempre basta durante um mês inteiro a um homem robusto e laborioso. E êsse módio se poderia comprar por seis ou sete, no máximo oito soldos"787.

\footnotetext{
786 A grande maioria dos autores que trataram da farinha de mandioca como pão da terra se limitaram a enfatizar a questão da herança indígena, negligenciando as mudanças na perspectiva da produção ocorridas com o domínio colonial luso.
} 
Em 1673, a farinha faltou aos soldados soteropolitanos que viviam de rações estipuladas de farinha de mandioca e carnes. Os militares que, teoricamente, deviam defender os moradores, se rebelaram assaltando barcos e carros de bois pelos caminhos e arrancando aos particulares um sustento que as autoridades coloniais lhes devia.

Em 17 de Agosto de $1674^{788}$, por ordem do governador, reuniram-se um juiz, os vereadores, o procurador do conselho da capital e um procurador do conselho da vila do Camamu para acertarem a produção de farinha para a alimentação dos soldados. Do Conchavo das farinhas, efetuado nessa ocasião com a vila do Camamu, resultou uma encomenda de 4000 sírios anuais de farinha, pelo prazo de três anos, comprados à razão de 320 réis o sírio, acrescentandose dois vinténs de frete (quarenta reis) para remunerar os barqueiros. Calculava-se que para 1000 praças servindo na capitania real, seriam necessários 6000 sírios anuais de farinha. Cairu forneceria 1700 sírios e Boipeba, 300. Parte do pagamento corria por conta da contribuição ao donativo para garantir a paz com a Holanda e o dote da rainha da Inglaterra. O restante devia ser pago na data programada para o pagamento à Câmara da dívida do contratador dos direitos sobre a venda do vinho.

Na redação da Ata dessa reunião, e de outras semelhantes, as autoridades coloniais fizeram questão de enfatizar sempre que sua maneira de proceder obedecia à forma e estilo do costume, para o bem comum dos colonos e o serviço de Sua Majestade. A forma de comercialização da farinha não apresentava grandes novidades, mas os trâmites da discussão, indicados nos relatos, envolveram discussões de claúsulas que pressupunham implicitamente, a ocorrência de problemas na vigência do conchavo anterior:

"perabem de sefazer entre as duas Câmeras comchauos de fa-| rinha que he necessária para o para o sustento da Infanteria naforma que sempre foi estillo entre as ditas Câmeras porquanto deuem estar pronta a dita farinha, como que foi dehum Anno a-esta Parte setinha seguido Roubos della nas estradas perquese- 
conduz a | estacidade Ena Praya nos barcos queatrazem aUender dadita villa, Esuas | Vizinhas, inquietações, violencias, brygas dos Soldados [Com] o Pouo; E tudo | sedeuia atalhar, tendo estaCamara farinha certa para a reção que selhes dá eisto | por mejo dos Comchauos, naforma que sempre ouue com as ditas vilas, Emelhor | se melhor podesse ser a bem de hua eoutra parte, porassi ser conuini mente ao seruiço de | s[u]a Alteza Ebom gouerno destacidade"789.

Três anos depois, um novo conchavo reiterava o argumento do estilo costumeiro nas tramitações:

"que adita Câmera contribuiria Com quatro mil alqueires digo Sírios de farinha neste Anno somente que Comesava aCorrer desdeoprimeiro | de Janejro de mil e seis centos esetenta eouto eacaba aos trinta dias domes de Abril | de mil eseis centos esetenta e noue apreço de du-zentos eoutenta reis Como Senper foi estillo cinco tostão defrete que este Sepaga- | ria aos mestre nesta cidade para que lhe apilcauão desde logo os trezentos mil reis de sua Contribuição que pagão para ajuda do dote da serenissima Rainha de gram bertanha| epas deolanda oqual Conthia são obrigados apagar ao tezoureiro des-se Senado elle fazper- | junto asua Alteza per inteiro eper elles ditos officiais da Câmara do Camamu foi dito | que aseitauão odito Conchauo..." ${ }^{\prime 790}$.

Exemplificando, discutiu-se em junho de 1687 a necessidade dos sírios conterem medida

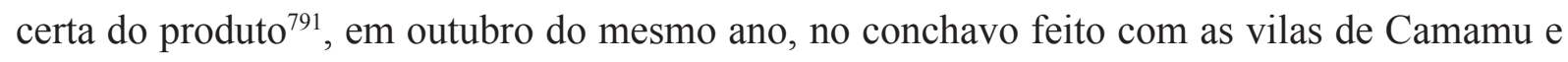
Cairu, a necessidade da Câmara de Salvador assumir os riscos de perdas e danos durante a viagem

\footnotetext{
789 ATAS da Câmara, Op. Cit., Vol. V, pp. 138 e 139.

790 ATAS da Câmara, Op. Cit., Vol. V, p. 222.

791 ATAS da Câmara, Op. Cit., Vol. VI, pp. 84 e 85.
} 
e a obrigatoriedade de se transportar as farinhas em navios cobertos para evitar que as chuvas danificassem o produto $^{792}$. Em 1690, estipulou-se a proibição de se confiscar farinhas que vinham das vilas, mas pertenciam a particulares e nada tinham a ver com as farinhas destinadas aos soldados ${ }^{793}$, em Agosto de 1693, os cuidados necessários para evitar que muita farinha se perdesse nos sírios embarcados sem os devidos cuidados ${ }^{794}$.

Em 29 de novembro de 1697, durante o governo de João de Lencastre, os vereadores se preocuparam em regulamentar formas justas para que todos os colonos pudessem adquirir as farinhas de mandioca que as Vilas de baixo, Camamu, Boipeba e Cairu enviavam à cidade. Com efeito, os homens mais ricos costumavam comprá-las por sírios inteiros, em grandes quantidades, nas próprias sumacas e lanchas de cabotagem que as traziam e antes mesmo que as embarcações atracassem. Estocavam reservas em suas casas. Inúmeros atravessadores lucravam em comprar para revender os mantimentos que escasseavam na capital ${ }^{795}$ :

"donde seguia ficarem os mais pobres de que nesta cidade a grande numero sem mantimento algum e que dezejando acudir a [este] dano eremediállo achaua ser mejo conu [eniente] que afarinha que uiesse das uillas debaixo senão uendesse abordo das embarcasoens ensirios e que uisto não auer nesta cidade [caza] publiqua de terreiro nem lugar comodo enada se pudesse fazer a fim de seuender a dita farinha en terra se as escolhessen nos bairos de Santo Antonio, Carmo , Desterro, Seé, São Bento, Piedade e praja pessoas das que custumam uenderen [em] sua caza adita farinha de sírios aos alqueires, mejos alqueires e quartas a respeito do tos [tão] per quarta e cruzados por alqueire sem si alterar o preço asima do dito"796.

792 ATAS da Câmara, Op. Cit., Vol. VI, pp. 94 a 96.

793 ATAS da Câmara, Op. Cit., Vol. VI, p. 152.

794 ATAS da Câmara, Op. Cit., Vol. VI, p. 224.

795 ATAS da Câmara, Op. Cit., Vol. VI, pp. 345 a 347.

796 ATAS da Câmara, Op. Cit., Vol. VI, livro II, pp. 345 e 346.

O tostão valia cem reis e o cruzado 400. A quarta, por sua vez, correspondia a uma quarta parte da medida padrão chamada alqueire. Porém, as medidas utilizadas no Brasil diferiam daquelas usadas em Portugal e mesmo no Brasil existiam diferenças, o sírios continha 2 alqueires, pela medidas da capital, enquanto que nas vilas de baixo 7 quartas perfaziam duas alqueires. 


\section{A questão da carne de corte e dos açougues}

No decorrer do último quartel do século XVII, os problemas do provimento soteropolitano em carne bovina voltaram à tona periodicamente nas discussões da Câmara Municipal. As atas de reuniões de vereança do período ostentam um leque diversificado de providências tomadas em razão de queixas da população soteropolitana relacionadas ao provimento de carne bovina. Gregório de Matos fez eco ao descontentamento dos colonos ao se queixar, em versos ressentidos, da "má vaca do jantar" "797, atribuindo à Câmara toda a culpa pela péssima situação do abastecimento.

De fato, a importância do consumo das carnes para a população soteropolitana se revelava na própria diversidade dos problemas relativos à comercialização do produto. As manipulações começavam quando os marchantes (e atravessadores) adquiriam reses às boiadas que chegavam do sertão. Semelhantes manipulações afetavam o conjunto da cadeia operatória da venda aos consumidores. Diferente da comercialização das farinhas, a venda das carnes aos soteropolitanos não se afigurava tão livre. Existiam contratos de arrendamento do direito de vender o produto nos açougues da cidade e leilões para decidir a que rendeiros se concederia esses contratos. Muitas atas de reuniões da Câmara apresentavam discussões de problemas ocasionados pelo abastecimento de carnes bovinas à população. Mas as soluções destinadas a sanear as falhas de abastecimento, não eram todas mantidas de ano para ano, alteravam-se quando novos vereadores assumiam o cargo.

Os marchantes adquiriam reses para corte dos criadores ou de seus representantes e as forneciam aos currais localizados, o primeiro perto da Igreja de São Bento, o segundo vizinho da igreja do Carmo. Nesses lugares, pessoas contratadas abatiam os animais. Os marchantes se empenhavam em todo tipo de artimanhas para criar situações artificiais de escassez, procuravam obter dos criadores bois a preços abaixo do valor e revendê-los o mais rapidamente possível com trabalho mínimo, gastos diminutos e lucro máximo, procedimentos que resultavam em aumento 
dos preços quando a municipalidade se abstinha de intervir. Dos currais, quartos dianteiros ou traseiros eram transportados para os açougues espalhados pelos diversos bairros da cidade. Tratavam-se de estabelecimentos mais comumente chamados de talhos. Cada um deles recebia um certo número de peças de carnes vendidas ao público por libras, a preços fixos, nos dias permitidos pela Igreja.

O talho privativo dos desembargadores (concessão do rei à magistratura) constituiu ocasionalmente um terreno de conflitos de poder entre a Relação e a Câmara ${ }^{798}$ operando por meio do abastecimento alimentar. Com efeito, o talho ocupado pertencia à Câmara que o alugava desde março de 1676, por quantia considerada irrisória, e que resolveu em 1679 alugálo a outro ocupante sem nenhum aviso prévio ${ }^{799}$. Nesse local privilegiado os desembargadores compravam para suas famílias carnes que tinham a obrigação expressa de serem gordas, ao mesmo preço pago noutros açougues de doze reis e meio a libra:

"outrossy convierão que visto a tacha $\mid$ queavia nesta Câmera sobre a carne era de doze reis e meio a libra que elles | que não que a pessoa nomeada lhes desSem no Seu talho a carne deste anno | pelo dito preço de doze reis e meyo porquanto oavião de obrigar a que | lha desse muito gorda"800.

A preferência da população por carnes gordas explicava-se facilmente. A presença de gorduras na carne indicava que o animal abatido não era rês doente ou esgotada pela viagem. Gregório de Matos também registrou o gosto de sua sociedade pela presença de gorduras nas carnes. Num poema satírico de teor fecal, cujas metáforas oscilaram entre comparações com doces ou com carnes, ele versejou o caso de um frade desastrado, que teria se atrevido a cortejar uma moça, recebendo cortesmente da jovem uma panela de "doces" que continha excrementos:

\footnotetext{
798 ATAS da Câmara. Op. Cit., Vol V. pp. 182 a 185 e pp. 248 a 250.

799 SCHWARTZ, Stuart B. Burocracia e sociedade no Brasil colonial. Op., Cit., p. 213.

800 ATAS da Câmara. Op. Cit., Vol. V, p. 183.
} 
"Dos cagalhões afamados/diz esta plebe inimiga,/que eram de ouro de má liga/ não dobrões, porém dobrados:/aos Fradinhos esfamiados, /que abrindo a panela estão,/daí por cabeça um dobrão/[...] Se os cagalhões são tão duros,/tão gordos, tão bem dispostos, /é porque hoje foram postos, /e ainda estão mal maduros:/[...] é de crer que abrandem mais,/porque a Môça cristãmente/não quer, que quebrei um dente,/mas deseja que os comais" ${ }^{801}$.

Os gostos alimentares de Matos se assemelhavam àqueles de seus conterrâneos. Ao enfatizar sua preferência pelas carnes gordas mais macias, ele atestava indiretamente que compartilhava com os demais soteropolitanos os critérios de sua época para avaliar uma boa carne.

Em 16 de novembro de 1672, o assunto em pauta na Câmara foi a falta de pastos nos arredores da capital para que as reses se refizessem do cansaço da viagem. Não foi a única oportunidade de discussão do tema. Era simples determinar que não deveria ser abatido gado algum que não fosse minimamente gordo ou que todas as reses magras e doentes deveriam ser retiradas pelos marchantes sob pena de pagamento de multa e de um mês de prisão. Menos fácil era a execução da medida e a vigilância constante dos almotacés que deveriam fiscalizar os procedimentos. Noutra oportunidade (em 29 de outubro de 1682), comentaram-se queixas do povo referentes à péssima qualidade das carnes vendidas:

"Com mao cheiro de talsorte que emtende os medicos desta cidade pRo-|fesores da Cliensia da medicina que he acarne ro-|im que seCome agora cauza das doensas que ha na rua |que n[ã] auai antigamente e Cau[za]do Roim go-|uerno do Senado daCamara porque estaua enduzi-|do a dar talhos aos marchantes atrauessadores |

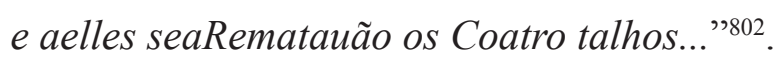

801 MATOS, G. Op. Cit., Vol. II, pp. 317 e 318.

802 ATAS da Câmara. Op. Cit., Vol. V, p. 332. 
No mesmo dia discutiram-se também os preços de venda da "carne boa e gorda" nos quatro talhos públicos e o costume dos empregados, nos currais ou nos talhos, de empilharem os quartos de bois uns sobre os outros em lugar de pendurá-los pelos pés para deixar o sangue escorrer, procedimento que acelerava a decomposição do produto.

Em 20 de março de $1683^{803}$, o tema em pauta foi o próprio sistema de venda. Havia então na cidade oito talhos públicos livres e dois talhos privilegiados, um dos quais fornecia carne aos desembargadores da Relação. Existiam ainda, ao que parece, um talho dito das sobras (vendendo miúdos e fressuras) e quatro talhos particulares (atribuídos em leilão ao arrematador que oferecia o maior valor, e adiantava, em condições estipuladas, boa parte do valor dos dízimos a serem cobrados na venda do produto).

O preço da libra de carne costumava ser tabelado e variava segundo os anos entre oito e doze reis e meio a libra. Mas as oportunidades de acesso à carne não eram as mesmas para todos. Outro motivo de discórdia residiu no costume de muitos homens ricos que mandavam comprar quartos de carne diretamente nos currais, aproveitando-se do prestígio social de que desfrutavam. Em conseqüência de tal deferência à hierarquia social, os açougues acabavam recebendo apenas quartos dianteiros de carnes menos tenras que os quartos traseiros. Em 1694, começou-se a proibir que qualquer pessoa exceto o governador pudessem se abastecer diretamente nos currais ${ }^{804}$, em 1697 as exceções foram ampliadas e as religiosas do Desterro foram incluídas entre as exceções ${ }^{805}$.

Em março de 1683, a Câmara assentiu na criação de dois tipos diferentes de açougues para "suavizar os clamores e queixas d[este] pouo". Diferenciaram-se então os talhos que vendiam carne magra a preços reduzidos, dos outros que vendiam a carne gorda a onze réis e meio a libra. Instituiu-se na cidade (informação datada de 27 de Abril de 1687) quatro novos talhos que vendiam carne de porco ${ }^{806}$ e foram arrendados a particulares. Ocasionalmente proibiu-se aos açougues que vendiam carne de vaca de cortarem também carne de carneiro.

803 ATAS da Câmara. Op. Cit., Vol. V, p. 348.

804 ATAS da Câmara. Op. Cit., Vol. VI, pp. 247 a 249.

805 ATAS da Câmara. Op. Cit., Vol. VI, pp. 329 a 331.

806 ATAS da Câmara. Op. Cit., Vol. VI, pp 82 a 84 
Em 29 de Agosto de 1696, constatou-se que os talhos vendiam lombos e línguas de vaca (carnes muito apreciadas), pelo preço excessivo de três vinténs. Ordenou-se então que os vendessem por pesos e não por peças ${ }^{807}$. De forma que a escassez de referências a esse tema prático, cotidiano e candente da comercialização das carnes figurou quase como uma lacuna nos versos do Doutor em leis.

Apenas num único poema do códice publicado por James Amado, Gregório de Matos aludiu a cortes diferenciados de carnes. Sua intenção, no caso, era de satirizar uma mulher acusada de pertencer simultaneamente a quatro amantes. Para o retalhamento moral, metonímico e irônico do corpo da moça, o autor recorreu à metáfora costumeira da gula e da luxúria indissoluvelmente atreladas, porém invertendo o procedimento usual e propondo uma solução culinária extravagante para a lubricidade excessiva da jovem:

\begin{abstract}
"A mim me tem parecido,/por fugir pesares artos, /que um algoz vos faça em quartos,/ que o tendes bem merecido:/e que cada qual Cupido/o que leva e o que atraca,/da vossa carne velhaca/leve um quarto por partilha,/e dos quartos a quadrilha/como irmãmente da vaca. // Para repartir-vos bem/entre os quatro quadrilheiros,/tiremse os quartos inteiros/soa, coxão, alcatra, acém:/e se entre êles houver quem,/vos dê mais prazer, e gôsto,/êsse leve o entrecosto,/a alcatra, quem bem vos quer,/o acém, o que mais vos der,/e o coxão a todo o posto" $" 808$.
\end{abstract}

Aliás, mesmo que os versos de Gregório de Matos pouco se preocupassem em discorrer sobre as condições do provimento soteropolitano de carnes, não deixa de ser interessante verificar como foi justamente a questão desse abastecimento um dos principais temas que o poeta utilizou para criticar o governador Antônio Luís da Câmara Coutinho acusado de não ter vindo no Brasil para governar as farinhas e as carnes, tarefa que deveria ter constituído uma de suas preocupações centrais.

807 ATAS da Câmara. Op. Cit., Vol. VI, pp. 321 e 322.

808 MATOS, G. Op. Cit., Vol. IV, pp. 983. 
Se não foi possível esclarecer melhor, a partir dos poemas de Matos, as questões relacionadas à comercialização soteropolitana das carnes, pelo menos comprovaram-se a importância extrema que os colonos atribuíam ao consumo desse alimento, já que o acesso às boas carnes configurava tanto um ingrediente indispensável da dieta, quanto um ingrediente prestigiado de afirmação social.

\section{3 - Iguarias e manejos de preparo soteropolitanos}

Inventariando o cardápio dos preparos soteropolitanos, que Matos saboreou, quando lhe guisavam um bocadinho caseiro $^{809}$, certas designações de manjares puderam ser notadas em seus versos, algumas elaborações, aliás, permanecendo em uso como a galinha de cabidela. Os mazombos comiam ordinariamente às refeições: frutas, olhas podridas (cozidos), à vezes acompanhados de biscoutos $^{810}$, caldos e carnes $^{811}$, caldos de grãos ("para os dias de peixe") 812 ou caldos de lentilhas ${ }^{813}$, sopas de pão com leite ${ }^{814}$, sopas de pão e broa ${ }^{815}$, sordas de vinha e alho ${ }^{816}$, galinhas de cabidela ${ }^{817}$, almôndegas e picados ${ }^{818}$, torresmos $^{819}$, tortas e pasteis ${ }^{820}$,

\footnotetext{
809 MATOS, G. Op. Cit., Vol. V, p. 1090.

810 MATOS, G. Op. Cit., Vol. VI, p. 1400.

811 MATOS, G. Op. Cit., Vol. III, p. 625.

812 MATOS, G. Op. Cit., Vol. V, p. 1092.

813 MATOS, G. Op. Cit., Vol. V p. 1107.

814 MATOS, G. Op. Cit., Vol. III, p. 588.

815 MATOS, G. Op. Cit., Vol. III, p. 632.

816 MATOS, G. Op. Cit., Vol. III, p. 629.

817 MATOS, G. Op. Cit., Vol. II, p.302.

818 MATOS, G. Op. Cit., Vol. V, p. 1092.

819 MATOS, G. Op. Cit., Vol. VI, p. 1474.

820 MATOS, G. Op. Cit., Vol. V, p. 1092 e 1093.
} 
panelas de camarões $^{821}$, repolhos ensopados, e arroz de leite ${ }^{822}$ ou arroz ${ }^{823}$, escabeches e saladas $^{824}$ (“moído em salada"), morcelas ${ }^{825}$, chouriços $^{826}$, lingüiças $^{827}$, paios salpimentados ${ }^{828}$, presuntos $^{829}$, cuscuz $^{830}$, pães $^{831}$, $_{\text {rotes }}^{832}$. (Deviam comer também farinha seca e beijus).

Quando podiam se empanturrar, os colonos não perdoavam nem arroz ou cuscuz quente nem os doces. Diversos doces de $\operatorname{araçáa~}^{833}$, de cidrão e de marmeladas ${ }^{834}$, bolos e bolinholos ${ }^{835}$, ovos moles com canela ${ }^{836}$, ambrosias ${ }^{837}$, rapaduras ${ }^{838}$, filhós, fatias, sonhos e mal-assadas ${ }^{839}$, doces em panelas ${ }^{840}$ ou confeitos $^{841}$ foram citados nos poemas como itens de luxo e fartura suscitando alegria.

Nos versos de Gregório de Matos, o lugar cativo do pão marcava ponto em refeições servidas a hóspedes ou oferecidas durante as festas de santos. Sopas de pão, broas, brotes e biscoitos

821 MATOS, G. Op. Cit., Vol. III, pp. 720 a 724.

822 MATOS, G. Op. Cit., Vol. III, p. 588.

823 MATOS, G. Op. Cit., Vol. III, p. 580.

824 MATOS, G. Op. Cit., Vol. II, p. 299.

825 MATOS, G. Op. Cit., Vol. IV, p. 877.

826 MATOS, G. Op. Cit., Vol. IV, pp. 877 a 879.

827 MATOS, G. Op. Cit., Vol. IV, p. 879.

828 MATOS, G. Op. Cit., Vol. IV, p. 979.

829 MATOS, G. Op. Cit., Vol. II, p. 420.

830 MATOS, G. Op. Cit.,Vol. III, p. 580.

831 MATOS, G. Op. Cit., (citações numerosas),

832 MATOS, G. Op. Cit., Vol. III, p. 711.

833 MATOS, G. Op. Cit., Vol. II, pp. 364 e 386.

834 MATOS, G. Op. Cit., Vol. V, p. 1092 e 1093.

835 MATOS, G. Op. Cit., Vol. II, p. 496.

836 MATOS, G. Op. Cit., Vol. II, pp. 314 e 315 e Vol. IV, p. 835.

837 MATOS, G. Op. Cit., Vol. IV, pp. 868 e 869.

838 MATOS, G. Op. Cit., Vol. II, pp. 364 e 386.

839 MATOS, G. Op. Cit., Vol III, p. 580. Vol. VI, pp. 1502, 1503, 1503, 1504 e também p. 1521.

840 MATOS, G. Op. Cit., Vol. II, pp. 317 e 318.

841 MATOS, G. Op. Cit., Vol. I, p. 158. 
indicavam a freqüência do consumo de farinha de trigo, produto eventualmente misturado, por medida de economia, com farinha de carimã, de arroz, de milho, ou de outros cereais panificáveis. Não surpreende o apreço mazombo por um alimento talvez dispendioso, porém, capaz de reafirmar a solidez dos vínculos mantidos com a origem ibérica dos colonos, bem como de atestar a prosperidade daqueles que o compravam.

Tal predileção, entretanto, não impediu a população colonial de se valer também da farinha de mandioca no âmbito cotidiano. Acompanhada de carne-seca ou fresca ou de pescado seco ou fresco ocupou posição de destaque como mantimento básico, tanto na dieta dos colonos quanto na alimentação dos escravos. Por vezes, bananas acompanhadas de farinha de mandioca ofereceram ainda uma merenda fácil ou uma dieta mínima emergencial na alimentação de colonos pobres.

As pimentas nativas, condimentos picantes que aqueciam as comidas e facilitavam sua digestão, agradáveis ao paladar e facilmente obtidos localmente, também se impuseram, provavelmente por seu efeito semelhante à pimenta-do-reino que as populações ibéricas apreciavam muito. Mas as iguarias nativas que, algumas décadas apenas antes de Gregório de Matos retornar ao solo natal, cronistas portugueses ou holandeses degustavam sem traumas identitários, serviram ao poeta de motivo de sarcasmo para ironizar certos colonos. Com efeito, no primeiro quartel do século XVII, os colonos que se diziam "moradores portugueses do Brasil" se deliciavam francamente com mingaus de carimã preparados com caldos de carnes ou de peixes apimentados ou então marmeladas de mandioca ${ }^{842}$ também preparadas com farinha de carimã, porém, adicionada de farinha de arroz, de açúcar e de água de flor.

Os versos de Gregório de Matos recendiam principalmente a cozidos portugueses, levando, além de carnes, miscelâneas de vegetais. Pois, mesmo que a escrita poética do autor não confirmasse a presença de talos, de folhas ou de raízes nessas iguarias, autores contemporâneos, como Sebastião da Rocha Pita, atestavam a presença de hortaliças e de 
legumes nas "olhas podridas", ao explicarem, por exemplo, que no Brasil, aipins, raízes cuja forma lembrava à dos nabos, entravam em sua composição:

"Outras raizes há do mesmo gênero e do mesmo feitio, mas de diversa qualidade, que se chamam aipis, de quatro espécies, Açu, branco, preto e poxá: de todos se fazem por vários modos agradáveis guisados; assadas têm o mesmo sabor que as castanhas de Portugal, e nas olhas se assemelham aos nabos" $" 843$.

Quanto às carnes colocadas à disposição dos colonos soteropolitanos, Luís da Câmara Cascudo num capítulo de sua História da alimentação no Brasil, onde analisou a "instalação da cozinha portuguesa no Brasil", apresentou um elenco corrente de animais domésticos europeus consumidos, lembrando a importância que, por motivos de carestia, os monarcas lusos da dinastia de Avis atribuíam aos hábitos de parcimônia, a ponto de se imiscuírem em assuntos de mesa dos súditos ao regulamentarem o número das iguarias que lhes era permitido comer em cada refeição ${ }^{844}$.

Galinha de cabidela, almôndegas, picados, tortas, pastéis, torresmos e fiambres povoaram, por conseguinte, os versos de Matos, sem que se possa dizer muita coisa a seu respeito. Teria sido necessário dispor de termos de comparação mais extensos com os cardápios lusos da época para arriscar hipóteses pertinentes.

843 PITA, Sebastião da Rocha. Op. Cit., p. 27, parágrafo 37.

844 CÂMARA CASCUDO, Luis, Op. Cit., p. 314.

"Os últimos soberanos da dinastia de Avis decretaram pragmáticas contra os excessos da mesa". A primeira, sob Afonso III em 1258 não fora tão rigorosa quanto as seguintes. D. Manuel, D. João III, D. Henrique e D. Sebastião incluíram esse controle entre suas preocupações. Reza uma delas transcrita por Câmara Cascudo: "que pessoa alguma não possa comer à sua mesa mais que um assado e um cozido, e um picado, ou desfeito, ou arroz ou cuscuz, e nenhum doce como manjar branco, bolos de rodilha ou outra coisa dessa qualidade”.

Não era permitido consumir mais do que duas variedades de carnes diferentes numa refeição ou duas variedades de peixe (permitindo-se que uma das carnes ou um dos peixes fosse acomodado de duas maneiras diferentes). 
Por essa razão (e a título apenas indicativo), um códice quinhentista se apresentou como fonte de reflexão bem-vinda: o livro de cozinha de uma infanta portuguesa, Dona Maria ${ }^{845}$, neta do rei D. Manuel o Venturoso e esposa do Duque de Parma Alexandre Farnese. A princesa, casada em Nápoles, documentou receitas aprendidas com as damas da corte portuguesa. Tratava-se, geralmente de preparos simples e clássicos, já que o livro não continha receitas de grande aparato. Se não fosse pela condimentação generosa que acrescentava especiarias caras às especialidades servidas, não configurariam refeições muito faustosas. Apesar de revelarem uma culinária cortesã usual, por volta de um século antes do retorno de Matos a Salvador, as receitas lusas do códice napolitano espelhavam, de modo conseqüente, conhecimentos técnicos de preparo alimentar que não desapareceriam ao cabo de algumas décadas e pareciam coincidir, em larga medida, com os preparos saboreados pelos soteropolitanos, mesmo que não se possa estender a mesma confiança aos princípios de sua condimentação.

Cerca de um terço das receitas no caderno dos manjares de carne comportava carnes picadas, confirmando a razão das brincadeiras de Matos com iguarias de carne moída. Merece reparo, pois, a "Receita da vaca picada em seco". Tratava-se de uma receita de carne bovina, lavada antes de ser picada crua. A infanta recomendava evitar a escolha de carne da posta de fora, muito dura. Mandava temperar o preparo com cebolas miúdas e ervas aromáticas (cortadas como para salada). Depois, o conjunto refogava-se em azeite de boa qualidade "em lugar de manteiga". Acrescentava-se vinagre, sal e adubos: cravo, açafrão, pimenta e gengibre. Cozinhava-se a carne, sem outro acréscimo de líquido, até que secasse bem. Uma vez pronta, serviam-na colocada sobre uma fatia de pão.

Figuravam, no entanto, poucas receitas de carne de vaca entre os manjares da princesa. Aparentemente relutava-se um pouco em consumir carne bovina em Portugal, fenômeno compreensível ao se pensar na necessidade de se preservar um contingente necessário de bois, animais indispensáveis de tiro e de vacas reprodutoras que outrossim forneciam laticínios, num

845 LIVRO De Cozinha Da Infanta D. Maria, Códice Português I e 33 da Biblioteca Nacional de Nápoles, Fac-símile, Imprensa Nacional/Casa da Moeda, Lisboa, sem data. Caderno dos manjares de carne., pp. 10 a 63. (A princesa , neta do rei luso D. Manuel I, desposou o Duque de Parma Alexandre Farnese). 
território de dimensões restritas, como bem argumentou Arnaut ${ }^{846}$. Abatiam-se sobretudo animais que não serviam mais para o trabalho e sua carne obviamente era dura. Apesar dos percalços do fornecimento da carne bovina em Salvador e no Recôncavo, a vida no Brasil, território espaçoso, parece ter oferecido um elemento de melhoria da qualidade de vida, permitindo que um número mais amplo de colonos tivesse acesso ao consumo de carnes.

Um preparo de almôndegas constava também entre as iguarias aristocráticas da princesa. Figurava sob denominação de "receita das boldroegas". Comportava carne de porco ou de carneiro muito gordo, desossada, picada e moldada em torno de uma dúzia de gemas de ovos duros. Cada bolota enfarinhada, era frita numa panela de manteiga ou cozida num caldo gordo de carneiro ao qual se tinha acrescentado manteiga, cheiros e especiarias. Abafava-se a panela, revirando os bolinhos de vez em quando, antes de servi-los.

Uma das duas receitas de morcelas do livro também levava carne picada. Preparava-se uma mistura de carne de lombo e de pernil de porco. Espremia-se essa mistura bem picada numa toalha a fim de retirar-lhe toda umidade. Temperavam-se as morcelas com sal e pimenta, adicionando-lhes carne gorda de porco, caso o preparo fosse considerado muito magro. Depois de embrulhá-lo em membranas do animal, era fervido em água. Uma segunda receita de morcelas comportava banha de porco fresca, derretida, pão ralado, água de flor, pinhões, amêndoas, cravo, canela e sal moídos, gemas de ovos e açúcar.

O livro da infanta acusava também um gosto pronunciado pelas tortas e pelos pastéis mencionados por Matos como preparações comidas em ocasiões festivas. Ressaltava, por exemplo uma "Receita da torta" feita de carne de carneiro ou de carne de porco bem picada e lavada, cozida em pouca água e adubada apenas com cravo. Colocavam-na depois sobre um omelete de seis ovos, frito em sertã (frigideira) com um pouco de manteiga. Em seguida, cobriam-na com outra camada de omelete de 6 ovos e serviam-na, afinal, sobre fatias de pão passadas no açúcar, salpicadas com açúcar e canela e borrifadas com água de flor. De fato,

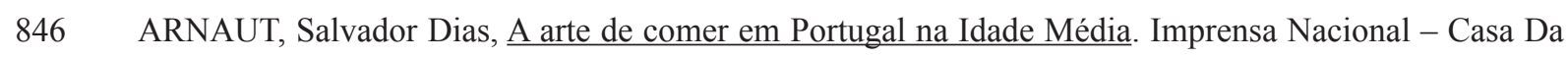
Moeda, Lisboa, sem data.
} 
Matos parecia gostar sobremaneira de refeições comportando grande cópia de ovos.

Destacava-se ainda uma "Receita dos pasteis lepardados" preparada com uma massa dura e bem sovada, de farinha, água e sal. Estendiam-na redonda, delgada (como para pastéis de tutano) e "lavavam-na" com manteiga derretida. Depois a massa era enrolada e fatiada em talhadas. Empurrando com o dedo o centro das fatias folhadas, deixava-se um espaço para colocar ali um bolinho redondo de carne picada, semi cozida e bem temperada. Cada fatia cobria-se com outra e o todo assava-se rapidamente ao forno. Para preparar pastéis de carne a Infanta, aliás, recomendava utilizar toucinho velho "porque põe mais sabor".

O livro oferecia ainda uma "Receita do desfeito de galinha", que levava galinha picada com toucinho e cozida em água com cheiros. Ao ferver, temperava-se o guisado com sal e vinagre e se deixava reduzir até sobrar pouco caldo. Pão ralado adicionado e dois ovos inteiros e duas gemas ligavam o molho. Adubava-se o preparo com uma colher de manteiga (de vaca ou de porco) e com cominho, pimenta, cravo e açafrão, servindo-se afinal o prato salpicado com canela.

Para a "Receita de pastel de fígados de cabrito" preparava-se uma mistura de carne de cabrito adoçada com açúcar, cravo e canela e cozinhava-se a mistura com gemas de ovos duros. Depois, bocados dessa carne embrulhados em véus de cabrito eram enfarinhados, fritos como beilhós, passados em calda de açúcar em ponto alto e salpicados com canela.

A carne de porco parece ter constituído um item favorito de alimentação, seja como carne preparada, seja sob forma de toucinho e acompanhava a grande maioria das receitas da princesa. Cozinhava-se o ingrediente em caldos e em guisados, ele entrava em pastéis assados regados com o caldo de outras panelas. Raramente frita, essa carne figurava ainda sob forma de toucinho numa receita de galinha alardada, recheada e costurada.

Segundo Lorimer, que comentou as receitas da infanta, as técnicas de preparo culinário utilizadas na época eram: refogar (fritar rapidamente em pouca gordura), cozinhar, assar, fritar, escaldar, caramelar (passar por uma calda de açúcar), engrossar (espessar o caldo), empanar e besuntar (passar manteiga sobre a superfície do alimento ${ }^{847}$. 
Quanto às preparações assadas, não pertenciam, estritamente falando, ao domínio da cozinha, mas ao domínio correlato do forno, externo à casa e devorador de lenhas. Na obra de Matos constaram poucas referências a preparos assados ${ }^{848}$. Em boa parte das celebrações referidas pelo poeta, o cardápio servido parecia dever mais aos fogões que aos fornos.

Mas as carnes de animais domésticos não eram as únicas consumidas. Caçava-se muito em Portugal, segundo afirmaram Salvador Dias Arnaut ${ }^{849}$ e Câmara Cascudo ${ }^{850}$. Os portugueses continuaram a caçar no Brasil. A observar os indícios de caçadas na obra do poeta, tratava-se de uma atividade esportiva apreciada até mesmo pelos colonos que residiam na cidade. Ao que parece mazombos e administradores graduados da colônia ocupavam agradavelmente o tempo, que não passavam em carteados, amores e negócios, esquadrinhando com cavalos e cães os campos na vizinhança da capital.

Também, por injunção religiosa, comia-se bastante frutos do mar. À diferença do provimento em carnes de caça, o provimento pescado ou mariscado dos colonos provinha de trabalho escravo. A importância dos peixes, dos mariscos e dos crustáceos, como fontes de aprovisionamento alimentar soteropolitano, não pode ser subestimada.

Em Salvador e adjacências alguns ingredientes da dieta lusa metropolitana foram parcialmente substituídos, enquanto que as variedades nativas de pimentas cruas ou preparadas sob forma de jiquitaia (amassadas com sal) ${ }^{851}$, foram amplamente adotadas nos preparos culinários. Mas a

848 MATOS, G. Op. Cit., Vol. II, p. 325. (Cf. o caso do cabrito roubado por um frade e encontrado assado num forno: "Do mé desaparecido/foi logo o dono avisado,/que o Frade lhe havia achado,/antes dele o haver perdido:/ se achou que a modo de pá/num forno o cabrito está,/que o Frade é destro ladrão,/porém nesta ocasião/saiu-lhe a fornada má").

849 ARNAUT, Salvador Dias, Op. Cit., p. 18.

850 CÂMARA CASCUDO, Luis da, Op. Cit.,

851 MARCGRAVE, Jorge. História natural do Brasil. São Paulo, Museu Paulista,1942. Livro II, p.67:

"Este pó [de carimã] lançado em água fervendo produz um polme denominado Mingau pelos indígenas; deve-se porém, agitar o líquido para que se torne ralo e sem caroços; é de sabor agradável e se come só ou com mistura de pimenta inteira ou socada, chamada pelos indígenas Quiya; também se pode misturá-lo com ervas, lagostins, peixe ou carne cozida; chama-se então Minguipitinga". 
crença nas virtudes terapêuticas dos condimentos apregoada pela medicina humoral e os procedimentos de condimentação dos alimentos permaneceram idênticos àqueles utilizados em Portugal.

Ervas aromáticas, especiarias orientais, condimentos tais como o azeite, o vinagre, o sal, o mel ou o açúcar e as aguardentes de açúcar, por conseguinte, prolongaram no ambiente do Novo Mundo os sabores familiares das receitas reinóis.

Gregório de Matos não foi realmente explícito ao se referir à condimentação, já que fez uso de metáforas que obedeciam sobretudo a intenções desvinculadas das práticas. Mas sua ironia ao afirmar que Pedro Alvarez da Neyva era o "perrexil” aos cheiros verdes, que davam sabor e requinte a quitutes locais semelhantes às iguarias portuguesas.

Da mesma forma, o poeta atestou indiretamente a presença de folhas de louro nas escabeches de peixes comidas na colônia, ao sugerir que o padre Loureiro, prejudicado pelo padre Chicória, teria sido transformado em escabeche, ou ainda ao afirmar que uma moça, Betica, tinha ficado de vinha-d'alhos ${ }^{853}$, comprovando, assim, o uso mazombo da técnica de macerar carnes em vinha-d'alhos para amaciá-las e lhes conferir sabor .

Ervas cheirosas européias: salsa, hortelã, louro, coentro e manjerona mencionadas por Matos e consideradas quentes e secas nas prescrições da Âncora medicinal; ou raízes cultivadas, como os alhos e as cebolas, classificados pelo Dr. Mirandela entre os vegetais quentes e secos e ainda as pimentas nativas, acrescidas eventualmente de especiarias orientais, aqueceram em preparos fervidos, guisados ou refogados ingredientes comestíveis vistos como perigosamente frios, sólidos ou viscosos e por isso difíceis de serem digeridos. Rocha Pita, inventariando as ervas cultivadas no Brasil, apontou de forma mais completa que Matos um cultivo usual de: "hortelã, segurelha, poejo, coentro, funcho, salsa, manjerona, endro, manjericão, alecrim, arruda e losna" ${ }^{854}$.

852 MATOS, G. Op. Cit., Vol. IV, p. 895.

HENRIQUEZ, Francisco da Fonseca. Op. Cit., p. 172.

853 MATOS , G. Op. Cit., Vol. IV, p. 979 a 981. A moça mostrando-se infiel, seu amásio lhe infligiu uma lavagem com molho de pimentas: "vendo que outro malho/vos punha de vinha-d'alho/quis pôr-vos de jiquitaia". 854 PITA, Sebastião da Rocha. Op. Cit., p. 28, parágrafo 40. 
Coentro $^{855}$ e manjerona (quentes e secos, segundo Mirandela ${ }^{856}$ ) mereceram comentários na obra do poeta. A manjerona, aliás, foi citada em associação com a decoração de uma Igreja, confirmando o recurso corrente às hortas e aos jardins dos monastérios para a decoração das igrejas, bem como a incorporação de pétalas de rosas adoçadas ou de água de flor de laranjeiras em diversas receitas culinárias:

“Verão um Doutor em Judá nascido/[...] Grande assistidor/de Igreja festeira,/que ao longe lhe cheira como Mangerona: forro minha cona"857.

Uma alusão rápida aos cominhos ${ }^{858}$, que em Portugal costumavam ser oferecidos ao carrasco encarregado de enforcamentos, pouco informou sobre o uso soteropolitano desse ingrediente comestível, ao contrário das brincadeiras numerosas referenciando alhos.

No caso do alho, condimento ibérico relevante, cedo introduzido no Brasil pelos imigrantes portugueses, o poeta documentou nos versos a fama que o vegetal tinha de aquecer comidas e de curar queimaduras:

"Que alguém que aqui se consome/com a sátira abundante,/diga, que está mui picante,/mas quem se queima alhos come" $" 859$.

"Mas como comei alhos,/vos queimais" $" 860$.

A citação freqüente do ingrediente na escrita poética do autor (em parte pela rima sugerida, em parte pelo cheiro forte exalado por esse vegetal e em parte pelo uso culinário tradicional) acompanhou consumos cotidianos:

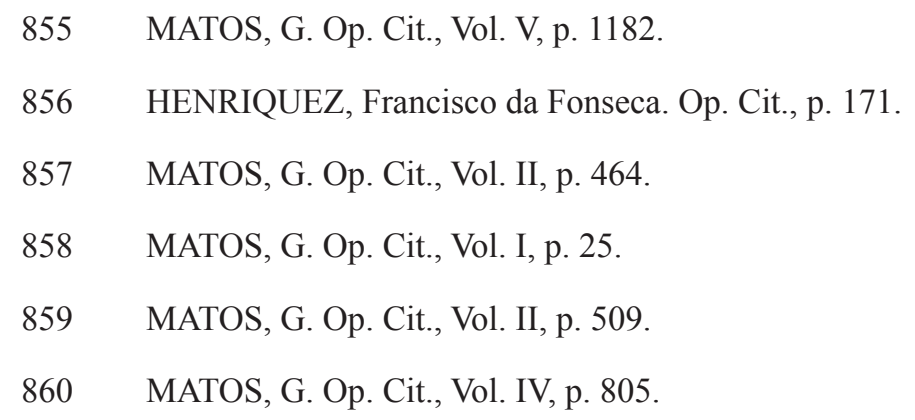


"Fretei-a a pouco trabalho,/e mui pouco me custou,/porque era do ferro, ou/porque era amiga do alho" $" 861$.

Segundo o Dr. Mirandela:

"O alho é a pedra bazar ou a triaga dos rústicos, como lhe chamou Galeno. É quente e seco. Coze se bem e nutre pouco. Tem virtude cáustica, mas comido não ofende com ela, porque se tempera com as umidades do estômago e com os mais alimentos. Serve mais de tempero e condimento, do que de alimento. Comido com freqüência, aquenta o sangue e inquieta a cólera, principalmente em naturezas quentes e biliosas. Ofende a vista e a cabeça com sua acrimônia, danos que mais certamente causa comendo-se cru, que sendo cozido ou assado, fica mais brando e menos acre" ${ }^{862}$.

Quanto às especiarias orientais: canela, pimenta, cravo e gengibre, todas consideradas quentes e secas em graus diferentes, foram temperos que continuaram tão apreciados na capital do Brasil quanto em Portugal. O gengibre em especial ao ser transplantado em território colonial se deu muito bem, tornando-se disponível em abundância. Não obstante tamanho favor, Gregório de Matos nem ao menos citou essa raiz. O uso de canela em sobremesas doces, em compensação, parece ter funcionado na escrita de Matos como um marco de celebrações festivas.

O hábito europeu de adubar ou temperar alimentos acrescentando-lhes ingredientes quentes e secos para aquecer o estômago e estimular a digestão do quilo formado no estômago, continuou no Brasil.

Eventualmente ingredientes frios eram utilizados para condimentar os alimentos. Segundo Mirandela o vinagre, dito frio e seco, penetrativo e adstringente, era reputado excitar o apetite,

861 MATOS, G. Op. Cit., Vol. VI, p. 1457. 
vigorar o ácido do estômago, auxiliar à cocção do quilo e à distribuição dos nutrientes pelo corpo $^{863}$. Quanto ao azeite, diferentemente das gorduras animais consideradas quentes e úmidas ${ }^{864}$, ele se apresentava:

"moderadamente cálido e úmido, amolece e abranda as fibras do estômago, e por isto, causa vômitos e laxa o ventre. Tempera a acrimônia dos humores, mata as lombrigas, resiste aos venenos e é antídoto geral para eles; conserva as coisas que nele se metem sem dano nem corrupção... " ${ }^{865}$.

Sal, açúcar e mel também eram vistos como quentes e secos, capazes de excitar o apetite, de auxiliar no cozimento dos alimentos e de ser útil na preservação dos alimentos. O mel em particular resumia em si as principais virtudes da condimentação:

“do mel geram-se bons humores, dos bons humores bons espíritos, com os quais se fazem bem as funções do corpo e as principais do cérebro, de que se segue que com o seu uso tenha maior agudeza o engenho e o entendimento, cuja operação consiste no verdadeiro conhecimento do bom e do mau" $" 866$.

Não surpreende, pois, que a condimentação dos alimentos, voltada para a necessidade médica de equilibrar os humores, fosse considerada principalmente em sua qualidade de recurso técnico de manejos corporais e não apenas como uma prática voltada para a satisfação do paladar. Claro estava, entretanto, que existia uma gramática em uso da condimentação e que o prazer de degustar pratos bem guisados também importava à saúde. Mas a própria ausência de tais considerações na arte poética de Matos parecia indicar que não tinha chegado ainda o tempo de 863 HENRIQUEZ, Francisco da Fonseca. Op. Cit., p. 205.

864 HENRIQUEZ, Francisco da Fonseca. Op. Cit., p. 109.

865 HENRIQUEZ, Francisco da Fonseca. Op. Cit., p. 205.

866 HENRIQUEZ, Francisco da Fonseca. Op. Cit., p. 206. 
valorizar a gastronomia como uma arte.

\section{Refeições lusas: almoço, jantar, merenda e ceia}

Segundo escrevia no início do século XVIII, o Doutor Mirandela, médico do rei, o corpo humano, apesar de estar "em contínuo dispêndio de sangue e de espíritos", e precisando repor energias através da ingestão de alimento: "nem por isto hão de tomá-lo sempre os homens, senão a certas horas, em diferença dos brutos, que de dia e de noite estão comendo". Importavam, não somente a hora da refeição, cujos parâmetros discutiam-se, mas ainda o escalonamento dos tipos de alimentos consumidos em função da natureza dos corpos e das atividades exercidas.

Os colonos lusos em Salvador ou no Recôncavo almoçavam no decorrer da manhã, jantavam no começo da tarde (em horário próximo do almoço atual), quando consumiam a refeição principal, e ceavam ao anoitecer. Nos intervalos das refeições regulares, às vezes, merendavam. Mantinham, por conseguinte, hábitos de alimentação recebidos da metrópole ibérica. O ritmo dessas refeições seguia um padrão estabelecido, pelo menos, desde a Idade Média.

Salvador Dias Arnaut ${ }^{867}$, que estudou as refeições medievais portuguesas, noticiou três refeições principais: almoço, jantar e ceia. As escassas referências a almoços, que ele observou na documentação, induziram-no a definir o repasto não por sua hora matinal ou tardia, mas por seu caráter de refeição secundária, configurando quase uma merenda. O jantar e a ceia, segundo concluiu, figuravam como principais refeições do dia: “O jantar era já dia bem andado, pelas onze horas/meio-dia, mas suspeitamos que também muitas vezes era antes". Jantar e comer, segundo o autor, apareciam freqüentemente como sinônimos nos textos: "A ceia era habitualmente ao cair da tarde, princípio da noite" ${ }^{968 .}$

Entretanto, o Doutor Mirandela, ao explicar a alimentação de fidalgos nos primórdios setecentistas, considerou:

\footnotetext{
867 ARNAUT, Salvador Dias. Op. Cit., pp. 55 e 56.

868 ARNAUT, Salvador Dias. Op. Cit., p.59.
} 
"Os cavalheiros, a quem sempre amanhece mais tarde, comem o desjejum pelas onze horas, almoçam pelas duas da tarde, merendam quando a outra gente almoça e vêm a jantar pela meia noite. Mas assim com esta ordenada desordem com que foram nutridos e criados, acham se muito bem, que são grandes os poderes da criação e os 'poderes do costume. Os rústicos, que trabalham e se exercitam muito, comem e bebem largamente quatro vezes no dia, sem ofensa; nem poderiam trabalhar muito, se não comessem tanto" $" 869$.

A obra de Matos, excetuando-se uma alusão metafórica pouco esclarecedora endereçada a uma freira: "Portanto vos admoesto, que o mimo, o regalo, o docelo secular vo-lo almoce, /que a um frade basta um cabresto" ${ }^{870}$, não explicitou o teor costumeiro dos desjejuns.

Outras metáforas desvinculavam-se obviamente das práticas cotidianas: “Que juradores parleiros/hajam, que sem mêdo algum/pela manhã em jejum/comam diabos inteiros..." ${ }^{" 871 .}$

Outra imagem metafórica, pareceu sugerir um consumo de doces na primeira refeição do dia, mas poderia provir apenas da necessidade de rimar doces com almoces. Matos na ocasião satirizava o vigário Antônio Marques de Perada da vila de São Francisco:

“De tua Perada mica/não te espantes, que me enoje,/porque é fôrça, que a entoje,/ sendo doce de botica:/o gosto não se me aplica/a uma conserva ${ }^{872}$ afamada,/e em botes tão redomada,/que sempre por ter que almoces,/achas para tão maus doces/a tutia preparada" $" 873$.

869 HENRIQUEZ, Francisco da Fonseca, Op. Cit., pp. 65 e 66.

870 MATOS, G. Op. Cit., Vol. IV, p. 857.

871 MATOS, G. Op. Cit., Vol. II, p. 498.

872 Chamavam-se conservas, na época, os doces de frutas cozidas em calda de açúcar, como demonstravam as receitas da infanta D. Maria.

873 MATOS, G. Op. Cit., Vol. II, p. 274. 
Matos mencionou também as iguarias servidas durante um passeio ao Rio Vermelho, quando Domingos Borges recebeu o poeta e alguns amigos em sua casa. No almoço foi oferecida uma sopa de leite: pão embebido em leite. No jantar os comensais saborearam um cozido provavelmente rico em carnes, verduras e legumes, qualificado como imperial. Além do cozido, serviu-se também um repolho ensopado, pratos de arroz de leite e uma bebida, que seria provavelmente vinho:

"que sem levarmos alforjes/nos pôs as panças inchadas/[...]/Sopas de leite almoçamos,/e logo o Guedes chegou, /que nem pão, nem leite achou,/e achou que o apregoamos:/mas todos depois jantamos/uma ôlha imperial./E houve repolho fatal/ ensopado, e não de azeite/com pratos de arroz de leite e vontade garrafal"874.

No relato de excursão semelhante, durante a qual risadas, brincadeiras, flertes, danças e farta comilança se confundiram, Matos e seus amigos também foram hóspedes numa casa dos arredores da Cidade da Bahia, perto do Dique do Tororó (segundo informava a didascália). Talvez a diversão ocorresse numa daquelas pequenas chácaras, que Reis afirmou se espalharem nos arredores da cidade ${ }^{875}$. Os moradores em busca de uma certa auto-suficiência de provimento alimentar dispunham ali de espaço adequado para hortas e pomares e de ocasiões para pescar em águas doces:

"Fêz-se a segunda jornada/da comédia ou comedia,/que inda nos deu melhor dia,/ do que a jornada passada:/vimos a mesma selada,/e de vinho a mesma cópia,/ de ovos maior cornucópia/que a de Almatéia florida,/e sendo a mesma comida,/ contudo não era a própria" ${ }^{" 76}$.

874 MATOS, G. Op. Cit., Vol. III, pp. 587 e 588.

875 REIS Filho, Nestor Goulart dos. Evolução urbana do Brasil (1500 - 1720). São Paulo, Pioneira, EDUSP, 1968. p. 44.

876 MATOS, G. Op. Cit., Vol. III, p. 590. 
Quando Matos esteve na vila de São Francisco (provavelmente em 1683), ele versejou por ocasião da visita do Arcebispo à localidade:

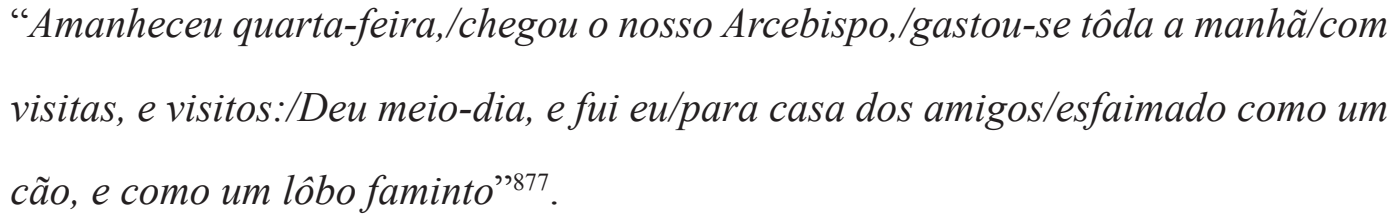

Ao amigo o capitão Bento Rabelo, censurado por não visitar Gregório de Matos na Ilha da Cajaiba - estava demasiadamente absorto em jogos de cartas - um convite versejado ofereceu uma tarde e uma noitada na Cajaiba, lugar onde o poeta parece ter residido por muito tempo (sem explicitar em que qualidade acolhiam-no naquele engenho). Ao amigo, que residia na vila de São Francisco, em frente à ilha, na outra margem do rio Serigi-mirim, o poeta sugeria:

\begin{abstract}
"Mas se deixais por remate/êsse jogo, esse monturo,/sois Príncipe, que de juro/ senhoreia. // Sois o Mecenas da veia/deste Poeta nefando,qque aqui vos está esperando/com jantar, merenda, e ceia"878.
\end{abstract}

Existiam, ao que parece, diferenças entre as iguarias que os mazombos comiam no almoço ou no jantar e aquelas que colocavam à mesa nas ceias, em dias que não eram magros, quando o consumo de produtos de animais de sangue quente era permitido: "Para o jantar as carnes saborosas/O pescado excelente para a ceia" ${ }^{\prime 79}$.

$\mathrm{Na}$ ceia, os colonos costumavam comer peixes ou frutos do mar recém-pescados ou mariscados, procedimento que Matos confirmou ao se queixar, durante um período de escassez

\footnotetext{
877 MATOS, G. Op. Cit., Vol. VI, p. 1408.

878 MATOS, G. Op. Cit., Vol. II, p. 379.

879 MATOS, G. Op. Cit., Vol. VI, p. 1522 - (Verso incluído no soneto Ilha de Itaparica).
} 
marcada do provimento alimentar, de receber na ceia apenas sobras do caldo do cozido do jantar (feito com carnes de pouca qualidade) ${ }^{880}$, por falta de peixe, já que as autoridades coloniais, dando preferência à frota, tinham mandado salgar todos os peixes disponíveis para abastecê-la. Reafirmava-se indiretamente o hábito mazombo, herdado do exemplo português, de consumir carnes ao jantar e de preferir peixes à noite, um hábito corrente que não contava com o favor do Doutor Mirandela:

“Com justiça pois me torno/à Câmara Nó Senhora,/que pois me trespassa agora,/ agora leve o retôrno:/praza a Deus, que o caldo môrno,/que a mim me fazem cear/ da má vaca do jantar/por falta do bom pescado/lhe seja em cristéis lançado;/mas se a saúde lhe toca:/ponto em boca"881.

"Tão alegre sexta-feira/não vi em todos os meus dias,/porque tivemos na ceia/sôbre tainha tainha" $" 882$.

O doutor Mirandela, analisando a precedência do peixe na refeição noturna dos nobres (um jantar tardio), confirmou o costume luso, acrescentando, contudo, doutas considerações pessoais à tese:

"No que toca comer peixe à noite, dirão que os jantares se devem fazer leves, como aconselhamos no capítulo antecedente, e que assim são as que constam de peixes e saladas, como ordinariamente se faz nesta terra. E se fossem de carne dariam maior enfado ao estômago e perturbariam o sono e a quietação, que se deve desejar muito de noite, para descansar do trabalho do dia. A isto respondemos que é verdade,

\footnotetext{
880 Cf. a questão da carne de corte e dos açougues: item 3.2. da tese

881 MATOS, G. Op. Cit., Vol. II, p. 437. Cristél: segundo o Diccionário Moraes: “ajuda, mezinha que se toma pelo ano".
}

882 Romance de Thomáz Pinto Brandão. Poema enviado de Pernamerim à Gregório de Matos. Texto incluído in: MATOS, G. Op. Cit., Vol. VI, p. 1417. 
que os jantares leves sempre são melhores. Mas que o serem leves, não consiste só em serem de peixes, que ainda que se coza com facilidade e dê pouco trabalho ao estômago, também de peixe se podem fazer os jantares largos e assim se fazem comumente. Quem aos jantares se fartar de peixe e salada, é certo que pelo excesso com que comer, dará trabalho ao estômago e poderá causar cólicas do estômago e ventre" $" 883$.

O médico terminava a preleção recomendando a quem tivesse comido em excesso na refeição diurna que se houvesse com parcimônia à noite: "deixando o peixe, que a Igreja deu para penitência, para os dias em que ela proíbe a carne".

No mundo ibérico, todavia, o peixe da ceia, não era comido sozinho. Serviam-no acompanhado de saladas. Um conselheiro do rei francês, Barthélemy Joly, que em 1603 visitou a Espanha, onde foi acolhido por círculos políticos e eclesiásticos bem alimentados, segundo relata Rafael Núñez Florencio, também comeu ali substancialmente ao meio-dia e levemente à ceia. A refeição noturna compunha-se, afirmava o autor, de um par de pratos de "picadillo" e de saladas bem temperadas com chicórias, azeitonas e cardos, terminando com laranjas ${ }^{884}$. Segundo Joly, a ordem de serviço dos pratos na principal refeição diurna espanhola era a seguinte: a refeição se iniciava com frutas frescas, laranjas inteiras ou em rodelas açucaradas, uvas, romãs, melões e saladas. Depois vinham à mesa, já trinchados, aves e carnes de caça, seguidas de outras carnes e de pratos contendo variedades de arroz com leite. Azeitonas e um cozido arrematavam a refeição.

No Brasil saladas de chicória ${ }^{885}$, de alfaces ou de pepinos temperados com limão e pimenta ${ }^{886}$ e peixes frescos ou peixes em escabeche parecem ter incrementado o cardápio das ceias. Matos, em suas descrições de refeições, criticou os perdulários que "Boa História”, destruíam o capital

883 HENRIQUEZ, Francisco da Fonseca, Op. Cit., pp. 73 e 74.

884 NÚÑEZ, Florêncio Rafael. Con la salsa de su hambre: los extranjeros ante la mesa hispana. Madrid, Alianza Editorial, 2004. pp. 68 a 71.

885 MATOS, G. Op. Cit., Vol. II, p. 299 e também Vol. VII, p. 1592.

886 MATOS, G. Op. Cit., Vol. II, pp. 429 a 434 e Vol. V, p. 1195. 
para se vestirem ostensivamente, "sendo à noite seus guisados/azeitonas e chicória!" 887 uma ceia plausível, mas frugal, por faltar-lhe o peixe.

No Brasil os colonos iniciavam também a refeição comendo frutas frescas, hábito que Piso aprovou: "É preferivel servi-las, excetas as adstringentes, antes que depois das refeições; e melhor preparadas com açúcar que cruas". O médico recomendava:

"as melancias e demais frutas refrigerantes, tanto crus como preparados, podem comer com proveito os em estado de jejum, que os consideram como divinas, de entre as frutas saborosas; pois são boas para o fígado quando, sobretudo nos meses do verão, chegam à maturidade. Por isso passou a provérbio: não entra médico nas casas em cujo vestíbulo se vêem de manhã numerosas cascas de laranjas" ${ }^{888}$.

Matos chegou a brincar com os hábitos alimentares ao comentar o caso escabroso do padre Manuel Domingues Loureyro, que se recusou a ir voluntariamente como capelão para Angola e foi preso, intervindo em sua nomeação intempestiva a circunstância de outro padre, conhecido pela alcunha de Chicória, lhe dever certa quantia em dinheiro:

"Aquentou muito a História/sobre outras ações velhacas/ter-lhe aborcado as patacas/o magano do Chicória:/mas sendo a graça notória,/diz o padre na estacada,/que ficarão a pancada,/quando um, e outro desfeche/se o Loureiro de escabeche,/o Chicória de selada" ${ }^{\prime 89}$.

887 MATOS, G. Op. Cit., Vol. II, p. 491.

888 PISO, Guilherme, Op. Cit., p. 11.

889 MATOS, G. Op. Cit., Vol. II, p. 299. 
Vale ressaltar ainda como a mulher da buzeira acreditava ter feito na véspera uma ceia parca $^{890}$ e adequada, ao tomar apenas um caldo de feijões da Pericoara quase sem adubos (portanto mais difícil de digerir e isso, justamente numa quarta feira que era dia magro), antes de ir para a igreja e de passar mal.

Colonos que não possuíam recursos ou que evitavam gastar dinheiro para desfrutar de uma alimentação condizente foram satirizado noutro registro de críticas, sendo reputados pelo autor como homens faltos de energia para um desempenho sexual. Luzia Çapata, segundo a didascália de um poema, "querendo, que o amigo lhe desse quatro investidas duas de dia, e duas de noyte", Matos versejou:

"Puta, se a vossa Ração/hão de ser quatro á porfia,/dormi com quatro em um dia,/e quatro se vos darão:/mas tirá-las de um Cristão,/que apenas janta e não ceia,/e não dará foda, e meia,/isso é mais do que crueldade" $" 891$.

Noutra oportunidade o autor escreveu ainda:

"Que andem com melancolia/sem comer e sem cear/para poder ajuntar/todos cheios de lazeira!/Boa asneira" ${ }^{\prime 92}$.

De fato, a noção soteropolitana de banquete não parece ter sido vinculada a grandes requintes ou a pratos muito rebuscados. Bastava um bom bocado para alegrar a companhia, desde que a comemoração não fosse uma ocasião macabra, como a festa que Matos acusou o governador Braço de Prata de oferecer para celebrar espetáculos de enforcamentos:

890 MATOS, G. Op. Cit., Vol. VI, p. 1345.

891 MATOS, G. Op. Cit., Vol. V, pp. 1107 e 1108.

MATOS, G. Op. Cit., Vol.III, p. 492. 
"que de puro malvado/desse êsse dia um banquete,/e alegrasse o seu bofete/com bom vinho e bom bocado" $"$.

Nos mosteiros soteropolitanos a subsistência cotidiana parecia mais tranqüila do que o provimento alimentar do clero regular. Matos refugiado no Carmo (após ter sido despojado de suas funções eclesiásticas pelo arcebispo e perseguido pelo governador), escreveu um poema que, por ser levemente irônico, permaneceu num terreno dúbio. O autor lamentava sua falta de vocação para a vida monástica serena, já que a fartura alimentar e o silêncio a ser respeitado entre as refeições lhe pareceram circunstâncias atraentes e muito apropriadas à tranqüilidade da digestão:

"Esta vida religiosa/tão sossegada e segurala tôda boa alma apura,lafugenta a alma viciosa:/há cousa mais deliciosa, /que achar o jantar e almoço/sem cuidado e sem sobrosso/tendo no bom, e no mau ano/sempre o pão cotidiano/e escusar o Padre nosso!" 894.

Mesmo presentes nos cardápios diários da colônia, os vegetais não mereciam o mesmo apreço que as carnes. Contudo, não faltaram saladas entre as iguarias servidas em jantares e ceias.

No que dizia respeito às merendas na obra de Gregório de Matos, o poeta apenas mencionou, sem maiores especificações, uma merenda de confeitos (preparações doces, frutos em conserva, pastilhas ou guloseimas doces) oferecida no palácio do governador.

"Ao teu palácio te acolheste, e logo/casa armaste de jôgo,/Ordenando as merendas por tal jeito,/Que a cada jogador cabe um confeito:/Dos Tafuis um confeito era um bocado,/sendo tu pela cara o enforcado" 895 .

\footnotetext{
893 MATOS, G. Op. Cit., Vol. I, p. 201.

894 MATOS, G. Op. Cit., Vol. II, p. 235.

895 MATOS, G. Op. Cit., Vol. I, p. 158.
} 
Poderia-se supor que os tremoços servidos durante um jogo de $\operatorname{cartas}^{896}$ fossem considerados merenda. Outras alusões do poeta a colações ligeiras designaram metaforicamente um frete de Maria Viegas: "Guardaste triste merenda/para o triste do coitado" ${ }^{897}$, ou criticaram amores freiráticos:

"Estamos na cristandade?/Sofrer se há isto em Argel,/que um convento tão novel/ deixe um leigo por um frade?/que na roda, ralo ou grade/Frades de bom, e mau jeito/comam merenda e eito,/e estejam a contento/feito papas do convento,/porque andam co papo feito?" ${ }^{898}$.

Na cidade e no Recôncavo, as festividades também seguiam padrões previamente estabelecidos. Constavam passeios com amigos e celebrações de caráter privado, porém, a maior parte das ocasiões festivas se concentrou em torno da celebração dos dias santos do calendário católico, em festas particulares que sacramentavam ritos de passagem como os batizados, ou em ocasiões importantes, como o desembarque de autoridades coloniais (arcebispos ou governadores) e ainda os acontecimentos felizes na vida da família real.

Ir à igreja ${ }^{899}$ era um dos raros passeios permitidos às mulheres de boa família. Para saírem de casa, geralmente carregadas em redes, mães e filhas adornavam-se com esmero e usavam mantos e saias de aparato, que integravam o patrimônio das riquezas da família e podiam ser confiscadas para pagar dívidas porventura devidas ao fisco ${ }^{900}$.

As numerosas festas do calendário religioso foram marcos obrigatórios de convívio social. Reuniam a população de ambos os sexos e de todas as condições sociais, sendo que as irmandades

896 Cf. poema colocado em epígrafe no primeiro capítulo da tese.

897 MATOS, G. Op. Cit., Vol. III, p. 574.

898 MATOS, G. Op. Cit., Vol. IV, p. 855.

899 Como já foi visto no segundo capítulo da tese

900 CARTAS do Senado, 1684 - 1692. $3^{\circ}$ vol., Salvador, Prefeitura Municipal do Salvador. 1953. pp. 18, 19. 
realizavam procissões e comemorações no dia dos santos de sua devoção. Aproveitava-se também os feriados para reunir os amigos em torno de comédias e cantos (acompanhados de comilanças e, por vezes, de bebidas). A procissão que levou uma pipa de vinho de malvasia até o refeitório do convento franciscano, na Vila de São Francisco, comprovava, ao merecer versos, a alegria do recebimento:

\begin{abstract}
"Na nova Jerusalém,/na nossa Cidade Santa,/onde São Francisco planta/mais virtudes que ninguém:/veio sobre um palafrém/um Rabi rubi empipado,/que por nos ser prometido,/foi com ramos aplaudido,/e entre palmas festejado" ${ }^{" 901}$.
\end{abstract}

Dois poemas de Gregório de Matos retrataram expedições náuticas até as ilhas onde havia árvores carregadas de frutas ${ }^{902}$. Pelo visto, não se mandava apenas escravos para coletar as frutas. Os colonos, como outrora os índios, se deslocavam pessoalmente para saborear cajus recémcolhidos. Às vezes, o passeio antecipava a maturidade da safra. Numa dessas ocasiões, o autor achou por bem brincar com a similitude entre reuniões de vereadores na Câmara Municipal e o termo câmaras utilizado para designar diarréias. A metáfora obscena logo assumiu conotação jurídica brincalhona:

“Achamos deserta ailha/sem câmaranem senado, que os cajus são restringentes, /não houve câmara êste ano. // Todos saímos com vara,/como meirinhos do campo/sôbre os pobres dos cajus/prendendo e executando./Indo a eles uma tarde,/prendemos quase um balaio,/outros deixamos pendentes, /que é o mesmo que enforcados./Os maduros se prenderam,/que era a ordem que levamos,/mas os verdes se enforcaram, por serem cajus velhacos"

\footnotetext{
901 MATOS, G. Op. Cit., Vol. VI, pp. 1485 e 1486.

902 MATOS, G. Op. Cit., Vol. III, pp. 604 a 606 e pp. 607 a 610.

903 MATOS, G. Op. Cit., Vol. III, pp. 604 e 605.
} 
Entre os agrados que a população costumava enviar aos amigos, figuravam obviamente os cajus. Confeitavam-se as frutas ou mandavam-se então aos amigos, por cortesia, cestinhas com exemplares frescos dessas frutas ${ }^{904}$.

Os mazombos não contavam a idade, como os indígenas tupi, pelo número de safras de cajus que acumulavam, porém Matos, por analogia com o tema bíblico, incorporou à poesia, uma das frutas soteropolitanas mais refrescantes. Brites, uma comadre do vigário da Madre de Deus, certa vez, interceptou e comeu um belo caju destinado ao poeta, motivando brincadeiras equívocas de Matos, nas quais o caju substituiu a maçã edênica ${ }^{905}$.

Outras concessões do poeta aos ingredientes da dieta indígena foram as pimentas nativas, que agradavam à maioria dos colonos, e sobretudo a mandioca, em sua versão farinha seca, derivada do produto que os índios Tupi preparavam em previsão de viagens ou de expedição bélicas. Nem as pimentas, nem as farinhas, entretanto, parecem ter motivado tantas alegrias quanto a sazonalidade festiva dos cajus.

Em nenhum momento da obra conhecida o poeta mencionou qualquer festividade em torno de colheitas de milho, que não constituía na região nordestina um alimento de uso primordial. Tampouco encontrei nos versos do poeta alusões a festividades para celebrar o início da colheita e da moagem das canas por ocasião das safras.

Examinando os trajetos de Gregório de Matos pela cidade, saltou aos olhos nos relatos poéticos, a grande visibilidade das ocasiões solenes. O Entrudo ${ }^{906}$, a Quaresma ${ }^{907}$, Endoenças ${ }^{908}$, a Páscoa ${ }^{909}$,

\footnotetext{
904 MATOS, G. Op. Cit., Vol. II, pp. 303 a 305.

905 MATOS, G. Op. Cit., Vol. IV, pp. 935 e 936.

906 MATOS, G. Op. Cit., Vol. III, p. 580.

907 MATOS, G. Op. Cit., Vol. I, p. 157.

908 MATOS, G. Op. Cit., Vol. VI, pp. 1344 a 1348.

909 MATOS, G. Op. Cit., Vol. VI, p. 1400.
} 
a Santa Cruz ${ }^{910}$, São João ${ }^{911}$, São Gonçalo ${ }^{912}$, Nossa Senhora do Amparo ${ }^{913}$, Nossa Senhora de Guadalupe ${ }^{114}$, Nossa Senhora do Rosário ${ }^{915}$, o dia de Todos os Santos ${ }^{916}$ e o Natal festejavam-se pomposamente e inspiraram versos encomiásticos ou burlescos ao autor. $\mathrm{Na}$ obra analisada, as festas natalinas apareceram com grande destaque. Constituíram oportunidades para o vigário da Madre de Deus receber a visita de padres vindos da cidade ${ }^{917}$ e para promover comédias ou cavalhadas na Cajaíba ${ }^{918}$.

Também ocorriam procissões e banquetes a cargo das irmandades, que incluíam distribuições de comidas e de bebida acompanhadas de danças animadas. Vinhos e aguardentes do reino eram oferecidos nas festas das irmandades mais elegantes e "jeribita" (aguardente de cana) nas festas populares durante as quais se bebia e, a crer os versos de Matos, se "desbebia" muito também ${ }^{919}$. Certa vez, a irmandade dos pretos do Rosário, pela voz do autor, pediu autorização ao governador Câmara Coutinho para organizar uma festa de Nossa Senhora do Rosário. Como escreveu Matos: "todo o negregado Irmão/desta Irmandade bendita/

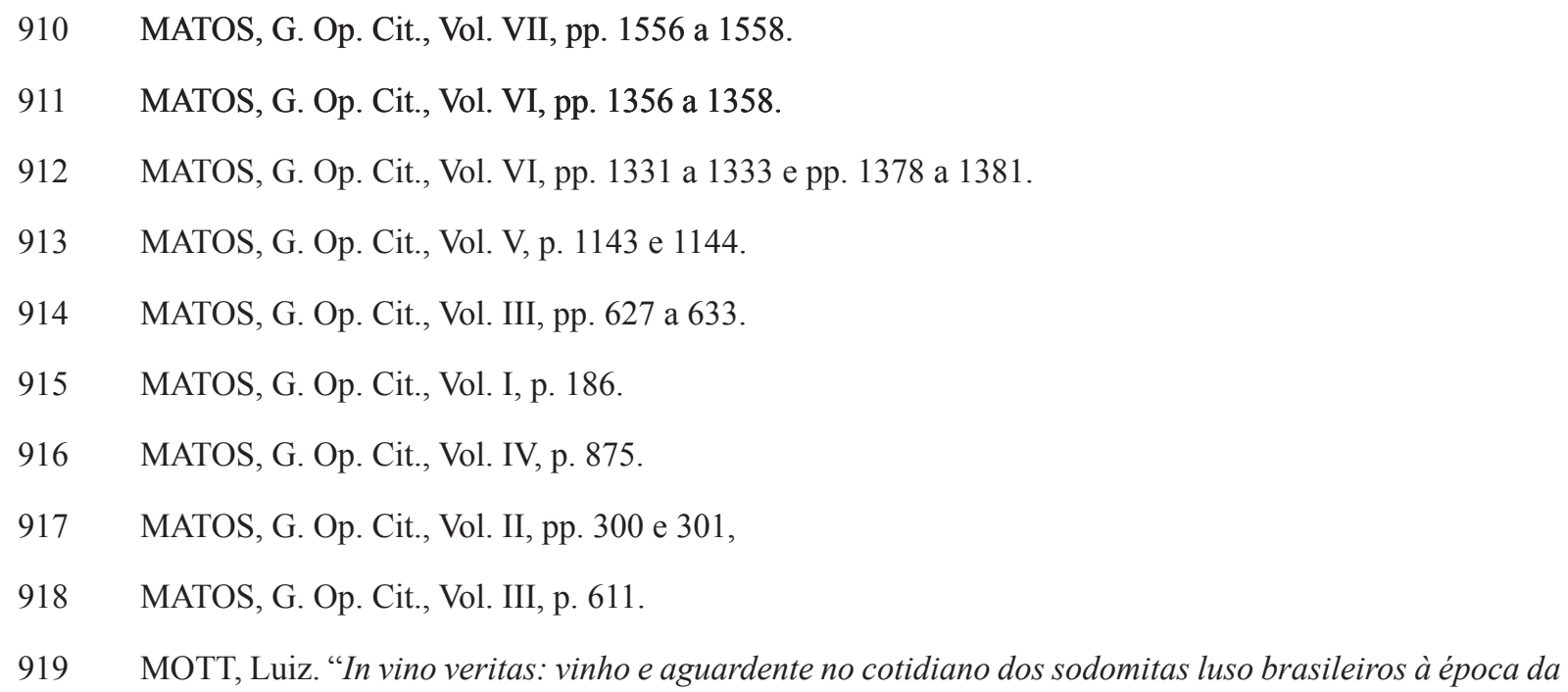
Inquisição", in Álcool e drogas na História do Brasil. VENÂNCIO, Renato Pinto e CARNEIRO, Henrique, São Paulo/Belo Horizonte, PUC. Minas/Alameda, 2005.

"São diversas as referências ao consumo de vinho e aguardente nos processos dos sodomitas luso-brasileiros presos pela Inquisição portuguesa. Seja como ingrediente constante nas refeições ou merendas mantidas antes ou depois da consumação de atos homoeróticos, quer na residência de um dos amantes quer em tabernas, ao ar livre ou em tascas públicas, seja apontado como álibi diariamente lembrado com vistas a excluir ou atenuar a culpabilidade dos réus na prática do "abominável e nefando pecado de sodomia". p. 47. 
pede, que se lhe permita/Ir ao alarde enfrascado/Não de pólvora atacados/calcados de jeribita" 920 .

As festas da Cidade da Bahia mencionadas nos poemas foram sobretudo festas de irmandades. Uma delas, que reunia mulatas, escolheu festejar Nossa Senhora do Amparo com um baile, dedicando outra festa, no ano seguinte, a Nossa Senhora de Guadalupe:

"Bertola devia estar/faminta, e desconjuntada,/pois vendo a pendência armada,/ tratou de se caldear:/bebeu naquele jantar/sete pratos não pequenos/de caldo, e sete não menos de carne,/e é de reparar/que um só a pudera matar"921.

“Inácia, chamada Ilhoa/para cada beiçarrão/não bastava um canjirão/com sopas de pão e broa:/bebeu vinho de Lisboa,/bebeu do Porto, e Canárias, /e vendo que em copas várias/outras o bebem do Beja,/disse picada de inveja,/Ô Virgem das Candelárias!"'922.

“Helena, a cu de borralho,/asmática, porém gorda,/se ensopou como uma torda na sorda de vinho, e alho:" ${ }^{923}$.

O poeta parece ter apreciado semelhantes festejos acompanhados de sôrvo e $\operatorname{trago}^{924} \mathrm{e}$ versejava facilmente casos divertidos ou escabrosos observados em ocasiões solenes. Por esse motivo, participando de bailes e de bebedeiras das mulatas e relatando, sem pejo, diversos episódios escatológicos, situados em recintos de igrejas, o autor consubstanciou hábitos soteropolitanos. A festa de Todos os Santos lhe proporcionou uma inspiração de

920 MATOS, G. Op. Cit., Vol. I, p. 186.

921 MATOS, G. Op. Cit., Vol. III, p.625.

922 MATOS, G. Op. Cit., Vol. III, p. 632.

923 MATOS, G. Op. Cit., Vol. III, 629. (açorda : sopa lusa de pão embebido com caldo).

924 MATOS, G. Op. Cit., Vol.VI, p. 1379. 
poema talvez com algum fundamento de veracidade (as freiras do Desterro enclausuradas pelas famílias por motivos econômicos, não primavam pela vocação e teriam mesmo, em época posterior, inquietado as autoridades eclesiásticas). Matos, pois, dedicou versos :“ $A$ certa freyra que em dia de Todos os Santos mandou a seu amante graciosamente por pam por Deos hum cará”:

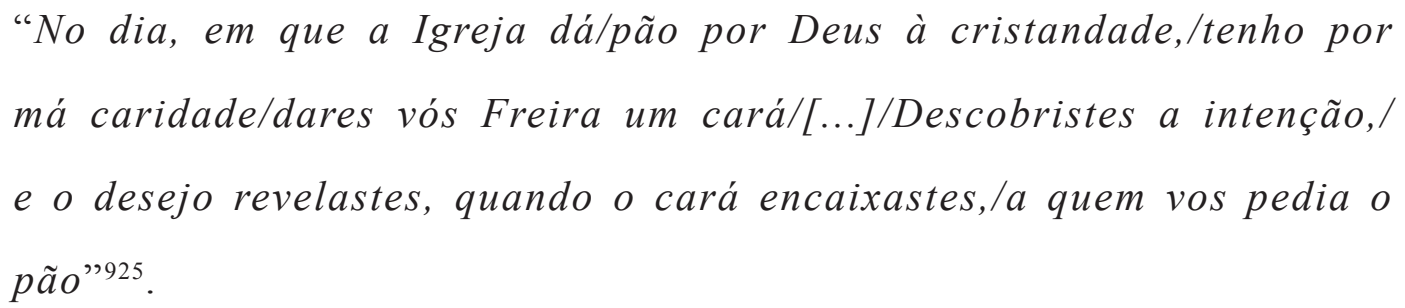

Certa vez a festa das Onze mil virgens resultou em festejos cívicos aparentemente não acompanhados de qualquer banquete público ${ }^{926}$. Na ocasião as autoridades coloniais organizaram cavalhadas no Terreiro de Jesus, exibições de destreza de cavaleiros montados que Mary Del Priore relatou recompensadas com uma farta distribuição de prêmios aos vencedores ${ }^{927}$. Toda a nobreza assistiu ou participou das demonstrações dos competidores. Cavaleiros montados correram touros, arrebataram argolas, cortaram canas no ar e Matos, num tom burlesco, se fez relator de suas proezas.

\section{MATOS, G. Op. Cit., Vol. IV, p. 875.}

DEL PRIORE, Mary Lucy. Op. Cit., p. 65 e 66. “Corrente era também a troca de comida que se ingeria por ocasião de uma determinada festa. As festividades em torno do 'pão por Deus' começavam em outubro e estendiam-se até dezembro; trocavam-se bilhetes recortados e rendilhados em que o remetente pedia a alguém um 'pão por Deus': uma prenda. Essa dádiva por várias vezes tomou a forma de alimento, o que permitiu a Gregório de Matos, no final do século XVII, fazer um poema 'A certa freira que em dia de Todos os Santos mandou a seu amante graciosamente por 'pão por Deus um cará'. Nesse texto o poeta sugere que a remetente desejava algo parecido com a dita raiz". 926 MATOS, G. Op. Cit., Vol. III, pp. 634 a 641 e pp. 642 a 654.

927 DEL PRIORE, Mary Lucy. Op. Cit.,_p. 57 e 60. “Avesso do popular na festa, havia um complemento dos folguedos populares que embora do gosto do povo, tinha origem nobre [...]. As cavalhadas ou cavalarias eram reminiscência das justas e torneios de nobres cavaleiros, a que vieram somar-se a celebração dramatizada das lutas entre cristãos e mouros [...]. Até o século XVIII foram divertimentos de fidalgos". 


\section{Iguarias africanas e indígenas}

A questão do papel que coube respectivamente às cozinheiras nativas, às senhoras lusas e às cozinheiras africanas na formulação de uma culinária local foi abordada por diversos estudiosos interessados no problema da formação de um estilo de vida brasileiro. Autores como Gilberto Freyre, Câmara Cascudo ou Ernani da Silva Bruno ${ }^{928}$, por exemplo, inferiram interações sociais intensas e uma troca assaz benevolente de saberes e de preparos culinários entre indígenas, lusos e africanos cedo ocorrida. Imaginaram um compartilhar imediato de procedimentos que subentendia por parte de todos os envolvidos uma grande disponibilidade do paladar em relação à experimentação e à adoção de iguarias alheias, tão óbvia e casual quanto as relações sexuais correntemente mantidas entre parceiros de origem e condição social diversificadas.

O fato de amásias e cativas indígenas ou de seus parentes de sexo masculino terem inicialmente ensinado aos forasteiros peculiaridades importantes de manejo ou de preparo dos gêneros comestíveis sul-americanos, associado ao rápido desaparecimento das cozinheiras nativas, substituídas por africanas nas casas grandes coloniais, sugeriu a diversos estudiosos a ocorrência de uma adesão imediata dos colonos lusos a iguarias temperadas com ingredientes africanos. Câmara Cascudo, por exemplo, chegou a afirmar:

"A negra caiu como avalancha, afastando a cunhã que desaparecia sem préstimo real. A mucama encheu as cozinhas senhoriais e, mesmo disputando a preferência do senhor-amo, foi discípula maravilhosa em ambas as fórmulas do sabor culinário e sexual solicitadas.

A cunhã ausentou-se dos centros mais povoados onde as chaminés lindavam os interesses de uma produção erguida nos braços africanos. A cunhã foi sendo

928 Em Casa grande e senzala, Gilberto Freyre parece ter presumido algo semelhante, ao exaltar a doçura das escravas. 
empurrada para o desertão, seguindo os homens de sua tribo, dizimada, inútil, taciturna. A negra serena, risonha, submissa aos ioiôs sequiosos e às sinhás gritadeiras, assenhoreou-se sub-repticiamente dos segredos de atender à fome branca e satisfazer aos imperativos mandões das iaiás insaciáveis na verificação da subserviência. Nos inícios do séc. XVII os engenhos e as cidades fervilhavam de africanos e as novas levas cobriam a terra. A mucama reinava na cozinha, ouvindo as ordens da senhora e piscando o olho ao senhor branco, conciliante e superior" 929 .

Ernani Silva Bruno, por sua vez, considerou que a partir do início do século XVII já teria ocorrido uma africanização da dieta alimentar local:

“De outra parte, já podiam contar os moradores da região - notadamente os mais abastados - com alimentos que não eram apenas os mantimentos comuns da terra e do bugre, embora êsses mantimentos (sobretudo os produtos da mandioca e do milho) continuassem a pesar no teor da dieta geral, ao lado daqueles que provinham de influências africanas - o uso do quiabo, do feijão preto, do côco de dendê e da própria maneira de preparo de certos quitutes, ensinada pelos negros"930.

O quiabo foi efetivamente mencionado desde cedo entre os ingredientes disponíveis na colônia. O feijão preto, no entanto, tinha origem sul-americana. O feijão fradinho, como visto acima, é que provinha da África. Quanto ao azeite-de-dendê, segundo Rosemeire Lorimer ${ }^{931}$, a produção local da palmeira de dendê ainda era fato recente. Ela teria sido transplantada na colônia em meados do século XVII, não pela vontade de cativos transportados nos navios

\footnotetext{
929 CASCUDO, Luis da Câmara. Op. Cit., Vol. I, pp. 174 e 175.

930 BRUNO, Ernani da Silva. História do Brasil geral e regional. 3. Bahia. São Paulo, Cultrix, 1967. p. 48.

931 LORIMER, Rosemeire. Tese de doutorado. Op. Cit., p. 120.
} 
negreiros, mas com a finalidade precípua de oferecer combustível para a iluminação. Parece improvável, à vista de tais circunstâncias, que os colonos lusos tão ciosos do lugar honroso que ocupavam na hierarquia colonial já tivessem, desde aquela época, saboreado prazerosamente iguarias preparadas com temperos africanos, conforme os ensinamentos de seus escravos. Citando Lima, Lorimer afirmou:

\begin{abstract}
“Neste tempo - final do século XVII-foram recriadas muitas das comidas cotidianas dos homens e dos santos. Pois que os santos comem o que os homens comem. E as comidas mais elaboradas das festas, das celebrações votivas. Esse foi o tempo do cozinheiro e da cozinheira escravos, reproduzindo o cardápio basicamente português, mas já substituindo, trocando ingredientes, colorindo ensopados com o vermelho do dendê, inventando as muquecas, usando o inhame, a banana cozida, recriando o caruru, o vatapá. Pratos novos com um sabor antigo que era o deles e um gosto novo que lhes ensinavam..." 932.
\end{abstract}

Os poemas de Gregório de Matos permitem perceber a ingenuidade otimista das explicações sobre o teor das interações sociais ocorridas. Os estudiosos constataram que, em algum momento da História brasileira, houve uma incorporação de ingredientes e de preparos africanos à dieta soteropolitana - semelhante à incorporação de ingredientes indígenas no cardápio dos colonos lusos atestada pelos primeiros cronistas. Basearam-se numa lógica retroativa e não nos usos observados para inferir os elementos do processo de ajustamento luso às condições de provimento local.

A emergência de uma dieta soteropolitana, sui generis, deveria ser procurada de preferência no desenrolar cronológico dos eventos que repercutiram no âmbito das práticas e também nas peculiaridades locais dos códigos de alimentação. Por isso, os poemas de Gregório de Matos, compostos no limiar do

932 LIMA, V.C. “As dietas africanas no sistema alimentar brasileiro”. In CARDOSO, B. e BACELAS J. Faces da tradição afro brasileira, Salvador, Ed. Pallas. 1999. Apud LORIMER, Rosemeire. Op. Cit., p. 122. 
século XVIII, mereceram atenção ao sugerirem que o ajustamento dos colonos lusos à colônia teria sido muito menos pacífico, unilinear e homogêneo do que se supôs inicialmente.

\section{A alimentação dos escravos}

As representações sobre a vida dos escravos, suas obrigações de trabalho ou suas atividades, incluídas nos versos de Matos, delinearam uma situação que não deixava de evidenciar contradições. Desgostoso com a existência soteropolitana, o autor, que lamentava amargamente a proibição de matar escravos rebeldes, era o mesmo homem que se arvorou em defensor de uma escrava castigada pelo roubo de um ovo, apelando para a clemência de sua senhora:

"Não sei, para que é nascer/neste Brasil empestado/um homem branco e honrado/ sem outra raça. // Terra tão grosseira e crassa,/que a ninguém se tem respeito,/salvo quem mostra algum jeito de ser Mulato. // [...] // Os Brancos aqui não podem/mais que sofrer e calar,/e se um negro vão matar, chovem despesas. // Não lhe valem as defesas/do atrevimento de um cão,/porque acode a Relação, sempre faminta"933.

Intercedendo, Matos, segundo afirmava a didascália do poema, pediu vênia: "A hum amigo apadrinhandolhe a escrava de alcunha a Jacupema. A quem sua Senhora queria castigar pelo furto de um ovo".

"Se acaso furtou, Senhor,/algum ôvo a Jacupema,/o fez só, para que gema/cos pesos do meu amor:/não creio do seu primor,/que furte a sua senhora,/sendo franca e não avara,/porque para ela campar,/escusa claras comprar,pois negra val mais que clara"934.

933 MATOS, G. Op. Cit., Vol. VII, p. 1585.

934 MATOS, G. Op. Cit., Vol. V, p. 1123. 
Entretanto, o mesmo homem criticava os colonos:

"Pois no que toca a guardar/dias Santos, e Domingos:/ninguém vejo em mim, que os guarde,/se tem, em que ganhar jimbo./Nem aos míseros escravos/dão tais dias de vazio,/porque nas leis do interêsse, é preceito proibido"935.

“Contados são, os que dão/a seus escravos ensino,/e muitos nem de comer,/sem lhes perdoar serviço./Oh quantos, e quantos há/de bigode fernandino, /que até de noite às escravas/pedem selários indignos" ${ }^{9936}$.

Antonil, o jesuíta italiano que apresentava uma mistura curiosa de compaixão cristã e de racionalidade empresarial, descreveu os escravos, em seu relato clássico, como sendo "mãos e pés do senhor de engenho"937, administrados segundo princípios de "pau, pão e pano"938. O jesuíta assinalava a carestia experimentada pelos escravos que mal dispunham de tempo para "buscar uma raiz e um caranguejo para comer"939, relatando ainda como, no espaço urbano da capital, os escravos comiam miúdos bovinos:

“comumente os negros, que são um número muito grande nas cidades, vivem de fressuras, bofes e tripas, sangue e mais fato das reses, e que no sertão mais alto a carne e o leite é o ordinário mantimento de todos" $" 940$.

\footnotetext{
935 MATOS, G. Op. Cit., Vol. I, p. 17.

936 MATOS, G. Op. Cit., Vol. I, p. 20.

937 ANTONIL. Op. Cit., p. 159.

938 ANTONIL. Op. Cit., p. 162.

939 ANTONIL. Op. Cit., pp. 160 a 163

940 ANTONIL. Op. Cit., p. 310.
} 
Rocha Pita, por sua vez, informava que os cativos recebiam carne de baleia (fresca durante a estação da caça entre Junho e Outubro ${ }^{941}$ e cozida, salgada e embarrilada o resto do ano). Alimentavam-nos também com peixes salgados, como os xaréus e, por vezes, com produtos frescos da pesca ou do mariscar.

No Recôncavo açucareiro Antonil observava:

"Costumam alguns senhores dar aos escravos um dia em cada semana, para plantarem para si, mandando algumas vezes com eles o feitor, para que não se descuidem, e isso serve para que não padeçam fome nem cerquem cada dia a casa de seu senhor, pedindo-lhes a ração de farinha" ${ }^{\prime 942}$.

Obviamente não havia consenso entre os senhores de engenho e outros proprietários de terras, nem em relação à melhor solução alimentar para nutrir os escravos na área rural seja ração provida a todos, seja tempo para prover o sustento, seja solução mista nem quanto às quantidades de alimentos que a mão-de-obra deveria receber. Parece que imperavam também diferenças na cidade, entre a dieta alimentar dos escravos de ganho (apenas obrigados a entregar os lucros de suas atividades) e a dieta alimentar de cativos ocupados no serviço das casas.

$\mathrm{Na}$ área rural açucareira, Antonil informava que muitos escravos recebiam em sistema de rodízio, durante a safra, a regalia de uma porção de garapa doce que deixavam fermentar pelo prazer de consumir uma bebida alcoólica. "Os negros usam da segunda escuma para fazerem sua garapa"943, afirmava o padre, assinalando também que a iguaria lhes permitia efetuar resgates de "farinha, banana, aipins e feijões" com "parceiros" que trabalhavam nas roças e dispunham de legumes, mas não tinham acesso à bebida apreciada. Por vezes no entanto, em lugar de garapa os cativos recebiam aguardente destilada, menos nutritiva e mais embriagadora.

\footnotetext{
941 PITA, Sebastião da Rocha. Op. Cit., p. 34, parágrafo 72.

942 ANTONIL. Op. Cit., p. 162.

943 ANTONIL. Op. Cit., p. 203.
} 
O jesuíta recomendava:

“O que há de evitar nos engenhos é o emborracharem-se com garapa azeda, ou água ardente, bastando conceder-lhes a garapa doce, que lhes não faz dano, e com ela fazem seus resgates com os que a trôco lhes dão farinha, feijões, aipins e batatas"944.

No caso dos escravos domésticos, o padre preconizava o hábito de se guardar sobejos da mesa dos senhores para os filhos pequenos dos escravos. Convinha desencorajar as práticas abortivas das escravas grávidas e valia a pena mimar um pouco as crianças para que os pais pudessem "servir de boa vontade". Com certa ingenuidade, o padre acrescentava: e "se alegrem de lhes multiplicar servos e servas" $" 945$.

Nos navios negreiros portugueses, os cativos também comiam feijões. Boxer, citando Mortamer, comentou as precauções higiênicas tomadas pelos traficantes lusos: duas refeições quentes diárias e água não deixavam de ser providas aos escravos. Segundo o autor, os barcos da Companhia das Índias Ocidentais (WIC.) holandesa, apesar de mais espaçosos que as caravelas portuguesas, contabilizavam maiores taxas de mortalidade, já que costumavam amontoar acintosamente os escravos:

“Os portugueses conseguem transportar numa caravela mais de quinhentos escravos muito melhor do que nós, levando trezentos num navio grande. Isso acontece porque os portugueses olham mais por eles, alimentam-nos melhor, sabendo que isso lhes rende o dobro na hora de vendê-los. Lavam todos os dias a coberta do navio com vinagre ordinário; dão aos seus escravos comida quente duas vezes por dia, sendo uma de feijão africano, a outra de milho, tudo bem cozido, de mistura com uma boa colher de azeite de dendê, juntamente com um pouco de sal e, às vezes, com um

\footnotetext{
944 ANTONIL. Op. Cit., p. 164.

945 ANTONIL. Op. Cit., p. 164.
} 
bom naco de peixe seco em cada prato. Durante o dia dão-lhes sempre um pouco de farinha e de água. No caso de doença, têm sempre á mão, especialmente para isso, algum vinho, e dão a cada escravo dois ou três pedaços de cobertor velho com que possam se cobrir"'946.

À vista dos sarcasmos ridicularizando iguarias nativas e dieta dos pobres ou dos escravos contidos nos versos de Matos, deixou de parecer plausíveis a idéia da larga aceitação mazomba de iguarias regadas com dendê, já naquela época. De modo que o fato do autor incluir elementos de cor local em seus versos não justificou as opiniões de uma benevolência inovadora do poeta em relação às aspirações dos mestiços soteropolitanos.

\section{As iguarias indígenas}

Dos alimentos indígenas, apenas a farinha de mandioca seca, mantimento básico da colônia, e as pimentas nativas, tão correntes quanto apreciadas pelo conjunto da população colonial, parecem ter escapado ao repúdio que Matos expressou contra as iguarias tupi. Os versos, no entanto, não permitem determinar até que ponto a ironia do poeta contra os preparos usuais da dieta nativa revelava um ostracismo amplamente aceito no âmbito das elites mazombas. Com efeito, apesar do consumo de farinhas de mandioca, acompanhando carnes salgadas ou secas e peixes secos permanecer essencial, os preparos indígenas proveram a Gregório de Matos um arsenal amplo de metáforas para desqualificar os colonos mestiços.

Não figuraram nos versos do poeta as tão decantadas "marmeladas de mandioca", mingaus de farinha de tapioca (subproduto obtido a partir do amido da raiz), adoçados com açúcar e temperados com água de flor de laranjeira (ingredientes introduzidos pelos colonos), iguaria

946 BOXER, C. R. Salvador de Sá e a luta pelo Brasil e Angola 1602 - 1686. p. 245. Cf. também PUNTONI, Pedro. A mísera sorte. Hucitec, São Paulo, 1999. p. 160. 
corrente dos portugueses durante a primeira metade do século XVII e que os holandeses também saborearam $^{947}$.

Existiam diferenças marcantes, no entanto, entre as versões lusas e nativas das raízes de mandiocas. No final do século XVI, Gabriel Soares de Sousa já apontava uma diferença entre os preparos favorecidos pelos índios e aqueles preferidos pelos portugueses:

“Os índios usam destas raízes tão curtidas que ficam denegridas e a farinha, azeda. Os portugueses não a querem curtida mais que até dar a casca, à qual mandam misturar algumas raizes de mandioca crua, com o que fica a farinha mais alva e doce..."948.

Segundo explicava o cientista Marcgrave, extremamente preciso:

"Da mandiopuba também se fabrica uma farinha mole e um tanto sêca, como se fosse miolo de pão de trigo fresco, a que os indígenas dão nome de Vipuba e Viabiruru e os portugueses Farinha fresca $e$ Farinha d'Agoa. A farinha é agradável para se comer, mas não dura mais de um dia, por isso é fabricada todos os dias. Formam também com as mãos umas bolas de vipubam e as secam ao calor do sol, recebendo então o nome de Viapuâ e Miapeteca; assim podem ser conservadas muito tempo; os tapuias geralmente fazem esta preparação e os demais indígenas ainda a misturam com viatâ para que se torne mais agradável"949.

O fenômeno do desmerecimento da dieta autóctone na poesia de Matos, coincidindo com a larga adoção entre os colonos do termo mazombo para designar lusos nascidos no Brasil, requeria, portanto, investigação.

947 MARCGRAVE, Jorge. Op. Cit., pp. 65 a 68.

PAPAVERO, Claude. Dissertação de mestrado. Op. Cit., p. 206.

948 SOUSA, Gabriel Soares de. Op. Cit., p. 176.

949 MARCGRAVE, Jorge. Op. Cit., p. 67. 
Tachos de aferventar, cumbucas, cabaços, cuias, tigelas para angu e pilões manufaturados na aldeia indígena de Pirajá (incitando Matos a chamar os índios pelo nome da localidade: "leve o diabo a Canoa, /que me trouxe sempre à proa/arrimado a um Pirajá..." $\left.{ }^{950}\right)$, continham subentendidos pouco benevolentes. Ao satirizar os ingredientes nativos o autor não fazia nenhuma apologia da dieta dos “Cobé”, não obstante as brincadeiras com as sonoridades exóticas da língua indígena constituírem um primeiro momento de visibilidade literária dos elementos locais $^{951}$, tanto no que dizia respeito às iguarias locais, quanto aos implementos utilizados no manuseio de gêneros alimentícios:

\section{"Indo á caça de tatus...// De massa um tapiti,/um cofo de Sururus,/dois puçás de Baiacus,/Samburá de Murici:/Com uma raiz de aipi/vos envio de Passé,/e enfiado num imbé/Guaiamu, e Caiaganga,/que são de Jacaracanga/Bagre, timbó, Inhapupê. // Minha rica Cumari,/minha bela Camboatá/como assim de Pirajáa52/ me desprezas tapiti:/não vedes, que murici/sou dêsses olhos timbó/amante mais que um cipó..." $"$ 953.}

Pedro Cabra da Índia, segundo um pseudo-testamento composto por Matos, foi ridicularizado a pretexto de possuir os apetrechos culinários de um feiticeiro nativo, que ele desejaria legar

950 MATOS, G. Op. Cit., Vol. VI, p. 1489.

951 Segismundo SPINA, entretanto, lamentou ingenuamente que o poeta tivesse passado tão pouco tempo de sua vida no Brasil. Uma permanência mais longa, segundo o autor, deveria ter incentivado Matos a compor até poemas em língua indígena.

952 Reiterando uma informação já apresentada no capítulo anterior, vale lembrar como Pirajá fora o primeiro aldeamento de concepção lusa organizado pelos Jesuítas. Eles tinham reunido ali um grande número de catecúmenos para instruí-los religiosamente e incentivá-los ao trabalho braçal. Os índios, que deveriam ter provido uma mãode-obra ao engenho vizinho de Jacaracanga, se revoltaram, destruíram o engenho e mataram os colonos. Comer caranguejos, que descendiam daqueles que se nutriram dos cadáveres de Jacaracanga, constituía uma referência que, além de não muito apetitosa, insinuava uma acusação indireta de antropofagia. 
a certa moça da Cajaíba: "O meu cabaço das ervas/cumbuca de carimá,/a tigela dos angus, o tacho de aferventar..."954.

Noutra passagem do mesmo poema, o moribundo alegava ainda seu desejo de não ser enterrado no cemitério local, mas de ser comido por caranguejos (situação melhor do que ver homens mariscarem caranguejos). A emergência do termo pejorativo cabra, utilizado por Matos, merecia reparo em tal contexto.

No que dizia respeito aos ingredientes e às iguarias da dieta indígena, o autor desmereceu em diversos poemas os caldos de aratú preparados com carimã, os mingaus de manipuba ${ }^{955}$, as raízes de aipim ou de cará, os mangarás, os vinhos de caju ${ }^{956}$ etc.. Ocasionalmente ironizou também o caruru ou o xinxim ${ }^{957}$. Os versos mais emblemáticos de seu desprezo por tudo que era nativo pareciam ser aqueles, já citados no capítulo anterior da tese, nos quais tratava desdenhosamente os descendentes do Caramuru como Adãos de massapé: "A linha feminina é carimá/Moqueca, pititinga, caruru/Mingau de puba e vinho de caju pisado num pilão de Pirajá" ${ }^{958}$.

Efetivamente o uso da farinha de carimã, obtida a partir de mandioca puba e transformada em mingau pela adição de líquidos, as moquecas: amontoados de peixinhos miudinhos (petitingas) embrulhados em folha de bananeira e assados ao borralho, ou o consumo do vegetal nativo chamado caruru ${ }^{959}$, bem como o gosto indígena pelos vinhos

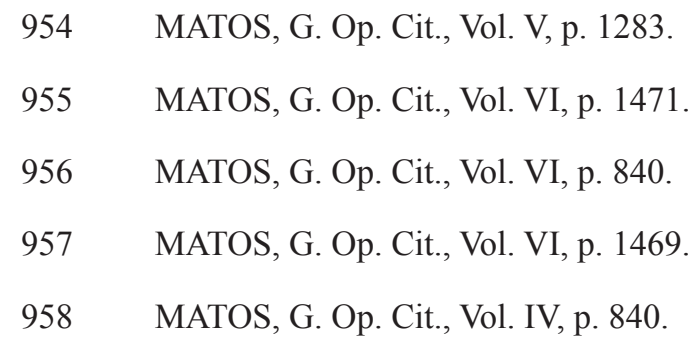
aprenderam a comer com os indígenas, foram uma iguaria bastante apreciada. Segundo testemunhou Piso: "Comese este bredo como legume e cozinha-se em lugar de espinafre; é do mesmo sabor e eficácia, juntando-se suco de limão para condimento". O preparo citado por Matos podia diferir bastante da iguaria atual desse nome, temperada com azeite de dendê e levando camarões secos.

PISO, Guilherme. História natural e médica da Índia Ocidental. Rio de Janeiro, Instituto Nacional do Livro, 1957. p. 503. 
de sucos de frutas fermentadas, estilizavam em traços largos, os contornos de uma dieta tupi.

Apenas através de uma referência dúbia a uma moqueca de petitinga, que figurou na obra de Gregório de Matos, sem indicação de receita, não foi possível determinar se a iguaria mencionada seria realmente o preparo suculento, à moda indígena, de um monte de peixinhos miúdos bem embrulhados em folhas e assados no borralho ou o guisado que incorporava azeite de dendê e leite de coco e que acabou se firmando nos cardápios brasileiros ${ }^{960}$.

Agradecendo à Suzana o presente dessas moquecas, Matos gracejou:

“A mim me tremia o cu/co’as moquecas, não em vão,/pois sendo da vossa mão/ qualquer peixe é Baiacu:/Jesu nome de Jesu!/ide pescar às restingas,/e mandaime petitingas?/ardo eu em tão vivas chamas/que por um molho de escamas/hei de dar as minhas pingas? // [...] Se sois a Susana mesmo/de juízo acreditado,/como imitais o pecado,/com manjares de quaresma:/ao nosso Abade Ledesma/pregando na freguesia,/ouvi dizer em um dia/(e é rifão dos Mazombos)/que a carne é que cria os lombos/e não peixe de água fria. // Mandai-me de carne um pouco/as galinhas, e as posturas, /que eu com minhas galaduras/vos porei franga de choco:/o mais é um intento louco,/em que a tontice vos dá,/pois que sois velhinha já,/e eu tenho grande jactância/de dar minha sustância/a quem sustância me dá"961

Avaliando em termos alimentares a retribuição devida para equivaler a um presente de peixes, Matos, apesar de agradecer a moqueca, se queixou jocosamente da desigualdade entre o que tinha recebido e o que deveria dar, sublinhando, uma vez mais, o apreço dos colonos pela carne em relação aos peixes. Outra referência a uma moqueca indígena, no poema que satirizava os descendentes do Caramuru, permitiu imaginar que seria talvez adequado matizar um pouco o

960 CASCUDO, Cascudo Luis. Op. Cit., Vol. 1, p. 159.

961 MATOS, G. Op. Cit., Vol. VI., p. 1534: 
desprezo literário, que Matos afirmava sentir em relação às iguarias nativas. Se ele as conhecia tão bem é porque seu consumo não tinha desaparecido.

Aliás, noutro poema, uma moça sendo ironicamente elogiada como xinxim das brancas, evidenciou-se a existência de uma preparação culinária, sem nenhuma indicação de receita, porém associada a descendentes dos índios, que era designada com esse nome.

Sobressaia também no conjunto dos poemas burlescos ou satíricos consagrados aos usos nativos, a lista dos animais comestíveis caçados: tatu, jacaré, teiú, paca, preá, além de cobras surucucu e jaratacacas. Uma grande variedade de cestas manufaturadas complementava o panorama da culinária nativa: tapiti trançado para espremer o sumo de mandiocas bravas e reter a massa ralada dessas raízes, cofos e puçás para transportar mariscos e peixes, samburás para carregar frutas de muricis comidas com farinha de mandioca e trançados de imbé para amarrar e transportar caranguejos vivos ${ }^{962}$.

O apego dos mazombos às iguarias lusas, um procedimento sugerido na poesia de Matos, mas que gerações anteriores de colonos não cobravam de seus pares, parece indicar que o enraizamento português em território sul-americano, longe de resultar num abandono progressivo de parâmetros reinóis de nutrição, teria, pelo contrário, desenvolvido, com o passar do tempo, preconceitos e tabus anteriormente inexistentes, supervalorizando o gosto dos guisados da terra natal em lugar de incorporarem aos poucos hábitos alimentares autóctones.

Havia, com efeito, uma arrogância tão segura do poeta em desmerecer mingaus de carimá, que a transformação dos principais ingredientes da dieta indígena em fatores emblemáticos de exclusão social não devia constituir uma idiossincrasia individual. É, portanto, possível concluir que, se o procedimento de recorrer às iguarias indígenas e aos apetrechos da culinária nativa para discriminar indivíduos com ascendentes indígenas não recebesse acolhida favorável, seria difícil explicar o tom jocoso dos poemas nos quais Matos fez pouco dos mestiços e a freqüência do tema em sua obra. 


\section{4 - A alimentação como fonte de vida social}

A alimentação dos colonos descrita nos poemas de Matos permanecia bastante próxima do modelo metropolitano. As mesas dos colonos apresentaram espécies da fauna e da flora local, guisadas à moda portuguesa, que coexistiram com iguarias preparadas a partir de animais e de vegetais do Velho Mundo aclimatados no Brasil. Os horários de refeições, como visto acima, reproduziam também procedimentos reinóis.

Na escrita poética de Gregório de Matos, técnicas de cocção e procedimentos culinários portugueses ou indígenas não foram sempre associados a preparos concretos. Assar, cozer e fritar, foram operações culinárias utilizadas geralmente numa forma passiva e desempenharam papeis sobretudo abstratos. Estar assado tornou-se sinônimo de desejar, estar cozido ou cosido referiu as tentativas de moças para disfarçar uma virgindade ensopada, enquanto estar frito sugeria a existência de discórdias.

Tampouco foram assinalados por Matos os problemas prementes de provimento em lenha para a cocção dos alimentos, enfrentados numa cidade ampliada pela expansão demográfica, que já experimentava a escassez das madeiras destinadas à construção em suas cercanias. As referências de Matos à transformação de alimentos crus em cozidos permaneceram abstratas, ressaltando-se todavia algumas exceções, como no caso de uma metáfora comprovando algum conhecimento de bastidores das cozinhas, segundo a qual o autor propunha colocar sua carne na olha de uma jovem e prometia escumar-lhe o cozido:

"Se reparais na limpeza,/ides enganada em suma,/porque em tirando-se a escuma,/ fica a carne uma pureza:/fiai da minha destreza,/que nesse apertado caso/vos hei de escumar o vaso/com tal acerto, e escolha,/que há de recender a olha/desde o Nascente ao Ocaso" ${ }^{963}$. 
No capítulo das vasilhas que iam ao fogo, os poemas apenas ressaltaram panelas de guisados, sem mencionar se eram feitas de barro ou de metal. Ao abade de Nossa Senhora das Brotas que recebeu regiamente uma procissão de colonos nobres, Matos, versejando em espanhol, desejou ao bom sacerdote: "Llena estè la cosina de sarten,/Y siempre el refectorio abunde en pan,/Que bien merece Frayle tan de bien"964.

Um elenco diversificado de vasilhas destinadas ao transporte ou ao consumo de líquidos, entretanto, foi mencionado de passagem ao longo da obra: vasos, odres, botas, frasqueiras, pipas e barris e ainda copos e taças. Em se tratando de utensílios para comer alimentos sólidos, palanganas, tigelas, pratos, escudelas e colheres de prata desempenharam função bastante modesta. Bem sugeria o autor sua preferência por comidinhas caseiras de poucos luxos. Falando metaforicamente dos olhos de uma moça ele gracejou:

"Os azuis de porçolana/força é, que pesar me dêem,/que porçolanas não servem,/ onde não hei de comer" ${ }^{965}$.

O vocabulário concernente ao transporte de mantimentos, fardos, sírios, balaios etc., foi utilizado com maior desenvoltura (o tema não constava como desabonador numa sociedade de produtores agropecuários). Os conselhos práticos, que Matos proporcionou a uma noiva, aconselhada a alimentar o futuro marido com "bocadinhos caseiros", a ir mais à panela que à janela e a ser a primeira a comer (para melhor se dedicar a servi-lo, evitando, contudo, tratálo como uma criança) esclarecem a maneira como o poeta concebia os papéis respectivos dos cônjuges no casamento.

Outra questão se colocava no mesmo poema. Se as mãos das escravas seiscentistas apenas executavam preparos escolhidos por uma dona-de-casa com poder de decisão, teriam as escravas da cozinha, nessa época, latitude para inventar quitutes, experimentar receitas e deixar a marca

964 MATOS, G. Op. Cit., Vol. II, p. 307.

965 MATOS, G. Op. Cit., Vol. V, p. 1129. 
de suas preferências pessoais na dieta da população mazomba? A considerar o teor dos versos de Matos, não parece crível, que os colonos ingerissem felizes uma dieta batizada com leite de coco e com azeite-de-dendê.

No estado atual dos conhecimentos, a idéia de uma incorporação progressiva à culinária local de sabores e de técnicas de preparo provenientes de tradições africanas introduzidas pela mão das escravas, parece associada à suposição formulada por estudiosos como Ernani da Silva Bruno e mesmo Câmara Cascudo, de que o processo de integração das três raças formadoras da população brasileira, a mestiçagem cedo iniciada, teria sido acompanhado por uma mescla imediata de hábitos alimentares. A questão, entretanto, requer maiores reflexões.

Analisar o desenrolar do processo social da colonização sem inferir retroativamente, em função de ocorrências posteriores, os parâmetros do sistema alimentar soteropolitano, poderia reservar algumas surpresas interessantes ao estudo da auto-identificação dos colonos. Despojado de postulados a priori, o estilo de vida mazombo celebrado na arte poética de Gregório de Matos parece indicar que o ajustamento luso ao Brasil não ocorreu de forma tranqüila e unilinear, sem idas e vindas.

Que nunca tenha existido uma identidade mazomba claramente definida amplia o escopo da questão, ao permitir discernir nas queixas de Matos o contraste flagrante entre a utopia colonial que ele preconizava e as alterações que os eventos da segunda metade do século XVII produziam na condução da vida econômica e social da capital colonial.

Por outro lado, os elementos de cor local existentes nos versos não deveriam mascarar o fenômeno da integração crescente de uma população de mestiços alforriados, de pequenos comerciantes lusos e de camadas menos favorecidas da população, que parecia preparar os alicerces de uma nova maneira de ser soteropolitana, à sombra e à revelia das elites coloniais.

\section{Os ritmos da vida social soteropolitana}

Retratando Salvador com autoridade de morador nato, letrado, católico e bom conhecedor dos códigos da sociedade mazomba ou dos preceitos medicinais, Gregório de Matos esboçou em 
seus poemas uma descrição instigante sobre os procedimentos cotidianos da vida soteropolitana. Seus versos apimentados evidenciaram o teor das idéias que regiam então a vida social, pois, foi em nome de um estilo de vida nobre, estabelecido após décadas de experiência colonial, que o poeta criticou as mudanças ocorridas nos procedimentos locais durante os trinta anos de sua permanência em Portugal.

Quanto ao abastecimento, ressaltavam algumas diferenças de provimento possível entre áreas urbanas e áreas rurais. Salvador recebia gêneros comestíveis frescos: peixes recém-pescados, reses a serem abatidas ou frutas e hortaliças produzidas no entorno da capital, pois, não havia como obter todo o necessário nos quintais dos moradores. Lavradores de mantimentos secos, farinha, arroz, milho, feijões etc., vinham periodicamente de suas roças situadas no Recôncavo, ou em lugares ainda mais longínquos, carregados de mantimentos que seriam vendidos na cidade. Transportavam-nos em embarcações de pequeno porte destinadas à navegação de cabotagem. Comerciantes, senhores de engenho e outros colonos compravam a farinha de mandioca, seja adquirindo sírios de sete quartas na medida da cidade, que continham uma farinha de melhor qualidade, seja alqueires de farinha transportada solta, cuja qualidade deixava um pouco a desejar.

Diariamente pescadores profissionais vendiam peixes na praia. A carne bovina era comprada em talhos espalhados pela cidade, enquanto que, no Recôncavo, senhores de engenhos, lavradores de canas e produtores de tabaco ou de roças de mantimentos adquiriam reses e abatiam-nas em suas propriedades ou compravam a carne por arrobas (unidades de 15 quilos), em lugar de libras.

Numa cidade que ocultava as mulheres de boa família nas casas onde residiam, atrás de rótulas munidas de urupemas ou de treliças de madeira, e que lhes permitia apenas ir à Igreja ou visitar familiares, transportadas em redes, o provimento alimentar parece ter se deslocado mais facilmente até os lares do que as compradoras até as feiras. As formas do provimento alimentar soteropolitano, nesse aspecto, lembravam muito aquelas registradas no provimento de Olinda e Recife. Comentários incluídos nas memórias de Zacharias Wagener, por exemplo, atestavam a 
semelhança dos procedimentos. O jovem, com efeito foi dispenseiro do conde de Nassau, por algum tempo, e acompanhou de explicações pertinentes o desenho aquarelado de uma: "Molher negra"966 que reproduzia uma tela de Eckhout onde figurava uma escrava carregando uma cesta cheia de frutas:

"As mulheres negras não são de talhe menos esbelto e bem proporcionado que os homens. Nem por isso, todavia, são poupadas, tendo de trabalhar de forma exaustiva nos engenhos e canaviais da mesma maneira que os homens e crianças. Há algumas delas que conhecem bem o dinheiro espanhol e holandês; mandam-nas então os donos à rua, a fim de venderem galinhas, pássaros, peixes secos e toda a sorte de magnificas frutas, tudo bem contado, item por item; quando, porém a negra é descuidada e aceita dinheiro falso ou de pouco valor, de volta a casa, deixa em seguida, de dar a correta conta ao senhor pelas mercadorias, é na mesma hora amarrada e duramente açoitada; por esse motivo, preferem ser empregadas em outros serviços mais penosos a ocuparem-se nessa perigosa mercancia" ${ }^{967}$.

O abastecimento alimentar urbano, soteropolitano, pesquisado se revelou basicamente semelhante aos manejos de abastecimento descritos pelo comerciante brabantino Adriaen Verdonck, num relatório de boas-vindas que ele endereçou aos holandeses, que acabavam de conquistar Recife e Olinda por volta de 1630:

"Ordinariamente vêm a Pernambuco todos os dias, por terra, de distâncias de 1 a 6 milhas, 350 a 400 mouros antes mais do que menos, todos bem carregados com

\footnotetext{
966 Nas memórias do jovem dispenseiro, transparecia efetivamente a intenção de documentar o sistema de distribuição dos víveres em uso na colônia.

967 WAGENER, Zacharias. In TEIXEIRA, Dante M. (Org.). Brasil Holandês: Documentos da Biblioteca universitária de Leiden (Vol. I), O "Thierbuch" e a "autobiografia" de Zaharias Wagener (Vol. II), Os quadros do Weinbergschlösschen"de Hoflössnitz (Vol. III). Rio de Janeiro, Index, Ed. Ilustrada, 1997. pp. 175 a 177.
} Cf. também PAPAVERO, Claude. Dissertação de mestrado. Op. Cit., p. 190. 
comestiveis, a fim de vendê-los para os seus senhores, e isto além dos barcos que diariamente chegam ao Recife, de todos os lugares atrás mencionados e ainda de outros, e que também trazem mantimentos [...]. na minha opinião devia haver na cidade de Pernambuco mais de 800 homens e bem 4000 ou mais mouros e ainda outras tantas mulheres e crianças" $" 968$.

O comerciante detalhava:

“todos os dias vão mais de 200 negros a uma ou duas milhas da cidade só a pegar caranguejos, e voltando à tarde para casa, carregados, vendem-nos todos; havia igualmente aqui cerca de 100 negros que diariamente saiam a pescar no mar, além de muito peixe apanhado na praia com redes e de uma grande barca de pesca que ia até 4 a 5 milhas e sempre voltava carregada"969.

A capital do Brasil alçada ao topo da colina, por medida de defesa local e ajustada livremente à superfície acidentada do território, ostentava outras dimensões que Olinda. Por volta de 1700, segundo o historiador Stuart B. Schwartz ${ }^{970}$, Salvador constituía o maior entreposto marítimo da colônia. Já contava 40000 habitantes, somente na parte urbana e se estendia simultaneamente nas alturas e ao longo da praia.

Segundo o arquiteto Nestor Goulart Reis ${ }^{971}$, Salvador se apresentava na época, como um aglomerado urbano construído em sua parte central segundo um plano razoavelmente 968 VERDONCK, Adriano. Descrição das capitanias de Pernambuco, Itamaracá, Paraíba e Rio Grande. In MELLO, J.A. Gonsalves de. Fontes para a História do Brasil holandês: $\mathrm{n}^{\circ} 1$ - A economia açucareira. Recife, Parque Histórico Nacional dos Guararapes/ MEC./SPHAN./Fundação Pró-memória, 1981.

969 VERDONCK, Adriano. Op. Cit.

970 SCHWARTZ, Stuart B. Segredos internos: engenhos e escravos na sociedade colônia 1550 - 1835. São Paulo, Companhia das Letras, 1999. ou Op. Cit., pp . 85 e 193.

971 REIS Filho, Nestor Goulart. Evolução urbana do Brasil (1500-1720). São Paulo, Pioneira,EDUSP, 1968. Capítulo II, A organização espacial dos centros urbanos. 
quadriculado sobre um outeiro protetor, sito às margens do melhor ancoradouro da costa brasileira para abrigar frotas de guerra ou de comércio. Por volta de 1682, as casas começaram a extravasar o perímetro murado da cidade, expandindo-se para fora das portas. Estendiam-se ao sul em direção ao convento do Carmo e, ao norte, prolongava-se para além do mosteiro de São Bento. Também começavam a empurrar ladeiras abaixo, em direção à praia, enxames de mocambos e sobrados dotados de uma loja no térreo e da residência de moradores no andar.

Amadeu Frezier, viajante francês, cujo navio fez escala em Salvador, em 1714, durante seu regresso à Europa após uma viagem às costas do Chile e do Peru, ficou impressionado pela topografia ingrata da Cidade da Bahia, como a capital era chamada "na língua do país" e criticou a solução imaginada pelos colonos para paliar a tais inconvenientes:

"El plano de la ciudad alta está trazado con todo el rigor que ha podido permitir la desigualdad de un terreno montuoso; pero aunque las calles están bien alineadas y tienen buen ancho, la mayoría adolece de una pendiente tan pronunciada, que serian impraticables para las carrozas y hasta para nuestras sillas de manos". La gente rica, pese a este inconveniente, no va a pie; siempre industriosa para hallar la manera de distinguirse del resto de los hombres, tanto en América como en Europa, se habrían avergonzado de servirse de las piernas que la naturaleza nos ha dado para caminar: se hace transportar cómodamente en lechos de red de algodón, suspendidos de sus extremos a una gran vara que dos negros llevan sobre la cabeza o sobre los hombros... Y a fin de estar ocultos y de que la lluvia o el ardor do sol no les incomode, ese lecho está cubierto por una imperial de onde cuelgan cortinas que se corren cuando se quiere"972.

Muitas moradias urbanas pertenciam a grandes proprietários rurais, que passavam a maior parte do ano em seus canaviais e seus engenhos do Recôncavo e que somente freqüentavam a 
capital por ocasião de cerimônias festivas ou quando, eleitos vereadores da Câmara Municipal, eram chamados a desempenhar funções públicas honoríficas. As residências dos colonos, sem respeitar os arruamentos, invadiam o espaço das ruas com balcões sobressalentes que dificultavam a circulação dos transeuntes.

A ocupação um pouco desleixada do solo não indicava o desconhecimento dos padrões arquiteturais renascentistas europeus. As autoridades coloniais fechavam os olhos a eventuais apropriações particulares de espaços públicos. O depoimento de Matos confirmava ao leitor, todavia, a fragilidade das condições do resguardo feminino, na descrição de sua visita à amásia de um mercador inglês:

"Ia eu por certo bairro /... Eis que em frente de uma porta,/que sua urupema tem,/ ouvimos um ruge-ruge/de um guarda pé /... Palavras não eram ditas, quando eu logo a quatro pés/me emboquei pela urupema,/tomei venia e me sentei/... Entrou uma linda moça, que mora logo através,/pela porta do quintal..."973.

O poeta, como já constatado, não gostava muito da vida em Salvador. Os olhares maldosos dos vizinhos sobre seu cotidiano incomodavam-no e também a inveja de sacerdotes ignaros, que desejavam ser considerados finos letrados. A ignorância ou a má-fé dos desembargadores da Relação facilmente corrompidos o enraiveciam. Quanto às negociatas duvidosas de comerciantes desonestos, elas o irritavam profundamente. Sua experiência de advogado soteropolitano parece ter sido penosa. É possível reparar, na obra do autor, um curioso escamoteamento dos trajetos urbanos. Ao falar da Cidade, Matos chegava sobretudo ao destino: "fui Babu à vossa casa"974, "fui hoje ao campo da Palma"975. Raramente lhe ocorreram estrofes como:

\footnotetext{
973 MATOS, G. Op. Cit., Vol.V, pp. 1042 e 1043.

974 MATOS, G. Op. Cit., Vol. III, p. 760.

975 MATOS, G. Op. Cit., Vol.III, p. 770.
} 
"Mulatinhas da Bahia,/que tôda noite em bolandas/correis ruas, e quitandas/ sempre em perpétua folia/porque andais nesta porfia/com quem de vosso amor zomba?"976.

O poeta não deixou de palmilhar os logradouros da cidade. Apreciava as festas de mulatas que celebravam santos de sua devoção, ou bailavam o paturi na ladeira da Água Brusca. Entretanto, em vários momentos, ele escolheu se refugiar da curiosidade alheia em arrabaldes mais amenos.

Em Salvador, Reis descreveu as ladeiras utilizadas diariamente pelos carregadores. Situados junto às encostas escarpadas do outeiro, entre a praia e a parte murada da capital, existiam dois grandes guindastes (que não foram citados nos poemas de Gregório de Matos). Eles permitiam içar mercadorias da cidade baixa até as duas praças centrais mais representativas da vida colonial. Escravos, obviamente, operavam-nos (teria existido, ao que parece, um terceiro guindaste, pertencente ao avô do poeta).

Efetivamente, a presença dos escravos dispensava a população colonial abastada de trabalhar com as próprias mãos (atitude considerada pouco nobre), ou de atravessar com as próprias pernas uma cidade, cujas ruas não primavam pela limpeza e na qual dominavam aclives e declives e um forte desnível entre cidade alta e cidade baixa, que complicava a vida cotidiana. Havia a qualquer hora uma multidão de escravos circulando no espaço urbano. Alguns, encarregados de prover água às casas, buscavam-na nas fontes mais próximas. Indicadas expressamente nos mapas da época, eram marcos importantes da vida urbana. As Atas da Câmara Municipal registravam as dissensões e quebras de vasilhas ocorridas nas brigas entre escravos causadas pelas filas formadas em torno de bicas insuficientes para atenderem uma população em franca expansão demográfica. Outros cativos ocupavam-se em descartar os dejetos domésticos, outros ainda transportavam pessoas abastadas em suas redes, carregavam mercadorias ou guiavam carros de bois ladeiras acima ou ladeiras abaixo.

976 MATOS, G. Op. Cit., Vol. V, p. 1247. Segundo o Diccionário Moraes: Em bolandas: “a toda pressa”. 
Salvador, a Cidade da Bahia era efetivamente um lugar no qual as cadeias operatórias do fazer urbano e as técnicas da vida cotidiana repousavam quase que inteiramente nos corpos de seus cativos. A presença maciça dos carregadores marcava a paisagem: "porque no pôrto claro é,/que lhe ficava um guinélcarregando mantimento"977.

Negras de ganho providas de cestas com gêneros comestíveis circulavam também pelas ruas ou vendiam comidas e doces caseiros, atividade que assegurava, por vezes, o sustento de famílias de boa estirpe ou a sobrevivência de viúvas sem arrimo financeiro, proibidas pelos usos coloniais de manter contatos ostensivos com as ruas: "Que o falar da janela, e da varanda,/só se achará em putas de quitanda"978.

A aparição em Salvador, ao final do período seiscentista, de um pequeno comércio e de ofícios mecânicos a serviço da população urbana parece ter estimulado a prosperidade local. Nestor Goulart Reis Filho, assinalou a instalação na cidade de muitos mercadores, os emigrantes recentes que Matos chamava os "mercadores ratinhos", ora alcunhados desdenhosamente como "vendelhões com tendas", ora como "sota-tendeiros" tornados comissários. Segundo Reis:

"Pode se dizer que, até meados do século XVII as atividades econômicas urbanas não foram suficientemente produtivas para adquirirem uma dinâmica própria. Até então apenas o comércio importador e exportador apresentava alguma vitalidade, mesmo assim concentrada em alguns pontos, mais especialmente Salvador. Foi somente depois dessa época, e por influência de condições exteriores, que ocorreram alterações estruturais, permitindo a consolidação da economia urbana e provocando o aparecimento de camadas sociais urbanas, com características urbanas: o comércio de maior vulto, os ofícios mecânicos e o pequeno comércio"979.

977 MATOS, G. Op. Cit., Vol. VI, p. 1294.

978 MATOS, G. Op. Cit., Vol. V, p. 1168.

979 REIS F., Nestor Goulart. Op. Cit., p. 50. 
A relevância da expansão urbana em Salvador, no entanto, foge ao escopo dessa tese.

As necessidades alimentares da população soteropolitana criaram oportunidades de trabalho para diversos profissionais. Os versos de Matos acusavam a presença de homens e de mulheres que, no espaço urbano, viviam de preparar e vender iguarias, tais como as confeiteiras ${ }^{980}$, as padeiras ou os pasteleiros ${ }^{981}$. Em alguns casos os preparos culinários que comercializavam requeriam alguma especialização técnica ou a posse de um forno. Nas ruas tolos que não entojavam ${ }^{982}$ manjares como os avarentos, aliviavam suas bolsas comprando bolos e bolinholos". Os poemas de Matos indicavam também a presença em Salvador de um certo número de taverneiros ${ }^{983}$ que vendiam vinhos e aguardentes a retalho, atividade socialmente pouco valorizada, porém, tão próspera quanto vigiada para evitar adulterações indesejáveis do produto vendido: "se em taverna não bebemos,/ao menos folgamos nela"984.

A descrição de Salvador apresentada por Reis permite imaginar o aspecto da cidade seiscentista. Na parte baixa, junto à praia, localizava-se a Ribeira das naus: isto é, o porto, lugar de embarques e desembarques (onde os versos de Gregório de Matos situavam a chegada das pessoas influentes governadores-gerais e bispos). Havia também o cais onde os pescadores atracavam, improvisando uma feira à beira-mar, ao lado da igreja da Conceição, para vender seu peixe. Destacavam-se ainda os trapiches, onde armazenavam-se as mercadorias, o prédio da Alfândega e as fortificações que defendiam a cidade (porém não mereceram nenhum comentário do poeta).

Outros estudiosos como o historiador Marins ${ }^{985}$ descreveram as casas das primeiras décadas setecentistas semelhantes àquelas que Gregório de Matos freqüentou. As casas invadiam as ruas

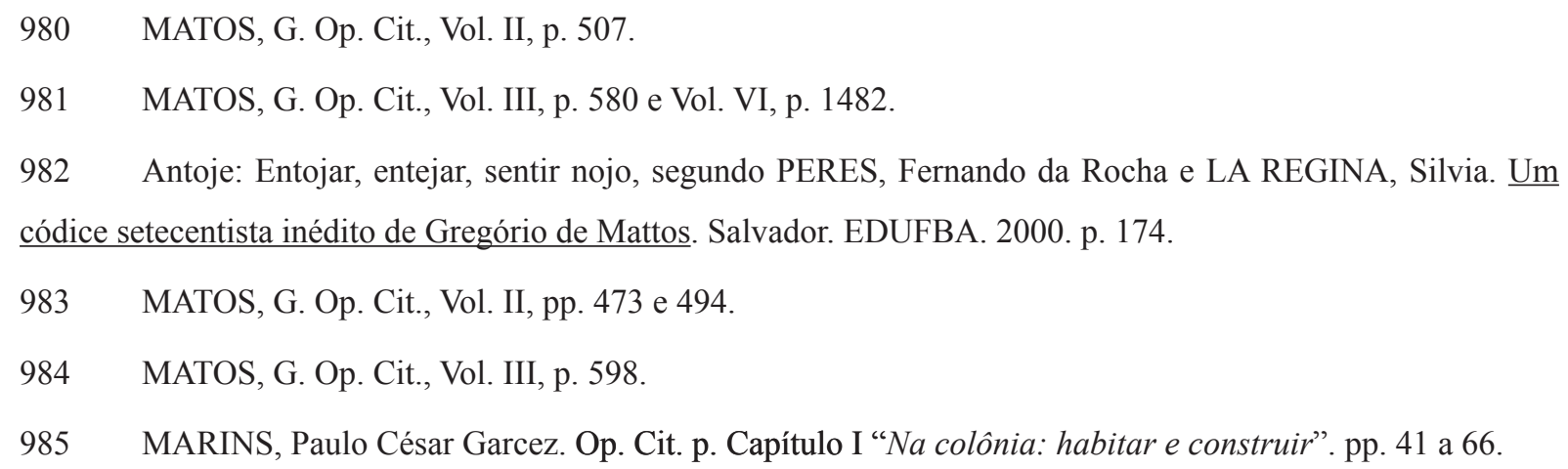


com portas que abriam para fora e balcões salientes dotados de rótulas cobertas de treliças de madeira ou de fibras trançadas (as urupemas), equipamentos que permitiam arejá-las, diminuindo os excessos da luminosidade tropical e resguardando a privacidade do lar. Durante o período pombalino, em fins do século XVIII, as autoridades proibiram essas rótulas, não somente por razões estéticas (a colônia prolongava a imagem de uma metrópole, que, após o terremoto de Lisboa, passava por uma reformulação urbana), mas porque facilitavam a comunicação entre os moradores das casas e os passantes, facilitando eventualmente a realização de emboscadas.

Os logradouros públicos citados com maior freqüência nos textos de Gregório de Matos foram aqueles que Reis e Marins, afirmavam possuir maior visibilidade: o Paço e o Terreiro de Jesus. No Paço se encontravam os edifícios da representação política e econômica: o Palácio do governo e a Câmara (que no térreo abrigava o espaço da cadeia). No entorno do Terreiro localizavam-se os principais edifícios da vida religiosa: a Catedral, o convento dos Jesuítas onde os jovens estudavam, a Santa Casa da Misericórdia etc.. Reis indicou complementarmente que um número relevante de igrejas dividia a cidade em paróquias. Ali registravam-se nascimentos, casamentos e óbitos. Elas congregavam moradores da redondeza, permitindo ao clero controlar o cumprimento das obrigações religiosas e, à administração colonial cobrar contribuições para tarefas públicas. As paróquias abrigavam irmandades de maior ou menor prestígio social e constituíam unidades territoriais de sociabilidade e de fé. Reuniam um público de ambos os sexos, sendo um dos raros destinos de passeio permitido às mulheres de boa família. Arrecadavam-se ali fundos para socorrer os pobres ou para festejar os dias santos.

As praças principais da cidade constituíam marcos de gestão urbana planejada, sendo que o conjunto imponente dos edifícios realçava o papel de cada um deles, a Igreja e o Estado cooperando no espaço físico, assim como as autoridades civis e as autoridades eclesiásticas se uniam no plano ideal para manter um certo controle sobre a vida colonial.

Por serem espaçosas e capazes de conter muitos colonos, animais e mercadorias, essas praças representativas do poder colonial constituíam locais adequados para os 
anúncios feitos à população, as comemorações festivas, as feiras e os espetáculos de enforcamento. Ali aconteciam as reuniões civis e realizavam-se os torneios de destreza em dias santificados. Cavaleiros montados corriam touros, arrebatavam argolas, cortavam canas no ar e procuravam merecer patos e carneiros oferecidos como prêmios ${ }^{986}$. Era para essas praças também que carregadores de mercadorias e negras de ganho convergiam os passos, sob o olhar atento dos almotacés.

Numa cidade vigiada pelas confissões ao clero, onde se acreditava que os malfeitos de indivíduos privados tinham o poder de atrair a ira divina sobre toda a comunidade e onde, em 1686, os castigos prenunciados pela aparição de um cometa davam asas às fofocas, não espanta o modo consistente como o domínio público se apoderava dos recatos da vida privada.

Nos arrabaldes imediatos da cidade, Reis tampouco deixou de citar a proliferação de chácaras de recreio junto ao dique que protegia a parte interiorana da cidade. Eram residências provavelmente semelhantes àquela que Gregório de Matos adquiriu e onde ele imaginou poder desfrutar por muitos anos de uma existência bucólica:

"Por bem afortunado/Me tenho nestes dias,/Em que habito este monte a par do Dique,/Vizinho tão chegado às taraíras frias,/A quem a gula quer que eu me dedique" 987.

\section{Os ritmos da vida rural nas freguesias do Recôncavo}

A freqüência das reuniões sociais e a descrição de comilanças festivas, evidenciavam o fato da colônia não constituir apenas um lugar onde se produzia açúcar, mas sobretudo um lugar onde portugueses enriquecidos pelas atividades agropecuárias exportavam açúcar, tabaco, couros ou

986 DEL PRIORE, Mary Lucy. Op. Cit., pp. 60 a 62.

987 MATOS, G. Op. Cit., Vol. V, p. 1221. 
algodão e procuravam viver em ócio, conforto e alegria, às custas do trabalho compulsório dos escravos.

Matos parecia apreciar particularmente a paz da vida bucólica. Pertencia, contudo, a um amplo círculo social, sendo freqüentemente convidado a participar dos prazeres da boa sociedade soteropolitana. A região do Rio Vermelho ${ }^{988}$ ao norte da cidade, e a área do Dique 989 do Tororó, nos subúrbios interioranos da Capital, foram destinos de excursões memoráveis e fontes inesgotáveis de versos inspirados. A Praia Grande ${ }^{990}$, nas imediações urbanas lhe serviu de refúgio (em 1684 ou 1685), quando ele se distanciou dos problemas que lhe valeram a oposição ao governador Braço de Prata.

Após o casamento com Maria de Povos, Matos adquiriu uma casinha justamente na região do Dique do Tororó. João de Lencastre, cunhado do governador Câmara Coutinho, vindo de Angola, se queixou de não receber uma visita de cortesia do poeta no palácio. Matos versejou então um pedido de desculpas no qual afirmava não freqüentar o palácio e se encontrar refugiado nos campos:

"Estou na minha quintinha,/que é chácara soberana,/ora comendo a banana,/ jogando ora a laranjinha:/nem vizinho nem vizinha/tenho, porque sempre cansa/quem vê tudo, e nada alcança,/e na cidade são raros/os olhos que não são claros,/se olhos são de vizinhança" ${ }^{991}$.

Após ofender o governador Câmara Coutinho com versos insultuosos, Gregório de Matos parece ter se tornado um hóspede assíduo nas duas principais freguesias do Recôncavo, as vilas de Madre de Deus, na ilha do mesmo nome, e a vila de São Francisco (hoje São Francisco do Conde), situadas ambas na região dos ricos e friáveis solos de massapé, tão 988 MATOS, G. Op. Cit., Vol. III, pp. 583 a 589, Vol. V, pp. 1270 e 1271.

989 MATOS, G. Op. Cit., Vol. III, 590a 592, Vol. V, pp. 1221 e 1222, 1270 e 1271.

990 MATOS, G. Op. Cit., Vol. I, p. 170 e pp. 418 a 420.

991 MATOS, G. Op. Cit., Vol. I, p. 192. 
propícios às canas. O Sítio da Catala ${ }^{992}$ e os engenhos de Caípe, de Marapé, de Pernamirim, mas sobretudo aquele da Cajaiba, na margem do rio Serigi-mirim, em ilha fronteiriça ao povoado de São Francisco, serviram de cenário a inúmeros poemas encomiásticos ou burlescos do autor. O vigário da Madre de Deus ${ }^{993}$ era amigo pessoal do autor, entretanto, foi sobretudo na vila de São Francisco ${ }^{994}$ que o poeta parece ter residido por longos períodos de tempo. Um exame atento dos poemas delineia os contornos impressionantes da vida regalada que os mazombos costumavam levar nas grandes propriedades rurais do Recôncavo. Em ambiente rural, seja no fundo do Recôncavo, seja na ilha de Itaparica, ou no rio Vermelho, Matos celebrou seus amores, os prazeres do campo, as mesas fartas e a poesia das varandas:

"O largo e fresco passeio me lembra da varandinha, onde se representavam/as comédias do Faísca".

"Outro vem, quando basta,/Fazer nesta varanda/Chacotas e risadas,/Porque o riso não corre na quitanda"995.

Foi provavelmente ali que Matos, além de jogar cartas, de participar de caçadas, de fugir diante da ira de uma vaca brava, de tanger sua viola e de cantar, recitou poemas semelhantes àquele que introduziu o primeiro capítulo. Em São Francisco ele se encontrava especialmente à vontade:

992 MATOS, G. Op. Cit., Vol. III, p. 618,Vol. V, p. 1278, Vol. VI, pp. 1506 a 1512.

993 MATOS, G. Op. Cit., Vol. I, pp. 42, 60, 300 e 301, 303 a 305, 326 a 330, 351, Vol. III, pp. 516 a 565,599 a 603, Vol. VI, pp. 1517 e 1518.

994 MATOS, G. Op. Cit., Vol. I, pp. 243, 244 a 248, 268 a 270, 271a 276, Vol. II, pp. 316 a 318, 378 e 379, Vol. III, pp. 568/ 577 - 593 a 598,Vol. V, pp. 1066 a 1070, Vol. VI, pp. 1382 a 1386, 1393, 1400, 1404, 1408 e 1409 , 1428 e 1429, 1464,1475 a 1477, 1481 a 1484,1485 e 1486. 
"Há cousa como estar em São Francisco,/Onde vamos ao pasto a tomar fresco,/ Passam as negras fala-se burlesco,/Fretam-se tôdas, tôdas caem no visco./O peixe roda aqui, ferve o marisco,/come-se ao grave, bebe-se ao tudesco,/Vêm barcos da cidade com o refresco,/Há já tanto biscouto como cisco" $" 996$.

Afigurava-se enorme a importância das atividades da pesca e do mariscar na região do Recôncavo. O provimento em peixes e frutos do mar, mostrava-se especialmente farto e saboroso $^{997}$. Pouco tempo decorria entre a captura dos animais e sua cocção na panela. Cada engenho contava com pessoas encarregadas de prover tais alimentos à comunidade. Aos servos cabia a tarefa de pescar, seja com redes, seja com linhas, enquanto que às negrinhas cativas reservava-se a obrigação de mariscar, um serviço de monturo como afirmou Matos num poema no qual cortejou Maria João. De volta aos engenhos, a repartição do conteúdo dos cestos respeitava regras de precedência:

"Já tenho dito a Marana,/que na casa onde habita,/se dê muito a respeitar/com as negras da cozinha,/Se lhe entra por um ouvido,/sai pelo outro: é menina,/o que faz, é andar folgando/co Cabra Vicente, e Chica./Com que lhe não tem respeito,/ e se ela toma farinha/para mandar a esta casa,/qualquer negrinho lhe grita./ Tenho lhe dito Marana, do peixe da pescaria/o melhor à vossa Mãe,/que assim faz a boa Filha./Em vindo as mariscadeiras/do mangue carregadinhas,/ninguém meta a mão nos Cestos,/que os melhores são de Quita./Remetei-os logo ao Sítio,/ e fique embora vazia/a casa de vosso amigo,/porque primeiro está a minha./Se

996 MATOS, G. Op. Cit., Vol. VI, p. 1400.

997 Durante uma semana de pesquisa de campo, em São Francisco do Conde, calorosamente acolhida pelos letrados, que hoje habitam os domínios de Gregório de Matos, foi possível perceber que a profusão de nomes de lugarejos dos tempos coloniais encontrada nos poemas, se concentrava efetivamente num raio de cerca de vinte quilômetros da cidade. Cachoeira e a Saubara situavam-se do outro lado da baía, em área de solos menos nobre que a região canavieira. 
lá tendes nessa casa/dez hóspedes cada dia,/cá tendes vossas irmãs,/vossa Mãe, vossas Sobrinhas" ${ }^{\prime 998}$.

Tornada amásia de um fidalgo, a jovem Marana alçou-se à posição de respeito na Cajaíba. Matos, porém, não deixou de ironizar o irmão da moça, Mandu caraça, rapaz encarregado de prover peixes ao engenho: "ninguém me verá jamais/sobre a proa em ceroulinhas/desonrando tais Irmãs"999.

Nas áreas rurais, se a pesca constituía atividade reservada a subalternos, a caça fazia figura de esporte nobre e os colonos abastados da área urbana (nunca muito distante dos campos) também se distraíam ao praticar seus talentos cinegéticos. Matos, satirizando as pretensões à nobreza de plebeus enriquecidos aconselhava ironicamente:

"Seja um magano, um pícaro abelhudo,/Vá a palácio, e após das cortesias/perca quanto ganhar nas mercancias, /e em que perca o alheio, esteja mudo./Sempre se ande na caça e montaria" 1000 .

Acaça com auxílio de cães, enquanto atividade esportiva e social, provia carnes apreciadas aos moradores. No cotidiano mazombo, os colonos restritos em sua movimentação pelo hábito de contarem com o trabalho braçal de escravos e pelo receio de parecer praticarem atividades plebéias, apreciavam muito os exercícios físicos, que lhes permitiam demonstrar sua destreza, como o malabarismo (jogar a laranjinha) ou a caça. No relato de uma disputa entre duas mulheres da Cajaiba, Matos aludiu de passagem a uma caçada aos tatus:

"Se é certo, que o General/em tal conflito roncou/é, que a prima noute andou/ visitando o arraial:/como por todo o arrebal/andou qual Jacurutu,/a espera de um Tatu,/que do laço lhe escapou,/com pé leve se deitou,/dormiu com pesado cu"1001.
998 MATOS, G. Op. Cit., Vol. VI, p. 1526.
999 MATOS, G. Op. Cit., Vol. V, p. 1282.
1000 MATOS, G. Op. Cit., Vol. IV, p. 838.
1001 MATOS, G. Op. Cit., Vol. V, p. 1125. 
A cidade e o campo, colonizados simultaneamente pelos portugueses, cresceram juntos e trocavam produtos, a despeito de problemas periódicos na rentabilidade do açúcar. Colonos rurais e citadinos confraternizavam de muitas formas. Sacerdotes iam e vinham. Mercadores propunham gêneros alimentares vindos de Portugal e levavam víveres frescos ou mantimentos do Recôncavo. Por falta de estradas praticáveis, a maior parte dos deslocamentos se efetuava por barcos de cabotagem. Escravos carregadores e barqueiros livres, como o ex-grumete do navio $^{1002}$ no qual Matos voltou ao Brasil, eram personagens indispensáveis no panorama da vida colonial:

"Fomos, e dobrando o mangue/encontramos um banquete,/em que vem Miguel Ferreira/cercado de muita gente./Allons, allons, lhe dissemos, /e êle nos disse: salvete,/trespassamos o saveiro,/que ia vendendo azeite"1003.

É curioso que, quase mudo ao tratar do espaço urbano atravessado, pondo o pé fora da cidade Matos desse tanta relevância aos deslocamentos. Nos passeios de seu lazer ("indo aos cajus" ou ao rio Vermelho), na casa dos amigos, nas vilas, nas ilhas ou nos engenhos do continente, o passo a passo da viagem recuperava significado. De barco, de rede ou montado em algum rocim, o autor compôs versos que expunham os vínculos sociais e os percalços do convívio mazombo.

Assim, em ocasiões festivas comia-se "a tripa forra"1004, também ria-se às canadas (bebia-se muito), como no batizado regado a vinho e chuva de Quitota, filha do Vanique em Marapé1005. Versejando sua despedida do engenho de Pernamerim ${ }^{1006}$, montado num cavalo chamado Tainha, o poeta dizia morrer de saudade e se queixava de não ter seduzido a formosa Catona:

1002 MATOS, G. Op. Cit., Vol. VI, p. 1530.

1003 MATOS, G. Op. Cit., Vol. III, p. 608.

1004 MATOS, G. Op. Cit., Vol. V, p. 1230.

1005 MATOS, G. Op. Cit., Vol. VI, pp.1536 a 1540.

Hoje, curiosamente, existe nos arredores de Marapé uma localidade chamada Vanique.

1006 Trata-se da localidade atual de Paramirim sita a cerca de 7 ou 8 quilômetros de São Francisco do Conde. 
“Adeus, meu Pernamerim,/que me vou sôbre o Tainha/engasgado em crueldades,/ espinhando em tiranias./[...] Adeus, Catona bizarra,/adeus gente da cozinha,/adeus putíssima Samba, e honestíssima Luzia./ [...] Adeus, ó fresca varanda, onde joga a rapazia/castanhas com mil trapaças,/e trapaças com mil brigas./Adeus Maria Pereira,/que sempre à mesa assistias/diligentemente alegre/co'a comida e co'a bebida./Adeus Brites gavachona,/que inda que sois concubina/do Gabriel, que vos sangra, nunca vos deixa ferida./Adeus terras agradáveis/cheias de canas tão ricas,/ que estão dizendo, comei-me,/a quem passa, a quem caminha"1007.

\section{A hospitalidade mazomba e seus problemas sociais}

Numa sociedade ciosa de ostentar riquezas, prestígio e generosidade, a importância das normas de hospitalidade foi item imprescindível na elaboração de uma auto-definição pessoal dos colonos. Na área urbana, segundo Antonil, era possível encontrar alojamentos pagos. Mas na área rural, doada por sesmaria a homens possuidores de cabedais, o espaçamento entre propriedades, respeitado para evitar que os engenhos competissem por suprimentos de lenha ou pelo direito de processar a cana dos lavradores livres de moê-las onde quisessem, resultara numa ausência de estalagens. Aos senhores de engenho e aos grandes proprietários de terras, cabia, por conseguinte, a obrigação moral, cristã, de acolher condignamente visitantes de passagem, oferecendo-lhes abrigo e refeições.

Segundo Antonil, jesuíta toscano que descreveu a manufatura açucareira no Engenho de Sergipe do Conde (situado nos arredores de Santo Amaro):

“A hospitalidade é uma ação cortês, e, também, virtude cristã, e no Brasil muito exercitada e louvada; porque, faltando fora da cidade as estalagens, vão necessariamente os passageiros a dar consigo nos engenhos, e todos ordinariamente

1007 MATOS, G. Op. Cit., Vol. VI, pp. 1406 e 1407. 
acham de graça o que em outras terras custa dinheiro; assim os religiosos que buscam suas esmolas, que não são poucos, e os missionários que vão pelo Recôncavo e pela terra dentro com grande proveito das almas, a exercitar seus ministérios, como os seculares que, ou por necessidade ou por conhecimento particular, ou por parentes, buscam de caminho agasalho" ${ }^{1008}$.

O padre enfatizava, entretanto:

"O tratamento não há de exceder o estado das pessoas que se recebem, porque no discurso do ano são muitas. A criação miúda, ou alguns peixes do mar ou rio vizinho, com algum marisco dos mangues e o que dá o mesmo engenho para doce, basta para que ninguém se possa queixar com razão. Avançar-se a mais (salvo num caso particular por justos respeitos) é passar dos limites e impossibilitar-se a poder continuar igualmente pelo tempo futuro" ${ }^{1009}$.

Quando o visitante era personagem importante, ou quando a ocasião comemorada, festividade do calendário religioso, batizado ou reunião de amigos, impunha celebração, a etiqueta exigia que os hóspedes fossem homenageados com lautos banquetes regados a bebidas alcoólicas, vinhos ou aguardentes, importadas do reino ou das ilhas atlânticas como as Canárias ou a Madeira ${ }^{1010}$. Contudo, segundo afirmou Núñez, exceder-se nas libações era

\footnotetext{
1008 ANTONIL. Op. Cit., p. 167.

1009 ANTONIL. Op. Cit., p. 167.

1010 MAURO, Frédéric. Portugal, o Brasil e o Atlântico. 1570 - 1670. 2 vol., Lisboa, Imprensa Universitária /Editorial Estampa, 1989. Vol. II, pp. 79 a 94.
} 
conduta especialmente mal vista em território ibérico ${ }^{1011}$.

As festas religiosas, sobretudo, propiciavam oportunidades para uma sociabilidade intensa. Promoviam-se cavalhadas, cantos, recitações, "comédias e comedias"1012. Não foram somente intenções satíricas que presidiram à versificação. Matos enfatizou seguidamente as alegrias de um estilo de vida ao qual a fartura alimentar conferia interesse e defendeu os hábitos de hospitalidade mazomba formalizados entre 1580 e 1624, na capitania real. Beber vinho nessas ocasiões sublinhava então a existência de vínculos da sociabilidade. Corria numa grande parte da obra uma veia burlesca e quase amena, apesar de um tanto irônica, como nos versos narrando as circunstâncias de uma festa de batizado, em Marapé, durante a qual choveu muito ${ }^{1013}$.

No engenho de Pernamirim, por exemplo, onde Matos, Tomás Brandão Pinto e outro amigo chegaram a bordo de uma canoa, os visitantes foram lautamente banqueteados:

“chegamos ao porto enfim,/e fomos com tal grandeza/banqueteados na empresa,/ que eu cri, quando isto passava,/que o homem nos esperava/ao Canto, porém da mesa .// Tal ano, e tal abastança,/tanto dispêndio em tal era,/bem mostra, que

1011 MOTT, Luiz. "In vino veritas: vinho e aguardente no cotidiano dos sodomitas luso brasileiros à época da Inquisição", in Álcool e drogas na História do Brasil. VENÂNCIO, Renato Pinto e CARNEIRO,

Henrique, São Paulo/Belo Horizonte, PUC. Minas/Alameda, 2005.

"São diversas as referências ao consumo de vinho e aguardente nos processos dos sodomitas luso-brasileiros presos pela Inquisição portuguesa. Seja como ingrediente constante nas refeições ou merendas mantidas antes ou depois da consumação de atos homoeróticos, quer na residência de um dos amantes quer em tabernas, ao ar livre ou em tascas públicas, seja apontado como álibi diariamente lembrado com vistas a excluir ou atenuar a culpabilidade dos réus na prática do "abominável e nefando pecado de sodomia". p. 47.

NúÑEZ, Rafael Florêncio. Op. Cit., p.75.

1012 MATOS, G. Op. Cit., Vol. III, pp. 590 a 592.

1013 MATOS, G. Op. Cit., Vol. VI, p. 1536.

"Choveu tanto ao Domingo em tal maneira,/Que cada qual Monsiur indo uma brasa/Ficou aguado o gôsto e o vinho aguado./Porque não quer a Virgem da Oliveira,/Que lhe entrasse pagão na sua Casa/Vinho que nunca fôra batizado". 
estava à espera/todo armado de papança:/investidos com pujança,le com valor assaltados/de uns pratos bem reforçados,/que havíamos de fazer?/foi-nos forçoso morrer/a puros saca bocados"1014.

Hóspedes de prestígio social também costumavam ser municiados de víveres antes de seguirem caminho. Gregório de Matos, ao receber em seu retiro da Praia Grande a visita do Desembargador Pedro de Unhão Castelbranco, então Provedor dos Ausentes e da Santa Casa, não permitiu que o magistrado seguisse viagem sem levar uma matalotagem substancial de gêneros (provavelmente importados), elegantemente acompanhados de um poema encomiástico:

"Atrevido êste criado/apresenta à companhia/limitada ninharia/para tão grande senado:/isto vai por desenfado,/e ter, em que se entreter,/quem saiu a espairecer,/e não há que reparar,qque quem anda pelo mar/há de ter, em que esmoer. // Quem caminha, ou faz viagem,/nunca se pode enfadar/do pôrto, que vai buscar/se leva matalotagem:/e inda que tenha estalagem,/bem é que vá prevenido/do bom presunto cozido,/paio, queijo, e salsichão,/porque tudo na ocasião/serve para o indivíduo" ${ }^{1015}$.

A relevância desse aprovisionamento não podia ser subestimada, como assinalava Matos ao compor um poema sobre o caso de um cabrito roubado e assado por um frade:

"foi o caso, que um verão/tratando o frade maldito/de ir da cidade ao distrito,/ querendo a cabra levar,/para mais a assegurar,/embarcou logo o cabrito. // [...]/Do mé desaparecido/foi logo o dono avisado, /que o Frade lhe havia achado, antes dêle

1014 MATOS, G. Op. Cit., Vol. VI, p. 1487.

1015 MATOS, G. Op. Cit., Vol. II, p. 420. 
o haver perdido:/e sendo o sítio corrido, se achou, que a modo de pá/num forno o cabrito está,/que o Frade é destro ladrão,/porém nesta ocasião/saiu-lhe a fornada $m a ́ " 1016$.

Por outro lado, como visto anteriormente, as excursões de verão aos arredores da cidade e sobretudo as idas aos cajus, receberam grande destaque na obra de Matos. Propiciavam descrições burlescas cheias de duplos sentidos. Em tais expedições o cardápio embarcado era simples, semelhante talvez àquele dos indígenas que, em tempos pré-cabralinos, apreciavam muito a estação dos cajus:

"O alforje lá me esquecia,/disse eu, e a vocês lhe esquece:/mandei logo um negro à casa,/que fosse num pé, e viesse./Veio logo carregado/o negro com uma serpe de bananas e farinha..."1017.

Porém, não era necessário esperar a estação dos cajus para organizar passeios. Na ilha de Gonçalo Dias, por exemplo, a filha dos proprietários acolheu certa vez o poeta com requintes de fidalguia:

"Deu-me a rapariga uns sonhos/tão ricos como ela própria,/sonhava em me
regalar:/não foi mentira, o que sonha./Visitou-me sua Avó,/que é mui honrada
pessoa,/só quem tem honra, dá honra./Assim o façam meus Filhos,/como então o
fez Macota"1018.

Foram sonhos também que Gregório de Matos recebeu de outra moça, em agradecimento por um poema escrito em sua defesa. Amásia de um pedreiro, que a espancava, a jovem decidiu

\footnotetext{
1016 MATOS, G. Op. Cit., Vol. II, pp. 324 e 325.

1017 MATOS, G. Op. Cit., Vol. III, p. 608.

1018 MATOS, G. Op. Cit., Vol. VI, p. 1521.
} 
trocar o brutamonte por um homem de bem e Matos escreveu um poema para celebrar o acontecimento $^{1019}$. Tempos depois, um barco da Guaíba carregado de sonhos deliciosos chegou à Cajaíba, onde o poeta se encontrava então, aparentemente em quantidades tais que todas as pessoas presentes ganharam seu bocado. Pedro Calmon, aliás confundiu os dois episódios atribuindo à Macota o presente de sonhos da outra jovem ${ }^{1020}$.

"Veio a frota da Guaíba,/entrou, e tomando terra,/achou duas naus de guerra/de comboio té a Cajaiba:/estava eu vendo de riba/o Serigipe famoso, /quando vi com vento airoso/vir entrando pela barra/por cabo Inácio Pissarra,/e por fiscal João Cardoso.// [...] Partiu-se o doce excelente,/em que os presentes têm parte,/que entre ausentes não se parte,/o que veio de presente: /cada um se foi contente/velhos, mancebos, meninos,/e estão em rogo contínos/pedindo co'a boca toda,/que o doce façais de boda, para que sejamos dignos"1021.

Por vezes, entretanto, havia penúria na casa visitada por estranhos e as obrigações se faziam onerosas:

"Vieram Sacerdotes dous e meio/Para a casa do grande sacerdote, dous e meio couberam em um bote,/Notável carga foi para o granjeiro. // [...]/Assustei-me em ver tanta clerezia,/que como o trago enfêrmo de remela,/Cuidei, vinham rezar-me a agonia. // Porém ao pôr da mesa, e postos nela,/Entendi, que vieram da Bahia,/Não mais que por papar a cabidela"1022.

"Padre, a casa está abrasada,/porque é mais danosa empresa/pôr três bôcas numa mesa,/que trezentas numa espada:/esta trindade sagrada,/com que tôda a casa

1019 MATOS, G. Op. Cit., Vol. VI, p. 1499.

1020 CALMON, Pedro. Op. Cit., pp. 91 a 93.

1021 MATOS, G. Op. Cit., Vol. VI, pp. 1502 e 1503.

1022 MATOS, G. Op. Cit., Vol. II, p. 302. 
abafa/a tomara ver já safa,/porque à casa não convém/trindade que em si contém/ três Pessoas, e uma estafa. // [...]/Se estamos na Epifania,/e os três coroas são Magos, hão de fazer mil estragos/no caju na valancia: mágica é feitiçaria, /é a terra é tão pouca esperta,/e a gentinha tão incerta, /que os três a vosso pesar/não vos hão de oferta dar, e hão de mamar-vos a oferta. // [...]/e se lhe formos á mão/no comer, e no engolir,aqui nos há de frigir como postas de cação" ${ }^{1023}$.

Existiam efetivamente os hóspedes inconvenientes, aqueles que se convidavam e não eram apreciados ou aqueles que davam presentes de péssima qualidade, como certo peru cego e doente que Gregório de Matos se queixou de ter recebido ${ }^{1024}$. E havia também solicitações indevidas. Pedidos podiam ser negados, mas a recusa desencadeava fortes rancores. Dona Marta Sobral, que não quis dar a Gregório de Matos uma arroba de carne solicitada (acabava de matar uma rês), foi vigorosamente satirizada:

“Ó tu, ó mil vezes tu,/que se uma arrôba de vacalte pedia, és tão velhaca,/que me ofreces do teu cu:/essa carne a Bersabu/a devias dar em pó,/a mim não, porque em meu pró/não me atrevo a escolher/nem teu cu pelo feder,/nem pelo podre teu co"1025.

O açúcar, que dava seiva econômica às atividades da colônia, previsivelmente se encontrava no centro das redes de reciprocidade social estabelecidas na colônia, que se apresentavam carregadas de valores honoráveis:

"Senhora minha: se de tais clausuras/Tantos doces mandais a uma formiga,/Que esperais vós agora, que vos diga/Se não forem muchíssimas doçuras. // Eu esperei

\footnotetext{
1023 MATOS, G. Op. Cit., Vol. II , pp. 300 e 301.

1024 MATOS, G. Op. Cit., Vol. VI, p. 1363.

1025 MATOS, G. Op. Cit., Vol. V, p. 1276. Uma arroba ou quinze quilos.
} 
de amor outras venturas:/Mas ei-lo vai, tudo o que é de amor, obriga,/Ou já seja favor, ou uma figa,/Da vossa mão são tudo ambrósias puras. // O vosso doce a todos diz, camei-me [sic]/De cheiroso, perfeito e asseado,/Eu por gosto lhe dar, comi, e fartei-me. // Em êste se acabando irá recado,/E se lhe parecer Glutão, sofrei-me,/Enquanto vos não peço outro bocado" ${ }^{1026}$.

\section{Os ritmos da vida social: os alimentos como fonte de auto-identificação}

Em que pese a enorme importância dos temas religiosos na vida soteropolitana, a obra poética satírica ou burlesca de Gregório de Matos não ofereceu nenhuma safra abundante de informações sobre maneiras especificamente mazombas de configurar a alimentação em termos católicos. As práticas alimentares locais associadas à vida religiosa foram relatadas de modo assaz comedido nos poemas do autor que ousaram se aventurar no universo do sagrado. No âmbito religioso, proibições e prescrições vigentes em Portugal parecem ter permanecido intactas. Os colonos, num domínio eivado do perigo de acusações de heresia ou de heterodoxia, não parecem ter procurado inovar muito. Ao que tudo indica, muitos hábitos alimentares de praxe em Portugal foram conservados.

Nas poesias líricas do poeta, a fé religiosa ecoava sincera, a despeito da tendência de gracejar com tudo e com todos. Não lhe faltaram ousadias como as brincadeiras referentes ao pecado original, mas claro estava que, se ele errasse a mão e se excedesse, encontraria certamente inimigos dispostos a denunciá-lo perante a Inquisição ${ }^{1027}$ :

"Pela dentada, que Adão/deu no vedado fruteiro,/de fôlhas fêz um cueiro,/e cobriu seu cordavão: a ti o querer ser glutão/de outra maçã reservada,/ao vento te pôs a

1026 MATOS, G. Op. Cit., Vol. IV, p. 870.

1027 PERES, Fernando da Rocha. Gregório de Mattos e a Inquisição. Salvador, Centro de Estudos Baianos, 1987. Matos escapou, segundo documentos analisado por Peres, de uma tentativa que não levou à formação de um processo efetivo. 
ossada,/[...]/mas com diferença muita,/que se nu te pôs a fruita,/tu não lhe deste a dentada"1028.

Nos poemas de inspiração sacra do autor, verificou-se a primazia das referências ao tema da eucaristia, à transformação do pão e do vinho em corpo e sangue de Cristo:

"À vossa mesa divina/como poderei chegar-me, se é triaga da virtude, e veneno da maldade?/Como comerei de um pão,/que me dais porque me salve?/um pão que a todos dá vida,/e a mim temo que me mate./Como não hei de ter mêdo de um pão, que é tão formidável/vendo que estais todo em todo,/e estais todo em qualquer parte?/ Quanto a que o sangue vos beba, isso não, e perdoai-me:/como quem tanto vos ama,/há de beber-vos o sangue?"1029.

"Bendito seja e louvado,/pelo que tem de amoroso,/um Deus, que é tão poderoso,/ um Senhor tão sublimado:/deixar de ser exaltado/poder tão grande, não temo,/pois se vê de extremo a extremo,/que a grandeza, que se sabe/cabendo em vós, toda cabe/Nessa Hóstia, rei Supremo" $" 1030$.

"Se no pão vos disfarçais,/por cobrir vossa grandeza,/já do pão na natureza/toda a grandeza expressais:/melhor no pão publicais/o poder a tôda a terra,/pasme o mar e trema a serra,/e reconheça o percito,/que o Pão é deus infinito;/Porque quem em pão se encerra?"1031.

1028 MATOS, G. Op. Cit., Vol. II, p. 320.

1029 MATOS, G. Op. Cit., Vol. I, pp. 49, 105 e 107.

1030 MATOS, G. Op. Cit., Vol. I, p. 98.

1031 MATOS, G. Op. Cit., Vol. I, p. 100. 
Segundo Matos, colonos havia que, desprovidos de fé, se gabavam muito no recinto da igreja:

"Não contam vidas de Santos,/nem exemplos ao divino,/mas sim muita patarata,/do que não há nem tem sido./Pois se há sermão, nunca o ouvem,/porque ou se põem de improviso/a cochilar como negros,/ou se vão escapulindo./As tardes passam nos jogos, ou nos campos divertidos/em murmurar dos governos,/dando Leis, e dando arbitrios" $" 1032$.

As metáforas envolvendo alimentos e religião raramente se atreveram a brincar senão ligeiramente, com temas sagrados. Quando Matos proferiu alusões a circunstâncias festivas, como os jejuns radicais (têmporas) e os dias magros obrigatórios do período da Quaresma, foi para criticar cautelosamente condutas de avareza que não se coadunavam com a honra. O poeta, por exemplo, satirizou a profissão dos meirinhos pertencentes aos quadros do sistema judiciário estabelecendo uma analogia irônica entre as privações que os cristãos experimentavam na quaresma e os padecimentos recorrentes de um gato mal alimentado por seus donos:

"Porque em casa de um meirinho/nas suas arcas, e armários/é quaresma tôda a vida,/e têmporas todo o ano"1033.

\section{Corpo, saúde e alimentos}

A poesia de Gregório de Matos se valeu de alusões aos hábitos alimentares soteropolitanos para defender valores ideais. $\mathrm{O}$ autor enveredou, de modo recorrente, pela questão dos efeitos fisiológicos e morais dos alimentos ingeridos em suas metáforas que pressupunham saberes 1032 MATOS, G. Op. Cit., Vol. I, p. 18.

1033 MATOS, G. Op. Cit., Vol. II, p. 457. Meirinho. Segundo o Diccionário Moraes: “Official de Justiça, que prende, cita, penhora, e executa outros mandados judiciais...". 
implícitos. Peres comentou a importância e a freqüência dos temas corporais na obra do poeta, presentes nos retratos hediondos de personagens satirizadas ou nas referências constantes a necessidades fisiológicas, sublinhando o fato do "rebaixamento como matéria poética" prolongar, em meados do século XVII, o realismo grotesco medieval analisado por Bahktin em seu estudo da obra de Rabelais ${ }^{1034}$. Efetivamente, o lugar que os saberes medicinais em geral e a alimentação em particular ocuparam na obra de Rabelais, médico de profissão, apresentava semelhança com aquele que lhes foi reservado na obra de Gregório de Matos. Os hábitos alimentares encontrados nos poemas do autor mazombo pressupunham um conhecimento implícito de noções correntes sobre a fisiologia dos corpos.

As referências à existência dos humores foram abundantes na obra do poeta, demonstrando o caráter fundamental dos saberes referentes à corporalidade humana. Citando alguns exemplos utilizados por Matos seria possível destacar alguns traços rápidos pinçados aleatoriamente nos poemas:

"Europa anda de humores mal regida"1035.

“O senhor João Teixeira/Mendonça de quando em quando/na cadeia está purgando/ humores de ladroeira"1036.

"ter do mal francês humor" ${ }^{1037}$, etc..

Em termos práticos, suadouros, ginástica, sangrias, vomitórios, purgantes e clisteres faziam parte integrante das maneiras que a medicina hipocrática, revista por Galeno (e resgatada no século XV por intermédio de médicos árabes), preconizava para agir sobre sangue, fleuma e 1034 PERES, F. da Rocha. Gregório de Mattos Guerra - uma re-visão biográfica. Op. Cit., p. 112.

1035 MATOS, G. Op. Cit., Vol. V, p. 1202.

1036 MATOS, G. Op. Cit., Vol. II, p. 366.

1037 MATOS, G. Op. Cit., Vol. VI, p. 1508. 
bílis negra ou amarela, levando em conta ainda o clima no qual se vivia, a idade, o sexo e o temperamento pessoal de cada paciente ou convalescente. A alimentação, por conseguinte, era fonte central de manejos corporais e de significados correlatos.

Sangrias e diagnósticos sobre o estado material do sangue, um dos principais humores, configuravam elementos importantes de representação pessoal, emprestando substância a duplos sentidos e comprovando ainda a relevância dos conhecimentos sobre os quais as brincadeiras repousavam:

“Como na veia acertou,/onde habita a saudade,/extinta a má qualidade,/a enfermidade acabou:/nunca Galeno alcançou/nas sangrias, que me aplica,/quanto oferro prejudica,/ e eu curada com dieta,/já sei que pica a lancêta,/e somente sangra a pica"1038.

Matos, além de formular considerações abstratas, gracejou, aproximando noções de medicina humoral e manejos alimentares. Versejou freqüentemente convites amorosos propondo "fretes" às moças ou explicando-lhes os motivos que o impediam de se declarar:

"Quem, o que deve a um amigo/em respeitos lhe não paga,/não é amigo, nem homem,lé uma bêsta asselvajada./Mas andar, fôda ele embora,/isso não importa nada,/teremos amôres secos,/seco é o biscouto, e campa./Falaremos sempre aos molhos, /e riremos às canadas,/folgaremos, que amor seco/sem molhar beiço se passa" 1039 .

“Tornei lá no outro dia,/e achei a pobre doente/mui sêca para a visita,/mui úmida para o frete" 1040 .

\footnotetext{
1038 MATOS, G. Op. Cit., Vol. VI, p. 1354.

1039 MATOS, G. Op. Cit., Vol. III, p. 570.

1040 MATOS, G. Op. Cit., Vol. VII, p.1582.
} 
Muitas ocorrências comentadas por Matos envolviam noções de medicina humoral associadas aos hábitos alimentares:

“como a parte é tão reimosa,/é sempre mui perigosa/junto do cu cutilada"1041.

“Item que está muito podre, e não escusa esta Páscoa,/para secar os humores/fazer da salsa salsada"1042.

"Não me espanto dos adornos/de uma dama singular,que em cornos venham parar,/porque ela parirá cornos:/mas que tantos caldos mornos de estíticas qualidades/em tantas calamidades/ não valham, são desenganos/da resolução dos anos, da carreira das idades"1043.

Sexo e comida sendo estreitamente vinculados, as formações perigosas de humores podiam ser corrigidas por meio de manejos apropriados. Os colonos procuravam obter um equilíbrio corporal adequado através de práticas alimentares:

“ao nosso Abade Ledesma/pregando na freguesia,/ouvi dizer em um dia/(e é rifão dos Mazombos)/que a carne é, que cria os lombos/e não o peixe de água fria. // Mandai-me de carne um pouco/as galinhas, e as posturas $" 1044$.

Com a saúde garantida, uma maior liberdade alimentar era possível. Indivíduos demasiadamente enfraquecidos eram dispensados do respeito aos dias magros. Na chácara que comprou junto ao Dique, depois do casamento, Matos tinha acesso fácil aos peixes de água doce, ressalvando, todavia, o caráter perigoso e a natureza fria de tais carnes:

1041 MATOS, G. Op. Cit., Vol. VI, p. 1305.

1042 MATOS, G. Op. Cit., Vol. V, p. 1113.

1043 MATOS, G. Op. Cit., Vol. VII, p. 1566.

1044 MATOS, G. Op. Cit., Vol. VI, p. 1534. 
"Por bem afortunado/Me tenho nestes dias,/Em que habito este monte a par do Dique,/vizinho tão chegado/Ás Taraíras frias,/A quem a gula quer, que eu me dedique" 1045 .

Bebido em quantidades moderadas, o vinho português era considerado um ingrediente fundamental da vida social mazomba. Supunha-se o vinho que aquecesse o sangue e seu consumo apreciado ocasionava tiradas humorísticas. Abusos, porém, não eram contemplados com indulgência. Quem se excedesse podia ser chamado de: "maganão, bêbado, jerebiteiro"1046.

A Manuel Fernandes, grumete da nau que trouxe Matos de Portugal, contratado como barqueiro em Marapé, o poeta versejou: "Pois trazieis o barco tão seguro,/quando passei para esta nova Flandes, /que o mar me parecia vinho puro"1047.

Excessos desmereciam os comensais e repercutiam negativamente no estado de saúde daqueles que infringiam os bons costumes: "Bebeu Pelica, um almude 1048 , e não faltou, quem notasse, /que mil saúdes tragasse; e ficasse sem saúde"1049.

O flamengo, Baltasar Vanique, também se excedia, por vezes:

"Se a vossa alma tão devota/de beber, e emborrachar/houvesse Deus de igualar o castigo co pecado,/gotas vos houvera dado,/como areias tem o mar. // [...]/Sempre tive grande mágoa/em cuidar, que um mosquitinho/quer antes morrer no vinho,/do que estar vivendo n'água:" ${ }^{1050}$.

\footnotetext{
1045 MATOS, G. Op. Cit., Vol. V, p. 1221.

1046 MATOS, G. Op. Cit., Vol. II, p. 330.

1047 MATOS, G. Op. Cit., Vol. V, p. 1186.

1048 Segundo o Diccionário da Língua portugueza de Moraes: “Almude: Medida de líquidos: contém doze canadas, dois potes...".

1049 MATOS, G. Op. Cit., Vol. III, p. 627.

1050 MATOS, G. Op. Cit., Vol. VI, p. 1538.
} 
Que o processo fisiológico da digestão fosse primordial à manutenção da saúde corporal, propiciando maneiras de cozer os alimentos no estômago, comprovam-no ainda as críticas mordazes de Matos ao jeribiteiro Andrezão, cuja casa se incendiou enquanto ele cozia um excesso de bebida:

"e roncando a seu prazer /, para a cachaça cozer,/e por mais que a palhoça arda,/ Deus lhe defende, e resguarda, /êle familia e mulher" ${ }^{\prime 051 .}$

"Sôbre camarões/Sem comer mais nada/Só de uma assentada/bebe dez tostões:/ vendeu os calções, só para beber" ${ }^{1052}$.

Matos também brincou com situações traduzidas em termos medicinais no discurso fictício do gato de um boticário, extremamente rico em alusões:

“há anos, que sirvo na casa de um boticário,/que a récipe de pancadas/me tem os bofes purgado./Queixa-se que eu lhe comi/um boião de ungüento branco,/e bebilhe a mesma noite/um canjirão de ruibarbo./Diz bem, porque assim passou;/mas eu fiquei tão passado/como de tal solutivo/dirá qualquer mata-sanos./Fiquei de humores exangue,/tão escorrido, e exausto, /que não sou gato de humor,/porque nem bom, nem mau gasto" 1053 .

Os princípios básicos da medicina humoral eram questões de conhecimento básico que os colonos compartilhavam, os profissionais, entretanto, não se encontravam ao abrigo das críticas do poeta:

\footnotetext{
1051 MATOS, G. Op. Cit., Vol. V, p. 1162.

1052 MATOS, G. Op. Cit., Vol. V, p. 1166.

1053 MATOS, G. Op. Cit., Vol. II, p. 458.
} 
“Que hajam médicos, que tratam/só de jogos e de amôres,/sendo como os caçadores, que vivem só, do que matam:/[...] que haja enfêrmo que se abrasa/em febres e dores mortais,/e que se cure com tais,/que só estudam na frasqueira! /Boa asneira"1054.

\section{O uso medicinal dos alimentos: os remédios}

Deixando de obedecer a preceitos do paladar, muitos alimentos normalmente saboreados apenas pelo prazer da gula, foram ingeridos para fins medicinais, visando sanar males que afetavam o bem-estar. Ingredientes comestíveis, apreciados como alimentos ou como condimentos, também serviam de remédio (ou de mezinha ${ }^{1055}$ ) para combater as doenças. Os manejos alimentares, incluídos entre os procedimentos de tratamento corporal para restabelecer equilíbrios comprometidos tais como os suadouros, a ginástica, os jejuns, os vomitórios, os purgantes, os clisteres e as sangrias, foram regidos efetivamente, no século XVII, pelos saberes de uma versão de medicina humoral vigente.

Um caso paradigmático de dupla função podia ser observado nos dois tipos existentes de açúcar de Alexandria ${ }^{1056}$ também chamado açúcar rosado. Tratava-se simplesmente de açúcar cozido com pétalas de rosas brancas pertencentes à variedade dita de Alexandria. Confeccionavam-se duas versões diferentes desses doces ${ }^{1057}$. Ao primeiro, um xarope de efeito laxante moderado, que pertencia à farmacopéia usual, cabia um uso sobretudo medicinal. Em seu preparo, as pétalas das flores eram escaldadas com uma água fervente utilizada para aviar o produto. Para recursos apenas culinários tomava-se o cuidado de descartar a primeira água e

\footnotetext{
1054 MATOS, G. Op. Cit., Vol. II, pp. 485 e 486.

1055 MATOS, G. Op. Cit., Vol. II, p. 255.

1056 MATOS, G. Op. Cit. Vol. VI, p. 1439.

1057 CARDIM, Fernão. Tratados da terra e gente do Brasil. São Paulo, Cia. Ed. Nacional. 1978. p. 214.

"Tem muitas rosaes de Alexandria, e porque não tem das outras rosas, das de Alexandria fazem assucar rosado para mezinha, e das mesmas cozidas, deitando-lhe a primeira água fóra, fazem assucar rosado para comer e fica sofrivel...".
} 
somente pétalas, açúcar e uma nova água entravam na confecção do doce. Na receita do caldo de frangos para hécticos ${ }^{1058}$, indicada pela infanta D. Maria, adicionava-se açúcar rosado ao preparo. Quanto a Rocha Pita, ele também referiu seu preparo na colônia:

"As flores estrangeiras que há nesta região em abundância grande, são rosas de Alexandria e de Portugal, que dão em todo o curso do ano, e de uma se faz já açúcar rosado maravilhoso" 1059 .

A água de flor de laranjeira, por sua vez, reputava-se calmante. Nos conselhos que deu a uma noiva o poeta sugeriu que, vindo sua doencinha (a menstruação), a jovem corresse à cozinha pedir à Madalena dessa água de flor ${ }^{1060}$. O Doutor Mirandela considerava a casca das laranjas seca e quente, acrescentando que da flor de laranjeira se fazia "florada que é doce de suavíssimo gosto e útil para estômagos fracos por falta de calor"1061.

$\mathrm{Na}$ escrita poética de Matos figurou também uma referência ao sal, remédio utilizado para curar desmaios. Clóri adoecendo, foi sangrada e desmaiou:

“Com sal na bôca diverte/o desmaio, mas eu sei,/que boca tão engraçada/nenhum sal há de mister./Que foi supérfluo o remédio/do sal, não duvide alguém,/porque quem é luz do mundo,/sal da terra deve ser"1062.

Vinagre e azeite tampouco estiveram ausentes no tratamento de doenças, mesmo quando a alusão poética escondia farpas. No testamento irônico do cavalo de Pedro Alvarez da Neyva Matos lamentava:

1058 HENRIQUEZ, Francisco da Fonseca. Op. Cit.. Glossário, pp. 287 a 292.

"HÉCTICOS: Tísico, tuberculoso".

1059 PITA, Sebastião da Rocha. Op. Cit., p. 29, parágrafo 45.

1060 MATOS, G. Op. Cit., Vol. V, p. 1090.

1061 HENRIQUEZ, Francisco da Fonseca, Op. Cit., p. 197.

1062 MATOS, G. Op. Cit., Vol. V, p. 1057. 
"quis Deus, que não lhe aproveite/nem das Brotas o azeite,/nem o vinagram dos Frades" ${ }^{1063}$.

Outras alusões a alimentos utilizados como remédios se revelaram de compreensão mais complicada, como certa referência a limões. Matos, satirizando um de seus desafetos afirmou num poema dedicado ao episódio que, para curar a impotência, doença dita fria, esse homem teria colocado talhadas de limão no ânus, a guisa de sacamano (ou sacatrapo), remédio utilizado contra as disenterias provocadas pelo maculo, uma infecção intestinal que podia ser letal se não tratada em tempo. Costumava-se debelar a infecção introduzindo no orifício anal, distendido pela doença, chumaços de trapos impregnados com uma mistura de pólvora, de pimenta nativa e de limão ou vinagre aos quais se punha fogo.

"porque se na realidade/sois tão frio fodedor/como curais o calor/se enfermai de frialdade". “Engano foi de capricho/a meizinha do Limão,/pois a cura do pismãolé uma é outra a do bicho:/para entesar êsse esguicho,/e endurecer êsse cano/o remédio é um sacamano,/e se sois de fria casta,/e nada disto vos basta,/sêde frade franciscano. // Meter um limão sem tédio/no cu é cousa de bruto, é remédio para puto,/não para as putas remédio" 1064 .

Noutro relato escabroso, Matos aludiu a um preparo de doce de araçá fabricado por vingança, com uma fruta na qual se tinha cozido um pinhão de purga, laxante tão potente que era preciso assá-lo previamente, inserido numa fruta, para retirar excessos perigosos de efeito. Uma vez cozido, descartava-se a fruta. Era o pinhão cozido, esmagado com um pouco de açúcar, que o paciente ingeria ${ }^{1065}$.

\footnotetext{
1063 MATOS, G. Op. Cit., Vol. IV, p. 888.

1064 MATOS, G. Op. Cit., Vol. V, pp. 1176 e 1177.

1065 MATOS, G. Op. Cit., Vol. II, p. 364 e p. 386.
} 
A certo capitão que, pelo furto de um papagaio, mandou encarcerar a amásia grávida e a mãe da moça, Matos lembrou o escândalo da vingança da mulata:

“alerta meu Capitão,/que há Puta que dá pinhão/com rebuço de araçá:/vosso Primo Mangará,/que nesta matéria bole,/diz, que quem tal purga engole,/e no cagar tanto atura,/já não será rapadura,/porque foi jalapa mole"1066.

Os versos de Matos proporcionaram um elenco bastante diversificado de termos e de procedimentos referindo purgas, purgantes e excrementos, que resvalava facilmente para um baixo corporal popular e jocoso, aparentado ao estilo das farsas medievais, que, em seu tempo, começavam a perder terreno literário. Expressões cruas como "calafetar a popa antes que saia o mingau"1067, ou alusões a diarréias fabulosas como no poema referindo os feijões da Pericoara, foram temas persistentes nos poemas que o autor compôs num registro poético satírico contraposto à idéia da nobreza. As brincadeiras de Matos multiplicavam os duplos sentidos e as alusões chulas, lembrando que o processo digestivo começado à mesa podia terminar em xaropes revigorantes de efeito cordial ou em ajudas, remédios para fins de clister (lavagem intestinal):

"O xarope é cordial,/e ajuda é culantrina,/xarope é coisa divina,/a ajuda é cousa infernal' 1068 .

Os manejos usuais de ingredientes comestíveis produzidos no Brasil ou obtidos por intermédio de naus portuguesas, reconstituídos a partir de uma leitura dos versos de Gregório de Matos compuseram, no decorrer da pesquisa, um panorama etnográfico consistente de hábitos alimentares coloniais.

\footnotetext{
1066 MATOS, G. Op. Cit., Vol. II, p. 386.

1067 MATOS, G. Op. Cit., Vol. VI, p.1339.

1068 MATOS, G. Op. Cit., Vol. VI, p. 1476.
} 
Obedecendo a princípios sistemáticos, os hábitos alimentares instituídos localmente combinaram argumentos oriundos das mais diversas esferas do conhecimento num todo modelado e coerente, a despeito de não existirem relações diretas de causa a efeito entre os procedimentos alimentares escolhidos e a auto-definição social dos colonos. Consumos vistos como adequados (em Salvador e adjacências) espelharam a concepção que os colonos lusos tinham do lugar e do papel que lhes cabia desempenhar na sociedade colonial. Na ausência de outras fontes, conviria resumir em suas grandes linhas os manejos concretos percebidos, para retomar, mais adiante, as questões que presidiram a organização das condutas alimentares locais. Houve, pois, em território soteropolitano uma mudança óbvia dos mantimentos. Reduziu-se a disponibilidade dos ingredientes que compunham a base da alimentação portuguesa: o pão de trigo, o vinho, e o azeite. A mandioca substituiu facilmente o pão como mantimento básico sem, entretanto, que pães, biscoitos e vinhos deixassem de ser valorizados como alimentos referenciais ${ }^{1069}$. Continuaram muito presentes na dieta dos colonos que dispunham de recursos para comprá-los e que, além desses gêneros, costumavam adquirir regularmente azeites, aguardentes, queijos e fiambres.

As carnes, bovinas, suínas ou ovinas continuaram, na capital da colônia, a ser os ingredientes mais apetecidos na dieta alimentar da população, substituídos nos jantares dos dias magros pelas iguarias de peixe que incrementavam também a ceias cotidianas, juntamente com outros alimentos considerados de digestão fácil:caldos de cozidos, saladas de alface ou chicórias com azeitonas.

A noção de fartura alimentar, pois, incluía antes mantimentos de carnes do que vegetais ou frutos do mar, apesar do Recôncavo rico em pescados, crustáceos ou mariscos parecer se especializar na preparação dessa riqueza do terroir. Menções a aves foram raras nos poemas de Gregório de Matos, excetuando-se algumas referências a galinhas-de-cabidela e alguns

1069 Considerou-se alimentos referenciais da dieta aqueles suscetíveis não somente de compor cardápios possíveis de se obter localmente, mas também de integrar cardápios idealmente apetecidos, comportando ingredientes de valor afetivo, enraizados na memória da sociedade e consumidos com prazer explícito vinculado ao reconhecimento de uma auto-identificação. 
comentários a um consumo de carne de perus. Pasteleiros profissionais, trabalhando com cepo e forno, parecem ter preparados empadas ou pastéis apreciados em ocasiões festivas.

O provimento da capital em carnes bovinas frescas não se mostrava isento de problemas, apesar de talvez ser mais freqüente que em Portugal, onde havia uma maior proporção de animais de tiro ou de vacas reprodutoras que de animais jovens e saborosos destinados ao corte. A grande distância entre o sertão onde criavam-se rebanhos de milhares de reses e o litoral implicou freqüentemente no abate de animais esgotados pela viagem, magros ou até doentes, enquanto a gordura dos animais saudáveis também era apreciada pelo seu sabor.

Grandes diferenças na possibilidade de acesso da população às melhores carnes, parecem ter acompanhado os parâmetros da hierarquia social soteropolitana. Esses, por sua vez, resultaram num favorecimento explícito aos homens mais poderosos. Os escravos, que dependiam da generosidade de seus senhores para fruir de uma alimentação razoável, pareciam carentes de alimentos protéicos, mesmo quando recebiam rações de carnes de baleias ou de fressuras ${ }^{1070}$. Por esse motivo, eles não relutavam em praticar pequenos e grandes furtos para satisfazer a fome. Carnes-secas preparadas no sertão serviram de mantimento básico no litoral, porém, exceto no sertão, os laticínios se fizeram raros.

As principais fontes de arrecadação de impostos colocadas à disposição da Câmara Municipal consistiam nas taxas cobradas sobre a venda de mantimentos produzidos localmente: carnes, peixes e farinha de mandioca e de mantimentos lusos enviados do ultramar. Eles sustentavam efetivamente a gestão da Res Pública colonial segundo o estilo do costume local.

Todavia, as iguarias saboreadas, mesmo quando incorporavam ingredientes raros ou ignorados em Portugal, utilizavam técnicas de preparo lusas e eram consumidas segundo padrões lusos de organização das refeições. Diversos legumes, raízes ou cereais, substanciosos, que eventualmente poderiam ter servido de mantimentos, foram preteridos na colônia. Nem os feijões, nem o milho, nem as batatas doces ${ }^{1071}$ desfrutaram de primazia na dieta soteropolitana.

\section{Miúdos.}

1071 As batatas doces forneceram, por exemplo, o poi, mantimento polinésio de batatas doces fermentadas. 
O milho, dado aos animais (aves e cavalos) em substituição às aveias, miletos e cevadas européias, não desfrutou de grande conceito na região nordestina do Brasil, antes de se firmar como mantimento europeu. Os feijões e as batatas doces, considerados nutritivos e saborosos, mas flatulentos e ofensivos ao decoro de gente importante (comer feijões com carnes podia denunciar cristãos novos judaizantes), serviram de alimento conveniente em situações de viagem, e foram destinados aos escravos e às pessoas pobres ocupadas em atividades braçais, já que a medicina hipocrática essencializava as distinções sociais existentes. As elites mazombas como as portuguesas transferiam preconceitos culturais para o plano da fisiologia humana. Imaginava-se na época que alimentos grosseiros convinham melhor à natureza de pessoas de menor qualidade social. Entre os cereais, contudo, o arroz, utilizado para preparar receitas semelhantes às portuguesas, quase fez figura de mantimento usual.

A condimentação usual das iguarias, voltada para a obtenção de um equilíbrio saudável dos alimentos ingeridos, destinava-se antes à facilitar a digestão que meramente aos deleites do paladar. Antecipando as conclusões do próximo capítulo é preciso assinalar que os condimentos destinavam-se ao aquecimento dos alimentos frios. Acreditava-se ainda que os temperos ao adubarem as iguarias amaciavam os alimentos sólidos, considerados indigestos, ou então que fosse possível esfriar gêneros comestíveis demasiadamente quentes e secos. Cada comensal individualmente, em virtude do temperamento possuído, acrescido dos efeitos que a idade, o sexo ou o clima local desencadeavam em seu organismo, procurava alcançar um equilíbrio alimentar saudável capaz de retificar os excessos ${ }^{1072}$.

No ritmo das refeições, as frutas frias e úmidas abriam os repastos, a despeito da opinião contrária do Doutor Mirandela. As iguarias servidas, em seguida, apresentavam-se num crescendo de propriedades secas e quentes imaginado para equilibrar o processo digestivo. Com efeito, as hortaliças e as frutas apreciadas por seu sabor, não foram consumidas sem cautela e o hábito de prepará-los com açúcar, em confeitos, em doces ou em compotas, preparos saborosos que

1072 As noções de alimentos fortes ou fracos relacionados à saúde ou à doença ou a convalescença dos pacientes não figuraram em nenhum momento nas brincadeiras apresentadas pelo poeta, apesar de presentes nos tratados do corpus hipocrático. 
aqueciam os ingredientes, permitia que arrematassem os repastos com seus aromas e sabores. estruturadas por um conjunto amplo de fatores materiais ou ideais.

Merece destaque ainda uma última ressalva. O método de trabalho utilizado, a procura de indícios que explicitassem os procedimentos da dieta alimentar soteropolitana, levou a considerar os hábitos alimentares como práticas refletindo os aspectos de um processo social de ajustamento dos colonos à terra. Porém, não foi examinado devidamente o caráter modelador desse estilo de vida local, que se desenvolveu conjugando um amplo elenco de premissas tácitas. Seria necessário examiná-lo mais adiante não somente como um elemento propício às alterações, mas como um modelo que também estruturou as condutas da sociedade colonial e os valores culturais. No próximo capítulo esse aspecto da questão deverá também ser observado. 


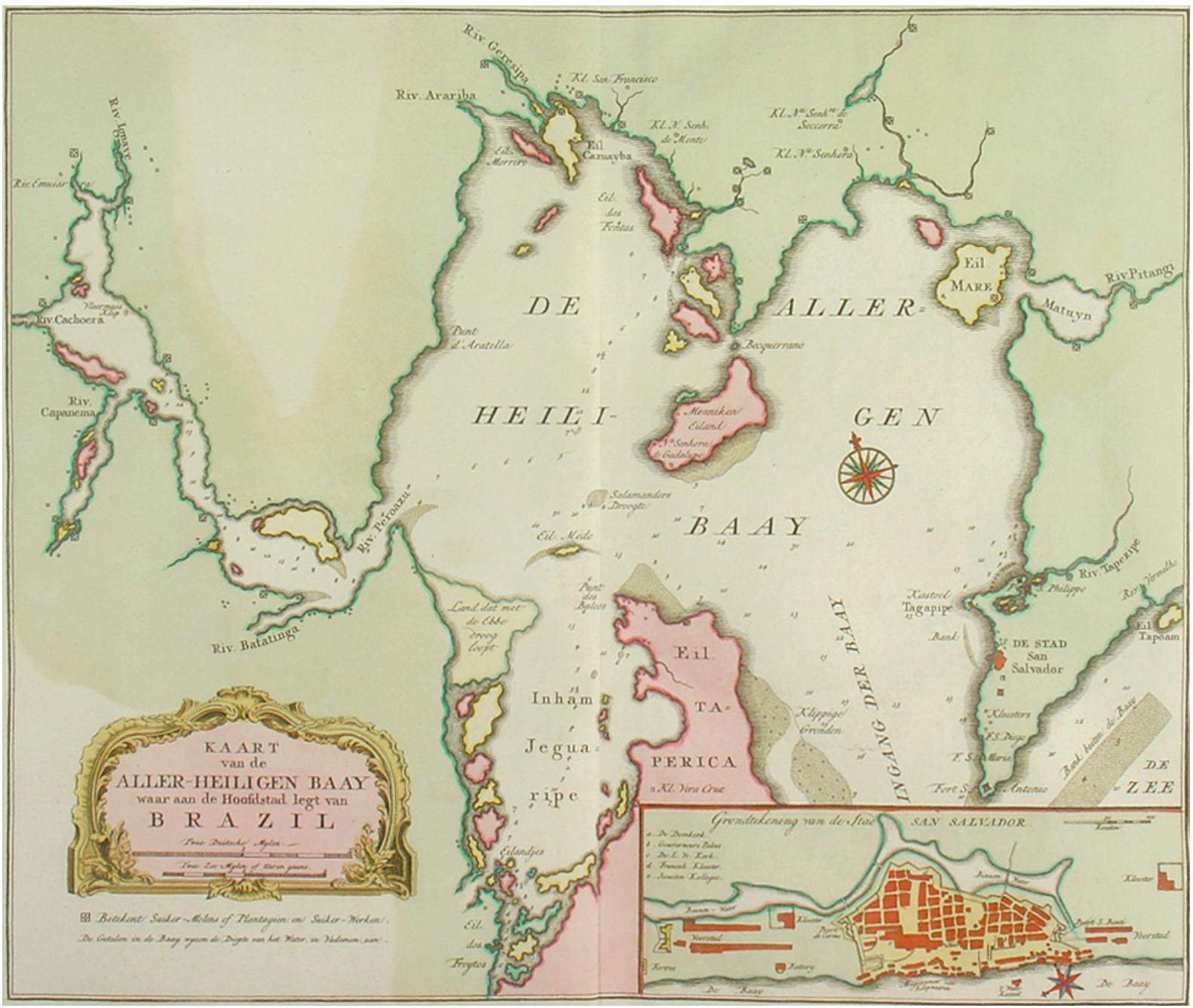

Brazil: San Salvador, Bahia - 1769 : aquarelado à mão: From Isaak Tirion’s "Nieuwe en Beknopte Hand - Atlas bestaande in eene Verzameling van eeinge der algemeenste en nodigste landkaarten”. Amsterdam: 1769. 41 x 49 cm. 


\section{Capítulo IV - As lógicas envolvidas na produção e no consumo dos alimentos}

"O beaux discours humains! Je suis venu si loin

Pour m'enrichir d'ennui, de vieillesse et de soin,

Et perdre en voyageant le meilleur de mon âge.

Ainsi le marinier souvent, pour tout trésor,

Rapporte des harengs en lieu de lingots d'or,

Ayant fait comme moi um malheureux voyage.

(Joachim du Bellay $(1522-1560)$, Les Regrets $\left.{ }^{1073}\right)$.

No decorrer da pesquisa pôde se verificar como as metáforas formuladas por Matos expressavam realmente "um protocolo de usos costumeiros, de situações e de condutas"1074, cujos parâmetros tendiam a ser confirmados pelo testemunho de outros autores seiscentistas. A metodologia de trabalho privilegiou a investigação dos aspectos da vida colonial espelhados nos procedimentos da dieta alimentar soteropolitana. Entretanto, os hábitos de nutrição “procurados em todos os lugares" e a "observação indireta na vida mental" da população dita mazomba apontavam também para a existência de um sistema alimentar que não era apenas estruturado por diversas considerações relevantes, mas que pretendia ainda estruturar o teor das interações sociais soteropolitanas. Não obstante o impacto de eventos e de processos sociais que alteravam as condições do provimento alimentar, a dieta soteropolitana configurava um vasto elenco de procedimentos, formava "um corpo de imagens" carregadas de significados subjacentes e fazia parte integrante de um estilo de vida sedimentado, impregnado de valores morais, estéticos ou práticos.

1073 Soneto : “Je me ferai savant”. in LAGARDE, André et MICHARD, Laurent. XVI ème Siècle. Paris, Bordas, sem data. p. 114.

1074 Cf. a citação de Barthes que serviu de epígrafe do capítulo de introdução. 
Desse modo, uma vez delineados a vida e a obra de Gregório de Matos no primeiro capítulo da tese, apresentadas as idéias que impeliram o poeta a criticar a sociedade colonial no segundo e observadas as práticas alimentares mazombas no terceiro, faltava ainda, retomar, situar e debater, numa perspectiva ampliada, algumas das principais questões pertinentes à vida cultural ou social da colônia que foram evidenciadas durante a análise dos versos atribuídos ao poeta.

Em termos práticos, os contornos da dieta local mazomba que a poesia de Matos permitia observar derivavam de manejos alimentares instituídos para disponibilizar mantimentos e víveres aos colonos. Fazia-se necessário identificar os principais processos sociais que revelavam um ajustamento luso às condições locais. Entre os processos dignos de nota sobressaiam, por exemplo, a questão da desmediterraneização forçosa da dieta lusa de origem ${ }^{1075}$ que, através dos procedimentos do aprovisionamento, desembocava sobre a questão do nativismo. Um outro tema que emergia insistentemente na leitura dos versos e precisava ser objeto de reflexão apropriada era a elaboração do conceito soteropolitano de uma dieta mínima fundamentada no consumo de certos mantimentos e complementada por outros víveres. Destacava-se também o problema da hierarquia social vigente na colônia indissoluvelmente associada aos diferentes tipos de consumos alimentares.

O recurso de Matos a costumes alimentares para falar de organização social promoveu floreios eficazes de linguagem que expressaram idéias de grande apelo afetivo. Criticando, por meio de tais metáforas, as formas de interação social que fugiam aos parâmetros tradicionais, o poeta versejou muitos aspectos manifestos do cotidiano soteropolitano. Os próprios códigos sociais mazombas estavam em foco nessa questão. Importava, pois, desvendar o teor dos nexos entre uma forma mazomba de viver o território colonial e o papel das elites soteropolitanas. $\mathrm{Na}$ medida em que gestos concretos do dia-a-dia definiam a importância social de cada indivíduo, falar de quem provia alimentos para quem ou assinalar quem comia alimentos preparados por

1075 Como bem observou Sahlins: "Plus ça change et plus c'est la même chose". Mudanças performativas de procedimentos alimentares mantinham, portanto, a dieta alimentar bastante semelhante à dieta de origem. SAHLINS, Marshall. Histórical metaphors and mythical realities. Michigan: The University of Michigan Press, 1981. 
quem, definia de modo claro o lugar que esse indivíduo ocupava na escala da hierarquia social. Ao ingerirem iguarias apetecidas ou recusarem alimentos considerados repugnantes eram os critérios morais de uma comestibilidade apropriada que os soteropolitanos colocavam em jogo.

A etnografia das condições de produção, de comercialização, de preparo ou de consumo dos ingredientes comestíveis possibilitava vislumbrar um sistema subjacente de práticas alimentares sedimentadas e conexões estreitas entre as representações ideais e os procedimentos materiais da subsistência colonial. Em torno dos ingredientes animais ou vegetais incorporados à dieta alimentar elaboravam-se teias intrincadas de significados. Para que fossem interpretadas, era necessário reunir sólidos conhecimentos a respeito dos contextos, literário, social ou cultural soteropolitano. Discutir o manejo dos ingredientes alimentares soteropolitanos implicava, pois, além de uma análise detalhada dos elementos pertinentes ao estilo de vida, uma certa amplitude e liberdade da reflexão.

Concluiu-se afinal que os principais fatores culturais que atuavam, no tocante à nutrição colonial, remetiam a conceitos de corpos mantidos em estados adequados de saúde e de honorabilidade católica e social. O corpo receptor de alimentos e promotor de gestos mediava clivagens sociais entre homens bons dedicados ao ócio e trabalhadores braçais rústicos. Não soava estranho que gestos retratando atos de alimentação se tornassem, debaixo da pena do poeta, instrumentos fundamentais de expressão poética.

No derradeiro momento da exposição dos dados investigados, fazia-se necessário ampliar a discussão para que o conhecimento adquirido pudesse realmente contribuir com novas perspectivas ao estudo dos parâmetros do estilo de vida colonial. Nesses termos, cabia ao último capítulo da tese propor novas perspectivas mais do que resolvê-las a contento. Por conseguinte, Gregório de Matos, porta-voz de muitos membros da elite açucareira mazomba e catalizador de muitos saberes relativos às hierarquias sociais soteropolitanas, precisava ceder o centro do palco a contextos mais abrangentes e autores de épocas que ele não viveu. 


\section{1 - Alguns processos sociais relevantes percebidos na etnografia alimentar}

\section{O processo de uma desmediterraneização ou deslusitanização da dieta}

Quando, aos treze anos, Gregório de Matos deixou Salvador a fim de estudar em Portugal, existiam hábitos alimentares locais e representações bastante definidas sobre formas condizentes de exploração do território. As práticas do abastecimento alimentar, da distribuição dos víveres, do preparo e do consumo de iguarias formavam, pois, um todo assaz coerente, concebido para solucionar problemas ambientais ou questões de mão-de-obra que decorriam do sistema econômico vigente. A dieta alimentar modelada para sustentar a expansão da rede de engenhos apresentava, por conseguinte, um rol relativamente coordenado de procedimentos carregados de significados culturais e sociais.

Voltando à colônia em 1683, em meio a uma forte crise que afetava os lucros dos produtores de açúcar e favorecia os grandes negociantes em detrimento das elites tradicionais, o poeta, não mais um adolescente mas um homem feito, recebeu o impacto das mudanças ocorridas durante os cerca de trinta anos de sua ausência. Talvez a distância no tempo e no espaço, durante a permanência em Portugal, tivesse também amplificado em sua memória uma utopia idealizada da nobreza soteropolitana. Deparou-se ao chegar com a ignorância, a má-fé e a inveja de muitos homens, as tramóias de autoridades ou de comerciantes e a lubricidade do clero. A situação pessoal precária do poeta certamente não amenizou sua ira diante de condutas que desrespeitavam os parâmetros tradicionais do estilo de vida mazombo. A virulência dos ataques que ele desfechou contra os infratores às normas e sua utilização de hábitos alimentares ridículos para retratar a derrocada da sociedade colonial atestavam simultaneamente a existência de valores locais, e o fato de que tinham deixado de ser praticados.

Três fontes principais de procedimentos puderam ser percebidas a partir dos dados sobre a alimentação soteropolitana incluídos na obra de Matos. Por um lado, merecia escrutínio a permanência das práticas alimentares lusas quinhentistas e seiscentistas, assegurada pelo 
transplante bem sucedido de inúmeras espécies vegetais cultivadas em terras portuguesas, sendo que todos os animais domésticos europeus prosperaram no Brasil. O ritmo cotidiano das refeições, as técnicas lusas de preparo culinário ou de condimentação e o envio de gêneros alimentícios que não podiam ser obtidos localmente, a bordo das naus da frota anual, também contribuíram para prolongar, em território colonial, a maioria dos hábitos alimentares provenientes da pátria de origem.

Por outro lado, é preciso observar como os forasteiros instalados em território colonial retiveram apenas certos alimentos e formas de preparo consumidos nas dietas indígenas. Nem todos os alimentos nativos encontraram a mesma acolhida benevolente. Somente uma parte dos recursos comestíveis regionais, que os nativos conheciam, sabiam preparar e comiam, foi incorporada à dieta lusa. Répteis, roedores e um grande número de frutas do mato que as mulheres nativas coletavam não foram mencionados por Matos ou pelos demais cronistas da época. Aliás, o poeta tampouco mencionou diversos vegetais de uso comprovado e freqüente na colônia, tais como as abóboras ou as batatas doces.

Além disso, os ingredientes comestíveis sul-americanos apreciados pela população lusa, não obstante constituírem empréstimos à alimentação autóctone, foram principalmente guisados e comidos à moda portuguesa e se encarregaram de assegurar a continuidade fundamental dos procedimentos culinários europeus no âmbito da colônia. $\mathrm{O}$ acréscimo de sal e de matérias graxas às iguarias preparadas, como, por exemplo, a manteiga e os ovos adicionados à massa dos beijus, a aclimação de árvores frutíferas nativas espalhadas pelos matos em árvores (sativas) cultivadas nos pomares, a utilização de frutas nativas (muitas delas comidas pelos índios com acompanhamento de farinha seca) transformadas pelo açúcar em confeitos doces, conservas ou compotas introduziram alterações relevantes na maneira como os recursos alimentares indígenas foram pensados pela população colonial. Houve efetivamente uma mudança de ênfase no aproveitamento de muitos víveres e mantimentos. Apesar do moquém, do tipiti e do consumo das pimentas nativas se perpetuarem entre os portugueses, já não obedeciam às mesmas lógicas de uso. Por exemplo, na obtenção da farinha seca, produto cujo uso prevaleceu entre os colonos sobre todos os outros preparos de raízes de mandioca, os procedimentos indígenas de manejo 
das raízes de mandioca brava foram parcialmente reformulados em mãos portuguesas. A prensa de lagar, utilizada em Portugal para espremer o azeite das olivas, entrou em ação na extração do sumo tóxico desses tubérculos, como bem referiu Holanda ${ }^{1076}$.

A questão foi, sobretudo, a imposição de certas técnicas para melhorar a eficácia da produção agrícola, já que o trabalho compulsório extenuava uma mão-de-obra cativa. Mas interveio também, no caso, a vaidade de colonos que possuíam escravos a quem impor suas decisões e que desprezaram profundamente a população lusa pobre, recém-desembarcada ou não, que exercia profissões manuais ou vendia mercadorias a retalho.

Sophie D. Coe ${ }^{1077}$ examinou as diferenças na acolhida dos produtos locais que os colonos estabelecidos nas colônias hispânicas do Novo Mundo reservaram aos ingredientes das dietas indígenas. Em Las primeiras cocinas de América, a autora ressaltou a preferência dos forasteiros pelas plantas, cujas características melhor se aproximavam das categorias existentes de alimentos espanhóis, como no caso do milho, cujo uso nativo lembrava o uso europeu do pão, dos feijões Phaseolus, das leguminosas da subfamília Papilionoidea, cujo sabor lembrava o gosto das leguminosas do Velho Mundo que costumavam ser embarcadas nas despensas de todos os navios do Império espanhol: favas, grãos-de-bico e lentilhas, ou dos amendoins utilizados pelos colonos como se fossem amêndoas, nozes ou sementes de cucurbitáceas. Outra fonte de aceitação assinalada por Coe foi o próprio gosto de vegetais ou de frutos, adotados como parte integrante da dieta por suas qualidades próprias, como os ananases. A estudiosa assinalava ainda como o preço baixo e a disponibilidade de gêneros alimentícios locais, cujo consumo não era especialmente atraente, podiam constituir fatores eventuais de valorização.

O terceiro processo de ajustamento da dieta às circunstância locais, que os textos de Matos e de outros autores permitiram entrever foi, afinal, um processo ininterrupto de experimentação alimentar. Não cessaram, ao longo do tempo, as tentativas lusas de aclimatar no Brasil espécies vegetais comidas e apreciadas noutras colônias do Império português, seja em virtude do sabor, 1076 HOLANDA, Sérgio Buarque. Caminhos e fronteiras. São Paulo, Cia. das Letras, 1995. p. 173

1077 COE, Sophie D. As primeras cocinas de América. Cidade do México, Fondo de Cultura Econômica. 2004. pp. 51 a 54. 
que incrementava a dieta cotidiana, seja pensando nas possibilidades de lucros decorrentes da ampliação do rol dos gêneros tropicais produzidos e exportados. Os versos de Matos falavam correntemente em bananas, cocos, quiabos, e canela e seus comentários permitiam inferir que as bananas mencionadas seriam antes bananas introduzidas que as pacovas indígenas, necessitadas de cocção para serem comidas.

Todavia, à diferença de outros autores soteropolitanos do período, como Rocha Pitta ou Botelho de Oliveira, Matos não manifestou nenhuma satisfação ufanista em relação à fertilidade de um Brasil capaz de sazonar, com aromas incríveis, vegetais comestíveis oriundos de outras paragens tropicais. O poeta, nem mesmo de passagem, se referiu ao gengibre, raiz que prosperou tanto em solo brasileiro que o monarca espanhol, durante a reunião das duas coroas ibéricas, proibiu o cultivo local para não prejudicar os lucros das colônias orientais. Mas as plantações de gengibre, segundo Ambrósio Fernandes Brandão ${ }^{1078}$, já inçavam os campos com tão grande profusão quando a medida foi promulgada, que as tentativas de erradicação não foram bem sucedidas. O rei apenas conseguiu restringir o uso dos rizomas à preparação de doces e de iguarias locais. Próximo à época do retorno do poeta apareceram também em Salvador mangas, cajás, jacas tomates, cacau e chocolate, sendo que a palmeira do dendê também começava a marcar presença na paisagem, implantada a fim de fornecer um óleo combustível às lamparinas.

Por questões práticas ocorreu uma desmediterraneização forçosa na dieta alimentar dos colonos lusos que não se estendeu ao domínio do paladar. Como já foi frisado anteriormente, nem o trigo, com o qual fabricavam pães e hóstias, nem as uvas, provedoras de vinho, puderam ser obtidos localmente, e tampouco as oliveiras produtoras de azeite frutificaram ${ }^{1079}$. Um certo número de barris de farinha de trigo já moído, de vinhos, de aguardentes e de azeite chegava anualmente a Salvador, nos porões dos navios da frota comercial. Da Capitania de São Vicente provinha também, através de navegação de cabotagem, alguma farinha dos trigais cultivados no planalto Paulista pelo trabalho compulsório da mão-de-obra indígena. Armazenado durante

1078 BRANDÃO, Ambrósio Fernandes. Diálogos da grandeza do Brasil. Op.Cit.

1079 MELLO, Evaldo Cabral de. Op. Cit., apontou as dificuldades da obtenção dessa tríade canônica. 
longos meses, acabava se deteriorando antes do ano terminar. Mais valia então consumir farinha de mandioca recém-fabricada que farinha de trigo embolorada. Em Salvador, durante parte do ano, escasseava a farinha de trigo de boa qualidade. Entretanto, por oferecer um ingrediente sobremaneira apetecido, valorizado não somente na fabricação do principal mantimento cotidiano, mas ainda, por seu uso sacramental, na transformação da hóstia em corpo de Cristo, o pão de trigo, base corrente da alimentação européia meridional, nunca deixou de constituir um alimento referencial na colônia. A sazonalidade do provimento era fator levado em conta. Parece aliás que, no Velho Mundo, a raridade e o custo elevado do abastecimento reforçaram o caráter de consumo reservado aos ricos, dos pães brancos sem farelo ou adição de outras farinhas. Comê-los demarcava a importância social daqueles que podiam adquiri-los. A existência de pães de menor qualidade e preço costumava ser freqüentemente um cuidado que cabia às autoridades ${ }^{1080}$.

À diferença do México, colônia espanhola onde trigais e videiras se desenvolveram sem maiores dificuldades ${ }^{1081}$, no Brasil foi necessário adotar a mandioca e as aguardentes de cana para suprir a escassez dos gêneros alimentícios desejados, cuja falta se fez sentir de imediato. Semelhante situação explica porque o trigo nunca deixou de ser apreciado, a despeito da farinha de mandioca seca impor presença enquanto mantimento básico local. Uma análise de Coe retratou com muita sensibilidade a interpretação da alimentação dos povos do Novo Mundo aos olhos de povos europeus:

"En lo que respecta a este tema los europeos del siglo XVI podían entender a los

Maya mucho mejor que nosotros. Su comida dependía de un alimento, el trigo, con el que se hacia pan. Éste bien pudo haber variado en forma y composición

1080 Em paises, onde o trigo se fazia raro, substituíam-no com adições de outros cereais panificáveis tais como a aveia, a cevada ou o centeio.

CAMPORESI, Piero. O pão selvagem. Lisboa, Editorial Estampa, 1989.

BRAUDEL, Fernand. Civilisation matérielle, économie et capitalisme, XV ème - XVIII ème Siècle, Tomes I, Paris, Armand Colin, Livre de poche, 1979.

1081 LISS, Peggy K. Origenes de la nacionalidad mexicana, 1521- 1556: la formacion de una nueva sociedad. Cidade de México, Fondo de Cultura Económica. 1996. p. 197. 
de acuerdo con la disponibilidad de abastecimientos o de los recursos del bolsillo del consumidor, mas todo era pan y se rezaba por tenerlo diariamente. Al llegar al Nuevo Mundo, se dieron cuenta de que el maíz tenía la misma importancia en la vida de sus habitantes que el trigo en sus propias vidas en el Viejo Mundo, y que el mantenimiento, sólido o líquido, que de el se obtenía era el pan, con toda la carga emocional que tal palabra lleva consigo. La palabra pan no tenía el mismo significado para ellos que para nosotros: una sustancia que tenemos a la mano y que podemos utilizar o no. El pan era la vida en si mismo y era cualquier cosa que, en forma predominante, se elabora a partir de este alimento; no solo un producto fabricado a partir de un cereal" ${ }^{1082}$.

Algo bastante semelhante parece ter ocorrido no Brasil colonial, a mandioca, pão da terra sob suas diversas formas de preparo, foi imediatamente considerada o nutrimento básico, o mantimento por excelência, mesmo que os colonos preferissem sobretudo comer carnes. Além de prover um vigor renovado àqueles que as ingeriam ${ }^{1083}$, as carnes, segundo Montanari, constituíam um símbolo de poder aos olhos da classe dominante: “o instrumento para obter energia fisica, vigor, capacidade de combate; qualidades que constituem a primeira e verdadeira legitimação do poder" 1084 .

Para colonos empenhados em desfrutar no Brasil de melhores condições de vida que em Portugal, um acesso irrestrito às carnes sinalizava no plano material a efetivação de sua ascensão social. Porém, à farinha seca e aos beijus pertenciam qualidades tão inegáveis de durabilidade, que a mandioca se tornou o staple food local primordial, disponível, saboroso, conveniente e barato.

Fundamentando-se antes nas informações dos Diálogos das grandezas do Brasil, que no entusiasmo excessivo de Gandavo ou de Frei Vicente pela transformação da colônia em autarquia

1082 COE, Sophie D. Op. Cit., p. 179.

1083 Como foi visto no capítulo III.

1084 MONTANARI, Massimo. A fome e a abundância: História da alimentação na Europa. Bauru, EDUSC, 2003. p. 28. 
independente do fornecimento de produtos europeus, Evaldo Cabral de Mello ${ }^{1085}$ citou o discurso de um dos interlocutores fictícios dos Diálogos, para assinalar o recurso usual dos colonos às farinhas de trigo já moídas, provenientes do reino ou da capitania sulina. Segundo o estudioso, o consumo de farinha de trigo não constituiu nenhuma novidade introduzida pela ocupação holandesa, no século XVII. Tampouco teria sido consumo esquecido e reintroduzido pelos ingleses no século XIX. Efetivamente, a idéia da adesão imediata dos colonos lusos à mandioca, argumentada por Gilberto Freyre ${ }^{1086}$, não parece proceder ao se coligir os dados historiográficos e literários do período. O consumo à moda européia de pães, que os moradores portugueses do Brasil adquiriam quando tinham dinheiro, analisado por Cabral de Mello, correspondeu aos procedimentos mencionados nos versos de Matos. O historiador devia estar certo também ao confirmar a manutenção na colônia da prática metropolitana de fornos domésticos coexistindo com os fornos de padeiras profissionais que costumavam comercializar sua produção.

A idéia da deslusitanização lenta e progressiva do paladar, adiantada pelo historiador, destoava bastante das predileções gastronômicas evidenciadas na obra de Gregório de Matos. Se ela existisse, essa deslusitanização implicaria intenções nativistas e uma valorização afetiva do rincão de residência. Os mazombos então valorizariam deliberadamente os alimentos locais em detrimento do apego à dieta lusitana de seus ascendentes. Resta a saber se tal processo ocorreu no período analisado e se os mazombos da época podiam realmente ser considerados nativistas. Seria talvez mais acertado caracterizar as mudanças ocorridas na alimentação dos colonos lusos, ao cabo de um século e meio de colonização do território brasileiro, como uma desmediterraneização pragmática da dieta, um mero ajustamento às condições ambientais circundantes. Saber lidar com o meio ambiente e com a sociedade soteropolitana desembocou sobre a constituição de formas específicas de proceder, mas o conhecimento e o aproveitamento dos recursos alimentares locais não anulou o fato que a população colonial continuou a compartilhar valores fundamentais com a população lusa da metrópole.

\footnotetext{
1085 CABRAL de MELLO, Evaldo. Op. Cit.

1086 FREYRE, Gilberto. Casa grande e senzala. R J., J. Olympio, 1966.
} 
Os versos do poeta, longe de evidenciarem a existência de um processo passivo de distanciamento em relação à naturalidade de origem, indicavam, pelo contrário, uma rejeição do poeta, e de seus pares que se diziam mazombos, ao paladar de uma grande parte dos ingredientes e dos preparos locais. O exame comparativo do consumo de pães e de produtos que incorporavam farinha de mandioca, revelou-se particularmente significativo em termos da formação, senão de uma identidade, pelo menos de uma auto definição pessoal dos colonos. Se, no final do século XVI ou em meados do século XVII, colonos ricos, como Gabriel Soares de Sousa, procuravam demonstrar importância social pela posse de um grande número de escravos dedicados ao provimento de sua mesa, entre os quais figuravam escravos que preparavam farinhas frescas, consideradas mais saborosas, já a situação parecia ter mudado no período da permanência soteropolitana de Matos.

A tripla fronteira disciplinar entre Literatura, História e Antropologia, vista pelo prisma das metáforas alimentares de Gregório de Matos conduziu efetivamente a investigação à questão do nativismo, ou seja, à questão dos sentimentos experimentados por colonos dotados de corpos sociais e simultaneamente de corpos físicos que precisavam nutrir de maneira honrosa, praticando escolhas representativas de ingredientes. Como observou Fischler ${ }^{1087}$, além do efeito fisiológico proporcionado pela ingestão, os alimentos cujas substâncias são escolhidas para serem incorporadas à própria pessoa, carregam significados, isto é, idéias valorativas que lhes facultam também o exercício de efeitos simbólicos:

“Essa representação da incorporação parece de fato traduzir uma característica essencial da relação do homem com seu corpo. É ela que parece fundamentar a tentativa, constante da maior parte das culturas, de dominar o corpo e por seu intermédio, o espírito, a totalidade da pessoa e, portanto, a identidade" ${ }^{1088}$.

\footnotetext{
1087 FISCHLER, Claude. Op. Cit., Capítulo “As funções do culinário”. pp. 60 a 88.

1088 FISCHLER, Claude. Op. Cit., Capítulo “As funções do culinário”. P. 81.
} 
O tom irônico das referências de Matos ao caruru, ao xinxim e à moqueca atestava a mudança. O retrocesso conservador à ortodoxia de uma dieta metropolitana do poeta acompanhava, aliás, um repúdio dos cristãos velhos de boa cepa às camadas mestiças ou pobres da população livre, das quais as elites soteropolitanas pareciam querer se distanciar idealmente. Pois, numa sociedade onde viver de trabalhos manuais era fator de desqualificação social, situações financeiras precárias prefiguravam sinais potenciais de desonra e os cardápios das refeições (próprias ou alheias) constituíam um tema associado intrinsecamente à classificação social de cada soteropolitano.

Que Gregório de Matos tenha dado preferência às metáforas alimentares para criticar, em seus poemas, o funcionamento da administração econômica e política da colônia teve muito a ver também com o uso medieval das metáforas corporais como fonte de representação social. Segundo Jacques Le Goff ${ }^{1089}$, com efeito, a importância das comparações entre organização social, anatomia corporal e fisiologia do corpo se revelou fundamental na expressão teológica medieval. O apólogo poético dos membros e do estômago remontava pelo menos até as fábulas de Esopo: “Logo, é provável que a utilização política das metáforas corporais seja um legado da Antigüidade greco-romana ao cristianismo medieval"1090.

Nesses termos, o consumo de uma dieta alimentar colonial que comportava numerosos ingredientes locais não resultou numa rejeição dos colonos em relação a sua origem lusa. Desejar comer a carne delicada de animais sul-americanos como os tatus, saborear cajus refrescantes ou participar de expedições de colheitas alegres nas ilhas do Recôncavo em épocas de safra das frutas não transformou, senão a longo prazo, os colonos lusos ou os mazombos em brasileiros, fossem eles educados em Portugal ou não. Seriam necessárias fraturas mais importantes que a distância atlântica para romper o cordão umbilical entre a metrópole e a colônia. Sérgio Buarque de Holanda observou:

1089 LE GOFF, Jacques e TUONG, Nicolas. Uma história do corpo na Idade Média. Rio de Janeiro, Civilização Brasileira, 2006. pp. 161 a 167.

1090 LE GOFF, Jacques e TUONG, Nicolas. Op. Cit., p. 162. 
“Renascimento, Barroco, Neo-classicismo setecentista correspondem a formas ou, para usar o termo consagrado entre modernos historiadores das artes plásticas, a vontades de expressão bem definidas e que se expandiram através de todo o mundo da civilização européia. Partindo dessas formas gerais, das idéias e modos de sentir que lhes correspondem, cumpre examinar até onde puderam ser representadas no Brasil ou afetadas pelas condições do nosso meio.

Tal critério eliminaria os escrúpulos de certos historiadores que, precisamente à falta de razões mais ponderáveis se apegam às da naturalidade como único elemento para determinar a "nacionalidade" brasileira ou portuguesa deste ou daquele autor"1091.

O historiador argumentava ainda:

"Dessa fidelidade ao pequeno rincão de origem pode se dizer, quando muito, que representa um patriotismo da espécie paroquial, patriotismo que como se sabe, costuma ser tanto mais exacerbado quanto mais deliberado e consciente. É um erro de perspectiva querer equipará-lo ao que em nossos dias, chamamos consciência nacional’1092.

Sílvio Romero, entretanto, considerou Gregório de Matos como um genuíno fundador da poesia lírica brasileira:

“Gregório é o genuíno iniciador da nossa poesia lírica de intuição étnica. O seu brasileiro não era o caboclo, nem o negro, nem o português; era já o filho do país, capaz de ridicularizar as pretensões separatistas das três raças" ${ }^{1093}$.

\footnotetext{
1091 HOLANDA Sérgio Buarque. Op. Cit., p. 411.

1092 HOLANDA Sérgio Buarque. Op. Cit., p. 410.

1093 ROMERO, Silvio. in MATOS, Gregório de. Crônicas do viver baiano seiscentista. Obra completa de Gregório de Matos, 7 Vol., Amado, James (Org.). Bahia, Ed. Universitária, sem data.
} 
O sentimento nativista dos lusos estabelecidos na região soteropolitana emergiu certamente em algum momento mais tardio, ao longo do processo de apropriação do espaço territorial brasileiro, quando seus descendentes e a população mestiça resultante do convívio com índios e africanos passaram a dissociar os interesses da metrópole dos seus próprios. Se houvesse em curso, ao término do século XVII, um processo de estranhamento entre colônia e metrópole, ele pressuporia indícios tangíveis de gretas na lealdade dos colonos à terra de origem. Viver em Salvador à moda local era situação que não implicava forçosamente um distanciamento ideal. Se os mazombos desenvolvessem então a consciência de serem brasileiros, e não mais portugueses, o fato se refletiria provavelmente em sua dieta alimentar. Porém, os hábitos alimentares das elites coloniais soteropolitanas, perscrutados por meio da leitura da obra de Matos, letrado e filho de lavrador de cana (pertencente à parcela dos colonos que, segundo Schwartz, mais sofreu perda de status na crise do açúcar dos anos 1680), longe de demonstrarem rejeição simbólica à alimentação lusitana e apego específico às iguarias locais, apenas assinalavam o desprestígio que advinha de se consumir mingaus de carimã, caldos de aratus, moquecas de peixinhos embrulhadas nas folhas de bananeiras, ou sucos de caju fermentados, iguarias que os cronistas da primeira metade do século XVII saboreavam sem ver desdouro em ingeri-las.

O caráter de mazombo explicitamente reivindicado pelo poeta prolongava, portanto, a origem lusa da família. Mesmo revelador de tensões sociais nas interações entre colonos e metrópole, reforçadas pelo descaso de algumas autoridades em relação ao estilo de vida local, o ponto de vista do poeta não poderia ser caracterizado como nativista. A atribuição da culpa pelos desmandos, todavia, fosse o poeta sincero ou somente prudente, recaía antes sobre a ação individualizada, relapsa de autoridades municipais ou judiciárias e de governadores, do que sobre a política colonialista propriamente dita.

Que Matos, por outro lado, recorresse aos serviços sexuais de moças providas de cricas cor de azeitonas não afetava sua própria corporeidade tanto quanto se escolhesse alimentar-se de preparos à moda indígena ou africana. À vista do tom de mofa utilizado pelo autor nas menções a tais preparos alimentares, não parece que já houvesse ocorrido uma integração cultural, paralela 
à mestiçagem física, de uma proporção importante da população colonial. Era duvidoso que os senhores de engenho se deliciassem livremente comendo os preparos de uma arte culinária soteropolitana concebida como uma fusão de procedimentos de preparo com origens diversas. Nada indicava que tais preparos encontrassem já guarida nas cozinhas senhoriais.

$\mathrm{Na}$ medida em que o contingente dos escravos alforriados se avolumava na cidade, aumentava, porém, a probabilidade de outras técnicas culinárias serem incorporadas e de novos ingredientes serem comidos no espaço territorial da capitania real. Quem comeria semelhantes preparos era a questão. A mescla peculiar de elementos humanos ocorrida na colônia, reforçada pelas interações sexuais entre senhores e escravas, resultou obviamente no nascimento de uma população mestiça. Talvez gerar mulatos e mamelucos com escravas bem apessoadas fosse uma fatalidade da vida colonial brasileira, isenta de macular a honra dos procriadores. Mas, apesar do paralelo freqüente entre cama e mesa na linguagem metafórica, à mesa, onde os próprios corpos e o próprio sangue fabricado com alimentos e condutas idôneas estavam em jogo, os colonos, a crer os versos de Matos, precisavam se mostrar cautelosos numa sociedade afeita a dar precedências à hierarquia social. Se todos os colonos assim procediam ou não, era outro problema. A questão que se impunha era provavelmente determinar em que medida a presença de fidalgos do pernil tostado alforriados afetaria o conjunto da sociedade, ao necessitar de um lugar na hierarquia social e de fontes de rendimentos para sobreviver. Como sublinhou Serge Gruzinski, ao comentar a colonização mexicana:

"Esse tempo linear carrega a sempiterna questão das origens, que, por sua vez, implica a idéia de uma autenticidade ou de uma pureza passada a ser reencontrada. E isso deve incitar-nos a redobrar a prudência quando procuramos identificar no século XVI ibérico as primícias de fenômenos que hoje parecem ocupar o primeiro plano da cena planetária: mestiçagens e globalização. Ora as mestiçagens quebram essa linearidade. Surgindo na América do século XVI, na confluência de 
temporalidades distintas - as do Ocidente cristão e dos mundos ameríndios - elas as colocam brutalmente em contato e as imbricam umas nas outras" ${ }^{\prime 1094}$.

O problema de se buscar retroativamente as fontes originais de mudanças ocorridas em épocas posteriores residiria, portanto, na própria hipótese presentista, que excluiria o contexto local como cadinho formador de significados. No caso, acompanhar de perto as críticas que Gregório de Matos endereçou à vida alimentar soteropolitana revelou um momento delicado no processo da formação de uma identidade local. A tentativa simbólica do poeta de desmerecer várias categorias sociais da população, que estavam firmando presença no panorama colonial, e de impedir que desfrutassem de prestígio social, atribuindo-lhes consumos alimentares vergonhosos, não condiz com as representações idílicas de uma integração progressiva entre conhecimentos culinários lusos, indígenas ou africanos e com o assentimento benevolente dos senhores de engenho saboreando de imediato iguarias preparados pelas negras da cozinha.

Seus poemas parecem ter procurado revivificar distinções à moda antiga, fundamentadas na idoneidade dos corpos (a limpeza do sangue) e das condutas sociais da população, definindo através de um crivo tradicional quem era quem na colônia. Em tais circunstâncias, o apego reforçado ao consumo de iguarias portuguesas em Salvador era, talvez, um sinal prenunciando futuros afastamentos e poderia ser interpretado como uma tentativa de preservar vínculos afrouxados sob o impacto de um grande contingente de população mestiça livre e de portugueses pobres crescido à sombra do viver nobre dos mazombos, cujos hábitos alimentares, por falta de recursos, afiguravam-se outros. Mesmo que se detecte um certo desconforto na arte poética de Matos, ele teve pouco a ver com a devoração de uma imagem paterna lusa, o parricídio cultural, imaginado por Lúcia Helena:

"O percurso histórico da literatura brasileira registra ao longo de seu desenvolvimento, o estigma de todas as culturas originadas da dominação; a

1094 GRUZINSKI, Serge. O pensamento mestiço. São Paulo, Cia. das Letras, 2001. p. 58. 
dependência cultural, expressa no transplante de formas, temas e modelos. [...] No entanto a crítica determinada pela consciência da sujeição já se manifesta no período colonial, através da voz brasileiríssima de Gregório de Matos. A partir de seu grito, a consciência nacional está nas ruas: com maior ou menor vigor nesta ou naquela fase, ela atravessa a nossa história literária no sentido de eliminar o transplante inicial e definir a natureza de um projeto literário inconfundivelmente brasileiro" 1095 .

\section{A questão da dieta mínima}

Ao analisar as informações sobre os procedimentos de alimentação soteropolitanos coletados na obra de Gregório de Matos ou nos textos de cronistas do período colonial brasileiro, uma noção implícita, porém atuante na organização da dieta, foi sugerida pela leitura dos poemas do autor: a noção de uma dieta mínima ${ }^{1096}$. Se na Ásia existia uma complementaridade reconhecida do fan/tsaï (arroz e complementos) ${ }^{1097}$, se na Europa o pão e o vinho ofereciam um dos menores denominadores comuns de refeição razoável (mesmo nas dietas de camponeses nutridos com sopas de vegetais), no Nordeste brasileiro, os colonos pareciam considerar como sustento mínimo necessário uma refeição composta de carne e de farinha de mandioca seca, nos dias onde a igreja autorizava o consumo de carnes, e de farinha de mandioca e de peixes em dias de abstinência de carnes.

O empréstimo aos hábitos alimentares dos tupi da costa brasileira, como a análise da obra de Matos permitiu constatar, não impediu várias outras substâncias nutritivas, frescas e sumarentas, de enriquecerem as refeições. Frutas, hortaliças, ovos, doces etc., complementaram

1095 HELENA, Lúcia. Uma literatura antropofágica. Op. Cit., pp. 11 e 12.

1096 Conceito proposto nessa tese e que poderia ser definido como o menor denominador comum de uma dieta alimentar satisfatória, envolvendo diversos mantimentos básicos complementares.

1097 CHANG, Kwang Chi. Food in Chinese culture: anthropological and historical perspectives. New Haven\&London, Yale University Press, 1977. 
normalmente a farinha seca ou os beijus. Esses, acompanhados de carnes ou de peixes também figuravam como um mantimento básico e garantiam um sustento armazenável estratégico para fazer frente a momentos específicos de carência alimentar ${ }^{1098}$. Os escravos que tinham oportunidades restritas de acesso aos alimentos e, por vezes, limitavam sua alimentação à ração (quando os senhores escolhiam lhes fornecer rações), não recuavam diante do furto de ovos, de canas de açúcar e de frutas para incrementar sua dieta. Quando conseguiam, se apoderavam até de algum cavalo de preço, imediatamente sacrificado. Além da garapa doce ou azeda, que recebiam às vezes, e dos caranguejos e dos grãos ou das raízes feculentas, carás, taiobas, aipins, batatas, feijões etc., obtidos com relativa facilidade, eles gostavam ocasionalmente de assar algum roedor ou réptil capturado durante o trabalho no eito ${ }^{1099}$.

Beijus ou farinha com peixes ou carnes, cozidos em caldos apimentados, asseguraram um esteio mínimo à dieta soteropolitana, garantindo aos colonos, senão o luxo, pelo menos um sustento básico complementado com a adição de outros víveres. Para ricos e pobres, o esteio da dieta alimentar residiu efetivamente nesse consumo de carnes ou de peixes, secos ou frescos, e de farinha, substituída quando possível por pães, broas, brotes ou biscoitos ${ }^{1100}$ nas mesas abastadas, para as quais era questão de honra continuar a praticar hábitos lusos de alimentação. Numa colônia que outorgava uma imensa importância aos critérios aparentes da hierarquia social, as iguarias saboreadas demonstravam de maneira simbólica a localização dos anfitriões na escala social. Os colonos apreciavam tais mantimentos, tanto no plano material do paladar e da energia provida aos corpos, quanto no plano ideal da afirmação da idoneidade social dos comensais.

A preferência daqueles que se encontravam em situação de escolher o que comeriam, ia para o consumo de carnes frescas e, sobretudo, para os melhores pedaços de quartos traseiros de carnes bovinas, mais macios que os dianteiros. Pagos por libras, em preços tabelados, eram

1098 Cf. PAPAVERO, Claude, Dissertação de mestrado. Op. Cit.

1099 ALDENBURGK Johann Gregor. Relação da conquista e perda da cidade do Salvador pelos holandeses em 1624 - 1625. Brasiliensia Documenta, Vol. I, 1961.

1100 Cf. capítulo III. 
disputados nos currais ou nos açougues da cidade em termos do prestígio do dono do escravo encarregado de comprá-los. Entre os víveres (conjunto de todos os alimentos), ressaltava o valor estratégico atribuído aos ingredientes considerados mantimentos. Dispor de reservas suficientes desses gêneros escolhidos como staple food garantia um sustento de segurança à população, permitindo que medidas de abastecimento fossem instituídas em casos de catástrofes. Carne e peixe, sob forma de ingredientes secos ou salgados e farinha podiam permanecer armazenados por longos meses nos trapiches, nos galpões, que margeavam a orla do mar na parte baixa da cidade, nas lojas ditas de portas abertas, que entre outras mercadorias vendiam itens alimentícios a retalho, e nas despensas das casas soteropolitanas, fossem elas residências urbanas ou rurais.

Adenominação de mantimento atribuída pela população colonial a esses gêneros diferenciados lhes conferia visibilidade primordial. Os impostos arrecadados para fazer frente aos gastos da gestão colonial provinham sobretudo de taxas cobradas com a venda desses gêneros ao público colonial e resultavam numa vigilância estreita e cotidiana da Câmara e dos almotacés sobre os procedimentos da comercialização. De vez em quando, promulgavam-se medidas autoritárias para impor a colonos, que podiam produzi-los em suas terras, uma ampliação confortável do volume disponível desses produtos. Uma dieta mínima de manutenção da saúde e da vida, desempenhou, por conseguinte, um papel fundamental na alimentação e monopolizou a atenção das autoridades e dos colonos.

Diversos outros ingredientes comestíveis obtidos localmente também poderiam ter servido de mantimento substancioso, como o arroz ${ }^{1101}$. Esse cereal, pouco produzido até meados do século XVII, já parecia constituir um gênero alimentício de presença notada nas últimas décadas desse século. Até mesmo escravos (nos engenhos onde dispunham de um pedaço de terreno e de tempo alocado para cultivar hortas próprias) desejavam produzi-lo para vendê-lo na cidade, contribuindo dessa forma à constituição de um pecúlio destinado à compra de sua manumissão ${ }^{1102}$.

\footnotetext{
1101 Importado da Península Ibérica a crer Manuel Botelho de Oliveira.

1102 SCHWARTZ, Stuart. Escravos roceiros e rebeldes. Bauru, EDUSC, 2001. p. 113.
} 
Os feijões nativos e as batatas-doces (que serviam de mantimento básico entre os havaianos na preparação do poi, uma massa de batatas-doces fermentadas), foram comidos até por pessoas abastadas, porém sem grande entusiasmo. Consideravam-nos causadores de flatos inconvenientes e apropriados às pessoas rústicas. A escala de nobreza ou de desonra atribuída aos diferentes tipos de ingredientes comestíveis afigurou-se, portanto, de suma importância como fator de coesão do grupo. Quem não podia contar com melhores opções de provimento contentava-se com a ingestão dos alimentos vegetais menos valorizados, sua grande vantagem consistindo em assegurar estômagos cheios à população mais pobre. O milho, por sua vez, situado no sopé da escala social extremamente hierárquica estabelecida pelos colonos da terra, provia angus aos escravos e alimentava os animais domésticos.

Quanto às bananas introduzidas na colônia pelos portugueses, à diferença das bananas da terra sulamericanas, não necessitavam de cocção. Eram saborosas, seu preço resultava módico e podiam ser transportadas facilmente sem que os cachos se deteriorassem imediatamente. Elas foram promovidas, por esse motivo à condição de mantimento substituto, proporcionando merendas rápidas e sem grandes compromissos. Versejando uma excursão à ilha Grande, Matos como já visto, descrevia:

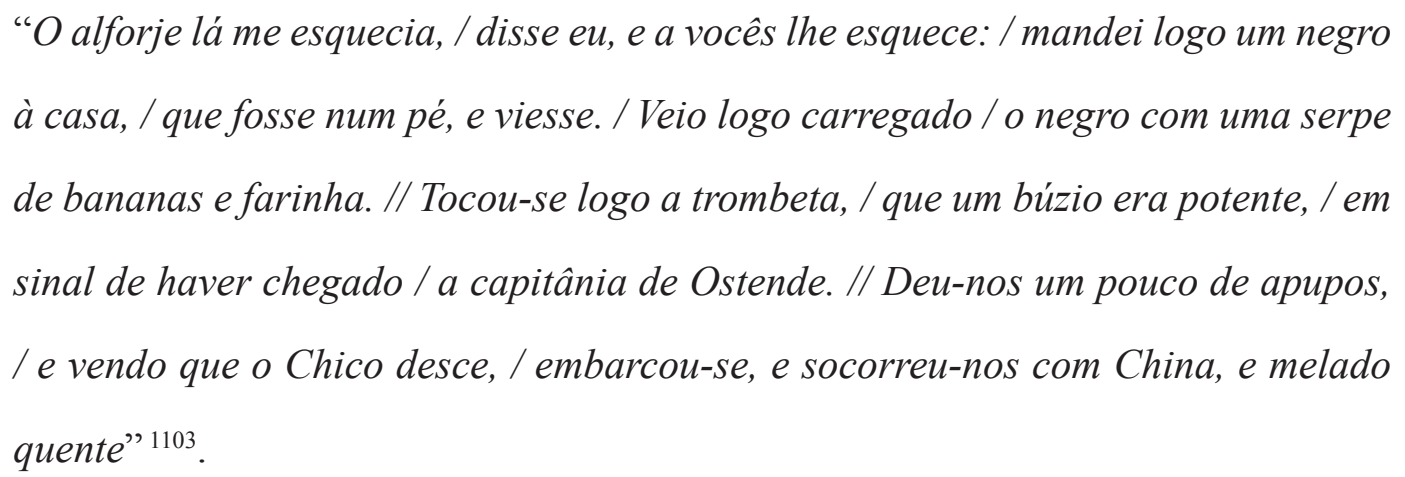

Eram também bananas com farinha que o padre Damásio da Sylva, estava condenado a comer, quando não o convidavam para o jantar. Não dispor de recursos numa sociedade onde a pecha de indigente ou de avarento afigurava-se especialmente desabonadora, trouxe à tona uma

1103 MATOS, G. Op. Cit., Vol. III, pp. 608 e 609. 
noção explícita de merenda mínima depauperada. Como já se viu no capítulo II, o ataque contra o padre desfechado pelo poeta calcava fundo:

"para passar todo um ano / nem dois vinténs faz de custo: / Que os amigos o sustentam, / e lhe dão como de juro / o jantar, quando lhes cabe / a cada qual por seu turno / Essa vez, que tem dinheiro, / que é de sete em sete lustros: / três vinténs com um tostão, / ou dois tostões quando muito: / Com um vintém de bananas, / e de farinha dous punhos, / para passar dia, e meio / tem certo o pão e conduto:" 1104 .

A noção do conduto sobressaía na dieta. Segundo o Diccionário Moraes considerava-se conduto: "Aquilo que se come com o pão; carne, peixe". Se pães ou farinhas proviam o pão $\mathrm{O}^{1105}$, isto é o sustento básico, os demais itens que complementavam o repasto forneciam o conduto. Que o consumo indígena de frutas, por vezes, dotadas de oleosidade tenha sido acompanhado freqüentemente de farinha de mandioca, instituía um parâmetro limítrofe de aceitabilidade, a fruta ocupando então o lugar da carne. Compunham uma versão abreviada, mínima e frugal de dieta básica mas ainda assim, ofereciam uma refeição apreciada e saborosa.

Manuel Botelho de Oliveira, autor de Músicas do Parnasso desenvolveu um raciocínio bastante semelhante em seus versos ufanistas dedicados às produções agrícolas na Ilha de Maré e atribuiu também às bananas o poder de substituir o próprio pão em caso de necessidade:

1104 MATOS, G. Op. Cit., Vol. II, pp. 278 e 279.

1105 FLANDRIN, Jean Louis. “A alimentação camponesa em economia de subsistência”, in FLANDRIN, J. L. e MONTANARI, Massimo (org) História da alimentação. São Paulo, Estação Liberdade, 1996. p. 593.

“O predomínio do pão era bem marcado na Idade Média, pelo conceito do 'companage’, termo que designava o que acompanhava o pão: o conjunto de condimentos e alimentos complementares. O fato de este termo ter caído em desuso na Idade Moderna, não significa o desaparecimento dessa realidade, nem da consciência que dela se tem. Até o século XX, faz-se a distinção, no campo, daquilo que nutre - o pão ou outro alimento básico destinado a ser comido em quantidade - dos outros alimentos, que de certa forma são vistos como temperos". 
"As bananas do mundo conhecidas / por fruto e mantimento apetecidas, / Que o céu para regalo e passatempo / Liberal as concede em todo tempo, / Competem com maçãs ou baonesas / Com pêros verdeais ou camoesas. / Também servem de pão aos moradores, / Se da farinha faltam os favores; / É conduto também que dá sustento, / Como se fôsse próprio mantimento; / De sorte que por graça ou por tributo, / É fruto ,é como pão, serve em conduto" $" 1106$.

Eram bananas, por exemplo, que proviam uma vida rústica e idílica a Matos em sua casa perto do Dique ${ }^{1107}$, e bananas com pastéis e doces que compunham o desjejum do poeta, após uma noitada com alguma moça. Essa última referência, entretanto, mesmo assinalando um gosto provavelmente verídico do poeta, por doces, pastéis e bananas - alimentos de forte presença em seus versos - não excluía a possibilidade de figurar também alusões de duplo sentido, já que o autor costumava repetir que o amor era doce:

"Quer-me mal esta cidade pela verdade, / [...] // Tirara cinzas tiranas

das bananas / Outro se os meus dez réis de pastéis, / E porque isento não fosse até do doce. // Teria assim com que almoce / o meu amancebamento, / pois lhe basta por sustento / Bananas, Pastéis, e Doce"1108.

A população mazomba transformou, assim, os ingredientes do sustento básico em massas pastosas de consistência entre o úmido e o seco, que acreditavam prover equilíbrio à digestão, adotando nesse ponto procedimentos alimentares nativos, a despeito das frutas referidas por Matos não serem as bananas da terra, porém variedades dessas frutas introduzidas pelos colonizadores.

\footnotetext{
1106 In SILVA, Rogério Forastieri. Colônia e nativismo: a História como "biografia da nação". Op. Cit.

1107 MATOS, G. Op. Cit., Vol. V. p. 1221.

1108 MATOS, G. Op. Cit., Vol. I, pp. 29 e 30.
} 


\section{A assim chamada questão da integração social das três raças}

A idéia, apresentada por Von Martius ${ }^{1109}$, de um rio misturando intimamente águas de procedências diversas para simbolizar a contribuição de brancos, negros e indígenas à brasilidade emergente serviu de referência para refletir sobre o teor das interações sociais efetivadas numa sociedade seiscentista ainda pouco afeita a apreciar semelhante representação simbólica. Ao se tornar estereótipo e perdurar, o conceito elaborado no século XIX mascarou o fato das contribuições culturais de cada um dos grupos humanos que deu forma ao estilo de vida colonial, serem efetuadas de forma assaz compulsória e pouco igualitária. O entrelaçamento complexo de procedências, de etnias e de condições sociais representadas na colônia deu lugar a interações sociais altamente hierárquicas, justapondo de modo assimétrico diversos grupos sociais, cujo aporte ao estilo de vida soteropolitano se deu por meio de empréstimos forçados de conhecimentos ou de técnicas locais, isto é, de saberes transformados em fatores de poder, ou por meio do fornecimento de trabalho braçal, permitindo uma apropriação lusa eficaz do território, que obliterou o caráter predatório das contribuições exigidas. Numa sociedade que reservava maior poder de decisão e oportunidades sociais aos colonos que menos exerciam atividades físicas produtivas, não surpreende que as formas materiais da vida cultural, sustentadas por hábitos alimentares pensados idealmente, possuíssem um valor heurístico e identitário tão exposto à hierarquização.

A colonização lusa bem sucedida ao enxertar núcleos de povoamento nas melhores angras do território sul-americano, não prescindiu do auxílio indígena em seus primórdios. Aliar-se aos principais chefes indígenas, guerrear e aprisionar nativos que, teoricamente, eram os inimigos dos inimigos e que, tornando-se escravos, poderiam ser salvos de serem comidos; ou, algumas décadas depois, adquirir nos portos da costa africana uma mão-de-obra cativa, que desfrutaria das vantagens inestimáveis da conversão ao catolicismo, foram estratégias locais. Enquanto aliados, os índios ditos mansos contribuíram de boa vontade ao bem-estar dos forasteiros

1109 VON MARTIUS, Karl Friedrich Philipp “Como escrever a História do Brasil”, in Revista do IHGB.t. 6. 1844. 
com seus conhecimentos dos recursos do meio ambiente e seus escambos voluntários mas, na medida em que um maior número de colonos recém-chegados, ávidos de terra e de mão-de-obra que lhes granjeasse fortuna, passaram a cobiçar serviços de catecúmenos para sobreviverem e enriquecerem, a boa vizinhança cessou. Mortos por epidemias letais de febre amarela, de tuberculose e de varíola ou por se rebelarem contra medidas autoritárias, fugindo para outras paragens ou sendo incorporados à população colonial, os índios tupi da faixa costeira cedo deixaram de reivindicar um domínio que lhes escapava sobre o litoral atlântico. Já em meados do século XVII, a quantidade de nativos que se gastara em tão pouco tempo provocava o espanto luso ${ }^{1110}$.

Se em meados do século XVI, o parentesco dos colonizadores com chefes indígenas constituía um motivo certeiro de prestígio social, percebe-se nos poemas de Matos uma mudança notável ocorrida nas representações. Talvez, o desaparecimento efetivo dos grandes aldeamentos tupi no espaço do Recôncavo Baiano teria, favorecido a emergência de preconceitos, pois o distanciamento da população lusa em relação aos nativos tornou desnecessário afagá-los para manter sem ameaças a posse do território. Mesmo que todos os colonos não apreciassem os sarcasmos do poeta contra alimentos reconhecidos como emblemáticos de uma sociabilidade indígena, o rancor do poeta e sua depreciação dos descendentes dos Paiaiá antropófagos (que ele também chamava Cobé ou Tapuia ${ }^{1111}$ ), evidenciavam uma idéia que provavelmente ia se alastrando. De modo que o repúdio paradigmático ao principal ingrediente fresco obtido a partir de raízes de mandioca, a farinha de carimã, seria antes simbólico que gustativo. Matos, porém, empenhado em fazer pouco dos descendentes de nativos alcunhados pelo termo pejorativo de cabras (substituindo as denominações anteriores: mamelucos ou caboclos), parecia conhecer demais as iguarias indígenas para não tê-las provado, evidenciando sua permanência nos preparos coloniais.

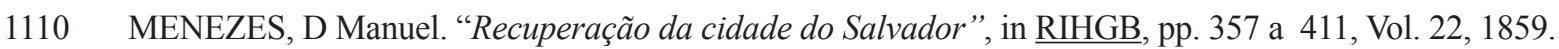

1111 Pertencentes ao tronco Jê. O padre Simão de Vasconcelos, escrevendo por volta de 1666, enfatizava sua dieta alimentar distinta daquela dos índios da costa.

VASCONCELOS, Simão de. Notas curiosas \& necessárias das cousas do Brasil. Lisboa, João da Costa, 1668. 
A idéia do corpo fisiológico nutrido por alimentos, cujo provimento, preparo ou consumo envolvia gestos determinantes para a qualidade do sangue correndo nas veias dos comensais, adquiriu um valor classificatório tão marcante nos versos do autor que o conjunto de sua obra traçou uma descrição coerente da concepção do poeta sobre a sociedade soteropolitana. Matos, encenando atos alimentares inteligíveis para seus conterrâneos, retratou a maneira de pensar dos colonos por meio de uma urdidura de significados, seja numa reificação insultuosa de partes dos corpos, como no caso dos sexos de homens metonimicamente transformados em nabos, carás ou mangarás amorfos, seja nas alusões a consumos indevidos, como no caso da ingestão de carne de baleia por homens livres, seja ainda nas menções depreciativas a profissões ligadas à venda a varejo de alimentos. $\mathrm{O}$ estilo de vida local, construção cultural soteropolitana, promovia, por conseguinte, entre seus principais elementos, uma dieta alimentar norteada por princípios acreditados e por escolhas seletivas de ingredientes aos quais propriedades nutritivas ideais eram atribuídas. Sobressaía, dessa forma, o conceito de um escalonamento social hierárquico dos colonos em função das atividades profissionais exercidas, da nobreza dos ascendentes e dos gastos efetuados e ainda da conveniência simbólica das refeições que podiam colocar à mesa.

Foi a presença de escravos no eito, nas casas, no porto ou nas ladeiras da cidade que libertou muitos portugueses de terem de trabalhar com as próprias mãos, permitindo que os senhores de escravaria numerosa gastassem em despesas suntuosas os lucros proporcionados pelo trabalho dessa mão-de-obra. Foi o trabalho dessas mulheres e desses homens cativos que deu asas à noção honrosa que os colonos tinham de sua própria importância, oferecendo a pícaros ousados perspectivas almejadas de enriquecimento e de ascensão social no ultramar. A emergência do valor da honra como guia das condutas soteropolitanas, exacerbando parâmetros emprestados aos velhos códigos medievais, não se desenvolveria com o mesmo vigor se os novos homens bons não dispusessem de braços, pernas, pés e costas alheios para carregar mercadorias da cidade alta para a cidade baixa, para remar canoas, moer canas, buscar águas, levar dejetos etc.. Nutridos de alimentos grosseiros, de custo reduzido, que os senhores julgavam convenientes à sua natureza inferior pois, segundo se acreditava, alimentos refinados causariam danos a 
sua saúde ${ }^{1112}$, os escravos forneciam jornadas de trabalho geralmente extenuantes. Na cidade, nem todos moravam na casa dos senhores, muitos viviam em casebres situados na periferia da cidade $^{1113}$ e alugavam seus serviços como negros de ganho, entregando aos senhores quantias em dinheiro (cf. os pais do ganho que levaram Matos em sua excursão ao Rio Vermelho). Teriam talvez nesses casos oportunidades para escolherem suas próprias comidas e na medida do possível integrarem procedimentos culinários africanos conhecidos com os gêneros alimentícios encontrados no meio ambiente regional.

O intento conservador de Gregório de Matos, desejoso de preservar o estilo de vida local dos homens bons da colônia (em sua maioria proprietários de terras), e o uso que o autor fez do termo mazombo, utilizado como sinônimo aproximativo da denominação homem bom, indicava a falta de fundamento nas interpretações de sua obra, que lhe conferiam a honra de ter sido o primeiro poeta de expressão brasileira. Ao se insurgir contra os mascavamentos em curso na sociedade local, Matos, por meio de imprecações satíricas, conseguiu a façanha paradoxal de atestar simultaneamente a emergência de uma sociedade mestiça soteropolitana e a resistência das elites à desagregação dos valores instituídos durante a livre expansão da rede de canaviais e de engenhos, entre 1580 e 1624, antes que as investidas da Companhia das Índias Ocidentais holandesa no Brasil afetassem a prosperidade colonial.

Tal radicalização apontava para a falácia de se conceber um processo unívoco de deslusitanização no ajustamento dos portugueses às condições materiais e sociais da região soteropolitana. A valorização repentina de uma ortodoxia alimentar lusa, procedimento que parece despontar no 1112 HENRIQUEZ, Francisco da Fonseca, Âncora medicinal: para conservar a vida e a saúde. Op. Cit.

1113 MARINS, Paulo César Garcez. Através da rótula: sociedade e arquitetura urbana no Brasil, séculos XVII a XX, São Paulo, Humanitas, FFLCH-USP, 2001. pp. 74 e 75.

"Dessa pretensa reclusão não podiam partilhar certamente a grande maioria dos soteropolitanos ou forasteiros que habitavam a maior parte das casas humildes da cidade. Erguidas no mais das vezes em materiais provisórios como o pau-a-pique, essas moradas nem mesmo chegaram a sobreviver como aquelas suas contemporâneas faustosas, que atravessariam os séculos seguintes testemunhando a ilusão de que a Salvador colonial compunha-se apenas de habitares estáveis e ricos, erguidos em pedra e cal. O costume de se permitir que escravos habitassem fora das casas dos senhores favorecia, aliás, o crescimento desregrado da cidade e a expansão de um casario de que não resta traço nos distritos históricos da atual capital baiana, mas que eram muito presentes em 1729..." 
último quartel do século XVI, e a virulência dos sarcasmos estigmatizando portadores de sangues impuros, ridicularizados por meio dos ingredientes alimentares impróprios que ingeriam, contradizia a noção ideal de um abrasileiramento progressivo e tranqüilo dos forasteiros, abertos à incorporação de hábitos alimentares indígenas, africanos ou cristãos novos na dieta alimentar da nova sociedade.

As construções estereotipadas de categorias sociais representadas pelo poeta por meio de hábitos alimentares classificatórios, pertenciam ao domínio de uma invenção das tradições locais $^{1114}$. Contudo, os elementos utópicos ressaltavam. As elites coloniais que desfilavam suas mazelas nos versos de Matos, defensor de uma honra local fidalga e perdulária, reivindicavam uma identificação pessoal que prolongava a origem lusa e faziam questão de se diferenciar dos comerciantes onzeneiros e avarentos que, no afã de enriquecimento imediato, consumiam carne de baleia como os escravos, ou verduras sem temperos e acabavam prosperando com uma certa conivência das autoridades coloniais.

Matos ao precisar se queixar de atropelos aos códigos culturais e sociais demonstrava que modos de agir pragmáticos também tinham curso em Salvador, a despeito da preeminência das representações dos colonos de maior peso social.

Que as camadas menos favorecidas da população não se tenham deixado enredar de bom grado nos códigos aristocráticos preconizados por Matos e seus pares faz sentido, da mesma forma que a generalização seiscentista do termo mazombo como auto denominação da população branca, nascida na colônia. Os colonos lusos que cerca de quarenta anos antes, se consideravam apenas como formando uma sociedade de "moradores portugueses do Brasil" 1115 passaram, no final do século, a constituir elites nativas, porém não nativistas, sendo que o termo crioulo foi reservado aos escravos nascidos na colônia. Reiterando a informação, destacava-se uma diferença curiosa entre a América espanhola e a América portuguesa pois, se na América

\footnotetext{
1114 HOBSBAWM, Eric e RANGER, Terence. A invenção das tradições. Paz e Terra.

1115 Frei Manuel Calado, antes de 1650, ainda designava a população colonial como "moradores lusos", apesar de Marcgrave, segundo Pedro Calmon já conhecer o termo mazombo. CALADO, Frei M. $\underline{\text { O valeroso }}$ Lucideno e triunfo da liberdade. 2 Vol., BH / SP, Itatiaia / EDUSP,1987.
} 
espanhola, os colonos locais se consideravam criollos $^{1116}$, no Brasil eram negros nascidos na terra que eram chamados crioulos; termo cunhado para diferenciar os cativos ladinos de outros recém-chegados que ignoravam os usos locais.

\section{2 - Os valores culturais que modelaram as práticas alimentares de um estilo de vida}

As metáforas alimentares de Gregório de Matos revelavam a existência de um estilo de vida local, sedimentado em termos coerentes, que parece ter servido de matriz às premissas tácitas soteropolitanas. Tratava-se, aliás, do termo com o qual os colonos designavam as premissas tácitas formais da sociedade soteropolitana que eles desejavam preservar. Os próprios mazombos chamavam de estilo da terra as maneiras de proceder experimentadas, aprovadas pela sociedade local e sedimentadas pelo uso. No último quartel do século XVII, por exemplo, as Atas da Câmara Municipal mencionavam corriqueiramente um "estilo da terra", designando assim o conjunto das formas de agir apropriadas em determinadas situações. Elementos relevantes desse estilo de vida, os hábitos alimentares da população lusa radicada em Salvador, pautavam tanto as atividades econômicas, quanto as atividades de lazer.

A cada novo contrato de comercialização das farinhas firmado entre a Capital e as Vilas de Baixo (do mapa, as localidades situadas ao sul de Salvador), Camamu, Cairu ou Boipeba, para o fornecimento da ração de farinha seca destinada à infantaria, o escrivão que redigia as Atas reiterava a constatação de que os termos do "conchavo" obedeciam ao estilo do costume. O termo estilo dizia respeito ao serviço de Sua Majestade e ao bem comum da colônia. Resultava na transformação de saberes em gestos carregados de significado. A leitura das Atas de conchavos revelava, entretanto, acréscimos de itens que não tinham sido cogitados anteriormente, a cada renovação dos contratos de fornecimento (cestos que deviam conter quantidades estipuladas de produto, proteção

1116 LISS, Peggy K. Origenes de la nacionalidad mexicana, 1521- 1556: la formacion de una nueva sociedad. Cidade de México, Fondo de Cultura Económica. 1996. pp. 207 a 209.

BASAVE, Benitez Agustín. México mestizo: análisis del nacionalismo mexicano en torno a la mestizofilia de Andrés Molina Enríquez. Cidade de México, Fondo de Cultura Económica. 2002. p. 19. 
contra a chuva em barcos cobertos, decisão sobre quem arcaria com o prejuízo em casos e roubos e pirataria etc.):

"a que foram chamados pello Senhor Gouernador o Capitão Geral deste estado Antonio Luis Gonçalves da Câmara e Coutinho para effeito dese fazer entre a Câmara desta cidade e os officiaes da Câmara da dita villa o Conchauo que sempre sefes dafarinha que he nessessário para aReção ordinária da enfantaria desta praça na forma do estillo outro dito..."1117.

O termo, com um sentido semelhante, figurou também no vocabulário de Matos. Foi utilizado, por exemplo, num poema no qual o autor repreendia colonos que abandonavam o estilo nobre dos mazombos para aderir ao estilo costumeiro das práticas mágicas da população africana:

"Não há mulher desprezada, / galã desfavorecido, / que deixe de ir ao quilombo / dançar o seu bocadinho. / E gastam belas patacas / com os mestres do cachimbo, / que são todos jubilados / em depenar tais patinhos. / E quando vão confessar-se, encobrem aos padres isto, / porque o têm por passatempo, / por costume ou por estilo"1118.

Reconhecer a existência de um estilo de vida local era apenas uma maneira dos colonos se auto definirem localmente e não abria então nenhuma perspectiva de ruptura da lealdade que a capital da colônia devia à metrópole. Mesmo que Matos percebesse as injustiças perpetradas contra as elites mazombas, foi sobretudo contra comerciantes desonestos e governadores relapsos que ele centrou o fogo de sua ira, jamais contra o domínio do soberano português. Tampouco ele tomou partido em favor do contingente em expansão da população mestiça livre que estava crescendo à sombra das elites mazombas. Matos ridicularizou sistematicamente as 1117 ATAS da Câmara, 1684 - 1700, 6º volume, Salvador, Prefeitura do Município do Salvador. 1951.

(Documentos históricos do Arquivo Municipal). pp. 150 a 152. (Conchavo de 1690).

1118 MATOS, G. Op. Cit., Vol. I, p. 15. 
camadas menos favorecidas da população soteropolitana que ameaçavam os valores culturais mazombos e escapavam aos padrões elegantes das elites. Como bem observou Peres, num opúsculo referente à denúncia de Matos perante a Inquisição em 1685,

"E são muitas as referências a judeus, judaísmo, cristãos novos, bruxaria, calundu, sodomia, lesbianismo etc, a um padrão religioso e moral de base popular-medieval na tradição - que vincou, de modo permanente, a obra apógrafa de Gregório de Matos"1119.

Um amplo acervo de referências ideais parece ter presidido a configuração dos hábitos alimentares soteropolitanos. Raciocínios implementados em termos filosóficos, econômicos, políticos ou sociais convergiram em torno da implementação dos procedimentos materiais, combinando elementos diversificados de modo a dar coerência às escolhas alimentares dos colonos. No decorrer da pesquisa, três fontes principais de referência destacaram-se na modelagem dos hábitos alimentares. As crenças religiosas revelaram-se fundamentais para entender a constituição dos ritmos alimentares soteropolitanos. A posição social dos comensais também manifestou uma relevância extrema. Quanto às crenças sobre a fisiologia dos corpos humanos, elas ofereceram uma chave indispensável para interpretar o valor que deveria ser atribuído a cada item alimentar, contribuindo de forma decisiva à formação do conjunto.

\section{Religião e corpo social dos mazombos}

Segundo Jean Robert Pitte, tanto no período da Época Moderna como durante a Idade Média, a teologia moral católica continuou a oscilar entre favorecer atitudes rigorosas de jejuns, abstinências e penitências para reprimir as manifestações de sensualidade, ou preferir atitudes mais liberais, considerando que os prazeres da boa

1119 PERES, Fernando da Rocha. Gregório de Mattos e a Inquisição. Salvador, ed. UFBA, 1982. pp. 36 e 37. 
mesa também tinham o poder de elevar as almas. O autor argumentava: "Que se encha a barriga ou que se coma gafanhotos não muda muita coisa para a fartura da graça" 1120 .

Ambos os procedimentos se alternavam na cidade da Bahia. O enquadramento religioso do corpo de colonos necessitados de sustento alimentar e a fé, que nutria o ritmo das principais atividades da comunidade soteropolitana, foram temas de cunho social que perpassaram toda a pesquisa e extrapolaram o âmbito da alimentação, se revelando essenciais à própria expressão da organização social. O corpo social da colônia, cujo controle a religião reivindicava, assinalava a importância moral e política dos atos fisiológicos da nutrição, por meio de atividades sociais traduzidas em ações corporais. Em dias santos, celebrados com grande pompa e alegria, havia banquetes, fartura, oferecimento de vinho, danças, cavalhadas e procissões. Os ritos de passagem familiares também serviam de contraponto à austeridade e proporcionavam ocasiões apreciadas de abundância. Nos dias magros, a população mazomba que gostava de comer carne de vaca, precisava se resignar a comer apenas "peixes frios".

Impor sacrifícios aos corpos ou celebrar festas, às quais o caráter sagrado emprestava brilho, resultava estratégico para que os paroquianos experimentassem com emoção redobrada as alternâncias de fartura e de frugalidade que ritmavam um calendário eclesiástico muito presente. Sacrificar os apetites, submeter-se ao poder de Cristo representado pela igreja equivalia à manter obediência a seus preceitos. Era tal o número dos dias nos quais a igreja proibia o consumo de carnes de quadrúpedes e de gorduras animais, que a amplitude da restrição demarcava vigorosamente o poder simbólico da religião ${ }^{1121}$. As preocupações com uma vivência moral reforçaram, assim, o universo dos preceitos medicinais e da alimentação considerada saudável. Boa digestão e moral, noções

1120 PITTE, Jean Robert. Gastronomia francesa: história e geografia de uma paixão. Porto Alegre, L\& PM., 1993. Cf. pp.42 e 43.

1121 Segundo Montanari: "abster-se de carne é um sinal de humiliação, de marginalização (mais ou menos voluntária, mais ou menos ocasional) da sociedade dos fortes".

MONTANARI, Massimo. Op. Cit., p.28. 
complementares entrosavam-se. Uso de ingredientes disponíveis, formas culturais de alimentação e sanções sobrenaturais se conjugavam, prontos para castigar as imprudências dos indivíduos ${ }^{1122}$.

Alain Drouart, por exemplo, demonstrou como o cristianismo influenciara profundamente a alimentação medieval, estabelecendo jejuns hebdomadários em pelo menos dois dias da semana, às quartas feiras ou às sextas feiras e aos sábados, sem contar os quarenta dias da quaresma e os jejuns que antecediam a ocorrência das grandes festas. Clemente de Alexandria, segundo o estudioso, teria invocado argumentos de ordem medical para conter os excessos alimentares: esquentariam o sangue, permitindo que o corpo fosse atacado. Santo Tomás de Aquino também, fundamentado em Galeno, teria afirmado que as doenças mortais provinham mais freqüentemente de excessos de alimentação do que de sua escassez, a frugalidade afigurando-se como o melhor dos remédios ${ }^{1123}$. Mas, por outro lado, o estudioso assinalava também a flexibilização das restrições alimentares, ocorrida na França, a partir do século XIII ${ }^{1124}$, quando a manteiga de vaca, os ovos e os queijos teriam passado a ser permitidos em período de abstinência ${ }^{1125}$.

Renunciar ao prazer de comer carnes e gorduras animais apreciadas pelo aporte de vigor e pela sensação de saciedade que traziam era uma atitude frugal que, ao ser compartilhada por toda a população colonial, promovia unidade. Celebrar ocasiões festivas em companhia de bons amigos, por sua vez, constituía uma maneira irrepreensível de dignificar as festas religiosas importantes. Excessos de ingestão de comida ou de bebida acontecendo em dias santos ofereciam boas desculpas e uma válvula de escape necessária. O sacrifício de prazeres corporais em dias magros, a privação das carnes que satisfaziam o apetite e forneciam vigor

1122 Seria talvez interessante investigar até que ponto intervinham nesse caso, os conceitos de lei natural e de lei positiva, conceitos teológicos de efeito político importante no Período Moderno. A lei natural concebida como diretamente emanada de Deus precisava ser respeitada, e era complementada pelas leis positivas que a Igreja e o rei cuidavam de impor.

1123 DROUART, Alain. Les français et la table: alimentation, cuisine, gastronomie du moyen âge à nos jours, Paris, Ellipses, 2005. pp. 26 e 27.

1124 Não foi possível obter dados a respeito da extensão dessas restrições no Brasil colonial seiscentista.

1125 DROUART, Alain. Op. Cit., p. 31. 
redobrado aos corpos e a permissão de se comer peixes (menos substanciosos) nessas ocasiões comprovavam a identificação católica daqueles que ingeriam alimentos e o enquadramento estrito de seus corpos.

Por outro lado, as celebrações das principais festas do calendário religioso operavam num registro de comilanças compartilhadas também promotoras de coesão local. Nos diversos núcleos de povoamento estabelecidos na colônia, do mesmo modo que em Portugal, os dias de fartura explícita despertavam as alegrias: "Vem chegando-se a Páscoa, e se eu me empasco, / Os lombos de um Tatu é o pão, que busco", afirmava Matos.

Em tais oportunidades, a crer seus poemas, os requintes cediam o passo à simplicidade. Os guisados oferecidos a visitantes não pareciam diferir muito dos bocadinhos caseiros que o poeta dizia apreciar. As iguarias mencionadas pelo autor não pertenciam ao domínio de nenhuma alta cozinha aparatosa, todavia, soteropolitanos da melhor sociedade, convidados a desfrutar da hospitalidade de senhores de engenho ou de lavradores da área rural, se fartavam de bom apetite, sem renunciarem tampouco aos prazeres que o sexo podia lhes proporcionar. Vale, a propósito, lembrar que o senhor do engenho de Pernamirim esperava seus convidados, conhecidos pelos cantares maviosos, "ao canto porém da mesa" e quase os condenou a morrer de tanto comer. ("morrer a puros saca-bocados"). Depois de tais banquetes Matos dizia precisar de sesta reparadora, não conseguindo piar enquanto tinha "pança farta e pé dormente".

Outro fio condutor ligado ao corpo necessário à compreensão da literatura de Gregório de Matos foi seu interesse pelo sexo. De fato, as mulheres soteropolitanas bastante resguardadas, quando pertenciam às camadas nobres da população, eram muito mais livres quando negras, cabras (termo designando mestiças com ascendência indígena, na obra de Matos) ou mulatas, serviam nas casas grandes, auferindo ganhos ocasionais em troca de favores sexuais. $\mathrm{O}$ autor circulava entre os logradouros da cidade e os engenhos e plantações de cana do Recôncavo. Cantava músicas em sua viola de cabaça, recitava poemas e procurava conquistar serviçais, nas casas onde o recebiam. Ressaltava em sua arte poética certa malemolência dos costumes, sugerindo, além do gosto pela comida, outros prazeres da carne. 
Além da proximidade entre sexo e religião, a arte poética do autor evidenciou a estreita imbricação entre sexo e comida, ambos necessidades vitais carregadas de valor simbólico, comemorado com festividades que implicavam ingestão de alimentos e de bebidas alcoólicas e oportunidades para excessos outrossim rechaçados. A luxúria parece efetivamente ter feito parte do cardápio colonial: "tenho grande jactância / de dar minha sustância / a quem sustância me dá’1126 escrevia Matos, confirmando a adequação do comentário de Stuart Schwarz, já referido anteriormente, sobre o fato de sexo e religião terem sido passatempos apreciados em Salvador ${ }^{1127}$. Dividido entre o prazer do pecado e a expressão viva de uma fé que ecoava sincera, o poeta, não obstante certas excentricidades de conduta e de vestuário, não parece ter destoado muito no âmbito da sociedade à qual pertencia.

Tendo renunciado à vida eclesiástica por saber que não respeitaria estritamente os votos de castidade, a hipocrisia de sacerdotes e frades que visitavam seus paroquianos para "papar a cabidela" ou navegar metaforicamente escravas imponentes como urcas escandalizava especialmente o poeta. As refeições fartas de monges que tinham o pão assegurado, numa sociedade que nem sempre desfrutava de tais regalias, pareciam the dar inveja. Em versos ásperos, como viu-se anteriormente, Matos atacou o cura da Sé namorador, clérigos "atravessa milho"1128, padres "papa-jantares"1129 e frades que freqüentavam o convento do Desterro, onde monjas enclausuradas tampouco primavam pela vocação monástica: "Que o pai pela descendência / do filho ou de seu aumento / meta a filha num convento / freira da conveniência ... Boa história"1130.

As visitas do poeta e de outros homens da cidade a esse logradouro afiguravam-se menos religiosas que sociais. $\mathrm{O}$ autor satirizava a permanência de frades no recinto, mas também atendia aos desejos das freiras. Satisfez um pedido de três monjas, ao glosar uma definição

1126 MATOS, G. Op. Cit., Vol. VI, p. 1534.

1127 SCHWARTZ, Stuart. Burocracia e sociedade no Brasil colonial. p. 194.

1128 MATOS, G. Op. Cit., Vol. I, p. 172.

1129 MATOS, G. Op. Cit., Vol. II, pp. 277 a 280.

1130 MATOS, G. Op. Cit., Vol. II, p. 489. 
poética do priapo. À outra agradeceu o sabor de ambrosias, afirmando-se guloso de tudo que era doce. Um terceiro poema girou em torno de peixe vermelho que uma freira, impedida de oferecer o quitute, quase lhe teria enviado. Noutro poema, ainda uma freira mandava a seu galante um cará simbólico em lugar de "pão por Deus".

O tratamento reservado aos escravos era outra questão de interesse da igreja perceptível nos versos do poeta. Os sacerdotes amiúde intervinham entre os donos e seus cativos em nome da caridade cristã. Se o padre Vieira, em início de carreira, apenas aconselhava resignação aos escravos por serem, como Jesus, filhos diletos de Maria, sofrendo os trabalhos excessivos e a alimentação insuficiente que padeciam em muitos engenhos ${ }^{1131}$, e se outro Jesuíta, o padre Jorge Benci, publicou um opúsculo contendo quatro discursos endereçados aos lavradores sobre deveres e direitos recíprocos de senhores e de escravos no mundo colonial, muitos colonos se ressentiram das ingerência da Relação ou da Igreja nos castigos dispensados à mão-de-obra cativa.

O padre Benci, pois, explicava como o pecado original e os apetites exagerados dos homens justificavam a servidão dos cativos vencidos em guerras entre nações, cuja vida teria sido poupada, permanecendo a partir daí em "perpétua sujeição e obrigação de servir aos vencedores" 1132 . O padre esclarecia o dever, que cabia ao dono, de dar ao jumento o comer, a vara e a carga e ao servo o pão, o ensino e o trabalho ${ }^{1133}$. O primeiro dos quatro discursos versou sobre os deveres dos senhores em relação à mão-de-obra cativa, população colonial hierarquicamente indefesa por não ter o direito de possuir nem seu próprio corpo, nem seu tempo. Benci argumentava:

“A primeira obrigação, que se inclui no nome de pão, que o senhor dá ao servo para que não desfaleça, panis, ne succcumbat, é o sustento. Esta obrigação não se funda somente em alguma lei positiva, senão também na mesma lei natural, que

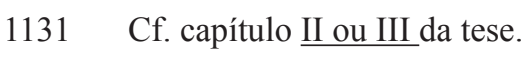

1132 BENCI, Jorge. Economia cristã dos senhores no governo dos escravos. São Paulo, Grijalbo, 1977. pp.48 e 49.

1133 BENCI, Jorge. Op. Cit., p. 51.
} 
obrigando a cada um a procurar o sustento da própria vida; como o servo, por dever a seu senhor todas as obras de seu serviço, o não possa granjear para si, obriga a que lho dê o mesmo senhor"1134.

O padre reconhecia que muitos senhores deixavam de cumprir suas obrigações:

"Sendo porém a obrigação, que têm os senhores de sustentar os escravos imposta pela lei natural, e tão autorizada pelo Direito humano, e muito mais pelo divino; é contudo tal a crueldade de alguns senhores, que até o sustento, que tão liberalmente dão aos animais brutos, negam aos cativos" ${ }^{1135}$.

Louvando o costume de alguns senhores que permitiam aos escravos disporem de um dia (que não fosse um domingo ou um dia santo consagrados ao repouso) para cultivar uma horta e prepararem os próprios mantimentos ${ }^{1136}$, o jesuíta ordenava : “dai de comer a vossos servos, ou dai-lhes tempo conveniente em que o possam granjear" ${ }^{1137}$. Proceder de outra forma, segundo o sacerdote equivalia a um assassinato. O padre apontava:

"Porque como é possivel que o escravo ou escrava andando em contínua lida e trabalho, sustente a vida com uma ração escassa de farinha de pau, sem outra coisa que a ajude a levar? Se é verdade que não pode o homem sustentar a vida unicamente com pão, ainda sendo o pão de trigo: Non in solo pane vivit homo;

1134 BENCI, Jorge. Op. Cit., p. 54.

Antonil mencionava a esse respeito, que os escravos ocupados na casa das caldeiras trocavam a garapa recebida contra "farinha, banana, aipins e feijões".

1135 BENCI, Jorge. Op. Cit., p. 55.

Segundo Antonil, como visto anteriormente, escravos havia que mal tinham tempo para "buscar uma raiz e um caranguejo para comer".

1136 BENCI, Jorge. Op. Cit., p. 58.

1137 BENCI, Jorge. Op. Cit., p. 61. 
como se há de sustentar o escravo sem outra coisa mais que uma triste ração de farinha de pau?"1138.

Destacou-se durante a leitura da obra de Gregório de Matos o papel fundamental da Igreja na condução da vida social soteropolitana. No século XVII as populações lusas, tanto em Portugal quanto nas colônias, tomavam precauções para não serem notadas pela heterodoxia. Bom grado, mal grado, os colonos se submeteram e dobraram as almas juntamente com os corpos. Mesmo no Brasil as ameaças de denúncias ao tribunal da Inquisição pairava sobre colonos suficientemente infelizes para dar motivos de escândalo aos olheiros que como, afirmava Matos, esquadrinhavam a vida alheia.

\section{Vida social e consciência mazomba da honra}

Como visto anteriormente, Gregório de Matos, ao brincar com as normas da sociedade colonial, mais esboçou alusões do que esmiuçou explicações detalhadas de significados, todavia, seus versos assinalaram eventos ocorridos, problemas soteropolitanos e valores culturais de uso cotidiano. Consideradas pelo prisma do abastecimento e do consumo alimentar, as metáforas ideadas para expressar seu ponto de vista, permitiram abranger em conjunto os dados recolhidos nos versos, as normas de criação poética vigentes, os acontecimentos históricos contemporâneos e os hábitos alimentares da população colonial mencionados noutros textos. Cotejar tais elementos apontou para a relevância extrema dos parâmetros da honra, conceito do código moral mazombo que parece ter norteado a maioria das ações sociais empreendidas.

Segundo Laima Mesgravis os códigos de honra lusos, fundamentados numa noção sui generis de sangue limpo, propiciaram uma matriz cultural lógica à organização social soteropolitana. Não viver do trabalho das próprias mãos, ser chefe de família respeitado, possuir cavalos de montaria ricamente ajaezados, dar ordens à criadagem numerosa, viver em casas bem aparelhadas, ostentar baixelas de ouro ou de prata, jóias, roupas magnificentes, acolher 1138 BENCI, Jorge. Op. Cit., pp. 62 e 63. 
viajantes de passagem, oferecer-lhes uma hospitalidade generosa eram regalias permitidas aos ricos, numa sociedade altamente hierárquica, onde o orgulho se encontrava sempre à flor da pele e as aparências prevaleciam sobre a realidade. Os senhores de engenho viviam, pois, cercados do respeito geral e todos os colonos, mesmo os mais humildes, parecem ter forçado o destino, escondendo taras eventuais, mantendo as aparências e não recuando diante de nada para alcançarem a prosperidade e o prestígio almejados. A nobreza da terra, constituída de homens bons procurava "viver a lei da nobreza"1139 e "tratar-se nobremente" em luxo e conforto, à maneira dos fidalgos metropolitanos.

Poder se fartar à vontade de alimentos apetecidos constituía uma das principais manifestações desse prestígio, mas o valor social da dieta não repousava apenas sobre critérios quantitativos de comida ingerida. A seleção de gêneros alimentícios vistos como nobres e saudáveis colocava em jogo os corpos dos colonos e seu caráter saudável. Nesses termos, as metáforas envolvendo ingredientes da dieta alimentar soteropolitana também referiam critérios sensíveis de gosto e avaliações de propriedades. Uma multiplicidade de atributos valorativos de gosto ou de propriedade denunciava a complexidade dos conceitos que davam forma aos procedimentos materiais de alimentação. Segundo observou Felipe Fernández-Armesto, “assim como o desperdicio o sabor tem um efeito enobrecedor" 1140.

Dádivas de alimentos finos, providos a hóspedes de passagem, colocavam em jogo a honra dos anfitriões, confirmavam a nobreza de quem oferecia iguarias convenientes e criavam laços de reciprocidade entre senhores de engenho, lavradores e comerciantes em torno dos quais giravam a economia e a sociabilidade da colônia. A ausência de hospedarias remuneradas no Recôncavo tornava necessária a hospitalidade dos proprietários de terras e permitiu estabelecer vínculos honrosos entre aqueles que recebiam a hospitalidade e aqueles que a proviam. Manter mesas hospitaleiras constituiu, em tais circunstâncias, um fator político indispensável, porém oneroso e potencialmente motivador de falências.

\footnotetext{
1139 MESGRAVIS, Laima. Op. Cit., p. 801.

1140 FERNANDEZ - ARMESTO, Felipe. Comida: uma história. Rio de janeiro, Record, 2001. p. 172.
} 
Na hospitalidade senhorial oferecida a forasteiros havia, talvez, resquícios de apreço pelos valores da hierarquia estamental medieval, transpostos no registro da superioridade dos cristãos velhos, mas nem todos os homens bons da colônia pertenciam à nobreza do reino. Para fazer parte integrante da nobreza da terra não bastava possuir substância corporal impoluta; era preciso ainda pautar as condutas cotidianas por padrões honrosos de desapego ao dinheiro que pressupunham, entre outros elementos, rendimentos prévios e gastos perdulários.

Existia um fator de degradação possível nas circunstâncias da pobreza. Era por essa razão que metáforas remetendo a procedimentos alimentares situavam a condição social de cada indivíduo e mereciam destaque na expressão poética do autor. Era bastante constrangedora a situação de mazombos católicos, honrados e pobres. Pelo mesmo motivo as mercês, pensões concedidas pelo rei para recompensar serviços relevantes eram tão cobiçadas. Gregório de Matos exclamava com grande convicção: "Porque o nobre enfim é nobre, / quem honra tem, honra dá, / pícaros dão picardias, / inda lhes fica que dar" ${ }^{1141}$.

Cronistas ou viajantes do período comentaram diversas situações semelhantes. O jesuíta Antonil, por exemplo, cuja crônica foi escrita cerca de quinze anos após o exílio do poeta, detalhou diversas questões relativas à honorabilidade, que transpareciam também na obra de Matos. Assim, ao lamentar (numa perspectiva diversa daquela defendida por Matos), o dispêndio de grandes fortunas para receber estranhos e as dívidas enormes contraídas por infelizes aspirantes à relevância social ${ }^{1142}$, o padre confirmava (num registro distinto) a relevância de ações sociais mencionadas nos versos dos poemas. Os comentários do padre possuíam intento moral. A ingerência eclesiástica no conteúdo das panelas, que ferviam nos lares coloniais, indicava ainda outro fenômeno presente na escrita de Matos. Numa cidade vigiada pelas confissões, na qual se acreditava que malfeitos privados de indivíduos podiam atrair a ira divina sobre a comunidade, fazia até sentido o modo como os recatos da vida privada foram invadidos pelo domínio público e como autoridades coloniais, atentas a minúcias dessa natureza, abriram espaço para discutir esses assuntos.

\footnotetext{
1141 MATOS, G. Op. Cit., Vol. VII, p. 1593.

1142 Pagas no acerto das contas, logo após a venda das caixas de açúcar (seu montante, por vezes, excedia as posses dos colonos).
} 
No decorrer da investigação, o fio de meada que a honra pessoal oferecia para entender valores culturais traduzidos em termos alimentares mostrou-se instrumento de análise insubstituível. Ao versejar a vida soteropolitana segundo regras eruditas de poesia barroca, Matos tentou provavelmente construir, a poder de floreios de linguagem e de fofocas argutas, um lugar de prestígio social que lhe compensaria um pouco as agruras do descaso oficial em relação a seus méritos. Os procedimentos alimentares soteropolitanos lhe proporcionaram um instrumento cômodo para criar duplos sentidos, pois, os códigos lusos de honra e de hospitalidade adquiriram uma ênfase exacerbada numa sociedade cujo bem-estar dependia inteiramente do trabalho compulsório de escravos.

Segundo cronistas quinhentistas e seiscentistas como Pero de Magalhães Gandavo, Gabriel Soares de Sousa ou Fernão Cardim, o Brasil, observado sobretudo em Salvador, era uma terra de fartura, onde os alimentos podiam ser obtidos sem grandes esforços; entretanto, os grandes proprietários de terras ocupavam para produzi-los um número bastante restrito de escravos e economizavam restringindo as quantidades e a qualidade dos alimentos destinados aos serviçais. Não houve distribuições eqüitativas de alimentos, apesar da facilidade do provimento alimentar.

Num poema muito revelador, Gregório de Matos cobrou de Marana que respeitasse as regras da precedência ao receber os cestos dos pescadores ou das mariscadeiras e repartir seu conteúdo entre as diferentes casas do engenho da Cajaiba. Existiam também conceitos nítidos sobre quais espécies de peixes ou crustáceos convinham a pessoas nobres e quais eram mais apropriados para o consumo de pessoas rústicas que precisavam comer, segundo se pensava, alimentos nutritivos e substanciosos, porém grosseiros, pois ingerir alimentos delicados os prejudicaria. Por semelhante motivo afigurou-se tão significativo poder comprar carnes, destinadas às pessoas de condição mais elevada. As competições acirradas para ser bem servido nos açougues e a existência de açougues de "sobras" na capital1143 apontavam nessa direção.

1143 Como visto no capítulo III. 
Comentando os padrões da alimentação européia, nos séculos XV e XVI, Allen F. Grieco observou:

"A idéia de que a carne boa era adequada principalmente para as classes sociais elevadas, enquanto a de pior qualidade bastava para satisfazer as necessidades das pessoas mais modestas da sociedade (uma concepção vista como científica pelos médicos que redigiram tratados sobre os regimes), é confirmada por uma carta de Francesco di Marco Datini" ${ }^{1144 .}$

Aspectos teatrais da alimentação, os preparos lusos soteropolitanos expressavam, por conseguinte, apetites imemoriais ou sinais de um poder adquirido na colônia. Segundo observou Jean Pierre Poulain:

“Quer ele seja percebido como um sinal, um emblema, um símbolo, o ato alimentar insere e mantém por suas repetições cotidianas o comedor num sistema de significados. É sobre as práticas alimentares, vitalmente essenciais e cotidianas, que se constrói o sentimento de inclusão ou de diferença social. É pela cozinha e pelas maneiras à mesa que se produzem as aprendizagens sociais mais fundamentais, e que uma sociedade transmite e permite a interiorização de seus valores. É pela alimentação que se tecem e se mantêm os vínculos sociais" ${ }^{1145}$.

Na colônia, todos faziam questão de viver com largueza e prestígio. Pareciam existir maneiras de se contornar os impedimentos, quando se pertencia à categoria dos pícaros. Matos apregoava, portanto, um retorno à ortodoxia das regras de escalonamento social, que tinham deixado de 1144 GRIECO, Allen F. "Alimentação e classes sociais no fim da Idade Média e na Renascença" , in FLANDRIN, J.L. e MONTANARI, M. (org.). História da alimentação. São Paulo, Estação Liberdade, 1998. p. 470. O Dr. Mirandela também era da mesma opinião.

1145 POULAIN, Jean Pierre. Sociologias da alimentação. Florianópolis, Ed. UFSC, 2004. pp. 197 e 198. 
prevalecer durante sua ausência. Mordaz e irônico, o poeta aconselhava aos comerciantes soteropolitanos sedentos de ostentar importância:

“Seja um magano, um pícaro abelhudo, / Vá a palácio, e após das cortesias / perca quanto ganhar nas mercancias, / e em que perca o alheio, esteja mudo. / Sempre se ande na caça e montaria" 1146 .

Vistas pelo prisma de uma rede complexa de premissas tácitas cristalizadas pela experiência vivida na colônia, as alusões críticas a hábitos alimentares inseridas nos poemas configuravam gestos corriqueiros, mas era sobretudo no âmbito da moralidade soteropolitana que repercutiam, expressando aspirações e indignações do autor e permitindo detectar pontos nevrálgicos como a questão da honra na urdidura da vida social e cultural. Versejar um acervo amplo de modos de agir que desqualificavam seus protagonistas subentendia o sistema das representações que norteava as formas usuais da vida social. Condutas que contrariavam os padrões tradicionais utópicos, aos quais o poeta ainda se aferrava, lhe forneceram elementos para efetuar um mapeamento de categorias estereotipadas de colonos, desenhando em negativo modelos ideais de interação social que tudo tinham a ver com as identidades pessoais assumidas por seus amigos ou por seus oponentes. A maior parte dos versos satíricos de Gregório de Matos, com efeito, não se concentrou nas críticas endereçadas a conterrâneos especificamente nomeados. Mesmo ataques motivados por ressentimentos pessoais, ao fustigar adversários por meio de hábitos alimentares ridículos, cujos significados nada tinham de misterioso para os ouvintes, foram propostos em nome de representações coletivas.

Curiosamente, a descrição que um viajante espanhol fez dos usos e costumes soteropolitanos do período, apresentou sob luz desfavorável elementos também presentes nos poemas de Matos: o sentimento exacerbado da honra dos colonos, a promiscuidade de suas mulheres, o tratamento indigno reservado aos escravos, etc.. A despeito das dúvidas de Taunay ${ }^{1147}$ sobre a veracidade do texto, a

1146 MATOS, G. Op. Cit., Vol. IV, p. 838.

1147 TAUNAY, Adolfo Afonso d' 'Escragnole. Impressões de viajantes estrangeiros na Bahia colonial (1610 -1774). Rio de Janeiro, Imprensa Nacional, 1925.

A existência de um espanhol anticlerical incitou o autor a recusar autenticidade ao depoimento. 
narrativa bem podia ser autêntica - por ser obra de um autor espanhol, Taunay acreditou que o relato da viagem contendo comentários malevolentes e anticlericais fosse texto apócrifo de algum protestante. Esse relato da viagem de Francisco Coreal publicado na França continha, com efeito, uma descrição pormenorizada e escandalizada dos usos locais observados durante sua permanência na capital da colônia. Coreal assinalava os excessos que Mazombos eram suscetíveis de cometer em defesa da honra ofendida. Apesar das diferenças radicais de pontos de vista, a avaliação de Coreal não deixava, contudo, de soar verossímil. Descrevendo os colonos Coreal afirmou:

“Não é que eles não pareçam corteses e afáveis em seus modos, mas eles são tão sensíveis nas questões relativas a sua honra, tão ciumentos no que diz respeito às mulheres \& tão vaidosos de sua própria importância, que é muito dificil, para não dizer impossível, de fazer amizade com eles. As mulheres são menos vistas que no México, por causa do grande ciúme dos maridos, mas para satisfazer sua paixão elas colocam em obra todo tipo de estratagema, apesar de agirem em detrimento de sua honra \& de sua vida, pois, caso flagradas na prática do crime, seus maridos as esfaqueiam sem mais nem menos \& seus pais ou seus irmãos as prostituem. Elas se tornam então cortesãs públicas servindo igualmente brancos \& negros. Se a persecução dos maridos não impede as intrigas de suas mulheres, aquela dos pais não impede as mães de socorrerem caridosamente as filhas tão logo se tornem núbeis" ${ }^{1148}$.

1148 COREAL, Francisco Voyages de François Coreal aux Indes Occidentales contenant ce qu'il y a vu de plus remarquable pendant son séjour depuis 1666 jusqu'en 1697. Paris, André Cailleau, 1722. pp. 170 e 171. (Citação em português : minha tradução).

“Ce n'est pas qu'ils ne paroissent courtois \& polis dans leurs manières, mais ils sont si chatouilleux sur le point d'honneur, si jaloux sur le chapitre des femmes \& si vains sur leur grandeur, qu'il est très difficile, pour ne pas dire impossible, de s'en faire des amis. Les femmes sont moins visibles qu'au Mexique, à cause de la grande jalousie des maris, mais elles mettent pour venir à bout de leur passion toutes sortes de stratagèmes en oeuvre, quoique aux depens de leur honneur \& de leur vie, car si elles sont surprises dans le crime, leurs maris les poignardent, sans qu'il en soit autre chose \& leurs peres ou leurs freres les prostituent. Elles deviennent alors des courtisannes publiques, également au service des blancs \& des noirs. Si la persecution des maris n'empêche pas les intrigues de leurs femmes, celle des peres n'empêche pas que les meres ne prétent leur secours charitable aux filles aussitôt qu'elles sont nubiles". 
O viajante assinalava também a grande distância que podia existir entre o sentimento religioso e as práticas caritativas:

"Apesar de tais costumes, não deixam de ser exteriormente muito religiosos. As Igrejas são muito freqüentadas, confessam-se comumente, provavelmente em razão da multidão dos pecados" ${ }^{1149}$.

O tratamento reservado aos escravos tampouco demonstrava caridade. Pelo contrário, para obter a obediência dos escravos ou coibir furtos e sabotagens, os senhores de escravos, imbuídos do respeito que lhes era devido, se excediam freqüentemente na aplicação de castigos cruéis:

"Me encontrei um dia na Bahia na casa de um cristão velho considerado pelos Portugueses como exemplar por sua devoção, mas tão pouco caridoso em seus atos, que supersticioso \& beato na aparência. Me encontrei, digo na casa desse homem, num dia em que ele mandava rasgar com golpes de agulhões um pobre negro que tinha derrubado uma xícara de chocolath. Enquanto isso esse homem religioso tinha em cima da mesa um Crucifixo diante do qual orava, mas ele estava virado de tal modo que enquanto rezava, tinha a cruel satisfação de ver rasgar seu escravo \& de ouvir os gritos desse miserável" ${ }^{1150}$.

1149 COREAL, Francisco. Op. Cit., p. 171. Citação em português: minha tradução.

"Avec de tels moeurs, on ne laisse pas que d'être très religieux quant à l'extérieur. Les Eglises y sont frequentées, la confession y est fort commune, sans doute à cause de la multitude des péchés".

1150 COREAL, Francisco. Op. Cit., p. 172. Citação em português: minha tradução.

"Je me trouvai un jour à la Baie dans la maison d'un Cristian veio de bon exemple aux Portugais pour sa dévotion, mais aussi peu charitable dans ses actions, que superstitieux \& bigot dans tout son extérieur. Je me trouvai dis-je chez cet homme, un jour qu'il faisoit déchirer à coup d'aiguillon un pauvre Negre, pour avoir renversé une tasse de chocolath. Pendant ce tems là cet homme religieux avait sur sa table un Crucifix devant lequel il disoit ses oraisons, mais il êtoit tourné de sorte qu'en même tems qu'il faisoit ses devotions, il avait la cruelle satisfaction de voir déchirer son esclave \& d'entendre les cris de ce misérable". Minha tradução. 
Outro elemento bastante perceptível nos poemas de Matos, confirmado também pelas atas da municipalidade, foi a diferença de oportunidades de acesso aos alimentos da população em função da posição ocupada na hierarquia social, isto é, em função do prestígio social auferido pelos donos dos escravos encarregados de comprar os gêneros comestíveis. Comprar os melhores quartos trazeiros, nos currais de abate de reses do Carmo ou de São Bento, e pagálos pelo mesmo preço tabelado cobrado pela libra de carne dianteira nos açougues da cidade, era privilégio teoricamente reservado apenas ao governador e a certas ordens religiosas, mas muitos colonos ricos também procuravam fazê-lo, sendo melhor servidos que o comum dos mortais e demonstrando importância social. Em diversas ocasiões a Câmara se viu na obrigação de reiterar a proibição. Contudo, parece que a quantidade disponível de carnes à venda na região soteropolitana era proporcionalmente maior do que teria sido em Portugal, a despeito de todas as queixas expressas sobre a qualidade do produto, seu estado de frescor ou seu preço.

Numa terra que, para os primeiros cronistas constituía um caso exemplar de fertilidade e de fartura em razão da bondade dos ares e das águas, da amenidade da temperatura e dos poucos esforços necessários para se produzir alimentos saborosos, teoricamente, não deveria ter existido escassez de alimentos. A terra bem podia ser farta, mas a venda de mantimentos produzidos não era atividade tão lucrativa quanto outras. Quem dispunha de capitais preferia produzir tabaco ou algodões, se não era suficientemente rico para ser lavrador de canas. Os senhores de engenho, muitas vezes, preferiam adquirir produção alheia a ocupar suas próprias terras no cultivo de mantimentos.

Colonos de menor potencial financeiro encarregavam-se de produzir os mantimentos com o auxílio dos poucos escravos que possuíam, mas eles deixavam a capitania real à mercê de eventuais situações de escassez. Em tais circunstâncias, aliás, eram sempre os colonos mais pobres que se encontravam em desvantagem, como indicavam os relatos da Câmara Municipal discutindo momentos de carestia na produção de farinhas, quando os colonos ricos açambarcavam de antemão todo o produto disponível, antes mesmo que as embarcações atracassem no porto. Os colonos mais pobres não conseguiam adquirir, então, nem mesmo os poucos alqueires de farinha necessários a seu sustento. 
Na Europa meridional, a partir do século VIII, a dieta preferencial de pão, vinho e azeite foi complementada por um consumo mais amplo de carnes entre os membros da nobreza, na seqüência da dominação das tribos germânicas ${ }^{1151}$. De modo que, ao tempo das Grandes Descobertas, a expansão demográfica européia dos séculos XVI e XVII reduziu a quantidade dos alimentos disponíveis para cada indivíduo e incentivou à imigração homens que tinham poucos alimentos em sua terra de origem, mas que continuavam a desejar os alimentos apetecidos pelos ricos em sua terra.

No Brasil, esses imigrantes encontraram caça e pesca relativamente farta. Sob seu impulso os animais domésticos se multiplicaram. Com a prosperidade do açúcar, não faltaram barris de frumento nos porões das naus, que vinham buscar os gêneros produzidos na colônia. Pães de trigo continuaram, portanto, a constituir um alimento básico na despensa dos colonos mais abastados e um alimento ocasional no cardápio dos menos remediados, sendo que a farinha de mandioca, dos mais pobres ou dos momentos de escassez de farinhas do reino, foi comida por todos. Não surpreende que carnes e farinhas tenham se tornado mantimentos fundamentais entre os descendentes de camponeses europeus, cuja dieta de origem se compunha sobretudo de pão, de vinho e de sopas de vegetais, mas que, enriquecidos na colônia, consideravam com uma certa reserva as ervas, as raízes e os vegetais saborosos que, todavia, continuavam a comer, em sopas e cozidos.

Obviamente ter o que comer à mesa e incluir carnes entre os ingredientes da dieta deve ter constituído um incentivo importante para muitos forasteiros imigrarem. Torna-se claro porque, nos versos de Matos, passar fome em território soteropolitano era sinal de fracasso social. A própria pobreza em tais circunstâncias fazia figura de tara e depunha contra o colono. No acesso à carne diversos significados se confundiam. Ter recursos para se fartar de carne bovina era comprovar honra em termos práticos e afastar suspeitas de vícios como a avareza ou a usura. Ser pobre equivalia não somente a abrir a porta à miséria, mais ainda à degradação social.

1151 MONTANARI, Massimo. Op. Cit., pp. 17 a 29. 
Por esse motivo provavelmente Matos, ciumento e enraivecido pelo esquecimento de seu pedido de mercê ordinária, satirizou tanto os néscios, faltos de juízo e de prudência que, desconhecendo os códigos sociais davam livre curso a suas ambições, sem se resignarem a ocupar o lugar inferior que lhes cabia na vida colonial.

\section{Crenças sobre o funcionamento dos corpos e a manutenção da saúde}

Além de privilegiarem certos ingredientes comestíveis e procedimentos europeus, nativos ou emprestados aos indígenas de outras colônias lusas, para produzirem alimentos, cujo consumo não afrontava os preceitos da honra mazomba ou da religião, os colonos deram também uma grande importância aos hábitos de consumo que julgavam apropriados à manutenção de sua saúde. A arte poética de Gregório de Matos outorgou uma ênfase especial à questão dos humores corporais, fluídos corporais aos quais os entendidos em medicina recorriam para explicar o funcionamento fisiológico dos corpos humanos. Com efeito, muitas reflexões esparsas nos versos do autor aludiram aos saberes medicinais, valendo-se das propriedades atribuídas aos ingredientes comestíveis e dos hábitos costumeiros de alimentação para compor trocadilhos. Sua compreensão subentendia um domínio prévio dos preceitos de medicina herdados de Hipócrates de Cós e de seus discípulos diretos, escritos durante os séculos V e IV a.C., ou dos comentários que Galeno acrescentou aos textos conhecidos, no século II a.C., corpus de conhecimentos que os tradutores árabes mantiveram vivo entre o desaparecimento da Escola de medicina de Alexandria em 642 d.C e o surgimento de uma nova escola inspirada nesses textos em Salerno, em meados do século XIII.

De forma que, mesmo relatando ações corriqueiras e cotidianas, as brincadeiras do poeta implicavam noções cujas premissas pertenciam às convicções da medicina humoral, propaladas até meados do século XVIII, quando novas descobertas européias, como a circulação sangüínea, ampliaram o horizonte dos conhecimentos científicos. Elas atestavam quão difundidos se apresentavam esses saberes tanto entre o público erudito, quanto entre aquele de educação 
menos formal. Acreditava-se, então, que manter o equilíbrio dos fluídos corporais permitia imunizar os corpos contra os ataques de doenças. O estado dos humores corporais, sangue, bílis amarela ou negra e muco (ou fleuma), preocupava os convivas. Procuravam evitar a viscosidade excessiva dos humores ou sua fluidez nefasta. Alimentar-se era prover energia aos corpos e agir diretamente sobre a consistência do sangue e dos outros fluídos corporais. As normas dietéticas preconizadas, assim como os exercícios físicos, as purgas, os clisteres, as sangrias, os vomitórios, os suadouros etc. visavam atuar sobre a consistência dos humores. O temperamento pessoal de cada indivíduo afigurava-se primordial, mas outros fatores precisavam ainda ser levados em conta. Prestava-se atenção às contingências climáticas, às estações do ano, à qualidade dos ventos e das águas e aos costumes locais. Contavam ainda fatores pessoais tais como a idade, o sexo e as atividades profissionais exercidas.

O fato da dieta alimentar constituir um meio de agir sobre os corpos para mantê-los em estado de harmonia transparece nos poemas de Matos. Condutas individuais corretas requeriam saber, inteligência e formação moral. Metáforas referindo procedimentos alimentares ofereciam, pois, um terreno propício à qualificação de diversos tipos de colonos reunidos no espaço colonial em função de escolhas à mesa, sábias ou extravagantes. Decorria daí a relevância moral do tema da saúde, fonte de comparações apropriadas por uma arte poética empenhada em promover a profilaxia dos hábitos sociais.

A precaução tomada pela população colonial portuguesa de iniciar a refeição com frutas frescas ditas frias, úmidas (e perigosas à saúde), continuando a refeição pela ingestão de alimentos classificados como quentes e secos, num crescendo progressivo, era costume ibérico que Barthélemy Joly, conselheiro do rei francês ${ }^{1152}$, assinalou com surpresa em 1603 e que Piso, médico do conde de Nassau e seu assistente, Marcgrave, também estranharam em Pernambuco. Segundo ressaltou Marcgrave os colonos portugueses saboreavam melancias e melões comendo essas frutas refrescantes "no princípio do

1152 NUÑEZ, Florencio Rafael. Op. Cit., p. 69. 
almoço ou do jantar" ${ }^{1153}$. Piso, mostrou-se igualmente entusiasta ao comentar os hábitos dos colonos portugueses:

"Tudo o amargo e ácido deve evitar-se, principalmente de manhã. Mas as laranjas, os limões pequenos, os grandes, as romãs, os melões, o murucujá, as melancias e demais frutas refrigerantes, tanto crus como preparados, podem comer com proveito os em estado de jejum, que os consideram como divinas, de entre as frutas saborosas, pois são boas para o fígado quando, sobretudo nos meses de verão chegam à maturidade. Por isso passou a provérbio: não entra médico nas casas em cujo vestíbulo se vêem de manhã numerosas cascas de laranjas" ${ }^{1154}$.

O médico de Nassau especificava, entretanto, algumas precauções úteis:

"Deve-se ter o cuidado de não colher fruta alguma antes de os raios solares as terem purificado das exalações noturnas. É preferivel servi-las, exceto as adstringentes, antes que depois das refeições; e melhor preparadas com açúcar que cruas. Muitas delas, sendo de pouca duração, estragam-se facilmente, sobretudo para os de estômago fraco e destemperado. Quanto a mim, imitando Galeno, sempre persuadi aos amigos raros se satisfizessem com frutas de fácil corrupção, o que muitas vezes lhes foi de grande proveito" 1155 .

O motivo para se preocuparem com a ordem da ingestão dos ingredientes da dieta, era a crença que os alimentos tênues, líquidos eram facilmente digeridos e deviam preceder nas refeições outros mais "crassos" 1156 e "sólidos", cuja digestão se efetuava mais lentamente no

1153 MARCGRAVE, Jorge. Op. Cit., Livro I, p. 22.

1154 PISO, Guilherme. Op. Cit., Livro I, p. 11.

1155 PISO, Guilherme. Op. Cit., Idem, ibidem.

1156 Espessos. 
estômago. $\mathrm{O}$ hábito alimentar referido repousava no conceito hipocrático do cozimento interno dos alimentos. O processo da digestão resultava na quilificação, isto é, numa fermentação química que dissolvia os alimentos ingeridos graças à ação de um ácido esurino secretado pelo estômago. A classificação dos alimentos em quentes ou frios nada tinha a ver com a temperatura dos manjares absorvidos. O Doutor Mirandela explicava:

"Assim como não se pode viver sem ar, também não se pode conservar a vida sem alimento. Está o corpo em contínuo dispêndio de sangue, que no seu sustento se gasta, e de espíritos, que nas suas operações se dissipam, e por isto tem carência de cotidiano alimento, com que a perda do sangue e dos espíritos se recobre, a fim de que sua nutrição se perenize, sem a qual a saúde logo se arruína e a vida brevemente caduca. [....] Donde se vê que a quilificação, ou cozimento do estômago, não se faz por obra de seu calor, senão por virtude do seu fermento, ainda que sempre seja necessário que esteja vigoroso o calor natural do estômago, para que se façam bem as operações de seu ácido" 1157.

Segundo o médico era indispensável que existisse certa analogia entre os alimentos comidos e o estômago, resultando de suma importância a natureza de cada indivíduo e seus costumes alimentares prévios. Citando Galeno, Mirandela sublinhava a relevância do apetite e do paladar na boa assimilação dos nutrientes, insistindo sobre o papel da intuição de cada um no que dizia respeito às escolhas alimentares favoráveis ${ }^{1158}$.

Estaria explicada desta forma a diferença que Mariza Peirano detectou entre a noção de um "quente-frio-térmico" e de um "quente-frio-qualidade", quando analisou dois fenômenos distintos utilizando expressões idênticas, ambos relacionados à alimentação e à saúde dos

\footnotetext{
1157 HENRIQUEZ, Francisco da Fonseca. Op. Cit., p. 46.

1158 HENRIQUEZ, Francisco da Fonseca. Op. Cit., pp. 47 e 48.
} 
$\operatorname{corpos}^{1159}$. Também se explicaria, por semelhante viés, a multiplicidade das classificações atribuídas em diferentes comunidades brasileiras a ingredientes alimentares similares, constatada entre populações que continuaram a se pautar pelos conceitos chaves da medicina humoral ${ }^{1160}$.

A declaração de Matos de que desejava "cozinhar o dado" 1161 num vaso de sangue queimado (designando o sexo que queria praticar com a negra Catona) ou sua afirmação de que morava perto do dique do Tororó, onde a gula queria que ele se dedicasse a comer taraíras frias, ou ainda seu esclarecimento, lembrando que a impotência era doença fria e não disenteria de origem quente, delineavam o lugar primordial que cabia na colônia às crenças relacionadas aos procedimentos que acreditavam prover saúde aos indivíduos. Os hábitos da alimentação colonial incorporaram, portanto, uma versão lusa seiscentista das crenças européias sobre o papel desempenhado pelos humores nos corpos humanos.

Os conceitos envolvidos na manutenção de um equilíbrio saudável dos humores, as noções primordiais de quente e frio e de reima ${ }^{1162}$, bem como as noções complementares de seco e de úmido, de duro (compacto e indigesto) ou friável (facilmente corruptível) e de tênue ou viscoso parecem ter permanecido vivos em releituras dos preceitos da medicina humoral, que produziram versões locais dessa teoria, depois que o avanço dos conhecimentos europeus no século XVIII, deixou o recurso às práticas da medicina humoral a populações menos ao par de resultados da experimentação científica.

Ao comentar a obra de Jean-Louis Flandrin, Massimo Montanari sublinhou a ênfase do historiador nos vínculos de proximidade existentes entre gastronomia e dietética, muitas

1159 PEIRANO, Mariza Gomes e Souza. "Proibições alimentares numa comunidade de pescadores (Icaraí, Ceará)”. Dissertação de Mestrado em Antropologia Social apresentada à Universidade de Brasília em 1975.

1160 BRANDÃO, Carlos Roberto. Plantar, colher, comer: um estudo sobre o campesinato goiano. Rio de Janeiro, Graal, 1981.

MAUÊS, Maria Angélica Mota \& Raymundo Heraldo. O folclore da alimentação: tabus alimentares da Amazônia (um estudo de caso numa população de pescadores do litoral do litoral paraense. Belém, 1980.

1161 MATOS, G. Op. Cit., Vol. VI, p. 1358.

1162 Propriedade perigosa de abrir feridas ou de impedir a cicatrização de feridas existentes que se acreditava inerentes a certas substâncias comestíveis. 
técnicas e práticas culinárias sendo justificadas, não pelas leis da química, mas pelas leis da ciência médica aplicada à dietética, que constituiriam um dos principais nós a ser desatados pela História da alimentação. As propriedades quentes, frias, secas ou úmidas atribuídas aos alimentos se erigiriam então em "coordenadas de interpretação do universo elaboradas pela ciência ocidental desde a época grega antiga até os séculos XVII e XVIII'1163.

Tabela I - A concepção corporal da manutenção da saúde na medicina humoral

\begin{tabular}{|c|c|c|}
\hline Temperamentos & Temperatura regulada: & Temperamentos \\
\hline Melancólicos - frios e secos & $\begin{array}{l}\text { alimentos umedecidos com } \\
\text { água e gorduras e temperados }\end{array}$ & Coléricos - quentes e secos \\
\hline $\begin{array}{l}\text { Precauções } \\
\text { amornar e umedecer os } \\
\underline{\text { alimentos }}\end{array}$ & com especiarias & $\begin{array}{l}\text { Perigo dos humores muito } \\
\text { viscosos se concentrarem } \\
\text { indevidamente em algumas } \\
\text { partes do corpo }\end{array}$ \\
\hline $\begin{array}{l}\text { Procedimentos } \\
\text { Evitar as doenças de causas } \\
\text { frias }\end{array}$ & $\begin{array}{l}\text { Equilíbrio humoral perfeito: } \\
\text { boa circulação dos humores, } \\
\text { corpos imunes às doenças }\end{array}$ & $\begin{array}{l}\text { Procedimentos } \\
\text { Evitar as doenças de causas } \\
\text { quentes }\end{array}$ \\
\hline Temperamentos & Temperatura regulada: & Temperamentos \\
\hline $\begin{array}{l}\text { Fleumáticos - frios e } \\
\text { úmidos } \\
\text { Perigo da fluidez excessiva } \\
\text { dos humores resultar em } \\
\text { doenças frias }\end{array}$ & $\begin{array}{l}\text { alimentos temperados com } \\
\text { especiarias ou umedecidos } \\
\text { com a adição de água ou de } \\
\text { gorduras }\end{array}$ & $\begin{array}{l}\text { Sangüíneos - quentes e } \\
\text { úmidos } \\
\text { Precauções } \\
\underline{\text { Alimentos ditos frios comidos }} \\
\underline{\text { antes dos quentes }}\end{array}$ \\
\hline
\end{tabular}

1163 MONTANARI, Massimo. "Un historien gourmand" in REDON, Odile. SALLMANN, Line. \& STEINBERG, Sylvie (org.) Le désir et le goût: une autre histoire (XIII e-XVIII e siècles), Saint Denis, PUV. 2005. p. 374 (minha tradução). 
A tabela antecedente permite visualizar o princípio operacional que norteava as prescrições alimentares, fossem elas preventivas ou curativas. Para anular o efeito dos humores pecantes e restaurar o equilíbrio corporal, médicos e colonos recorriam a diuréticos, laxantes, expectorantes, sangrias etc.. Desejavam contrabalançar os excessos. Além de amornar, umedecer ou secar os ingredientes ingeridos, retificavam ainda a solidez ou a friabilidade dos alimentos com adições de substâncias emolientes ou adstringentes. 
Tabela II - O equilíbrio dos humores por meio da alimentação

\begin{tabular}{|c|c|c|c|}
\hline $\begin{array}{l}\text { Substância } \\
\text { alimentar }\end{array}$ & Seca & Tratamento & Úmida \\
\hline Quente & $\begin{array}{l}\text { Natureza } \\
\text { individual: } \\
\text { Quente e seca } \\
\text { Humor: Bílis amarela } \\
\text { Te m p e r a m e n t o } \\
\text { colérico }\end{array}$ & $\begin{array}{l}\underline{\text { Preparos }} \\
\text { umedecidos com uma } \\
\text { adição de água ou de } \\
\text { gordura. }\end{array}$ & $\begin{array}{l}\text { Natureza } \\
\text { individual: } \\
\text { Quente e úmida } \\
\text { Humor: Sangue } \\
\text { Temperamento } \\
\text { Sanguíneo }\end{array}$ \\
\hline Morna & $\begin{array}{l}\text { Preparos amornados } \\
\text { com uma adição de } \\
\text { temperos (quentes ou } \\
\text { frios). }\end{array}$ & $\begin{array}{c}\text { Equilíbrio humoral } \\
\text { Ideal } \\
\text { Pastoso e morno }\end{array}$ & $\begin{array}{l}\text { Preparos aquecidos } \\
\text { por cocção em açúcar } \\
\text { ou por defumação. } \\
\text { Alimentos úmidos e } \\
\text { frios ingeridos antes } \\
\text { dos outros }\end{array}$ \\
\hline Fria & $\begin{array}{l}\text { Natureza } \\
\text { individual: } \\
\text { Fria e seca } \\
\text { Humor: Bílis negra } \\
\text { Te m p e r a m e n t o } \\
\text { melancólico }\end{array}$ & $\begin{array}{l}\text { Preparos secos } \\
\text { Por meio de salga ou } \\
\text { então de salmoura. } \\
\text { Exposição ao sol, aos } \\
\text { ventos ou ao fumo. }\end{array}$ & $\begin{array}{l}\text { Natureza } \\
\text { individual: } \\
\text { Fria e úmida } \\
\text { Humor: Muco } \\
\text { Temperamento } \\
\text { fleumático }\end{array}$ \\
\hline
\end{tabular}

Algumas classificações de gêneros comestíveis, assinaladas pelo Dr. Mirandela, são apresentadas a seguir, apenas no intuito de ilustrar o modo como os colonos lusos conceberam os alimentos vegetais ou animais soteropolitanos. 
Tabela III - Classificação de ingredientes da dieta segundo o Dr. Mirandela

\begin{tabular}{|c|c|c|c|c|c|c|}
\hline \multirow{2}{*}{\multicolumn{2}{|c|}{ Alguns exemplos }} & \multicolumn{2}{|c|}{ Quente } & \multirow[b]{2}{*}{ Amornado } & \multicolumn{2}{|c|}{ Frio } \\
\hline & & \multirow{2}{*}{$\begin{array}{c}\text { Um } \\
\text { pouco }\end{array}$} & \multirow{2}{*}{$\begin{array}{l}\text { Bastante } \\
\text { - Javali } \\
\text { - Pombos } \\
\text { - Gengibre }\end{array}$} & & \multirow{2}{*}{$\begin{array}{l}\quad \text { Um } \\
\text { pouco } \\
\text { - Fava } \\
\text { seca } \\
\text { - Clara de } \\
\text { ovo }\end{array}$} & \multirow[t]{2}{*}{ Bastante } \\
\hline \multirow[b]{2}{*}{ Seco } & $\begin{array}{c}\text { Um } \\
\text { pouco }\end{array}$ & & & & & \\
\hline & Bastante & $\begin{array}{l}\text {-Feijão } \\
\text { branco } \\
\text { - Couve } \\
\text { - Açúcar }\end{array}$ & $\begin{array}{l}\text {-Feijão } \\
\text { vermelho } \\
\text { - Pimenta } \\
\text { - Cebola } \\
\text { - Alho } \\
\text { - Hortelã } \\
\text { - Canela } \\
\text { - Mel } \\
\text { - Vinho } \\
\text { forte }\end{array}$ & & $\begin{array}{l}\text { - Laranja } \\
\text { azeda } \\
\text { - Limão } \\
\text { - Pão de } \\
\text { centeio }\end{array}$ & $\begin{array}{l}\text { - Lentilha } \\
\text { - Galo } \\
\text { - Chicória } \\
\text { - Marmelo } \\
\text { - Vinagre } \\
\text { - Carne de } \\
\text { vaca } \\
\text { - Miolos }\end{array}$ \\
\hline \multicolumn{2}{|c|}{ Umedecido } & \multicolumn{2}{|c|}{ - Vinho brando } & $\begin{array}{l}\text { - Pão de trigo e vinho } \\
\text { aguado } \\
\text { - Conservas }\end{array}$ & & \\
\hline \multirow[t]{2}{*}{ Úmido } & $\begin{array}{l}\text { Um } \\
\text { pouco }\end{array}$ & $\begin{array}{l}\text {-Gema de } \\
\text { ovo } \\
\text { - Laranja } \\
\text { doce } \\
\text { - Azeite }\end{array}$ & $\begin{array}{l}\text { - Romã } \\
\text { - Leitão } \\
\text { - Fígado }\end{array}$ & $\begin{array}{l}\text { - Galinha } \\
\text { - Capão } \\
\text { - Peru }\end{array}$ & $\begin{array}{l}\text { - Favas } \\
\text { verdes } \\
\text { - Peixes } \\
\text { - Marisco } \\
\text { - Leite }\end{array}$ & $\begin{array}{l}\text { - Frango } \\
\text { - Pepinos }\end{array}$ \\
\hline & Bastante & - Nabo & $\begin{array}{l}\text { - Uvas } \\
\text { - Figos } \\
\text { - Pato } \\
\text { - Gergelim } \\
\text { - Cordeiro }\end{array}$ & - Porco & $\begin{array}{l}\text { - Alface } \\
\text { - Peixes } \\
\text { - Vitela }\end{array}$ & $\begin{array}{l}\text {-Melão } \\
\text {-Melancia }\end{array}$ \\
\hline
\end{tabular}

O distanciamento no tempo da sociedade colonial permitiu estudar melhor as articulações entre as diferentes fontes lógicas de ação, que incidiram sobre os manejos alimentares dos colonos lusos. Os conselhos dos médicos sobre os parâmetros de uma alimentação saudável não impediram a expressão dos gostos. Foi possível perceber nos versos de Gregório de Matos, uma curiosa combinação de preceitos científicos e de elementos gastronômicos indicadores da 
presença de um estilo de vida mazombo bem definido. Vinculados à saúde, alimentos e remédios ingeridos ou aplicados, tais como água de flor de laranjeira, purgantes, vomitórios, suadouros e sangrias, teciam a existência soteropolitana de acordo tanto com os preceitos da medicina humoral hipocrática, quanto com as preferências do paladar e expressavam uma estética de gostos e de sabores sujeitos ao repúdio ou à aprovação social e religiosa.

\section{3 - A arte de Gregório de Matos observada pelo prisma dos alimentos}

O interesse despertado pela "arte verbal" de Gregório de Matos dizia respeito ao teor dos conceitos que, um século e meio após a fundação de Salvador, regiam o convívio social soteropolitano, impondo à população um estilo de vida elaborado ao longo do processo de povoamento da capitania real. Os procedimentos costumeiros desse estilo entraram em crise no último quartel do século XVII. Tinham sido instaurados em função das condições ambientais, dos propósitos econômicos da colonização e das ambições sociais dos homens bons. As representações dos colonos influentes a respeito do papel que lhes cabia desempenhar na organização social da colônia delineavam uma questão cultural de relevância. Não foi por acaso que Matos se arvorou em porta-voz de elites atingidas em suas prerrogativas e se fez juiz dos desatinos sociais ocorridos na Cidade da Bahia ou em seu entorno rural. Uma forma simultaneamente lusa e local de pensar a colônia alinhavou o rol extenso das alusões inseridas nos versos. O fato dos hábitos nutricionais se apresentarem permeados de saberes e crenças e respaldarem uma concepção local da existência conferiu importância privilegiada às metáforas que serviram de veiculo à expressão poética do autor e de instrumento de estudo a essa tese.

As metáforas de Matos, imaginadas no contexto de uma ilustração concreta de idéias e de sentimentos acalentados, insistiram em defender valores cruciais, ora através de fórmulas consagradas (o rapaz assado por uma moça cosida, cujos atos empanariam o lustro de sua honra), ora através de paralelos simbólicos inesperados (os amores secos como biscoitos do poeta, contrastando com risadas líquidas consumidas às canadas, quando o poeta cortejava a 
amante de um amigo), ora pela multiplicação de gestos ridículos (como as refeições de homens livres que comiam carne de baleia ou pepinos sem limão e pimenta, escolhas alimentares contrárias à moral por sua avareza).

As comparações desejavam seróbvias, atreladas a gestos simples e facilmente decifradas. Elas exemplificaram atitudes inadequadas, de impacto visual calculado por um homem inteligente. Inspirados na arte poética de Quevedo, os poemas de Matos esboçaram, além de caricaturas satíricas, instantâneos de vida cotidiana colonial. Associaram-se a noções de prazer gustativo, a passeios bucólicos, a afetos e a hábitos predadores de caça e de coleta, mas acima de tudo à consciência aguda que o poeta possuía dos ditames de um modelo ideal de condutas sociais. A condição de metáforas escritas por um poeta do período barroco, entretanto, não levou as imagens rumo ao hermetismo gongórico sonoro e vistoso, mas de significado vago. Muito pelo contrário. O que ressaltou nos versos do autor, apesar da ausência de intenção deliberada de descrever o sistema alimentar das elites mazombas, foi a relevância de um conjunto de práticas de cultura material pertencentes ao imaginário local, que configuravam maneiras soteropolitanas hierárquicas de viver a condição humana.

\section{Obscenidade, decoro e moralidade social}

O uso que Matos fez de metáforas se referindo a procedimentos de alimentação tinha provinha da tradição literária ibérica. Compondo versos na linha de uma literatura cômica popular, o autor procurou resgatar o estilo de vida tradicional das elites lusas da colônia às quais ele pertencia por suas conexões de família. Quando, impossibilitado de exercer cargos condizentes com sua capacidade profissional, ele se dedicou à escrita poética, a atividade que escolheu não foi somente a arte de um ser marginalizado, desejoso de se vingar de inimigos pessoais. As sátiras e os poemas burlescos apresentados aos conterrâneos, lhe proporcionaram uma maneira de demonstrar seu talento de letrado. Modelos exemplares da arte satírica praticada na península ibérica não lhe faltaram, tanto medievais, quanto renascentistas. 
Ele enveredou pelas grosserias ambivalentes, degradou e mortificou alguns de seus pares no intuito de despertar a consciência da moralidade tradicional, numa sociedade colonial cujos parâmetros de conduta se afastavam da utopia social acalentada nos anos de ausência. O intuito de escandalizar os mazombos, aplicando regras engenhosas de composição poética não foi a única meta do poeta. O uso que fez de expressões chulas, de imagens grotescas e de uma linguagem popular constituíram, segundo Gomes, um "fator de potencialização poética" das críticas formuladas ${ }^{1164}$. Os conselhos que Matos deu aos colonos e os insultos que ele proferiu, seguiram uma linha coerente de argumentação no conjunto da obra. Todos apresentaram um forte viés social, moral e político.

Ao produzir poemas de forte apelo erótico e incluir em seus versos metáforas cruas sobre as funções do baixo ventre, Matos, de fato, aderiu a caminhos literários previamente traçados. Gomes enfatizou sua filiação a "uma linha escarnina e fescenina" que vinha da Antiguidade e se prolongava nos fabliaux do século XIII, nos servanteses provençais ou nas cantigas de mal dizer de poetas célebres como Rutebeuf, Bernard de Ventadorn, Peire Cardinal: “temerários poetas que engordam a rica poesia mundana e 'suja' dos goliardos", ou ainda nas obras de Villon, Rabelais, Boccacio ${ }^{1165}$. Segundo o mesmo autor, pelo modo andejo de poetar Matos teria agido, além do mais, como um autêntico goliardo tropical. Talvez a comparação esteja acertada, apesar do poeta freqüentar o Recôncavo sobretudo a convite de amigos, que gostavam de ouvi-lo cantar e recitar. Porém a cor local, mesmo proveniente de uma fórmula previamente traçada de redação poética, não constituiu nenhum aspecto secundário. A realidade soteropolitana, seja como utopia a ser defendida, seja como inspiradora de ações sociais cotidianas, foi parte constituinte do empreendimento literário. O sucesso que o público mazombo reservou às descrições satíricas ou burlescas não deixa dúvidas sobre o prazer que os poemas do autor proporcionaram aos conterrâneos.

\footnotetext{
1164 GOMES, João Carlos Teixeira. Op. Cit., pp. 356 e 357.

1165 GOMES, João Carlos Teixeira. Op. Cit., p. 336.
} 
Não foi sem motivos que o padre Vieira declarou os versos de Matos mais eficientes que seus próprios sermões para impor decoro à sociedade colonial. O modo como o poeta desejou influir sobre formas soteropolitanas de pensar e de agir, atingindo poderosos cujas condutas destoavam dos padrões, rebaixando homens considerados ignaros, invejosos ou pretensiosos - retratados de forma caricata nos poemas através das piores mazelas físicas - teve, de fato, muito a ver com a impossibilidade de exercer cargos prestigiados. A ausência de uma posição social de poder o levou, portanto, à reafirmação de seu conhecimento das leis e da justiça e à comprovação do vigor de seu poder simbólico.

Fazendo uso da obscenidade para criar imagens de forte impacto, Matos produziu obras de realismo grotesco um pouco aparentado à maneira rabelaisiana analisada por Bakhtin. Sua arte, como aquela de Rabelais, expôs corpos em movimento e ingestões de bebidas e de comidas que nada tinham de comedido, sublinhando a ocorrência de satisfações sensuais e de desordens fisiológicas de efeito desastroso ${ }^{1166}$. O autor se voltou de forma contundente contra o povo miúdo soteropolitano. Na verdade, antes mesmo de desmerecer, segundo a expressão de Bakhtin ${ }^{1167}$, com um riso festivo e carnavalesco de caráter popular, autoridades coloniais relapsas que não desempenhavam suas obrigações a contento, o olhar impiedoso de Matos fustigou os apetites vorazes do povo. Como bem observou Peres, Matos não foi jamais um paladino do nativismo e da miscigenação.

O poeta, mesmo ameaçado de decair socialmente por falta de recursos, não deixava de pertencer às elites. Sua situação divergia muito da condição social do escudeiro de Dom Quixote, do qual o aproximava, entretanto, sua voracidade pelas benesses da vida.

\footnotetext{
1166 Personagens delineados por Matos tendiam a demonstrar as conseqüências de suas ações desastradas por meio de inconvenientes fisiológicos advindo dos erros, enquanto que os heróis de Rabelais costumavam ressaltar o caráter moral das ações de forma mais positiva, através de acúmulos de pequenos gestos carregados de valor metafórico.
}

1167 BAKHTIN Mikhail. A cultura popular na Idade Média e no Renascimento: o contexto de François Rabelais, Op. Cit., pp.15 e 16. 
Bakhtin analisava:

"O materialismo de Sancho, seu ventre, seu apetite, suas abundantes necessidades naturais constituem o "inferior absoluto" do realismo grotesco, o alegre túmulo corporal (a barriga, o ventre, a terra) aberto para acolher o idealismo de Dom Quixote, um idealismo isolado, abstrato e insensivel; ali o "cavaleiro da triste figura" parece dever morrer para renascer novo" 1168 .

Interessa, a esse respeito, o contraste existente entre as interpretações que Matos e Bakhtin fizeram de Dom Quixote e de seu fiel escudeiro. Pois, como foi constatado acima, Quixotes, segundo Matos, não cultuavam ideais honrados: eram apenas aventureiros inescrupulosos e esfomeados que subvertiam a vida social a custo de tramóias.

O corpo como lugar de representações sociais capazes de despertar emoções profundas e de canalizar rancores, proveu metáforas expressivas ao poeta, defensor das normas hierárquicas de conduta ameaçadas pela ambição de colonos que desejavam um lugar ao sol, apesar de não fazerem jus à fidalguia: mulatos, mamelucos, oficiais mecânicos ou cristãos novos com os quais os cristãos velhos temiam ser confundidos. Além do repúdio a impedimentos étnicos, formulado em termos pragmáticos, imperou efetivamente na boa sociedade um desprezo profundo pelo trabalho braçal capaz de desqualificar um homem, seus filhos e seus netos. O mundo luso, com efeito, até Pombal abolir oficialmente o caráter infamante do trabalho manual e as diferenças entre cristãos novos e cristãos velhos, durante a segunda metade do século XVIII, apregoou a pureza ontológica do sangue de cristãos velhos tratados à lei da nobreza, descartando das posições de mando colonial indivíduos cujos antepassados carregavam máculas étnicas ou tinham auferido rendas na prática de trabalhos manuais.

A limpeza original do sangue, humor considerado como principal substância corporal, e a manutenção de sua higidez por meio de condutas morais abriram caminho à reificação de diferentes categorias de homens, que viviam justapostas em território soteropolitano. A crença

1168 BAKHTIN. Mikhail. Op. Cit, p. 20. 
em diferenças de qualidade de sangue entre os rústicos e os homens bons, se não fez parte das convicções do Dr. Mirandela, deixou lugar à idéia da importância dos hábitos alimentares para a manutenção da saúde e também da necessidade de um certo comedimento nas escolhas alimentares dos homens mais favorecidos:

"Hoje não há mesa tão simples que conste de um só alimento, nem ainda a dos rústicos, em que sempre há de haver pão, vinho, queijo, leite, legumes e nos que se regalam, couves com toucinho. Os que vivem com melhor fortuna e se tratam modestamente compõem a sua mesa de umas sopas, um assado, e olha de vaca, presunto e arroz. E a esta proporção, nos dias em que a Igreja proíbe a carne, fazem a sua mesa de peixe. Os ricos e grandes senhores, ou por crédito da magnificência, ou por lisonja do palato, compõem a sua mesa de toda a variedade de alimentos, de que fazem massas, guisados, fricassês e várias iguarias com que estragam os estômagos e perdem a saúde..." $" 1169$.

Acreditava-se até que comer alimentos demasiadamente delicados poderia prejudicar a saúde de camponeses ${ }^{1170}$. Em tal circunstância, que a alimentação, meio de agir sobre os humores tenha adquirido poder metafórico discriminatório se explica facilmente. Os conceitos geminados de nobreza da terra e de sangue limpo constituíam critérios classificatórios relevantes. Matos, por conseguinte, encontrou nos ingredientes da dieta colonial um veículo ideal de expressão simbólica, traduzindo em termos de alimentação prudente ou néscia um universo amplo de categorias de colonos, identificados em função de suas práticas nutricionais ou de sua semelhança física com ingredientes da dieta alimentar. O recurso poético à obscenidade se contrapôs, por conseguinte, ao sentimento da honra, transformando ingestões alimentares indecorosas em demonstrações de inadequação social.

\footnotetext{
1169 HENRIQUEZ, Francisco da Fonseca. Op. Cit., p. 58.

1170 HENRIQUEZ, Francisco da Fonseca. Op. Cit., p. 50
} 
Numa sociedade construída em torno da exploração do trabalho compulsório de escravos e particularmente sedenta de prestígio, a mestiçagem dos descendentes de colonos lusos mascavados (parcela da população que parecia aumentar numericamente), tornou relevante a localização de cada indivíduo na hierarquia da sociedade colonial. Colonos nascidos no Brasil ou imigrantes recentes enriquecidos não pertenciam à nobreza lusa, mas fizeram questão de regular sua vida segundo os valores honoríficos portugueses, exacerbando os padrões de prestígio, uma maneira local de se afirmarem lusos. Semelhante perspectiva deixou em situação assaz delicada homens bem-nascidos e formados, como o poeta, que pertenciam à boa sociedade mas, desprovidos de fortuna, estavam expostos aos perigos que a pobreza oferecia à manutenção da honra. A própria miséria e a fome afiguravamse como motivos de vergonha. A defesa irascível que Matos, empobrecido, fez do estilo de vida local nobre passou, em conseqüência, por atitudes ostensivas de desapego à riqueza. $\mathrm{O}$ fato permite que se entenda melhor os motivos de seu rancor contra o descaso do governador Câmara Coutinho em relação à mercê ordinária solicitada que lhe permitiria manter decentemente a mulher e os filhos.

O trato da vida nobre, elemento fundamental na constituição da honra, cujos valores prolongavam uma concepção portuguesa de sociedade estamental, parece ter sido exacerbado. Resultou numa mise em objet soteropolitana das atividades corporais cheia de restrições, limitando o acervo dos gestos que indivíduos desejosos de reconhecimento social podiam efetuar sem desdouro. O ócio nobre e os lucros do trabalho escravo permitiam a colonos honrados caçarem, demonstrarem perícia em competições esportivas, se reunirem, promoverem comédias, praticarem sexo e passearem pelos campos (correndo atrás de porcos selvagens, fugindo de vacas, colhendo cajus, cavalgando, navegando, se vestindo com esmero, jogando cartas, paquerando, cantando, rindo, bailando, comendo e bebendo - desde que não abusassem das bebidas alcoólicas).

O forte teor erótico e obsceno dos versos, bem como o tom jocoso dos poemas burlescos merecem reparo. Esses poemas se destinaram, obviamente, antes ao deleite de ouvintes 
masculinos que à compreensão das moças interessadas. Assinalavam também a importância do sexo como tema preferencial nas conversas dos homens, reunidos nas varandas das casas grandes para passar o tempo agradavelmente:

"Senhora Cota Vieira, / [...] Tive debaixo da língua / o pedir-vos uma lasca / da nata do vosso cono, / se é, que tem côdea essa nata. / Quando a culatra vos vi / tão tremenda, e rebolada, / meti logo a mão à porra, / e estive saca, não saca. / Mas reverente adverti, / que ali o Capitão estava / senhor das minhas ações / e dono da vossa casa. / [...] Quem, o que deve a um amigo / em respeitos lhe não paga, / não é amigo, nem homem, / é uma bêsta assalvajada. / Mas andar, fôda ele embora, / isso não importa nada, / teremos amôres secos, / sêco é o biscouto, e campa. / Falaremos sempre aos molhos, / e riremos às canadas, / folgaremos, que amor sêco / sem molhar beiço se passa..."1171.

A dieta alimentar apresentando ritos usuais permitiu que Matos criticasse a sociedade colonial em termos de ingredientes comestíveis desfrutados. Nutrindo corpos, os alimentos serviram-lhe ainda de veículo de estilo para desmerecer identidades alheias. Seus trocadilhos metonímicos, por exemplo, sublinharam o caráter passivo e vil de adversários satirizados, ao ridicularizarlhes o sexo transmutado de carne nobre em vegetal plebeu, pobre em valor nutritivo e por esse motivo reservado sobretudo a gente pobre.

O motivo para as lacunas e omissões, que puderam ser percebidas durante a redação deste trabalho, referentes a alimentos de uso corrente, se tornou mais evidente ao se examinar o propósito metafórico das alusões a gêneros comestíveis. Por saborosas que fossem, as abóboras e as mangabas pouco significaram em termos simbólicos e literários. Mas os princípios fundamentais que atuaram na organização da dieta se prestaram com grande vigor à formulação de trocadilhos prenhes de significados.

1171 MATOS, G. Vol. III, pp. 568 a 570. 
Que as metáforas proporcionarem expressões literárias sugerindo obscenidade, talvez induziu Matos a manter alguma cautela, quando se referiu a hábitos alimentares nobres, por motivos de decoro. Ele quase não mencionou as carnes assadas correntemente consumidas na época. Guisados (como a galinha-de-cabidela), chegaram a ser citados por ele, mas figuraram nos versos com grande parcimônia, assim como os pastéis. No entanto, o poeta não economizou vocabulário para mencionar doces ou conservas de frutas doces, possivelmente por ornamentarem sobretudo poemas de tom laudatório.

\section{Uso simbólico e uso emblemático dos alimentos}

Obrigação biológica indispensável à continuidade da vida, porém modelada em suas formas diárias através de idéias, de disponibilidade local dos ingredientes comestíveis e de preferências de um paladar educado pelo costume, a alimentação de uma sociedade costuma se apresentar como um fenômeno aberto aos perigos físicos e simbólicos. Rondavam efetivamente os versos do poeta perigos imediatos de toxicidade das iguarias ingeridas (como a carne dos peixes baiacus) e perigos latentes de perda de vigor e doenças, por carência ou por excesso de comida. Inspiravam medo também os perigos simbólicos da perda de prestigio em virtude de incorporações de alimentos pouco idôneos à substância corporal íntima ${ }^{1172}$.

$\mathrm{Na}$ análise de Maria Eunice Maciel ${ }^{1173}$, a teia de relações sociais urdidas em torno da alimentação humana, sublinhou a situação de espaços privilegiados que os sistemas alimentares oferecem por sua atribuição de significados particulares culturais e sociais aos atos alimentares. As escolhas e classificações de cada grupo social, afirmou a autora, refletem processos sociais que marcam a especificidade do grupo e possibilitam que os membros de uma sociedade sejam reconhecidos e se reconheçam eles próprios através de hábitos de consumo tomados como sinais diacríticos, isto é, como elementos simbólicos de uma identidade social e cultural reivindicada. Ao assinalar a importância das circunstâncias contextuais e o caráter dinâmico das maneiras 1172 FISCHLER, Claude. L'homnivore: le goût, la cuisine et le corps. Op. Cit.

1173 MACIEL, Maria Eunice. "Identidade cultural e alimentação", in CANESQUI, Ana Maria e GARCIA, Rosa Wanda Diez. Antropologia e nutrição um diálogo possível. Rio de Janeiro, Ed. Fiocruz, 2005. 
codificadas de se alimentar, impossíveis de serem confundidas com meros inventários de pratos consumidos, a autora examinou casos de cozinha emblemática, que implicavam pertencimento cultural, histórico e geográfico. Referindo-se a procedimentos de alimentação observados em países colonizados, a autora apresentou diversos casos de usos alimentares representativos e mencionou ainda, rapidamente, a questão dos costumes alimentares utilizados para estigmatizar pessoas consideradas inferiores.

Nesses termos, sobressaiu um aspecto da dieta alimentar soteropolitana que, no desenvolvimento da tese permaneceu um tanto na penumbra em razão da metodologia de trabalho. Uma vez elaborados em torno de confluências heteróclitas de razões práticas e simbólicas que configuravam o uso de cada ingrediente da dieta, os hábitos alimentares instaurados deixaram de ser somente reflexos de acontecimentos ou de idéias. Tornados premissas tácitas do viver colonial, serviram também para modelar a forma das interações sociais.

Inspirado na literatura picaresca de seu tempo, Matos condimentou os versos com metáforas e metonímias que apresentavam comparações picantes e irônicas, recursos de uma arte poética que manejava os duplos sentidos engenhosos. Ele aludiu seguidamente a manejos de cultura material para expressar os valores culturais das elites soteropolitanas. Mas, a ira do poeta contra os desmandos, motivada pelo desrespeito flagrante dos pícaros às normas mazombas e por seu desejo de forçar os recalcitrantes a se dobrarem às regras, também indicou as limitações impostas ao poder estruturante dos hábitos.

Na obra de Gregório de Matos, rica em críticas acerbas contra indivíduos e grupos sociais destoantes, uma ampla variedade de consumos recriminados estigmatizou todos aqueles que faziam sombra a um ideal concentrado em torno da preeminência social dos cristãos velhos limpos de sangue, dos letrados cultos e dos lavradores abastados. Algumas representações poéticas, provavelmente imagens simbólicas particularmente apreciadas pelo poeta e seus ouvintes, foram retomadas em diversas ocasiões, conferindo recorrência emblemática às imagens e criando uma equivalência substancial entre os consumos representativos e os indivíduos representados.

Como foi constatado em capítulos anteriores, as iguarias nativas e os pernis tostados, 
quando citados nos versos, se transformaram em sinais emblemáticos de uma inferioridade social creditada a ascendentes mestiços. Os próprios feijões, que constituíam um mantimento apreciado a bordo das naus da frota comercial ou nas refeições dos escravos e de gente pouco remediada, e que, comidos sob forma de caldos de substância, estancavam a fome dos colonos em dias magros, quartas e sextas-feiras ou sábados nos quais era proibido comer carne, serviram ao poeta para desmerecer inimigos acusados de judaizar ${ }^{1174}$. Matos, por exemplo, em seu poema destinado a uma noiva frisou: "Para os dias de peixe / caldo de grãos" ${ }^{1175}$.

Alimentos utilizados para ridicularizar cristãos novos, os feijões de Gregório de Matos trouxeram à tona a lembrança de um ensaio clássico de Peter Fry sobre a feijoada brasileira, iguaria emblemática de brasilidade, que o estudioso constatou ser também soul food, refeição típica de uma identidade regional entre negros norte-americanos radicados no sul do país.

A ênfase de Matos sobre os diversos motivos de repulsa que merecia o consumo de feijões flatulentos, bons apenas para alimentar marujos e escravos e identificar hereges, permite avaliar melhor a amplitude da reviravolta cultural ocorrida em meados do século XVIII com a aceitação do feijão, alimento diacrítico antes estigmatizado de forma negativa e sua promoção a mantimento básico. Como bem sublinhou Câmara Cascudo: "Comia o indígena feijões e favas mas, ao deduzir-se dos registos dos séculos XVI e XVII, não constituíam preferência ou aquela atração irresistivel que a farinha de mandioca provocava" ${ }^{1176}$. O autor acrescentava ainda: "No Brasil as referências atestam a existência dos feijões e das favas mas não sua popularidade" 1177 .

1174 Valeria a pena relembrar, uma vez mais, que os cristãos velhos se abstinham de associar carnes aos caldos de grãos, pois, comer feijões e outras leguminosas cozidas juntamente com carnes bovinas eram indicativo de ascendência judaizante, sendo que as próprias vagens e os feijões eram denominados judias em espanhol.

1175 MATOS, G. Op. Cit., Vol. V, p. 1093.

1176 CASCUDO, Câmara Luis da. Op. Cit., p. 494.

1177 CASCUDO, Câmara Luis da. Op. Cit., p. 492. 
A idéia correntemente divulgada da feijoada inventada nas senzalas do Brasil colonial ou do Brasil imperial como derivação do cozido português incorpora, aliás, um equivoco suplementar, além da afirmação de que derivaria do cozido português. Como bem destacou Carlos Augusto Silva Ditadi:

"Quanto ao gosto, a aparência e a utilidade, por que considerar os rabinhos, pezinhos, orelhinhas e os miúdos como restos? Não será um preconceito moderno a respeito desses pedaços? Afinal, não são estes os ingredientes das receitas portuguesas Tripas à moda do Porto $e$ pezinhos de porco de coentrada, das italianas Trippa alla fiorentina e Paiata (primeira parte do intestino delgadoda vitela) alla caciatora, das francesas Tripes à la mode de Caen..."1178.

Rodrigo Elias compartilhou a mesma opinião:

"Vale lembrar que as partes salgadas do porco, como orelha, pés e rabo nunca foram restos. Eram apreciados na Europa, enquanto o alimento básico nas senzalas era uma mistura de feijão com farinha".

No que tangia ao feijão preto, vegetal de origem americana, o mesmo estudioso assinalava:

"Era uma cultura essencialmente doméstica que facilitou a fixação das populações no território luso-americano". O autor considerou ainda que: “A dispersão populacional dos séculos XVIII e XIX [...] foi extremamente facilitada pelo prestigiado vegetal. Atrás dos colonos foi o feijão" ${ }^{1179}$.

Despojada teoricamente de qualquer caráter judaizante pelo acréscimo de carnes de porco, a mistura do feijão com a carne, iguaria de cocção prática e gosto saboroso, acabou provavelmente prevalecendo no Brasil, a partir do momento em que a Inquisição deixou de perseguir os 1178 DITADI, Carlos Augusto. "Feijoada", in Revista Gula, No. 67, Maio de 1998.

1179 ELIAS, Rodrigo. "Breve História da feijoada”, in Nossa História, Ano I, no. 4, Fevereiro 2004. 
cristãos novos. A permanência dos dias de preparo da feijoada (aos sábados e quartas-feiras) parece indicar o motivo, outrossim relativamente misterioso, pelo qual uma iguaria atribuída por conveniência à cozinha das senzalas galgou com muita facilidade os degraus da hierarquia social, numa sociedade extremamente ciosa do prestígio pessoal de cada indivíduo.

O caso do feijão transformado em ingrediente da feijoada, ao cabo de muitas evasivas e falsos pretextos confirma, em contra-luz, uma presença notória de cristãos novos na colônia, assim como a importância dos valores culturais vigentes no estabelecimento de hábitos alimentares.

Numerosos hábitos emblemáticos de alimentação satirizados na obra de Matos estigmatizaram negativamente categoria de colonos considerados indignos de prestígio social. Em compensação, os versos salientavam uma grande semelhança das iguarias correntes com aquelas que eram apreciadas na metrópole. Não pareciam existir ainda receitas reconhecidamente locais, capazes de serem assumidas como representativas de reivindicações de autoctonia regional.

Resumindo magistralmente os principais elementos em jogo na questão levantada (e, quiçá, refletindo a partir de casos semelhantes àqueles ora apresentados), Jean Pierre Poulain analisou:

“Quer ele seja percebido como um sinal, um emblema, um símbolo, o ato alimentar insere e mantém por suas repetições cotidianas o comedor num sistema de significados. É sobre as práticas alimentares, vitalmente essenciais e cotidianas que se constrói o sentimento de inclusão ou de diferenciação social. É pela cozinha e pelas maneiras à mesa que se produzem as aprendizagens sociais mais fundamentais, e que uma sociedade transmite e permite a interiorização de seus valores. É pela alimentação que se tecem e se mantêm os vínculos sociais" $" 1180$

Parece significativo, a esse respeito, que os mazombos avessos às mestiçagens, apregoassem uma visão conservadora do estilo de vida colonial, pela voz de seu representante Gregório de

1180 POULAIN, Jean-Pierre. Op. Cit., pp 197 e 198. 
Matos e, que às vésperas das mudanças econômicas, sociais e políticas desencadeadas pela descoberta do ouro nas Minas Gerais ${ }^{1181}$, rejeitassem o consumo de muitos ingredientes nativos, disponíveis, nutritivos e saborosos.

\section{4 - Alimentação soteropolitana e significados culturais e sociais nos poemas de Gregório de Matos}

Ao final de um longo périplo pelos meandros das metáforas poéticas seiscentistas e dos hábitos alimentares soteropolitanos, seria interessante voltar rapidamente à questão do "Seqüestro do barroco na formação da literatura brasileira" proposta por Haroldo de Campos ${ }^{1182}$. Lastimando a opinião de Antônio Cândido de Mello e Souza $^{1183}$, que negava relevância à poesia barroca de Matos ao alegar que o autor não teria contribuído à formação de um sistema literário brasileiro, Campos citava Oswald de Andrade ${ }^{1184}$ para exaltar as qualidades inerentes aos versos de Matos, o poder da imaginação, a curiosidade e a independência, o conhecimento das técnicas de versificação, a riqueza do vocabulário. Ressaltando a injustiça feita à obra do poeta mazombo, caracterizada por Mello e Souza como literatura "pobre e fraca"1185, Campos se insurgia contra a "perspectiva histórica" e "ideológica"1186 de Mello e Souza, para quem estilos, temas, formas e preocupações locais somente começaram a ser produzidos na colônia por volta de 1750, a partir do surgimento das Academias dos Seletos e dos Renascidos.

1181 Ocorridas após 1695.

1182 CAMPOS, Haroldo de. O seqüestro do barroco na formação da literatura brasileira: o caso Gregório de Matos. Salvador, Fundação Casa de Jorge Amado, 1989. p. 9.

1183 SOUZA, Antônio Cândido de Mello e. Formação da Literatura Brasileira. BH./RJ., Itatiaia, 9a ed., 2000.

1184 CAMPOS, Haroldo de. O seqüestro do barroco na formação da literatura brasileira: o caso Gregório de Matos. Salvador, Fundação Casa de Jorge Amado, 1989. p. 9.

1185 CAMPOS, Haroldo de. Op. Cit., p. 13.

1186 CAMPOS, Haroldo de. Op. Cit., pp. 15 e 16. 
Campos se recusava a associar a emergência de uma estética literária brasileira apenas ao "projeto literário do Romantismo ontológico-nacionalista"1187. Em sua opinião: "a contribuição de nosso maior poeta barroco (e um dos maiores de toda nossa literatura) é julgada severamente".

Segundo o estudioso afirmava, a exclusão de uma arte lúdica em benefício da estética romântica resultava de preconceitos contra o "culteranismo amaneirado" ainda que Mello e Souza somente outorgasse voz e vez ao inexistente "Boca do inferno" 1189 ao se referir na Dialética da malandragem à "comicidade malandra" do poeta:

\begin{abstract}
“Como se pode proclamar esse vazio historiográfico, contestado por uma inscrição historial que o texto gregoriano exibe gozosamente em sua trama, sem no mesmo passo, pôr em questão a própria noção de história que condiciona essa perspectiva excludente?""190.
\end{abstract}

Sem pretender resolver as celeumas suscitadas pelo valor estético brasileiro ou luso dos poemas compostos por Gregório de Matos, poderia-se concluir em favor do ponto de vista de Mello e Souza, avaliando a questão apenas em termos de metáforas alimentares reveladoras de premissas tácitas locais. Os homens que fruíam a recitação das obras poéticas de Matos eram os mesmos que se deliciavam com iguarias preparadas em território soteropolitano. A arte poética e os preparos culinários, ambos parte de um mesmo estilo de vida colonial que considerava os mestiços como seres pouco nobres, apimentavam as reuniões sociais das elites soteropolitanas. Existia um vínculo óbvio entre a ira do poeta contra mulatos e mamelucos, sua rejeição das aspirações desses homens à honorabilidade e sua recusa de saborear formas abominadas de preparos da mandioca puba.

Apesar da presença indubitável da realidade soteropolitana nos versos de Matos, nada em sua poesia sugeria o despertar literário precoce de um sentimento nativista. Tampouco foram
1187 CAMPOS, Haroldo de. Op. Cit., p.32.
1188 CAMPOS, Haroldo de. Op. Cit., p. 54.
1189 CAMPOS, Haroldo de. Op. Cit., p. 72
1190 CAMPOS, Haroldo de. Op. Cit., p. 44. 
encontradas evidências de uma ruptura entre Lisboa e a Cidade da Bahia na eloqüência ufanista e amaneirada com a qual Manuel Botelho de Oliveira ou Sebastião da Rocha Pitta, autores contemporâneos de Matos, descreveram seu enorme apreço pela capitania real.

Reiterando uma observação de Sérgio Buarque de Holanda, é preciso reafirmar como ser natural do lugar, então a maior colônia do Império português, não implicou necessariamente o advento de sentimentos nacionalistas brasileiros na escrita do poeta. Se, por um lado, os poemas de Matos retratavam efetivamente uma consciência de pertencimento ao ambiente social da colônia, formulavam queixas mazombas e percorriam de barco, de rede ou a cavalo o meio geográfico soteropolitano, por outro lado, as refeições que colonos abastados lhe ofereceram delineavam uma continuidade fundamental com a maneira lusa de conceber a vida.

Talvez já existissem até outros hábitos alimentares soteropolitanos em gestação entre pessoas de menor poder aquisitivo, mas não seria nos versos de Matos que indícios do conteúdo de suas panelas deveriam ser procurados. O contingente dos escravos alforriados e dos mulatos nascidos livres que residia em Salvador incluía ainda escravos de ganho, moradores de casebres na periferia da capital, que apenas entregavam o produto de seus ganhos aos senhores e se alimentavam por conta própria com ingredientes de pouco custo. Esse contingente da população devia ter uma certa latitude para experimentos culinários que incluiriam reminiscências africanas ou nativas, caso dispusesse de tempo para cozinhar.

Maiores ocasiões de se alimentar a seu bel prazer teriam provavelmente os escravos urbanos. Aqueles adstritos ao serviço dos engenhos recebiam gêneros alimentícios sob forma de rações ou cultivavam pequenas roças. Na cidade, a limitação quiçá figuraria na escassez dos produtos frescos.

Além do mais, o número dos escravos aportando a Salvador nas naus do tráfico negreiro era maior que o número das escravas, sendo que cozinhar constituía sobretudo uma tarefa feminina e que nem todas as escravas constituíam família. Se não cozinhassem para os seus mas apenas se alimentassem haveria realmente espaço ou tempo em sua vida para pensar em elaborar fusões complexas de procedimentos culinários e de ingredientes comestíveis de diversas origens? Caso semelhante fenômeno ocorresse 
mesmo, a despeito das dificuldades, seu valor identitário seria provavelmente enorme na vida daqueles que mais sofriam na carne a falta de prestígio social, para não mencionar a dura servidão.

A repulsa de Matos por iguarias vistas como toscas não deixava dúvidas a respeito das limitações impostas às experiências culinárias. Matos freqüentou procissões e festas das irmandades de negros ou de mulatos, admirou mulatas que dançavam o paturi na ladeira da Água brusca e não considerou um atentado contra sua honra pagar ninharias a mulheres promíscuas, porém satirizou veementemente os colonos que freqüentavam quilombos e participavam de calundus. Relações sociais com seus inferiores podiam até ser íntimas, mas elas não deixavam de marcar distâncias convenientes. Aliás, a poesia erótica do autor parece mais destinada aos ouvidos dos amigos reunidos nas varandas do que propriamente às moças amadas, mesmo nos elogios mais gongóricos. Valeria a pena refletir sobre as nuances expressas em semelhantes maneiras de agir em função da analise que Le Breton apresentou em sua Sociologia do corpo:

“Ao mesmo tempo em que é lugar de valor, o corpo é lugar de imaginários, de ligações contestáveis cujas lógicas sociais é preciso compreender. O racismo repousa, entre outras coisas, sobre uma relação imaginária com o corpo. Ele finca raizes no interior dos alicerces passionais que alimentam a vida coletiva, alimentam projetos, mobilizações, mobilizam tolerâncias ou violências. O racismo é o exemplo de uma forma-pretexto, socialmente disponível, para acolher as paixões mais divergentes, as razões mais ambíguas e dar-lhes enfim ramificações. Reprimida a afetividade, as frustrações, as designações são sugadas para essas formas vacantes que oferecem uma superfície de proteção a qualquer gradação 
possivel de rancor" ${ }^{1191}$

Obviamente, o imaginário mazombo sobre a inferioridade da população escravizada não elaborou os argumentos desenvolvidos em épocas posteriores. No entanto, alguns preconceitos já estavam explícitos. A maneira displicente como os vereadores da Câmara Municipal, por exemplo, coibiram, de repente, soldados e mulatos de serem contratados para servir o público nos açougues, limitando posteriormente a proibição apenas aos escravos mulatos que não respondiam por seus próprios atos (e colocavam seus senhores em risco de processos), demonstraria, se ainda fosse preciso, como Matos, ao vituperar os colonos, externava preconceitos que retratavam efetivamente os modos de pensar e de agir de seus contemporâneos.

Á sombra da sociedade mazomba nasceu uma maneira de ser local suficientemente diferenciada e expandida para que Matos se sentisse obrigado a vituperá-la em seus costumes. Não seria lógico esperar que ele exaltasse tais inovações. Ao desprezar a arte do poeta por não se fundamentar na expressão de um folclore brasileiro e "copiar" apenas premissas tácitas lusas, Silvio Júlio não deixava de ter alguma razão. Apenas não foi capaz de perceber que os elementos do folclore local retratados nos poemas de Matos pertenciam a um universo de hábitos mistos, lusos e regionais. Os soteropolitanos regozijaram-se com a nobreza dos governadores designados pelo rei para dirigir a colônia, sem dissolver em rancor contra Portugal a auto definição lusa de origem para demonstrar independência.

1191 LE BRETON, David. A sociologia do corpo. Op. Cit., Cap. V p. 72.

LE BRETON, David. La Sociologie du corps. Op. Cit., p. 91.

"En tant qu'il est lieu de valeurs, le corps est aussi lieu de fantasmes, d'attachements contestables dont il faut saisir les logiques sociales. Le racisme repose, entre autres, sur une relation fantasmastique au corps. Il s'enracine à l'intérieur das soubassements passionnels qui alimentent la vie collective, nourrissent ses projets, ses mobilisations, motivent ses tolérances ou ses violences. Le racisme est l'exemple d'une forme-pretexte socialement disponible pour accueillir les passions les plus disparates, les raisons les plus ambigües, et leur donner enfin une voie de dérivation. L'affectivité refoulée, les frustrations, les résignations, sont drainées par ces formes vacantes qui offrent une surface de projection à toutes les nuances possibles de la rancoeur". 
A crise econômica e as mudanças introduzidas no governo da colônia durante a segunda metade do século XVII afetaram um estilo de vida cristalizado antes mesmo da restauração de um monarca luso no trono português, permitindo entrever as razões das tensões surgidas entre colonos, negociantes e certas autoridades locais.

O termo mazombo distinguiu lusos descendentes de cristãos velhos, nascidos na colônia e designou afinal de contas uma categoria de colonos mais complacente em relação à origem lusa do que próxima da população local dos mestiços, dos índios, dos cristãos novos ou dos escravos africanos. Mas o termo designou também colonos que, não obstante a auto definição local específica, nunca chegaram a constituir realmente uma categoria social consistente, já que o ouro das Minas Gerais foi descoberto, que as naus portuguesas desembarcaram anualmente novas levas de pícaros esfomeados e que a situação colonial configurada mudou.

Da mesma forma que não se deveria considerar uma imitação a maneira lusa de versejar de um poeta nascido no Brasil e formado em Portugal, cobrando dele formas originais de arte poética apenas por compor versos no Brasil, seria difícil falar em plágio no plano da alimentação. Haveria, no contexto da vida colonial, um certo paralelismo entre a criação literária e as preparações culinárias. Expressaram o mesmo tipo de consciência de si impregnada de regionalismo e de memórias. Pelo viés dos alimentos mencionados pelo poeta é possível adivinhar os primórdios de um aproveitamento do terroir soteropolitano comportando escolhas e exclusões regidas por usos culturais. Mariscos ou peixes fartos ferveram seus aromas nas panelas mazombas e nas panelas crioulas. Cajus refrescaram bocas ressecadas pelo verão tropical. Carne bovina fresca, seca ou salgada acompanhou farinhas de mandioca, beijus e gêneros comestíveis que ofereceram vantagens práticas ou paladar delicioso. Todos, deram início à novas criações de costumes em torno de refeições de feijões ora comidas, ora caricaturais. 




Gravura: Ville de Salvador Brésil, 1695 - Froger, François. (1676 - 1715) Buril, 13 x 26,5 cm. 


\section{REFERÊNCIAS}

ABDALA, Mônica Chaves. Receita de Mineiridade: a cozinha e a construção da imagem do mineiro. Uberlândia, EDUFU. 1997.

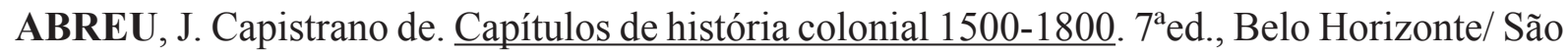
Paulo, Itatiaia/EDUSP, 1988.

Caminhos antigos e povoamento do Brasil. Belo Horizonte/São Paulo, Itatiaia/EDUSP, s/data.

ALDENBURGK, Johann Gregor. Relação da conquista e perda da cidade do Salvador pelos holandeses em 1624 - 1625. Brasiliensia Documenta, Vol. I, 1961.

ALENCASTRO, Luiz Felipe. O trato dos viventes: formação do Brasil no Atlântico Sul. São Paulo, Cia das Letras, 2000.

ALONSO, Damaso. Luis de Gongora y Argote. Madrid, Csic, 1950.

AMARAL, José Roberto do. A Bahia e a Carreira da Índia. São Paulo, Ed. Nacional/EDUSP, 1968.

ANTONIL, André João. (João Antonio Andreoni). Cultura e opulência do Brasil. $2^{\mathrm{a}}$ ed., (Texto da ed. de 1711), São Paulo, Ed. Nacional, 1967.

ATAS da Câmara, 1669 - 1684, $5^{\circ}$ volume, Salvador, Prefeitura do Município do Salvador. 1950. (Documentos históricos do Arquivo Municipal).

ATAS da Câmara, 1684 - 1700, $6^{\circ}$ volume, Salvador, Prefeitura do Município do Salvador. 1951. (Documentos históricos do Arquivo Municipal).

ARISTOTE, Poétique. Paris, Livre de Poche, 1990.

ARNAUT, Salvador Dias. $\underline{A}$ arte de comer em Portugal na Idade Média. Imprensa Nacional - Casa Da Moeda, Lisboa, sem data.

AMADO, James (Org.). Gregório de_MATOS, Crônicas do viver baiano seiscentista. Obra completa de Gregório de Matos. 7 Vol., Bahia, Ed. Universitária, sem data.

BAKHTIN, Mikhail. A cultura popular na Idade Média e no Renascimento: o contexto de François Rabelais. São Paulo/Brasília, Hucitec, 1999. 
BARLÉU, Gaspar. História dos fatos recentementes praticados durante oito anos no Brasil. BH /SP, Itatiaia/EDUSP, 1974.

BARTHES, Roland. "Pour une psycho-sociologie de l'alimentation contemporaine", Paris, Revue Des Annales, ESC, 1961.

BASAVE, Benitez Agustín. México mestizo: análisis del nacionalismo mexicano en torno a la Mestizofilia de Andrés Molina Enríquez. Cidade de México, Fondo de Cultura Económica. 2002.

BENCI, Jorge. Economia cristã dos senhores no governo dos escravos. São Paulo, Grijalbo, 1977.

BOSI, Alfredo. Dialética da colonização. $4^{\mathrm{a}}$ ed., São Paulo, Cia. das Letras, [1992] 2005.

BOUDAN, Christian. Géopolitique du goût: la guerre culinaire. Paris, PUF. 2004.

BOXER, Charles R. Salvador de Sá e a luta pelo Brasil e Angola, 1602 - 1686. São Paulo, Ed. Nacional/EDUSP, 1973.

A Índia portuguesa em meados do século XVII. Lisboa, ed. 70, 1980.

BRANDÃO, Ambrósio Fernandes. Diálogos da grandeza do Brasil. São Paulo, Melhoramentos, 1977.

BRANDÃO, Carlos Rodrigues. Plantar, colher, comer: um estudo sobre o campesinato goiano. Rio de Janeiro, Graal, 1981.

BRAUDEL, Fernand. Civilisation matérielle, économie et capitalisme, XV ème - XVIII ème

Siècle.Tome I, II et III, Paris, Armand Colin, Livre de Poche, 1979.

BREZILLON, Michel, (Org.). Dictionnaire de la préhistoire. Paris, Larousse, 1969.

CALADO, Frei Manuel. O valeroso Lucideno e triunfo da liberdade. 2 v., BH./ SP., Itatiaia /EDUSP, 1987.

CALMON, Pedro. História da Fundação da Bahia, Rio de janeiro, Publicações Museu do Estado, 1949.

Vida espantosa de Gregório de Matos. Rio de Janeiro/ Brasília, José Olympio/ INL., 1983. 


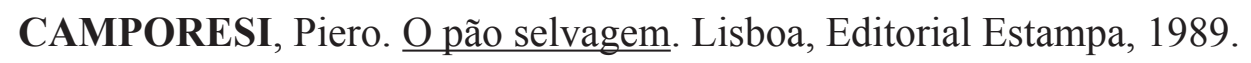

CAMPOS, Augusto de. Da América que existe: Gregório de Matos, in MATOS, Gregório de. Crônicas do viver baiano seiscentista. Obra completa de Gregório de Matos, 7 Vol., Amado, James (Org.) Bahia, Ed. Universitária, sem data.

CAMPOS, Haroldo de. $\underline{\mathrm{O} \text { seqüestro do barroco na formação da literatura brasileira: o caso }}$ Gregório de Matos. Salvador, Fundação Casa de Jorge Amado, 1989.

CANABRAVA, Alice P. João Antônio Andreoni e sua obra, in ANTONIL, André João. (João Antonio Andreoni). Cultura e opulência do Brasil. $2^{\text {a }}$ ed., (Texto da ed . de 1711), São Paulo, Ed. Nacional, 1967.

CARTAS do Senado, 1673 - 1684. $2^{\circ}$ vol., Salvador, Prefeitura Municipal do Salvador. 1952.

CARTAS do Senado, 1684 - 1692. $3^{\circ}$ vol., Salvador, Prefeitura Municipal do Salvador. 1953.

CARDIM, Fernão. Tratados da terra e gente do Brasil. $3^{\text {a }}$ ed., São Paulo, INL. MEC./Cia. Ed. Nacional, 1978.

CASCUDO, Luís da Câmara. História da alimentação no Brasil. 2 Vol., BH/ SP, Itatiaia/EDUSP, 1983.

CAVAlCANTE, Paulo B. Frutas comestíveis da Amazônia. Belém, Museu E. Goeldi. 1988.

CHANG, Kwang Chi. Food in Chinese culture: anthropological and historical perspectives. New Haven \&London, Yale University Press, 1977.

CHAVES, Maria Anunciada Ramos. O açúcar na História do Brasil. Belém, FUNTEC, 1999.

CHEVALIER, Máxime. Quevedo y su tiempo: la agudeza verbal. Barcelona, Editorial crítica, 1992.

COE, Sophie D. As primeras cocinas de América. Cidade do México, Fondo de Cultura Econômica. 2004.

COELHO, Duarte de Albuquerque. Memórias diárias da guerra do Brasil. Pernambuco, Secretaria do Interior de Pernambuco, 1944.

COREAL, François. Voyages de François Coreal aux Indes Occidentales contenant ce qu'il y

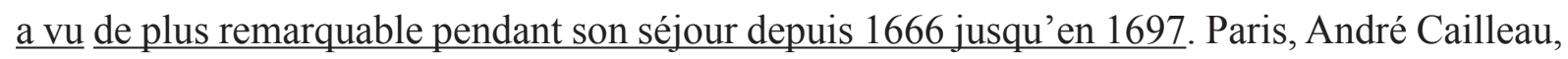
1722. 
CUNHA, Mafalda Soares. \& MONTEIRO, Nuno Gonçalo F. "Governadores e capitãesmores do império atlântico português nos séculos XVII e XVIII', in Optima Pars, Elites Ibero -americanas do Antigo Regime, Lisboa, Estudos e investigações 36, 2005.

CUNHA, Manuela Carneiro da. Antropologia do Brasil: mito, história, etnicidade. Sãp Paulo, Brasiliense/EDUSP. 1986.

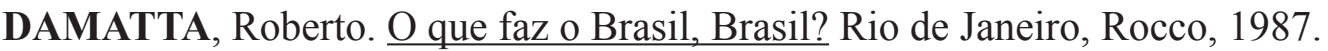

DAMPIER, Guillaume. Voyage aux terres australes, á la Nouvelle Hollande, \&c., fait en 1699.

DARNTON, Robert. $\underline{\mathrm{O} \text { grande massacre de gatos e outros episódios da História cultural }}$ francesa. Graal, Rio de Janeiro, 2a ed., 1988.

DELSON, Roberta Marx. Novas vilas para o Brasil-colônia. Brasília, Alva-Ciord, 1979.

Del PRIORE, Mary Lucy. Festas e utopias no Brasil colonial. São Paulo, Brasiliense, 2002.

DIMAS, Antônio. Gregório de Matos, seleção de textos, notas, estudos biográficos históricos e Críticos. São Paulo, Abril, 1981.

DITADI, Carlos Augusto. "Feijoada", in Revista Gula, No. 67, Maio de 1998.

DOUGLAS, MARY. Pureza e perigo: ensaio sobre as noções de poluição e tabu. Lisboa, ed. 70, Sem data.

"Les structures du culinaire" in Communications (31), 145-170. 1979.

DROUART, Alain. Les français et la table: alimentation, cuisine, gastronomie du Moyen Âge à nos jours, Paris, Ellipses, 2005.

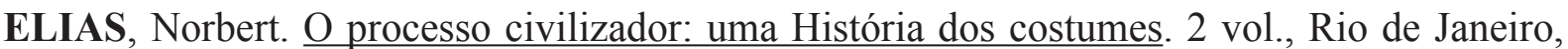
Zahar, 1990.

ELIAS, Rodrigo. "Breve História da feijoada", in Nossa História, Ano I, no. 4, Fevereiro 2004.

ELLIS, Myriam. A baleia no Brasil colonial: feitorias, baleeiros, técnicas, monopólio, comercio, iluminação. São Paulo, Ed. Melhoramentos/EDUSP, 1969.

ESPIRITO SANTO, José Jorge. Resgate de uma riqueza cultural: São Francisco do Conde. São Francisco do Conde, Antares Comunicação. 1998. 
EVREUX, Yves D'. Viagem ao Norte do Brasil. Rio de Janeiro, Livraria Leite Ribeiro, 1929.

FERLINI, Vera Lúcia do Amaral. Terra, trabalho e poder: o mundo dos engenhos no nordeste colonial. Bauru, EDUSC., 2003.

$\underline{O}$ engenho Sergipe do Conde: contar, constatar e questionar Bahia (1622 - 1653).

Dissertação de mestrado em História Econômica apresentada ao Departamento de História da FFLCH-USP. São Paulo, 1980.

FERNANDEZ - ARMESTO, Felipe. Comida: uma história. Rio de Janeiro, Record, 2001.

FINNEGAN, Ruth. Oral tradition and the verbal arts: a guide to research practices. London, Routledge, 1992.

FISCHLER, Claude. L'homnivore: le goût, la cuisine et le corps. Paris, Odile Jacob, 2001.

FLANDRIN, Jean-Louis e MONTANARI, Massimo (Org). História da alimentação. São Paulo, Estação Liberdade, 1998.

FLANDRIN, “A distinção pelo gosto", in História da vida Privada: da Renascença ao século das luzes, Vol 3, ARIÈS, Philippe e DUBY, Georges (Org.). São Paulo, Cia das Letras, 2002.

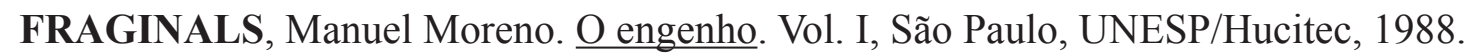

FREYRE, Gilberto. Casa grande e senzala. R J., J. Olympio, 1966.

Sobrados e mucambos. 3 Vol., 2 a ed., Rio de Janeiro, José Olympio. 1951.

A presença do açúcar na formação brasileira. Rio de Janeiro, Instituto do Açúcar e do Álcool, 1975.

Açúcar: uma sociologia do doce com receitas de bolos e doces do nordeste do Brasil. São Paulo, Cia das Letras. 1997.

FREZIER, Amédée François. Relation du Voyage de la mer du sud aux côtes du Chily et du Pérou, fait pendant les années $1712,1713 \& 1714$.

FREZIER, Amadeo. Relacion del viaje por el mar del sur. Caracas, Biblioteca Ayacucho, s. data.

FRIEIRO, Eduardo. Feijão Angu e couve. Ensaio sobre a comida dos mineiros. $2^{\mathrm{a}}$ ed. B.H./ S.P., Itatiaia/EDUSP, 1982. 
FROGER, Relation d'un voyage fait en 1695, 1696 \& 1696 aux Côtes d'Afrique, Détroit de Magellan, Brésil, Cayenne, \& Isles Antilles par une escadre des vaisseaux du Roy, commandée par Monsieur de Gennes. Faite par le Sieur Froger, ingénieur volontaire sur le Faucon Anglais. FRY, Peter. A persistência da raça: ensaios antropológicos sobre o Brasil e a África austral. Rio de Janeiro, Civilização Brasileira, 2005.

FURTADO, Celso. Formação Econômica do Brasil. Rio de Janeiro, Fundo de Cultura, $5^{\text {a }}$ ed., 1963.

GANDAVO, Pêro de Magalhães. Tratado da Província do Brasil e História da Província de Santa Cruz. Belo Horizonte/São Paulo, Itatiaia/EDUSP, 1980.

GARCIA, Rosa Wanda Diez. Antropologia e nutrição um diálogo possível. Rio de Janeiro, Ed. Fiocruz, 2005.

GARDES-TAMINE, Joëlle, La stylistique, Paris, Armand Collin, 1997.

GEERTZ, Clifford. A interpretação das culturas. Rio de Janeiro, LTC, 1989.

GINZBURG, Carlo. A micro-história e outros ensaios. Rio de Janeiro, Bertrand Brasil, 1991. Mitos, emblemas, sinais: Morfologia e História. $2^{\text {a }}$ ed., São Paulo, Cia. das Letras, 2002. Relações de força: História, retórica, prova. São Paulo, Cia. das Letras, 2002.

GODELIER, Maurice. L'idéel et le matériel, pensée, économie, société. Paris, Fayard, 1984. GOMES, João Carlos Teixeira. Gregório de Matos, o Boca de Brasa: um estudo de plágio e criação intertextual. Petrópolis, Vozes, 1985.

GOODY, Jack. Cooking, cuisine and Class a study in comparative sociology. London/New York, Cambridge University Press, 1982.

GRIECO, Allen F. "Alimentação e classes sociais no fim da Idade Média e na Renascença”, in FLANDRIN, J.L. e MONTANARI, M. (Org.). História da alimentação. São Paulo, Estação Liberdade, 1998.

GRUZINSKI, Serge. O pensamento mestiço. São Paulo, Cia. das Letras, 2001.

HANSEN, A sátira e o engenho: Gregório de Matos e a Bahia do século XVII. $2^{\mathrm{a}}$ ed., São Paulo, Atelier Editorial/UNICAMP., 2004. 
HELENA, Lúcia. Uma literatura antropofágica. Rio de Janeiro, Cátedra /Instit. Nac. do Livro /MEC, 1982.

HENRIQUEZ, Francisco da Fonseca, Âncora medicinal: para conservar a vida e a saúde. Cotia, Ateliê Editorial, 2004.

HERCKMAN, Elias. Descripção geral da Capitania da Parahyba por Elias Herckman. In RIAGP, tomo 4, 31, pp. $239-288,1886$.

HIPPOCRATE l'art de la médecine. Traduction Jacques Jouanna, et Caroline Magdelaine, paris, Flammarion, 1999.

HORACE, Satires. Trad. François Villeneuve, introduction et notes d'Odile Ricoux, Paris, Les Belles Lettres, 2002.

HOLANDA, Sérgio Buarque de. Raízes do Brasil. Rio de Janeiro, 12a ed., José Olympio, 1978.

(Org.). História geral da civilização brasileira - "A época colonial", 2 Vol., Rio de Janeiro/São Paulo, Difel, 1977.

Caminhos e fronteiras. São Paulo, Cia. das Letras, 1995.

Capítulos de Literatura colonial. (Org.) e introdução de Antônio Cândido, São Paulo, Brasiliense, 2000.

JÚLIO, Sylvio. Fundamentos da poesia brasileira. Rio de Janeiro, Coelho Branco Fo, 1930.

JUVENAL. Satires. Paris, Les Belles Lettres, 2002.

LAGARDE, André et MICHARD, Laurent. XVI ème Siècle. Paris, Bordas, sem data.

LAPA, José Roberto do Amaral. A Bahia e a Carreira da Índia. São Paulo, Ed. Nacional/EDUSP., 1968. pp. 22 e 23.

LA REGINA, Silvia. A recepção de Gregório de Mattos no século XVIII. in Merope 8, Pescara, Gennaio 1993.

. Gregório de Mattos e la mouvance. in Merope 26 (XI), Pescara, Gennaio1999.

LEACH, Edmund. "Aspectos antropológicos da linguagem: categorias animais e insulto verbal”, In DA MATTA, Roberto. Edmund Leach, Antropologia, São Paulo, Ática, 1983. 
LE BRETON, David. Anthropologie du corps e modernité. Paris, Puf., $3^{\mathrm{a}}$ ed. 2003. La sociologie du corps. Paris, Que sais-je?, PUF., 5 ème edition, 2004. A sociologia do corpo, Petrópolis, Vozes, 2006.

LE GOFF, Jacques e TUONG, Nicolas. Uma história do corpo na Idade Média. Rio de Janeiro, Civilização Brasileira, 2006.

LEMONNIER, Pierre. Les salines de l'ouest: logique technique, logique sociale. Lille, Maison des Sciences de 1'Homme/Presses Universitaires de Lille. 1980.

LEROI-GOURHAN, André. Milieu et technique. Paris, Albin Michel, 1945.

Le geste et la parole. 2 T., Paris, Albin Michel, 1964 e 1965.

LERY, Jean. Histoire d'un Voyage faict en la terre du Brésil, texte établi, présenté et annoté par Frank LESTRINGANT, Paris, Livre de Poche, 1994.

LINHARES, Maria Yedda Leite. História do abastecimento: uma problemática em questão (1530-1918). Brasilia, Binagri, 1979.

LISS, Peggy K. Origenes de la nacionalidad mexicana, 1521- 1556: la formacion de una nueva sociedad. Cidade de México, Fondo de Cultura Económica. 1996.

LIVRO de Cozinha Da Infanta D. Maria, Códice da Biblioteca Nacional de Nápoles, Facsímile, Imprensa Nacional/Casa da Moeda, Lisboa, sem data.

LORIMER, Rosemeire Bertolini. O impacto dos primeiros séculos de História da América Portuguesa na formação da brasilidade alimentar. Tese de Doutorado apresentada ao Departamento de Nutrição da Faculdade de Saúde Pública da USP, São Paulo. 2001.

MACIEL, Maria Eunice. "Identidade cultural e alimentação", in CANESQUI, Ana Maria e GARCIA, Rosa Wanda Diez. Antropologia e nutrição um diálogo possível. Rio de Janeiro, Ed. Fiocruz, 2005

MARCGRAVE, Jorge. História natural do Brasil. São Paulo, Museu Paulista, 1942.

MARGARIDO, Alfredo. As surpresas da flora no tempo dos descobrimentos. Lisboa, Ed. Elo, sem data. 
MARINS, Paulo César Garcez. Através da rótula: sociedade e arquitetura urbana no Brasil, séculos XVII a XX. São Paulo, Humanitas, FFLCH-USP, 2001.

MASCARENHAS, Maria José Rapassi. Tese em História econômica apresentada ao Departamento de História da FFLCH-USP. São Paulo, 1998.

MATOS, Gregório de. Crônicas do viver baiano seiscentista. Obra completa de Gregório de Matos, 7 Vol., Amado, James (Org.). Bahia, Ed. Universitária, sem data.

MAUÊS, Maria Angélica Mota \& Raymundo Heraldo. $\underline{\mathrm{O} \text { folclore da alimentação: tabus }}$ alimentares da Amazônia (um estudo de caso numa população de pescadores do litoral paraense. Belém, 1980.

MAUSS, Marcel. "Ensaio sobre a dádiva" e"as técnicas do corpo", in Sociologia e Antropologia. São Paulo, Cosac e Naify, 2003.

MATTOSO, Kátia de Queirós. Ser escravo no Brasil. São Paulo, Brasiliense, 1982.

MAURO, Frédéric. Portugal, o Brasil e o Atlântico. 1570 - 1670. 2 vol., Lisboa, Imprensa Universitária/Editorial Estampa, 1989.

Nova História e Mundo Novo. São Paulo, Perspectiva, 1969.

MELLO, Evaldo Cabral de. Nas fronteiras do paladar, in Folha de São Paulo. Caderno Mais, $28 / 5 / 2000$.

MENESES, Ulpiano Bezerra de. e CARNEIRO, Henrique. "A história da alimentação: balizas historiográficas". In Anais do Museu Paulista, São Paulo, 1998.

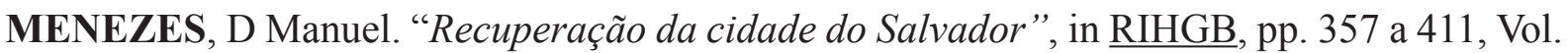
$22,1859$.

MENNELL, Stephen. All manners of food: eating and taste in England and France from the Middle Ages to the present. Urbana and Chicago, University of Illinois Press, 1996.

MERLEAU-PONTY, Maurice. $O$ olho do viajante, in Textos selecionados. São Paulo, Abril Cultural, 1980.

MESGRAVIS, Laima. Os aspectos estamentais da estrutura social do Brasil colonia, in Estudos econômicos, nº 13, pp. 799 a 811, 1983. 
MINTZ, Sidney W. Sweetness and power: the place of sugar in modern history. New York, Penguin Books, 1985.

MONTANARI, Massimo. A fome e a abundância: História da alimentação na Europa. Bauru, EDUSC, 2003.

“Un historien gourmand” in REDON, Odile. SALLMANN, Line. \& STEINBERG, Sylvie (org.). Le désir et le goût: une autre histoire (XIII e-XVIII e siècles), Saint Denis, PUV. 2005.

MORENO, Diogo de Campos. Livro que dá Razão do Estado do Brasil. Recife, Arquivo Público Estadual, 1955.

MORAES, Antônio da Silva Diccionário da língua portugueza. 2 tomos. Lisboa, Tipografia Lacerdina, 1813.

MOTT, Luiz. "Sergipe del Rei: Três sonetos seiscentistas", in Estudos Humanísticos. Aracajú, ano 1, no. 1, 1990. pp. $123-130$.

"In vino veritas: vinho e aguardente no cotidiano dos sodomitas luso brasileiros à época da Inquisição", in Álcool e drogas na História do Brasil. (Org). VENÂNCIO, Renato Pinto e CARNEIRO, Henrique, São Paulo/Belo Horizonte, PUC. Minas/Alameda, 2005.

NOVAIS, Fernando. “O Brasil nos quadros do antigo sistema colonial”, In Brasil em Perspectiva, C.G. Mota (ed.), São Paulo, Difel, 1968.

Estrutura e dinâmica do Antigo Sistema Colonial (séculos XVI -XVIII). $6^{\text {a }}$ ed., São

Paulo, 1996.

NÚÑEZ, Rafael Florêncio. Con la salsa de su hambre: los extranjeros ante la mesa hispana. Madrid, Alianza Editorial, 2004.

OLIVEIRA, Manuel Botelho de. Poema “Ilha de Maré”, in SILVA, Rogério Forastieri. Colônia e nativismo: a História como “biografia da nação". São Paulo, Hucitec, 1997.

OMEGNA, Nelson. Diabolização dos judeus e presença dos sefardins no Brasil colonial. Rio de Janeiro, Record, 1969.

ONG, Walter. Oralidade e cultura escrita. Papyrus. 1998. 
OROZCO, Emilio. Introducción a Góngora. Barcelona, Editorial Crítica, 1984.

ORS, Eugenio d'. Du baroque. Paris, Gallimard, 2000.

PAPAVERO, Claude. Mantimentos e víveres: o domínio colonial holandês no Brasil. Dissertação de Mestrado em Antropologia Social apresentada à Universidade de São Paulo em 2002.

PÉCORA, Alcir. (Org.). Antônio Vieira - Sermões. Tomo I, São Paulo, Hedra, 2001.

PEIRANO, Mariza Gomes e Souza. "Proibições alimentares numa comunidade de pescadores (Icaraí, Ceará)". Dissertação de Mestrado em Antropologia Social apresentada à Universidade de Brasília em 1975.

PERES, Fernando da Rocha e LA REGINA, Silvia. Um códice setecentista: inédito de Gregório de Matos, Salvador, EDUFBA, 2000.

PERES, Fernando da Rocha. Gregório de Mattos Guerra - uma re-visão biográfica. Salvador, Macunaíma, 1983.

Gregório de Mattos e a Inquisição. Salvador, Centro de Estudos Baianos, 1987.

Gregório de Mattos: o poeta devorador, Rio de Janeiro, Manati, 2004.

A família Mattos na Bahia do século XVII. Salvador, Centro de Estudos Baianos, 1988.

PINHO, Wanderley. História de um engenho do Recôncavo, 1552 - 1944. Rio de Janeiro, Zélio Valverde SA., 1946.

História social da cidade do Salvador. Salvador, Prefeitura Municipal do Salvador. 1968.

PIO CORRÊA, M. Dicionário das plantas úteis do Brasil: e das exóticas cultivadas. 6 v. ilustr., Rio de Janeiro, Ministério da Agricultura/IBDF, 1984.

PISO, Guilherme. História Natural do Brasil. São Paulo, Companhia Editora Nacional, 1948. História natural e médica da Índia Ocidental. Rio de Janeiro, Instituto Nacional do Livro, 1957. PITA, Sebastião da Rocha. História da América portuguesa. São Paulo/Belo Horizonte, EDUSP/ Itatiaia, 1976.

PITTE, Jean Robert. Gastronomia francesa: história e geografia de uma paixão. Porto Alegre, L\&PM.,1993. 
POULAIN, Jean-Pierre. Sociologias da alimentação. Florianópolis, Ed. UFSC, 2004.

PUNTONI, Pedro. A mísera sorte. Hucitec, São Paulo, 1999.

A guerra dos bárbaros: povos indígenas e a colonização do sertão nordeste do Brasil, 1650 - 1720. São Paulo, FAPESP/Hucitec/EDUSP, 2000.

QUEVEDO, Francisco de. Antologia poética, Buenos Aires, Espasa - Calpe, 1948.

QUEVEDO, Francisco de. Quevedo: Antologia poética. Ed. introdução e notas de José M. Pozuelo, Barcelona, RBA, 1994.

RABELO, Manuel Pereira de. "Vida do excelente poeta lírico, o doutor Gregório de Matos Guerra", in MATOS G, Crônicas do viver baiano seiscentista: obra completa de Gregório de Matos. Vol. VII, pp. $1689-1721$.

REDON, Odile. SALLMANN, Line. \& STEINBERG, Sylvie. (org.). Le désir et le goût: une autre histoire (XIII e -XVIII e siècles), Saint Denis, PUV. 2005.

REIS, Filho, Nestor Goulart. Evolução urbana do Brasil (1500-1720). São Paulo, Pioneira, EDUSP, 1968.

Imagens de cidades e vilas do Brasil colonial, São Paulo, EDUSP, 2000.

REVEL, Jean François. Um banquete de palavras: uma história da sensibilidade gastronômica. São Paulo, Cia das Letras, 1996.

RICHARDS, Audrey. Hunger and work in a savage tribe, a functional study of nutrition among the southern Bantu. London, Routledge \& Sons Ltd., 1932.

Land, Labour and diet in Northern Rodesia. Oxford, Oxford University Press, 1939.

RIEIRA-MELIS, A. "Sociedade feudal e alimentação (séculos XII e XIII)" in FLANDRIN, Jean-Louis e MONTANARI, Massimo. (org.). História da alimentação. São Paulo, Estação Liberdade. 1998

ROMERO, Silvio. História da literatura brasileira. 5 Vol., Rio de Janeiro, José Olympio, sem data.

RUSSELL-WOOD, A. J. R. Fidalgos and philanthropists: the Santa Casa da Misericórdia of Bahia, 1550 - 1755. Berkeley, University of California Press, 1968. 
SAHLINS, Marshall. Histórical metaphors and mythical realities. Michigan: The University of Michigan Press, 1981.

SAMPAIO, Theodoro. História da fundação da Cidade do Salvador. Bahia, Tipografia Beneditina, 1949.

SANTOS, Corsino Medeiro dos. Cultura indústria e comércio do arroz no Brasil colonial, in RIHGB., 1978. pp. 36 a 61.

SCHWARTZ, Stuart B. Burocracia e sociedade no Brasil colonial. São Paulo, Perspectiva, 1979. $\underline{\text { Segredos internos: engenhos e escravos na sociedade colonial } 1550-1835}$. São Paulo, Companhia das Letras, 1999. “Gente da terra braziliense da nasção’. Pensando o Brasil: a construção de um povo". In MOTA, Carlos Guilherme (Org.). Viagem incompleta (1500- 2000): formação: histórias, São Paulo, SENAC, 1999.

Escravos roceiros e rebeldes. Bauru, EDUSC. 2001.

SILVA, Rogério Forastieri. Colônia e nativismo: a História como "biografia da nação". São Paulo, Hucitec, 1997.

SILVA, Paula Pinto. Farinha, feijão e carne seca: um tripé culinário no Brasil colonial, São Paulo, Senac, 2005.

SOUSA, Avanete Pereira. Poder local, cidade e atividades econômicas (Bahia, século XVIII). Tese em História econômica apresentada ao Departamento de História da FFLCH-USP. São Paulo, 2003.

SOUSA, Gabriel Soares de. Tratado descritivo do Brasil em 1587. $4^{\mathrm{a}}$ ed., São Paulo, Cia. Ed. Nacional/EDUSP, 1971.

SOUZA, Antônio Cândido de Mello e. Formação da Literatura Brasileira. BH/RJ, Itatiaia, $9^{\mathrm{a}}$ ed., 2000. SPINA, Segismundo. Gregório de Matos: Introdução seleção e notas, São Paulo, Ed Assunção Ltda. S. data.

TACHOS, panelas e companhia: pequena historiografia da alimentação na Bahia. Fundação Pedro Calmon, Série exposições, ano 1, no. 1, 2001. 
TAUNAY, Adolfo Afonso d'’Escragnole. Impressões de viajantes estrangeiros na Bahia colonial (1610 - 1774). Rio de Janeiro, Imprensa Nacional, 1925.

TEIXEIRA, Dante M. (org.) Brasil-Holandês : Miscellanea Cleyeri, Libri Principis \& Theatrum rerum naturalium Brasiliae. 5 V., Ed. Ilustrada, Rio de Janeiro \& Lisboa, Index, 1995.

(org.) Brasil-Holandês: Documentos da Biblioteca universitária de Leiden: (Vol. I), O "Thierbuch" e a "autobiografia" de Zaharias Wagener: (Vol. II), Os quadros do Weinbergschlösschen”de Hoflössnitz: (Vol. III). Rio de Janeiro, Index, Ed.Ilustrada, 1997.

THEVET, André. As singularidades da França Antártica. Belo Horizonte/São Paulo, Itatiaia/ EDUSP, 1978.

TOPA, Francisco. O mapa do Labirinto: inventário testemunhal da poesia atribuída a Gregório de Mattos, Salvador, Bahia Prosa e Poesia, Secretaria de Cultura e Turismo/Imago, 2001.

VAINFAS, Ronaldo (org.). Dicionário do Brasil colonial (1500 - 1808). Rio de Janeiro, Ed. Objetiva, 2000.

VANSINA, Jan. Oral tradition as History. The University of Wisconsin Press, 1985.

VASCONCELOS, Simão de. Notas curiosas \& necessárias das cousas do Brasil. Lisboa, João da Costa, 1668.

VERDONCK, Adriano. Descrição das capitanias de Pernambuco, Itamaracá, Paraíba e Rio Grande. In Mello, J.A. Gonsalves de, Fontes para a História do Brasil holandês: $\mathrm{n}^{\mathrm{0}} 1$ - A economia açucareira, Recife, Parque Histórico Nacional dos Guararapes/MEC/SPHAN/ Fundação Pró- memória, 1981.

VERÍSSIMO, José. Gregório de Matos. Estudos Brasileiros? Rio de Janeiro, Cia. Tipográfica do Brasil, 1894.

Gregório de Matos. in Revista da Academia Brasileira de Letras, 7, 1912. História da literatura brasileira. Rio de Janeiro, Francisco Alves, 1916.

VIRGILE. Bucoliques. Paris, Les Belles Lettres, 2002.

VON MARTIUS, Karl Friedrich Philipp. “Como escrever a História do Brasil”, in Revista do IHGB., t. 6. 1844. 
WISNIK, José Miguel. (Org.). Gregório de Matos, poemas escolhidos. São Paulo, Cultrix, 1976.

WARNIER, Jean-Pierre. Construire la culture matérielle: l'homme qui pensait avec ses doigts. Paris, PUF. 1999. 